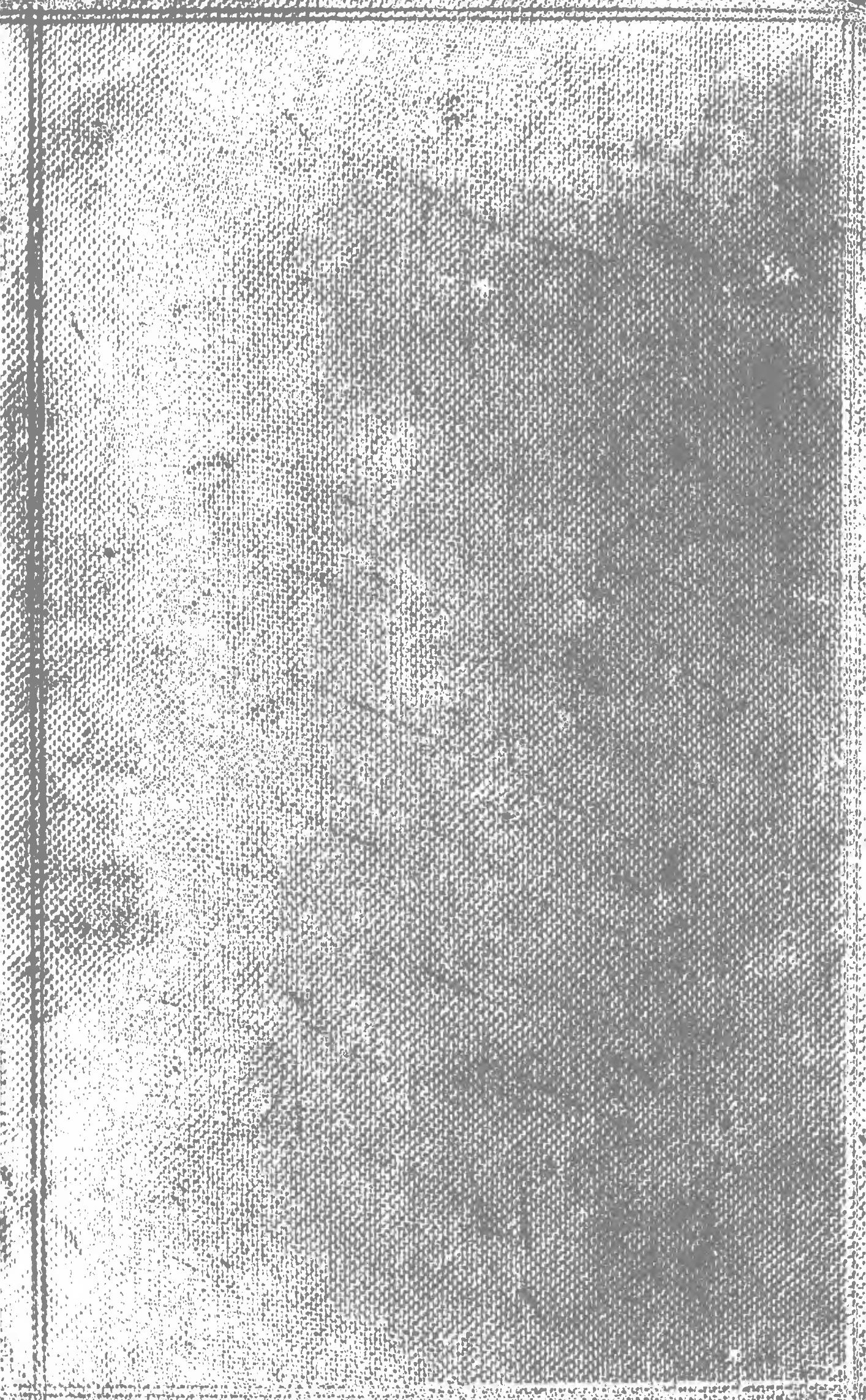




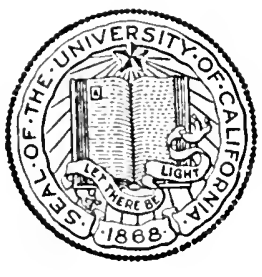

\section{THE LIBRARY OF} THE UNIVERSITY OF CALIFORNIA LOS ANGELES

SCHOOL OF LAW 


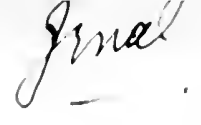



Digitized by the Internet Archive in 2008 with funding from Microsoft Corporation 



\title{
THE ELEMENTS OF THE LAW
}

oF

\section{NEGOTIABLE INSTRRUIENTS,}

PY

\author{
JOHN W. DANIEL, \\ OF THE LYSCHBURG (VA.) B.IR, AND
}

AUTHOR OF "DANIEL ON NEGOTIABLE INSTRE'MENTS."

AND

CHAS. A. DOUGLASS, OF THE BAR OF THE DISTRICT OF COLTMBIA, AND PROFESSOR OF THE LAW OF NEGOTIABLE INSTRUMENTS IN GEORGETOWN LNIVERITY, OF WASHINGTON, D. C.

NEW YORK:

BAKER, YOORHIS \& COMPANY, 1903. 
Copyright, 1903 ,

BY BAKER, VOORHIS \& COMPANY.

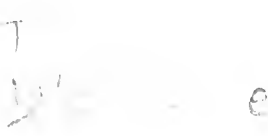

J. 2. LYOS COMPANY

PRINTERS ANT, HINIJRS ALHANY, $\therefore$. $r$ 
JOSEPH J. DARLING'TON, LL. I., of the bar of tile district of colimbia,

PROFESSOR, ACTHOR, WND LAWYER, WHOSE GREAT AHIITY AXD EXALTED CHAIACTER HAVE GIVX ADDED SPLEXDOR TO THE PROFESIOX OF THE IAW, AND WHOSE GENEROLS AID TO STREgGLNG YOUXG LAWYERS HAS MADE HIM AN INSPIRATION,

THIS WORK

IS, WITH HIS PERMISSION,

RESPECTFUILY INSCRIBED

BI THE A T THORS. 



\section{PREFA CE.}

The work which follows is designed exclusively for the use of students and instructors in law schools, and it has, therefore, been styled "The Elements of the Law of Negrotiablo Instruments."

It is based upon the treatise known as "Daniel on Negotiable Instruments," and upon the leetures of Mrs Douglass on that subject in the Law Department of Georgetown (D. C.) University. To the student should be rouchsafed the substantial benefits, on the one hand, of the point of view and professional experience of the lawyer-author, and on the other, of the lecturer's practical appreciation of the usual diffienties attendant upon the study of the law. These were the considerations in mind in determining upon the eom. bined sources of information and material for a student's text-book on this important subject.

Wherever it has been practicable, free use has been mado of the text of "Daniel on Negotiable Instruments," ineluding both language and arrangement, but pains have been taken to regulate and apportion the space deroted to the many sub-subjects, as their relative importance, from the standpoint of the student, requires. In addition, the subject-matter has been rearranged and transposed and new matter added; in fine, everything has been done that seened to the authors necessary to make the subject both intelligible and attractive. The rolume contains no notes except the bare citation of the eases, and they have heen prineipally confined to, and earefully selected from, well-considered cases cited in "Daniel on Negotiable Instruments." While it is a radical departure from prevailing methods, it has been esteemed wise to omit in the notes themselves all comments upon, and referenee to, the scope and effect of the deeisions, 
whether in hammony, or in confliet, with the text, preferring to inelude in the body of the work. itself all that is thought necessary for the student's nse. The experience, both of teateher and pupil, amply establishes the fact that comments and statements in the notes, especially when in conflict with, or in modification of, the law ats announced in the text, are well-springs of confusion, doubt, and diffienlty to the student, lowever faitlifully and diligently he may seek to master the suljeet in liant.

The "New Negotiable Instruments Law," first enacted by the Legislature of New York on May 19, 1897, has beeome law in nineteen States, and also in the Territory of Arizona ant the District of Columbia, and it is destined in the near future to be the miform law throughout the United States. The full text of this important statute will be found in an appendix to this work.

We are indeloted to Mr. E. B. Sherrill, of the Bar of the District of Columbia, for the earefully prepared index and table of asce, and also for valuable assistance given in the preparation of the text.

JNO. W. DANTEL.

CHAS. A. DOUGLASS.

Wasingtox, I). C., December 1, 1902. 


\section{TABLE OF CONTENTS.}

\section{BOOK I.}

\section{THE MAKING OF THE INSTRUMENT.}

\section{CHAP'IER I.}

Nature, History, and Uses of Negothabe Ixstrinexts...... l l

SECTIOx I. Natme, origin, and history of bills and notes..... I

II. Foreign and inland bills .............. 5

III. The etreet of a bill of exchange - when it is an assignment, and when not ................ $i$

CHAPTER II.

Differext Kinds of Negotiable Ixstri mexts . . . . . . . 11

Section I. Definitions of bills of exchange and promissory notes, and the differences between them .......... 11

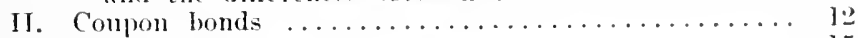

III. Bank notes .......................... 15

IV. Certificates of deposit $\ldots \ldots \ldots \ldots \ldots \ldots \ldots \ldots \ldots$ lit

V. Cheeks .......................... 17

VI. Pills of credit ..................

VII. Quasi-negrotiable instrmments .............. 2t

CHAPTER III.

Fommal Requisites of Negothble Ixstriments........... 34

Sectiox I. Difference in structure between hills of exchange and promissory notes ..................... 34

II. Formality in respect to sty le and material........ 31

III. The several parts of a foreign bill ralled a set...... 39

IV. Stamps upon negotiahle instruments.......... 40

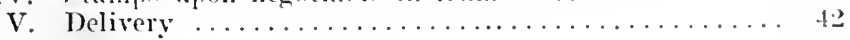

\section{CIIAPTER IV.}

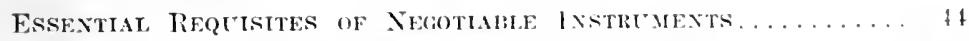

Section I. The paper must be open - that is. unsealed....... 44

II. Certainty as to engagement to pay............. 45

III. Certainty as to fact of payment.............. $46^{\circ}$

IV. Certainty as to amomnt to be paid..............

V. Cortainty as to the medim of parment. which must he

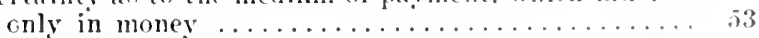




\section{CHAPTER V.}

Page.

Consideratiox of Negotiable Ixstruments............ 56

Section I. Consideration presumed $\ldots \ldots \ldots \ldots \ldots \ldots \ldots \ldots \ldots, 56$

11. Good and valuable considerations........... 57

11. What are illegal considerations $\ldots \ldots \ldots \ldots \ldots \ldots \ldots, 62$

IV. By what law legality of consideration is determined. 6.5

$\checkmark$. Partial want, failure, or illegality of consideration.... 66

V1. Between what parties the consideration is open to in-

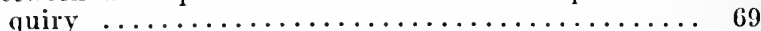

VII. How illegality may be purged - renewal of instrument

\section{BOOK II.}

FARTIES TO THE INSTRUMENT.

\section{CHAPTER VI.}

Persons Qunlified $\ldots \ldots \ldots \ldots \ldots \ldots \ldots \ldots \ldots \ldots \ldots \ldots \ldots \ldots \ldots \ldots$

Section I. Fiduciaries as parties $\ldots \ldots \ldots \ldots \ldots \ldots \ldots \ldots \ldots \ldots$

II. Agents as parties ....................... 75

III. Partners as parties .................... 83

IV. Corporations as parties $\ldots \ldots \ldots \ldots \ldots \ldots \ldots \ldots, 88$

CHAPTER VII.

Persoxs Partially or Whiolly Disqualified............. 94

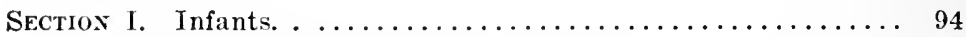

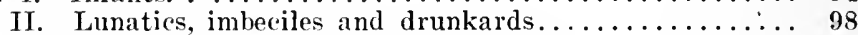

III. Alien encmies . .......................... 101

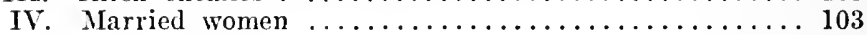

\section{BOOK III.}

THE NEGOTIATION OF THE INSTRUMENT.

\section{CHAPTER VIII.}

Traxsfer by Delivery and Indorsenent $\ldots \ldots \ldots \ldots \ldots \ldots \ldots$

Sectiox I. Nature of, and lialilities created by, contract of in-

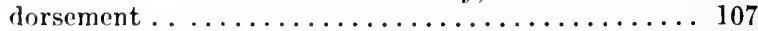

II. Form and varicties of indorsement............ 111 


\section{CHAPTER IX.}

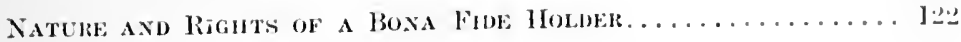

Section 1. The rights of a bona fide holder.............. 122

11. lixceptions to, and moditications of, the rule as to the

rights of a bona fide holder.............. 137

III. What constitutes a bona fide holder ............ 14:

\section{BOOK IV.}

\section{FIXING LIABILITY TO PAY THE INSTRUMENT.}

\section{CHAPTER X.}

Presentalent for Acceptaxce, axi Acceptaxce......... 162

SEctiox I. What bills of exchange should be presented for accept-

ance. ...................... 162

II. By and to whom presentment slould be made ....... lij.j

III. The place where, and how, presentment should be made . ....................... 167

IV. Time of presentment for aceeptance ........... 16is

V. The nature and effect of acceptance ..........

VI. By whom, and when, bills shonld be acecpted...... 17s

VII. Form and varieties of acceptanee........... ISs

\section{CHAPTER XI.}

Presentment for Payment . . . . . . . . . . . . . . . 199

SECTION I. By and to whom the instrument should be presented. . 200

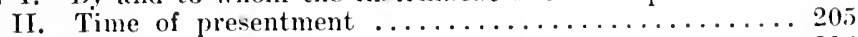

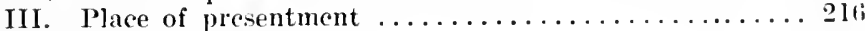

IV. Mode of presentment $\ldots \ldots \ldots \ldots \ldots \ldots \ldots \ldots \ldots .219$

CHAPTER XII.

Protest and Notice of Disiloxor.........

Section I. Protest . . . . . . . .

II. Notice of dishonor .......................

CHAPTER XIII.

Circumstances of a Gexeral or Special Nature Wincil Excese

Want of Presentmext, Protest, or Notice of Disiloxor... 254

SEctiox I. Circumstances of a general nature which excuse want of presentment, protest, or notice of dishonor..... 254

II. Circumstances of a special nature which either excuse want of, or show absence of a right to require, presentulent, protest, or notice of dishonor ........ 257 


\section{BOOK $\mathrm{V}$. \\ ACTIONS AND DEFENSES.}

CIIAPTER XIV.

Page.

Actroxs . . . . . . . . . . . . . . . . . . . . . . 268

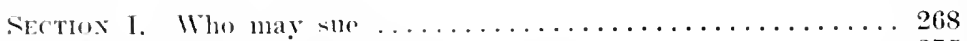

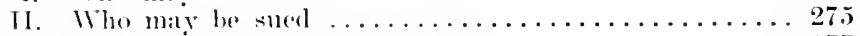

111. When right of action acernes.............. 277

IV. When right of action expires $\ldots \ldots \ldots \ldots \ldots \ldots \ldots .280$

\section{CHAPTER XT.}

DefExses . . . . . . . . . . . . 282

Sectiox I. The defendiut did not make the instrument....... 283

II. The contratet sued upon is in law nonenforceable.... 303

III. The plaintiff is not entitled to sue........... 305

IT. The obligation ereated has been discharged........ 306

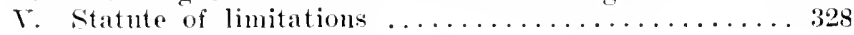

CHAPTER XVI.

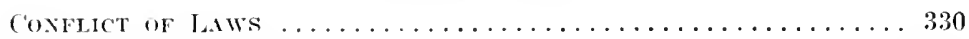

SEctiox I. l.f.r loci contrartus ..................... 332

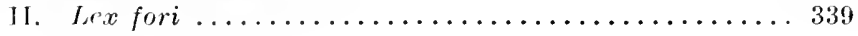




\title{
TABLE OF CASES CITEI.
}

\author{
[The referenees are to paragraphs marked \$.]
}

Abel $r$. Sutton, 141 .

Alair $x$. lenox, $45 \overline{5}$.

Alams $\because$. Ilackensack Co., 464.
i. Leland, 397 .
r. Otterback, 328.
r. lieeves, 452 .
r. IVilson, 60.
$r$. Wordley, 310.
$r$. Wright, 378 .

Administrators of Beaman $i$. Russell. 443.

Agnel r. Ellis, $2 \pi$.

Agnew v. Alden, 108.

r. Bank of Gettysburg, 259.

Agricultural Bank r. Burr, 4 .

Alderson $r$. Langdale, 441 .

Alleman $r$. Wheeler, 423.

Allen r. Bratton. 497.

v. Frazee, 214.

$v$. Hearn. 10:2.

$r$. Merehants Mank, 132 .

$r$. Newlumy, 405.

r. O'Donald, 478.

r. Pegram, 45.

r. Nuvdam, 257, 268.

r. Tate, 399 .

Alston r. llartman, 402.

Amherst Acadomy r. Cowles, 405.

Ammidown r. Woodman, 330.

Amner $r$. Clark, 7 .

Anderson r. Bullock, 73 .

$r$. De Soer. 12.

ז. Drake, 264. 397.

ז. Hiek, 300.306 .

$r$ Warne, 477.

Andover liank r. Cirafton, 222.

Andover Savings liank $v$. Adams, 401.

Aullessen r. First Nat. Bank, 299.

Andrews r. Fanklin, 7 . i. Pond, 245, 486, 490

Androseoggin Bank $r$ Kimball, 62. Angel r. MeClellan, 151 .

Angle r. Ins. Co. 245, 251, 427, 432. 44 I.
Anketel $v$. Converse, 459.

Annvile Nat. bank $r$. Kettering, 359.

Ansel $r$ Olson. 333.

Appleby $r$. Bealolph, $7 T$.

Applegarth $r$. Abbott, 355 .

v. Robinson, 108.

Arents $r$. Commonwealth, 195.

Aruendiaz v. Sanis, 486 .

Almitt $v$. Breame. 62.

Armstrong. $I n$ re, 297.

Armitrong $r$. Am. lix. laink, $i$.

r. Chadwick, 389.

$i$. Toler, 485.

Arnold $r$. Dresser, 319.

v. Jones, 437.

v. Kinloch, 354 .

i. Potter, 491.

$r$. Surague, l:2s.

$r$. stackpole, los.

Arnot $\because$. Eie Railway Co.. 145.

Ashurst r. Royal liank. 203.

Aspiawall $r$. Vake, 275.

Atkins r. Owen, 46it.

Atkinson r. Hawden. 441.

Allanta Nat. Bauk r. Douglatsi. tos.

Attorner-Generil r. Continental Life Ins. Co., 14.

Attwool r. Mumnings. 2S3. $\therefore$. Weeden, 10:2.

Atwook $r$. Crowlie, 98.

Aluerbach $r$. Pritchett, SG.

Averett's Adur. v. Booker, 9l. 9..

Aymar r. Beers. 395.

$i$. Sheldon, 500 .

Bachellor $r$. Priest, 268, 3l:2, 314. $450,454$.

Banckus $u$. Sheplerel. 389.

bailey $r$ Dozier. 347 .

$\therefore$ Rawley. 124 .

$r$. Tavlor, 44:3.

Bain r. Ihitehaten, ete. li. R. Co., 496.

Baker r. Sitackpole, 460. 
Ballwin $r$. Farnsworth, 336 .

liallard $l$. Ins. Co., 430.

Ballingills 2 . Gloster, $174,413$.

Balme $r$. Wambalugh, 131 .

Binbury $t$. Lisiett, $30 \mathrm{~s}$.

Fiank i. ( Cit-on, 248 .

r. Mitlin, 406.

r. l'ittell. 38 .

Bank of Alexandria $r$. Swan, 362 , 378.

Bank of America $r$. Indiana Banking Co., 40 .

Bank of British North Ameriea $t$. Ellis, !3, ] $]$ ].

Bank of Columbia $r$. Lawrenee, $3 \overline{3} 3$, 375.

r. Patterwon's Admr., I46.

Bank of Commerce r. logy, 11. r. Cnion bank, 280, 431.

bank of C'ommonwealth $\iota$. Curry, 285.

l. Mudgett, 335, 357 .

Bank of England $r$. Newman, 316.

Lank of Fayetteville $r$. Lutterloh, 337.

Bank of Fort Madison $\iota$. Alden. $\mathrm{I} 34, \mathrm{I} 38$.

Bank of Genesee $r$. Patchin Bank, 437.

Bank of Genera $v$. Howlett, 372, 376.

Bank of Hlamburg $v$. Flynn, 252.

Bank of Ireland $r$. Archer, 303.

liank of Kansas City $r$. Mills, 314.

liank of Kentucky $v$. Pursley, 348 .

Bank of Ionisville $r$. Ellery, 286.

lank of Metropolis $r$. Now England Bank, 98.

Bank of Missouri $r$. Vaughn, 366.

liank of Mobile $v$. Brumn, 32.

lbank of Ohio Valley r. Lockwood, $430,43 \mathrm{~S}$.

bank of 0$]_{1}$ l Dominion 1 . McVeigh, 360,361 .

Bank of Republie $v$. Millard, 40.

Bank of Sandusky $v$. Sroville, 100.

Bank of Troy $r$. Toppiner, 118.

Bank of Tniterl States $i$. Bank of Gormeria, 45l.

$r$. Tierne, 369.

$r$ Carncal, 364, 375, 379.

$r$ Dandridge, 146.

v. Donally, 4!33, 496 .

$r$ Gorldard, $36 \%, 366$.

$v$. Ilateh, 475,476 .

$r$ Norwond. 37 ?.

$r$. Enited States, 3]4, 454, 492. Jienlam $r$. Bishop, 155.

Barber $i$. Gingell, 125.
Bank of Ltical r. Smith, 259, 312, $314,342,454$.

$r$ Wager, 326 .

Bank of Vergemnes $v$. Cameron, 339, 353,356 .

Bank of Washington $v$. Triplett, $257,258,326,500$.

Barelay $r$. Bailey, 323 .

Baring $v$. Clark, 293.

Barker $v$. Barker, 94. $v$. Hall, 373.

Barnes $v$. Gorman, 89.

v. MeMullins, 474 .

$v$. Reynolds, 37 .

Barnet $v$. Smith, 38, 298.

Barnett $v$. Offerman, 110.

Barr 1 . Boyer, 478.

Barrett $v$. Barrett, 494 .

Barring $\%$ Clark, 453.

Barry v. Clark, 294.

$v$. Morse, 389.

Bartlett $x$. Benson, 203.

$v$. Robinson, 376 .

Bass $r$. Clive, 275.

Bassenhorst $v$. Wilby, 325.

Bassett $\ell$. Avery, 201.

$v$. Haines, 298.

Batchelder $r$. White, 431.

Bathe $r$. Taylor, 429.

Baumgarden $v$. Reeves, 393.

Bausmann $r$ Kelley, 313.

Baxter $r$. Earl of Portsmouth, 160. v. Little, 204.

v. Stewart, 89 .

Bay $v$. Frazer, 57.

Bayley's Admr. $r$. (luubb, 276.

Bealls $v$. Peek, 371.

Bean $v$. Briggs, 499.

Beckerdike $i$. Bollman, 387.

Beckwith $v$. Smith, 377.

lieerhing $r$. Glower, 338 .

Beeler $r$. Frost, 389.

Beeman $v$. Duck, 278, 422.

Beenel $v$. Tourmillon, 376 .

Beghi v. Levi, 288.

Belknap r. Nat. Bank, 420.

Bell $v$. First Nat. Bank, 257, 326. 332.

r. Hagerstown Bank, 374, 376.

$v$. Morrison, 481 .

$v$. Norwood, 409 .

Bellamy $v$. Majoribanks, 33 .

Bellasis $v$. Hester, 287.

Bellows $r$. Lovell, 478.

Pender $r$. Bern, 468. 
Benjamin $v$. McCommell, 469:

Benuell $v$. Wilder, 459.

Best r. Crall, 234.

liettis $r$. Bristol, l:2.

Bevely's Case, 157 .

Bigrelow $r$. Benedict, 102.
r. Colton, 190.
$r$. Heninger, 255.
r. Stepliens, $43 \mathrm{I}$.

liggs $v$. Piper, tiz.

Billgery $v$. Branch, 29, 164, 384.

Billiug $r$. Devaux, 299, 302 .

Billings $v$. Collins, 238.

Binney $v$. Plumley, 70 .

Bird $v$. Daggett, 145.

$r$. Le Blane, 389

Bissell $v$. Adams, 481.

$r$ Jellersonville, 129.

Black $r$. Ward, ss. $r$. Zacharie, 47.

Blacknan $v$. Green, 168. $r$. Lehnan, 77 .

lilackstone Bank $r$. Hill, 459.

Blair $r$. Bank of Tennessee, 437, 475.

$v$. Carpęnter, 459.

Blair \& Hoge $r$. Wilson, 2S, 384, 385.

Blake $v$. MeMillen, 319 .

Blakely $v$. Grant, 372.

lilakey $r$. Johnson, 439.

13lane $r$. Mutual Nat. Bank, 132.

liliss $r$. Houghton, 498.

boalt $v$. Brown, 431.

Bobe $v$. Stickney, 459.

Bochm v. Garejas, 306.

Bogarth $v$ Breedlove, 432.

Bogert $r$. Hertell, 119 .

Bolton $v$. Dugdale, 82 .

Bond $r$. Farnham, 396.

Bomman $r$. Van Kuren, 248.

looe r. Mix, 154.

Booth r. Powers, 436, 440, 441.

Borden $r$. Clark, 186.

Borouglı v. Perkins, 347.

liosinquet $と$. Dudman, 98.

linsch r. Cassing, 244 .

Boss r. Hewitt, 243.

Bouchell v. Clary, 15l.

Pongluner $r$. Mayer. 102.

liowen $v$. Newell, $30,34$.

liowerbank $r$. Monteiro, 59, 310.

Bowie r. Duvall, 314, 405.

Powker $r$. Childs, 468.

Bowman $r$. Hiller, 177. 1. MeChesney. 82l.
Bownan $v$. llood, 395, 403.

- Jowyer $r$. lianpton, 176.

bogee r. Edwards, 304 .

$r$. Geyer, 253.

$r$. Tabb, 105, 106.

Boyd $r$. Cleveland, :ss9.

r. Johnson, Ils.

$\imath$. NleCamn, 111.

$r$ Nasmitl, :36.

r. Plnmb, 135.

$x$ Vanderkamp, 25.5.

boyd's Admrs. 1. City Sav. Bank, 318, $360,371,374$.

Bracton $r$. Willing, $27 \cdot 2$.

Bradlee $x$. Boston Cilass Co., 126.

Bradley $r$. Ballard, 148.

$r$. Northern liank, 316, 345, 357.

Brage $r$. Netter, 469.

Braham $\varepsilon$. Bubb. 7 .

Brailesford $\imath$. Williams, 365.

Braithwate $r$. Garlner, 275.

Braley $v$. Buchaman. 370.

Branel state Bank $r$. MeLeran, 319.

Bray r. Hadwen, 380.

Brennan $r$. Merehants' Bank, 454.

Brent's Exrs. $r$. Bank of Metropolis, 333.

Bresenthal $r$. Williams, 75 .

l3rewster $v$. Sime, 51. v. Williams, 80 .

Bridgeport Bank $r$. Dyer, 268.

Bridges $r$ Berry. 359.

Brigas $r$ Boyd, 249.

$r$. Cent. Nat. Bank, 132.

$\imath$ Merill, 238 .

Brigham r. Potter, 109.

Brill $r$. Tuttle. 14.

Briscoe $v$. Bank of Kentueky, 42.

Bristol $r$. Warner, $i s$.

Britain $r$. Dierker. 429. r. Nieliols, 33 .

British Linen Co. $r$. Drummond, 495.

Bromwiek $v$. Iloyd, 5.

Brooks $r$. Hanover Nat. Bank, 55. $\imath$. Mitehell, 324.

Broughton $r$. M. \& S. Water Works, 143.

Brown, In re. 29.

Brown r. Baker, 127.

v. Bank of Abington. 373 .

$r$. Barry, 346.

$r$ Buteliers, ete.. Bank, 5s.

v. Callowar, 236.

$\imath$. Chancelior. 327 . 
Brown $r$. Dickinson, 187.

$i$. Hull. $17 l$.

i. Jones 431 .

i. Laley, 459 .

i. N1) Bermott, 316.

$t$. Reed. 439 .

$r$ sipetiord, 60.

Browne $\because$ Coit, 308.

Bruce $r$ liptle. 397 .

r. Westcott 436 .

Brush r. lieeves, lis.

Buchanan $r$. Findley, 248 .

Buck r. Smiley. tig.

Buckner $r$. Finley, $i$.

$$
r \text {. Sayre. } 110^{\circ}
$$

Buckston 2 . Junes. 317.

Bulger r. Roche. 495.

Bull $r$. sims. $1+9$.

Burbauk $r$. licach. 35.3.

Burbridge 2 . Nlanners. 45.5. 456.

Burehticld $r$. Noore, 430 .

Burgess r. Forthern lank of Kentucky. 4.24.

r. Vreeland, 379

Burke r. Mekay, $347,348$.

Burleigh $r$. Strott. 482.

Burlingame $x$. Foster, 376.

Burmester $r$. Barron. 376.

Burnes r. Sicott. 60, 111 .

Jimrough, r. Mross, 400.

Burrow $x$. Zapp, inf.

Burrows r. Jemimo, $48 \pi$.

Burton $\%$. Slaughter, 450 .

bush $r$. Balelrey. 4.58.

$x$. Brown, 224.

Busard r. Levering. 330, 375.

Butler $r$. Duval. 370. r. Gambs. 47s.

pyrel $r$. Holloway. 118 .

byom r. Thompson, 436.

Calont lank $r$. Morton. 424.

$$
\text { r. Warmes. } 37 t \text {. }
$$

Caloun r. Moore. 119.

Caldwell r. Cacidy toit.

$r$ Fvans. 13i.

r. Lawrence, 398.

Callom r. Calhoun. iog.

Callahian $r$. Sank of Kentucks, 172, 371.

Cillin $r$. Sterrett. 114.

Cantlen $r$. Doremus, 343 .

Cammor $r$. Jarrison. 411.

Campledl $r$. Alford. 52.

r. French, 327.

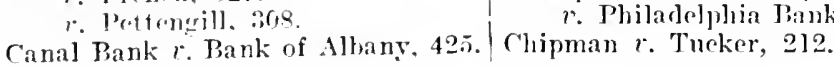

Caulkins r. Whisler, 222.
Cannon $t$. Grigsby, 438.

Capital City Ins. Co. $t$. Quinn, 272 .

Cardwell $i$ Allen, 36 i

Carlton $\imath$. Woods, 109.

Carpenter $r$ MeLaughlin, 481 .

$x$. Murphee, 469 .

$\therefore$ Northboro Nat. Bank, 426 .

Carr $x$. Nat. See liank, 38.

Carroway $i$. Odeneal, 468.

Carruthers $r$. West, 205.

Carson $i$. Russell, 257.

Carter $x$. Burley, 348 .

$v$. Flower, 268 .

v. Union Bank, 376 .

$c$. Whalley, 140 .

r. Zemblin, 4 (i9).

Cartwriglit $r$. Williams, I69.

Cashman $r$. Haymes, Sz.

Castle $v$. Rickley, 196.

Catskill Bank i. Stall. 284.

Caunt r. Thompson, 360.

Caverick $r$. Vickery, 18 .

(alviness $v$. Rushton, 7 (i)

Cayuga County Bank $r$. Bennett, 371.

r. Hunt. 267. 319, 378.

Central Bank $r$. Allen, 393, 397.

Challiss $x$. $11 \mathrm{c}$ Crum, 173 .

Clialmers $r$. Lanion, 201. $v$. McNurdo, 1 ss.

Chamberlin r. White, 468.

Champion $r$. Gordon, 31 .

Chandler $r$. Johnson, 103.

Chanoine $r$. Fowler, 348.

rhapman $r$. Black, 115.

$v$. Keene, 365 .

$r$. Lipscombe, 392 .

$r$. Robinson. 491.

$v$. Rose, 210.

$r$. Wright. 77.

Chappelear $r$. Martin, 454.

Chapple $x$. Durston, 414 .

Charles $v$. Marsden, 205, 216.

Charlton $r$. Reed. $7 ?$.

Clase $r$. Taylor, 355.

Chaters $r$. Bell, 3isl.

Chautauqua County lank $r$. Davis, 314.

Cheek $r$. Roper, 260.

Cheney $r$. Cooper. 221.

Chester Glass Co. $r$. Dewey, 45. $r$ Dorr, 242.

Chick r. Pillshury. 379.

Chicope Bank $r$. Chapin. 236. r. Philadelplia Pank, $71,342$.

hipman $r$. Tucker, 212. 
Chouteau $\imath$. Allen, 232 . r. Webster, 376 .

Christian $r$. Keen, 272.

Christie v. I'earl, 2S6.

Christmas $r$. Russell, 13.

Church v. Clark, 32.2. $r$. Howard, 432.

Citizens' liank r. Lay, 456 .

City of Alrora r. West, 23 .

Cily of Fort Sicott $r$. Schulenberg, 415.

City of Williamsport $\iota$. Commonwealth, 147

Clallin $r$. Briant, 169.

v. Farmers' l3auk, 38.

$v$. Wilson, 185.

Clark $r$. Caldwell, lil.

v. Connor, 49.5.

$v$. Peace. 113.

$r$ Thayer, 248.

Clark Nat. Bauk $v$. Bank of Albion, 38.

Clarke $r$. Pereival, 82. r. Russell, 346 .

$r$ Sigourney, 70.

Clason $r$. Bailey, 58 .

Claxon r. Demaree, 61, 107.

Clay County $r$. Oakley, 368 .

Clayton $r$. Gosling, 415.

Cloveland $r$. Sljerman, 55 .

Clewer $r$. Wrnn, 209.

Cline r. Tenipleton, 112.

Clippinger $r$. Heploungh, 99.

Clode 2 . Bailey, 370.

Clopton $\varkappa$. Elkin, 109.

Closson $v$. Stearns, 58.

Clute $r$. Small, 438.

Coates v. Doran, 40.

Colurn r. Webb, 431.

Cocke $\because$. Dickens, 402.

Corgill $r$. Ameriean Ex. Bank. 278.

Cole $r$. Pennell, 155.

$v$. Withers, 45?.

Coleman થ. Fwing, 410. $r$ Forbes, 48I.

ध. Sayes. 327, 330.

Collins $v$. Gilbert, 200. $r$ Trotter. 321 .

Colorado Nat. Bank $r$. Boetteher. 299.

Commereial Bank $r$. Barksdale, 348. 1 . Gove, 372 .

$r$ King. 379 .

Commereial Nat. Bank $\varkappa$. Proctor, 141.

Commissioners $v$. Chandler, 23 .
Conmmonwalth r. Chander, 4l?.

r. Fostror, +1!).

r. Halas, tis.

r. Johnu-011, 103.

r. Saukey, 4:0.

Compton $r$. Blair, :3st.

Condon r. l'alre, Is3.

Conn r. Coburn, 152.

$r$. Thornton, $7 \mathrm{~s}$.

Connelly $r$. Mrkean, 287.

Conner r. Clark, l:0, 200 .

Conrald r. Fisluer, 5.5.

Continental Nat. Bank $r$. Townsend, 23.5.

r. Wvens, 18.5

Cook $r$. Baldwin, egs.

v. Lillo, 10.5.

$v$. Motfat, 458.

$v$. Satterlee, 89.

$r$. Wolfendale. 308.

Cooke r. Branch liank, 137.

$\imath$. Colehan, 7 s.

$r$ State Nat. liank, 38 .

Cookendorfer $x$. Pl't:-Lon, 328 .

Cooley r. Rose, 41:3.

Coolidge $x$. Payson. 304.

$r$. Ruggles, $7 \pi$.

Cooper $r$. Meyer, 275. 27s.

Coore $r$. Callaway, Zs3.

('ор) r. MeDngall, 172, 391.

Coppunan $\because$. liank of kentueks. 4.5 .5 .

Corbett r. Hughes. 457 .

Cornthwaite $r$. First Nat. Bank. 117.

Cota 1 . Purck. 78

Cotes r. Daris, 166 .

Couch $r$. Neeker, 212.

Cowan i. Halleck, 76 .

Cowee 1:. Cornell. an.

Cowie $\because$. Halsall, 430.

Cowing $r$. Altman, 39. 69.

Cowperthwate $r$. Sheflield. 13, 366.

Cowton r. Wiskersham, 275.

Cox $r$. Coleman. 300.

r. Nat. Paluk. 270, $311,333$.

$r$. Troy. 285 .

Cragin $r$. Lovell. $1 \geq 7$.

Cratigr. State of Missonri. 4.3.

Cramlington r. Evans, tìt.

Crampton r. Perkins. 200 . 246.

Crandall r. Sehroeppel. :3:39.

Crandell r. Vickery. 247.

Cranston r. Gioss. 70 .

Crawford 2 . West Side Bank. 42?.

Crawsluy $r$. Collins, 141. 
Cregler $\because$. Durham, 140 .

Creswell $t$. Lanahan, 146 .

Crim $v$. Starkweather, $\$ 15$.

Cromwell $r$. County of silc, 217 . $\imath$. IIynson, 317,372 .

Crooker $i$. Holmes, 79 .

Crookshank $t$. liose, 115 .

Crosby i. Roub, 180.

Crossin $t$. May, 214.

Crosse $r$ smith, 368.

Crossly $r$. IIam, 245.

Crostliwait $r$. Ross. 137.

Crowley $r$. Barry 319.

Cruger $r$. Armstrong, 29.

Crutchley $i$. Clarenee, 404.

Cumber $r$. Wane, 468.

Cumberland Bank $\imath$. Hall, 433.

Curry $\iota$. Reynolds, 28:.

Curtis $x$. Leavitt, 144.

Cushman $r$. Thayer Mfg. Co., 48 .

Cutts $v$. Perkins, 13, 286 .

Da Costa $r$. Jones, 102.

Daggett $u$. Whiting, 248 .

Dair $\imath$. U. S., 213.

Dakin $r$. Grares, 356.

Dale $v$. Pope, 60.

Daniels $v$. Wilson, 217.

Darbishire v. Parker, 378, 381.

Darey $v$. Jones, 375.

Darwin $v$. Rippey, 432.

Davis r. Allen, 140.

v. liriggs, 399 .

r. Clarke, 282.

$v$. Clemson, 491 .

v. Coleman, 433 .

$v$. Henry, 431.

$r$ Miller, 242. 453, 455, 474 .

r. Smith, 139.

$r$ Thomas, 214.

$r$. Wait. 247 .

Davis Machine Co. $v$. Pest, 251.

Davison $r$. City liank, 457 .

Dean $r$. Newhall, 470. $r$. Richmond, 400 .

Deardorf $r$. Thacher, 137.

Deck $\imath$. Works, 196.

Deener $v$. Brown, 31.

Dehers $x$. IIarriott. $314,327$.

De La Vega $r$. Vianna, 493, 496.

Deminds $r$. Kirkman, 379 .

Demuth r. Cutler, 403.

Dennie $v$. Walker, 412.

Dennistoun $r$. Stewart, 351, 362.

Denny $r$. Dana, 109.

Derg $r$. Abbott, 393.
Desesse $r$. Napier, 12.

Desha $v$. Stewart, 271.

Devendorf $x$. West Virginia O. \& O. L. Co., 100.

Devries $r$. Shumate, 69.

Dewey $r$. Coehran, 477. $\imath$. Reed, 431 .

De Wolf $v$. Johnson, 491.

Dews $v$. Eastham, 411 .

Dexter Sav. liank $r$. Copeland, 113.

Dick $v$. Leverick, 278.

Dicken $v$. Hall, 374,376 .

Dickens $v$. Beal, 355, 387.

Dickerson $v$. Davis, 157. $v$. Turner, 357 .

Dickinson $v$. Dickinson, 140.

Dietz $v$. Harder, 431.

Disher $v$. Disher, 69.

District of Columbia $v$. Cornell, 147 , 245.

Ditehburn $v$. Goldsmith, 102.

Dixon $v$. Nuttall, 327.

Dobbins $v$. Oberman, 16 .

Dodge $r$. Nat. Ex. Bank, 33 .

Dollfus $t$. Froseh, 124.

Donegan $v$. Wood, 326.

Donnell $v$. Sav. Bank, 387.

Donner $v$. Remer, 372.

Doty v. Kinox County Bank, 109.

Doubleday $r$. Kress, 454.

Dougherty $r$. Deeney, 449.

Dow $v$. Updike, 84.

Dowdy $r$. McClellan, 106.

Dowee $r$. Schutt, 214.

Downer $v$. Reed, 214.

Downes $x$. Church, 66.

Downs $v$. Webster, 61 .

Drage $r$. Netter, 470.

Drake $r$. Markle, 27.

$v$. Rogers, 62.

Draper $v$. IIill, 468.

$v$. Jackson, 400.

$v$. Rice, 454 .

$v$. Wood, 434 .

Drayton $v$. Dale, 276 .

Dresser $r$. M. \& 1. R. R. Co., 233 , 247.

Drexler $v$. Smith, 428, 474-

Drovers' Nat. Bank r. Provision ('o. :34).

Dubois $r$. Jason, 190.

Dubreys $v$. Farmer, 328.

Dufour $r$. Oxenden, 301.

Dugan $v$. United States, 314, 453, 454. 
[References are to

Duggan $v$. King, 395.

Duke of Norfolk $v$. Howard, 339.

Dumont $\iota$. P'ope, 356. $v$. Williamson, 173 .

Dunean $r$. McCullough, 397. $v$. Pope, 213.

Dunean \& Sherman $v$. Gilbert, 230, 249.

Dunn v. Ghost, 216. i. Weston, 242 .

Dupays $r$. Shepherd, 284.

Durden $r$. Smith, 383.

Durein v. Moeser, 238.

Durnford $r$. Patterson, 332.

Dutehess County Bank $v$. lbbottson, 355.

Duvall v. Farmers' Bank, 389.

Dwight $v$. Newell, 119.

Dye $r$. Scott, 389 .

Eagle Bank $v$. Chapin, 379 .

Earhart $v$. Gant, 238.

Easeley $v$. Crockford, 228 .

Eason $v$. Isbell, 333.

Eastman $v$. Plumer, 449. $v$. Turman, 368 .

Easton $v$. Hyde, 27.

Eberhart $v$. Page, 193.

Ebersole $i$. Ridding, 455.

Edwards $\imath$. Thomas, 124.

Ehriclss $r$. De Mill, 14.

Eldred $v$. Malloy, 77.

Elford $v$. Teed, 267,322 .

Elias $v$. Finnegan, 237.

Elliott $r$. Nichols, 481.

Ellsworth v. Brewer, 408, 450. $r$. Fogg, 468.

Elminger $\iota$. Drew, 108.

Ely $\iota$. Kilborn, 60.

Emery $v$. Hobson, 388. $i$ Vinall, 70 .

Emmett $v$. Tattenham, 403 .

English $v$. Wall, 257.

Erickson v. Rochm, 214.

Einst v. Steckman, 79.

Erwin $r$. Downs, 319. $r$ Lynn. 183.

Espy $v$. Bank of Cineinnati, 30, 31, 38.

Essex County Nat. Bank $x$. Bank of Montreal, 3i.

Etheridge $r$. Gallagher, 111. $r$. Ladd. 339.

Evans $r$. Anderson, 486.

$r$ Gee. 171,183 .

i. Underwood, 78.
Evansville Nat. Bank $r$. Kaufman, 93.

Everett $v$. Vendryes, 492.

Fairbanks $x$. Snow, 224.

Fairchild $v$. Alams, 402. v. IIolly, 460.

Fairley $v$. Roch, 461.

Hairlie $r$. Herring, 306.

Fall River Union laank $x$. Willard, $265,266$.

Fant $\iota$. Miller, 93, 486, 488.

Fareira $x$. Gabell, 102 .

Farina $v$. Home, 53 .

Faris $t$. Wells, 168.

Farmers' Bank $i$. Allen, 353.

$r$ Bank of Allen County, 36.

i. Duvall, 320, 379.

i. Gunnell, 375, 383 .

v. Reynolds, 478.

Farmers \& Citizens' Nat. Bank $v$. Noxon, 248.

Farmers \& Mechanies' Bank $r$. Butchers, ete., lank, 38.

Farquhar $v$. Southey, $43 \pi$.

Farwell $v$. IIilliard, 407 .

Faulknes $r$. Bailey, 482 . c. liaulkner, 393.

Fay $v$. Smith, 431.

Fenn $v$. Harrison, 179.

Fenno $x$. Gay, 415.

Field $v$. Tibbetts, 243.

Finan $r$. Babcock, 128 .

First Nat. Bank $r$. Bensley, 306.

$v$. Carson, 431 .

v. Clark, 297.

v. Coates, 11 .

v. Day, 470.

$v$. Dubuque S. R. R., 11.

$v$. Gay, 84, 126.

v. Hatch, 265.

v. Hunt, 62 .

v. Johns, 210.

$r$ Leach, 37.

v. Loyhed, 255 .

$v$ Owen, 322.

$x$ Price, 327 .

$r$. Reno County Bank, 185.

$r$ Ryerson. 360 .

v. Whitman, 40.

v. Wood, 374 .

Fisher $r$. Beckwith, 265.

v. Bradford, 406.

$v$. Evans, 372.

v. Fisher. 23fi.

v. Leland, 23 ? 
Fisk $r$. Brackett, 494.

Fiteh $r$. Citizens' Nat. Bank, 367.

i. Hammer, 464.

$i$ Sitton, 468 .

Flagg r. Baldwin, 491.

Flannagan $r$. Brown, 469 .

Flaum $v$. Wallace, 110.

Fleckner $r$. Bank of Unitel States, 146.

Fletcher" $v$ "Thompson, 89.

Flonr City Nat. liank $r$. Traders' Nat. Bank. 36.

Flower $r$ Saller, 111.

Flowers $r$. Billing. 58 .

Floyd Acceptances, 222.

Fogarties $r$. State Bank, 40.

Folger 1 . Chase, 180, 342, 437 .

Follain $r$. Drupre, 377 .

Foot $\because$. Sabin, 138 .

Forbes $v$. Boston \& L. R. R. Co., 52. 1. Cochrane, 485.

๖. Omaha Nat. Bank, 373.

Ford r. Beech, 470.

Forman $\imath$. Wright, 113.

Foss $v$. Nutting, 494.

Foster $v$. Clifford, 310.

Foulke $r$. Fleming, 499.

Fox v. Bank, 244 .

Fraker $r$. Little, 426.

Frank $r$. Irgens, 91 .

$\imath$. Lazier, 426 .

$r$ Quast, 249.

Franklin Bank $r$. Lyneh, 304, 305.

Freeman $v$. Boynton, 259, 264.

Freeman's Bank $v$. Ruckman, 490.

Freese $r$. Brownell, 488, 492.

French $r$. Bank of Colımbia, 387 . $r$. Turner, 179 .

Frick $r$. Moore, 101.

Friend $r$. Wilkinson, 366 .

Frost r. Wood, 1:4.

Fuller r. Green, 437. $r$ Melonald, 389.

Fullerton $r$. Bank of United States, $342,379$.

Fulton ". Longhlin, 135.

$v$. McCracken, 366 .

Gaar $r$. Louisville Banking Co., 84. Gaines $r$. Dorsett, 80 . $r$ Sihelton. 89 .

Gale $r$. Wajsh, 346,347 .

Gallery $v$. Prindle, 308.

Gallway $r$. Matthews, 137.

Gardner $r$. liank of Tennessee, 357. r. Barerer, 79.

$v$. National City Bank, 12.
Garnett $v$. Woodcock, 323.

Garrard $r$. Haddan, 439.

Gates $v$. Beeeher, 259.

Gay $v$. Kingsley, 165.

Gazzam v. Armstrongr, 290, 291, 2!2, 293.

Geill v. Jeremy, 379.

George $r$. Surry, 58.

Georgia Nat. Bank $v$. Henderson, $3 t$.

Geralopulo $r$. Wieler, 463.

Gibbon $v$. Seott, 59.

Gibbs $r$. Howajd, 498.

Gibson v. Carruthers, 51 . $r$. Smith, 306, 309.

Gilbert $r$. Dennis, $339,362,363$. v. Iron Mfg. Co., 46.

Gill $v$. Morris, 114.

Gillespie $v$. Hamnahan, 397.

Gilman $v$. County of Douglas, 458. v. New O. R. R. Co., 250 .

Gimmi $v$. Cullen, 216.

Gist 1 . Lybrand, 373,374 .

Glasseock $r$. Glasscock, 92 .

Glatt $v$. Fortmann, 131.

Glick $v$. Crist, 482 .

Glicksman $v$ Early, 362.

Glossup r. Jacob, 288.

Goddard r. Lyman, 399. r. Merchants' Bank, 451.

Godwin $v$. Crowell, 103.

Goetz $v$. Bank, 111, 273.

Golder $v$. Foss, 405.

Goldman $v$. Blum, 59.

Goldsmid v. Lewis County Bank, 230 .

Goldsmith $v$. Blane, 372.

Good $r$. Elliott, 102. $v$. Martin, 193, 194.

Goorlale $v$. Iloldridge, 103.

Goodall $v$. Polhill, 293.

Goodman $v$. Ilarvey, 228, 245. r. Simonds, 200.

Goodnow v. Warren, 371.

Goodsell $\varkappa$. Myers, 154, 155.

Goodwin $r$. Ameriean Nat. Bank, 34 . $v$. Jones, 494.

r. MeCoy, 310 .

$v$. Nickerson, 61 .

Gordon $v$. Adams, 69.

r. Brown, 472.

$\imath$. Milener, 40.

$r$ Sutlerland. 434 .

Gore $v$. Gibson, 161.

Goudy v. Gillam, 482.

Gough $v$. Findon, 69.

Conld $r$. Roloson, 475. v. Segree, 230 . 
Goupy v. Harden, 269.

Goveruor $r$. Daily, 121.

Gowall $v$. Jackson, 369.

Grafton Bank $r$. Cox, 392.

Cialum $t$. Rolertison, 415. $r$. Sangston, 376 .

Grammel $r$. Carmer, II, 13.

Grant bank $\imath$. Blanchard, 343.

Granite Bank $r$. Ayres, 335.

Grant $r$. Sluaw, 285. $r$. Wood, 77.

Graves $r$. Ameriean Ex. Bank, 451. Gray $r$. Bank of Kentucky, 248. r. Cooper, 153. v. Milner, 282.

Great Lake $r$ lirown, 259.

Glecle r. Parker, 302, 304.

Greeley $\because$ Prople, 23. $r$. Thurston, 410 .

Green $\iota$. Raymond, 309.

Greenough $i$. Smead, 194, 259.

Greensdale $\iota$. Dower, 134.

Gregory $r$. Allen, 389. $r$ L Leigh, 117 .

$v$. Wendell, 102.

Griffin r. Goff, 320 .

Grifhth r. Sitgreaves, ]13, 477.

Grimstead r. Briggs, 438.

Griswold $r$. Davis, 70 . r. Wadington, ]63.

Grosvenor $r$. Stone. 368 .

Grover $v$. Grover, 398.

Grutacap $\Vdash$. Woulloise, 83.

Guidon 2 . Rolsson, 399.

Gunnis 1 . Weigley, 475, 476.

Guthrie 2 . Murpliy, 151.

Gwinmell ^. Herbert, I68, I89.

Haas $r$. Sackett, 169.

Hacker $v$. Brown, 108.

Hadklen r. Rodker, lis.

Haddock $v$. Woods, 87

Haight $r$. Joyee, 22l

Hale r. Houghton.

Ilalifax $r$. Jyle, 275.

Hall $r$ Fuller, 439.

Inallenbach $r$. Dickinson, 481.

IIaly $\varkappa$. Lane, $17 \%$.

Ham r. Smith, 103.

Ianilton $r$. Howper, 43

r. Vouglst, 229.

r. Wilson, 25].

Itammond $r$. Barelay. 286 . r. Dufresue. 3si.

Hamauer $r$. Doane. 109.246.

Handy $r$. Sibley. 236.
Hanessler r. Greene, 204.

Harden $x$. Boyce, 384.

Harding 1 . Ederecumbe, 482.

Harlman $r$. Bollhomse, 468.

Hardy $r$. Waters, 153.3.

$i$. Woodroofe. 333 .

Hare $r$. Henty, 320.

Harker 1 . Anderson, 29.

Harpending r. 1): unicl, 398.

Harper $r$. Butler, 494.

r. West, 2!)8.

r. Young, 221 .

Harris 1 . Brooks, 47 .

r. Clark, 2.59.

$r$ Lewis, 80 .

ฯ. Robiuson, 392.

Harricon $r$. Edwards. $49 \pi$.

r. Nicollet Nat. liank. 34.

v. Richardson. 15i.

r. Robinson, 366 .

$\because$ Ruseoe, 365, 366.

Harsh $r$. Klepper, $4.31,4+1$.

Hart $r$. Clouser, 431 .

$r$. Stevens, 400.

$r$ Stickney, 243.

Hartor $r$. Kervolian, 23.

IIartford liank $r$. [3arry. 3]2.

Hartley $r$. Case, 450 .

$r$ Manton, $469,470$.

$r$ Rice, 103.

r. Wilkinson, 59.

Harvey $x$. Cane, 285.

r. Girard Nat. Bank, 3] I, 340. 450.

i. Martin, 299 .

Hascall $r$. Life Assn. of America, 281.

Haskell $r$. Champiom, 433.

Ilatch $r$. Burroughs, 104.

Haugriton $r$ Ewbank, 125.

Hawkey r. Bolwick, 333.

Haxton r. Bishop, 398.

Hay $r$. Golkmidt, I24.

Haynes $r$. Rudd, 10:3.

Hays $r$. Hathorn, 403.

$r$ N. W. Wamk, 358 .

Hayward r. Bank of England, 341. $r$. French, I36.

Haywod r. Stearns, 204.

Hoilt $r$. Rhodes, 4.7.

Heath 1 . Blake. 427.

Heaton $r$. llyers, laz.

IIodger r. Steavenson, 363.

Ifedley $r$. Bainbridge. 137.

Hetron $\ell$ lIanaforel. 13s.

lletmer $\imath$. Krolick, 227 . 
Hemminway $r$. Stone, 434.

Henry $r$. Jones, 330.

$i$. Sneed, 253, 255.

Herrimon $i$. Shomon, 457.

Hertell $i$. Bogert, 119.

Heurtematte $r$. Morris, 272, 274.

Hevey's Case, 419.

Hewing v, Cargill, 431.

Hickligg $r$. Hardey, 258.

Hilborn $i$. Alford, 58.

Hildeburn $r$. Turner, 354 .

Hill $r$. Ileap, 258.

$v$. Henry, 411 .

$v$. Lewis, 328 .

$v$. Norvell, $330,376$.

$v$. Shields, 202.

Hilton $v$. Shepherd, 365, 385, 395.

Hindlaugh $v$. Blakey, 301 .

Hindley $v$. Marean, 496.

Hine $v$. Allely, 393, 456.

Hinton $r$. Bank of Columbus, 272.

Hoagland v. Erck, 81.

Hoare $v$. Cazenove, 289. $\imath$. Graham, 59.

Hoffman \& Co. $r$. Bank of Milwaukee, $111,273$.

Hofheimer $r$. Losen, 367 .

Holcomb $v$. Wyckoff, 216, 217.

Holden $v$. Cosgrove, 106, I13.

Holdsworth $v$. Hunter, 66 .

Holland $v$. Hatch, 437.

Holmes $v$. Kerrison, 327 .

Holt $r$. Ross, 278.

Holtz $r$. Boppe, 259, 318 .

Home Bank $x$. Drumgoole, 77.

Hook r. Pratt, 185.

Hooper $v$. Keay, 460.

Hoopes $v$. Collingwood, 43!.

Hoover $v$. Kilander, 214.

Hopkinson $x$. Forster, 40.

Horah $v$. Long, 402.

Horn $v$. City Bank, 433.

Hortsman v. Henshaw, 274, 278, $423,424$.

Houck $v$. Graham. 61, 493.

Houghton $v$. Francis, 437.

House $v$. Adams, 383,394 .

Houston \% IBruner, 194

Howard Bank v. Carson, 355.

Howard $r$. Stratton, $i l$.

Howe $v$. Bradley, 401.

$v$. Merrill, 175 .

$v$. Ould, 69.

$v$. Potter, 217.

Howell $v$. Crane, 242.

Howry $r$. Eppinger, 229.
Hoyt $r$. Lynch, 57 .

$v$. Wilkinson, 408.

Hubbard $v$. Chapin, 221. $i$. Matthews, 319, 368, 369.

Hubbly $v$. Brown, 475.

IIuffaker $v$. National Bank, 348 .

Huffmanns $v$. Walker, 449.

Hughes $v$. Fisher, 59, 306.

Hulbert $v$. Douglass, 252.

Hull $v$. Conover, 313.

Hume $v$. Watt, 369 .

Humphrey $v$. Hitt, 478.

Humphreys $r$. Guillow, 434.

Humphreyville $v$. Culver, 398.

Humphries $v$. Nix, 73.

Hunt $v$. Bell, 102.

$v$ Bridgham, 482.

$v$. Johnson, 499.

v. Massey, 155.

v. Maybee, 342.

Hunter $v$. Robertson, 482.

Huntington $v$. Branch Bank, 209.

Huse $v$. Hamblin, 27.

Hussey $v$. Jacob, 292.

Hutchins v. State Bank, 45.

Hutehinson $r$. logg, 113.

$v$. Crane, 399.

Hyde $v$. Goodnow, 488.

Hyslop v. Clark, 109.

$v$. Jones, 374 .

Indiana Nat. Bank $v$. Holtzelaw, 222.

Ingalls $v$. Lee, 171.

Ingham $v$. Dudley, 89.

Ingraham $v$. Gibbs, 65 .

Ingram v. Forster, 287.

Insurance Co. $v$. Wilson, 355, 366.

Ireland $v$. Kip, $372,373$.

Irvin $v$. Villiar, 102.

Irvine $v$. Lowry, 87.

Ivory $v$. Michael, 431.

Jackson $v$. Hudson, 281.

$v$. Love, 312.

v. Newton, 320.

v. Parks, 165 .

$v$. Van Dusen, 157.

Jacob $v$. Hart, 429 .

v. Town, 372 .

James $v$. Wade, 383 .

Jameson r. Swinton, 322, 378, 380 .

Jansen $v$. Thomas, 327.

Jarvis v. Garnett, 334.

$v$. Wilson, 75 . 
[References are to

puragraphs marked $\$$.

Jetlerson County $v$. Railroad Co., 93.

Jemners $v$. Howard, 161.

Jenys $v$. Fawler, 273.

Jeune $v$. Ward, 299.

Jewell $\ell$. Wright, 500.

Johnson $v$. Biank, 451.

v. Bank of United States, 436.

$v$. Berlizheimer, 14l.

$v$. Butler, 231

$v$. Catlin, 402.

$v$. Chadwell, 158 .

$v$. Collings, 303.

r. Frisluie, 83.

$r$. Henderson, 87.

$r$. Meeker, 221.

$v$. Mitehell, 183.

$v$. Thayer, 12.

$v$. Underlill, 46.

Johnson Township $r$. Citizens' Bank, 76.

Johnston $v$ Laflin, 46, 49.

Johnston Harvester Co. $v$. MeLean, 439.

Jones $r$. Dareh, 276 .
t. Fales, $3+3$.
$v$. Fort, 453 .
v. Hook, 495 .
$r$. Jones, 482.
$v$. Lewis, 373.
$v$. Simpson, 82 .

Joseph $v$. Salomon, 367 .

Joslyn $v$. Simitl, 481, 482.

Josselyn $\iota$. Lacier, 81.

Julian $v$. Shorebrook, 308.

Juniata Bank $v$. Hale, 31s, 360, 365.

Kampmann r. Williams, 324.

Kanaga $r$. Taylor, 486 .

Kaufman $r$. Barringer, 298.

Kearney $r$. King, 9.

$i$. WT. Gramada Min. Co., 64.

Feeler $r$. Bartine, 469.

Keenan r. Nash, 281.

Keller $r$. Hicks, 14 ?.

Kelley $r$. Whitney, is6. 243 .

kelloge r. Curtis, 237 . r. French, 254.

Kempner $r$. Corner, 238 .

Kennedy $r$. Geddes. 303.

r. Goodman. 110.

$r$ Knight, 491.

Kenner $r$. Creditors, 332.

Kerriek $v$. Stevens, 403.

Kershaw $r$. Cox, 436.

Feyes r. Fenstermaker, 324. $r$. Maun, Ilt.
Kilgour $v$. Finlayson, 124.

Limbro $1 \%$ linllit, 1:37.

Kincatid $r$. Higrgins, 79 .

King $r$. Baldwin, tis.

r. Crowell, 336, 339.

$v$. Ellor, 75 .

v. Faber, 137 .

v. Fleece, 403 .

v. Gillet, $46 \overline{7}$.

r. llamilton, 88 .

$\therefore$ Holmes, 336 .

$r$ Sarria, 486 .

$v$. Thom, 117 .

Kinney $v$. Ford, 71 .

Kinyon $r$. Wohlford, 207.

Kirk $\iota$. Strickwood, 103.

Kirkman $x$. Benham, 11 $7,118$.

Kirtland $r$. Wanzer, $34 \bar{\tau}$.

Klein $r$. keyes, 110.

Klopfer $r$ Levi, :-74.

Knapp $r$. Mayor of Hoboken, 147.

Knickerboeker Ins. Co. r. Pendleton, 353.

Knight $r$. Ickeynolds, so.

Knill $r$. Willians, 435.

Knisely $r$. Sampson, 62.

Knox Co. $r$. Aspinwall, 23, 129.

Konig $r$. Bayard. 289, 291.

Koont $z r$. Central Nat. Bank, 426 .

Lost $r$. Bender, 112 .

Kountz $r$. Kemedy 443 .

Krampt's Exr. $\bullet$ Hatz: Exr., 195.

Kuenzi r. Elvers, 499.

Kintz r. Tempel, 330.

Laeey $x$. Woolcot, 140.

Lafayette Bank $i$. St. Louis Stoneware Co., 145.

Laflin \& Rand Powder Co. $r$. Sinsheimer, 111.

Lakeshore Nat. Bank $x$. Colliery Co., $125,368$.

Lamar $r$. Brown. 431.

Lambert, Ex parte, 462 .

Lambert $r$. Ghizelin, 392.

Lancaster Co. Nat. lank $r$. Huver, 233.

Laneey $r$. Clark. 4t?.

Landrum r. Trowbidge, 2.56. 257.

Lang $r$. Smyth, bit.

Langenberger $r$. Kroeger. 339.

Langston $r$. Corney, $30 f$.

Langton $r$. Tazaris. 280 .

Lannay $r$. Wilson, 399.

Lanuesa r. Massieot. 334.

Lapriee $r$ Bowman. 106.

Lash r. Edgerton. 459. 
Lathop $r$. Commerial Bamk, 455.

Lalubaluch rersell, 96.

1.ıw $r$ l'anell, 3!s.

Lilwrence $r$. bissett, 4Ss.

i. Dumerlierty, st.

r. lils-ell, is.2.

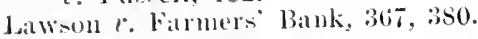
r. Sayter, tis.

Jean r. Luzardi, 6:.

leathers $\because$. Commercial lus. Co., $3 \mathrm{~s} 4$.

Learens: Thompson, 127.

Lealvitt $\tau$. Sintes, 344 .

Lebanon Sar. laank $r$. Penney, 61.

Lee $r$. Solleck, 494, 500.

$r$ Starbird. 431 .

Leftly r. Mills, 312, 351, 410.

1.ergere $r$. Thorpe, 387.

legro $r$. Staplese, 82.

Lefintan $\iota^{\circ}$. Jones. 397 .

Leighton $\ell$. Jowen, 1 I3.

Le Neve $r$. In Neve, 255.

Lenhuim r. Fay, 246.

Lennier 2 Ralston, 9.

Lemox $r$. Cook. $41: ;$.

i. Leverett. 381.

r. Pront. 478 .

r. Roberts, 378 .

Leonard $r$. Mason, 57. r. Phillips. 437 .

Iermed $v$. Johns, $12 \pi$.

Te lioy $r$. Peard, 49ti.

Leslie r. Matsings, 301.

Lester r. Given, 40.

Lewis $r$. [ialewell, 37].

r. Gompert\%, 363 .

v. Jones. flis.

Time liock F. \& II. Ins. Co. v. Hewitt, 82 .

Lincoln \& Kommelsec liank r. Page, 34.3 .

Lindell r. Rokes. 9\%.

Tindrulbererer re liall, 275.

Jind:ev r. Mr.Clallatn, 27.

Lingle r. Corok. 459.

Lionlurerer $r$. Ninealy, 449.

Litrlifirlal biuk $r$. Peck, 238.

Little r. Blunt, 4]5.

r. Phornix Bank. 22.

r. Slackford. 75 .

Tittlorlale r. Maybery. 354.

Tivingaton $r$. Pronswelt, 284.

Cloyd $r$. Jore ] fis.

r. Wrest Branch Bank, 148.

Joan Assn. r. Tripka, 23.

Lorkett's Case. 439.
Lockhart $v$. Ifullinger, 10:2.

Lockwood $r$. Craw ford, 339.

Logan r. Cassell, 403.

lomax $r$. P'icot, 186.

Lomsdale $l$. Brown, 314.

Loring $r$. Halling. 330 .

Louisiana $r$. Wood, 426.

Louisiana ins. Co. $r$. Slamburylı, 397.

Lonisiana State Bank r. Ell'ry, B̈tis. r. Rowell, 373.

Louisville R. R. Co. r. Caldwell, 9l.

Louviere $r$. Laubray, 409.

Lovejoy $r$. Whipple, 70 .

Lovell $r$. Evertson, 399 . $v$. Hill, 76 .

Lovinger $v$. First Nat. Bank, 4:ti.

Low $l$. Argrove, 435.

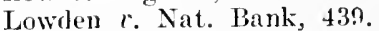

Lowe $r$. Peers, 103.

Lowell $r$. Boston, 23.

Lowenthal $r$. Chappell, 481 .

Lueas $r$. Ladew, 499.

Lunt $r$. Adanns, 323.

Lyman $r$. Goulney, 454.

Lyuch $r$. Reynolds, 476 .

Lynn Nat. Bank $r$. Suith. 370 .

Lyon $r$. Aiken, 469.

Lyons $r$. IJolmes, 58.

Lytle r. Wheeler, 106.

McClellan $r$. Coffin, 86 .

McComick $r$. Littler, 160.

$v$. Trotter, 87.

$v$. Williams, 238.

McCrady $r$. Jones, 481.

MaCramer $r$. Thompson, 432.

Mr.Cullis $\imath$. Bartlett. I60.

NaCurbin $r$. Tmmbull, 430.

MeCurdy r. Bowes, 81 .

Mr.Cutchen r. Rice, 299.

MeDonald $r$. Lee, 332. v. Magrmeler, 408.

MeElvain $r$. Nudd, 106 .

MeEvers $r$. Mason, 302.

MeFarland r. Pir.o, 412.

MeGregor $i$. Bishop, 107.

McEruler $r$. Bank of Washington, $311,340,397$.

MeIntye $r$. Sates, 100.

Mr.Monigal $r$. Brown, 324.

XI.Murchey $r$. Robinson, 329.

ICNamara $v$. Gargett. 109.

Mr.Names $v$. Carpenter. 399.

Nc.Nincli $\tau$. Ramsey, 80 . 
MeVean r. Ścott, 433.

Mcloigh $r$. Pank of Old Dominion, 374.

Maccoum r. Atchafalayia Bank, 356 .

Jace $i$. Kennedy, 246 .

MacGregor $r$. Rihodes, 4:2t.

Mackay $v$. St. Mary s Church, 119.

Maddur $x$. Bevan, 45\%.

Magoun $r$. Walker, 357 .

Magruder $v$. Union lank, 318.

Mahaiwe Bank $r$. Douglasi, 430.

Malıoney $r$. Ashland, 7 .

Matland r. Citizens Nat. Bank, 235.236.

Malden Bank $r$. Baldwin, 338 .

Maltz $v$. Fletcher, 108.

Mammon $r$. Hartman, 193.

Manchester Bank r. Follows, 412.

Manchet $r$. Cason, 437 .

Mandeville $r$. Welclı, 10, 11, 12, 13.

Maniort $r$, Roberts, 404 .

IFanl $r$. King. 122. v. Moors, 376 .

Mamufacturers' Nat. Bank $r$. Newell 232.

Marbourer. Brinkman, 324.

Marr $v$. Johnson, 376 .

Marret r. Equitable Ins. Co., S2.

Marryats $r$. White, 459.

Marsh $\because$ Gold, 137. $r$. Hayford. 405.

Marshall $\because$. B. \& O. R. R. Co., 99. $r$ Clary, 308.

$x$. Gougler, 434 .

Martenclale $r$. Follett, 432, 441.

Martin r. Bacon, 300.

i. Chauntry. 89 .

r. Graginsky, 392 .

$r$. Mayo. 15.5.

r. Morgan, 452 .

r. Juney, 272.

$r$. Wade, 103.

Mason 1 . Barff, 299.

r. Bradley. 433.

r. Franklin. $3 \pm 6$.

$r$. Ilunt, 308.

$\therefore$ Metcalf, 77 .

$r$ Morgan. I65.

$r$ Runisey, 284.

Massachusetts Bank $r$. Oliver. 371.

Massie $r$. Brrd. 415 .

Massman $r$. Holscher, 212.

Maspern $r$. Pedeselaux, 371.

Master r. Miller, 429.

Matthews $r$. Havdon. 316 . r. Foughton, 86 .
Manry $r$ C'oleman, 2014.

May r. Boisscau, 11.5, 400.

r. C'hapmin, "25:.

e. Coflin, 397 .

$r$. Kelly, 28I.

Mayhew $r$. Boyd, 478 .

Meicluer r. Fort, 4:3, 4:4.

Mead $r$. Younge. 182, 419.

Meadow :". Bird, 99.

Mechanices liank $v$. Bank of Coluntbia. l丷o.

r. Tivingston, 285.

Mechanies, etc.. Bank r. Crow, 9s. r. Firmers. etc., Pank, 52.

Meelıanies" Bank. Assn. $i$. Jiace, $37 \%$.

Merlbury r. Watrous, 1.54.

Melick $i$. First Nat, liank, 47i.

Mellish r. Rawdon, -26s.

Mercantile Bauk $r$. MeCarthy, 37.2.

Merchants" Bank 1 . Birch, 371.

v. Elderkin, 342.

v. MeClelland, 237.

r. Spicer, 29, 58.

r. State Bink, 31, 34, 36, 38.

Ierchants' Nat. Bank $r$. Comstock, 113.

$x$ Ritringer, 34 .

Merritt $r$. Duncan, 238.

Mersman $r$. Werges, $42 \pi$.

Mertens $r$. Withington, 461.

Merz r. Kaiser, 314, 372, 404.

Mretealfe 1 . Richardson. 360.

Metzres $\iota$. Waddell, 320.

Mever r. IIaworth, 165.

Mevers r. Standart, 309.

Michigan Bank r. Eldred. 209.

Miehigan Ins. Co. $r$. Leavenworth, 62.

Michigan State Bank $r$. Leavenworth, 305 .

Miers $r$. Brown, 360. 364.

Millard $r$ Barton, 232.

Miller $r$. Austen, 27.

r. Borkin. 234.

1. Butler. 29s.

r. Finley. I6I.

r. Gilliland. 429.

r. Reed, 434.

Milliken r. Brow- 469.

Million $r$. Ohmsberg. 103.

Mills v. Bank of United States, nos. 344. 362.

r. Barber, 113.

1. Davis. 415 .

1י. lowlkes. 4is. 
Mills $r$. Gleason, 23.

$r$. Kuvkentiale, 81.

r. Mills, 99.

Milnes $r$. 1)uncan, 45:

Mineral loint R. R. Co. r. Barron, $495,498$.

Misher $r$. Carpenter, 175.

Mitehell $r$. Baring, 333.

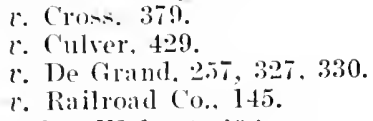

Mitford $r$. Walcott, 296 .

Mobile Sal. Bank $r$, MeDomell, 415.

Motfat $r$. Edwards. 77.

Moge $r$. Herulon, 44:2.

Mograridge $r$. Jones, 108.

Moline, Ex parte, 371, 456.

Molson's biank $r$. lloward, 297.

Nonroe $r$. Fohl 459.

Monson r. Drakeley, 433.

Montagne $r$. Perkins, 285, 310.

Iontgonery County Bank $v$. Albany City Pink, 287.

Montpelier liank $r$. Dixon, 478.

Moorlie $r$. Morrell. 317.

Mcody $r$. Threlkeli, 285.

Noore $r$. Baird, 216.

$r$. Intchinson, 441 .

$r$. Robinson, 214.

Morgan $r$. Cnited States, 21, 203. $239,324$.

Morris $r$. Ilusson, 376. $r$. Norton, 249.

Morrison $\ell$. Bailey, 31. $x$. Buchanan, $2660,287$.

Morse $r$. Chamberlain, 377.

Hortee $r$. Edwards, 80.

Jorton 1 . Naylor, 12, 14. $x$. Ringers. 113.

Moses $i$. MreTerlar, 426.

Mosher $r$. Allen, 405.

Nowat $r$. Brown, 99.

Moxon $r$. Pulling, 179.

Muilman v. D'Egnino, 269, 381.

Muncy Borough School Dist. Commonwealth, 324.

Junn r. Baldwin, 375.

Munro $v$. King, 61.

Murpliy $r$ Keyes, 110.

Murray $c$. Beckwith, 229.

$v$. Lardner, 229.

$v$. Snow, 468 .

Musson $r$. Lake. 339, 35.3, 358.

Mutual Nat. Bank $x$. liotge, 37.
Nailor r. Bowie, 339.

Nance $r$. Lary, 222.

Nash $x$. Fugate, 213.

National Bank $r$. Brewster, 165.

$r$. Caide, 375 .

$r$. Dorset Marble Co., 190.

$r$. Gunhouse, 256.

$r$. Howe, 255.

$r$ Kirby, 243.

v. Kirk, 103.

v. Law, 138.

$r$. Smoot, 488.

$v$. Wells, 145.

National Exch. Bank $v$. Wilder, 55.

National state Bank $r$. Rising, 438.

National State Capital Bank $v$. Noyes, 137.

Nave $r$. Richardson, 316, 353.

Nazro $v$. Fuller, 430.

Neal $r$. Irving. 125.

N. E. Bank $r$. Lewis, 412.

Noff $t$. llorner, 431.

Nefl's Appeal, 478.

Neil $r$. Case, 443.

Nelson $r$. Fotterall, 354, 357. $r$. Mamning, 80 .

Nevada Bank $r$. Luce, 297.

Nevins $r$. Bank of Lansingburgh, 372.

New $r$. Walker, 104.

Newberry r. Detroit, etc., Iron Co., 47.

Neweomb $r$. Raynor, 475, 476.

Newell $r$. Gregg, 243 . v. Mayberry, 440.

New England Mortgage Co. v. Gay, 255.

Newhall r. Central P. R. R. Co., 51.

New Orleans, etc., l'. Montgomery, 241.

New York, etc., Co. v. Selma Sav. Bank, 368.

Niagara Bank $v$. Fairman, 309.

Nichols $x$. Gross, 402. $v$ Nichols, 97. $v$. Webb, 348.

$v$. Nicholson $v$. Sedgwick, 26.

Nicolay v. Fritschle, 403.

Nicolls $v$. Rodgers, 495.

Niglitingale $v$. Withington, 153.

Norris $r$. Badger, 453.

$r$. Despard, 383, 384.

Nortl Pritish Ins. Co. $v$. Lloyd, 477.

North River Bank $v$. Aymar. 123.

Northwestern Coal Co. v. Bowman, $30,34,375$. 
Norvill $v$. Hudgins, 250.

Nott $v$. Beard, 353 .

Oakley $v$. Ooddeen, 253.

Ocean Nat. Bank $v$. Williams, $34 \tau$, 348.

Odd Fellows $v$. First Nat. Bank, 126.

Ogden $v$. Dobbin, 366 .

$v$. Saunders, $174,175,326$.

Ogle $v$. Graham, 4:31.

O'Keefe $r$. Dunn, 203.

Oridge $v$. Sherborne, 321,327 .

Oriental Bank $v$. Blake, 371 .

Ormsbee $v$. Howc, 252.

Orr $v$. Maginnis, 347 .

Ort $i$. Fowler, 210.

Osborn v. Adams Co., 23.

$v$. Bryce, 474 .

v. Nicholson, 106 .

Osnond $v$. Fitzroy, 158.

Otis $v$. Barton, 464 .

Otisfield $v$. Mayberry, 453.

Otsego Co. Bank $r$. Warren, 354 .

Oulds $v$. Harrison. 204.

Outlowaite $v$. Luntley, 429.

Overman $v$. Hoboken City Bank, 287.

Overton $v$. Tyler, 1.

Owen $r$. Hall, 441.

v. Moody. 494.

$v$. Van Uster, 284.

Pacific Bank $r$. Mitchell, 449.

Packwood $v$. Gridley, 254.

Paese $v$. Hirst, $40 \overline{\text { 5. }}$.

Page v. Gilbert, 363.

Paige $v$. Carter, 62.

Palmer $v$. Hummer, 79.

Pardee $r$. Fish, 27.

Parish $r$. Stone, 107.

Park $v$. Nichols, 274 .

Parker $r$. City of Syracuse, 12.

$r$. Gordon, 306. 322, 378.

$r$. Reddiek, 324 .

Parks $x$. Erans, 488.

Parmelee $x$. Williams, 479.

Parr v. Jewell, 205.

Partridge $v$. Bank of England, 32. v. Davis. 179 .

Paton r. Coit. 221.

Patrick r. Beazley, 373.

Patten v. Gleason, 248.

Pitterson $x$. Todd, 17 I. $r$. Wright, 243.

Pattison $v$. Hull, 459.

Payme $r$. Commereial Bank, 478. v. Elliot, 45. l'acock $v$. Purcell, 359

$r$ liliodes, 183.

Pearl v. MeDowell, 160.

Pearsall $t$. Dwight, $485,486$.

Pearson $x$. Garrett, 77.

Pease $v$. Latndaner, 13.

$v$. Warren, 131, 313.

Peasley $v$. Poatwright, 92 .

Peck $v$. Hozier, 496 .

Pendleton $r$. Knickerbocker, 320 .

lenny $v$. Graves, 60.

$v$. Innes, 189.

People $r$. Getehell, 420.

People's Bank $v$. l'rooks, 342, 353.

$v$. Gridley, 48.

$v$. Keech, 369 .

Percival $t$. Frampton, 98.

Perkins $r$. Barstow, 481 .

$v$. Franklin liank, 328, 332 .

$v$. White, 247,391 .

Perring $r$. Hone, 434 .

Perry $\iota$. Barret, 195.

$v$. Harrington, 308 .

Peters $x$. Hoblss, 376.

I'fiel $v$. Vanbatenberg, 453.

Phelps $r$. Stocking. 378 .

Phillips $t$. Astberg, 317.

$v$. Frost, 298 .

$r$. Gould. 360 .

v. McCurdy, 346 .

$r$. Meilly, 61 .

$r$. Paget, 153.

$v$. Plato, 195.

$r$ l'oindexter, 357.

$r$. Thurn, 295.

Philliskirk $r$. lluckwell, 400.

Philpott $v$. Bryant, 257, 318.

Picr $\varepsilon$. Heinrickshoffen, 340 .

Pierec r. Cate, 410.

$v$ Indsetli, 348,490 .

Picrey $r$. Piercy, 434.

Pillow $r$. Hardeman, 371.

Pine $r$. Smith, 244.

Pinkerton $r$. Manchester R. R., 48.

Pinkuey $r$. Hall, 5, 284 .

Pitman $v$. Breckenridge, 358. v. Crawford, S1.

Plain $v$. Roth, 459.

Planters' Bank $\%$ Kesce, 30, 31.

Planters Rice Mill Co. $c$. Merchants' Nat. Bank, 54.

Platt r. Beebe. 9s.

$r$. Jerome, 215.

$r$ Snipes, 110.

Polhill r. Walter. 2st.

Polk $r$. Spinks, 374 . 
Pomeroy $v$, Ainsworth, 490 .

$$
r \text {. 'اamner. 47\%. }
$$

Poorman $\iota$. Mills, 404.

Pope $r$. Huth, 13 .

Porter $r$. Cushman, 313, 454. $r$. l'ittsburer steel Co., 20l.

Potter $r$. Earmest, 60 . $i$. Tyler, lis.

Powell $\varepsilon$. Commonwealth, 418. $r$. Jones, 300.

Power $r$. Matlaway, 495.

Powers 2 . Waters, 248 .

Pratt $\iota$. Parkman, 52.

Prescott 13ank $\because$. Caverly, 166, 269.

Preston $r$. Jackson, 115.

Price $r$. Jones, $7 \mathrm{~s}$.

$\imath$. Keen, 111.

r. Young. $378,390$.

Prins $r$ L Lmmber Co., 251 .

Pulsifer $v$. llotchkiss, 108.

l'urcell r. Allemong, 29.

Purviance $t$. Jones, 69.

Putnam $v$. Sullivan, 209, 220.

Quaker City Bank $r$. Showacre, 488. Quimby r. Nerritt, 86.

Quinn $v$. Tuller, 94.

Raborg $v$. Peyton, 274.

liailroad Co. $r$. County of Otoe, 23. $v$. Howard. 44.

$v$. Nat. Bank, 8.

$r$. Siclutte, 217 .

Rand $v$. Barett, 449 .

$v$. Dovy, 168, 404 .

$v$. Reynolds, 377 .

Raphael $r$. Bink of England. 228.

Rasmussen r. State Nat. Bank, 468.

Ray $v$. Smith, 3!)

r. Tubbs, 151 .

Pavmond $r$. Middleton, 63 .

Read $r$. Bank of lientueky, 348.

$v$. Wilkinson, 306 .

Reamer v. Bell, 182.

Reed $r$. Batrhelder, 15í.

$v$ Poark, 58.

r. Wilion, 322, 328, 330 .

Rees $r$. Conororlheague Bank, 404.

$r$ Warwick. 302.

Pegina $v$. Wilson, 418.

Reid $\varepsilon$. Coats, 25i?.

v. Morrison. 397 .

$r$ Pavne. 375 .

Renner r. Bank of rolumbia, 328.

Rex $r$. Atkinson. 420.

$v$. Hales, 418.
Rex $v$. Ilart, 418.

v. Palmer, 421 .

$v$. Parke, 419.

$i$. Post, 4.20.

$r$. Rogrers, 419 .

$v$. Treble, 420 .

r. Webb, 419 .

Rey $r$. Simpson, 193, 194.

Rhett $v$. Poe, $369,387$.

Rhode $i$. Proctor, $37 \mathrm{l}$.

Rhodes $v$. Lindley, 86 .

Riclıards $v$. Richaids, 400.

Richardson $\varkappa$. Carpenter, 81.

$v$. Ellet, 62.

$\iota$. Lincoln, 70 .

v. Mellish, 103.

$v$. Strong, 160 .

Richmond $v$. Diefendorf, $23 I$.

Ridgely Bank $\iota$. Patton, 28.

Riegel $r$. Cunningham, 242.

Riggin $r$. Collier, 9.

Robb r. Bailey, 399.

Robbins $v$. Eaton, 155 .

Roberts $v$. Austin, 40.

$v$. Bethel, 286, 288.

$v$. Hall, 238 .

i. Hardy, 163 .

v. Mason. 393

$\tau$. Peake, 77.

$v$. Roberts, 103 .

$v$. Smith, 86 .

Robertson $r$ Allen, 177.

Robins $r$. Gibson, 387.

Robinson $v$. Ames, 257, 413.

$v$. Perryman, 433.

$v$. Blanil, 109 .

$v$. Blen, 320 .

$v$. St. Louis, 23.

$r$ Wilkinson, 405.

ध. Yarrow, 277. 278, 279, 451.

Rock County Nat. Bank $v$. Hollister, 403.

Pogers $r$. Blythe, 103.

r. Burlington. 23.

$v$. Hadley, $227,446$.

Rohde, Ex pirte, 397.

Rolin r. Stewart, 41.

Roof $r$. Stafford. 154.

Ross $v$. Bedell, 387.

r. Herd, 389.

Rothsrhild v. Currie, 358.

Roundtree $v$. Baker, 106.

Rowe $r$. Young, 262.

Rowland $r$. Fowler, 251.

Rovee $r$. Nye. 405.

Rubelman $i$. McNichol, 403. 
Rucker r. Wadlington, 118.

Ruddell v. Phalor, 210.

Rull $r$. IVebb, 75.

Rimulel $r$. keelor, 151.

Rustell $l$. Lee, 151.

v. Mhillips, 25s.

Rust $r$. Gott, 102 .

Rutlaud, ete., R. R. Co. $v$. Cole, 402.

Sabine $r$. Bauk of Worcester, 48 .

Sackett $r$. Kellar, 215 .

Saco Nat. Bank $\because$. Sanborn, 376 .

Sacriber $r$. Brown. 348.

Sager $v$. Tupper, 58.

st. Jolnu $v$. Rednuan, 125. $v$. Roberts, 370 .

St. Louis Bank $r$. Altheimer, 369.

Salinas $r$. Wriglıt, 77.

Salishury $v$. Bartleson, 337 .

Salt Siprings Nit. Bank $r$. Burton, 322.

Salter $r$. Burt, 330.

Sanderson $r$. Oikey, 393.

Sands $r$. Sunith, 491 .

Saunderson r. Judge, 342 .

Savage $r$. Merle, 449.

Savings Bank $r$. Shaffer, 441.

Savings Bank of Kansas $v$. Nat. Bank of Commerce. 104.

Sawyer $v$. Wiswell, 112, 114, 201.

Saylor $v$. Busliong, 40 .

Seaife $r$ Byrd, 70 .

Schepp v. Carpenter, 100.

Schimmelpennich $v$. Bayard, 291, 304.

Schmidt $r$. Gates, 481.

schlesinger $v$. Arline, 84.

Srhindel $v$. Schmaelter, 58.

Schneider $r$. Norris, 58.

Schofield $v$. Bayard, 293.

Scholey $r$. Wajsby, 453.

Sehultz. $v$. Ashley, 285.

Seluntt $v$. Evans, 114.

Sehuylkill Comnty r. Copely, 220.

Sehwalm v. McIntre, 432.

Seolluns $r$. Flyn, 102.

Seotland County r. Hill, 201.

Seott $r$. Lefford, 469 .

$r$ Ocean Bank, 132.

Scoville r. Canficld, 493.

Sears $r$. Wright. 79 .

Seaton r. Siovill. $370,380$.

Sebag r. Ahithol. 309.

Second Nat. Bank r. Howe, 95.

Security Rank r. Tuttgen, jl.

Secley $r$. Engell, 107.
Sireley r. Rienel, 17:3.

Seeligson $r$. Lewis, 11 \%.

Seneca County liank $t$. Neass, 33. $37 i$.

Sessions $i$. Moncly, :39s.

Seventl Nat. Bank $r$. (iouk, 41).

Sewanee Mlining l'o. r. Mcelall, l24.

Seymour $v$. Farrell, 19:3.

Siliade r. C'reviston, 410 .

Sliank $r$. lintich, j8.

Sluarpe $t$. Bellis, 128.

Sllaw r. Railroal Co., 51. r. Sipencer, l20.

Slasylor r. Mix, 374.

Sheild $r$. Brett. $319,366,412$.

Shelburue Falls Nat, lank $v$. lownsley, 373, 375, 37\%.

Shelton r. Buathwate, 362.

Slloplievd $r$. Evans, 402 . $r$. Graves, 62 .

Slieply $r$. Waterhomse, 481.

Sherrington $r$. Sates, 400.

Sherwood $r$. Roys, 398.

Shimman $r$. Cook, 359.

Shirley $v$. Howard, 113.

Slloe \& Leather Nat. Bank $r$. Irood. 490.

Shoemaker r. Benerlict. ISI. $\imath$. Mechanies Bank, 374.

Slultz r. Payne, 62.

Shintlowortli 1 . Noyes, 166.

Shutte 1 . Fingal. $4 \dot{7} 6,478,479$.

sibree $r$. Tripp, 468 .

Siebeneck $r$. Anclior Sav. Bank, 47\%.

Sirgerson $r$. Mathews, 389 .

Simon $\varkappa$ Ingham. 460.

Simonton's Estate. 213.

Simons $r$ Morris, 242.

Sims r. Nat. Commereial Bank. 311.

Singleton $r$. Townsend, 481.

Skelton r. Dunston, 322, 353.

Slack r. Kirk, 188.

Sloan r. Macarty. 77.

Sloman $r$. Cox. 441.

Small r. Franklin Mining Co.. 4...

Smalley r. Wright, 37 .

Smedes $r$. l3ank of [tica, 192. ltiti.

Smitl, $r$. Albott. $30 \mathrm{~S}$.

r. Allen, 76 .

r. Bank of Washington, 41.2.

r. Caldwell. 4S.2.

r. Chester. 425, 451.

r. IInnie, 3!?.

r. Innsen, 231.

$r$ Kendall. S3.

r. Lockridge. "̈sl. 
Smith $t$. McClure, 70 .

$r$. MeNair, 424.

r. Marsack, $166,276$.

r. Melton, 284 .

$r$ Nluncie Nat. Bank, 272.

$r$. Nightingale, 82 .

v. Philbrick, 337.

$r$. Sereven, 459.

r. Smith, 437.

$r$ Stranger, 130.

$r$. Whiting. 119, 362 .

Snead $r$. Coleminn, 117, 118.

Solarte $r$. Palmer. 364.

Solser r. Brock. 477.

Sondheim $r$. Gilbert, 221.

Soule $r$. Bonney, 103.

Southeot $r$. Watson, 24.

Spalding $r$. Andrews. 255.

Sparhawk v. Willis, 401.

Spaulding $\ell$. Kelly, 136.

Spear $r$. Pratt, 298. 301.

Speck $\imath$. Pullman Car Co., 239.

Spencer $r$. Harvey, 389.

Sperry $r$. IIorr, $S 4$.

Spiller $r$. Creditors, 459.

Sprigg r. Cuny. 314.

Sproat $r$. Mathews, 306.

spurgeon $r$. McPliceters, 94, 110.

Stafford $r$. Yates, 36.5.

Stainback $r$. Bank of Virginia, 123, 316. 354, 357.

Stanley $r$. Mr.Elrath, 360 .

Stantón $r$. Plossom, 3(i.), 412.

Stanwood $r$. Stanwood, 400.

Staples r. Franklin Jank, 410.

Star Ins. Co. v. Pank, 224.

Stark $v$. Alford, 398, 409.

Starr $v$. Richmond, 459.

Sitate $r$. Cilley, 432 .

r. Crawford, 29.

$v$. Toomis, 55.

$r$ Madison, 23.

$r$. Peck, 213.

$v$. Polk, 433.

v. Taplor, 84.

State Bank $v$. Fearing, 424.

$\because$ Hennen, 372.

r. Mr.Coy, 161 .

State ex rel. v. Osakec Township, 23.

Staunton $v$. R. R. Co., 81.

Stearns $r$. Burnham, 494.

Steele v. Mr.Dowell. 118.

$v$. Mckinlay, 30].

$r$. Sonle, 481 .

Stephens $r$. Monongahela Nat. Bank, 93,248 .
Stephenson $v$. Dickson, 379.

Stevens $v$. Graham, 429, 431, 432 .

Stevenson $x$. Woodhull, 454.

Stewart $v$. Lispenard, 158.

Stivers $r$. Prentice, 317 .

Stoddard $r$. Kimball, 216, 236, 248.

Stokes $v$. Anderson, 71 .

Stone $v$. Peake, 108 . $v$. Seymour, 459.

Strachan $v$. Muxton, 59 .

Straughan $v$. Fairchild, 235.

Strawbridge $v$. Robinson, 9 .

Strol $r$. Hinehman, 125.

Stroud $r$. Marshall, 157.

Studebaker $v$. Man. Co., 253.

Styles $v$. Wardle, 62 .

Sudler $v$. Collins, 430.

Sullivan $v$. Bonesteel, 103. v. Rudisill, 433.

Sultzbacher $v$. Bank of Charleston, 393.

Supervisors $v$. Schenck, 129, 145.

Sussex Bank $t$. Baldwin, 334, 335.

Sutcliffe $v$. NcDowell, 387 .

Sutton $v$. Toomer, 327.

Swan $r$. Steele, 135.

Swansey $v$. Breck, 308.

Swasey $v$. Tanderleyden, 152.

Swayze $v$. Britton, 365.

Sweat $v$. Hall, 400.

Sweet $v$. Swift, 367 .

Swift $v$. Tyson, 8, 98, 100, 111.

Swire $v$. Redman, 479.

Swope $v$. Leffingwell, 449. $v$. Ross, 271.

Taft's Case, 419.

Talbot $v$. Nat. Bank, 452 .

'lannant $r$. liocky Mountain Nat. Bank, 126.

Tardy $v$. Boyd, 384.

Tassel $r$. Cooper, 41.

Tassey $v$. Church, 308.

Tavloe $v$. Sandiforl, 459 .

Taylor $v$. Bank of Illinois, 354 .

v. Croker, 275.

$v$. Newman, 306.

$v$. Thomas, 71 .

Texas Banking Co. $r$. Turnley, 234. $v$. Hardenburg, 203.

Texas Land Co. 1 . Carroll, 12\%.

Thackeray $v$. Blackett, 387.

Thateher $v$. Dinsmore, 120. $r$. West River Nat. Bank, 248.

Thayer $v$. Buffum, 399. 
The Distilled Spirits, 255.

The Julia, 163 .

Thillman $v$. Gueble, 370 .

Third Nat. Batuk r. Lange, 120, 251. $r$. Snyder, 137 .

Thomas $r$. Bank of British North Ameriea, 36.

r. Shoemaker, 329 .

$t$. Thomas, 110.

Thompson $v$, Brown, 460.

v. Flower, 314, 409.

$\imath$. Harrison, 102 .

r. Ketchmm, 321, 480 .

$v$. Samuels, 104.

$x$ Sloan, 88.

$r$. Warren, 106 .

$v$. Wharton, 99.

$v$. Williams, 361 .

$v$. Wilson, 494 .

Thorington $v$. Smith. 105 .

Thornburg $v$. Eimmons, 268.

Thornton $v$. Rankin, 120.

Thrasher $v$. Everhart. 496.

'Throop $v$. Grain Cleaner Co., 14.

Thurman $v$. Van Brunt, 409.

Ticonic Bank $v$. Stackpole, 347.

Tidmarsh $v$. Grover, 430.

Tindal $v$. Brown, 364, 378 .

Todd $r$. Bank of Kentucky, 490. $v$. Wick, 201.

Toledo Iron \& Agr. Works $v$. Heisser, 128.

Tolman $r$. Haurahan. 284.

Tompkins $v$. Woodward, 138.

Tonne $v$. Wasson, 403.

Tooke $v$. Newman, 236.

Tooting $v$. Hubbard, 281.

Torinus r. Buekham, 108.

Torrey $v$. Foss, 387.

Townsend $r$. Dry Goods Co., 336, 364.

v. Lorain Bank, 364.

$v$ Star Wagon Co.. 430.

Township of Burlington $v$. Beasly, 23.

Township of Pine Grove $v$. Talcott, 148.

Townsley $v$. Sumrall, 100, 256, 257, 268,355 .

Trapp $i$. Spearmian, 430.

Treanor $v$. Yingling, 478.

Tredick $x$. Wendell. 339.

Trickey $\imath$. Larne, 108 .

Trimbey $v$. Vigmer, 494.

Troy City Bank r. Lauman, 309.

True $r$. Collins, $37 \pi$.
'Tucker $v$. Randall, 413.

'lurner $v$. Browder, 274.

$v$. Keller, $17 \overline{5}$.

v. Leach, 3 ij, 395.

v. Ross, 451 .

v. Samson, 370 .

I'utt $v$. Thornton, 437.

Twopenny $v$. Young, 470.

Tyree $v$. Lyon, 138.

Tyrell $v$. Cairo, 499.

Tyson $x$. Oliver, 376.

Union Bank $x$. Fowlkes, 353.

r. IIyde, 347 .

$x$. Willis, 319, 369.

Union Nat. Bank $v$. Barber, 200, 406.

$v$. Fraser, 104 .

$\imath$. Marr, Adnir., 384.

$\imath$. Roberts, 436 .

United States $v$. Jiank of Metropolis, $111,310$.

v. Barker, 257, 379.

$v$. Clinton Nat. Bank, 426.

$r$. Dodge Co., 23.

$r$. January. 459.

v. Kirkpatriek, 459 .

v. Linn, 434.

$r$ Nat. Park Bank. 425, 426.

United States Bank $r$. Binney, 136. $r$. Carneal, 322.

['ther $r$. Rich, $2 \mathbf{2 7}$.

Valett $v$. Parker, 104, 221.

Valk $r$. Gaillard, 368.

$r$. Simmons. 387 .

Vancleave $r$. Beach, 472 .

Vandewall $v$. Tyrrell, 461, 463.

Van Duzer $r$ líowe, 280, 439.

Van Eman $x$. Stanchfield, 168.

Van Rensselaer's Exrs. $\imath$. Roberts, 460.

Van Steenburg $r$. Hoffman, 165.

Vanstrmm $r$. Liljengren, 309.

Virnum $r$. Milford, 255.

Vathir $e$. Zane, 113.

Vinton $r$. King, 243.

Violett r. Patton, 93, 209.

Vogle $r$. Ripper, 440.

Vourhees $r$. Atlee, 389.

Vreeland $t$. Blunt, 13.

Wackerbath, E.x parte, 462 .

Wager r. Brooks. 42s.

Wainer $r$. Diedrich. 248 . $r$. Kenner, 329. 
Walker $r$. Bank of New York, 307. $r$. Kimble, 401 .

$r$ Turner, 356 .

Wall $r$. Mlonroe County, $14 \pi$.

Wallace $r$ Ayry, obs. r. Cirilleo, 323.

r. MeConnell, 475.

Walmsley Action, 353. $r$ cooper, 470.

II alter $r$ llilyes, 37 .

Wilters $r$. Brown, 374 .

Walton r. Hastings, 429.

Walwin $r$ st. Quintin, 408.

Walz r. Allack, 193.

Wanger $r$. Tupper. 347.

Ward r. Allen, 280, 298.

r. Churn, 2l3.

r. Doine, 103.

$r$ Smith, 131, 164.

$r$ Vass, 478.

Wardell $r$. Howell. 249.

Warden $r$. Rvan, 428.

Warfllow $r$ List, 438.

Warren $r$ Chapman, 109.

r. Gilman, 367.

$r$. Lynch, 496.

r. Martin, 139.

Warrington $r$. Early, 431.

Warwick r. Hrince, 153.

Waterman $v$. Vose. 431.

Watson $v$. Flanagan, 111.
$r$ IIeasel. 15].
r. Hoag. 2]:5.
r. Loring, 346.
$r$ Tarpley, 256.

Wayland Lniversity r. Boorman: 60 .

Weakly r. Bell. 376.

Weaver $r$. Barden, 24

$r$. Bromley, $39 ?$.

$r$. Carnall, 126 .

Weble r. Fairmance, 327, 410.

$$
r \text {. Nears, } 257 .
$$

Weber r. Orten. 312.

Webster $v$. Swit\%er, 120. $r$ Ray. 127 .

Wegner $r$. Biering, l]4.

Weir $r$. Walmsley, 428.

Weismer $r$. Village of Douglas, 23 .

Vielby r. Drake. 46is.

Weatrib rindo, : 14.

Wells r. Brigham, :3]0. r. Morrison. 468.

Wemple $v$. Dangerfield. 379.

Wescell r. Glenn. 439.

Wrat $r$. Brown. $37 ?$ ?.

II estern Bank $r$. Mills, 113.
Westgate $r$. Healy, 398.

Wharton $r$. Morris, 87.

Wheatley $v$. Strobe, 10,75 .

Wheeler $r$. Field, 392.

v. Guild, 453, 455.

v. Johnson, 406.

$r$. Weloster, 282.

Wheelock $r$. Freeman, 59, 420,440 .

Whidden $r$. Seelye, 499.

Whipple $r$. Stevens, 482 .

Whiteoml, $r$. Whiting, 481 .

White $r$. Continental Nat. Bank, $280,425,426$.

v. Hopkins, 476.

v. Nat. Bank, 185 .

r. Smith, 77 .

v. Stoddard, 315, 366, 395.

Whiteford $r$. Burekmeyer, 406 .

Whitehonse $r$. Hansen, 194.

Whitesirles $r$. Northern Bank, 430 .

Whitewell $\varepsilon$. Johnson, 343 .

Whitmer $r$. Frye, 431 .

Whittier $r$. Havden, 404.

Whitwell $v$. Winslow, 60.

Whitworth $v$. Adams, 95.

Widoe $r$. Webb, 109.

Wiggle $r$. Thomasson, 412.

Wilcox $v$. Routh, 368.

Wilds $r$. Savage. 305.

Vildman, Ex parte, 407.

Wilkinson $r$. Adams, 363.

Williams $r$ Bank of United States, 372.

v. Cheney, 221.

$r$. Drexei, 278 .

$\imath$. Germaine, 294, 296.

v. Hoogewerff, 335.

$r$. James, 40 ?.

$r$.Jones, $407,495$.

$r$. Mathews, 140 .

$v$ Moore, $15 \pi$.

r. Potter. 185.

r. Putnam, 347, 500.

v. Tishomingo Sav. Jnst.. 178.

Williamsen $r$. Ifarrison, 152.

$v$. Watts, 152.

Willis $r$. Green, 259.

Willoughby $r$. Monlton, is.

Wilson $r$. Codman's Exrecutor, 1 se.

$r$ Ellsworth, 110.

$r$ Holmes, 185.

r. Lazier, 221, $4 ! 9$.

$r$ Second Nat. Bank, 25.5.

Wilson Sewing Machine (o. $i$. ipears, 406.

Windham Bank $r$ Norton. 320.355. 
Wintermute $r$. l'ost, 308.

Wisdom $r$. Becker, 117.

Wise 1 . P'rowse, 407.

Wood r. Callagham, 360 .

$r$ corl, :3:s.

r. P'ngh, $290,2911,463$.

$r$. Steele, 4.29 .

Woodhridge $r$ l'sigham, 342.

Woodford $t$. Dorwin, 70 .

Woodhonse $v$. Simmons, 48:2.

Woodman $r$. Churchill. 201. $r$. Thurston, 388.

Woodruff $r$. Hill, 497.

$r$. Merchants lank, 33, 327.

$r$. Momroe, 42.2.

Woods $r$. Armstromg, 104. $v$. North, 84.

Woodthorpe $v$. Lawes. 366.

Woodward r. Row, 256.

Woodworth $v$. Anderson. 431. $r$. Bank of America, 438.

Woonsocket Inst. for Sav. $v$. Ballou, 481.

Worden $v$. Nourse, 366.

Worden $r$. Silter, 19:3.

Workman $r$. Wright, 42.2.

Works $r$. Hershey, 79.

Worth $r$. Case, is.

Wright $r$. Andrew-, $3: 4$.

$r$ L Liling. 4.3!.

$r$ liobin-on \& Co., 464 .

$r$. Travers, st.

Wyatt $r$. Hodnoll. the.

Wyllie $r$. Pollen, -5.5 .5$

Wynne r. Raikes, asti. esti.

Tale $r$. Wood. 9.

Veager $r$. Falwell, 859.

York $r$. Jones, 434.

Young $r$. Bryall. 34 .

v. Durgin. 375.

r. Grote. 280 .

$r$ Harris, 490.

$r$ Lehmian, 280, 426.

$r$ Ward. 400.

Zellner $r$. Cleveland. 120 .

Zinmmerman $l$. Rote, 439. 



\title{
THE ELEMENTS OF THE LAW
}

\author{
or \\ NEGOTIABLE INSTRUMENTS. \\ (xxxiii)
}





\section{ELENENTS OF THE LAW}

OF

\section{NEGOTIABLE INSTRUUIENTS.}

\section{BOOK I.}

THE MAKING OF THE INSTRUMENT.

\section{CHAPTER I.}

\section{NATURE, HISTORY, AND USES OF NEGOTIABLE INSTRU: MENTS.}

\section{SECTION I.}

SATURE, ORIGIX, AND IIISTORY OF BILLS AND NOTES.

\$1. An instrument is called negotiable when the legal title to the instrument itself, and to the whole anount of money expressed upon its face, may be transferred from one to another by indorsement and delivery by the holder, or by delivery only. The peculiarities which attach to negotiable paper are the growth of time, and were acceded for the benefit of trade.

It was a rule of the common law of England, that a chose in action - by which is meant a elaim which the holler would be driven to his action at law to recover-could not be assigned to a stranger, our forefathers conceiving that if claims and debts could be assigned, "pretended titles might 
be granted to great men, whereby right might be trodden down and the weak oppressed, which he common law forbiddeth." 1 The first relaxation of chis rule was made in respect to bills of exchange, and was gradually extended to notes and other securities, until the rule itself disappeared.

But while all choses in action are now transferable, the negotiable instrument is the only species which carries, by transfer, a clear title and a full measure; and like an instrument under seal, imports a consideration. It has, therefore, three peculiar aud distinguishing characteristies:

First. Respecting the title.- If a horse, or other personal chattel, or a nonnegotiable instrument, be stolen, no purchaser, however inmocent or ignorant of the theft, can aequire title against the true owner, who may at any place, and at any time, identify his property and reclaim it. But if a negotiable instrument, payable to bearer, be stolen, and transferred by the thief to a third person in the usual course of business, before maturity and for a valuable consideration, the person so acquiring it may hold it against the world.

Second. Respecting the amount.- If a nonnegotiable note be assigned, the assignee steps into the shoes of the assignor, and if the instrument has been paid, or is subject to any defense or equity against the original maker, they attach to and encumber it into whosesoever hands it may fall. But a negotiable paper earries the right to the whole amount it secures on its face, and is subject to none of the defenses which might have been made between the original or interrening parties, against anyone who aequired it for value, with notice, in the usual course of business and before maturity. It is a circulating credit like the currency of the country, and, hefore maturity, the genuineness and solvency of the parties are alone to be considered in determining its value. It has been fitly termed " a courier without huggage." 2

Third. Respecting the consideration.-By the common law. an instrument under seal imports a consideration, by virtue

1 Coke, Litt. 214a; Chitty on Bills [*7], 9; Edwards on Bills. 55 .

2 Overton v. Tyler, 3 Barr, 346, Gibson, C. J. 
of the solemn ceremony of its execution; and no other nonnegotiable instrument does. A negotiable instrument, however, by the usages of merchants, prima facie imports a oonsideration. As between immediate parties, the true state of the case may be shown, and the presumption of consideration rebutted. But when the instrument has passed to a bona fide holder for value, and before maturity, no want or failure of consideration can be shown.

$\S 2$. Bills of exchange were probably the first instruments for the payment of money that were aecorded a negotiable quality, though promissory notes, being simpler in form, were doubtless used as evidenees of debt before bills of exchange eame in vogue amongst merchants. Certainly these two securities were recognized as negotiable instruments bofore any other paper representatives of moner or property passed currently from hand to hand in liko manner as money; and from them, as fruitful parents, have spring all the varieties of negotiable instruments now known.

\$3. Origin and history of bills.-In respeet to bills of exchange, it is said by Pothier that there is no vestige of them among the Romans, or of any contract of exchange; for though it appears that Cicero direeted one of his friends at Rome, who had mony to receive at Athens, to cause it to be paid to his son at that place, and that friend aceordingly wrote to one of his debtors at $A$ thens, and ordered him to pay a sum of money to Cicero's son, although it is doubtful whether this amounted technieally to a bill of exchange. ${ }^{3}$

Chaneellor Kent finds warrant for the opinion that bills were used among the Greeks, while Story adheres to a contrary riew. ${ }^{4}$

Blackstone sars: "This mothod is said to have been brought into general use by the Jews and Lombards when banished for their usury and other viees, in order the more easily to draw their effects out of France and England into those countries in which they had chosen to reside. But

3 Pothicr de Change, note 6.

43 Kent Comm., Lect. 44; Story on Bills, $\$ 6$, note 4. 
the invention of it was a little earlier; for the Jews were banished out of Guieune in 1287, and out of England in 1290 ; and in 1236 the use of paper credit was introduced into the Mogul Empire in China," 5 There is no eertainty on the subject, though it seems clear foreign bills were in use in the fourteenth century, as appears from a Venetian law of that period; and an inference drawn from the statute 5 Rich. II, stat. 1, chap. 2, warrants the conclusion that foreign bills were introduced into this country previously to the year 1381." " And there is reason to believe that bills of exchange were known in England as early as 1307 , since in that vear King Edward I ordered certain money collected in England for the Pope, not to be remitted to him in coin or bullion, but by way of exchange (per viam Cambii). ${ }^{7}$

$\$ 4$. Origin and history of promissory notes.- Promissory notes have as obseure an origin as bills of exchange. There is no doubt that they were in use among' the Romans, but they seem never to have acquired those negotiable qualities which now import to them their chicf value as instruments of commerce. They were in use upon the continent of Europe before their introduction into England, where they first came in vogue about the middle of the seventeenth eentury, although it has been thought that they have a more recent origin.

It has been a much debated question whether or not the common law of England recognized the negotiability of promissory notes; and most vigorously was the negative adrocated by Lord Holt, who declared that the effort to place them on the same footing as bills of exchange "proceeded from the obstinacy and opinionativeness of the merchants who were endeavoring to set the law of Lombard street above the law of Westminster Hall." This controversy was terminated by the passage of the statute 3 and 4 Aniie, chap. $9[1705]$ (made perpetual by the statute 7 Anne, chap. 25), which made promissory notes "assignable or indorsable over

52 Pl. Comm. 467.

6 Chitty on Bills $\left[{ }^{*} 11\right], 16$.

7 Anderson's History of Commerce, vol. I, 361. 
in the same manner as inland bills of exchange are, or may be according to the custom of merchants."

This statute has been adopted in some of the States of the United States, or in its lien, other statutes prescribing the criteria and conditions of negotiability. By some authorities it is contended that the statute of Anne was only declaratory of their then existing status, while by others the result of Lord IIolt's reasoning is concurred in. ${ }^{8}$

\section{SECTION II.}

\section{FOREIGN AND INLAND BILLS.}

5. Bills of exchange are either foreign or inland,- foreign, when drawn in one State or country, and made payable in another State or country; inland, when drawn, and made payable, in the same State ol comntry. Inland bills are of later origin than foreign bills, not having been in urso in England at a much earlier period than the reign of Charles II. Inland bills, like them, were at first mose restrieted in their operation than at present, for it was deemed essential to their validity that a special custom for the drawing and aceepting them shonld exist between the trows in which the drawer and acceptor lived; or if they lived in the same town, that such a enstom should exist therein. ${ }^{?}$ At first, also, effect was only given to the custom when the parties were merehants, thomgh afterward extenderl, as in the ease of foreign bills, to all persons whether traders ou not. $^{10}$

$\$ 6$. The chief difference between foreign and inland bills is this: that the former must be protested in orter to charge the drawer, while the latter need not be. ${ }^{11}$ But there are other important differenees which will be hereafter considered.

s Caton v. Lenox, 5 Rand. 31: Davis v. Miller, 14 Gratt. 18; First Nat. Bank v. Hunt, 2.5 Mo. App. 170.

9 Pinkney r. Hall, Jd. Raym. 175: Chitty on Bills [*11, 12]. 16.

10 Bromwick v. Iloyd. 2 Lutw. 155:.

11 Daniel on Negotiahle Instruments. \& 926 et seq. 


\section{\$ $\tau$. When bills are deemed foreign in England and in this} country.- In England, a bill drawn in Ireland and payable in England is deemed a foreign bill, ${ }^{12}$ but one drawn and payable in Great Britain is an inland bill. ${ }^{13}$ For the purposes of the law of negotiable instruments, the several States of the Cnited States are foreign to each other. ${ }^{14}$

Thus a bill drawn in New York eity, N. Y., and payable in Chicago, Ill., is a foreign bill, while one drawn in Philadelphia, Pa., and payable in Pittsburg, in the same State, is an inland bill of exchange.

§. Rules of decision of Federal courts.- In the courts of the Inited States, the decisions are sometimes in conformity with those of the State courts of last resort in respect to the liabilities of parties to bills and notes, but not uniformly. Where any controversy arises as to the liability of a party to a bill of exchange, promissory note, or other negotiable paper, in one of the Federal courts of the United States, which is not determined by the positive words of a State statute, or by its meaning as construed by the State courts, the Federal courts will apply to its solution the general prineiples of the law merchant, regardless of any local decision. ${ }^{15}$

\section{The face of the bill does not always disclose its char-} acter. - If the bill does not disclose, on its face, the place. where drawn, the omission may be supplied by evidence, but the court will not take judicial eognizance of political divisions of foreign States, and therefore will not conclude from the fact that a given city is named, that the place named is situated in a certain country or State. For example: it has been held that a bill dated "Dublin," the court, without proof, will not presume was dated at Dublin, Ireland, or that a note dated "Pliladelphia," was made in

12 Mahoney v. Ashlin, 2 B. \& Ad. 478.

13 Amner v. Clark, 2 Cromp., M. \& R. 468.

1+ Buckner v. Finley, 2 Pet. 586; Armstrong v. American Exch. Nat. Bank, 133 U. S. 433.

15 Swift v. Tyson, 16 Pet. 1; Railroad Co. v. Nat. Bank, 102 U. S. 14. 
Pennsylvania, or that a bill ditted "New Orleans," was drawn in Louisiana. ${ }^{16}$

If the instrument, upon its face, purports to be a foreign bill (although actually drawn and payable in the sames country), and innocent third parties take it in the belief that it is what it appears to be, the presumption that it is foreign will be conclusive. ${ }^{17}$ As between the original parties and others haring notice of the circumstances under which it was drawn, the question would be doubtful, although the better view seems to be that it would be even then held to he a foreign bill. ${ }^{18}$

If a bill be on its face an inland lill, the fact that it was actually drawn and delivered in a foreign State will not divest it of its inland character. The principle is that it is competent for the parties to provide, by agreement, that it shall be governed by the laws of any particular State or country. ${ }^{19}$

\section{SEC'TION III.}

TIF EFFECT OF $A$ BILL OF EXCIIAXgE - WILN IT IS AN ASSIGNMEXT, AXD WILX XOT.

$\$ 10$. Bills of exchange and promissory notes have long been exceptions to the rule of the common law that interdicted assignments of things in action. Courts of equity have for many years discredited the common law rule, and held ralid the assignments of a naked possibility, and courts of law, following in the footsteps of equity, now recognize and enforec such assignments brought in the name of the assignor for the bencfit of the assignee. ${ }^{21}$

The effect of the drawing of a bill of cxchange, upon the

16 Kearney v. King, 18 Eng. C. L. 28 ; Yale v. Wood, 30 Tex. 17 ; Riggin v. Collier, 6 Mro. 568.

17 Daniel on Negotiable Instruments, \$ 12; Lennig v. Ralston, $23 \mathrm{~Pa}$. St. 137 .

18 Daniel on Negotiable Instruments, $\&$ I2; Parsons on Notes and Bills, 57.

10 Strawbridge $v$. Robinson, 5 Gilman, 472.

203 Leading Cases in Equity [* 652$], 307$.

21 Mandeville v. Weleh, 5 Wheat. 277; Wheatley $\vee$. Strobo, 12 Cal. 98 . 
rights and interests of the parties in the fund in the hands of the drawee - whether or not it operates as an assignment of the funds - is always a practical, pertinent question.

$\$ 11$. What is the effect, if drawn for the whole amount of the fund in the hands of the drawee.- If the bill is accepted, it is generally held to constitute an assigmment, ${ }^{22}$ but the doctrine that an unaccepted bill for the entire debt or fund operates as an equitable assignment thereof is opposed to the current of anthority in the United States, and in England as well, it being considered, that the bill of exchange is an independent security resting on the commercial responsibility of the parties thereto. ${ }^{23}$ But it is conceded that the bill, whether for the whole of the fund or debt, or only a part, may be evidence to show an assignment; and that with other circumstances indicating that sneh was the intention, will rest in the holder an exclusive claim to the debt or fund, and bind it in the hands of the drawee after notice. ${ }^{2+}$ Very slight circumstances in addition to the bill ought to effectuate an equitable assignment; and while the current of anthority is undoubtedly otherwise, the better opinion, as it seems to $n s$, is that a bill for the entire anount of a debt or fund slould operate as an equitable assignment thereof. The doctrine of equitable assignment is the creature of courts of equity, and the phrase "equitable assignment" is nsed because, by the technicalities of pleadings at law, no legal assignment can be effectuated. ${ }^{25}$

\$12. What is the effect of a nonnegotiable order for the whole of the fund.- It may be regarded as a settled doctrine, that an order founded upon a good consideration, given for a specific debt or fund owing by or in the hands

22 Daniel on Negrotiable Instruments, $\$ 18$; Mandeville v. Welch. 5 Wheat. 277: Buckucr v. Sayre, 17 B. Monroe, 754.

23 Bank of Commerce v. Bogy, 44 No. 15; Gramnel v. Carmer. 5.) Mich. 201.

24 First Nat. Bank r. Dubuque S. R. Co., 52 Iowa, 37s; Bank of Commerce v. Bogy, 44 Mo. 17.

25 Danicl on Negotiable Instruments, $\$ 20$; First Nat. Bank v. Coates, 8 Fed. 540. 
of a third person, operates as, or rather is evidence of, an equitable assignment of the demand to the holder.: It is clearly an assignment, as between the drawer and the payee, beeause so intended. ${ }^{27}$ It is equally so as between them and the drawee, as soon as it is presented to him and he il:sents, ${ }^{28}$ and whether he assents or not, the holder may, in equity, recover the debt or fund from him."

$\$ 13$. What is the effect of a bill of exchange or nonnegotiable order for part of a fund.- The doctrine is laid down with emphasis by many anthorities that an order or a bill drawn for part of a fund loes not operate as an assigmment of that part, or give a lien as against the drawee, unless lic consents to the appropriation by an acceptance of the draft. Mr. Justice Story, delivering the opinion of the United States Supreme Court and speaking of the rights of the debtor", said: "ITe has a right to stand upon the singleness of his original contract, and to decline any legal or equital,l. assignments by which it may be broken into fragments. When he undertakes to pay an integral smm to his creditor, it is no part of his contract that he shall be obliged to pay in fragments to any other persons. So that, if the plaintiff could show a partial assigmment to the extent of the bills, it would not avail him in support of the present suit."

This doctrine is correct in so far als it applies to legal assignments. But it has been held in numerous cases, and. we think, should now be regarded as law, that a nonnegotiable order for part of a fumd operates as an equitable assigmment pro tanto. ${ }^{31}$ Clearly this is the ease when it hat been aceepted or assented to by the drawee. ${ }^{32}$ And when

2f Mandeville v. Weleh, 5 Wheat. 27t; Anderson r. De Soer, 6 Gratt. 364: Parker v. City of Syraeuse, 31 N. Y. 379.

27 Jorton v. Noylar, 1 Hill (X. Y.) 583: Gardner v. Nat. City Baluk. 39 Ohis St. 604 .

28 Johnson v. Thayer, 17 Me. 403: Desesse r. Napier. 1 MeCord, 104i. 2) Story's Eq. Jur.. \$ $10+4$.

30 Nandeville v. Welch, 5 Wheat. 27 : Grammel v. C'armer, jis Mich. 201: Cowperthwaite $v$. Sheffied, I Sandf. 416.

31 Christmas v. Russell, 14 Wall. S4: Pope v. Huth, 14 Call. 40 i.

32 Vreeland r. Blunt, 6 Barb. 182; Cutts v. Perkins, 12 Mas-. 20ti. 
it has not been acepted, our own riew is this: that a nonnegotiable order for part of a fund does operate as an equitable assignment pro tanto as between the drawer and paree, becanse obvionsly so intended. And if the payee or indorsee goes into equity, or the parties are brought therein by any proceeding, so that all of them are before the court, the holder of the order may enforce it as an equitable assignment as against all subsequent claimants, whether by assigmment from the drawer, or by legal process served upon the drawce. ${ }^{33}$

\$14. In New York there have been numerous cases inrolving the questions under consideration, and there the doctrine obtilins that a bill or check payable generally, does not operate as an assigmment of the part of the fund for which it is clrawn, monless assented to by the drawee ${ }^{34}$ but that an order for part of a specified fund then due or to become due operates as an assignment, and that the drawee may be compelled by action to apply the fund as directed, after notice of the assignment. ${ }^{35}$ In that State the rules of practice are such that the same effect is given to the partial order at law as in equity; and hence we do not observe in the decisions of its conrts the distinctions generally taken between legal and equitable assignments. ${ }^{36}$

33 Daniel on Negotiable Instruments, \& 23:3 Leading Cases in Equity, 3.56: Pease v. Landaues. 63 Wis. 20.

34 Attorney-General v. Continental Life Ins. Co., 71 N. Y. 325; Throop Grain Cleaner Co. v. Smith, 110 N. Y. 90.

35 Ehrichs v. De Mill, 75 N. Y. 370 ; Brill v. Tuttle, 81 N. Y. 457. 36 MLrton v. Naylor, 1 Hill, 583. 


\section{CHAPTER II.}

\section{DIFFERENT KINDS OF NEGOTIABLE INSTRUMENTS.}

\section{SEC'TION I.}

DEFINITIONS OF HILLS OF EXCHANGE AXI PROMISSORY NOTES, AND TIE WIFFREXCES BETWEEX TILM.

$\$ 15$. Bills of exchange. $-A$ bill of exchange is an open letter addressed by one person to a second, directing him, in effect, to pay absolutely, and at all crents, a certain sum of noney therein named, to a third person or to any other to whom that third person may order it to be paid; or it may be payable to bearer or to the hrawer himself."

The person who draws is ealled the drawer, the one on whom drawn, the drawee, and to whom payable, the payee.

$\$ 16$. Promissory notes. A promissory note is an opell promise in writing by one person to pay to the order of another therein named, or to bearer, a specified sum of money absolutely and at all events." The person who makes the note is called the maker, and the one to whom the promise is made, the payee.

The term "holder" is a general word applied to anyone in actual or constructive possession of the bill or note, and entitled in law to recover or receive its contents from the partics to it.

$\S 17$. Difference between bills and notes. - In their original structure, a bill of exchange and a promissory note do not strongly resemble each other. In a bill, there are three original parties: drawer, drawee, and payee; in a note only two: maker and payee. In a bill the aceeptor is the primary

1 For various definitions of a bill of exchange and a promissory note, see Daniel on Negotiable Instruments, $\$ 2 \pi$. note.

2 Dobbins v. Oberman. 17 Neb. 165: Daniel nu Nemotiable Instrmments. $\$ 28$. 
debtor. In a note the maker is the only debtor. But if the note be transferred to a third party by the payee, it becomes strikingly similar to a bill. The indorser becomes then, as it were, the drawer; the maker, the acceptor; and the indorsee, the payee. ${ }^{3}$

\section{SECTION II.}

COLPON BONDS.

\$18. Coupon bonds are issued by the Federal Government, by the States, hy territorial governments or local divisions thereof, by mmicipalities, by railroad, canal, and steamboat companies, and all manner of trading corporations. A rast portion of the weath of the country is represented in "compon bonds," and the subject is one of growing importance.

$\$ 19$. Description of coupon bonds.- A coupon bond is anl instrument complete in itself, and yet composed of several distinct instruments, each of which is in itself as complete as the whole together. Is originally issued, the "coupon bond " consists of (1) an obligation to pay a certain amount of money at a future day; and (2) annexer to it is a series of compons, each one of which is a promise for the payment of a periodical instament of interest. The contract between the payor and the holder is contained in the bond, but the coupons are furnished as couvenient instruments to enable the holder to collect interest without presenting the bond, by separating and presenting the proper coupon; and it also enables him to anticipate his interest by negotiating the conjon which represents it, to another person, at any time before its maturity. ${ }^{4}$

\$20. The term " compon" is derived from the French "couper," meaning " to cut," and has been well defined to be "one of the interent certificates attached to transferable bonds, and of which there are usually as many as there are payments to be narle - so called, because it is cut off when

3 Daniel on Negotiable Instruments, $\$ 29$.

4 Daniel on Negotiable Instruments, \$ 1488. 
it is presented for payment. They may be severel and negotiated before maturity of the interest they represent, and thus pass as separate and independent negotialble instruments." Coupons are substantially a minute repetition of what is contained in more elaborite terms in the bond itself. They are more closely as-imilater to promissory notes than to bank notes, bills of exchange, or ehecks, although in their formal wording they may sometimes less resemble them. ${ }^{5}$

$\S 21$. Negotiability of coupon bonds.- Since the seal does not affeet the negotiability of such securities issued by corporations and States, there is no reason why the same principle should not be extended to them when issued by individuals. As a general rule a bond is a sealed instrument, but it does not follow that it always is or must be. While it is usual that sueh instruments are authentieated by a corporate seal, the old idea that States and corporations ean only bind themselves under seal is utterly obsolete.

There no longer remains a shadow of doubt that the coupon bonds of the United States, of the sereral States, and of municipal and other corporations, when expressed in negotiable words, are as negotiable to all intents and purposes as bills of exchange or promissory notes."

\$22. Municipal bonds.-If the bonds are issued by a municipal or public corporation, the purpose must be a publie one. In the United States the following propositions are sustained by the weight of authority:

1. That whenever a municipal corporation has power conferred to contract a debt, borrow money, or issue a negotiable security, it is to be regarded quoad hoc as a private corporation.

2. 'That a municipal corporation has implied power to contract a debt whenever necessary to earry out any power conferred upon it.

\footnotetext{
5 Daniel on Negotiable Instruments, \$s 1489,1490 .

¿ Daniel on Negotiable Instruments, \$ 1500 ; Morgan v. United States. 113 L. S. 491.
} 
14 DFFEREXT KIXID OF NEGOTIABLE INSTRUMENTS. $\$ 2 \ddot{8}$

3. That whencver it may contract a debt, it may borrow money to pay it.

t. Thit whenever it may contract a debt or borrow money, it may issue its negotiable coupon bonds for its payment. $^{7}$

$\S 23$. As to what purposes are public.- The construction aud grading of streets; ${ }^{*}$ the construction of waterworks;" of a brilge $;^{10}$ of a town liall $;^{11}$ gas works $;^{12}$ markets $;^{13}$ the providing of fire engines; ${ }^{14}$ the laying ont of cencteries, ${ }^{15}$ are proper objects of mmicipal care, and undoubtedly the Legislature may authorize the mumicipality to contract with reference to them, to borrow money for the purpose of effecting those objects, and to issue its negotiable securities therefor. ${ }^{10}$ But the loaning of money to enable citizens to rebuild their burned houses, ${ }^{17}$ to equip and fumish manufacturing establishments of individuals, ${ }^{18}$ to construct saw or grist mills ${ }^{19}$ (unless such mills be made public institutions, in which ease it would be different ${ }^{20}$ ), to improve a water privilege and manufacture lumber, ${ }^{21}$ to establish a citizen in business, ${ }^{22}$ to provide destitute eitizens with provisions and grain for seed and feed, ${ }^{23}$ would not be within the scope of public purposes, and the Legislature could confer no authority to subseribe to such objects.

7 Daniel on Negrotiable Instruments, \& $1527 a$.

8 Rogers $v$. Burlington, 3 Wall. 362.

9 Hale v. Ifoughton, 8 Mich. 458.

10 Commissioners v. Chandler, 96 U. S. 205; United States v. Dodge County, 110 U. S. 156.

11 Greeley v. People, 60 11l. 19.

12 City of Aurora v. West, 9 Ind. 74.

13 State v. Marlison, 7 Wis. 688.

14 Robinson v. St. Louis, 28 Mo. 488.

15 Mills v. Gleason, 11 Wis. 470 ; Robinson v. St. Louis, 28 Mo. 488.

161 Dillon on Municipal Corporations, $\& 66$.

17 Lowell v. Boston, 111 Mass. 454.

18 Loan Assn. v. Topeka, 20 Wall. 655.

19 Osborne v. Adams County, 109 U. S. I.

20 Township of Burlington $v$. Beasley, 94 U. S. 314.

21 Weismer v. Village of Donglass, $4 \mathrm{Hun}, 211$.

22 Cooley on Constitutional Limitations, 494.

23 State $e x$ rel. Griffith v. Osawkee Township, 14 Kan. 418. 
Whether or not the construction of a railroar or other highway is a public purpose to which a municipal corperation may be authorized to contribute is a much debated question. The Supreme Court of the Cnited states, in numerous decisions, has aflimed that it is, and so likewise have many of the State courts of last resort.".

\section{SECTION IIT.}

\section{BANK NOTES.}

\$24. Bank notes or bank bills (as they are equally as often called) are the promissory notes of incorporated banks, designed to cireulate like money, and payable to bearer on demand.

The terms "bank notes" and "bank bills" are of the like signification, and for the purposes of interpretation, both in eriminal and eivil jurisprudence, are equivalent and interchangeable.

In form and substance they are promissory notes, and they are govemed by very many of the prineiples which apply to the negotiable notes of individuals given in the course of trade. But they are designed to constitute a circulating medium, and this ciremstance imparts to them peculiar characteristies, and essentially varies the rules which govern promissory notes in general. They have been held not securities for money, but money itself. ${ }^{25}$

$\$ 25$. Chief characteristics of.- Bank bills are (1) always payable on demand; ${ }^{26}$ (2) usually payable to bearer, though sometimes expressed to be payable to a person named or bearer; ${ }^{27}$ (3) a lawful tender in payment of debts, unless objected to because they are not money. ${ }^{28}$

24 Railroad Co. v. County of Otoe, 16 Wall. 667; Harter v. Kernochan, 103 U. S. 568; Knox County v. Aspinwall, 21 How. 539; Daniel on Negotiable Instruments, $\$ 1523$ and eases cited in note.

25 Southeot v. Watson, 3 Atk. 226; Daniel on Negotiable Instruments, \& 1664 .

20 Daniel on Negotiable Instruments, \& 1666.

27 Daniel on Negotiable Instruments, \& 1665.

2s Daniel on Negotiable Instruments, \& 1672a. 
Bank notes are not, legally spealing, money, but in a popular sense are often spoken of as money, and are conventionally used in its stead with the like effect.

\section{SECTION IV.}

\section{CERTIFICATES OF DEPOSIT.}

\$26. Definition. - A certificate of deposit is a receipt of a bank or banker for a certain sum of money received upon deposit, and it is generally framed in such a form as to constitute a promissory note, payable to the depositor, or to the depositor or order, or to bearer.

It appears to have been at an early day the practice of the goldsmiths in England, who generally engaged in the business of banking, to give receipts to their customers for moneys deposited with them, in the form of promissory notes payable to the bearer on demand, or to the depositor or order. ${ }^{30}$ And the statute of Ame placed them, as other promiscory notes, on the same footing as bills of exchange. ${ }^{31}$ Thus originated the instrument now so eommonly used, and called a certifieate of deposit, which is, in short, generally a promissory note for the payment of an amount which it certifies to be deposited in bank.

\$27. Negotiability of.- It was onee questioned whether ol not certificates of deposit are negotiable, but there is now no doubt that they are, where expressed in negotiable words. This view las been adopted by the Supreme Court of the Lnited States. ${ }^{32}$

In order, however, to be negotiable, a eertificate of deposit must possess the requisite features of eertainty in respect to parties, and time and mode of payment; and the same causes which deprive bills and notes of negotiability would affect it in like manner. Thus, if payable "in eur-

29 Danirl on Negrotiable Instruments, \$ 1672 .

30 Nicholson v. Sedgwiek, 1 Ld. Raymond, 180; Chitty on Bills [*522], 591.

313 and 4 Anne, chap. 9.

32 Miller v. Austin. 13 How. 218. 
rency," it would not be negotiable aceorting no the prineiples which preval as to bills and notes;" thongh it lats been lecled oflerewise." so if payable in " Lnited States six per cent. interest-bearing bonds," it is a nere contlatet to deliver such bonds, and not negotiable. ${ }^{35}$

\section{SEC'TION V.}

cll belis.

$\$ 28$. A check is (1) a draft or order (2) upon a bank or banking house, (:3) purporting to be drawn upon al deposit of funds (4) for the payuent at all events of a certain smm of money, (5) to a certain person therein named, or to him or his order, or to bearer, and (6) payable instantly on demand. This definition has been approvingly quoted:a

The Suprene Court of the United States, in the leading case of Merehants Bank r. State Bank, says of cheeks when eontrasted with bills of exchange: "Bank checks are not inland bills of exchange, but have many of the properties of such eommereial paper, and many of the pules of the law merchant are alike applieable to lontli. Each is for a specified sum, payable in money - in both eases, there is a drawer, a drawee, and payee. Withont aceeptance, no action ean be maintained by the holder, upon either, against drawee. The chief points of difference are that (1) a check is always draw on a bank or banker; (2) the drawer is not diseharged by the laches of the holder in presentment, mless he ean show that he has sustained some injury by the default: (t) it is not due until parment is demanded, and the statute of limitations runs only from that time: (5) it is, by its face, the appropriation of so much money of the drawer, in the hands of the drawee, to the parment of an admitted liability of the drawer: (6) it is not neeessary that the drawer of a

33 Iluse r. Hamblin, 29 Iowa, 501: Lindsay v. MeClelland, 15 Wis. 481 .

31 Pardee v. Fish, 60 X. Y. 265: Drake r. Markle, 2l Ind. 433.

sis Easton v. Hyde, 13 Minn. 90.

3f Blair \& Hoge v. Wilson, 28 Gratt. 170; Ridgely Bank v. Patton, 109 111. 484. 
bill should have funds in the hamds of the drawee - a check in such case would be a fraud." 37

529 . (1) A check is a draft or order. $-\Lambda$ bill is also a dratt or order; and it is often said that a check is, in lexal effect, a bill of exelange drawn on a bank or banking honse, with some peculiarities." In some cases it is called a bill paryalite on demand, and in others an inland bill, or in the nature of an inland bill, payable on demand: "and the expression that a check is " like a bill" has been criticized on the gromend that " nithil simile est idem," whereas "ehecks are bills, or rather bill is the genus, and rheck is a species." 41 In form a check is a bill on a banking honse, and it is perfectly correct to say that it is a bill with some peenliarities, or in other words, a species of bill of exchange.

$\$ 30$. (2) It is absolutely necessary that the draft, in order to be a check, should be drawn upon a bank or banker.Upon this point the anthorities are agreed. ${ }^{42}$ A bill may also be drawn upon a banker; and, therefore, while it is neecsary that a check should be so drawn, that alone does not distinguish it. It does not seem neessary that the drawee, when an individual, shonld be deseribed as a banker; and an order addresed simply to "Messrs. A. \& B.," has heen held a eheck, it being proved that they were bankers, ${ }^{43}$ although on sound principle it would seem that the instrument shonld not he so consilered unless its face showed that it: was llawn on a lanking lonse.

\section{\$31. (3) A check purports to be drawn upon a deposit.-} It is frequently said a check is drawn upon a deposit

37 Terchants' Bank r. State Bank, 10 Wall. 647.

38 Pillgerry v. Braud, 19 Gratt. 418; Cruger v. Armstrong, 3 Johns. Cas. is: State r. Crawford, 13 Ta. Anm. 301.

39 Harker v. Inderson. 21 Wend. 372: Edwards on Bills, 396.

sn Merrhants Pank v. Spicer. o Wend. 445; Purcell v. Allemong. 22 Giatt. 742 .

41 Tatter of Bromen. 2 Story, 502.

42 Espy $v$. Bank of Cincinnati, 18 Wall. 620; Bowen v. Newell, 8 X. Y. 195: Nortluwestern Coal Co. v. Powman, 69 Iowa, 152.

4:3 Planters' Bank r. Kesee, 7 Heisk. 200. 
in the banker's hands; and the tact that it is $\rightarrow$ s

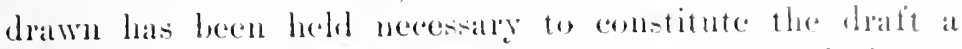
check. $^{\text {ti }}$ but this annot be the true criterion. It is mot the fact that the order is actmally drawn on a depesit, lute the fact that it purports to be so drawn, which comstitules it a eleck; and it is mole aromlate to say that it is mpon jts face a draft upon a deponit." Jo hold otherwi-c womld anthorize the construction of a witten contract be the light of an extrancons faret of which the holder hat no motice. If there were no deposit, it would he a fiandulent reherek-

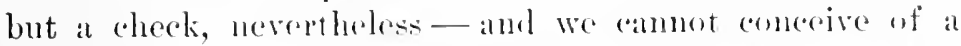
wider departure from principle than to hold that the frand varied the nature of the instrmment itsolf. ${ }^{47}$

In the case of Melehants' Bank r. State Bank, to which reference has alleally been made, a contraly princeiple was announced, but, fol the reasons herein assigucel, the droeision in this partienlar does not seem to he consonant with correct principle.

$\$ 32$. (4) A check must be for the payment at all events of a certain sum of money. In this lesect it does not differ from other negotiable instrmuents: and though, perliaps, it might still be termed a check, although not payable in money, by which is meant the legal tender currency of the comntry, it wonld certainly not be negotiahle if expressed to be parable " in hank hills" or " in cur'eney," ts or if it lacked words of negotiability, or were deticient in any of the characteristics in repect to eertainty in fact and time of payment and party to whom payment is to be made. 50

4t Morrison r. Balley, of Ohio st. I3: Espry r. lank of C'incimnati. Is Wall. 620.

4. Planters" Bank v. Kesre. T Heisk. ?200.

16 Champion $\checkmark$. Fordon, 70 Pa. St. 476 : Deener 8 Brown, 1 MacArthur. 350.

47 Merchants" Bank v. State Bamk, 11 Wall. (it7.

4s Bank of Mobile v. Brumu, 42 Ma. 108: Little v. Phenix Bank, "2 Hill (X. Y.) 425.

49 Partridge r. Bank of Fuglind, 9 Q. P. 396.

50 Daniel on Negotiable Instrmments. 5 soto. 
$\$ 33$. (5) A check is payable to a certain person therein named, or to him or his order, or to bearer.-There is no common law obligation, according to the English anthoritics, upon a bank to pay checks other than those payable to bearer, it being considered that the bank has a right to require that it should not r'm the risk of nistaking the signature of the party to whose order it is payable, and thus becoming responsible in the event of its turning out to he a forgery; and this has led some text writers and judges to declare that a check numst be parable to bearer. ${ }^{52}$ But the custom of banks for years (and it prevails everywhere, certainly in this comtry) is to pay checks drawn payable to order, and as to the law in the Inited States, it has been properly said that the opposite doctrine "is $\mathrm{m}$ supported either by reason or authority." 53

\$34. (6) A check is payable instantly on demand.This is, as we conceive, the touchstone by which a check is tested..$^{5 t}$ Usually, no time of payment is expressed upon its face, but all commercial instruments in which no time of payment is expressed are understood to be, and impliedly are, parable on demand; and when so payable by implication, or in express terms, they are payable instantly, withont the allowance of grace, which pertains to those payable on a particnlar day. ${ }^{55}$ The whole theory and use of a check points to its immediate paybality as its distinguishing feature, and its name imports it. I person deposits money with his bank or hanker, where it is subject at any time to his order. By an order he appropriates so much of it to another person, and the bank or banker, in consideration of its temporary

51 Bellamy v. Majoribanks, 8 Eng. L. \& Eq. 519.

52 Byles on Bills [*13], 84 (Sharswood's ed.) ; Chitty on Bills [*511], 578: Woodruff v. Merchants' Bank, 25 Wend. 672.

53 Dodge v. National Exch. Bank, 30 Ohio St. 8.

54 Harrison v. Nioollet Nat. Bank, 41 Minn. 488: Merehants Nat. Bank v. Ritzinger, 118 111. 486; Georgia Nat. Bank v. Henderson, 46 ('a. 496; Northwestern Coal ('o. v. Bowman, 69 Iowa, 152; Daniel on Negotiable Instruments, \$1572.

55 Daniel on Negotiable Instruments, \& 617; Nerchants' Bank v. State Bank, 10 Wall. 647. 
use of the money, agrees to pay it in whole, or in parmets, to the depositor's order when demanded. ${ }^{515}$ But he does not agree to contract to pay at a future day ly aleceptance, and the depositor cannot require it. It follows that a checek is not entitled to arace." And the preponderance of anthority sustains the view that if the instrment is not immediately payable, it is elassed as a bill of exchange. ix

$\$ 35$. Certification of checks. - The liolder hils no right to demand from the bank anything but parment of the check. And the bank has no right, as against the drawere, to do anything else but pay it. Consequently there is no such thing as acceptanee of ehecks in the ordinary sense of the term. For aceeptance ordinarily implies that the drawer requests the drawee to pay the amomt at a future dar, and the drawee "accepts" to do so, thereby becoming the principal debtor, and the drawer being his surety. But still. by consent of the holder, the bank may enter into an engagement quite similar to that of aceptance, by certifying the eheck to be "goorl" instead of paying it. ${ }^{59}$

§36. Effect of certification.- By certifying a cheek (1) the bank beeomes the principal and onle debtor; (ㅁ) the holder by taking a certitieate of the eheck from the bank, instead of requiring payment, discharges the drawer; and the eheek then circulates as the representative of so much cash in bank, payalble on demand to the lolder. Such in brief is the effeet of the certitiation of a check. It hats been said to be, and obviously is, "equivalent to areeptance" ${ }^{\text {ar }}$ in respect to the obligation it creates upon a bank;

nis Goodwin v. Amerisan Nat. lank, ts Conn. 5.50: Daniel an Negontiable Instruments. \$ $15 \pi 2$.

57 Morse on Banking, 243: 2 Parsons on Notes and Bill- (is, 199; Daniel on Negotiable Intruments. $1.5 \%$.

is Harrison v. Nicollet Nat. Bank, 41 Mimn, 458; Bowen v. Newell. 5 Samlf. (X. Y.) 32ti: Daniel on Xegotiable Instruments, s $150 t$.

59 Daniel on Negrotiable Instruments. \$ 1601.

to Boyd r. Nasmitl, 17 Ont. 42, citing Daniel on Srgotiable Instruments. s 1, 160lu.

Wr Merchants" Bank r. Gatate Bank, 10 Wall. 647. 
but it would be confounding terms to regard it as altogether the same thing in its effect upon the relations of the parties.

The certification by a bank of an acceptance made payable at its connter by one of its customers, has the same effect and imports the same obligation on the part of the bank as the like certification of a eheck draw upon it. ${ }^{62}$ It is a short-liand certificate of deposit.":3

$\$ 37$. Holder taking certified check discharges drawer-The lokler, by taking a certificate of the eheck instead of parment, discharges the drawer. This results from what hats leen already said. If the hank refuses payment, the drawer should be notified. But if the holder receives something else in lien of payment, it is the same as payment; and is the drawer camnot lecally withdraw the funds after checking on them, it would be imjust that they should be hele at his risk or his liability on the eheek extended. ${ }^{64}$ The indorser of a check who is a new drawer would also ordinarily be discharged if the holkle had it certified instead of requiring payment; but if the indorser request or eonsent to the certification, this rule would not apply; ${ }^{65}$ and if tho holder of a certified cheek indorse it, his indorsee mas hold him liable as well as the bank. ${ }^{66}$

$\$ 38$. Form of certification, and by whom made.- No particular words are esecntial to a legal certification of a cheek — it is usnal to use the word "good" 6 - it is sufficient if the names or initials of the proper officer is written on, or across, the face of the cheek. "is In England, by statute, a distinct promise, written and signed, is requisite. In the Tnited States, some authorities hold that a verbal statement

G2 Flour City Nat. Bank r. Traders' Nat. Bank, 42 Hum, 244.

63 Thrmas v. Pank of Pritish North America, 82 N. Y. 1; Farmers' Bank v. Bank of Allen County (Temn.), 12 S. IV. 54.5.

64 First Nat. Bank v. Lach, 52 X. Y. 350: Morse on Banking, 382;

Essex County Nat. Pank v. Bank of Montreal, 7 Biss. 197.

fis Mutual Nat. Bank v. Rotge, 28 La. Ann. 933.

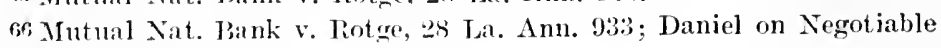
Instruments, \& 1604 .

6i Tarnet r. Simith. 10 Fost. 256.

68 Morse on. Banking. 294. 
(if communieated) that the check is good is tantamount to certifieation, ${ }^{69}$ while the Suprene ('ourt of the Linited States announces the proposition that such rerbal eertitication, even when commmicated, would not bind the bank further than as to the genuineness of the drawer's signature and the state of his account. ${ }^{\text {io }}$ 'The alshier has implied anthority to cortify cheeks, and likewise the board of directors, or any other officer specifically authorized. ${ }^{i 1}$

\$39. Stale checks. $-\perp$ check is payable instantly on demand; and should be presented within a day when the pasee receives it in the place where drawn, and forwarded by the next day, when forwarding is necessary, in order to preserve the payee's recourse against the drawer, in the event of a failure of the bank. ${ }^{2}$ But if the bank remains solvent the holder may retain the check as long as he pleases, and lold the drawer liable mutil the time for suit is ended by the statute of limitations. ${ }^{73}$ But while age camot invalidate a good cheek (mless the linitation has applied), and the fact that it was dishonored when transfered, and that presentment was delaved, does not lessen the drawer's liability ${ }^{7 t}$ muless he has suffered loss; ${ }^{75}$ yet the lapse of a long period from its date before its parment, is a cireumstanee so out of the orlinary course of husiness that it ought to arouse suspicions and excite inquiry. And the bank paying, or the party receiving such a check, acts at his peril. ${ }^{\text {ie }}$

$\$ 40$. Right of holder of uncertified check to sue bank.This is an msettled question, hut the weight of authority

(a) Bank v. Pettel, 41 Ill. 492: Carr v. National Secy. Bank, 107 Mass. 48.

io Espy v. Bank of Cincinnati, Is Wall. 62l.

71 Xicrehants' Bank r. State Pank, 10 Wall. 648; Claflin v. Farmers Bank, 25 N. Y. 293: ('larke Nat. Bank r. Bank of Albion, 52 Barb, 592; Cooke v. State Yat. Pank, 52 X. Y. 115: Farmers \& Mechanics' lank $v$ liutehers, ete., Bank, $14 \mathrm{~N}$. Y. 624; Dituicl on Negotiable Instrument: $\$ \$ 1609-1611$.

T2 1) nniel nu Negotiable Instruments, \$ 1590 et seq.

73 Thompson on 13ills, 118: Daniel on Negotiable Instruments. \$ 163:.

it Cowing v. Altman, 79 N. Y. 168.

ir Daniel on Negotial, ]e Instruments, ş 1590.

i: Danicl on Negotiable Instruments, \& 1632. 
in this country and in England supports the riew that such suit cannot be maintained. The courts of last resort in South Carolina, Louisiana, Illinois, Missouri, and Kentucky, and possibly other States, in well considered eases adhere to the view that the check holder ean maintain such a suit, ${ }^{77}$ while the courts of very many States have taken the contrary view. 'The Supreme Court of the United States has, in a number of deeisions, adopted the latter, but it has qualified its opinion by remarking: "It may be if it could be shown that the bank had charged the check on its books against the drawer and settled with him on that hasis, that the plaintiff eonld recover on the count for money had and received, on the ground that the rule ex aequo et bono would be applicable, as the bank having assented to the order, and communicated its assent to the paymaster (the drawer), would be considered as holding the money to the plaintiff's use; and therefore under an implied promise to pay it on demand." is And in Pennsylrania the exception thus suggested is established. ${ }^{79}$ The general doetrine, as announced by the Cuited States Supreme Court, is supported hy the English cases. ${ }^{\text {so }}$

§41. Damages for improper dishonor of check.- Of course the check holder may sue the drawer of the eheek on its dishonor. The depositor may always recover nominal damages from the bank improperly dishonoring his eheek, and a trader may recover substantial damages. If not a trader, the depositor would have to allege and prove speeial injury. ${ }^{81}$ An agent who has put to his private aceount funds

it Fogarties v. State Bank, 12 Rich. Law (S. C.), 518; Gordon v. Mulcher, 34 La. Ann. 60s; Bank of Ameriea v. Indiana Bkg. Co., $11+$ Ill. 483; Rolerts v. Austin, 26 Jowa, 316; Coates v. Doran, 83 Mo. 337 ; Lester v. Given, 8 Bush. 358.

78 Bank of Republic v. Millard, 10 Wall. 152; First Nat. Bank v. Whitman, 94 T. S. 343 .

79 Seventh Nat. Bank v. C'ook, 73 Pa. St. 485: Saylor v. Bushong, 100 Pa. St. 23.

so Hopkinson v. Forster, 18 Fq. ('is. T. R. 74. For full disenssion of the cases fro and con, see laniel on Negotiable Instruments, \& 1635 et ser.

81 Rolin v. Stewart, 14 C. P. 607. 
of an undisclosed principal, may recover damages from the bank for refusal to honor his check upon them, although he had improperly obtained them.

\section{SECTION VI.}

BILLS OF CREDIT.

$\S 42$. The tenth section of the first article of the constitution of the United States contains certain prohibitions and restrictions upon the power of the States; and the first clauso of the section reads as follows: "No State shall enter into any treaty, alliance, or confederation; grant letters of marque and reprisal; coin money, wat 131LLs of CREDrT; make anything but gold and silver coin a tender in payment of debts; pass any bill of attainder, ex post facto law, or law inpairing the obligation of contracts." But the inlibition contained in that instrmment is linited to the States; and although the bill may be designed to cirenlate as currency, if it be not enitted by a State, it is as free from impeachment, as in violation of the constitution, as any other negotiable paper. I State may therefore grant acts of incorporation anthorizing banks or other associations to issue that description of paper to answer the purposes of money, and it may be issued by private persons and partnerships. This was detemined by the United States Supreme Court in a case involving an act of the Lecrislature of Kentucky, which incorporated the "Bank of the Commonwealth of Kentncky," in behalf of the conmonwealth, the president and directors of which were chosen by the Legislature. ${ }^{83}$

\$43. Definition and nature. $-A$ bill of credit is a negotialle paper designed to pass as eurreney and eireulate as moner: Such a bill of eredit as comes within the constitutional prohibition is a negotiahle paper issued by the sor-

s2 Tassell $\checkmark$. Cooper, 9 C. B. 509: Daniel on Negotiable Instruments, $\$ 1642$.

s3 Briscoe $v$. Bank of Kentucky, 11 Pet. 433. 
eneign power of one of the United States, and designed to palss as currency and cireulate as money.

The nature of this elass of negotiable instruments, and the object and spirit of the constitutional restriction, first received a judicial exposition in the case of Craig v. State of Missonri. ${ }^{s+}$ In that case it appeared that the State of Missonir, with a riew to relieve the necessities of the times, established loan offices to loan eertain sums to citizens, taking security by mortgage redeemable in instalments.

\section{SECTION VIT.}

\section{QUASI-NEGOTIABLE INSTRUMENTS.}

$\S 44$. The phrase quasi-negotiable has been termed an unhappy one; and certainly it is far from satisfactory, as it convers no accurate, well-defined meaning. But still it deseribes better than any other short-hand expression the nature of those instruments which, while not negotiabie in the sense of the law merchant, are so framed and so dealt with, as frequently to convey as good a title to the transferee as if they were negotiable.

Tery frequently by application of the principles of estoppel, and to effectuate the ends of justice and the intention of the parties, the courts decree a better title to the transferee than actually existed in his transferrer; and the result reached in many cases is the same as would be reached if the instrument were negotiable. ${ }^{55}$

$\$$ 45. Nature of certificates of stock.- A share in the capital stock of a corporation is not a debt, nor money, nor a security for money, but it is a species of ineorporeal personal property. The capital stoek of the corporation is so much money, or property assessed at money valuation, which is divider into a number of shares, which shares are the holder's interest in the corporate estate. The stock of the corporation is generally raised by mutual subseription of

s4 Craig v. State of Missouri, 4 Pet. 411.

85 Railroad Co. v. Howard. 7 Wall. 415.

86 Allen v. Pegram, It lowa, 173. 
the members in the first instance, and its amonnt is renulated by the statutory provisions by or moler which the corporation is chatered. The persons interested in the cor-

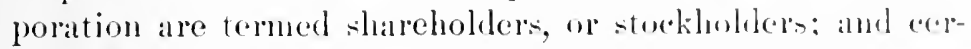

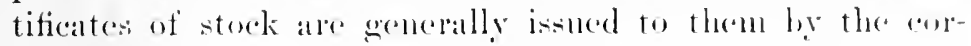
porate anthorities of the mumiments of their title to a por portionate part of the protits of the corporatione and as evidence of their right to participate in its concerns. I nuless otherwise provided ly statute, the slanes in the corporation are generally deemed personal estate.

The certificate of storek is the costomary and convenient evidence of the holder's interest in the corporation which issues it, but in the alsence of legal provisions requiring it, no certificate of stock is necessary to attest the rights of the shareholder. ${ }^{88}$

$\S 46$. Transfer of certificates of stock. - Is between transferrer and transferee of a stock certificate, - It is rery well settled that, in the absence of statutory restrictions, the beneficial interest passes by assigment, and delivery of the certificate, as in the case of any other species of personal property, or chose in action, no particular formality being necessary to invest the transferee with the right and title of the transferrer, as between the parties to the transfer. ${ }^{\text {s9 }}$ The equitable title passes as between the immediate parties, whatever may he the rights of others in the premises. $^{90}$ And, as a gencral rule, statutory restrictions do not affect the immediate parties to the transfer, being designed for other purposes.

\section{\$ 47. As between transferee of certificate and creditor of} transferrer.- It would secm that any bona fide casigmment of the stock for value would effectually pass the transfer-

si Hutehins v. State Bank, 12 Mete. (Masi,) 421: Payne v. Eliott. 54 Cal. 339: Daniel on Negotiable Inatruments. \$ liosn.

8s Chester Glass Co. $v$. Dewey. 16 Mass. 94: Agrieultural Bank v. Burr, 24 Me. 2.56.

89 Daniel on Negotiable Instruments, \$ 1708b.

9o.Johnson v. Underhill, i2 X. Y. 203; Jolunston v. Laflin, 103 U. S. 804: Gilbert v. Iron Mfg. Co.. 11 Wend. 628. 
rer's interest therein, so far as to supersede the right of an attachment or exeeution ereditor to levy upon it for a debt due by the transferrer. For whether such assignment rest the legal or equitalle interest of the assignor in the assignee, no property right of the assignor remains that is sulject to legal process; and the provisions of eorporate charter's that no transter of stock shall be valid or effectual until entered or registered upon the books of the corporation, are manifestly designed for the security of the corporation itself, and of third persons taking transfers of stock without notice of any prior equitable transfer, and are not male with reference to the rights of creditors of a stockholder. ${ }^{91}$ This is in aceordance with the general principles applicalble to all mamer of equitable assignments of personal property.

$\$ 48$. As between the transferee of a certificate of $s t c 3 k$, and a third party who has purchased the shares, the better opinion is that a bona fide transfer of the certificate carries with it the transferrer's interest in the stock, and that a subsequent purehaser who simply relies on the books of the corporation for information as to who are stockholders, and who buys the shares without taking the certificate, does so at his peril. The certificate is the mmiment of title. It is generally dealt with as the representative of the proportionate interest it assures; and if not in possession of the party offering to sell the shares, a purchaser would be put upon inquiry to ascertain the true conclition of things. And on the other hand, a purchaser of the certificate from one whom it testifies to be a shareholder, would have a right to suppose that no one would have bought the shares without taking the customary evidence of title. ${ }^{92}$ If the corporation should actually transfer the shares upon its books to a subsequent purchaser without surrender of the certificate, it would act wongfully and would be bound to

91 Black v. Zacharie, 3 How. 483: Newberry v. Detroit Iron Co., 17 Mich. 141; Daniel on Negotiable Instruments, \& 1708e.

92 People's Bank v. Gridley. 91 Ill. 457 ; Sabin v. Bank of Worcester, 21 Me. 353; Pinkerton v. Manchester R. Co., 42 N. H. 424. 
issue certificates to the prior purchaser, who hat arequired the stock by transfer of the certificate in due (o) 1 rese.

$\$ 49$. Usual methods of transfer of stock. Un the lack of tho certiticates there is gencrally a printed form of sale and assignment, with an incrocable jower of attorney in blank, anthorizing the numaned person to do all things: requisite to jerfect the transfer on the books of the corporation. When such tormal assignment, and power of attolney in blank, is signed ly the shatreholder, and the certitieate is delivered therewith, an apparent ownership in the shates represented is created in the holder. And the gereral prinriple sustained ly the great weight of authority, as well as of reason, is that when the owner of a certiticate of stock with such a power of attomey in blank theroon written, or therenuto attached, intrusts it to an agent with power to deal therewith, a bone fide purehaser for ralue without notice will be protected in his acepuisition of the certifieate, although the agent to whom it has bern intrusted has diverted it from the pmposes for which it was put in his charge, or has heen guilty of a fraud or breach of trust in reference thereto. This doctrine does not rest upon the idea that the certificate of stoek is a negotiable instrument; but upon the equitahle prineiple that where a person confers upon another all the indicia of ownership of property, with comprehensive and apparently unlimited powers in reference thereto, he is estopped to assert title as against a third person, who, acting in good faith, aceures it for value from the alplarent owner. ${ }^{94}$

$\$ 50$. Bills of lading, their nature. - I bill of lading may be defined to be a witten acknowledgment by the master of a ship, or the representative of any common carricr, that he has received the goods therein described for the vovage or journey stated, to he carried upon the torns and delivered to the persons therein specitied. It is at once a

93 Cushman v. Thaver Mfo. Co., if X. Y. 206: Daniel on Negotiable Instruments, $\$ 1708 f$.

a4.Tohnston v. Laflin. 103 C. S. sno, and eases eited in note to Daniel on Negotiable Instrument $s$, $1708 g$. 
receipt for the goods which renders the carrier responsible as their custodian, and an express written contract for their transportation and delivery. And to facilitate commercial transactions. it hat grown to be regarded as the symbolical representative of the goods which it describes; and its trans. fer calries with it such rights as the party in possession of the good could transmit by actual corporeal transfer of the goods themselves. ${ }^{95}$

$\$ 51$. Analogous to negotiable instruments.- The idea that bills of larling are negotiable arose from the nse to which ther were appropriated in the transfer of goods purchased, before they were delivered to the purchaser, or before they were paid for: but it will be seen that their peculiar properties are attributable rather to a liberal application of the doctrine of equitable estoppel for the benefit of trade, than to any eustom or statute which placed them upon the footing of negotiable instruments, ${ }^{95}$ for both of these sources of negotialility are wanting. The consignor of goods shipped takes from the master of the ship a bill of lading, and sending it to the consignce who has ordered the goods, draws upon him by bill of exchange for the purchase money. Before the groods reach their destination the consignor, who in the case instanced is the vendor of the goods, learns that the vendee is insolvent; and to prevent the injustice which would be done, if, in consequence of the rentee's insolvency, and while the price is ret umpaid, they were to be seized upon in satisfaction of his liabilities, the law confers upon the vendor the riglit to stop the goods in transilu, and to retain them until the whole purchase moner is paid. ${ }^{9 \pi}$

But suppose the consignee has received the bill of lading of the goods, deliverable to him or his assigns, or indorsed to him or his ascigns, by the consignor, and has assigned the lill by indorsement to a bona fide third party, then the vendor's right to stop the goods in transitu and hold them as security for the purchase money is defeated, and the as-

95 Daniel on Negotiable Instruments, \$ 1728.

mi Seeurity Bark r. Luttgen, 29 Minn. 366.

stribson r. Carruther. S II. \& W. 336. 
signee of the bill ancpuires as perfeet a tithe to the geonth. although they have nut reached the hurer's hamels, as if they had atetually pased thromgh his hamds ame heen delivereed bodily to him. This was decided in the bealing aber

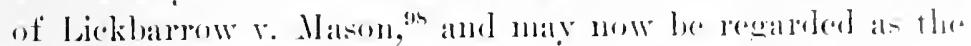
settled law of England and of thre Inited States:" but this captacity of the hill of lanling for transferring the riglat of property, moler these ciremustances, does mot imply that it is a negotiable instrument to all intents and purposes. The assignee of the bill of lading is protected hereatuse the rendor of the goods has placed in the hands of his assignos. a muniment of title, (dothing him with alparent ownership) of the goods, and it is inequitalle that a secret trust shombl be enforeed in favor of the ventor, who has irmed such muniment of title against a person who has taken an assignment of it for valuable consideration, and without notice of such circumstances as render it not fairly and honestly assignable.

52. Transfer of bill of lading.- Thus the bill of lading passes the property, when it is indorsed and intented on to operate, in the same manner as a direct delivery of the poods would do if so intended, and it operates no further. It constitutes a symbolic and constructive delivery of the goods," being the proper sulstitute for the actual delivery of goods at the time at sea en route to the consignee, and the arrival and delivery of which the consignor has placed it in his power by the lill of lading to anticipate. ${ }^{3}$

Delivery of the bill without indorement, has been held snfficient to pass the title where the person to whom it was

191 Smitlis Lead. Cas. S95.

49 Newhall r. Central P. R. (co. il ('il. 345: Daniel on Negrotiable Instruments. \$ 1729.

1 Shaw v. Railroad Co., 101 C. S. 56t: Brewster v. Sime, 42 Cal. 1:31.

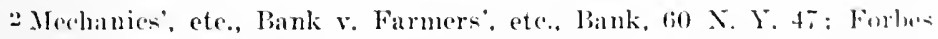
r. Boston \& Lowell R. Co., 133 Mass. 154; Daniel on Negotiable In-truments, \$ 1731 .

: Pratt r. Parkman, 24 Pick. 42. 
delivered, was recognized upon the face of the bill, as the person entitled to the ultimate possession of the goods. ${ }^{+}$

$\$ 53$. Warehouse, or dock, receipts. - This species of contracts is, independent of statnte law, of modem invention, and does not rest like bills of lading upon ancient mercantile custom imprarting to them a quasi-negotiability. "These docments," says Blackburn, J., "are generally written contralets, by which the lolder of the indorsed doemment is rendered the person to whom the holder of the goods is to deliver them, and in so far they greatly resemble bills of lading; but they differ from them in this respeet, that when goods are at eal, the purchaser who takes the bill of lading has done all that is possible in order to take possession of the goods, as there is a physical obstacle to his seeking out the master of the ship, and requiring him to attorn to his rights; but when the goods are on land, there is no reason why the person who receives a delivery order, or dock warrant, should not at onee lodge it with the bailee, and so take actual or constructive possession of the goods. There is, therefore, a very sufficient reason why the custom of merehants shonld make the transfer of the bill of lading equiralent to an aetual delivery of possession, and yet not give such an effect to the transfer of doeuments of title to goods on shore. ${ }^{5}$

$\$$ 54. Their nature.- Warehouse receipts, pure and simple, with only the incidents annexed to them by law, and none superadded by special contract, conduct, or representation, are no more obligatory in the hands of bona ficle holders for value, than in the hands of the bailor of the property stored; hut, if warehonse receipts of a special form and character be adopted and issned in due course of business, for the express purpose of being pledged as seenrity to obtain money, and if, as a part of the regular system of using them the warehouseman acknowledge in writing on each receipt notiee of assignment by the pledgor to the

4 Campbell v. Alford, 57 Tex. 161.

5 Blackhurn on Sales, 297 ; Penjamin on Sales, 613; Fairina v. Home, I6 M. \& W. 119. 
piedgee before the latter advanees his money thercon, the pledgee after alvancing his money in good faith, is antitled to stand on the terms of the pledged receipt. Thus, though in fact no goods had been received for storage, the recital in the special receipt being utterly false, nevertheless the recital will have the same effect in protecting such bona fide pledgee, as if the goods had been received and stored." :

$\$ 55$. Statutory changes.- There are statutory enactments in England which greatly enlarge the effect of such instruments. ${ }^{7}$ In Virginia, by aet of Assembly, warehouse receipts (for produce) are male negotiable moler certain rules and regulations, ${ }^{s}$ and in Minnesota they are negotiable by indorsement and delivery." And so in Ohio, and perhaps in other States. ${ }^{10}$

G Planters' Rice Mill Co. v. Merehants' Nat. Bank, 78 Ga. 582.

7 Benjamin on Sales, 607.

S Acts of Assembly of 1874, p. 233.

a State v. Loomis, 27 Minn. 521; National Exch. Bank v. Wilder, 34 Mim. 149; Brooks v. Hanover Nat. Bank, 26 Fed. 301.

10 Cleveland v. Sherman, 40 Ohio St. 176; Conrad v. Fisher, 37 Mo. App. 367. 


\section{CHAPTER III.}

\section{FORMAL REQUISITES OF NEGOTIABLE INSTRUMENTS.}

\section{SECTION I.}

DIFFEREXCE IN STRUCTURE BETWEEN BILLS OF EXCILANGE AND. PROMISSORY NOTES.

56. Difference between bills and notes.-In their original strueture, a bill of exchange and a promissory note do not strongly resemble each other. In a bill, there are three original parties: drawer, drawee, and payee; in a note only two: maker and payee. In a bill, the aceeptor is the primary debtor. In a note, the maker is the only debtor. But if the note be transferred to a third party by the payee, it becomes strikingly similar to a bill. The indorser becomes then, as it were, the drawer, the maker the aceeptor, and the indorsee the payee.

\section{SECTION II.}

FORMALITY IN RESPECT TO STYLE AND MATERIAL.

\$7. The law does not require any partieular form, either as to a bili of exchange or promissory note, or other negotiable instrument, and while it would be unwise to depart from the approved forms in vogue amongst merehants, yet the law respects substance more than form; and where the intention appears to assume the obligations which derolve upon drawers and makers of negotiable instruments, it will be enforced, although not evideneed in the nsual commercial form. Thus, an order written under a note, "Please pay the above note, and hold it against me in our settlement," signed by the drawer and aecepted by the drawee, has been held a good bill ${ }^{1}$ and so, also, it has been held that a like order written under an aceount is at

1 Leonard v. Mason, 1 Wend. 252. 
bill of exchange." And where an indorsement was mate on a bond, ordering the contents to be paid to order for value received, it was held a good bill. ${ }^{3}$

\$58. Signature and material.- It does not matter upon what portion of the instrument, the maker or drawer affixes his name, so that he signs as drawer or maker." It i. not material whether the writing is in pencil or ink, although as matter of permanence and security, ink is, of course, preferable. And the name may be printed as well as written, though, in such cases, it camnot prove itself, and must be shown to have been adopted and nsed by the party as his signature." If another sign the name of the party in his presence and at his request, it is the same as if lie did it hinself $;^{\top}$ and if another sign the jarty's name by verbal or other anthority, it is sufficient. ${ }^{8}$ The full name may be written; and at least the surname should appear, and generally does. But this is not indispensable - the initials are sufficient, ${ }^{9}$ and any mark which the party uses to indicate his intention to bind himself will be as effectual as his signature, ${ }^{10}$ whether there be a errtificate of witnesses on the instrument or not. ${ }^{11}$ But, of course, a mark does not prove itself like a signature, althongh it is an adminicle of proof. ${ }^{12}$ Any peculiarity in it may he shown as eridence of its genuineness; ${ }^{13}$ but, mless there be an attesting witness, or one who saw it written, or is familiar with its character-

2 IIoyt v. Lỵneh, 2 Sandf. 328.

3 Bay $r$. Frazer, 1 Bay, 66.

4 Clason v. Bailey, 14 Johns, 48.4; Schunilt v. Schmaeller, 45 M10. 502.

5 Reed $v$. Roark. It Tex. 329: Closson v. Stearns, 4 Vt. 11.

"Brown r. Butchers' Bank, 6 Hill, 443; Schneider v. Norris, 2 Maule \&. S. 286 .

T Sager v. Tupper, 42 Mich. 605.

8 Daniel on Negotiable Instruments, \$\$ 274, 299.

9 Merchants' Bank v. Spicer, 6 Wend. 443; l Parsons on Totes and Bills, 36.

10 Lyons $\vee$. Holmes, 11 \&. C. 429.

11 Willoughby v. Moulton, t7 N. II. 205; Siank r. Butseh, 28 Ind. 19. 12 Hilborn v. Alford, 22 Cal. 482; Flowers $v$. Billing, 45 Ala. 488. 13 George v. Surrey, 1 Moody \& M. 5l6; 2 Parsons on Notes and Bills. 480. 
istics, the plaintiff eamnot recover. ${ }^{14}$ Nor is it necessary that the substance upon which the instrument is writteu should be paper - parchment, eloth, leather or any other substitute for paper will suffice. ${ }^{15}$

\$5. Whole instrument must be in writing.-The whole of the bill or note must be expressed in writing. But all of it need not be in the body of the instrument; ${ }^{16}$ and a contemporaneous memorandum or indorsement on any part of it may qualify its terms by making it payable upon a contingeney, ${ }^{17}$ or at a particular place, ${ }^{18}$ or providing that it may be renewed. ${ }^{19}$ And there may be a written stipulation on a detached paper affecting the instrument, which wonld be admissible as between the original parties and their representatives; ${ }^{20}$ but such stipulation would not affect a bona fide holder for value, who aequired it without notice. $^{21}$ But a party having notice would stand on no better footing than the original parties. ${ }^{22}$ Whether the instrument be a bill of exehange or a promissory note, or otherwise, and whether or not it be negotiable, must be determined by its faee, without reference to any other source. ${ }^{23}$

$\$ 60$. Parol evidence.- It is a general prineiple of law that parol evidence is inadmissible to vary or contradict a written contract. Therefore, if a negotiable contract be absolute and complete upon its face, no evidence of a verbal agreement made at the time, qualifying its terms, ean be admitter. ${ }^{24}$ This principle applies to every element of the

14 Thompson on Bills, 30, 31, 33.

15 Daniel on Negotiable Instruments, \& 77 .

16 Daniel on Negotiable Instruments, \& 79; Goldman v. Blum, 58 Tex. 636 .

17 Hughes v. Fisher, 10 Colo. 385; Wheelock v. Freeman, 13 Piek. 168. 18 Hughes v. Fisher, 10 Colo. 385; Wheelock v. Freeman, 13 Pick. 168. 19 Hartley v. Wilkinson, 4 Maule \& S. 25.

20 Bowerbank v. Monteiro, 4 Taunt. 844.

21 Hoare v. Graham, 3 Campb. 57.

22 Gibbon v. Scott, 2 Stark, 286.

23 Strachan v. Muxton, 24 Wis. 21.

24 Burnes v. Scott, 117 U. S. 582; Whitwell v. Winslow, 133 Mass. 343. 
instrument, and it follows that no condition can be engrafted in the instrument by verbal testimony - as that it should be void unless others interested agreed to the settlement in which it was given ${ }^{25}$ or was to be roid if cortain bills should be paid at maturity ${ }^{26}$ or was to be roid or smrendered up in the event the ease in which it was given for a fee was compromised, ${ }^{27}$ or in any other contingener. ${ }^{2 s}$ Nor can it be shown that it was only to be paid out of a particular fund or estate. ${ }^{20}$ The Supreme Court of tho United States, in the easo of Brown $v$. Spofford, thus conprehensively and tersely states the law: "Negotiable notes are written instruments, and as such they eamot be contradieted, nor ean their terms be varied by parol eridenee; and that proposition is miversally true where the promissory note is in the hands of an innocent holder." 30

$\S 61$. Contemporaneous written agreements.-But contemporaneous written agreements are almissible for the purpose of controlling the effeet of a negotiable instrunent, as between immediate parties and those having notice; $;^{31}$ and a purchaser after maturity, of a negotiable instrument, would be bound by sueh agreenent, when established. ${ }^{32}$ Parol evidence is generally admissible, as between the parties, to show their real relations to each other ${ }^{33}$ and if there bo a latent ambiguity, to explain it. ${ }^{34}$ And if by mistake the instrument were given for too large an amount, the better opinion is that it may be shown, for as to the mistaken

25 Bly v. Kilborn, 5 Den. 514.

2is Penny v. Graves, 12 Ill. 187.

2i Dale v. lope, 4 Litt. 166.

as Potter v. Earnest, 45 [nd. 418 ; Wayland Univ. v. Boornan, $5 t$ Wis. 660.

29 Brown r. Spofford, 95 L. S. 482; Adams v. Wilson. 12 Mete. (Mass.) 138.

30 Brown r. Spofiord, 95 U. S. 482.

31 Goodwin v. Nickerson, 51 Cal. 166; Lebanon Sav. Bank v. Penney, 46 N. W. 331.

32 Munro v. King, 3 Colo. 238.

33 Honck v. Graham, 106 Ind. 195.

34 Wharton on Evidence, \$ 956. 
excess there is partial want of consideration. ${ }^{35}$ And, in general, parol evidence is admissible between the original parties to show frand, aecident, or mistake in the ereation of the instrument. ${ }^{36} \mathrm{Also}$ to set up a verbal agreement by performance of which the written contract has been discharged."

\$62. The date- The date is usually written in the righthand comer of the instrument; but a date is not essential to the ralidity of the instrument; $;^{38}$ and it is of no consequence on what portion of the paper it is written. ${ }^{39}$ If there be no date, it will be considered as dated at the time it was made, ${ }^{40}$ and parol evidence is admissible to show from What tine an undated instrument was intended to operate, ${ }^{41}$ or to shom that there was a mistake in the date. ${ }^{42}$ If dated, it will be presumed to have been executed on the day it bears date." If undated, but containing a reference to date, it will date from delivery. ${ }^{44}$ When a note without late is made for another's accommodation, the maker authorizes him to fill up the date as he sees fit. ${ }^{45}$

$\$ 63$. Words of negotiability.- No precise form of words i. necessary to impart negotiability. As has been said in Pennsylyania, " "order" or "bearer' are convenient and ex-

35 Claxom v. Demaree, 14 I3ush, 173; Daniel on Negotiable Instruments. \$s 816, 179, 201. But see Downs v. Webster, Brayt. 79; ב Parsonis on Notes and Bills, 505.

36 Phillips v. Meily, 106 Pa. St. 536 .

37 Howard $v$. Stratton, 64 Cal. 487.

35 Michigan Ins. Co. v. Leavenworth, 30 Vt. 11; Drake v. Rogers, 32 Ne. 524.

39 Shepherd v. Graves, 14 How. 505.

40 Cowing V. Altman, 71 N. Y. 441; First Nat. Bank v. Hunt, 25 Mo. App. 174.

41 Richardion v. Ellet, 10 Tex. 190; Lean v. Lozardi, 27 Mich. 424.

42 Piggs v. Piper, 86 Temu. 589; Paige v. Carter, 64 Cal. 489.

43 Kincely v. Sampson, 100 Ill. 574.

44 Armitt v. Breame, 2 Ld. Raym. I076; Styles v. Wardle, 4 B. \& C. 908 .

45. Androscoggin Pank v. Kimball, 10 C'ush. 373; Shultz v. Payne, 7 La. Ann. 222.

4t: Daniel on Negotiable Instruments, § 106: Raymond $r$. Middleton. 29 Pa. St. 530. 
pressive, but elearly not the only words which will communieate the quality of negotiability. Some equivalent words may be used. Words in a bill, from which it can be inferred that the person making it, or any other party to it, intended it to be negotiable, will give it a transferable yuality against that person. It may be stated, therefore, that if the maker of a note, having omitted the usual words of negotiability, had said, "this is and shall be negotiable, it would have been negotialle."

\section{SECTION III.}

THE SEVERAL PARTS OF A FOliEIG BILL CALLED A SET.

$\$ 64$. In order to avoid delay and ineonvenience which may result from the loss or miscarriage of a foreign bill, and to facilitate and expedite its transmission for acceptance or payment, the custom has prevailed from an early period for the drawer to draw and deliver to the payee several parts of the same bill of exchange, which may be forwarded by different converances, and any one of them being paid, the others are to be void. These several parts are ealled a set, and constitute in law one and the same bill. ${ }^{47}$ Sometimes there are four, but usually three parts. ${ }^{48}$ And if any person undertakes to draw or deliver a foreign bill to another person, it seems that he is bound to deliver the usual number of parts, ${ }^{49}$ and it has been thought that the promisee may, in such a case, demand as many parts as he pleases, ${ }^{50}$ but this is questionable. ${ }^{51}$

\$65. Condition in each part of set.- It is usual for the drawer, and to his protection it is essential, to ineorporate in each part of the set a condition that it shall only be parable provided the other remains unpail. This operates

47 Daniel on Negotiable Instruments, \$ 113: Story on Bills, \& 60. 48 Daniel on Negotiable Instruments, \& 113: Story on Bills, $\$ 66$.

49 Learney v. West Granada Mining Co., 1 II. \& N. 412.

50 Chitty on Bills [*154]. 178; Byles on Bills $\left[{ }^{*} 3761,556\right.$.

51 )aniel on Negotiable Instrun:ents, \& 113: Story on Bills. \$ 66. 
as notice to the world that all the parts constitute one bill, and if drawee pay any part, the whole is extinguished. ${ }^{52}$

$\S 66$. Only one part of set should be accepted.-The drawee should accept but one part of the set. And having aceepted one part, he should not pay another part, for he would still be liable on the aceepted part. ${ }^{53}$ When, however, he pays the part he acepts, the whole bill is extinguished. ${ }^{5 t}$ The party entitled to the bill should claim and hold all the parts, for the payment of any one part to another person might defeat him. ${ }^{55}$ But he to whom any one part of the set is first transferred aequires a property in all the other parts, and may maintain trover even against a bona fide holder, who subsequently, by transfer or otherwise, gets possessiou of another part of the set. ${ }^{56}$ For it is the duty of the person taking one part to inquire after the others; and he is advertised by their absence that they, or one of them, may be ontstanding in the hands of a prior bona fide holder. ${ }^{57}$ There is some contrariety of opinion as to whether the plaintiff, in a suit against drawer or indorser, must produce all of the set or satisfactorily account for their nomproduction, but the Supreme Court of the United States has held that it is sufficient if the part protested is produced. ${ }^{58}$

\section{SECTION IV.}

STAMPS UPON NEGOTIABLE INSTRUMENTS.

$\$ 67$. It seems that stamp duties were first levied on the continent of Europe, in Holland, in the year 1624, being employed to raise revenues for the prosecution of war

52 Daniel on Negotiable Instruments, § 114; Ingraham $v$. Gibbs, 2 Dall. 134.

53 Iloldsworth v. IIunter, 10 B. \& C. 449 ; Chitty on Bills [*15.5], 17s.

54 Holdsworth v. Hunter, 10 13. \& C. 449 ; Chitty on Bills [*15.5], 178.

55 Holdsworth v. liunter, 10 B. \& C. 449.

56 Holdsworth v. Hunter, 10 B. \& C. 449 ; Byles on Bills [ $\left.{ }^{*} 376\right], 556$.

57 Jang v. Smyth, 7 Bing. 284, 294; 5 M. \& P. 73.

58 Downes v. Church, 13 Pet. 20.5. 
against Spain. ${ }^{59}$ In England, they were tirst imperced in 1694, war then being waged against liance." In the ["niter] States, individual States have at different periods imposenl stamp duties; but such duties were nerer imposed by the Federal Govermment until July 1, 1Stjz, during the progeress of the war against the Confederate States. It that time, a sweeping act, requiring deeds, bills, notes, checks, and oth"' agreements and evidenees of debt to be stamped, was pasiod,

being framed for the most part upon the model of the British statutes. Subsequently the entire act was repealerl. and from the date of the said repeal there was no statute of the United States requiring a stamp upon negotiable instruments until the act of Congress of June 13, 1598.

$\$ 68$. Stamp Act of 1898. - Upon the declaration of war with Spain, and in order to raise the increased revenue needed to meet the exigeneies of that period, the Congress of the United States enacted what is known as the " $\mathrm{W}^{\text {all }}$ Revemue det," which provided, among other things, for the stamp upon bills of exchange, forcign and inland, promissory notes, money orders, certificates of deposit, warehonse receipts, bills of lading, and quite a number of evidences of indebtedness not herein enumerated. Bills of $\mathrm{ex}^{-}$ change if drawn singly were taxed four cents for cach $\$ 100$, and if drawn in two sets, two eents for each \$100. Upon fromissory notes, the same stamp duty (in the graduated seale) as in case of hills of exchange wat: imposed, while upon checks a two-cent stamp was required, withont regard to the amount speeified therein. Congress, by the enactment known as the "Revenne Reduction Law," approved March 2, 1901, repealed s" much of the act of 1895 as required stamp taxes upon checks, eertificates of deposit, promissory notes, money 11 ders, bills of lading and warehouse receipts, learing bill: of exchange subjeet to and governed by the provisions of the act of 1 s9s; and by a still more recent statute. approved April 12, 1902, the stamp tax on bills of excilange was abolisherl. 


\section{SECTION $\mathrm{V}$.}

DELIVERY.

\$69. Delivery is the final step necessary to perfect the existence of any written contract; and, therefore, as long as a bill or note remains in the hands of the drawer or maker, it is a mullity. ${ }^{61}$

So essential is delivery that it has been held that where a promissory note, the existence of which was unknown to the grantee, lay in the grantor's possession, and was found amongst his pipers after death, the payee could not claim or sue upon it; $;$ and though such a note should be found, accompanied with written directions to deliver it to the payce, the parce will still have no right of action, unless the directions be ralid as a testament. ${ }^{63}$

Delivery may be constructive as well as actual.

A direction to a third person, who is in actual custody of the instrument, to hold it subject to the payee's or transferee's order, or an order to the depositary to deliver it, or a delivery to a third person for the payee without condition is sufficient in legal contemplation. In either of the cases suggested the delivery would be constructive. ${ }^{64}$

$\S 70$. Presumption of delivery.-. Whenever a bill or note is found in the hands of the payee, it will be presumed that it was delivered to him, ${ }^{65}$ and that the delivery took place on the day of its date, if it be dated, ${ }^{6 ;}$ and, at any rate, before the day of its maturity. ${ }^{67}$ But the presumption both as to the fact and the time of delivery may be rebutted. ${ }^{\text {se }}$ As a bill or note takes effect only by delivery, so it takes

61 Devries v. Shumate, 53 Md. 216; Purviance v. Jones, 120 Ind. 164.

62 Disher v. Disher, 1 P. Wms. 204.

es Gough v. Findon, 7 Exch. 48.

64 Gordon v. Adams, 127 Ill. 225; Howe v. Ould, 28 Gratt. 7.

in Griswold v. Davis, 31 Vt. 390.

6is ('ranston r. Goss, 107 Mass. 439; Emery v. Vinall, 26 Me. 295.

67 Smith v. MeClure, 5 East, 477; Dinney v. Plumley, 5 Vt. 500.

68 Woodford v. Dorwin, 3 Vt. 82; Scaife v. Byrd, 39 Ark. 568. 
effect only on delivery; and if this be subsequent to its date, it will be binding only from the day of actual delivery."'

If the bill or note bear no date, the time must be computed from its delivery; and if the day of actual delivery cannot be proved, it will be computed from the earliest day on which it appears to have been in the hands of the payeo or sury holder. ${ }^{i 0}$

$\$ 71$. Intention essential.- It is essential to delivery that the minds of both parties should assent, in order to bind them; and if, throngh inattention, infirmity, or otherwise, one does not assent, the act of the other is mugatory. ${ }^{71}$ Therefore, leaving a check on the desk of a elerk of a bank, and without the knowledge of such clerk or of an officer of the bank, does not constitute delivery. ${ }^{\top 2}$ Where papers were taken up in the presence of the party sought to be charged, and placed in the safe of a third person, it was held no delivery on his part, as between the immediate parties, when he had done or said nothing to indieate an intention to deliver. ${ }^{i 3}$ i bill or note, as well as a deed, may be delivered in eserow - that is, delivered to a third party to hold until a certain event happens or certain conditions are complied with - and then the liability exmmences as soon as the event happens or the condition is fulfilled, without actual delivery of the instrument. ${ }^{7 t}$ But there is this distinetion between negotiable and sealed instrmments: If the custodian of the former betrars his trust, and passes off the negotiable instrument to a bona fide holder before maturity, and without notice, all parties are bound; but if the instrument be sealed, the rule is otherwise. ${ }^{75}$

(99 Lovejoy v. Whipple, $18 \mathrm{Vt}$. 379.

70 Clark $v$. Sigourney, 17 Conn. 511: Riehardson v. Lineoln, is Mete. (Mass.) 201.

i1 Daniel on Negotiable Instruments, $\$ 67$.

72 Chieopee Bank v. Philadelphia Bank, S Wall. 64l: Kinney v. Ford. 52 Barb. 194.

73 Stokes v. Anderson, 118 Ind. 533.

it Daniel on Negotiable Instruments, $\$$ 6s: Taylor r. Thomas, 13 Kan, 217.

in Daniel on Negotiable Instruments. \$ 68. 


\section{CHAPTER IV.}

\section{THE ESSENTIAL REQUISITES OF NEGOTIABLE INSTRU- MENTS.}

\$72. A negotiable instrument must carry its full history upon its face and embrace the following requisites: First. It nuss be open, that is, unsealed. Second. The engagement to pay must be certain. Third. The fact of payment must be certain. Fourth. The anomt to be paid must be certain. Fiftl. The medium of payment must be money. ${ }^{1}$

\section{SECTION I.}

THE PAPER MLST BE OPEN - THAT IS UNSEALED.

$\$ 73$. What is an unsealed obligation; effect of seal on negotiability.- By the term "open" is meant "unsealed;" and thongh the instrument possesses all the other requisites of a bill or note, its character as a commercial instrument is destroverl, and it becomes a covenant, governed by the rules affecting common-law securities, if it le sealed. ${ }^{2}$ It is to be olserved, however, that merely attacling a seal to the signature does not make it a specialty contract, unless there he a recognition of the seal in the body of the instrument hy some snch phrase as "witness my signature and scal," or "signed and sealed," for otherwise the door. would be thrown open to frauds and forgeries, by the facility with which scals conld he superadded. ${ }^{3}$ And it seems to be establisherl by well considered cases that corporations cannot use the seal withont destroying the negotiable character of the instrument, although the decisions are not miniform. ${ }^{4}$

1 Daniel on Negotiable Instruments, \& 30.

2 Daniel on Negotiable Instruments, $\S 31$ : Story on Bills, $\$ 62$.

3 Anderson v. Pullock, 4 Munf. 442; Humphries v. Nix, 77 Ga. 93.

4 Daniel on Nexotiable. Instruments, \$ 32 . See also $\$ 146$, post, and authorities there cited. 
$\S 74$. Statutes as to sealed instruments.- In some of the States of the United States, sealed instruments for the payment of money are placed by statute upon the same footing as bills and notes in respect to their negotiability; and the addition of a seal to a bill or note payable to order or bearer in no way impairs its negotiability.

In others, bonds are made transferable, and may le sned upon in the name of the assignee, but the latter takes them subject to all defenses that were available to the original obligee. $^{5}$

\section{SECTION Ií.}

CERTAINTY AS TO ENGAGEMEXT TO PAY.

\$5. Meaning of the requirement.- If a bill, it must contain a certain direction to pay - if a note, a certain promise to pay. A bill is, in its nature, the demanding of a right, not the mere asking of a faror, and therefore a supplication made or authority given to pay an amount is not a bill. The language, "Mr. Little, please let the bearer have $\mathfrak{i} \overline{7}$, and place it to my account, and you will much oblige your humble servant," was held not a hill $;^{6}$ and so "Please to send $£ 10$ by bearer, as I am so ill I cannot wait upon rou;" 7 but on the other hand where the language was: "Mr. Nelson will mueh oblige Mr. Webb by paying I. Ruff, or order, on his aceount, twenty guineas," it was held to import an order, and therefore a good bill. ${ }^{8}$ The usual and appropriate expression used in bills is, "Please pay," and it has been well said by Justice Story that the language should not be too nicely seanned nor be regarded beeause of its politeness as asking a faror rather than demanding a right. ${ }^{9}$ It is a perfeetly valid phrase, being a mere form of civility. "Please let the bearer have $\$ 50$; I will ar-

6 Daniel on Negotiable Instruments, $\$ 33$.

GLittle v. Slackford, 1 Moody \& M. 3il.

7 King v. Ellor, 1 Leach Cr. Law, 323.

8 Ruff v. Webb. 1 Esp. 129.

a Story on Bills, $\$ 33$.

10 Wheatley $r$. Strobe, 12 Cal. 92; Jarvis $r$. Wilson, 46 Conn. 90. 
range it with you this forenoon," and signed, "yours, most obedient," was held sufficient in Kentucky.

\$76. Certainty of promise in a note. A promissory note must contain a certain promise to pay. " I promise to pay, or cause to be paid," would suffice, because the undertaking. that the payment be made is definite and certain. ${ }^{12}$ It is said by Story, that " it seems that to constitute a good promissory note, there must be an express promise upon the face of the instrument to pay the money; for a mere promise implied by law, founded upon an aeknowledged indebtedness, will not be sufficient." 13 But we think the better languago is used by Byles, who says: "No precise words of contract are necessary, provided they amount, in legal effect, to a promise to pay." 14 In other words, if over and above the mero acknowledgment of debt, there may be collected from the words used a promise to pay it, the instrument may be regarded as a promissory note. ${ }^{15}$

In England, it seems to be well settled that an ordinary due-bill does not amount to a promissory note, while in the United States the decisions are eonflicting. ${ }^{16}$ When negotiable words, however, are inserted in the due-bill, or it eontains the words "on demand," the instrument is generally held to be a promissory note. ${ }^{17}$

\section{SECTION III.}

CERTAINTY AS TO FACT OF PAYMENT.

\$77. Fact of payment must be certain.- The instrument must be payablo meonditionally and at all events in order to be negotiable.

11 Bresenthal v. Williams, 1 Duv. 329.

12 Lovell v. Hill, 6 Car. \& P. 238: Caviness v. Rushton, 101 Ind. 500. 13 Story on Promissory Notes, \& 14.

14 Byles on Bills, 8.

15 Daniel on Negotiable Instruments, \& 36 ; Cowan v. Hallack, 9 Colo. 578.

19 Daniel on Negotiable Instruments, \& 36a.

17.Johnson School Township v. Citizens' Bank, 81 Ind. 515; Smith v. Allen, 5 Day, 337. 
If the order or promise be payable provided terms mentioned are complied with; as, for instance, that a railroal be built to a certain point by a certain tince, it is not at bill or note; $;^{1 s}$ and likewise if payable provided a certain act be not done $;^{19}$ or that a certain receipt be precheced $;^{20}$ or another person shall not previonsly pay ; or provided a certain ship shall arrive $; 2$ or provided the maker shall be able; $; 23$ or provided the maker slabll live a certain time $;^{24}$ or "On account of contract when completed and satisfactory;" ${ }^{25}$ or provided one person shall first pay another a certain sum, ${ }^{26}$ or upon any contingency. ${ }^{2 \pi}$

The form or language nsed to give expression to the conditions is immaterial, i.e.- "When A. shall mary," ${ }^{24}$ or "after arrival and discharge of coal by Brig A." In all these cases the contingeney implied deprives the instrunent of its negotiable character, as the events named may never happen. If payable in instalments, no time for the payment of the instalments being mentioned, it is not a promissory note. ${ }^{30}$ In Illinois, where the promise was to pay a railroad company or order a certain sum, in such instalments and at snel times as the direetors of the payee conpany might assess or require, it was held negotiable, and in effeet payable on demand, or in instalments on demand. ${ }^{31}$

§78. Time need not be definitely ascertainable, if sure to come.-If the time must eertainly come, althongh the partienlar day is not mentioned, the instrument is regarded as

18 Blackman v. Lehman, 63 Ala. 547; Eldred v. Malloy, 2 Colo. 320.

19 Appleby v. Beddolph, 8 Mod. 363.

2) Macon v. Metealf. 8 Baxt. 440 .

21 lioberts v. Peake, 1 Burr. 323.

20olidge $r$. Ruggles, 15 Mass. 387.

23. Salinas v. Wright, 11 Tex. 572.

24 Braham $v$. Bubb, Chity on Bills [*135], 136.

25 Home Bank $v$. Drumgolle, 15 X. E. Rep. 747 .

26 Chapman v. Wright, ig Me. 595.

27 Sloan v. Mecarty, 134 Mass. 245.

es Pearson v. Garrett, 4 Mod. 242.

29 Grant r. Wood, 12 Gray, 220.

so Moffatt v. Elwarts, Car. \& M. 16.

31 White $r$ Snith, it Ill. 351 . 
negotiable, as the fact of payment is certain. ${ }^{32}$ If the instrument is payable at, or within a certain time after, is man's death, it is sufficient, becanse the event must oceur; $; 3$ and a pronise to pay " on demand, after my decease, $\$ 850$," signed by the promisor, is a good note, negotiable as any other, and binding on the promisor's estate at his death. ${ }^{34}$ So a note payable " one day after date or at my death," ${ }^{35}$ and if the day of payment must come at the same time, it has been said that the distance is immaterial. ${ }^{36}$ The English courts have gone so far as to hold that if payable at a certain time after a govermment ship is paid off, it would be good, becanse govermment is sure to pay ${ }^{37}$ but this decision has been justly criticized and distrusted. ${ }^{38}$

In Massachusetts, held that a note payable "as soon as realized, to be paid in the course of the season now eoming," is negotiable, for, whatever time may be understood by the "coming season," whether harvest time or the coming year, it must come by mere lapse of time and that must be the ultimate limit of the time of payment. ${ }^{39}$

\$79. Rule liberally interpreted in favor of negotiabiliıy.The tendency of the courts is to liberally construe language used, in favor of upholding the negotiability of the instrument, and hence in many cases, especially in the United States, apparent uncertainty of time has been rendered certain by giving to the debtor a reasonable time thereafter (the time prescribed) to make the payment. Illustrations:

A note payable on demand after date, "when convenient," has been held payable absolutely in a reasonable time $;^{40}$

32 Daniel on Negotiable Instruments, \$ 43.

33 Cooke v. Colehan, 2 Stra. 1217; Conn v. Thornton, 46 Ala. 587; Price v. Jones, 105 Ind. 544.

34 3ristol v. Warner, 19 Conn. 7.

35 Conn v. Thornton, 46 Ala. 588.

36 Wortlt v. Case, 42 N. Y. 362.

37 Andrews v. Franklin, 1 Stra. 24: Evans v. Underwood, I Wils. 262.

38 I Parsons on Notes and Bills, 40; Edwards on Bills, 142.

39 (Cota v. Buck, 7 Mete. (Mass.) 588.

40 Works v. Hershey, 35 Iowa, 340. 
and so a note payble "as soon as I cant." "l so a note payable in six months, "or as soon as I an with dise diligence make the money out of said patent right;" t2 a noto payable in nine montls, " or as $\Lambda$. 's lonres earns the money in the cavalry service;" 43 a note parable twelve montls after date, "or sooner if made out of a certain sale," t4 have eacl heen held to be a valid, negotiable note payable absolntely at the termination of the time expresser, and carlier, provided the alternative event transpired. I note payable "fiom the avails of logs honght of M. M., when there is a sale made;" 45 or "when I sell my place where I now live," t5 have been held in Maine payable absolutely after a reasonable time.

$\$ 80$. Cases arising out of Confederate War.-During the war between the United States and the Confederate States, obligations were frequently given, payable when, or a eertain time after, peace should be declared. Where a note was expressed to be payable "six months after peace is declared between the United States and the Confederate States of Ameriea," it was held actionable six months after peace ensued. ${ }^{47}$ And the like ruling prevailed as to a note payable "thirty days after peace between the Confederate States and the Enited States," ts and as to a note payable "one day after the treaty of peace." 49 But in West Virginia, where a bond was payable "six months after the ratification of peace between the United States and Confederate States," it seems to have been regarded as a wager upon the suecess of the Confederacy; but the ease went off

41 Kincard v. Higgins, l Bibb. 396.

42 Palmer v. Hummer, 10 Kan. 464.

43 Gardner v. Barger, 4 Heisk. 669.

4 Ernst v. Steckman, 74 Pa. St. 13; Charlton v. Reed, 61 Iowa, 166.

45 Sears v. Wright. 24 Me. $2 \pi 8$.

46 Crooker $v$. Holmes, 65 Me. 195.

47 Brewster v. Williams, 2 s. C. 455.

48 Mortee v. Edwards, 20 La. Ann. 236.

49 Gaines v. Dorsett, is La. Ann. 563. 
on a formal point. ${ }^{50}$ In Nortl Carolina, this view las been adopted and applied, ${ }^{51}$ and certainly is not without foree. Only the United States Senate can ratify a peace, and a peace atified between two countries implies the independence of eacli. And further, it may be said that until the condition precedent is fulfilled, no liability aeemes. We think the better view is that "six months after peace" would fulfill the meaning of the terms as they were used in the country, though they are the very words of Confederate treasury notes; and it has been so deeided in a number of eases, the courts construing the language according to its popular import, and the probable intention of the parties, rather than in its striet technical sense. ${ }^{52}$

$\$ 81$. Where payable out of a particular fund, not negotiable. - In aecordance with these principles the negotiable character of the instrument is lestroyed if $i$ be made payablo expressly or impliedly out of a particular fund. Illustrations: The insertion in an order to pay a certain sum "on account of brick work done on a certain building" 53 or "out of rents," 54 or " out of my growing substanee," 55 or "ont of a certain elaim," "56 or "out of my part of the estate of $\Lambda ., " 57$ or "out of amount due on contract." 58 On the same principle, receivers' certificates are not regarded as negotiable, although framed with the negotiable words usual in promissory notes. ${ }^{59}$

50 Jarris v. Lewis, 5 W. Va. 576.

51 MeNinch v. Ramsey, 66 N. C. 229.

52 Kuight v. McReynolds, 37 Tex. 204; Mortee v. Edwards, 20 La. Ann. 236; Nelson v. Manning, 53 Ala. 549.

53 P'itman v. Crawford, 3 Gratt. 127.

541 Parsons on Notes and Bills. 43.

55. Josselyn v. Lacier, 10 Mod. 294.

5f Richardson v. Carpenter, 46 N. Y. 661.

$5 \pi$ Mills v. Kuykendale, 2 Blackf. 47.

58 Hoagland v. Erck, 1] Neb. 580.

r9 Staunton v. Railroad Co., 31 Fed. 587; McCurdy v. Bowes, 88 Ind. 583. 


\section{SECTION IV.}

CFRTAINTY AS TO MMOUNT TO BE l'AID.

\$ 82. Amount must be in figures or written out or ascertainable from the instrument.- The amount which the del,tol promises or engages to pay must either be stated in the instrument itself, in figures or words, or must be ascertainable from data somewhere on the paper. Illutrattions: A note to pay a certain sum, "and all other sums which may be due" is not negotiable, as the aggregate amount is not capable of definite ascertaimment. ${ }^{\text {sin }}$ So, if it be for" a certain sum "and whatever smm you may eollect of me for C.;" "il or if it be for "the proceeds of a shipment of goods, ralue abont $\$ 2,000$, consigned by me to you;" t2 or "the demands of the sick club in part of interest;" "or " "a certain sum, the same to go as a set-off; " 64 $\mathrm{ol}^{\circ}$ if it be expressed, "deducting all advances and expenses;" 6ro or if it be for " $\$ 500$ and such additional prenium as may be due on policy No. 218,171." But a promise to pay bearer a certain sum per acre for so many acre: as a certain tract contained was held to be negotiable as soon as the number of acres was indorsed upon it. ${ }^{67}$

\section{\$ 83. Payable with exchange does not destroy negotiability.} - While the authorities are not miform, it may be safely stated to be fairly well settled that if there be added to the amount, "with exchange," or " with current exchange on another place," the commercial dharacter of the paper is

co Smith v. Nightingale, 2 Stark. 375.

61 Legro v. Staples, 16 Me. 252 ; Lime Roek F. \& M. Ins. Co. v. Hewitt, 60 Me. 407.

62 Jones v. Simpson, 2 B. \& C. 318.

6is Bolton v. Dugdale, 4 B. \& Ad. 619.

64 Clarke v. Pereival, 2 B. \& Ad. 660.

65 Cashman v. Haynes, 20 Pick. 132.

66 Marret v. Equitable Ins. Co., 54 Me. 537.

67 Smith r. Clopton, 4 Tex. 109. 
not impaired, as that is capable of definite asecrtainment. ${ }^{\text {ss }}$ Exchange is an incident to the nse of negotiable instruments for the transmission of noney from place to place, and its nature and effect are well understood in the commercial world. Exchange preserves the equivalence of amomits in ralue, and does not introduce such an element of uncertainty as destrors the negotiability of the instrument which enbodies it in its terms. ${ }^{69}$

\$ 84. Stipulation to pay attorney's fees.-Quite frequently in recent year's bills and notes are met with framed in other respects in the usual negotiable forms, but containing the additional stipulation on the part of the drawer or maker to pay collection or attorney's fees, and they have elicited from the courts varions and conflicting decisions. The cases may be divided into four classes.

First. Those which sustain both the validity of the stipulation and the negotiability of the instrument. ${ }^{\text {io }}$

Second. Those which enforce the stipulation, but deny the negotiability of the instrument. ${ }^{71}$

Third. The class that upholds the negotiability of the instrument, but regards the stipulation as penal and void. ${ }^{22}$

Fourth. Those which adhere to the view that the stipulation to pay the additional amount renders the transaction usurious, and subjeets the instrument to the operation of the statutes against usury. ${ }^{73}$

\$85. Correct view.- Such instruments should, we think, be upheld as negotiable. They are not like contracts to pay moner and do some other thing. They are simply for the parment of a certain sum of money at a certain time, and the additional stipulations as to attorney's fees can

68 Daniel on Negotiable Instruments, \& 54; Grutacup v. Woulloise, 2 MeLean. 5sl: Johnoon v. Frisbie, 15 Mich. 286.

os Smith v. Kendall, 9 Mich. 242.

70 Schle-inger v. Arline, 31 Ferl. 648: Sperry v. Horr, 32 Iowa, 184.

71 Woods v: Jorth, 84 Pa. St. 410: First Nat. Bank v. Gay, 71 Mo. 627.

72 Wright v. Traves, 79 Mich. 494; Gaar v. Louisville Banking Co., 11 Tush, 182.

73 State r. Taylor, 10 Ohio, 378; Dow v. Updike, 11 Nebr. 95. 
never go into eflect if the terms of the bill or note are complied with. They are, therefore, incidental and ancillary to tho main engagement, intended to assure its performanee, or to compensate for trouble and expense chtailed lyy its breach. At maturity, negotiable paper ceases to be negotiable in the full commercial sense of the term, though it still passes from hand to hand by the negotiable forms of transfer; and it seems paradoxical to hold that instruments evidently framed at bills and notes are not negotiable during their currency becanse when they cease to be eurrent they contain a stipulation to defray the expenses of eollection. it But whatever may be said for and against the negotiability of an instrmuent containing a provision "with reasonable attorney's fees," it would seem that if the amount is fixed by a certain percentage or a certain sum, the objection either to the negotiability or validity of the paper would be extremely techmical, if not mitenalle.

\section{SECTION $\mathrm{V}$.}

CERTANTY AS TO THE MEDIUM OI PAYMENT, WHICII MLST BE ONLY IN MONET.

\$86. Medium of payment must be money.- It is indispensably requisite, in order to constitute a bill of exchange or negotiable promissory note, that the direction or promise bo to pay in money. ${ }^{75}$ And if the instrument be expressed to be parable "in eash or speeific articles," in the alternative, ${ }^{76}$ or in merchandise, as, for instance, "in good merchantable whisky at trade priee," it or "in gimned cotton at eight cents per pound," is or "in work," "ig or in any other article than money, ${ }^{80}$ as, for instance, "an ounce of

it Daniel on Negotiable Instruments, $\$ 62 a$; Benjamin's Chamers' Digest, 17.

75 Chitty on Bills [*132], 153.

To Matthews v. Houghton, 2 Fairfax, 377.

it Rhodes $v$. Lindley. Ohio (ond. 465: Chitty on Bills [*132].

is Lawrence v. Dongherty. 5 Yerg. 435.

is Quimby v. Merritt, 11 Humphr. 439.

so Auerbich v. Prichett, 58 Ala. 45l; McClellan v, Cotlin, 93 Ind. 456. 
gold," ${ }^{81}$ it becomes a special eontraet, and by the law merchant loses its eharacter as commereial paper.

\$ 87. Legal tender.- Strietly speaking, the instrument must bo payable in legal tender, and hence a note payable in "eurrent bank bills or notes," 82 or "office notes of a bank," "s3 or "in eur'rency," 84 is not negotiable.

If payable in "good eurrent money" or "current money," the words thus employed have been construed to mean legal tender money. ${ }^{85}$

$\$ 88$. It is not necessary, however, that the money should be that current in the place of payment, or where the bill is drawn; it may be in the money of any country whatever. ${ }^{80}$ But it has been held that it is neeessary that the instrument should express the specific denomination of money when it is payable in the money of a foreign country, in order that the courts may be able to ascertain its equivalent value; otherise it is not negotiable, ${ }^{87}$ but such a requirement does not seem to be consonant with sound prineiplẹ.

Intention, to be gathered from the face of the paper, according to fixed rules, is the test of negotiability, and we do not see how the idea of its possessing a negotiable quality is excluded by the mere fact that the denomination of foreign money is not set out. A case, remarkable for its learning and ability, decided by the Supreme Court of Miehigan, adopts this view; and thero it has been held that a note payable "in Canada eurreney" is negotiable, the terms being equivalent to Canada money. ${ }^{88}$

$\S 89$. Contract must be only for the payment of money.It is essential to the negotiability of the bill or note that

81 Roberts v. Smith, 58 Vt. 494.

82 McCormick v. Trotter, 10 Serg. \& R. 94.

83 Irvine v. Lowry, 14 Pet. 293.

84 Haddock v. Woods, 46 Iowa, 433; Johnson v. Henderson, 76 N. C. 227.

80 Wharton v. Morris, 1 Dall. 124; Daniel on Negotiable Instruments, \& 56 .

86 King v. Hamilton, 12 Fed. 478; Thompson v. Sloan, 23 Wend. 71.

87 Thompson v. Sloan, 23 Wend. 71.

88 Black v. Ward, 27 Mich. 193. 
it purport to be only for the payment of money. Such at least may be stated to be the general rule, for if any other agreement of a different character be engrafted upon it, it becomes a special contract elogged and involved with other matters, and has been deened to lose thereby its character as a commereial instrument. ${ }^{x 9}$ In aceordance with this gencral rule it has been held that a note or a certain amount given for the hire of a negro, to which is added, "said negro to be furmished with the usual quantity of clothing," was not a negotiable promissory note, but a special contract for the hiring and clothing of the negro. ${ }^{00}$ And this would seem to be the correct doetrine, though the riew has been taken that such a paper is negotiable, the obligation to pay the money only passing to an indorsee. ${ }^{91}$ So it has been held that if the instrmment be to pay money, and also "to deliver up horses and a wharf;" 92 or to pay money "and take up a certain outstanding note," ${ }^{93}$ it is not a negotiable note.

\$9 Fleteher v. Thompson, 55 N. H. 308; Ingham v. Dudley, 60 Iowa, 16. 90 Barnes v. Gorman, 9 Rich. 297.

91 Baxter v. Stewart, 4 Sneed, 213; Gaines v. Shelton, 47 Ala. 413. 92 Martin v. Chauntry, 2 Stra. 1271.

93 Cook v. Satterlee, 6 Cow. 108. 


\section{CHAPTER V.}

\section{CONSIDERATION OF NEGOTIABLE INSTRUMENTS.}

$\$ 90$. By consideration, is meant a benefit or gain of some kind to the party nuaking the promise, or a loss or injury of some kind to the party to whom it is made. By the common law a promise made without consideration was invalid, and in order to enforce any contract it was necessary to aver and prove a consideration.

The most ancient exception to this rule was made in reference to promises under seal, the solemn act of the party in attaching a seal to the evidence of his contract being regarded as importing a consideration and estopping him from denying it. The necessities of trade soon produced another relaxation of the rule; and by the usage and custom of merchants, bills of exchange and promissory notes came to be regarded as prima facie evidences of consideration; and peculiar qualities were accorded to them which were possessed by no other securities for debt. These qualities, so far as they relate to the consideration of such instruments, we propose now to discuss. ${ }^{1}$

\section{SECTION I. \\ CONSIDERATION IRESUMED.}

§91. Difference between negotiable and nonnegotiable contracts. - There is no doubt that if the instrument sued on be negotiable, it is munecessary to aver or prove consideration, for it is imported and presumed from the fact that it is a negotiable instrument. ${ }^{2}$ But if the paper does not possess the quality of negotiability, it does not, per se, import a consideration and it must be averred and proved, mless it be stated on its face that it was given for "value

1 Daniel on Negotiable Jnstruments, \& 160.

2 Daniel on Negotiable Instruments, $\S 161$; Averett's Admr. v. Booker, 15 Gratt. 169; Louisville R. Co. v. Caldwell, 98 Ind. 251. 
received," or contains some other equivalent expression, in which case it would be prima facie evidence of consideration. ${ }^{3}$

\$ 92. At common law an action of debt eannot be sustained mpon a promissory note, as of itself importing a deht, but the plaintiff must declare upon the eontract as in assmmpit, and must aver and prove a valuable consideration. But the English statute of Quecu Anne provided that an action might be maintained on a promissory note without alleging a consideration; and such is the effect of all statutes which make promissory notes negotiable." It follows, therefore, that all such notes as are not negotiable by statute, or upon which no action of debt is authorized by statute, remain as at eommon law; and not importing consideration, it must be alleged and proved. ${ }^{0}$

\section{SEOTION II.}

\section{GOOD AND VALUABIE CONSIDERATIONS.}

\$ 93. Accommodation bills and notes.-The mercantile eredit of parties is frequently loaned to others by the signature of their names as drawer, acceptor, maker, or indorser of a bill or note, used to raise money upon, or otherwise for their benefit. Snch instruments are termed accommodation paper. An accommodation bill or note, then, is one to which the accommodating party has put his name, without consideration, for the purpose of accommodating some other party who is to use it, and is expected to pay it. $^{i}$ Between the accommodating and accommodated par-

3 Averett's Admr. v. Booker, 1.j (iratt. 169; Frank v. Irgens, 27 Minm. 43.

4 Daniel on Negotiable Instruments, \$ 162.

5 Glasscock v. Glasscock, 6t; Mo. 6i27.

6 Peasley v. Boatwright, 2 Leigh, los: Averett's Admr. v. Booker, l.5 Gratt. 165.

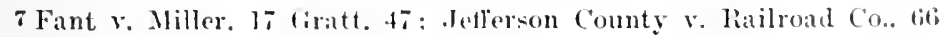
Iowa, 389. 
ties, the consideration may be shown to be wanting, ${ }^{8}$ but when the instrument has passed into the hands of a third party for value, and in the usual course of business, it cannot be; for as between remote parties, as we lave already seen, the consileration which the plaintiff gave for his title, as well as that for which the defendant contracted the liability, must be impeached in order to defeat a recovery. ${ }^{8}$ And the cireumstance that the accommodation maker was assured that the payee would protect it being known to the holder, does not weaken in any degree his title to recover.

\$94. In accommodation indorser, who has paid the amount of the note to a subseqnent indorsee, may recover of the maker without being subject to an offset of the maker against the payee, althongh he knew when he indorsed it that the maker was a creditor of the payee for an amount greater than the amount of the note. ${ }^{10}$ And the payee may recover against the acceptor, although he knew when he took the bill that the acceptance was for accommodation of another party. ${ }^{11}$ And it has been held that the accommodation payee and indorser may recover the full amount of the note, although he took it up by paying only a part. ${ }^{12}$ But this is, we think, erroneons.

If one member of a firm obtains an accommodation note payable to himself, and afterward indorses it to a third person, who reindorses it to the same firm, before maturity, and for good consideration, such firm eannot recorer against the maker, both parties being affected with the notice of a want of consideration. ${ }^{13}$

\$9. An accommodation bill or note is not considered a real seeurity, but a mere blank, until it has been negotiated,

8 Evansville Nat. Bank v. Kaufman, 93 N. Y. 273; Bank of British North America v. Ellis, 6 Sawy. 98.

9 Violett v. Patton, 5 Cranch, 142; Stephens v. Monongahela Nat. Bank, $88 \mathrm{~Pa}$. St. 157.

10 Barker v. Harker, 10 Gray, 339.

11 Spurgeon v. McPheeters, 42 Ind. 527.

12 Daniel on Negotiable Instruments, $8 \S 190,1353$.

13 Quinn v. Tuller, 7 Cush. 244. 
and it then becomes binding upon all of the accommodation indorsers in like mammer and to the like effect as if they were successive indorsers, ${ }^{14}$ but until it has been negotiated any party may withdraw his indorsement, acceptance, or other liability upon it, and reseind his engagement; ${ }^{15}$ and that right is not impaired by the eireumstance that he may be indemnified by an assigmment, or other security. ${ }^{16}$

\$96. A person who indorses a note as an accommodation indorser for the paree, such note having been made br an accommodation maker, is subject to all the obligations and acquires all the rights of a party to negotiable paper. ${ }^{17}$

If obliged to take up such note, the accommodation maker cannot set up frand on the part of the payec, in the inception of the note, as a defense to his suit. ${ }^{18}$

§97. Valuable considerations. - Jot only will money paid, or adrances made, or credit given, or work and labor done, constitute a sufficient consideration for a bill or note, but receiving a bill or note as security for a debt or forbcarance to sue upon a present claim or debt, or the dismissal of a pending suit, or the surrender of a prior valid note, or the compromise of a supposed cause of action, or becoming a surety or giving an extension of tine to an imputed debtor, or doing any other act at the request of the drawer, indorser, or acceptor, will be equally sufficient to enforce his engagement. ${ }^{19}$ A note on condition that the payce abstain for a certain time from intoxicating drink would be valid. ${ }^{20}$ So, also, a note in consideration of a release of an inchoate right of dower. ${ }^{21}$

\$98. Bankers receiving the bills or notes of their customers for collection are considered holders for sufficient

14 Whitworth v. Adauns, 5 Rand. 342; May" v. Boisseau, S Leigh, 164. 15 Second Nat. Bank v. Howe, 40 Minn. 390.

16 May v. Boisseau, 8 Leigh, 164.

17 Daniel on Negotiable Instruments, $\$ 192$.

18 Laubach v. Pursell, 35 N. J. L. 434.

19 Daniel on Negotiable Instruments, \& 183.

20 Lindell v. Rokes, 60 Mo. 249.

21 Nichols v. Nichols, 136 Mass. 256. 
consideration, not only to the extent of advances already made by them either specifically or upon account, but also for future responsibilities incurred upon the faith of them. ${ }^{22}$ The balanees upon an account are a shifting consideration for bills and notes deposited as security with the banker." Thus, where one bank, which we may eall $A$., sent an aecommodation lill aceepted by C., to another bank, which we miay call B., to secure an indebtedness upon account; and when the bill became due, the latter bank had become indebted to the former, but the bill was not withdrawn, and subsequently the indebteduess shifted baek, and the original debtor, bank L., became bankrupt, owing to the correspondent, B., a sum upon account, it was held that the latter could recover against $C$. upon the aceommodation bill accepted by hin. ${ }^{2 *}$ Where a bank diseounts a bill before maturity, paring part of the proceeds in money and applies the residue in parment of a past due note of the payee which is surrendered, it is a holder for valuable consideration. ${ }^{25}$ Where a note was delivered by the maker to the payee to be discounted for the maker's benefit, and the payee left it at the bank with the understanding that he, the payee, might draw against it, it was held in a suit against the maker, of whose interest in the note the bank lad no notice, that the maker was liable for the sums drawn against the note by the payee, the payment of which sums was in effect a di-count of the note to the amount so paid; also that the result would be the same if it should be considered that the note was simply pledged for the sums paid upon the draft. ${ }^{26}$

\$99. Services. - Professional services, whether of a physician, attornery or other person, in the learned or skilled

22 Byyles on Bills (Sharswood's ed.), 230; Bosanquet r. Dudman, I Stark. 1; Percival v. Frampton, 2 Cromp., M. \& R. 180.

23 Bank of Metropolis $v$. New England Bank, 1 How. 239, 17 Pet.

174; Swift r. Tyson, 16 Pet. 21.

24 Atwood v. Crowdie, 1 Stark. 483 (2 Eng. C. L.).

25 Mechanies, retc., Bank v. Crow, 60 N. Y. 85.

2 f Platt v. Beebe, 57 N. Y. 339. 
professions, constitute, in general, a sufficient consideration for' a bill or note; and the consideration that the plaintiff, an attorney, should prevent the approval of the commanting general to the sentence of a military court condemunge a gnerrilla to death, is valid. ${ }^{27}$ Services of any business character are sufficient, and the inadequacy of the servion or extraragance of the compensation is not material." Services rendered in procuring a parton for an offene have also been respected :293 though it has heen said by some of the authorities that this would contravene public policy unless done by leave of the court. ${ }^{30}$ This is, we think, too severe. Services exerted in procuring the patsage of an act through a legislative body are not recognized as the legitimate exercise of the legal profession; and compensation for them canuot be reeovered. ${ }^{31}$ If contingent upon the passage of a bill, it would be obvious that ther' were illegitimate. ${ }^{32}$

$\$ 100$. As to pre-existing debts. - There is no doubt that a pre-existing debt of the drawer, maker, or acceptor is a ralid consideration for lis drawing or accepting a bill or executing a note, and indeed is as frequently the consideration of negotiable paper as a debt contracted at the time, ${ }^{33}$ and it is equally as valid and sufficient consideration for the indorsement and transfer to the ereditor of the bill or note of a third party which is in his hands. And the best eonsidered, as well as the most numerous, authorities regard the creditor who receives the bill or note of a third party from his debtor either in payment of , ${ }^{34}$ or as collateral se-

27 Thompson v. Wharton, 7 Push, 463; Mowat r. Brown, 19 Fed. si. as Cowee r. Comell, 75 N. Y. 91.

20 Meadow v. Bird, 22 Ga. 246.

30 Chitty on Bills (13th Am. ed.), 100; Thompson on Bills (Wilson ed.), 70 .

31 Marshall v. B. \& O. R. Co., 16 Hlow. 334; Clippinger v. Hepbangh, 5 Watts \& S. 315.

32 Mills v. Mills, 40 x. Y. 543.

33 Swift v. Tyson, 16 Pet. 1: Townsley r. Sumrall, \& Pet. 170: MeIntyre r. Yates, 104 11l. 500.

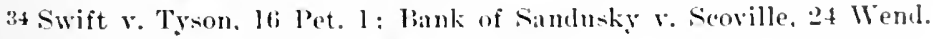
115: Schepp $\because$ Carpenter, 51 X. Y. 1902. 


\section{CONSIDERATION OF Negotiabe instrumexts. \$101.}

curity for, his debt, as entitled to the full protection of a bona fide holder for value, free from all equities which might have been pleaded between the original parties. ${ }^{35}$ But there is much controversy on this subject, and it is hereinafter more fully treated. ${ }^{3 \mathrm{u}}$

\section{SECTION. III.}

WHAT ARE ILLEGAL CONSIDERATIONS.

\section{$\$ 101$. As to illegal considerations generally.-A nego-} tiable contract which is founded upon an illegal consideration, in whole or in part, is void $;^{3 \pi}$ for the law will not aid ono who seeks, or has consented to, its violation. Sometimes the consideration is illegal, because opposed to tho general principles of the common law; and sometines because it is specially interdicted by statute. The considerations which are illegal at common law are: 1 . Such as violate the rules of religion, morals, or public decency; and, 2. Such as contravene public policy. ${ }^{38}$

$\$ 102$. Illegal considerations by the common law; wagers, futures, etc.- Is a general rule, wagers were not illegal by the common law. ${ }^{39}$ But wagers upon the sex of a person; ${ }^{40}$ that an ummarried female would bear a child; ${ }^{41}$ upon the result of a prize fight $;^{42}$ or the result of a criminal trial $;^{43}$ or the result of an election ${ }^{44}$ or upon the question of war or peace, ${ }^{45}$ would be illegal as opposing public policy and

35 Daniel on Negotiable Instruments, $\S 832$; Devendorf v. W. Va. O. \& O. L. Co., 17 W. Va. 176.

36 Daniel on Negotiable Instruments, $\$ \S 820,826,827,831$.

37 Frick v. Moore, 82 Ga. 163; Daniel on Negotiable Instruments, $\S 204$.

38 Daniel on Negotiable Instruments, \& 195.

39 Good v. Elliott, 3 T. R. 693.

40 Da Costa v. Jones, Cowp. 729.

41 Ditchburn v. Goldsmith, 4 Campb. 152.

42 Hunt v. Bell, 1 Bing. 1, 7 Moore, 212.

43 Allen v. Hearn, 1 T. R. 57 ; Rust v. Gott, 9 Cow. 169.

44 Lockhart v. Hullinger, 2 Ill. App. 465; Attwood v. Weeden, 12 R. I. 293.

45 Thompson v. Harrison, S. C., Tex., Dallam's Dee., 466. 
sound morals. And, as a general mule, in the Lnited staltaall manner of wagers are declared illegal hy statutory enaletments; and eren where not prohibited hy statute, ther ale regarded as opposed to public policy and somel morality.4. Putting np margins in stock speculations is regarded at a species of ganbling, and notes given for such margins alle void as upon illegal consideration. ${ }^{47}$ In Massachusetts mon who pays a gambling debt for another cannot recoser the anomnt. $^{\text {As }}$ Ind also, as at general rule, in the Lnited States, contrats for the sale or purchase of commodities, such ats cotton or grain, when no actual delivery of the same is contemplated or intended, such transactions being contmonly known as "futures," are lield contrary to public policy and roid. A bona fide contract for the future delivery of any article is valid, but if the contract amount to a mere staking of margins to eover the difference between the price of the article at the time of purchase and the time of delivery, it is roid. ${ }^{49}$

$\S 103$. As to considerations which oppose public policy.Considerations which oppose public policy are never respected by the law, and contracts founded upon them are universally condemned. Contracts in general restraint of trade ${ }^{50}$ or restraining or preventing marliage even for a time; ${ }^{51}$ or to assist another in furthering a marrage where the promisor has no right to interfere .2 $^{2}$ ehampertons eontracts between attorney and client, ${ }^{53}$ to procure or sell a public office ${ }^{54}$ or votes; or to induce a candidate to withlraw; ${ }^{55}$ to suppress evidence or interfere with the course

46 Bonghner v. Mayer, 5 Colo. 75.

4 ti Fareira v. Gabell, 89 Pa. St. 89.

48 Scolluns v. Fly'll, 120 Mass. 271.

49 Bigelow v. Benediet, 70 N. Y. 202; Gregory $\mathrm{v}$. Wendell, 30 Mich. 337 ; Irwin v. Williar, 110 L. S. 499.

so ('hitty on Bills [*83], 99.

51 Hartley $r$. Rice, 10 last, 22 : Lowe v. Peers, 4 Burr. 22.25.

52 Roberts v. Roberts, 3 P. Wins. 66; 1 Parsons on Contracts, 555, 556.

5.: Million v. Ohmsberg. 10 Mlo. App. 432.

54 Richardson v. Mellish, 2 Bing. 2.29; Martin v. Wade. 3i Cal. 165.

Ei Ham v. Smith, 87 Pa. St. 63. 
of justice by dropping a criminal proseention ${ }^{56}$ and eontracts to indemnify a person in doing an act of known illegality as inducenent thereto $;^{57}$ or to do anything reprehensible for its injurious effeets upon the feelings of third persons; or in frand of the rights and interests of third persons, ${ }^{58}$ are instances of the kind of eontracts which the law will not recognize.

Abandomment of the prosecution of an offense against the public of which the law requires prosecution is not a good consideration. ${ }^{59}$ It is not neeessary to stamp the transaction with illegality that a felony should have been eommitted; ;i) but a note given to a prosecutor after trial and convietion for the expenses of the prosecution wonld be valid; ${ }^{61}$ other instanees of a similar character might be multiplied. The true question in such cases seems to be, was the note given for the money, or to settle the prosecution. In the first event, it would be valid; in the latter, illegal and void. ${ }^{62}$

$\S 104$. As to considerations illegal by statute.-The bona fide holder for value who has received the paper in the usual course of business is unaffected by the fact that it originated in an illegal consideration, without any distinction between cases of illegality founded in erime, involving moral turpitnde, which are termed mala in se, and those founded in positive statutory prohibition which are termed mala prohibita. The law extends this peenliar protection to negotiable instruments, because it would seriously embarrass mereantile transactions to expose the trades to the consequences of having the bill or note passed to him impeached for some covert defeet. ${ }^{63}$ There is, however, one

5f Commonwealth v. Johnson, 3 Cush. 454; Soule v. Bonney, 37 Me. 128.

$5 \pi$ Chitty on Bills [*85], 102; Goodale v. Holdridge, 2 Johns. 193.

59 Sullivan v. Bonesteel, 79 N. Y. 631 ; Ward v. Doane, 43 N. W. 980.

59 Haynes v. Rudd, 102 N. Y. 372; National Bank v. Kirk, 90 Pa. St. 49.

(x) Rogers v. Blythe, 51 Ark. 523; Chandler v. Johnson, 39 Ga. 85.

61 Kirk v. Strickwood, 4 B. \& Ad. 421.

62 Godwin v. Crowell, 56 Ga. 566.

63 New v. Walker, 108 Ind. 365; Thompson v. Samuels, 14 S. W. 143. 
exception to this rule; that when a statute, expressly or by necessary implication, declares the instrument absolutrly roid, it gathers no vitality by its circulation in respect to the parties executing it, ${ }^{\text {it }}$ though eren upon such instruments an indorser may be held liable to a bona fiele lusbler without notice. ${ }^{\text {is }}$

There are a very few cases in which the statute remilers sucle instruments absolutely void; and the nost important, if not the only instances now to be met with, are the statutes against usury and gamingr. ${ }^{60}$

\section{SECTION IY.}

\section{BY WHAT LAW LEGALITY OF CONSIDELATION IS DETERMINED.}

$\$ 105$. Determined by the law of country where made.'The legality of the consileration of a contract is to be determined by the laws of the State or comntry where the contract is made and not by those of the State or conntry where the suit is brought. The rules of every nation, from comity, admit that the laws of erery other nation in foree within its own linits ought to have the same force everywhere, so far as they do not prejulice the rights of other govermments or their citizens. ${ }^{\text {it }}$ The rule is founded not merely on the convenience, but on the necessity of nations; for otherwise it would be impracticable for them to carry on an extensive interconrse or commerce with each other, or eren for sceial order to exist. ${ }^{\text {is }}$

$\$ 106$. Governed by law in existence at the time contract was made. - The laws in foree at the time a contract was entered into detemine its legality and effect; and where a

(it Vallett v. Parker, 6 Wend. (115: Hateh r. Burroughs, l Woods, 439;

Foods v. Armstrong, 54 Ala. 150.

6o Daniel on Negotiable Instruments, s 67 i3 et seq.

6o Savings Bank of Kansas r. National Bank of Commerce, 38 Fed. 800; Union Nait. Bank v. Frater, (i3 Miss. 231.

67 Thorington v. Smith, 8 Will. 11: Cook v. Lillo, 103 C. S. 793;

Daniel on Negotiable Instrmments. \$ Stis et seq.

68 Boyce v. Tabb, 18 Wall. 545; Danicl on Negotiable In-truments, $\S 866$. 
law prohibiting the sale of spirituous liquors has been repealed, it does not thereby validate a note given in violation of the statute when it was in force. ${ }^{6}$ And accordingly it has been held by the Suprene Court of the United States that a note dated March 26,1561 , and given for a slave, could be recovered on, notwithstanding that slavery was abolished on tine 1st day of Jamuary, 1862, and the contract of sale eontained the warranty, "the said negro to be a slave for life," "and also notwithstanding the thirteenth amendment to the constitution, made in 1865, by which it is ordained that "neither slavery nor involuntary servitude shall exist in the Inited States nor in any place subject to their jurisdiction."

In the State tribunals of the Southern States, where this question has been of much consequence, conflicting views have been taken, but many of the cases concur in judgment with the Supreme Court of the United States, ${ }^{71}$ and in other States of the Cnion, both before and since the war, the principles of these decisions have been asserted. ${ }^{22}$

\section{SECTION $Y$.}

PARTIAL WANT, FAILURE, OI ILLEGALITY OF CONSIDERATION.

$\$ 107$. Partial want of consideration.- Whenever the defendant is entitled to go into the question of consideration, he may set up the partial as well as the total want of consideration. ${ }^{73}$

So, where a father gives lis son a note partly for services and partly as a gratuity, the partial want of consideration

69 Daniel on Negotiable Instruments, § 168; Holden v. Cosgrove, 12 Gray, 216.

io Osborn v. Nicholson, 13 Wall. 655; Boyce v. Tabb, 18 Wall. 548.

71 McElvain v. Mudd, 44 Ala. 48; Thompson v. Warren, 5 Coldw. 644; Dowdy v. McClellan, 52 Ga. 408; Calhoun v. Calhoun, 2 S. C. 283. Contra, Laprice v. Bowman, 20 La. Ann. 234; Lytle v. Wheeler, 21 La. Ann. 192.

72 lioundtree v. Baker, 53 Ill. 241.

7. McGregor v. Bishop, 14 Ont. 10; Daniel on Negotiable Instruments, $\S 201$. 
might be pleaded as to such portion of the anomut as was gratuitoms; and it would be mo objection that no distinct amomt was fixed 11 ron ats compensition for the services, but it would be for the jury to settle what amonnt was fonnded on the one consideration, and what on the other. it If a note be given by mistake on settlenent of aceonutis for an amomnt greater than that actually due, there is want of consideration as to the exeess, and between the partics it may be pleated."is

$\$ 108$. Total and partial failure of consideration.-The total failure of consideration is as grood a defense to a suit upon a bill or note as the original want of it, and is confined to the like parties. If the contract is rescinded, the consideration of the hill or note totally fails, and parment of it camnot be enforced.i:

And a partial failure of the comsideration is a good defense pro tanto. ${ }^{i 7}$ But such part as is allegenl to lave faileal must be distinct and definite, for only a total failure, or the failure of a specific and asecotained part, an be availed of by way of defense; and if it le an moliguidated clain the defendant must resort to his cross-aletion. is Thus, where bills have been acepted in consileration of the payce giving the acceptor the lease of a house, and he let him into possession, but gave no lease, it was held no defense to an action on the bill, but that there wats merely a comteredaim for damages. ${ }^{3}$ So where the hill was wiven for work to be done, and the work when done was bungled in part, and not worth the amount of the hill." It may be observed, howerer, that in most of the states the common-law mle restrieting the defense of set-off to liquidated claims, is so far modified as to admit equitable defenses in the natme of

74 Parish v. Stone, 14 l'ick. lns.

is Secley v. Engell, 13 X. Y. 542: Claxon v. Demaree. 14 Bush. 173.

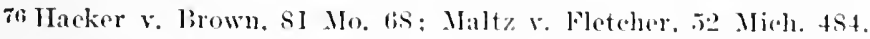

7t Agnew v. Aden, 84 Ala. 502: Torinus v. Buckham, og Minn. I2s. is Elminger v. Drew, 4 MeLean, 3ss; Stone v. Peake, 16 Vt. 213;

Pulsifer r. Hotchkiss, I2 Conn. 234.

79 Moggridge $v$. Jones, 14 East. 4s. .

80 Trickey v. Larne, 6 M. \& 11.278. 
set-off, as fraud or mistake in the procurement of a contract, or any other matter entitling the party to relief in equity against the obligation of the contract. ${ }^{11}$

$\$ 109$. Partial illegality of consideration.- When the defense is founded on illegality of consideration, it is to be distinguished from a defense on the ground of a want or failure of consideration by this peculiarity - that a partial illegality vitiates the bill or note in toto, while the partial want or failure of consideration only vitiates it pro tanto. ${ }^{82}$

And a mortgage to seeure a bill or note of which the consideration is in part illegal is also wholly void. ${ }^{83}$ The reason of the distinction is hased mainly upon the ground of public poliey, the courts not undertaking to mrarel a web of fraud for the benefit of the party who has woren it. If: If, however, the legal portion of the consideration were distinctly severable, the party conld still recover by the proper action to its proportionate extent, ${ }^{55}$ though not upon the bill or note. ${ }^{86}$ There is authority, however, to the effect that there may be a reeovery on the bill or note to the extent of the distinctly severable and valid consideration. ${ }^{87}$ Where the legal part of the consideration exceeds the amount of the note, though another part of the consideration be illegal, the note will be ralid. ${ }^{\text {ss }}$ And it has been held that where a bill is given in renewal of other bills, one of which was upon an illegal consideration, it would be valid as to the amount which the legal bills evideneed and roid as to the rest for want of consideration. ${ }^{89}$

$81 \Lambda_{\text {Pplegalth }} v$. Robinson, 65 Md. 493.

82 Hanauer $v$ Doane, 12 Wall. 342; Hyslop v. Clark, 14 Johns. 465; MeNamara v. Gargett, 68 Mich. 454.

83 Brigham v. Potter, 14 Gray, 522; Denny v. Dana, 2 Cush. 160.

84 Byles on Bills [*140], 256.

85 Carlton v. Woods, 8 Fost. 290 ; Widoe v. Webb, 20 Ohio St. 431.

8s Robinson v. Bland, 2 lurr. 1077; Hanauer v. Doane, 12 Wall. 342.

87 Clopton $v$. Elkin, 46 Miss. 95.

88 Warren v. Chapman, 105 Mass. 87.

89 Doty v. Knox County Bank, 16 Ohio (N. S.), 133. 


\section{SEC'TION VI.}

BETWEEN WHAT PARTES TIE CONSHORRATON IS OPLA TO INULIRY.

$\S 110$. Who are parties privy in negotiable instruments.'Tho sane rule which adnits inguiry into the consideration of negotiable paper between the origimal payor and prageo extends to admit such inguiry in any suit between partics between whom there is a privity. 'That is to say, between the inmediate farties to any contract evidenoed by the drawing, aceepting, making, or indorsing a bill or note, it may be shown that there was no consideration (as, that it was for accommodation) $;^{90}$ or that the consideration has failed, or a set-off miy be pleaded; but as between other parties remote to each other, none of these defenses are admissible. It becomes important then to detemnine who aro to be regarled as the immeliate parties, or parties between whom there is a privity, to a nogotiable instmment, and who are remote. Among the former may be classed: (1) The drawer and aceptor of a hil ;" or (2) The drawer and payee $^{92}$ of a hill as a general rule; (:) 'The maker and payee of a note; ${ }^{93}$ and ( 4 ) The indorser and immediate indorsee of a bill or note. ${ }^{94}$

\section{$\S 111$. Who are remote parties to negotiable instruments.-} But the want of consideration, or the failure thereof, cannot be pleaded in a suit brought: (1) By an indorsee against the maker of a uote:

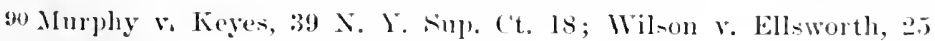
Nebr. 246.

91 Thomas $v$. Thomas, 7 Wis. 476; śpurgeon v. Melpheeters, 42 Ind. 527.

92 MeCulloch v. Hofman, 10 IIun, 133; Spurgeon v. IfoPheeters, 42 Ind. 527 .

93 kemedy v. Goodman, It Nebr. 5si, Flaum v. Wallace, 9 s. L. 571.

94 Barnett v. Offerman, T Watts, 130; Klein v. Keyes, J7 Mo. 320; Platt v. Sinipes, 43 Ark. 23.

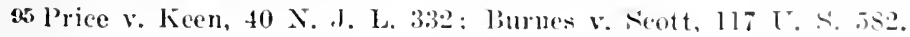


prior, but not his immediate indorser ; $^{97}$ (3) By the indorsee against the acceptor of a bill, ${ }^{9 \pi}$ nor by the payee against the aceeptor of a lill, as a general rule. ${ }^{98}$ They are regarded as remote parties to each other, and between such parties two distinet considerations must be inquired into in order to perfect a defense against the holder: (1) The consideration which the defendant received for his liability; and (2) That which the plaintiff gave for his title. ${ }^{99}$ And if any intermediate loolder gave value for the instrument, that interening consideration will sustain the plaintiff's title. ${ }^{1}$

$\S 112$. Want, failure, or fraudulency of consideration.If the original consideration were tainted with frand or illegality, or has failed in whole or in part, and the bill or note has passed into the hands of a bona fide lolder for value withont notice, yet if it he returned for a valuable consideration to the payee who is a privy to the original consideration, he cotill stand upon no better footing than if the instrmment had remained in his hands."

$\$ 113$. Defenses between privy parties. - That the bill or note has bren lost or stolen, ${ }^{3}$ or was executed under duress, ${ }^{4}$ or under fraudulent misrepresentations," or for fraudulent consideration," or for illegal consideration," or has been frandulently obtained from an internediate holder, ${ }^{8}$ or

93 Etheridge $v$. Callagher, 55 Miss. 464; 1 Parsons on Notes and Bills, 17 ris.

эз F’lower \&. Sadler, 10 Q. B. Div. 572.

48 Laflin \& Ramd Powder (o. r. Sinsheimer, 48 Md. 411; Hoffman \& Co. v. Bank of Milwaukee, 12 Wall. 181.

99 Cuited States r. l3ank of llotropol:s, 15 Pet. 393; Swift v. Tyson, 16 Pet. 1 ; Goetz v. liank of Kamsas City, 119 U. S. 556.

1 Foyd r. Mccaum, 10 Ml. 118; Watson v. Flannagan, 14 Tex. 3.54.

a Sawyer v. Wiswell, ! Allen, 42; Kost v. Bender, 25 Micl. 5l6;

Cline r. Templeton, is ky. 550.

3 Mills v. Biutiber, I M. \& WV. 425.

4 Clark r. Peare, 41 X. Il. 414: Grifith v. Sitgreaves, 90 Pa. St. 161.

5Vathir v. Zane, (j Gratt. 246; Hutchinson v. Bogg, 28 Pa. St. 294.

6 Pogers v. Morton, 12 Wend. 484.

T Shirley v. Howard, 53 Ill. 45.5; Holden v. Coegrove, 12 Gray, 216.

s 1 l'arsons on Notes and Bills, 188. 
been in any way the suleject of framl of felony, or lias been misapplopriated and diverted, ${ }^{10}$ or that it wals given ats collateral security " or for a loss for wheh the party was mot liable, or that othervise it was without valuable consirlerattion, ${ }^{2}$ is a good defonse as between the partion privy to il. And in some alses that it was given by mistalke for tor gureat a sum, or when no stm was due, the eridence showine framel or a total or partial want of eonsideration. ${ }^{13}$ The sane defense which the defendant might make to an action hy an indorsee of the uste given hy lime and the sane requirement of proof, may he made by him in an action on a renewal of a forner note, hoth notes being regarded as given upon the sane consideration. ${ }^{14}$

\section{SECTON VII.}

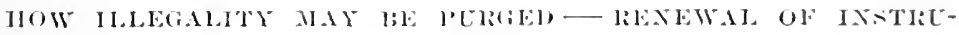
IIENT.

$\$ 114$. As to bills and notes given in renewal.- It the consideration of the miginal bill of note be illegal, a rencwal of it will be open to the sanne objection and defense; ${ }^{15}$ and if the original instrument was obtained by fand, a renewal of it by the original parties without knowledge of the fraud, would stand moon the same footing." Bu but if at the time the senewal was exernted the jatrties siening knew of the frand in the original, they will be regaled as proging the eontract of the framl, and rament then plear it. ${ }^{17}$ so if the maker of a note held by an indorse who knew that the

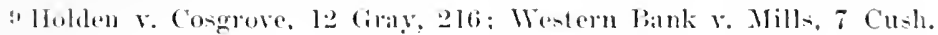
546 .

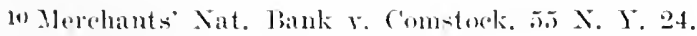

11 Jeighton r. Bowrn, 75 Me. 504.

12 boxter sav. Bank v. Copeland, 7t Mle. 269.

$1:$ Forman v. Wricht, 11 com. 13. 481.

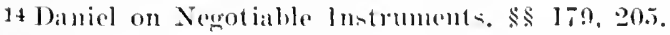

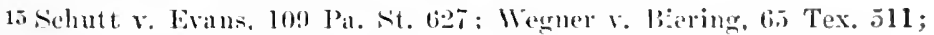

Sawyer r. IViswell, ! Mllen, 39.

14: silwer v. Wiswall, 9 Mllen, 39.

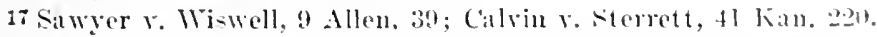


consileration between the maker and the payee lad failed when he took it, executes to him a new note, it has been liek to be a wairer of the defense, and the payce of the new note can recover. ${ }^{18}$

\$115. Partial illegality of instrument.- If a note or bill be given for a consideration which is in part illegal, a new note for the same, or in renewal of the first, is equally void. ${ }^{19}$ But a new note for that part of the consideration which is legal is good and ralid. And if several new notes are given for the old one, sone of the new ones may be taken to be for the legal part, and so be valid, especially if they are only adequate to this part or if the deduction be otherwise favored by circumstances. $^{20}$

1 Gill ^. Morris, 11 Meisk. 614; Keyes r. Mann, 63 Iowa, 560.

19 Chapman v. Black. 2 B. \& Alıl. 588; Seeligson v. Lewis, 65 Tex. 115: Preston v. Jackson, 2 Stark. 237.

20 Daniel on Negrotiable Instruments, \& 206; Crookshank v. Rose, 5 Car. \& P. 19. 


\section{BOOK II.}

\section{PARTIES TO THE INSTRUMENT.}

\section{CHAPTER VI.}

\section{PERSONS QUALIFIED.}

\$116. It was once thonght that none but merehants eould be parties to negotialse instruments, but this notion long since became obsuleter, ${ }^{1}$ and it is now well settled that any person laboring moler no persomal or political disability may be a party to any negotiable contract.

Tro shall first speak of those who may be parties, ant then of those who are purtially, or wholly diequaliticed.

\section{SECTION I.}

FIIUCLARIES AS PARTIES.

$\$$ 117. Personal representatives. - In administrator $91^{\circ}$ executor camnot bind the decedent's estate by any negrotiable instrmuent; he can mly bind himself. If he make. acept, or indorse a negotialle instrmuent he will bind himself personally, even if he athes to his wrm nane the designation of his office as personal representative. Thus, if he

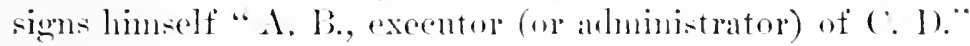
or "A. B., as executor of ('. I).," the representative terme will he rejected as surphuage." And an alecommodation indoreer, or aceeptor, who privs the amomt of the instrument. has no claim and the deecelent sestate." But if the hibl or note of the personal representative he talien for a dut

1 Chitty on Bills [*15], 20: Daniel on Negotiable Instrument=, s. 2ns.

2 king v. Thom, 1 T. R. 4s.: cirengry ve Leigh, 33 Tex. 813: Snend v. Coleman, 7 Gritt. 300.

3 Kirkman v. Benham, 2S -11a. 501. 
of the decedent, the estate is discharged from liability, and the representative alone is bound. ${ }^{*}$

\section{$\$ 118$. Personal representative individually bound.- Assets} in the hands of the personal representative eonstitite a sufficient consideration for a promise to pay the decedent's debt. Ile is presumed to have sufficient assets, and henee it is presumed that the obligation is based upon a sufficient consideration. ${ }^{5}$

Is between the original parties, the presumption is rebuttalble, and he may, therefore, show total or partial deficiency or insufticiency of aseets, and thus defeat liability in tolo or ino tunto; but in the hands of a "holder for value," the better opinion is that the presumption of consideration would be eonclusive. ${ }^{6}$

But if he dexires to exchude all personal liability, he ean do so by restricting his promise to pay "out of the assets of ('. D.," or ly the use of any other expression of similar import. ${ }^{\top}$

$\$ 119$. Power to transfer.-If the instrument he payable to the order of decedent, the personal representative may transfer it ly indorsement; and if there be several executors or arlministrator's, the title mar be transerred by the indorsement of any one of them. ${ }^{8}$ While it has been held otherwise where the note was made payable to the several exeentors for a deht due the estate, the view sustained by the weight of authority seems to recognize no such distinction. ${ }^{9}$

4 Wisdom v. Becker, 52 III. 346; Cornthwaite v. First Nat. Bank, 57 Ind. 2 tio?.

¿. Snead v. Coleman, T Gratt. 303: Boyd v. Johnson, 14 S. W. 804.

"Bank of Troy $v$. Topping, I3 Wend. 273; Rucker v. Wadlington, 5 .J. J. Marsh. 23s; Stecle v. McDowell, 9 Smedes \& M. 193; Byrd v. Holloway. 6 Sinedes \& M. 199; Edwards on Bills, 78.

T. Snead v. (oleman, 7 Gratt. 303; Kirkman v. Boulaum, 28 Ala. 501. \& Cahoun r. Moore, 11 Vt. 604: Mackay v. St. Mary's Church, 15 R. I. I21; Dwight v. Newell, 15 Ill. 333; Hertell v. Bogert, 9 Paige, 52. a Simith v. Whiting. ! Mas. 334: Bogert v. Hertell, 4 IIill, 492; 1 Parsons on Notes and Bill, 15in; Mackay v. St. Mary's Church, 15 R. I. 121. 
$\$$ 120. Guardians and trustees. - Guardians camnot bind their warels' estaten, nor trustecs the estates of their cestuis que lauslent by lills or notes; and heneer, thongh they sign themselves as gualdians or trustees, they are pelesomally bound, beeanse otherwise the instrument would be invaliul." It is true that they may contract to pay ont of an estate: lut then the parronent would he combitional on the sullivieney of the estate, and the instrument, therefore, not regotiable. ${ }^{11}$ If a mandian take a note payable to his oreler ats enaldian for the property of his warl, and indorse it to a bona fide party for valure, it has heren helel that it is a wood transfer, the worre, "als whardian," ete., berng mere descriplio persone." lint the better opinion seems to be that while if the fieluciary, indicated as paree, may transfer at enod title, provided he makes the transfer within the anthority of and for the hemetit of his trust, yet that such Wouds as trustee, ete.e suffixed to a payer's name put his inclorser upon inguiry as to the title, and if the transfer he in fraud of the trust, the inclorsee must suffer the consequence. 13

\section{SEO"TION II.}

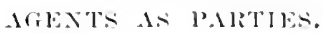

S121. All persons who are themselves competent to become parties to a newotiable contrat, in their own individual right, ean do so thromely the instrmmentality of an agent.

'Three things are osential to the coreation of an obligation wh the part of ome intivinual ly and through the act of another, viz.: (1) The principal himself must he competent: (2) the agent must he competent to act as such; (8) anthoritre, express or implied, verlual or in writing, must be confermed ly the principal npon the acent.

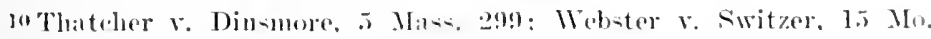
Iple. 351; Commer v. Clark, 12 Cal. las.

11 latsons on Notes and lills, 90: Ntory on Bills. 5 74. 75.

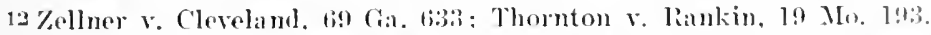
1: Third Nat, Bank v. Lange, il Mal. 138: Shaw v. Spencer, lo0 Man. 382. 
Enough has been already said with referenee to the eapacity of the principal, and no further elaboration on that subject is deemed necessary. But, referring to the contpeteney of the agent, it should be obeerved that it is not necessary that the agent should be himself competent to make a contract. Ile is the mere instrument of the eontracting capacity and will, and Mr. Chitty says: "As this ageney is a mere ministerial office, infants, feme coverts, persons attainted, outlawed, excommmieated, aliens and others, thongh incapalle of eontracting on their own accomt, so as to hind themselves, may be agents for these purposes." 14

During the existence of slavery in the Lnited States it was held that a slave night be an agent. ${ }^{\text {th }}$ But imbeeiles, lmatics, and children of tender years, who actually lack capacity to be intelligent instrmments, and have not the power or discretion to consent, conld hardly be regarded as competent to be eren the agents of another.. ${ }^{16}$

$\$ 122$. Express authority. - It is not neeessary that express anthority shonld be granted in any particular form. moless it be anthority to execute an instrument muler seal, in which ase it also must he muler seal. Otherwise the anthority may be written, or oril; and the agent, to execute or inclorec a negotiable instrument, needs nothing more than verbal anthority so to do, ${ }^{17}$ though it was once thonght that a formal power of attorney was necessary. ${ }^{18}$ It is obrious, howerer, that it is safer for one, dealing with an alleged agent, to require production of written authority; or ot herwive ummistakalble oral proof that authority haul been given. If the anthority is in witing, it eannot be disputerl by parol proof of contrary verbal instructions to

14 Chitty on liills [\%28], 36. See Edwards on Bills, 95; Coke's Littleton, 52e.

15 Governor $r$. Daily, It Ala. 469.

16 Thompen on Bills. 147.

17 C'hitty on Bills |

18. Inum v. King, d; Munf. 428. 
the agent, or otherwise ${ }^{19}$ besicles, it proves itself whenerer produced, and its gemineness is etablisherl.

\$123. Authority "by procuration." - While it is truse, at stated in all text-books on the general subject of (c)ntract law, that there are some positions of ageney in which, in the nsual erompe of businese, the agent maly draw, inder'se, or accept negotiable instruments, althomgh postively again-t the principal's instructions, - $i$. e., general acents, aleting within the general seope of their authority - the principle, howerer, is subject to this linitation, that wheneser an anthority purports to be derived firom a written instrument, ol the agent signe the palper with the work " by procurat tion," in such a case the party dealing with him is bound to take notice that there is a witten instrument of procuration, and he onght to all for and exanime the instrunent itself to see whether it justities the ate of the agent. Cuder such cirenustances, he is chalreable with inquiry as to the extent of the agent's anthority: and if, withont cxamining inte it when he knows of its existence - and especially if he has it in his presecsion - he ventures to deal with the agent. he acts at his peril, and must lear the loss if the agent transcended his authority." Do but uo such duty exists to make inquiry respecting private instructions to the agent from his prineipal, whether written or oral, for they may well be presumed to be of a secet anel confidential nature. ${ }^{21}$

$\$ 124$. Implied authority from express authority. - From the express anthorization by the principal, the law will imply such additional power andi anthority as may be absolutely necessary to effectuate the intention of the principal and to fully execute that which is expressed. Thus, when the authority to execute or iurlorse a negotiable instrument. is souglit to be deduced from an aneney to do ceptain other acts it must be made to appear affirmatively that the signing or indorsement of such an instrument was within the

19 Thompson on Bills. 147. 148.

9u Stainback v. Bank of Virginia, 11 Gratt. 259: North River Pank r. Aymar, 3 Hill, 262.

21 North River Bank v. Aymar, 3 Hill, 262; Story on Ayency, 53. 
eneral objects and purposes of the authority which was actually conferred. And in interpreting the anthority of the agent, it is to be strietly construed.: ${ }^{2}$ 'Thus a general anthority to transalet busines for the principal, will not anthorize the agent to hind him as a party to negotiable paper, accorting to many anthorities, and the general principles "ft the law of acener.: It has been held that anthority to transact all business for the principal, would empower the agent to transfer a negotiable instrument in his principal's name $;^{2 t}$ but the weight of anthority is to the contrary." Authority to conduct, in one's place and stead, his commer(ial business, and sign the principal's name whenever reyuisite or expedient in the attorney's good discretion, wondd, lowever. he hroad enough to cover cases of drawing bille of exchanger, and so likewise authority" to act. "as lawful "ashier and financial agent." $2 \pi$

$\$ 125$. Authority implied from custom.- If the principal stand by and tacitly eoncur in the act of the agent signing lis name, he womld be as strictly lomd as if he hat expressly authorized the agent so to do. So, anthority may be inplied from the comrse of business and employment, or from repeated reergnitions by the prineipal of the agents anthority ${ }^{2 s}$ Thus, where a drawce hat previonsly paid ser(ral bills aceepted in his name by a thind person, with whon lor had connections in trade, he womll be liable to an indorsee, although the bill aceepted in like manner had been $-\infty$ arecepted without his authority. ${ }^{29}$ And it has been held that if a perion usually sulseribes a negotiable instrument with the name of another, proof of his having done so in

22 Byles on Jills [*32], 108; Sewanee Mining Co. v. MeCall, 3 Head, (i)!.

2: Sewance Mining (o. $\mathrm{r}$. MreCall, 3 Head, 619; Chitty on Bills [*2?, $30], 39$.

24 Bailey v. Rawley, 1 Swan, 205; Frost v. Wood, 2 Conn. 23.

25 Kilgour r. Finlayson, I H. Bl. 155; Hay v. Goldsmidt, 2 J. P. Smith, 79.

2: Dollfus v. Frocch, 1 Den. 368.

27 Filwards $v$. Thomas. fif Mo. 482.

2s lake Shor Xat. Bank v. Colliery Co., 58 N. Y. Supp. 63.

st liarber v. Gingell. 3 F॰p. 61 : Stroh v. Hinchman, 37 Mich. 490. 
many instances is suflicient to chalge the party who-e name is subscribed, withont producing any lower of attoney otler proof of agency. ${ }^{30}$ but when it is solght to bind the principal on the ground of prior sindiar transatetions, or recognition of such acts hy the rrincipal, it mu-t lue. shown that the bill or note was taken upon the falith of them. 31

\$126. How agent should sign. - Tho best mode for an agent to sign or indorse a negotiable instrmucnt for lis principal, so that it may elearly appear that he is " the mon"e scribo" who applies the executive hand as the instrunent of another, is as follows: "A. B., by his attorney or acent, C. I.; " or, "A. B., ly ('. 1)., agent;" or, “ (. I)., for 1. I3.; " or, "C. D., agent for A. 13." 32

But it is competent and proper also for the agent to sign simply the principal's name, and to show his anthority to do so by extrameons evidence:" ford, as said ly the linited States Supreme Comrt, per Johm-on, J.: " It is by no neans true that the acts of agents derive their validity from professing on the face of them to have leen lone in the excrciso of their agency." 34 But this style is not favored, as it inereases the difficulties of proot, and at one time was questioned.35

\$ 127. Undisclosed principal. _ It is a general principle of commercial law that a negotiable instrument must wear no mask, hut must reveal its character mon its face. And it extends to the liability of parties thereto, who must alpean as distinctly as the terme of the instrument itsolf, in ordele to be homil therely. It follows, therefore, that mo party

:0 Neal v. Irving, 1 Esp. 61; Haughton v. Ewbank, 4 Camph. Isa.

21 St. John v. Rechmond, 9 Port. 42s: Elwiads on Bills, s!.

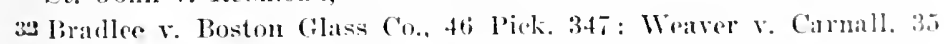
Ark. 19S; I Parsons on Notes and Bills, 9I; Tannant v. Rocky Mountain Nat. Bank, I Co!o. 2-is.

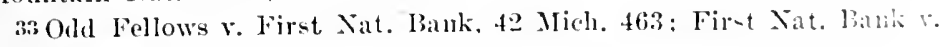
Gay, 63 Mo. 33.

34 Meehanies Bank r. Bank of Columbia. 5 Wheat. 326.

an larsons on Jotes and 13ills, 91. 92. 
can be charged as principal upon a negotiable instrument mless his niane is disclosed thereon. The reason of this rule is that each party who takes a negotiable instrument makes his contracts with the parties who appear on its face to be bound for its payment; it is " a conrier without lugsgage." whose countenance is its passport; and in suits upen negotiable instrments, no evidence is adnissible to charge any person as a principal party thereto, muless his name in some way is disclosed upon the instrmment itself ${ }^{36}$ although upon other written contracts, not negotiable, it is often competent to show that, although signed in the name of the agent only, they were execnted in the business of the principal, and with the intent that he shonld he bound. And in such eases he is bound upon them atcordingly. ${ }^{37}$ The rule exchuling parol evidence to charge an munamed principal as a prarty to negotiable paper is derived from the nature of snch paper, which being made for the purpose of being transferred from hand to hand, and of giving to every -nceesive holder as strong a claim mon the original party as the paree himself has, must indicate on its face who is bound for its parment; for any adlitional liability not expresend in the palper would not he negotiable. ${ }^{38}$

$\$ 128$. When agent individually bound.- If the agent sign a note with his own name, and discloses no principal, he is personally bound. The party so signing must have intended to bind somebody upon the instrument, and 110 promisor but himeelf thereon appearing, it must be construed as his note or as a nullity ${ }^{39}$ And though he term limself "agent," such suftix to his name will be regarded as a mere descriptio personer, or as an earmark of the transaction, and may be rejected as surplusage. ${ }^{40}$

3" Cragin v. Lovell, 109 L. S. I94; Texas Land Co. v. Carroll, 63 Tex. 51: Brown v. Baker, 7 Allen, 339.

3i Lermed v. Johns, 9 Allen, 419; Leavens v. Thompson, $55 \mathrm{~N}$. Y. Supp. 391.

25 Mebster v. Wray. 19 Nelsr. 558; Heaton v. Myers, 4 Colo. 62.

39 Arnold v. Stackpole, 11 Mass. 27: Sharpe v. Bellis, 61 Pa. St. 71 ; Finan $\because$ Babcock, 58 Mich. 305.

40 Toledo Iron \& Agr. Works v. Heisser, 51 Mo. I28; Arnold v. sprague, 34 Tt. 409. 
It the agent exceed his anthority in signing his principal's name, or sign his own professedly as hinding his principal, who is named, he is not bound as a party to the palpere itcelf, but only in an action of tort for falsely assmung authority

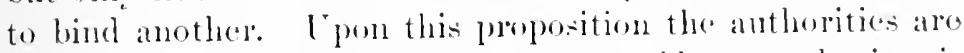
not muform, but the weight of reason, if not antlority, is clearly in its faror, both in England and in the Lnited Sitates.

129. Ratification.- A corporation, as well as an individual, may ratify the acts of another, when such acts aro done and performed in the name of the alleged principal; and the ratification maly be by express consent, or by conduct of the alleged prineipal inconsistent with any other lypothesis than that he approved and intended to adopt what had been done in his name. Intelligent aequiescenco anuounts to a bincling ratification. ${ }^{42}$

Three things are csecential to a ratification: (1) The party must lave capacity to have made the contract in the particular node adopted; $(2)$ the principal must have known all of the facts attending the transaction; (3) the contract must have been originally lawful. ${ }^{43}$

$\$ 130$. Revocation of agency.- A general authority to an agent is presumed to continue until its revocation is generally known. And if $A$. is the agent of $B$. to draw bills in his name, B. will be liable as drawer to ignorant indorsees, who had no knowledge of the change in the relationship of the parties, or of the revocation of the ageney. ${ }^{4}$

Death or insanity operates as a revocation of all agencies not compled with an interest vested in the agent; ${ }^{45}$ but war between the countries of the principal and the agent does not."

41 Daniel on Negotiable Instruments, \$ 306, and cases cited.

42 Knox County v. Aspinwall, 21 llow. 54t; Supervisors v. Sehenek, 5 Wall. 782; Bissell v. Jeffersonville, 24 How. 299: Damiel on Negotiable Instruments, $\$ 317$.

43 Daniel on Negotiable Instruments, $\$ \$ 318-320$.

44 Chitty on 13ills [*32], 42: Ntory on Ageney, $\$ \$ 470,473$; Smith v. Stranger, Peake Add. 116.

45 1 Parsons on Contracts, 71 .

4*: Daniel on Negotiable Instruments, $\$ 2.2$. 
\$ 131. Banks as collecting agents.- For the convenience of the mercantile world banks are frequently made the collecting agents for the owners or holders of commereial paper. But the mere fact that a bill or note is made payable at a bank does not of itself confer any agency upon the bank, on the part of the payee, to receive the amount. In order to make the bank the payee's agent to receive the mones, the paper must be indorsed to, or lodged with, it, for collection, or it must have received anthority from the payee to collect the amomnt due; ${ }^{47}$ and without such circmustances or sucls authority any amount which the bank receives to apply in payment, it will be deemed to have taken as the agent of the paror. ${ }^{48}$

\section{\$132. Duty of collecting agent to present for acceptance} and for payment. - It is the duty of the bank, as soon as the bill, note, or check is placed in its hands for collection, to take the aprropriate steps necessary to its prompt payment or prompt acceptanee, by making presentment for acceptance withont delay, and presentment for payment at maturity. And if the instrument be not duly aceepted or paid, the lank must take all neeessary steps to fix the liability of the drawer, if it be a foreign bill, by plaeing it in tho hands of a notary for protest, and by giving due notice of its dishonor to the party who indorsed the instrument to it for collection, whether it be a bill or note, inland or foreign. If the bank fail in any of these duties, it becomes immediately liable in clamages to the holder. ${ }^{49}$ Assuming that the collecting hank properly and promptly discharges its duty as to presentment for acceptance and for payment, it is not bomul to pay the amount of a bill, note, or check placed in its luands for collection to the holder, until such amount is received, or would be received but for the default of itself or some agent for whose act it is responsible. ${ }^{50} \mathrm{It}$

47 Caldwell v. Erans, 5 Bush, 380; Balme v. Wambaugh, 16 Mim. 120: Glatt v. Fortman, 120 Ind. 385.

48 Ward v. Smith, 7 Wall. 447; Pease v. Warren, 29 Mich. 9.

49 Allen v. Merchants' Bank, 22 Wend. 215; Smedes v. Bank of Utica,

20 Johns. 372; Blanc v. Mutual Nat. Bank, 28 La. Ann. 921.

50 Briggs v. Cent. Nat. Bank, 89 N. Y. 184. 
is frequently the case that for the accommodation of customers they are permitted to draw before, and in anticipation of, the reception of such amounts. But this habit is mere faror, and, though long continued, gives the customer no right to demand that it be done in any particular case. $^{51}$

\section{$\$ 133$. Ownership of paper in hands of collecting bank. -} I variety of circumstances give rise to controveries a to the right to clain paper, or the proceeds of paper, which was put in bank to be collected.

When the holder places his paper in bank, he n-wally does so in one of three ways: First. As a principal employing the bank as a mere agent for collection, in which easo the restrictive indorsement "for collection" is, $O \mathrm{I}^{\text {" }}$ should always be, used, so that all subsequent holders may be advised of the bank's want of title. This is the form of indorsement generally used when the holder is not a customer of the bank. Second. Is an arowed seller to the bank, in which case the indorsement is in blank and the transaction a plain one. Third. Is a enstomer having an aceount with the bank, in which ease the restrictive indorsement is or is not employed, according to the relations established by agreenent between the parties. If the bank treats the paper as a cash deposit, and allows the customer to draw against it in anticipation of the collection, the indorsement is generally in blank. ${ }^{52}$

\section{SECTION III.}

PARTNERS AS PARTIES.

$\$$ 134. General authority of partner to bind firm.- The general authority of a partuer to hind the finm springs from the mutual agency of the copartners for each other: and from the course and usage of the business in which they ale engaged. It follows, therefore, that a person contemplating partmership with another camot, without a special authol-

51 Seott v. Ocean Bank, 23 X. Y. 289: Morse on Banking. 365. 52 Danicl on Negrotiable Instruments, \$ $340 a$. 
ity lind him by a contract for the proposed partnership benefit - for eximple, for the purpose of raising capital his ageney not commencing until the connection is consummated. ${ }^{53}$ The copartnership being formed, the copartner can bind his associates only in such transactions as pertain to tineir partnership business; and the eopartnership business must be of such a character that the giving of negotiable paper would he the convenient and proper mode of conducting it, in order to create the presumption of agency in a copartner to give a bill or note in the firm's name.

\section{$\$$ 135. Implied authority of partner to bind the firm.- It} resnlts from the very nature of partnership - from the very fact that the copartners are mutnal general agents for each other in their copartnership affairs - that the express assent of one to the act of another within the scope of their busines: is mnecessary. The authority to each partner is implied to bind the firm within the legitimate scope of its hmines by the very fact that it is a tirm, and it has been said by Lord Ellenborough, C. J.: "It would be a strange and novel doctrine to hold it necessary for a person receiring a bill of exchange indorsed by one of several partners, to know whether the others assented to such indorsement or that it should be roid." 54

$\S 136$. Trading partnerships. - The borrowing of money and negotiation of bills and notes being incidental to, and usual in, the bnsiness of copartnerships fomed for the purpose of trade, it follows that when a copartner borrows money professedly for the firm, and executes therefor a negotiable instrmment in the copartnership name, it will bind all the partners, whether the borrowing were really for the firm or not, and whether he diverts and misapplies the funds or not, provided the lender is not himself cognizant of the intended frand. And the burden will not be

53 Pank of Fort Madion v. Alden, 129 U. S. 373; Greensdale v. Domer, 7 B. \& C. 635.

54 Swan v. Sterle, 7 East, 210; Fulton v. Loughlin, 118 Ind. 286. 
thrown on hine to show that he was not connizant of such framl, or to pure value given for the palper.

\$137. Nontrading partnerships.- In mencral, it maly les said that if the partuceship be a nontraling onc, there is no implied aneney or anthority in one partuce to sign the firm name, and thus bind the partureship, withont express authority foum all the members lheroot. Hence, the Linted States Supreme Comet has held that a lill draw by a partnel in the name of a firm engaged in farming, working a steam sawnill, and in trading, was binding, beranse trarling and ruming the mill repuired capital and the use of eredit; but if the fim had been engaged in farming alone, no one partner conld have hound it by a lill or note. ${ }^{5 ;}$ A firm engaged in mamnfacturing lmmber from logs, has been considered noncommereial, and that one of the partners could not bind the other by a note. ${ }^{5 \pi}$ So, also, one cungacel in the real estate and collecting husiness;"s so, also, one dealing as coftec-brokers, in the absence of custom or nsage to the contrary. [pon these principles one of a law fimm camot hind it ly a promissory note without consent of all the members; ${ }^{60}$ nor (an one of a firm practieing medicine hind it in a like mamer except for merlicine and other necessaries of his profession; ${ }^{\text {ir }}$ nor can one of a firm keeping a tarem bind his copartners except strictly within the husiness. ${ }^{62}$ It is said, however, that if the concerns were of such vast magnitude as to require large capital and eredit, the rule would he of doubtful application, and that it would depend vers much upon the usage of the particular fim and others simjlarly engaged. ${ }^{63}$ The general authority of a partner to bind

5n Hayward v. French, le Gray, 453; Cnited States Bank $v$. Bonnes, 5 Mason. 176; Spaulding v. Kelley, 50 X. Y. Supp. 244.

5 ti Kimbro v. Bullit, 22 How. 256.

$5 \pi$ National State Capital Bank r. Noyes, 62 X. H. 44.

ss Deardorff $r$. Thacher, 78 Mo. 128.

59 Third Nat. Bank v. Snyder, 10 Mo. App. 211.

bolley v. Mainbridge, 3 Q. B. 316: Marsh v. Gold. 2 Pick. 255.

61 Crosthwait s. Ross, 1 Humphr. 23; Elwards on lills. 102.

fiz Cooke v. Branch lank, 3 Ala. 175.

(i:3 1 Parsons on Notes and Bills, 139): National State Cap. Bank r. Noyes, 62 X. II. 44. 
the firm exists only by implication, and may be rebutted by evidenee that the party who took the security had previous notice that no such authority existed. ${ }^{6+t}$

$\$ 138$. As to accommodation paper- - No one member of a firm can bind it, without the consent of all of its members, by signing the eopartnership name as drawer, maker, acceptor, or indorser of a negotiable paper for his private aecommodation or for the accommodation of a third party, for the obrious reason that such a transaction is not within the scope of copartnersinip business, unless expressly or impliedly made so, and would ordinarily be without authority, and in frand of the firm. And every holder of such paper, chargeable with notice of its character, would be disqualified to reeover upon it; ${ }^{65}$ and if the plaintiff be payee, he would be required to prove the assent of the copartners before he could do so. ${ }^{\text {rit }}$

If it appears on the faee of the bill or note that it was signed by a partner, in the name of the firm, as surety, this will be notice to the world that it was not given in due course of the partnership business; and the burden would be thrown upon the holder not only to show that he gave value for the instrument, but also that all the parties assented to its execution in their name. "If the word "surety" be attached to the partnership name, that would impress upon the paper notice of its charaeter. ${ }^{\text {cis }}$

\section{$\S 139$. As to private debts of a member of the firm.- No} one nember of a fim can, without the consent of all of his copartners, bind them by making, drawing, aecepting, or indorsing a bill, note, or check for his private debt, in the partnership name; and the creditor who receives such an instrument, or the indorsee who takes it with notice of the consideration, cannot recover upon it. ${ }^{69}$ Aeeordingly, it has

(jat Gallway v. Matthews, I0 East, 264; King v. Faber, 22 Pa. St. 21.

6.5 Bank of Fort Madison v. Alden, 129 U. S. 372; Heffron v. Hanaford, 40 Mieh. 405.

6is Tompkins v. Woodward, 5 W. Va. 230.

67 National Pank v. Law, 127 Mass. 72 ; Tyree v. Iyon, 67 Ala. 1.

r\& Foot v. Sahin, 1! .Jolns. 154: Boyd v. Plumb, 7 Wend. 309.

6) Daniel on Negotiable Instruments, § 366. 
been held that where a creditor drew on his debtor through bank for an individual debt, and the debtor gave the check of the firm to which he belonged in payment, the creditor was held ehargeable with notice of the misappropriation by the very nature of the transaction, and through the bank as his agent. ${ }^{70}$ But in Nebraska a different conclusion has been reached. ${ }^{71}$

$\$ 140$. Effect of dissolution.- The dissolution of a partnership may occur by agreement between the partners; by a change in the membership of the firm, by the retirement of one or more of the partuers; and by operation of law. The death or bankruptey of a partner are the most familiar instances of dissolution by operation of law, and as a general rule it is well settled that in those cases no notice is necessary to exonerate the estate of the deceased or bankrupt partner from liability for future acts done by other memhers in the natme of the dissolved firm. ${ }^{\text {T2 }}$ Nor is notice necessary when a dormant partner retires, for he has not been held out as a nember of the firm. ${ }^{73}$ But when dissolution occurs by agreement between the partners, or by retirement of one or more of them, notice of dissolution is necessary to avoid liability for future transactions in the firn name. And the general prineiples stated may be affected by peculiar eircumstances. Thus, if a dormant partne' is known to eertain individuals to have been a partner he must notify them of his retirement, to avoid future liability for acts of the firm. ${ }^{\pi 4}$ And eontinuing members will be bound by the acts of a bankrupt partner in the firm's name if they hold themselves out as still in partnership with him. ${ }^{75}$

$\S 141$. Dissolution by agreement, or by death; compared.When the dissolution has been effected by retirement or

70 Davis v. Smith, 27 Minn. 390.

i1 Warren r. Martin, 24 Nebr. 273.

72 Dickinson v. Dickinson, 25 Gratt. 321; Williams v. Mathews, 14

La. Ann. 11.

73 Carter v. Whalley, 1 B. \& Ad. 11.

it Davis v. Allen, 3 X. Y. 163 : Cregler v. Durham, 9 Ind. 375.

ii Lacy v. Woolcot, 2 Dowl. \& R. 438. 
agreement, one ex-partner has no implied authority to inlorse in the partnership name negotiable instruments given to the firm before dissolution. Is was said by Lord Kenyon, " the moment the partnership ceases, the partners beeome distinet persons; they are tenants in common of the partnership property undisposed of from that period; and if they send any sccurities which dicl belong to the partnership into the world after such dissolution, ail must join in so doing." its

But where the dissolution is by the death of one of the partners, the survivor may indorse a note, payable to the firm in his own name. ${ }^{i t}$ The reason of the distinetion between the anthority of a partner after dissolution while his eopartner is living, and the anthority of the survivor when discolution has been caused by death, is that in the former ease the implied authority for one partner to aet is all gone; whereas in the latter case the bill or note rests exclusively in the surviror, although he must account therefor as part of the partnership assets. ${ }^{\text {is }}$ And for the like reason the surviving partner may draw a cheek on partnership funds to pay a firm debt. ${ }^{79}$

\section{SECTION IV. \\ CORPORATIONS AS PARTIES.}

\$142. Public and private corporations.-Corporations are either private or public — public when " the whole interests and franchises are the exchusive property and domain of the govermment itself; " otherwise private. Public corporations are established exclusively for public purposes, and comprise cities, towns, villages, eounties, townships, parishes, and all other corporations erected by the govermment as goverumental agencies. Private corporations comprise banks, building associations, railroad companies, and all other

Tf Abel v. Sutton, 3 lisp. 109.

77. Johnson $v$. Berlizheiner, 84 Ill. 54.

is Story on Notes, \& 125; Crawshay v. Collins, 15 Ves. 218.

79 Commercial Nat. Bank v. Proctor, 98 Ill. 558; Daniel on Negotiable Instruments, $\$ \& 370 a, 370 b$. 
associations formed for mamufacturing, trading, or other objects of private gain, emohment, gratification, or benefit."

$\S 143$. Authority of private corporations. - It is quite cal $-y$ to detcrmine whether or not there is express power in tot $i$ dem verbis to issue the particular instrunent by eonsulting the terms of the corporate charter. If not expressed, them the infuiry arises, is the power implied in some power conferred, or from the general character of the institution? In England the rule is well established that trading and banking corporations only can draw or accept bills of exchange, or otherwise becone parties to a negotiable contract. without express anthority to do so - the principle being that such acts by trading and banking corporations are necessary to the very objects of their existence. ${ }^{\text {s1 }}$

In the United States, however, the cases go to great lengths in upholding the validity of corporate negotiable instruments. Here "the power of eorporations to become parties to bills of exchange or promissory notes is coextensivo with their power to contract debis. Whenerer a corporation is authorized to contract a debt it may draw a lill or give a note in payment of it. Every corporation, therefore, may become a party to bills or notes for some purposes. Thus, a mere religious corporation may need fuel for its rooms, and as an economical measmre may buy a caroo of coal, and give its note for it; and such a note rould mudoubtedly be valid in this comtry." s2

$\$ 144$. The American doctrine stated.- In this commtry three propositions respecting private corporations may be regarded as settled. First. That it has implied power to contract debts like an individual whenever necessary or convenient in furtherance of its legitimate objects. Second. That whenever it may contract a deht, it may borrow money to pay it. And, Third. That whenever it contracts a deht for materials, services, or otherwise, in the scope of its busi-

so Daniel on Negotiable Instrument», $\$ 379$.

s1 Broughton v. Manchester \& \&. Waterworks, 3 B. \& Ali. 1.

s2 1 Parsons on Notes and Bills, 164, 165; Daniel on Negotiable Instruments, $\$ \$ 380,381$. 
ness, or borrows money, it may exeeute a negotiable bill, note, or hond, and secure it by mortgage, to the ereditor in parment. ${ }^{\mathrm{s} 3}$

And in accordance with the propositions just announced, it was said, in a well-considered case, that " the right of corporations in general to give a note, bond, or other engagement to pay a debt is so nearly identical or so inseparably connected with the right to contract the debt, that no doubt upon the question onght to be admitted. When a corporation can lawfully purehase property, or procure money on loan in the course of its business, the seller or the lender may exact, and the purchaser or borrower must have, the power to give any known assurance which does not fall within the prohibition, express or implied, of some statute. Tho particular restriction must be sought for in the charter of the corporation, or in some other statute binding upon it; but if not found in that examination, we may safely affir'm that it has no existence." st

$\$ 145$. Presumption of regularity.- When a corporation has a general power, express or implied, to be a party to negotiable contraets, such instruments will be presumed to have been exceuted in the legitimate course of its business, and whether so executed or not will be valid in the hands of a bona fide holder without notice. ${ }^{\mathrm{s}}$ Unless the corporation be specially authorized to do so, the execution or indorsement of accommodation paper for the benefit of a third person is an act beyond the seope of its corporate anthority ${ }^{813}$ lut according to the prineiples stated, a bona fide holder taking without notice of its character could enforce it. $^{87}$ Its indorsement on the paper is presumahly valid, and it cannot be inferred in the absence of proof that it was

8.3 Daniel on Negotiable Instruments, \& 382, and cases cited. 84 Curtis v. Leavitt, 15 N. Y. 66.

si Supervisors v. Schenck, 5 Wall. 784; Mitchell v. Railroad Co., 17 Ga. 574 .

si: Field on Corporations, 306.

si Bird r. Daggett, 97 Mass. 494; National Bank v. Wells, 79 N. Y. 498. 
for accommodation. ${ }^{\text {ss }}$ Where a railroad company transforrel and guaranteed bonds of another, itself receiving the proceeds, it was held estopped to deny its liability upon the gilatranty. 89

$\$ 146$. Authority of agent of corporation.-It wits the ancient doctrine of the common law that a corporation could not express its assent, and therefore could not constitute an ofticer or agent, save by instrument. under seal. ${ }^{\text {gf }}$ 'This doctrine is now eompletely obsolete in the United States, and here there is no lonbt that such a body may, by nere rote, or other appropriate corporate act not under seal, appoint an offieer or agent whose acts and contracts within tho scope of his anthority would bind the corporation. ${ }^{91}$ And if a corporation employ a person to diseharge official duties - such as a bank, which places a person behind its comnter to exereise the duties of cashier - it will be bound by his acts although the formalities of qualification have not been complied with, mless the statnte creating the corporation provides that his acts shall be void until such formalities be performed. ${ }^{92}$ Indeed, the doetrine is well settled that if officers of a corporation openly exercise a power which presupposes a delegated authority for the purpose, and other corporate acts show that the corporation must have contemplated the legal existence of such authority, the acts of such officers will be deemed rightful, and the delegated authority will be presumed. If a person acts notoriously as cashier of a bank, and is recognized by the directors, or by the corporation, as an existing ofticer, a regular appointment will be presumed, and his acts as ansher will bind the corporation, although no written proof is or can be adducel of his appointment. In short, the acts of artificial persons afford the same presumptions as the acts of natural persons.

s8 Lafayette Bank v. St. Louis Stoneware Co., 2 Mo. App. 299.

s9 Arnot v. Erie R. Co., $5 \mathrm{Hun}, 608$.

90 Angell \& Ames on Corporations, chap. IX, \$ 3. p. 214.

91 Bank of Columbia r. Patterson's Admr., 7 Cranch, 305; Fleckner $\therefore$ United States Bank, s Wheat. 357.

92 Bank of the United States v. Dandridge, 12 Wheat. S3. 
Each affords presumptions, from acts done, of what must have preeeded them, as matters of right or matters of duty.

147. Municipal corporations.-There is no doubt that public corporations may have the power conferred on them to execute bills, notes, eheeks, and indeed all varieties of negotiable instrmments. But the better opinion is, that such power does not exist, unless expressed or elearly implied. ${ }^{9 t}$ The ordinary orders, warants, certificates of indebtedness, and obligations to pay issued by munieipal corporations, if negotialle in form, will in general enable the holder to sue in his own name. But they are not negotiable instrmments so as to exclude inquiry into the legality of their issue, or preelude defenses which are available as against the original parees. ${ }^{95}$ To invest such instruments with the character and incidents of commercial paper, so as to render them in the hands of bona fide holders absolute obligations to pay, however irregularly or fraudulently issued, would be an abuse of their true character and purpose. ${ }^{\circ}$

$\S 148$. Difference between public and private corporations.If private corporations, to increase their profits, embark in enterprises not authorized by their charter, still, as to third persons, and when necessary for the advancement of justice, the stockholder's will be presumed to have assented, since it is in their power to restrain their officers, when they transeress the limits of their chartered authority. ${ }^{97}$ But municipal corporations stand upon a different ground. They are not organized for gain, but for the purpose of government; and debts illegally contracted by their officers cannot

93 Bank of the United States v. Dandridge, 12 Wheat. 64: Creswell v. Lanahan, $101 \mathrm{U}$. S. 352.

94 kinapp v. Mayor of Hoboken, 39 N. I. L. 394: City of Williamsport v. Commonwealth. 84 Pa. St. 487.

95 Knapp r. Mayor of lloboken, 39 N. .T. H. 394: 1 Dillon on Municipal Corporations, \& 406.

90 Wall $v$. Monroe County, 103 U. S. 74; District of Columbia v. Cornell, 130 U. S. tifil.

97 Lloyd v. West Branch Bank, 15 Pa. St. 174. 
be made binding upon the taxpayers from the juremumen assent of the latter. ${ }^{\text {as }}$

The principle is alp plicable to both public and private corrporations, as it is to individuals, that where they lworow money from a bank or other institution, it does not lio in their mouth to slow that the transaction was of a charactere prohibited by the charter of such bank or other institution."

\$149. Indorsements. When a municipal eorporation warrant is deened a commercial instrmment, negotiable like an ordinary bill of exchange, the party who transfers it with his indorsement is sulject to the liabilities and entitled to the privileges of an ordinary indorser of a negotiable inst rument. ${ }^{1}$ But when such in instrmuent is regarded as a mere voucher, and not a bill or note, the transferrer by indorsement is not deened an "indorser," in the eommercial sense of the term, and could not be held liable as such, though the form of the paper be negotiable. He wonld be liable, however, to refund the consideration if the instrument were not valid and legal aceording to its purport. ${ }^{2}$

s. Bradley v. Ballard, 55 Ill. 420.

9 Township of Pine Grove $v$. Talcott, 19 Wall. 619; Daniel on Negotiable Instruments, $\$ 423$.

1 Bull v. Sims, 23 X. Y. 571.

2 Keller v. Hicks, 22 Cal. 460; Daniel on Negotiable Instruments, $\S 427$. 


\section{CHAPTER VII.}

\section{PERSONS PARTIALLY OR WHOLLY DISOUALIFIED.}

\section{SECTION I.}

INFANTS.

\$150. General rule.-Persons nnder twenty-one years of age are minors, or infants, as they are more generally termed, and contricts made by them have been divided into three classes: First, roid contracts, which are those elearly to the infant's disadvantage - as, for instance, a bond made with a penalty; second, voidable contracts, which are those which may or may not be for his benefit, according to circumstances - as, for example, a lease of his lands rendering rent; and third, valid contracts, which are such as are entered into for necessaries. ${ }^{1}$ And by necessaries are meant those things which are needed by the infant, and are suited to his means and rank in life.

But this distinction as to void and voidable contracts is now regarded as practically obsolete; all the contracts of an infant, not in themselves illegal, being capable of ratifieation by him after he has attained his majority, and, therefore, being voidable only. For if absolutely void, they would be incapalle of ratification. ${ }^{2}$

$\$ 151$. Necessaries and torts.- For necessaries an infant may undoubtedly bind himself, and the better opinion is that he may execute a note not negotiable for the amount, the consideration of which might be inquired into, and his protection from imposition insured - he being bound not absolutely for the amount of the note, but only for the real value of the necessaries for which it was given. ${ }^{3}$ But it is

1 Story on Notes, \$ 77.

21 Parsons on Contracts, 295; Byles on Bills [*59], 145; Daniel on Negotiable Instruments, $\$ 223$.

3 Ray v. Tubbs, 50 Vt. 68s; 1 Parsons on Notes and Bills, 68. 
denied by some of the authorities that an infant can execute any note whatever, of any binding foree, even for neressaries." In England it has been held that an infant may" execute a single bill (a bond without a penalty) for the exact sum due for necessaries; but not a boud with a penalty, or carrying interest. ${ }^{5}$ An infant cannot bind limicelf for neeessaries when he has a parent or guardian who supplies his wants; but when he has anthority from his gnardian or parent, he may purchise them and lind himself for them. ${ }^{7}$ An infant is in general liable for his torts as any other person would be; and if he give a note in satisfaction of damages it has been held that he is hound thereby. ${ }^{3}$

$\$ 152$. Negotiable paper signed by infants. - In respect to negotiable paper to which infants have signed their names as parties, it may be stated as a general principle, universally recognized wherever the common law prevails, that an infant camot bind himself absolutely as drawer, indorser, acceptor, or maker of a bill of exchanso or negotiable note." In a case where the acceptor of a bill pleaded infancy, and it was replied that it was given for necessaries, Lord Mansfield, C. J., said: "Did anyone ever hear of an infant being liable as an acceptor of a bill of exchange? The replication is nonsense, and onght to have been demurred to." 10 And althongh the tenor of the modern anthorities is to liberalize the law on the subject of infaney, the doctrine is generally followed that an infant camnot be a party to a negotiable instrument - the reason assigned being, that otherwise, should it be transferred to a bona fide holler for ralue, and withont notice of the infaney, the infant, if bound at all, would be bound for the entire sum, and if inquiry

4 Bouehell v. Clary, 3 Brev. 194; Chitty on Bills [*19], 26.

5 Russell v. Lee, 1 Lev. 86 ; Chitty on l3ills [*19]. 26 .

B Angel v. McClellan, 16 Mass. 2s: Guthrie $v$. Murphy, 4 Watts, so.

7 Rundel v. Keeler, 7 Watts, 237 : Watson $v$. Heasel, 7 Watts. 344.

8 Ray v. Tubbs, 50 Vt. 68s: Daniel on Negotiable Instruments, s. .2.24.

9 Williamson $v$. Iarrison, Holt, 359, 3 Salk. 197; Story on Notes.

$\S 78$.

10 Williamson $v$. Watts, 1 Campb. 552. 
were admitted into the consideration, the instrument would lose its character as negotiable paper. ${ }^{11}$

\$153. Infant as payee and indorser.- An infant may undoubtedly be the payee of a bill or note, and may sue upon and enforce it, since it camnot be but for his benefit if the consileration thereof does not move from himself but from sone third person, or if it be for a debt justly due to him. ${ }^{12}$ But whether or not an infant ean personally receive payment is a different question. As a general rule, payment should be made to his guardian, and if it be made to the infant personally, and be thereby dissipated and lost, tho laver would not be discharged. ${ }^{13}$ An infant may also indorse a bill or note made payable to him or order, so far at, least as to enable the indorsee to reeover against the drawer, acceptor. or maker, who, by undertaking to pay to him or to his order, are estopped to deny his capacity to order parment to be made to the indorsee. ${ }^{14}$ And to this extent the infant's indorsement would be valid, even if made by his authorized agent or attorney. ${ }^{15}$ "It would be absurd," it has been said by Parker, C. J., "to allow one who has made a promise to par to one who is an infant, or his order, to refuse to pay the money to one to whom the infant had ordered it to be paid, in direct violation of his promise." 18 And in respect to the drawer of a bill payable to an infant or order, Lord Mansfield said: "The drawer says, "let anyborly trust the paree on my eredit." " 17

$\$$ 154. Infant's indorsement voidable only.-An infant's indorsement is voidable, not absolutely void. ${ }^{18}$ And it has

11 Swarey v. Vanderheyden, 10 Johns. 33; Conn v. Coburn, $7 \mathrm{~N}$. H. 368.

12 Warwick v. Bruce, 2 Maule \& S. 20s; Story on Notes, $\$ 79$.

1:: Plillips v. Paget, 2 Ark. 80.

14 Nightingale $v$. Withington, 15 Mass. 272; Hardy v. Waters, 38 Ie. 450 .

15 Hardy v. Waters, 38 Me. 450.

16 Nightingale $v$. Withington, 15 Mass. 272.

17 Grey v. Cooper, 3 Doug. 65; Daniel on Negotiable Instruments, $\$ 227$.

18 Goodsell v. Myers, 3 Wend. 479; Fdwards on Bills, 245. 
been thought that where he receives a full consideration for the transfer of property, such as a negotiable bill or note, and makes a manual delivery of it, his right to rescind or avoid the contract is suspended milil he becones of age. ${ }^{13}$ And then he is not allowed to disathirm the contract muless he returns the consideration paid to him. ${ }^{20}$ We should say that he might disaftim the contract and retum the consideration at any time, provided it was not unreasonably delayed after lie became of age. ${ }^{21}$

\section{$\$$ 155. Ratification by adult of bills and notes executed when} an infant. - The bill of exchange or promissory note of an infant is not absolutely void, but roidable only at his election. And if, after reaching full age, the then anlt ratify and confirm his bill or note execnted while he was an infant, whether it were framed so as to be negotiable or not, he will be bound to pay the instrument according to its terms. For by ratifieation the adult validates the instrmment in all respects, and it becomes the same as if it had been exeeuted by an adult. 22 The effect of the ratification, as stated by Shaw, C. J., is " to ratify and confimm the contract, and give it the same legal effect as if the promisor had been of legal capacity to make the note when it was made." 23 And consequently the bill or note may be sued upon, without any allegation of ratification - that being necessary to appear only in rebuttal of the plea of infancy, when pleaded. ${ }^{2+}$

Unless a written ratification be required by statute, a rerbal ratifieation will be effectual. As to what words will amount to a ratification, a mere recognition that the debt existed, or contract was made, is not sufficient. ${ }^{25} \mathrm{No}^{2}$ peculiar form of words is requisite, lunt there must be a direct

19 Roof $v$ Stafford, 7 Cow. 179, 9 Cow. 626.

20 Medbury v. Watrous, $7 \mathrm{Hill}, 110$.

21 Bool v. Mix, 17 Wend. 119.

2 Cole v. Pennell, 2 Rand. 174; IVilliams v. Moore, 11 II. \& T. 266;

Hunt v. Massey, 5 B. \& Ad. 902 .

23 Reed v. Batchelder, 1 Mete. (Mass.) 5.59.

24 Daniel on Negotiable Instruments. $\$ 230$, and notes.

s Martin v. Mayo, 10 Mass. 137; Robbins v. Eaton, 10 N. H. 581;

Benlam $\because$ Bishop, 9 Conn. 330. 
and explieit recognition of the contract, and words expressing or necessarily inplying a promise to fulfill it. The pronise of the adult must be made to the party with whom he contracted, or his anthorized agent, in order to amount to ratifieation; and if made to a third party, it will be insufficient. ${ }^{26}$

It follows, therefore, that mere part payment does not amount to ratification by the adult, but expressions of intention to alide by a former award, or aceepting its benefits, would suffice. Ilence the infant's conduct may be such as to amount to ratification, but mere silence and failure to disaffirm will not be sufficient alone. ${ }^{27}$

$\$ 156$. Written ratification.- In England and some of the United States, ratification must be in writing. In 1825, Parliament cuacted the statute of 9 George IV, chap. 1t, commonly called Lord Tenterden's act, whereby it is provided that " no action shall be maintained whereby to charge any person, upon any promice made after full ace, to pay any debt contracted during infancy, or upon any ratifiention after full age, of any promise or simple contract made during infaney, mless such promise or ratifieation shall he made by some writing signed by the party to be chargen therewith." And similar statutes have been enacted in most of the United States.

Wherever snch a statute exists, a written promise, in accordance with the enactment, is essential to a legal ratification.

\section{SECTION II.}

LUNATICS, IMBECILES, AND DRUNKARDS.

$\S 157$. Presumption of sanity.-Every person is presumed to be of same mind until the contrary be shown by hin who asserts it $;^{24}$ insanity or imbecility cammot in England he shown under a general plea that the defendant did not exe-

20 Goodsell v. Nyers, 3 Wend. 479; Reed v. Boshears, 4 Sneed, 118.

27 Danicl on Negotiable Instruments, § 234.

28 Jaekson v. Van Dusen, 5 Johns. 144; 1 Parsons on Notes and Bills, 150. 
cute the bill, note, or other instrument declined an, lut must be specially plearled."

The earlier anthorities of the English law helel that at man should not be allowed to stultify himself ly alloging his own lunacy or imbecility; ${ }^{30}$ but such a doctrinc somels more like the gibberish of a lmatic than like the deecese of at humane and enlightened lawgiver. And it may now lee regarded as a general role of miversal law that the negentiable contracts of a lumatic, idiot, or other person non compos mentis, from age ar personal infimity, are utterly vojd.:"

$\$$ 158. Degree of incapacity.- Mere weakness of miml, not amounting to imbecility or insanity - mere immaturity of reason, or want of experience and skill in business, is 110 ground of defense either in law or equity, provided no firand las been practiced on the party. ${ }^{32}$ But if the weakness of mind bo so great as to incapareitate the party to guard against imposition and undue influence, it will suffice to racate liis contracts. ${ }^{33}$

$\S 159$. Ignorance of incapacity.- It lhas been held by quite a number of courts that in order to render effectual the defense of insanity or imbecility, it must be malle to appear that the other contracting party had knowledge of the defeet of mind of the lunatie or idliot, and this view hils bean upleld not only by many of the conrts of last resort in the United States, but also in England. But nejther the English nor the American conrts ane in harmony upon the proposition, there being many well-considered eases which support the entrary view.

$\$ 160$. Necessaries; exception to rule.- In this regarel : 11 imbecile stands upon the footing of an infant. And his

29 Harrison v. Riclardson, l Moody \& R. 504.

8) Beverly's Case, 4 Rep. I26; Strond r. Marshall. Cro. Eliz. 392.

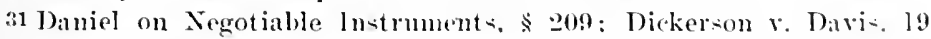
N. E. 145 .

32 Stewart v. Lispenard, 26 Wend. $29 ! 1$ : Osmond r. Fitroy. :3 P. Wms. 129.

33 Johnson r. Chadwell, S IIumphr. 145.

at Daniel on Negotiable Instruments, $\$$ 210, and eaces cited. 
exeented contraets for neessaries, made while he was temperarily or apparently sane, with a party acting in entire good faith, would be enforced. ${ }^{35}$ And if a bill or note were exeruted by hin for necessaries under such ciremustances, it would doubtles be ralid, at least to the extent of their actual and proven value." A lunatic has been held boumd for medical scrvices rendered his wife; ${ }^{37}$ and in England, where a nobleman ordered carriages suitable to his rank, and the conchmaker smpplied them bona fide, and they were getually need, it was held that an action was maintainable on the contract, notwithstanding there had been an inquisition of lmaer finding him to be of unsomed mind at the time the carriages were ordered. ${ }^{38}$ The recovery for neeessaries. instead of being condemned, is encomaged by eonsiderations of humanity. And the courts may safely go farther. and anthorize recovery where the consideration has been full and fair, and has entered into the betterment of the lumativ's estate, it being followed like trust money inio his hands, and restored in kind or its equivalent. ${ }^{39}$

\&161. Persons intoxicated.-Drunkenness is a species of mental aluerration, produced by intoxicating stimulants. And if a person beeome so drunk as to be deprived of understanding and reason, there is no doubt that, while in such a conlition, he has no capacity to enter into a contract. And if he should sign a negotiable instrument, either as maker, drawer, indorser, or aceeptor, it would certainly be void as to all parties having notice of the condition in which he signed it." If the drunkenness were so complete as to suspend all rational thought, the better opinion is that any instrument signed by the party wonld be utterly void even in the hands of a bona fide holder without notice, for, although it may have been the party's own fanlt that sneh an aberra-

35 Richardson v. Strong. 13 Ired. 106; McCullis v. Bartlett, 8 N. H. 569.

if MreCormick v. Littler, 85 Ill. 62.

37 Pearl v. McDowell, 3 J. J. Marsh. 658.

38 Paxter r. Farl of Portsmouth, 7 Dowl. \& R. 614.

$\because 8$ Danicl on Negotiable Instruments, § 212.

40 Jenners v. Howard, 6 Blackf. 240; Clark v. Caldwell, 6 Watts, 139. 
tion of mind was produced, when produced, it s-11-penderi for the time being his capacity to eonsent, which is the tirst essential of al contract." "It is just the same," says Allerson, B., "as if the defendant harl written his nance on the bill in his sleep in at state of sommambuliom." t:" But it has been thonght and held, that even when the drunkenness mas complete, a bill or note then signed wond be valid in the hands of a bone fide holder without norice. ${ }^{43}$ If the party were fully aware of what he was doing when he signed the paper it wonld clearly be binding, as we think, in the hands of a bona fide holder." Clearly, "the merment of a cheerful eup, which rather revires the spirits than stupeties the reason, is no hindrance to the contracting of just obligations." 45

\$162. Ratification.- The same general principles of the law of ratification applieable to infancy govern in cases of hmaer, and hence a lmatic, either during a distinet luciel interval, or after permanent reeovery, can ratify a contract entered into while the mind was in a state of disease. In case of drunkenness, the law does not require an aftimative act or a positive pronise in order to constitute ratification. If a party, therefore, while intoxicated, buy goods, and keep them when sober, the failure on his part to return the goods is tantamount to ratifieation, upon the principle of estoppel. ${ }^{45}$

\section{SECTION III.}

\section{AIEN ENEAIES}

\$163. General principles. - The mere fact that a person is an alien and a resident of a foreign comntry in nowise inpairs the right of the eitizents of another comntry to contraet with him, or his right to contract with them. On tise

41 l Parsons on Notes and Pills, Ini.

42 Gore v. Gibson, 13 M. \& W. 623.

43 State Bank v. MaCoy, 69 l'al. St. 204.

44 Miller v. Finley, 26 Mich. 249.

45 Puffendorf. Book 3, chap. (i, \& 4.

4t Daniel on Negotiable Instruments. $\$ 215$. 
contrary, commercial interconse between different nations, under relations of amity with each other, are to be favored and encouraged. But if war should break out between two conntries, it at once interposes a barrier to, and an interdiction of, all commereial correspondence, interconrse, and dealing between the citizens of the two countries. The hostile comtries become sealed as against each other; and both for the purpose of identifying the eitizen thoroughly and emphatically with the policy and interests of his comtry, and of preventing communications to the eneny which might be damaging in their character, the law of nations absolutely prohibits all intereourse between the citizens of belligerent conntries, and pronounces all contracts between them utterly roid. Snch contracts are not merely voidable, but ab origine void, and incapable of being enforced or confimed. ${ }^{47}$ Ind the rule applies not only to citizens and native suljects, but as well to all persons domiciled in the respective countries. ${ }^{48}$

This disability of alien enemies to contract does not rest upon any peculiarity of English or American law, but upon the miversal public law of nations, as stated and approved by the most eminent writers, such as Grotins, Puffendorf, Vattel, Brnkershoek; and in the present age, Wheaton, Story, Kent, Parsons, and others.

$\$ 164$. As drawer, acceptor, indorser, or indorsee.- If two comntries are at war, a citizen of one camnot legally draw a lill of exchange upon a citizen of the other. The same prineiple likewise applies to an acceptance or indorsement, and even to an indorsee, if the latter knew at the time of the state of war existing. ${ }^{49}$

In the late war between the Confederate States and the United States, many transactions between parties on opposite sides of the hostile line ocenred, and the prineiple that forbids communication between alien enemies has been regarded ly the conts of the United States, and of the

47 Crriswold $v$. Waddington, 16 .Johns. 438: The Julia, 8 Cranch, 131. 4 S Roberts v. Hardy, 3 Maule \& S. 533.

15 Daniel on Negotiable Instruments, \$\$ 217, 218. 
several States, as applicable to them. For while the ('onfederates States were short-lived, for the tine heing they waged war like an independent nation, and were accorded belligerent rights. ${ }^{50}$

\section{SECTION IV.}

\section{MARIRIED WOMFX.}

$\$ 165$. Incapacity of married woman to contract at ccmmon law.- Wherever the common law prevails a maried woman camnot bind herself as the drawer, acceptor, maker, or indorser of a negotiable instrument, and such instruments signed by her (unless as agent for another) are absolutely roid.51 And even a promise made by her after her husband's death to pay a bill or note which she executed during his lifetime will not bind her unless upon a new and good consideration. ${ }^{52}$

Following the principle just announced, it may be added that the wife's identity is so completely merged in the lunsband's that she can no more contract with him than with a stranger. ${ }^{53}$ Therefore the drawing or indorsenent of a bill or note br a husband to his wife is roid, and she camnot sue upon it either in his lifetime, or against his executor after his decease. ${ }^{54}$

$\$$ 166. Married woman as payee and indorser.- If a bill or note be nade payable to a single woman, and she afterwarl marries, it becomes the property of her lusband; and if made to her after marriage, it is the property of her husband, For two reasons, therefore, a married woman, who is the payee of a negotiable instrmment, cammot transfer a perfect legal title to it, or hind herself by indorsing it; first, hecanse she has no capacity to contract; and, second, loe-

fo Billgerry v. Braneh, 19 Gratt. 393: Ward v. Smith, 7 Wall. 447. 51 Vau Steenburgli r. Hoffmam, 15 liarb. 2s: Mason r. Morgan, 22 Ad. \& E. 30 .

52 Lloyd v. Lee, I Stra. 94; Meyer v. llayworth. S Al. \& El. 467.

5is National liank r. Brewster. 49 X. J. L. 231.

54 Gay v. Kingsley, 11 Allen, 345; Jackoon r. Parks, 10 Cush. 550. 
cause the instriment is her husband $\mathrm{s}^{55}$ But still, although the husband might recorer the instrument which has been transferred by his wife, in an action of trover against the holder, the drawer, and aceeptor of a bill and the maker of a note, who have bound themselves to pay to the payee or order, are estopperl, when that order is nade, to deny its suffieiency. It does not lie in their months to declare the effect of their own engagement to be different from its terms; and the holder, mder the indorsement of a payee, who is a married woman, may recorer against them. ${ }^{56}$ And if there be an indorser, after the married woman, he eamnot dispute her capacity, as his indorsement warrants it. ${ }^{57}$ But other parties to the instrument, not heing estopped by their relation to it, may show that one - not the payee - who has indorsed it, is a married woman. These views elearly apply where the paper has been executed to the woman after her marriage; lut if made to her before, disability subsequently created might be pleaded by any party. ${ }^{58}$

$\$ 167$. Exceptions to the general rule- - There are six general exceptions to the rule that a married woman camot make a ralid contract: (1) When the husband is an alien enemy; (2) when the wife has a separate estate, and the contract is made with reference to or for the benefit of snch estate; (3) when the wife is a sole trader; (4) when the contract is made for the wife's necessaries; (5) when the hushand ardopts the wife's name: (6) when the wife is the agent of her husband. ${ }^{59}$

In either of the instances given, the wife can hecome a party to a negotiable contract, and be bound as sueh.

The eontractual power of married women has been made the subject of leqislation in very many, if not in all the States. The general scope of this remedial legislation is

55 Shuttleworth $v$. Noyes, 8 Mass. 229; Cotes v. Javis, l Campb. 485.

so Simith v. Maroark. of Com. P. 486.

5 freseott bank v. (avely, 7 Gray, 217.

6s Smith $v$. Marsiak, f Com. 1). 486; Daniel on Negotiable Instruments, \& 242 .

59 Daniel on Neagotiable Instruments, \$ 244 rt seq. 
either to give to her unlimited contractual power, or to make valid and legal all contracts made by her with reforence to or for the benetit of her separate estate. The recisions by the different State courts are ats varied as is the language of the different enactments, but it may he fairly and generally stated that to the extent of her contractual power, whether it be limited or unlimited ly statute, slue may become a party to a negotiable instrument. 


\section{BOOK III.}

\section{THE NEGOTIATION OF THE INSTRUMENT.}

\section{CHAPTER VIII. \\ TRANSFER BY DELIVERY AND INDORSEMENT.}

$\S 168$. Methods of transfer.- The legal title to all negotiable contracts is transferred either by mere delivery, or by indorsement and delivery. A negotiable instrument payable to bearer, or indorsed in blank, may be transferred like curreney by mere delivery; other bills and notes, by indorsement of the transferrer's name thereon, and delivery to the individual named, muless they are not expressed to be payable to the order of any person, or to bearer, in which ease, unless by statute, they are not negotiable in the United States and in England; but it is otherwise in Scotland. But if the paper be payable to $A$. B., or order, and A. B. indorse it to C. D., without adding "or order," C. D. may, nevertheless, transfer it by indorsement and delivery, and it retains its original negotiable character. ${ }^{1}$

While commercial paper payable to bearer, or indorsed in blank, may be transferred by delivery merely, yet if the payee puts lis name npon it, and transfers it, he is liable as an indorser, such indorsement being valid between the indorser and smbequent indorsees ${ }^{2}$ and the holder of paper payable to bearer and indorsed may sue upon it as bearer or indorsee, at lis clection. ${ }^{3}$ Then the instrument is made parable to "order," the indorsement of the payee, followed by delivery, is necessary to transfer the legal title; and the transferee. without indorsement, takes it as a mere chose

1 Potter v. Tyler, 2 Mete. (Ky.) 58: Blackman v. Green, 24 Vt. 17. 2 Gwinnell v. Herbert, 5 Ad. \& El. 436 ; Brush v. Reeves, 3 .Johns. 439. S Story on Notes, $\$ 132$. 
in action, and must aver and prove the consideration. ${ }^{4}$ And he takes it sulject to all equities that attached to it in the hands of his transferrer." The negotialility of a note is not affected by the fact that a corporation indoreses it through its seal. ${ }^{6}$

\$ 169. Delivery by indorser.- As has been seen, deliverr, in any event, by the indorser is esecential to completion of his contract; and delivery implies its acceptance by the indorsee. If a transferee of a bill or note hy indorsement send it back to his indorser as worthless, the indorsenent is declined, and becomes invalid; and he acquires no new title by merely getting possestion, without a new transfer; but there need not be a new indorsement, becanse the former. indorsement is capalile of becoming again valid by ratification or confirmation. ${ }^{\top}$ In offer to indor'se for another munt be acepted in a reasonable time. ${ }^{8}$ If the proposed indorsee wrongfully retain the note after refusing its aceptance, he cannot upon parment of a judgment for the wrongful conversion hold the indorser liable; such parment will invest him with title to the converted property as of the date of the eonversion, which is merely the obligation of the makers of the note, the contract of indorsement having never been consummated. ${ }^{9}$

\section{SECTION I.}

NATURE OH, AND LIAblthes chiten Hi, CONTRACT OF IXDORSEMEXT.

\$170. Meaning of term "indorsement."- Indorsing an instrument, in its literal sense means writing one's name on the back thereof; and, in its technieal sense, it means writing one's name thereon with intent to pass title thereto and to ineur the liability of a party whe warrants parment of the

4 Van Eman v. Stanchficld, 10 Minn. 25.5; Faris v. Wells, 6s Gat. 604. 5 Iadden v. Rodkey, 17 Kan. 429.

a Rand v. Dover, $83 \mathrm{~Pa}$. St. 280: Daniel on Negotiable Instruments, $\$ 663$ et seq.

TCartwright $v$. Williams, 2 Stark. 340.

8 Claflin v. Briant, 58 Ga. 414.

9 Haas $\nabla$. Sacket, 40 Minn. 5:?. 
instrument, provided it is duly presented to the principal at maturity, not paid by him, and such fact is duly notitied to the indorser. Indorement, strictly speaking, is applicable only to negotiable paper, and the term inchudes delivery for value to the indorsee, but it is otherwise as to an instrument not negotiable. ${ }^{10}$

\section{\$171. An indorsement a separate and independent contract.} - The indorsement of a negotiable contract is not merelya transfer thereof, but it is a fresh and substantive contract in itself, embodying all the terms of the instrunent indorsed. ${ }^{11}$ The indorsement of a bill is equivalent to the drawing of a new bill by the drawer upon the drawee (or acceptor, if it be accepted) in favor of the indorsee; and the indorsement of a note is equivalent to the drawing of a bill upon the maker, who stands in the relation of acceptor, as it were, in faror of the indorsce. ${ }^{12}$ So entirely distinct and independent is the contract of the indorser of a note from that of the maker that at common law a separate action against each was indiepensable. ${ }^{13}$

$\$ 172$. Liabilities assumed by indorser. - The indorser engages (1) that the negotiable instrument will be aceepted or paid, as the case may be, according to its purport; but this engagement is conditioned upon due presentment or demand, and notice ${ }^{14}(2)$ that it is in every respect genuine: (3) that it is the valid instrument it purports to be; (4) that the ostensible parties are competent; (5) and that he has good title to it and the right to indorse it. And if it turns out that any of these engagements but that first named are not fulfilled, the indorser may be sued for recovery of the original consideration which has failed, or be held liable as a party, withont proof of remand and notice. ${ }^{15}$

10 Daniel on Negotialole Instruments, \& 666.

11 Brown v. Hull, 33 Gratt. 27; Bank of Britisl North America v. Ellis, 6 Sawy. 98.

12 Evans $\checkmark$. Gee, 11 Pet. 80 : Ingalls v. Lee, 9 Barb. 947.

13 Brown r. Inull, 33 Gratt. 29; Patterson v. Todd, Is Pa. St. 426.

14 Callahan v. Bank of Kentucky, $82 \mathrm{Ky} .235$.

15 Chitty on Pill; [\%9.], ]16; Story on Billa, § 108; Copp r. MeDugall, 9 Mass. 1. 
$\$$ 173. Liability of indorser "without recourse." - When the indorsement is " withont recourse" the indorser specially. declines to assume any responsibility as a party to the bill or note; but ly the very act of transfering it, he congages that it is what it purports to be - the valid obligation of those whose names are upon it. lle is like a drawer who draws withont recourse; but who is nevertheless liable if he draws upon a fietitious party, or one without funds. Inul, therefore, the holker may recover against the indorsel "without reconse," (1) if any of the prior signatures were not genuine; or $(2)$ if the note was invalid between the original parties, because of the want, or illegality of, the consideration; or if (:3) any prior party was incompetent, or (4) the indorser was without title. ${ }^{16}$

Contrasting the liability of a general indorser with an indorser without recourse, it will be scen that the liability of the latter embraces all of the obligations of the former except the first, viz., that the negotiable instrument will be accepted or paid, as the ease may be, according to its purport.

$\$$ 174. First, as to acceptance and payment.- The indorser of a bill contracts to pay it at maturity, if, on presentment for acceptance, it is not aceepted according to its purport, and he is duly notified of the lishonor. ${ }^{17}$ And the indorser of an accepted bill, or of a note; likewise contracts to par it, if it be not duly paid by the aceptor or maker. ${ }^{18}$ It matters not what may be the cause of the drawer's or maker's refusal. The indorser eontracts to pay on being duly notified that lie refuses to pay. Ile therefore warrants the solveney of the parties — or, in short, warrants that it will be paid, cither by them or by himself, on receiving notice of their failure.

\$ 175. Second, as to genuineness. - The indorser contracts that the bill or note is in every respect genuine, and neither

13 Dumont v. Williamson, 18 Ohio (X. S.) 515: Seeler r. Reed. 28 Fed. 167: Challiss v. MeCrum, 22 Kan. 127.

17 Ballingalls $v$. Gloster, 3 East. 481.

ss Ogden v. Saunders. 12 Wheat. 313. 
forged, tictitious, or altered. Undoubtedly, and by universal admission, this prineiple applies to the signatures of the drawer, acceptor, and maker of the bill or note, who are the original parties, and it is often expressed in langnage to the effect that the indorser warrants that it is a genuine instrument. ${ }^{19}$ This rule, however, wonld not apply where the holder procured the indorsoment of a forged note with knowledge of the forgery, and represented to the indorser that it was gennine, or where the hohler has received the paper after maturity and without consideration. ${ }^{20}$ Thether or not the indorser's engagement extends to the genuineness of prior indorsements is not so well settled. Undoubtcdly the indorser admits their gemuneness, as he is estopped to deny his title, which would otherwise be invalid, ${ }^{21}$ and notwithstanding the doubts and dissents which have been expressed, it is clear upon principle that the indorser warrants the instrument throughont. ${ }^{22}$

$\$ 176$. Third, as to validity.- The indorser cngages that the hill or note is a ralid and subsisting obligation, binding all prior parties aceording to their ostensible relations; and he maly be held liable althomgh the instrument be entirely null amd roid as hetween prior parties themselves; and also as between prion parties and even bona fide holders without notice. ${ }^{23}$ In an carly English case, where the suit was by the intorsee against the maker of a note void for gaming, Lee, C. .I., saill: "The plaintiff is not without remedy. for he may sne ("hurch (the indorser) upon his indorsement." 24

$\$ 177$. Fourth, as to competency of original parties.- The indorser contracts that the original parties to the bill $\mathrm{or}$ note were competent to hind themselves, whether as drawer, acceptor, or maknr; for otherwise, althongh ostensible, they

19 Edwards on Pills, 188, 289: Howe v. Merrill, 5 Cush. 83.

20) Turner r. Keller, 66 N. Y. 6 .

21 Ogden v. Siumders, 12 Wheat. 313: Story on Bills, \$\$ 110. 111.

22 Daniel on Negotiable In-truments, \$ 672.

2? 1 Parsons on Notes aml 13ills. 218; Story on Bills, \$ 190.

24 Powyer 5 . Pampton, 2 Stra. 1155. 
would not be real parties to it. 'Therefore, if the drawer, acceptor, or maker lecame a larty under duress, or wrepe an infant, lunatic, or married woman, the indorecer's conttract is broken," and he may be sued for recorery of the oliginal consideration which has failed, or mpon the instroment itselt, without proof of demand and notice. $2 \%$ Su, if the instrument purporterl to be signed hy procuration, he engages that there is competent anthority in the agent.

But whether on not the indorser's engagenent is that all of the antecedent parties ase competent to contract is questionable. Quite a $111 \mathrm{~m}$ lere of cases are to be found, both for and against the proposition. ${ }^{2}$

$\$$ 178. Fifth, as to title. - The indorser contracts that he has a good title to the hill or note, and a right to transfer it. ${ }^{29}$ If he has stolen or fonnd the instrument, or otherwise acquired possession without title, and it be payable to bearer or inclorsed in blank, he might, before its maturity. invest a bona fide indorsee withont notice with a perfect title, althongl not himself jossessing it; and even after maturity, the bona fide indorsee might get from him some superior lights to his own. ${ }^{30}$

\section{SECTIOX IT.}

FORM ANI VARIETIES OJ INDORSEMEXT.

\$179. As to place of indorsement._ While an indorsement. as its derivation and meaning would indieate, shonld be, and generally is, placed on the back of the instrument, it may be written - although unusual and inregular - on any othed postion of it, even on the face, and muler the maker's nane.":

si Bowman v. Hiller. 130 Mas.. 153; Haly r. Lane, 2 Atk. 1S1: Robertson $r$. Allen, 59 Tenn. 233.

2i Daniel on Negotiable lnstruments. $\$ \$ 669,675$.

2 E Elwards on Bills, 289: Story on Bills. \$ 110.

es Danicl on Negotialble Instruments. \$ titi, and cases eited.

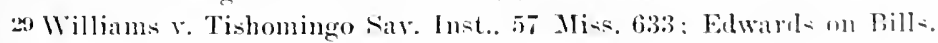
28?.

3n Dimiel on Negotiable Instruments, s 077.

31 Partridge $r$. Davis, 20 Vt. 449; Bigelow on Bills and Notea. 13.5. 
At any rate, the indorsement must, as a general rule, be somewhere on the paper itself, or attached thereto, and unless it is, the party eamnot be held liable as an indorser, ${ }^{32}$ but a promise made on a suftieient consideration will sustain an action upon its breach. ${ }^{33}$

$\$ 180$. Allonge. - It is not necessary, however, that the indorsement should be upon the original bill or note, in order to constitute it such, in the full sense of the term. It sometimes happens that by rapid circulation from hand to hand, the back of the paper is completely covered by indorsements: and in such cases the holder may tack or paste on a piece of paper sufficient to bear his own and subsequent indorsements, and thereon the indorsements may be made. Such addition to the original instrument is called an allonge, and it hecomes for the purposes above named, incorporated as a part of it. ${ }^{34}$

$\$ 181$. Varieties of indorsement.-There are rarious liabilities which may be engrafted on a negotiable instrument, evidenced by the character and terms of the indorsement thereon. An indorsement may be (1) in full or (2) in blank; it may be (3) absolute or (4) conditional; it may be (5) restrictive; it may be (6) without recourse on the indorser; and there may be ( 7 ) joint indorsements of the instrument, (8) successive indorsements, and also (9) irregular indorsements. ${ }^{35}$

$\$ 182$. First, an indorsement in full.- It is one which mentions the name of the person in whose favor it is made; and to whom, or to whose order, the sum is to be paid. For instance: "Pay to B., or order," signed $A$., is an indorsement in full by $A$., the payee or holder of the paper to $B$. An indorsement in full prevents the bill or note from being indorsed by any one but the indorsee. ${ }^{36}$ And none but the special indorsee or his representative can sue upon it. ${ }^{37}$

32 Fenn v. Ilarrison, 3 T. R. 757 ; Daniel on Negotiable Instruments, $\$ 748 a$.

33 Moxon v. Pulling, 4 Campl. 51: French v. Turner, 15 Ind. 59.

34 Crosly v. Roub, 16 Wis. 622; Folger v. Chase, 18 Piek. 63.

2.5 Daniel on Negotiable Instruments, $\$ 691$.

3 . Mearl $v$. Young, 4 T. R. 28.

37 Lawener v. Fuseell, 7т Pa. St. 460: Reamer v. Bell, 79 Pa. St. 292. 
$\$ 183$. Second, an indorsement in blank. - It is one which does not montion the name of the indorsee, and generally consists simply of the name of the indorser written on the back of the instrument. When the lill or note is indor-ced in blank, it is, as las been said, transferable hy mere delivery to the transferee; but one indored in full must be indorsed again by the indorsee, in oreler to render it transferable to every intent - for lie who indorses to a particular person, declares his intention not to be made liable exeept by that person's indorsenent over. As to an indorsonent in blank, it was said by Lord Mansfield: "I see no difference between a note indorsed in blank and one payable to bearer. 'They both go by delivery, and posession proves property in both cases." 38

The reeciver of a negotiable instrument indorsed in blank, or any bone fide holder of it, may wite over it an indorsement in full to himself, or to another, or auy contract consistent with the character of an indorsenent: ${ }^{39}$ lnt he cannot enlarge the liability of the indorser in liank ly writing over it a waiver of any of his rights, such as demand and notice; ${ }^{40}$ and he cannot fill it $u$ so as to make the instrument payable in part to one person and in part to another. The indorser's contract is single and entire, and the obligation ereated thereby cannot le broken into framents, and the indorser required to pay in fractions to different persons. ${ }^{41}$

s 184. Third and fourth, as to absolute and conditional in. dorsements. - In absolute indorsement is one ly which the indorser binds himself to pay, upon no other condition than tho failure of prior praties to do so, and of lue notice to him of such failure (protest preceding it when necessary, as in the case of a foreign bill). I combliomal indores-

3s Peacock v. Rhodes, 2 Dong. (is3.

:9 Evans v. Ciec, 11 Pet. so: Combon r. Pearce, 43 Md. S3: Tohnson v. Mitehell, 50 Tex. 2l2.

40 Daniel on Negotiable lu-trument-. \$ 694.

41 Erwin v. Lymm, 16 Ohio $( \pm,), 54$. 
ment is one by which the indorser annexes some other condition to his liability. Sometines the condition is precedent, and sometimes subsequent. Thus, "Pay to 1 . P., or order, if he arrives at twenty-one years of age," or, "if he is living when it becomes duc," is an indorsement upon a condition precedent. "Pay A. B., or order, unless, before payment, I give you notice to the contrary," is upon a condition subsequent. The condition attached to the indorsement in 110 manner affects the negotiability of the paper. ${ }^{42}$

$\$ 185$. Fifth, as to restrictive indorsements. - An indorsement may be so worded as to restrict the further negotiability of the instrment; and it is then called a restrictive indorsement. Thus, "pay the contents to J. S. only," or "to J. S. for my use," or "to order for my use," or " for me," are restrictive indorsements, and put an end to the negotiability of the paper. ${ }^{43}$ Of the like character is an indorscment, "eredit my account," or "pay J. S. or order" for account or on accomt of C. D.," or "fo" collection," or "for collection and immediate returns." 44 These and similar restrictive words indicate that the indorsee is merely an agent to receive the money, and that he paid no consideration for the paper, as a purchaser would not intelligently accept such an indorsement. The indorsee in such a case can only collect the money; he cannot sell or hypothecate the instrument for his own benefit, nor can he hold the indorser liable to himself. The restrictive words of the indorsement give notice of the trust engrafted upon it, and if the indorsee passes it off for his own debt, or in any other manner violative of the trust, the transferee would take it subject to the trust. ${ }^{45}$

$\S 186$. Sixth, as to qualified indorsements, or indorsements without recourse.- $\Lambda \mathrm{n}$ indorsement qualified by the words "withont recourse," "sans recours," or "at the indorsee's

42 Story on Notes, \& 149: Daniel on Negotialble Instruments, \& 697. 43 Wilson v. Holmes, 5 Mass. 543; Williams v. Potter, 72 Ind. 354.

44 First Nat. Tank v. Reno County, 3 Fed. 257: White v. National Bank, 102 U. S. 658; Continental Nat. Bank v. Weems, 69 Tex. 489. 45 Hook v. Pratt, 78 N. Y. 371: Claflin v. Wilson, 51 Iowa, 15; Daniel on Negotiable Instruments, \& 698 . 
own risk," renders the indorser a mere assignor of the tit le to the instrument, and relicves him of all responsilility for its payment, ${ }^{46}$ thomgh not from certain liabilities which have been alleady enmmorated. ${ }^{47}$ but snch an indorsenent does not throw any suspicion upon the character of the pajpres. ${ }^{44}$

$\$$ 187. Seventh, as to joint indorsements. - If a lill ol notr be nade payable to sereral persons not partmors, the transfer ean only be male ly a joint indorsement of all of throm; and as Chitty says, " If a bill has been transfered to several persons not in partuership, the right to transfer is in all collectively, and not in any one individually." 49 Where, however, one of two or more joint parees or transferces undertake to transfer the instrmuent, the extent of the transfer will depend upon the nature of his interest. Such interest, whatever it is, passes to his indorsee or assignce; but nothing beyond that, as against his coparty, muless indeed there be some other eloment in the transaction in the nature of frand, ageney, or other circmustance, modifying the rights of the parties. ${ }^{50}$ No action eomld be maintained on the indorsenent of one of the joint parties, ${ }^{51}$ the interest passing thereby being equitable merely.

$\$ 188$. Eighth, as to successive indorsements. When several persons inclorse a bill or negotiable note in succession, tho legal effect is to subject them as to each other in the order they indorse. The indorsement imports a several and snecessive, and not a joint obligation, whether the indorsements be made for accommodation or for value receired, unless there be an agreement aliunde different from that evidenced by the indorsencuts. When the successive indorsements are for accommolation of other parties, the in-

46 Wilson r. Codman's Exr., 3 Cranch. 192: Borden r. Clark, 26 Mich. 410.

47 See ante, $\$ 173$.

48 Lomax v. Picot, 2 Rand. 2ho: Kelley v. Whitney, 4. Wis. 117.

49 Chitty on Bills [*201], 232: Daniel on Negotiable Instruments,

$\$ 701 a$.

60) Brown $\checkmark$. Dickinson, 27 Gratt. 693.

s1 Caverick v. Vickery, 2 Doug. 652. 
dorsers for accommodation may make an agreement to be jointly and equally bound, but whoever asserts such an agreement must prove it. In cases, therefore, in which no such agreement is proved, the indorsers are not bound to contribution amongst themselves, but each and all are liable to those who succeed them. ${ }^{52}$

It follows from the principles stated that while the right of contribution exists between equal indorsers, contribution does not arise between successive indorsers. The presumption is that the indorsements were made in the order appearing upon the instrument, but it should be noted, however, that the indorser is not necessarily bound by and according to the actual date of the indorsement, for the contract deternines the natmre and extent of his liability; and if it appear that the instrument was indorsed by one party with the arreement that another should become prior indorser, the latter will be held responsible first in point of contract thongh seeond in point of time. ${ }^{53}$

$\$ 189$. Ninth, as to irregular intervening indorsements.There are some cases of irregular indorsements that eall for attention. Thus, suppose a bill be indorsed specially to A., and then, before $\Lambda$.'s indorsement, there appears the indorsement of $\mathrm{B}$. In snch a case, Alderson, B., said: "The indorsment only operates as against the party making it, and then as a fresh drawing:" "5t Tpon such an indorsement of a note, the party camnot be sued as a maker. Littleclale, J., said, in such a case: "It may be correct to say that an indorsement of a bill is in the nature of a new drawing. But supposing the indorser of a bill to be strietly in the situation of a drawer, it does not follow that the indorwer of a note is a maker." It was held, therefore, that the party must be snerl as an indorser; but that a prior party could not be sued at all, as a link in the chain of title was lacking. 55

52 Janiel on Negotiable Instruments, \$703.

53 Daniel on Negotiable Instruments, \$ 704; Chalmers v. MeMurdo,

5 Munf. 2.52; Slack v. Kirk, 67 Pa. St. 380.

E\& Penny v. Innes, 5 Tyr. 107.

5. Gwinnell v. Herbert, 5 Ad. \& Fl. 430. 
$\$ 190$. Party whose name is on back of note payable to bearer, or which has become so by being made payable to maker's order and indorsed by him.- If the noto be payablo to bearel aither in terms or beenues so in effect lyy being made payable to the maker's order, and then being indorsed by him, in eithor case the baty who places his name on the back of it will be deemed an indersere only." Snch a case as this, as said by bigelow, J., in Mlasachusetta, in a case where the mote was payable to and inclorsed hy tho maker, "does not fall within that anomaloms elass of cases where a thind person, neither maker nor paree, puts his name on the hack of a note bofore its indorsonent hy the payee, but is the ordinary ase of an indorsment of a note payable to bearer, the ceflecet of which cannot he raried or controlled by parol prout." 57

$\S 191$. Whether or not one not payee writing his name on back of paper before him is an indorser.- Mhen a note is made payable to the order of the payere, and the name of another apprars indorsed in likuk upon it, and was then indorsed betore the note was delivered to, or indorsed by, the payee, a very different guestion, and one upon which tho authorities are very much at issme, arices. In such cases such person does not appear upon the faee of the paper to have held, and to have transferred the title, but rather to have placed his name mpon its bark and to add strength and credit to it, and thus render it more ass of circulation; and the inquiry is presented whother he intended to lind himself for its parment as a joint maker or surety, as a guanantor, or only as an indorser, whose liability can only be fixed by due demand and notiee. 58

$\$$ 192. Conflict of decisions. - Referring to the question presented in the foregoing paragrath, it may he stated that one class of eases adhere to the view that such party is a joint

50 Dubsis v. Mason, 127 Mass. 37: National Bank v. Dorset Marble Co.. 6il V't. 106 .

57 bigelow $v$. Colton, 13) Gray, 30!) : Daniel on Negotiable Instruments,

$8707 a$.

58 Diniel on Negotiable Instruments. \$ 709. 
maker; another, that he is presumably a surety or guarantor in the form of a joint maker; another, that he is seeondarily liable as a guarantor; another, that he is presumably a second indorser, and still another, that he is prima facie first indorser. The authorities in support of the five eonflicting views stated will be found collated in the notes to sections 713 to 715 , inelusive, of Daniel on Negotiable Instruments.

Very many, if not a majority, of the cases, ineluding the Supreme Court of the United States, support the riew that such party should be regarded as a joint maker; yet, upon reason, it would seem that the party who puts his name on the back of a negotiable instrument before it is indorsed by the payee should be presumed to be a first indorser. Parties often so sign their names for aceommodation of the maker, and are themselves as much surprised as the holders of the paper to find that difficult questions arise as to the nature of their obligation. And the law merehant shoukl, in its elastieity to fit all manner of commereial transactions, recognize customary transactions, and apply to them the natural and simple presumptions that render them intelligible and practical. Strained technical dissertations and conchisions have so bungled and confounded the question which we have considered, that a fresh mind investigating it is lost in labyrinths of suggestion and decision, while as we think an easy solution may be found in adopting the views above presented.

$\S 193$. Admissibility of parol evidence to ascertain intention as between immediate parties. - The authorities very generally concur, though not with entire unanimity, that, as between the inmediate parties, the interpretation ought to be in every case such as will carry their intention into effect, and that their intention may be made ont by parol proof of the facts and circumstances which took place at the time of the transaction. ${ }^{59}$ If the person who places his namo on the back of the note before the payee intended 
at the time to be bound to the payee only as a guarantor of the maker, lie shall not be decued to be a joint promisor or an alssolute promison to the payee. If If he intended to bind himself as a surety or joint nuaker of the note, hr. will not be permitted to cham afterward that he was only a guarantor." And if he intended to be bound only as an indorser, the better opinion is that this also may be shown as between him and the payee."

$\$ 194$. Parol proof between remote parties.- Whether or not there is the sanc liberty in the use of parol proof when the note has been passed to a bona fide holder for value, and without notice, is a question upon which the authoritics are by no means so miform. Sume of them confine parol proof to eases in which the note is still in the hands of the original party to whon it was first delivered as a valid instrument; ${ }^{63}$ but otlers declare that it is equally competent in a suit by a bona fide holder on the ground that the contract is ambiguous. In a comparatively recent case before the United States Supreme Court, where the question arose between a bona fide indorsee and the original party so signing his name, the court, while recognizing "irreconcilable conflict" of the anthorities, said: "But there is one principle upon the subject ahmost miversally admitted by them all, and that is, that the interpretation of the contract ought in every case to be such as will carry into effect the intention of the parties, and in most cases it is adnitted that proof of the facts and circumstances which took place at the time of the transaction are admissible to aid in the interpretation of the language emploved." 6

$\S$ 195. Difference between guaranty and ordinary suretyship. - Guaranty is a peculiar lind of suretyship, as is also an

60 Seymour v. Farrell, 51 Mo. 95: Worden v. Salter, 90 Ill. 160. 61 Rey v. Simpson, 22 How. 241: Walz v. Allack, 37 Mr. 404. 62 Eberhart v. Page, 99 Ill. 5.50: Mammon v: Hartman, 51 Mo. I69. 63 Houston v. Bruner, 39 lnd. 353; Whitehouse v. Hansen. 4.2 X. Ii. 18.

64 Creenough v. Smead, 3 Ohio St. 415 ; Rey v. Simpson, 22 How. 2H. 65 Good r. Martin, 95 U. S. 95. 
indorsement; but guaranty differs from indorsement, and it differs also from the ordinary contract of a surety. The distinction between a guarantor and an ordinary surety is not easily defined, and the terms have been frequently used as convertible. A surety is generally a comaker of the note, while the guarantor never is a maker; and the leading difference between the two is, that the surety's promise is to meet an obligation which beeomes his own immediately on the prineipal's failure to meet it, while the guarantor's promise is always to pay the debt of another. ${ }^{6}$ A surety is liable as much as his prineipal is liable, and absolutely liable as soon as default is made, without any demand upon the principal whatever, or any notice of his default. He may be damaged by reason of no demand being made or notice given, and he may be sued as a promisor. ${ }^{67}$

The guarantor's liability is less stringent, and unless demand is made within a reasonable time, and notice given in case of default, he is discharged to the extent that he may be damaged by delay. Thus, if the debtor has, in the meantimc, become insolvent, so that he could not have recourse upon him, he could not be held. ${ }^{68}$ Thus, we see the surety's liability is primary and direct, like that of the principal. The guarantor's is secondary and collateral. And, in general, the guarantor contracts to pay, if, by the exercise of due diligence, the debt cannot be made ont of the prineipal debtor, while the surety undertakes direetly for the payment at once, if the principal debtor makes default. As has been well said, the surety " is an insurer of the debt; the guarantor is the insurer of the solveney of the debtor." 69 Nor does his guaranty inure to the benefit of an indorser signing before lim, and with whom he is not in privity. ${ }^{70}$

662 Parsons on Notes and Bills, 118.

e7 Perry v. Barret, 18 Mo. 140.

es Perry v. Barret, 18 Mo. 140.

69 Krampt's Executrix v. Hatx's Exceutors, 52 Pa. 525; Arents v. Commonwealth, 18 Gratt. $7 \%$.

70 Phillips v. Plato, 42 Hun, 189; Daniel on Negotiable Instruments, $\S 1753$. 
\$ 196. Difference between guaranty and indorsement,- Tho' liability of a guarantor also difler's materially from, and is more onerous than, that of an indorser. The internere contracts to be liable only mpon condition of due presentment of the bill of note on the exact day of maturity, and dur: notice to him of its dishonor. And he is abrolutely discharged by failure in either particular, althomgh lic may suffer no actual damage whatever. 'The guarantor's antract is more rigid, and he is homel to pay the anome npon a presentment made, and notiece given to him of dishonos, within a reasonalle time. And in the event of a failure to make presentment and give notice within such reasomalile time, ho is not absolutely discharged from all liability, lut only to the extent that he may have smetained loss or injury by the delay. ${ }^{i 1}$ The same person may be gulluantor, and also indorser of a note; and in such ease, while failure to give him due notice of demand and nonpaynent will discharge him as indorser, he will still he bombl als guarantor."

71 Castle v. Rickley. $4 t$ Ohio St. 490 ; Burrow v. Zapp, 69 Tex. 4 ti6.

72 Deck v. Works, 57 N. Y. Pr. 292. 


\title{
CHAPTER IX.
}

NATURE AND RIGHTS OF A BONA FIDE HOLDER.

\author{
SECTION I. \\ THE RIGITS OF A BONA FIDE HOLDER.
}

$\S 197$. It is a general principle of the law merchant that, as between the immediate parties to a negotiable instrument - parties between whom there is a privity - the only superiority of sueh an instrument over other unsealed evidences of debt is that it prima facie imports a consideration. But a bona fide holder for value of such an instrument takes it discharged of all the equities existing between antecedent parties, and may recover on it although it be without any validity as between the parties prior to himself, as, for example, if it was withont consideration originally, or the consideration has failed, or the instirument was subsequently released or paid, or even though it was originally obtained by fraud, theft, or robbery. ${ }^{1}$ This general rule is subject to certain exceptions, treated of in the suceceding sections.

It shonld be observed, however, that as between him and his immediate predecessor, or party between whom and himself a privity exists, he stands upon the same footing as the payee of a note against the maker. Frand, illegality, want or faihre of consideration may be plearled against him by such immediate party as freely as if the instrument were not negotiable. ${ }^{2}$

$\S 198$. As to anterior parties to the transfer of the instrument, the rule is, as between them on the one part and the holler on the other, altogether different. They are not in

1 Daniel on Negotiable Instruments, $\S 769 a$, and cases cited.

2 Daniel on Negotiable Instruments, $\$ 810$. 
privity with him, and they camnot set 1 , against him defenses which might be valid as between them and any party prior to him, unless he is affected hy surh defenses thromgh mala fides, notice, or otherwise having taken the paper without value, or without the usual eourse of business," which ciremustances will be hereinafter discuseded.

$\$ 199$. Meaning of term "bona fide holder;" presumption. Two propositions nily be considered as settled principles of commercial law - principles which have been, for the mont part, reiterated by the Supreme Court of the United States, and prevail thromghout the Lnion:

First. 'That to entitle one to the rights and protection of a purchaser or holder of a negotialble instrument, als set ont in the preceding paragraphs of this chapter, the paper must have been acquired (1) bona fide, (2) for a valuable consideration, (3) in the nsual and ordinary course of business, (4) before maturity, or rather when it was not overdue, and (5) without notice of facts which impeach its ralidity as between antecedent parties. ${ }^{4}$

Second. The mere possession of a negotiable instrument, produced in evidence by the indorsee, or by the assignee where no indorsement is necessary, imports prima facie that he acquired it bona fide for full valne, in the usual course of business, before nuaturity, and withont notice of any circumstance impeaching its validity; and that he is the owner thereof, entitled to recover the full anomt against all prior parties. In other words, the produetion of the instrmment and proof that it is gemine (where indeed such proof is necessary), prima facie establishes his ease; and he may there rest it. ${ }^{b}$

$\S 200$. What rebuts the presumption.-Countervailing proof that the instrument was exeented without consideration as between the original parties - as, for instanee, that it was exeented for aceommodation as between them, or that

3 Daniel on Negotiable Instruments, \& \$11.

4 Daniel on Negotiable Instruments. $\$ 769 a$.

5 Danicl on Negotiable Instruments, \$ $8 I_{2}$, and eases eited. 
the consideration, originally ralid, has subsequently failed - does not impair the hohler"s superiority of position, and lo may still rest his case upon the instrument itself, from which it will still be presumed that he acquired it in a mammer entitling him to stand upon the vantage ground of a bona fide holder for value." White the authorities are not miform, it may be considered fairly well settled that proof of mere misapplication of the instrument, where it has subserved its substantial purpose, does not slift the burden of proof.

But if the maker or acceptor, who is primarily liable for parment of the instrument, or any party bound by the original eonsideration, proves that there was frand or iliegality in the inception of the instrument; or if the cireumstances raice a strong suspicion of frand or illegality, the owner must then respond hy showing that he aequired it bone ficle for value, in the usual course of business, while current, and under circumstances which create no presumption that he knew the farts which impeach its ralidity. This principle is obvionsly salutary, for the presmmption is natural that an instrument so issued would he quickly transferred to another; and mules he gave value, which conld be easily proved if given, it would perpetrate great injustice, and reward fraud to permit him to recover. ${ }^{\top}$ And if it be shown that the original owner lost the bill or note, then, also, the hurlen of proof is mon the holder to prove his title.

\section{$\$ 201$. Owner, though not himself bona fide holder, acquires} title of his transferrer.- A transferee can generally get as good a title as his transferrer possesses, and it is, therefore, a sottled principte that if the party who transferred the instrument to the holder acquired the note before maturity, and was himself maffected by any infirmity in it, the holder acquires as good a title as he held, althongh it were overdue

“Commissioners v. Clarke, 94 U. S. 285; Goodman r. Simond*, 20 How. 343.

T Collins v. Gilbert, 94 I. S. 761 ; Crampton v. Perkins, 65 Ml. 24.

8 Uniom Nat. Bank v. Barber, 9 N. W. 809. 
and dishonored at the time of trunsfer." Thus, it has lw...n held that in an action by a second indorece of a bill given for a smuggling debt, he conld recover against the areceptor, althongh he took it orerdue, his indorser having acpuired it bona fide, without notice before it fell due." And, therefore, even if he have notice that there was frand in the inception of the paper, or that it was lost or stelen, or that the consideration has failed between sone anterion parties, or the paper be overdue and dishonored, he is, nevertheless, entithed to recover, proviled his inmediate indorser was a bonn fide lolder for value muaffected hy any of these defenses. As soon as thr papere connes into the hands of a holiter, nnaffected hy any defeet, its character as a negotiable security is established: and the power of transferming it to others. with the sane innmmity which attaches in his own hand, is incident to his legal right, and necessary to sustain the character and value of the instrument as property, and to protect the bone fide holeler in its enjoyment. 'To prohibit hin from selling as good a right and tite as he himself has, would destroy the very object for which they are seeured to him - would indeed he paratoxical. Ind it has been justly said that this doctrine " is indingensable to the security and cireulation of negotiable instruments, and is fommled on the most comprehensive and liberal prineiples of public poliev. ${ }^{11}$

Bit this rule is subject to the single exception that if the note were invalid as hetwen naker and payee, the payce conld not himself by purchase from a bond fide holder beeome a suecessor to his rights; it not heing esential to such bona fide lobler's protection to extend the principle so far. ${ }^{12}$

202. Equities of third persons. - The indorsee of overduc negotiable paper, even if his transferrer does not answere the deceription of a bome firle holder, is not subject, it has

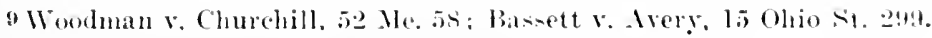
1" Chalmers v. Lanion, ] ('amplis. 3s:3.

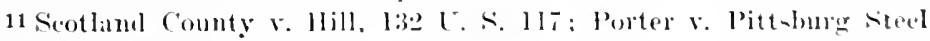
Co.. 12.2 L. S. 2067.

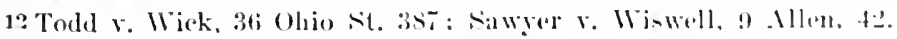


been held, to equitics which may have intervened between remote indorsers and indorsecs, but only to those which exist, at the time of indorsenent to him, between the principal parties and the original holder, and between himself and his own indorser. ${ }^{13}$ But if there be an equity attaching directly to the bill or note itself, it has been held in England that it may he asserted against an indorsee after maturity br a third party who claimed the right to follow the bill. ${ }^{4}$ And if the equity be a claim of some right to the instrument directly attached to it, we perceive no good reason why it may not be asserted against an indorsee after maturity by any party whatsoever. ${ }^{15}$

\$203. After maturity, negotiable paper circulates, but transferee only acquires the right and title of the transferrer. - After maturity negotiable paper still passes from hand to hand ad infinitum until paid. Moreover, the indorser, after maturity, writes in the same form, and is bound only upon the same condition of demand upon the drawer and notice of nonpayment as any other indorser. The paper retains its commercial attributes, and circulates as such in the commmnity; but there is this rital distinction between the rights of a transferce who recciverl the paper before, and of one who received it after maturity. The transferee of negotiable paper to whom it is transferred after maturity, acquires nothing but the actual right and title of the transferrer; ${ }^{16}$ and the like rule applies to the transferee who takes the paper after a refusal to accept by the drawee, provided he had notice of such refusal. ${ }^{17}$ in other words, the transferee of negotiable paper refused acceptance (with notice therrof), or overdue, takes it subject to all the equities with which it was encumbered in the hands of the

13 Hill v. Shields. 81 X. C. 250.

14 Ames on Bills and Notes, vol. I, 891; Benjamin's Chalmers' Digest, 140.

15 Daniel on Negotiable Instruments, \& $726 b$.

1f Texas v. Hardenburg, 10 Wall. 68; Morgan v. United States, 113 T. S. . .00.

17 OKeefe v. Dunn. 6 Taunt. 305; Bartlett v. Benson, 14 M. \& W. 733. 
party from whom he received it; for it comes, to nse Lombl Ellenborough's words, " disgraced to him." Thus, if lu. took it from a thef, or finder, or from a bankmpt incalpar tated by law to make the transfer, he ronld not recover mon it, inasmuch as the thief, finder, or bankrupt conld not."

$\S 204$. Defenses to which such indorsee is subjected.- l'nt an indorsee of an overdue bill " note takes it subject t" equities arising ont of the transaction in which the instrument was executed, and existing at the time of the transter. and not to a set-off ani-ing ont of collateral matters; in other words, he takes the paper subject to its existing equitice. This doetrine was settled in England by the case of Burrough v. Moss, and has been minformly followed, and has been held to apply even thomgh the indorsee had notier, gave no eonsideration, and took the paper on purpose to defeat the set-oft. ${ }^{21}$ Bat no equity arising after the transfer ean affeet the holuer. ${ }^{2}$ Ile is therefore subject to the defenso-(1) That it was afferted in its inception with some inherent vice, as, for instanee, frand, illegality, or duress: or (2) that the consideration falled, or that parment laat been made, or that there harl been accord and satisfaction at the time of the iulorsement. or that there was some equitable defense arising ont of the transaletion, in which the papel was giren, which disabled his indorser in whole or in part to recover. ${ }^{22}$ Any of these defenses is called an equity attaching to the instriment.

$\S 205$. Whether accommodation character of instrument is an equity attaching to it after maturity.- The general rule. that the purchaser of overdue paper ean stand in no better position than his transferrer, does not apply so far as to

18 Byles on Bills [*161], 2s4; A-hur-t r. Royal Bank, 2i Law Times. 168 .

1910 B. \& C. 558.

20 Oulds v. Harrion, 10 Fxch. 5i2: Hareseler v. Greene, s Mo. App. 454 .

21 Baxter v. Little, 6 Mete. (Mas.) i: Haywood v. Stearms. 39 Cal. 58.

22 Daniel on Negotiable Instrumenta. $5.25 a$. 
invalidate bills and notes drawn, indorsed, or accepted for alcommodation, overdue at the time they are negotiated or transferred, it being considered that parties to accommodation paper hold themselves ont to the publie, by their signatures, to be bound to erery person who shall take the same for value, the same as if it were paid to themselves. ${ }^{23}$ And the fact that the purchaser knew that the paper was so drawn, indorsed, or aceepted for accommodation, does not weaken his position. ${ }^{24}$ This prineiple is well established in England, and it is to be regretted that the decisions in the United States do not uniformly follow the English rule.

In the Inited States a number of eases follow the English rule, but in others it is presumed that the aceommodating party intended to lend his eredit only until the maturity of the paper, and did not contemplate its subsequent negotiation; and it is aceordingly held that prima facie he is entitled to defend against an indorsee after maturity. ${ }^{25}$ If there was an agreement, express or implied, not to negotiate an accommodation bill after maturity, the weight of authority is justly to the effect that such agreement would constitute an equity attaching to it upon its transfer after maturit ${ }^{26}{ }^{26}$ but in an English case, demurer was sustained to a plea that it was agreed by the parties that the paper shonld not he negotiated after maturity, knowledge of the purchaser of such agreement not being averred. ${ }^{27}$

206. Rights of bona fide holder, where the instrument originated in fraud or violation of authority. - There are numerous asses in which the line of demareation between the fram whicls does not affect the bona fide holder for ralue, and withont notice, and that which utterly vitiates the instrument in all hands whatsoever, is narrow and difficult to distinguish. The distinctions taken are frequently

2: Charles v. Marsden, 1 Taunt. 224; Carruthers v. West, 11 Q. B. 143 .

24 Charles v. Marsilen, 1 Taunt. 224.

25 Daniel on Nexotiable Instruments, $\$ 726$, and eases eited.

26 Charles v. Marslen, 1 Taunt. 224: Parr v. Jewell, 16 C. P. 684.

27 Carruthers v. West, 11 Q. B. 143. 
very refined and metaphysical; hut the test puestions to lo applied, we think, are these: (1) Ilas the party somght on

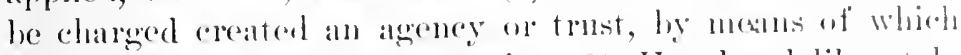
the frand has locent committed! (2) II as ho deliberatoly given the alplearamere of ralidity to the instrmment? (:i) Has he committed negligenee respecting it, ly means ot

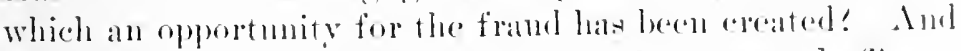

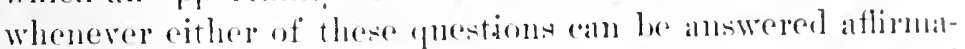
tively upon a fair consideration of all the cipremustances of the case, the balanee of equity ise in favor of the bome fide holder for value and withont untiee, the axiomatie principle of law then applying, flat where one of two imorent persons must suffer", the one who areates the trust, or dores the aet from which the loss results, must bear it.

The cases in which the bonre fide holder camont recover will be separately discussed in the sueceeding section of this clapter. $2 \mathrm{~s}$

$\$ 207$. Instrument completed, but not delivered._- While it camnot be said that the anthorities ale muform, it may bo stated to be safoly settled that it a negotiable instrument has been fully completed in fom and signed by the drawer or maker, and, before delivery, is stolen from the possession of the party who has signed it, and pased by the thief to a bone fide holder for value in the msmal comlse of hmsiness, it would afforel him no defense against sneh bone fide holder. Whether the instrmueat be payahle to bealere or to the alder of the thief, if it be indorsed by him, we cam see ne. reason why the bona fide holder shomld not le entitled to recover. The want of delivery is a defeet not appanemt om the fare of the hill or note. The party has wiven the alppealune of validity to his paper. ITis signature is itself an assurance that his ololigation has been perfected hy delivery: and it being neecsiry that the loss shomld tall mpon one of two innocent parties, it shonlel fall npon the one whose act had opened the door for it to enter.

2x See post, \$s $218-2.25$.

29 Danicl on Jegotiable Instrmments. \$ 837 ; Kingon v. Woblforl, 7 Minn. 239. 
$\$ 208$. Where the maker has perfeeted the instrument, and left it undelirered in a safe, desk, or other receptacle, it should then be at his hazard. Such papers are marle for nse, and not for preservation. The maker areates the risk of their being eloigned, by keeping them on hand, and places them on the sime basis as negotiable papers which lave been put upon the market. When once issued the purchiser. is protected and the owner loses, even thomgh he had guarded his property with bolt and bar; and if bankers and others who must mecessarily be in possession of negotiable securities in the course of trade are not protected, we can discover no principle which can be invoked to protect one who holds his own paper contrary to the ordinary wants and nsages of trade. ${ }^{30}$

But, as will be seen in a suceceding section, if the instrmment be incomplete, and there has been no delivery of it to an agent in trust or otherwise intervening, no negligence can be imputed to the maker, and he is not, therefore, bomul, even to a bonu fide holder without notice. ${ }^{31}$

209. When instrument has been intrusted to another with blanks. - If the party songht to he charged upon the negotiable instrument has been betrayed by his agent, or some other party to whom he has intrusted his signature on a blank paper, and who has fraudulently written over it a bill or note. There is no doubt that if the bill or note were complete with the exception that there was a blank left for the smm, the parties who had signed, accepted, or indorsed it would he bound to pay any sum with which it might be filled up to a bona fide holder without notice of the limitation of anthority to the agent or other person having it in hand,.32 and it is immaterial that such holder knew that it had been signed, accepted, or indorsed in blank, unless

:0 Thompson on Bills (Wilson's ed.), 92; 1 Parsons on Notes and Pills, 114.

s1 See post. \& $22: 3$.

32 Michigan Bank v. Eldred, 9 Wall. 544; Vinlett v. Patton, 5 Cranch, 142. 
he was also cognizant of its being fraudulently filled 11 , : If ho knew when he took the paper that anthority as to filling it up was excerded, he could not recorer. ${ }^{3 / 4}$

It seems, also, to be well settled that if the party sought to be charged las intrusted his blank signature to an agent or other person, and lats anthorized such agent or other fereson to fill the blank in some form, for some purpose, that he would be bound to a bona fide holder if the agent or person wrote over snch signature a hill or note. Thus, where papers indorsed in blank were left with a clerk, with anthority to use them for certain purposes, and they were frandulently obtained from him and used differently, the indo:-er was held liable. ${ }^{35}$

210. When executed under mistake and misrepresentation. - If the party possesses ordinary faculties and knowledge, and is betraced into signing a bill or note by the assurance that it is an instrument of a different kind, and is guilty of any negligence in signing the paper, it is generally agreed that he is bound $3^{36}$ and the aet itself can hardly be committed without negligence. ${ }^{3 \pi}$ i man has no right to have eves and see not; or ears and hear not; and while the law shonld protect those who suffer from the want of the senses in their proper development, or ordinary education, it should not permit those who have both capaeity and elucation to throw the burden of their failure to use them upon imocent third parties. In such cases we should say the act of signing the paper without intending to do so, as a general rule, imported negligenee $p^{\rho r}$ se, and rendered the party liable. ${ }^{38}$ If he has full and unrestricted means of ascertaining the true character of the instrmment before signing it. but neglecting to arail himself of such means of information, and relying on others' representations, he signs and

\footnotetext{
33 Huntington v. Branch Bank, 3 Ala. 186.

34 Clewer v. Wymu, 59 Ga. 246.

35 Putnam v. Sullivan, 4 Mass, 45.

36 Chapman v. Rose, 44 How. Pr. 364; Ruddell v. Plialor, 72 Ind. 533.

37 First Yat. Bank v. John 22 W. Ya. 520.

38 Ort v. Fowler. 31 Kan. 478.
} 
delivers a negotiable paper, instead of a different paper, which he intended to sign, he camnot be heard to impeach it when it has been passed to a bona fide holder.

While the doetrine herein annomeed is supported by the strongest cases, in quite a number of the States the courts go far to protect the defrauded parties to the paper rather than the innocent holders; and in England it would seem that the holder under such eireminstances is not protected. ${ }^{39}$

$\$ 211$. When delivered by third party in violation of instructions.-- Still another class of eases, presenting a question sonewhat different from any yet discussed, has arisen where parties have signed their names to bills and notes, either perfect in form, or in llank, with anthority only to deliver them as complete and ralid instrmments upon condition that some other peron shall become a party, or some contingency be fulfilled. In these cases it will be observed the person with whom such instrment is left is its mere custodian, and not an agent having any absolute power to dispose of it. He is not, as to the instrmment, an agent with limited powers, but the ageney itself is conditioned upon the happening of the event upon which he is to becone the agent to deliver. In such case the weight of authority in the Cnited States, with reason, supports the view that the bona fide holder for valne ean recover, notwithstanding such defene; but there is high anthority in England $f \circ \mathrm{l}^{\text {the contrary view. }}{ }^{40}$

\$212. Escrows. - In none of the cases, however, is it maintained that a bill or note, either in full or in blank, intrusted to the payee, to be valid upon a condition, will not be linding if the condition is violated. Such delivery to the payee is in law absolute and complete; and whether the instrument be negotial,le or under seal, the doctrines which apply when third parties are the custodians do not extend to them. ${ }^{41}$ In instrument muder seal deposited with a third party, to be helivered upon condition, is called an escrow;

39 Janiel on Nrogtiable Instruments, \& 850.

40 Janiel on Negotiable Instruments, \$ 854.

41 Tassman $r$. Houlscher, 49 No. si. 
and, according to some Euglish and American decisions, at negotiable instrument may also be deposited with a third party as an escrow, and the parties to it will not lee lomml if the depositary issue it in heach of the trust reposed in liim. ${ }^{42}$

\section{$\S 213$. Difference between sealed and unsealed instruments.}

- It should he horne in mind that there is a cardinal distinction between the perversion of instruments in form negotiable, or capalble and intended to be made so in a certain contingency, and that of instruments meler seal. 'The latter, when complated, may be delivered to thimd personsthat is, to other than the parties - with authority only to deliver them ujon condition; and in such case, if the condition be violated, the partr intending to be only conclitionally bound will not be hound absolutely ${ }^{43}$ I sealed instrument so delivered to a third person is called an escrow.

But negotiable instruments, as it seems to us, stand on a different footing entirely. They ale letters of eredit, and proclamations that all is right to every purchaser or transferee; and one who chooses to put his name on an instrument possessing these characteristies, instead of confining his liability by shaping it in a form expressive of his meanins, slould not he permitted to ansuare others, and escape himself unseathed. To hold othervise wonld be a wide departure from the principles which ramify the law mereluant. and would he as repmenant to reason as a decision that an instrument absolute on its face miglut he varied by a parol condition. And eren as to souled instruments the doctrine now finds favor that, if complete, and signed by sureties with endition that other sureties shall join, the signiner sureties will be boumd if they laue them with the principal obligors, and then deliver them without poemring the artditional sureties, ${ }^{44}$ thongh it is othelwise in rases where such instruments, when loft with the oblignrs. indicate on their face that they are incomplete, and that additional par-

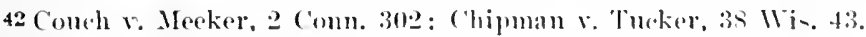

4:3 Xash r. Fugrate, 24 ciratt. 202.

44 Dair v. Cnited States, 16 Wall. 1: State v. Prok, is Me. 2S4. 
ties are contemplated, ${ }^{45}$ and also where the party taking them has notice that the condition is violated. ${ }^{.6}$ If the sealed instrument, perfece on its fale, be left with the obligee, mpon condition that it shomld le ralid only npon its execution by a thind person, the delivery is complete, and it is valid and operative though not so executed. ${ }^{47}$

$\$ 214$. Defenses excluded by estoppel in pais.-Defenses that might otherwice he sucessfully interposed against the bona fide holder for value may be exchuded by reason of the representations or conduct of the defendant, which is called in law estoppel in pais. Thus, if the holder purchased the note with the defendant's knowledge and consent, it has been held that the latter camnot set up prior payment, or other lefense against it. ${ }^{45}$ It is to be observed that estoppel does not arise mnless the act or course of conduct alleged to constitute it is acted upon by the party sceking to benefit by it, ${ }^{49}$ and therefore a statement made by the maker to the indorser of a note after he acquires it, that it is all right, does not amount to estoppel.50 Nor does it arise where there is a mistake or mismulerstanding as to the identity of the note concerning which the representation is made. ${ }^{51}$

Representations, referring only to the then existing status of the instrument, will not exclude defenses subsequently arising. ${ }^{52}$ And where they are made by an indorser, and not by the maker, they bind the former, but not the latter. ${ }^{53}$ This plea, on the part of the plaintiff, which excludes the right of the defendant to set up the true condition of affair's as a lefense, is called "estoppel in pais," it being an extraneous matter dehors the record. And whenever

\footnotetext{
45 Warl v. Churn, 18 Gratt. 801.

4 4i Nash v. Fugate, 32 Gratt. 595.

47 Simonton's Fitale, 4 Watts, 180: Duncan v. Pope, 47 Ga. 445.

48 Downer v. Reed, 17 Minn. 493.

49 Moore v. Robinsou, 62 Ala. 537.

5.) Crossan v. May, fis Ind. 242; Hoover v. Kilander, 83 Ind. 420.

51 Erickson v. Roehm, 33 Minn. 53.

52 Maury v. Coleman, $24 \mathrm{Ala} .381$; Allen v. Frazee, 85 Ind. 283.

5: Dowee v. Schutt, 2 Den. 621.
} 
it is relied npon where the system of common law pleading prevails, it hats been held that it must be specially plearted.'s

$\$ 215$. Good faith essential to estoppel. - It is to le observed respecting estoppel that while it exacts good faith from the party bound, it likewise exacts good faith in the party dealing with him. Therefore, if the latter is hinself cognizant of a fraud upon the maker at the tine of the purchase, and knows, also, that the maker is ignorant respecting it, good faitl wonld require that he should inform the maker of it, and if he does not so inform him, the maker will not be estopped by having told the purchaser that the note was all right, and would he paid at maturity, from setting up the fraud of which the purchaser had notice. ${ }^{5 \cdot}$ And so the holder will not be protected if he knew of any illegality in the instrument. ${ }^{5 i}$ In other worls, estoppel is a plea that is born of, and must be nomrished by, equity, and he that asks equity must do equity. If he conceals facts from the maker he acts inequitably and cannot recover. ${ }^{57}$

$\$ 216$. Amount of recovery; general rule. The holder may recover the full amount if the note wats made, or bill aleeepted, mon a valuable consideration. And even if there was $n$ o ensideration, as hetween the original parties, but a mere becoming a party for accommodation, the holder, although he knew the fact, could recover the whole anount, provided he paid full ralue. ${ }^{5 x}$ But if he paid less than full value, it is a matter of dispute whether or not he is limited, in his reevery, against the maker, to the amount advanced. The English eourts sustain the aftirmative of the proposition, but the authorities in the Inited States are direetly at war. The true doctrine secms to he, that the party paring lese than its face value for paper made, accepted, drawn, or indorsed for accommodation, and not knowing the faet at the time of purchase, is cutitled to reeover the full amount

54 Davis v. Thomas, 5 Leigh. I.

55 Sackett v. Kellar, 2.2 Ohio St. 554.

56 Watson v. Hoag, 40 Iowa, 143.

57 Platt v. Jerome, 2 Blatehf. 186.

58 Charles v. Marsden, 1 Taunt. 224. 
against the accommodation parties, because they have deliberately and intentionally put forth themselves to be treated as being bound in the mamer indicated. ${ }^{59}$ But the riew has been taken in a number of eases that he is only a bona fide holker to the extent of the consideration paid by himself or a prior party, and can recover that only against the aceommodation party. ${ }^{6 \prime \prime}$ And even if he knew they were accommodation parties at the time of purchase, it wonld make no difference, provided the party he purchased it from was a bona fide holder, who conld himself enforee it, or was a subsequent hokler to the parties between whom the accommodation existed, and appeared to the purchaser to be himself a bona fide holder, and not an agent for any of the parties to the accommodation. ${ }^{61}$

\section{$\$ 217$. Amount of recovery when bill or note has inception} in fraud.- When the execution of the bill or note has been induced by frand, a different mle, according to a number of anthorities, wonld apply. The bona fide holder of it for value, and withont notice, is mulonbtedly entitled to be protecterl against a loss which would befall him if the party deframled were permitted to set up the defense of framd on the part of the payce against him, as we have already seen. But it does not, therefore (as has been considered), follow that he may recover of such party the whole amount, when he has paid a less sum. For his protection and security against loss, it is only necessary that he shonld be paid back the amount which he was induced to give for the instrument by its appearance of validity, and therefore sneh amount is the limit of lis recovery against the drawer or maker who was defranded into the execution of the instrument. $^{62}$ Put the Tnited States Supreme Court has expressed itself in favor of the doctrine that the purchaser

56) Moore v. Baird, 30 Pa. St. 138; Dumn v. Ghost, 5 Colo. 139.

co Inolcomb v. Wyekoff, 35 N. J. L. R. 37 ; Stoddard v. Kimball, 6 ('ush. 469 .

sid Holcomb r. Wyrekoff, 35 N. J. J. R. 37; Gimmi v. Cullen, 20 Gratt. $43 \%$.

f2 IIolcomb r. Wyekoff, 3., N. I. T. R. 38; Story on Bills, \& 188. 
of a negotiable security before maturity, in cases where ho is not personally clargeable with framb, is cutitled tw recover its fall amomnt against its makel, thomgh he ma! have paid less than its par value, whaterer may hatre her+u its original intimity, and this view seems to be the settled conclusion of that trihumal."

Where, however, some legal consideration exists in the inception of the paper, it seems that in New York the bomm fide holder may recever the full amomut, no matter what amount he may give for it." 'This seems to us tho true distinction in such cases. It the paper is issued in frand without consideration, the bona fide purchaser should be limitod in recovery to the amomnt paid with interest." But it there was an original valid consideration, or the paper was issued fairly and intentionally withont ensideration, then he is entitled to recover the whole amount regardless of the amount lie pays. ${ }^{6}$

\section{SECTION II.}

ExCEPTIONS TO, ANI MODIFICATIONS OF, TIEE RUIE AS TO TIE RIGHTS OF A BONA FIDE HOLDER.

\$218. Exceptions stated,- There are some defenses which are as available against a bona fide holder for ralue, and without notice, as against any other party. 'They are those which go to show that the instrument was absolutely and utterly roid, and not merely voilable, (1) ly reason of the incapacity of the party assming to contrat; or, (2) by reason of some positive interdietion of law; or, (:3) by reason of the want of consent of the party sought to be bound to the particular contract. ${ }^{67}$

\$219. (1) As to incapacity.- If the maker of the note were an infant, a married woman, a lmatic, or a perion

fai Cromwell v. County of Sac, 96 U. S. 60; Railroad Companies $v$. Schutte, 103 [`. S. 118.

lit Ilowe r. Potter, 61 Barb. 357.

as Holcomb v. Wyckoff, 35 N. J. 1. 38.

ef Daniels v. Wikon, 2I Minn. 530.

6i Daniel on Negotiable Instruments. \$ so6. 
under guardianship, the signature would impart no validity to it, and the bona fide holuer could not recover against him, or her, howerer ignorant of the incapacity when he took the paper. ${ }^{6 *}$

$\$ 220$. Instrument obtained by imposition on infirm or illiterate persons. - If one laboring muler the disadrantage of some natural infirmity or defect of edneation has been inposed upon, and thereby deceived into exeenting a negotiable contract, under the impression that it was for a different amount, or was a contract of a different character, the defense of frand and imposition arails against a bona fide holder for value. The case suggested is closely allied in principle to the defense of incapacity. Thus, if a note were frandulently or falsely read to a blind man, and he were to sign it believing it to have been correctly read; or if the party were unable to read, and signed a note, after due inquiry and precantion, under the assurance that it was an agreement of a different kind, we should have a new element entering into the consideration of his liability. In such cases the want of faculties to deteet the fraud shields the party from its consequences, and the authorities justly exonerate him. ${ }^{69}$

He has created no agency or trust. He has not intentionally or knowingly given the appearance of validity to the paper. It cannot be said that he has acted negligently, because his infirmities prevented that diligence which men of ordinary faculties and of education possess. ${ }^{70}$

§221. (2) As to instruments declared void by law.- If the statute law pronomees the contract evidenced by the instrument to be roid, because made upon a gambling, usurious, or other illegal consideration, it is an absolute mullity; and, althongh in form negotiable, no curreney in the market, and no degree of innocence or ignoranee on the part of

68 Daniel on Negotiable Instruments, § 806a.

69 Putnam v. Sullivan, 4 Mass. 45; Schuylkill County v. Copley, 67 Pa. St. 386.

70 Daniel on Negotiable Instruments, § 847 . 
the holder ean impart any validity to it. ${ }^{71}$ But althongh tho party executing such bill or note eammot be bound even to a bona fide holder, the indorser will be liathe upon his. indorsencent, which warrants its valielity, and is at sepalrate and independent contract. ${ }^{72}$ And in many localities negotiable instruments exeruted upon gaming or usurious considerations are upen the sance footing as those executed for other illegal considerations - that is, void between the parties, but ralid in the hands of a bona fide holiter. ${ }^{33}$

But sometines the statute declares a contract void as between original parties, and in such eases a boun fide purchaser is not affected by the illegality; ${ }^{\text {it }}$ and when the instrument was executed upon an illegal consideration, especially if illegal by statute (but not absolutely aroiding the instrument), it throws upon the holder the burden of proving bona fide ownership for value. ${ }^{i 5}$ But a failure of consideration does not throw this burden upon him. ${ }^{7 i}$ And in all eases where the statute does not declare the instrument roid, bona fide ownership for value being proved, the holder is entitled to recover. ${ }^{77}$

222. (3) Want of consent.- So where the party las never in fact signed the instrument as it then stands, as, for instance, where it was forged in its inception, and is not genuine, or was subsequently materially altered; or if such signature were written on the fly-leaf of a book loaned to such person, or in an album, or were left with him for any legitimate purpose, such as to be used as a means of identi. fying the writer's handwriting. ${ }^{\text {is }}$ In such eases the bona fide

i1 Sondheim v. Gilbert, 117 Ind. 76: IIarper v. Young, 112 Pa. St. 419.

i2 Daniel on Negotiable Instruments, \$ 6 il et seq.

73 Haight $r$. Joyee, 2 Cal. (it: Cheney v. Cooper, 14 Nebr. 415.

it Paton $\mathrm{v}$. Coit, 5 Mich. 50.).

is Vallett v. Parker, ti Wend. 615: Johnson v. Meeker, 1 Wis. 436.

76 Wilson v. Lazier, 11 Gratt. 478.

7t Willams v. Cheney, 3 Gray, 22t5; Hubbard s. Chapin, 2 Allen, 323.

78 Indiana Nat. Bank v. Holtzdaw, 98 Ind. 8.; Caulkins v. Whixler. 29 Iowa, 495: Nanee v. Lary, 5 19. 370: Daniel on Negotiable Instruments, chaps. XLII and XLIII, on Forgery and Alteration. 
holder cannot enforee it, for the defendant has only to say: "This is not nuy contract," " non hac in foedra reni." So if executed by one acting as agent of the prineipal, but exceding his anthority, the bona fide holder cannot recover unless the principal were in fanlt in indncing him to believe that the agent had anthority. ${ }^{\text {is }}$

$\$ 223$. Instrument incomplete and undelivered. $-A$ class of cases, illustrative of want of consent, arises when in an incomplete instrmment has been signed and stolen, without any delivery to an agent in trust, or otherwice, intervening. In snch cases no trust for any purpose has been created. No instrument has been perfected. No appearance of validity has been given it. No negligence can be imputed. Therefore if the blank be filled, it is sheer forgery, in which the maker is in nowise involved, and he is not therefore bound, even to a bona fide holder without notice. ${ }^{80}$

$\S 224$. Duress. - Any contract entered into under duress lacks the first essential of validity - the consent of the contractor - and negotiable instruments form no exeeption to the rule. As between immediate parties, proof of duress at once annuls the instrument, or rather enables the party who was under duress to aroid it, at his option ${ }^{81}$ but whether or not, in the hands of a bona fide holder for valuo without notice, the duress in its inception renders it voirlable, is a question upon which the anthorities do not altogether agree. In England the rule seems to be that the defense of duress cannot be pleaded against the bona fide holder for value, and the English doctrine is cited by many text-writers on hills and notes (including Byles, Chitty, and Story) withont eriticism or dissent, and as a correct statement of the law. Thut Roscoe, in his Digest of Bills and Notes, agrees with the proposition stated in the text, as

79. Andover Bank v. Girafton, 7 N. H. 298; The Floyd Acceptance, ? Wall. 666.

so 1 Parsons on Notes and Bills, 114; Daniel on Negotiable Instruments, \$ 839.

81 liush v. Brown, 49 Ind. 573; Fairbanks v. Snow. 145 Mass. 153. 
does also the most recent and thorongh of the American writers on this subject."

Whaterer may be saib about the cates on the subject, pro and con, there surely is no somul principle which wonld compel any person, whether a party to a negotiable or ot her kind of instrument, to pay it, when moler violent duressthat is, under the compmlsion of foree with the only alternative of subnitting to great bodily injury or indignity. Consent is of the essenee of every contratet, and if it is mot given, the party should not be bound if he had no alternattive but to seem to give it, or suffer grievons wrong. IJe ereates no trust, he commits no negligence, whereby the confidence of another can be betrayed. He is in no lefanlt, having a right of self-defense in preferring his own life and safety to the ehanes of peemiary injury to others: and his extorted act is nothing more nor less than the act of the wrongdoer who nes his person as the instrument of forging his name. Threats to inflict slighter wrongs would stand on a different. footing. ${ }^{83}$

\$225. Real and personal defenses.- Mr. Norton, in his treatise on the subject of Bills and Totes, adopts the classification of Professor Ames in his work on that subject, and elassifies defenses into real and personal,- grouping all defenses that are good against a bona fide holder for value under the class deseribed by him as "real defenses," and all the defenses good as between immediate parties, lint not availalble against a bona fide lolder, he groups under the elass denominated as "personal defenses." IIe thus defines the two classes of lefenses:

"(a) Real - Or those that attach to the instrument itsolf, and are good against all persons.

"(b) Personal - Or those that grow out of the agreement ol conduct of a particular person in regard to the instrument, which renders it inequitable for him, thom h holding the legal title, to enforee it against the defendint,

s2 Roseoe's Digest of Bills and Notes, 117, note 20: 1 Parsons on Notes and Bills, $2-66$.

s.3 Daniel on Negotiable Instruments, $\$ 858$. 
but which are not arailable against bona fide purchasers for value withont notice." st

\section{SECTION III.}

WHAT CONSTITUTES A BONA FIDE HOLDER.

$\$ 226$. Requisites of ; general rule-As has been seen, to entitle the purchaser or holder of a negotiable instrunent to the peculiar rights and protection set out in the first section of this chipter, such purchaser must have aequired title to the instrument (1) bona fide, (2) for a valuable consideration, (:3) in the ordinary course of business, ( 4 ) before maturity, and (5) withont notice of facts which impeach its validity as between antecedent parties.

$\$ 227$. Bona fides essential.- The hoider, in order to be cntitled to protection against offsets and equities and defenses based upon frauds, pleaded by prior parties, must have acquired the paper in good faith from his predecessor. "Frand cuts down everything," sis and althongh the holder may pay value, yet, if his acquisition of the paper be in any respect fraudulent - as where it is made or transferred to give him preference over other parties to a compromise of creditors - he cannot chaim the position of a bona fide holder." In pleading, mala fides must be distinctly alleged, and an allegation that the party is not the bona fide lobler is not sufficient. ${ }^{s i}$ It is the bona fides of the holder alone that is to be eonsidered, not that of his transferrer, and the fact that the pavee had an interest to part with the paper, is not a cireumstance which affeets the rights of his intor:ese. .89

$\$ 228$. Effect of negligence on bona fides.-For quite a long period of time the conts of England oscillated between two propositions, viz: Whether good faith alone, or good faith in conjunction with the exercise of due diligenee, ennstituted the test of the holder's right to recover. But the

st Norton on Jills and Notes, 216.

sis liogers v. Hadley, 32 L. .J. Exch. 248.

so Dariel on Newotiable Instruments, § I93 et seq.

4 i Ther v. Rich. 10 Ad. \& El. 784.

s4 Helmer v. Krolick, 36 Mich. 373. 
Court of King's bench finally decided that, while grosis negligenee might be eridenee tending to show mala fictes, and as such admissible, it dil not in itself anoment to proot of mala fides, and wats not sutlicient to deprive the holden of his right to recover.: Thus the bona fides of the purchaser or holder wats restored as the test of his right to recover, and, after a wide departure, the law re-establishenl upon the original basis estallished by Lord Kenyon. Anl Lord Demman, C. I., silil: "The question I offered to sul,mit to the jury was whether the plaintiff hat been guilty of gross negligence or not. I believe we are all of opinion that gross negligence only would not be a sufticient answer where the party has gives consideration for the bill. Gross negligence may he evidenee of mala fides, but it is not the same thing. IVe have shaken off the last remuant of the contrary doctrine. Where the lill has pasied to the plaintiff without any proof of bad faith in him, there is no objection to his title."

The rule thus tinally re-established in England laas been followed and approved there in subsequent eases, ${ }^{; *}$ and has met with the alpprobation of most all of the witers on negotiable instruments, on the ground that it relieves them of the clog which the contrary doctrine imposes on their negotiability, and presents at once the clear and intelligible question of bona fides for the consideration of the jury'; whereas. to leave it to a jury to determine as to the degree of camtion which a prulent man must exereise on taking such an instrument, would learl to much perplexity and to frequent injustice. ${ }^{91}$

\$ 229. American view, - In the Inited States the decisions of the eourts have varied, some following the rule in the case of Gill v. Cubitt. ${ }^{2}$ in which the prineiple was laid down

so Goodman r. Inarvey, 4 Al. \& lil. sio.

m Easely r. Crockford, I0 Bing. 243: Raphael r. Bank of Englant. 33 Fing. L. \& Eq. 278.

91 Story on Totes. 5 s 197. 382: Edwardi on Dills, 506: 2 Parsons on Notes and Bills, 27-2029.

923 l. \& C. 466. 
that, although the holder had giren value for the bill or note, ret, if he took it under circunstances which ought to have excited the suspicions of a prudent and careful man, he conld not recorer, bnt by far the greater number concurring in the principle which has been finally established as the law of England.93 Chancellor Kent, in his Commentaries embodies the riews taken in Gill v. Cubitt; but at that time the present prevailing doctrine had not been reestablished, and it is to be supposed that he merely incorporated in his text the then existing decisions of the English courts." But both upon prineiple and authority, it is safe to say that the experience of the commercial world, and of the courts before which the doctrines here discussed have so often passed in review, have satisfied jurists, as well as men of business, that the interests of commerce are best subserved by the liberal view which promotes the circulation of negotiable instruments; and that the bona fides of the transaction shonld be the decisive test of the holder's rights. It is not the duty of parties about to purchase negotiable paper to make any inquiries not required by good faith, as to possible defenses of which they have no notice, either from the face of the paper, or facts communicated at the time. ${ }^{96}$

In a case before the United States Supreme Court, Mr. Justice Swayne, who delivered the opinion, disapproved Gill v. Cubitt, 3 B. \& C. 466, and quoted with approral Goodman r. Harrey, 4 Al. \& El. 870, in which Lord Denham sairl: "I believe we are all of opinion that gross negligence only would not be a sufficient answer where the party has given a consideration for the bill. Cross negligence may he rvidence of mala fides, lut is not the same thing. Te have shaken off the last remunt of the contrary doctrine. Where the bill has passed to the plaintiff

\footnotetext{
93. See cases rited in support of both views, Daniel on Negotiable In-truments, \& 775 .

943 Kent Comm. 103, 104.

95 Hamilton v. Vought. 34 N. .T. T. 187.

96 \[urray v. Beckwith, 81 Ill. 43; Houry v. Eppinger, 34 Mich. 29.
} 
without any proof of bad faith in him, there is no objection to his title." 97

$\S 230$. What is meant by valuable consideration.- The purchase must have acquired the instmment for a valuable consideration." In some cases it is said that the holder must have parted with "full value," cometimes "far value," and sometimes the expression " for value" is used.

In New York it has heen said that " the consideration for the transfer must be full and fair als well as valuable," while in another it is said that "when a parting with value is proved, the amount of the consideration is not otherwise important than as bearing on the question of actual or eonstructive notice." "This latter view seens to us the correct one. The ormer of a lill or note has as much right to sell it as he has to sell his horse. The prior parties, by making it negotiable, have warranted the right of the paree or indorsee to make title to another.

And if he does so at any price, the holder aequires full rights and interests in the instrument as against all parties, unless he had notice of defects, or willfully abstained from inquiry under cireumstances which justify the imputation of bad faith.

$\S 231$. When price paid conveys notice of fraud.-The price at which the paper is offered may amount prima facie to notice, and ereate the presmuption of had faith in the purchaser. If a person were to offer a fine horse for sale for five cents, the very nature of the offer would wam the purehaser that he acted at his peril. And so if the amount which the holder offers to take for a negotiable instrument is totally insignifieant as compared to its face value, it might be under the cireumstances implied notice that there was something wrong about it: and if he took it without inquiry, lie should not be protected. There is no eonflict hetween this view and the eases which hold that gross negli-

97 Murray r. Lardner. 2 Wall. 710.

98 See ante, $\$ \$ 90-115$.

99 Gollsmid v. Lewis County Pank, 12 Barb. 410 : Gould r. Segee. is Duer, 370: Daniel on Negotiable Instruments, $\$ 77$. 
gence will not of itself be sufficient to impeach the holder's or purchaser's title. This is not merely gross negligence, but may be regarded as willful or fraudulent blindness, and abstincince from incuiry, so great as to amomnt to evidence of bad finth. For it is the obvions suggestion of reason that a bone fide owner would not throw away his property for a mere song, and that the purchaser acted in bad faith when he acepuired it for comparatively nothing. ${ }^{\text {. }}$

$\S 232$. Line of demarcation between negligence and notice.It is difficult, indeed impossible, to lay down the exact line of demarcation and state what proportion the amount paid must bear to the face of the paper in order to charge the purchaser prima facie with notice, or raise the presumption of bad faith on his part. But, in general terms, it may be said that the consideration should be so utterly trifling as to bear upon its face the impress of frand to leave open no reasonable conjecture but that the purehaser must have known, from the very nature of the facts, that they could not have originated from any but a corrupt sonree." The known solvency of prior parties would of course strengthen the argument of implied notice and bad faith wherever they were alleged. If the amount paid for the paper were not so insignificant as, per se, to charge the transferee with notice, it might still be so inadequate as to be a pregnant fact to be given dne ennsideration in connection with others, in determining whether he should be so chargeable or not." As said in Rhode Island by Potter, J.: "The fact that the plaintiff purchased the note for a sum much below its face, even if he did not know of any equities between the original parties, might le a cireumstance tending to show that he harl willfully shut his eyes to the means of knowledge of the facts." 4

1.Johnson v. Butler, 31 La. Ann. 776 ; Snitlı v. Jansen, 12 Nebr. 125; Richmond v. Diefendorf, 58 N. Y. Supp. 538.

2 Daniel on Nexotiable Instruments, $\$ \S 795,796$.

3 Chonteau v. Allen, 70 Mo. 341.

4 Millard v. Barton, 13 R. I. 610; Daniel on Negotiable Instruments, $\$ 779$. 
$\S 233$. The apparent purchase must have been a purchase in fact, and not a mere bookkeeping entry. Mere dixonut and eredit do not of themselves constituto a bome fide purchaser for value. To oeculy that position the holker mu-t. actually have parted with some thing of value for the note. Thus, where a bank discounted a note for a comprany, ambl credited it with the amomit, the eredit, on aceonnt of othere deposits, subsecuently increasing, so that at the tine of suit on the note the bank had aetnally paid nothing for it, it was held not a purchatere for value, and that its remedy was to tender the note batek to the comprny, and eancel the eredit."

$\$ 234$. When taken as collateral security for debt contracted at the time. - When the bill or note of a third party, payable to order, is indorsed as collateral security for a debt eontracted at the time of such indorsement, the indorsee is a bona fide holkler for value in the usual course of business, and is entitled to protection against equities and offsets and other defenses arailable between antecedent parties provided, of course, that the bill or note transferred as collateral seenrity is itself at the timo not overdue. And the same prineiple applies where the collateral bill or note is payable to bearer, and is transferred to the ereditor by delivery. 'This doetrine rests upon cleare gromeds. There is an evident present consideration for the transfer of the collateral bill or note; a present change in the legal rights of the parties. And the text-writers, supported by an almost mubroken train of decisions, angere that the indorsee is entitled to protection to the extent of the debt secenred."

And likewise, when the debt is not pet due and the collateral bill or note is indorsed as security and there is an agreement for delay mith the collateral shall mature, such

5 Mamfacturers Xat. Batuk r. Sewell, il Wis. 312: Drescer v. M. \& I. R. Co., 93 T. S. 92; Lancaster County Sat. Bank r. llurer, $11+$ Pal. St. 216 .

a Texas Banking ('o, v. Turnley, til 'Tex. 369); Best r. ('rall, ö3 kan. 482; Miller v. Bogkin, 70 Mlit. titi. 
agreement by the creditor constitutes a consideration and makes him a holder for value. ${ }^{7}$

$\$ 235$. When taken as collateral for pre-existing debt.When there is no express or implied agreement for forbearance and lelay as to the pre-existing debt, the transferee of the collateral camnot be regarded as a bona ficle holder for ralue within the law merchant, unless simply becoming a party to the bill or note transferred as collateral security for the debt, and the existence of the debt, are sufficient to create that relation. Niany eases deny that it is. But this alone is, in our judgment, sufficient. The maker has sent out a negotiable contract to pay the bearer or indorsee a certain sum. It has been aequired before maturity for a raluable consideration, and the burden of fixing the liability of the indorser (if any) assumed. The holder is naturally lulled into security and inactivity, by crediting the face of the note; and he should not be made to suffer by the maker for confidence which his own promise created. In Maryland this subject has been fully considered and the riews of the text approved; and so likewise in Indiana, and in New York.

In the United States Supreme Court the question under consideration was fairly presented, and it was called on to determine whether the transfer of a negotiable note, merely; as collateral security for a pre-existing delt, was such a negotiation as excluded defenses which were available between anterior parties. In the case referred to, it appeared that the Brooklyn (ity and Newtown R. R. Company executer and delivered to $\mathrm{H}$. \& J. a eertain note for the purpose only of raising money for the company; and that H. \& J. indorsed it in blank, and transfered it as security for a call loan to the National Bank of the Republic. The court sustained the right of the bank to recover against the railroad company, notwithstanding the fact that the transaction was in $\mathrm{New}$ York, in which State the decisions of the courts are, in principle, opposed to snch right. And the 
opinions of Judges IIarlan, Clifford, and Bradley are most learned and able expositions of the subject in all of its ramifications. ${ }^{8}$

$\S 236$. Amount and mode of recovery. When it appear's that the bill or note was acquired hy the holder ats collateral security for a debt, and he is deemed entitled to recover upon it, he is still limited to the amomit of the delit which it secures, if there be a valid defense aganint his transferrer, being regurded as, at all events, a bonu fide holder, and entitled to. stand upon a better footing only pro tanto." Thus such a holder conld recover against an accommodation party no more than the consideration actually advanced ${ }^{10}$ but in the absence of proof he will be deemed to have advanced the full amount of the paper. ${ }^{11}$ In Maryland, however, it has been said in respect to an accommodation note, which was transferred as collateral security merely: "Sueh being the case, it was clearly incumbent upon the plaintiff to show what debts were embraced by the security, and the amount dne thereon." 12 Although the debt secured by the collateral be less in amount, yet if there be no defense to the collateral note, the holder may in general recover the full amount, holding the balance as a trustee. $^{13}$ If the paper has been pledged to a bona fide pledgee in fraul of the true owner, as the pledgee has only a lien for the amount of his debt, the true owner nuar, by paying that debt and discharging the lien, repossess himself of the instrument. ${ }^{14}$

8 Maitland v, Citizens' Nat. Bank, 40 Md. 540; Continental Nat. Bank v. Townkend, 87 N. Y. I0; Daniel on Negotiable Instruments. $\$$ $831 a, 831 b$.

9 Handy r. Sibley, 46 Ohio St. 15; Duncan \& Sherman r. Gilbert, 30

N. J. L. 527; Fisher y. Fisher, 98 Mass. 303.

10 Maitland $v$. Citizens' Nat. Bank, t0 Mld, 540 : Brown v. Callaway, 41 Ark. 420.

11 Dunean \& Sherman v. Gilbert, 30 N. J. L. $52 \pi$.

12 Maitland V. Citizens" Nat. Bank, 40 Mld. 540.

1:3 Tooke $v$ Newman, 55 Ill. 215.

14 Stoddard r. Kimball, \& Cush. 469: Chicopere Bank r. Chapin, S Mete. (Mass.) 40. 
237. Ordinary or usual course of business. - The holder must have acepuired the paper in the ordinary or usual course of husiness, by which phrase is meant to describe a transfer according to the usages and customs of commereial transactions. ${ }^{15}$ Whether or not a transfer in payment of preexisting debt is of this character, was for a long time questioned: but the doctrine is now settled that it is. ${ }^{16}$ And when the paper is transferred as collateral security for a contemporancous or pre-existing debt, there are many variations of the question, and many riews taken, as to whether or not it is in the usual course of business for a valuable consideration, according to the mereantile use of those terms. ${ }^{17}$

$\$ 238$. Transfers which are not in usual course of business.There are some transfers, however, in which the legal or equitable title to the instrunent passes, but which are not in the usual course of business.

T'hus, a receiver appointed by a court, and who comes in possession of a bill or note of a litigant by operation of law acquires no better title than such litigant possessed, for, as said in New York, "he aecquires title by legal process, and not in the regular course of dealing in commercial paper." 18 The like decision was rendered in Connecticut, in respect to the receiver's of assets of a bank, for the benefit of its crerlitors. ${ }^{19}$ So the assigmment of a bill or note by operation of a bankrupt or insolvent law, is an instance out of the usual course of commercial business. So also is a transfer by the paree or holder to a trustee for the benefit of creditors. " [nder statute in the State of Iowa, it has been held, that an indorsement of a note by the sheriff, who had levied upon it, had the same effect as if marle by the holder himsclf. ${ }^{21}$ But if the note levied on were not the property

$15 \mathrm{~K}$ (llogr $\mathrm{v}$. Curtis, 69 Me. 212; Elias v. Finnegan, 37 Minn. 145. 16. Ante, \& 100; Merchants' Bank v. MeClelland, 9 Colo. 611.

17 Antr, $234,235$.

1s Briggs v. Merrill, 58 Barb. 379.

1: Litchfield liank v. Peck, 29 Conn. 384.

a) Billings v. Collins, 44 Me. 271 ; Roberts v. Hall, 37 Conn. 205.

21 Earlart v. Gant, 32 lowa, 481. 
of tho debtor, neither the purchaser nor anyone claining under him could aequire a title by its sale under execution.:2

A bill or note in the hands of one not the payee, and unindorsed where it is not payable to the payee or bearer, would bo open to defenses in the hamds of the transferee, for such possession and transfer are not in the nsual course of business. ${ }^{23}$ A bill in the hands of the drawer, and payable to his order, might be properly aequired from him, and the holder under his indorsenent wonld be protected against defenses, for the acceptor is the primary debtor, and the drawer the original ereditor. ${ }^{24}$

$\S 239$. Meaning of term "before maturity." - The holder in order to acquire a better" right and title to the paper than his transferrer, must become possessed of it before it is overdue. For if it were already paid by the maker or aceptor, and had been left outstanding, it would be already discharged, and they would not be bound to pay it again to anyone who aequired it after the period when payment was due. And if it were not paid at maturity, it is then considered as dishonored; and although still transferable in like manner and fom als before, yet the fact of its dishonor, which is apparent from its face, is equivalent to notice to the holder that he takes it subject to its infirmities, and can acquire no better title than his transferrer. ${ }^{25}$ The doctrine applicable to this subject has been admirably stated by Chief Justice Shaw, who says: "Where a negotiable note is found in circulation after it is due, it carries suspicion on the face of it. The question instantly arises: Why is it in circulation? Why is it not pail! Here is something wrong. Therefore, although it does not give the indorsee notice of any specific matter of lefense, sllch as set-off, payment, or fraululent aequisition, yet it puts him on inquiry: he takes only such title as the indorser himself has, and subject to any de-

22 MaCormick v. Williams, it Iowa, 50.

23 Kempner v. Comer, 73 Tex. 201; Durein $r$ Moeser. 36 Kan. 44.

24 Merritt r. Duncin, 7 Hei-k, 156.

25 Morgan r. Enited States, 113 U. S. 500 : Speck r. Pullman Car Co.. 121 111. 5 . 
fense which might be made if the suit were brought by the indorser:" ${ }^{6}$ But there is this limitation to this doctrine: that if the holder acquired the paper after maturity, from one who became a bona fide holder for value and without notice before matmity, he is then protected by the strength of his transferrer's title. ${ }^{27}$

$\$ 240$. Whell instruments payable on sight or demand deemed overdue. - The test has been well and aceurately stated by Parsons in his work on Notes and Bills. He says: "A reasonable time must elapse before mere nonparment dishonors the bill or note. What this time is, has not heen and cannot be fixed by any definite and precise rnle. One day's delay of paper on demand certainly would not dishonor it; five years certainly would. And in each case, how many dars, or weeks, or months are requisite for this effect, must depend upon the test, whether so long a time has elapsed, that it must be inferred from the particular circumstances and the general conduct of business men, both of which shonld be considered, that the paper in question must have been intended to be paid within this periorl, and if not paid, must have been refused." 28

$\S 241$. Presumption that bill or note is acquired before maturity.- There is always a presumption when the payee's or an indorser's name is indorsed upon the bill or note, that it was done before its maturity; and likewise the presumption that the holder aequired the instrument before maturity, whether the legal title be transferable by indorsement, or by delivery merely. ${ }^{29}$ Indeed the law will presume in favor of the holiler, according to many authorities, that the indorsement or assignment was of even date with the instrument itself $;^{30}$ but it can rare $y$ be the case that any stronger or more definite presmuption will be needed than that he acquired it lefore matmity, as he is then protected against

so Fisher v. Ioland, 4 Cush. 456.

27 Ante, \$201.

281 Parions on Notes and Bills, 263, 264.

s) New Orleans. etc. v. Nontgomery, 9: U. S. 16.

30 Danirl on Nesotiable In-truments, \& 728. 
defenses available to his transferrer. We ean eonceive, how ever, of eases in which the further presimption that the transfer was of even date might be desiable to the holder - as whero it were proved that at al certain time after date of the paper he had notice of a defeet which would prevent his better title, if it were not then established.

$\$ 242$. Rule as to accommodation paper acquired overdue.While it is the eneneral rule that if the paper be overdue at the time of the transfer that circmustance of itself is notice, and he can alequire no better title than his indorser'; ret, the falet that the paper was executed for accommodittion withont ennsideration, and that the indorsee knew it, is no defense even when the paper was overdue at the time of the indorsement, it being considered tiat parties to acconmodation paper hold themectres ont to the public by their signatures to be hound to every person who shall take the same for value, to the same extent as if paid to him personally. ${ }^{31}$ If the holder received the paper after matmity from an indoreer who took it bona fide before maturity, there is no question as to his right to recover: $3^{32}$ but if he takes it after maturity from the party for whose aceommodation it was male, indorsed, or accepted, there is confliet of decision on the subject: ${ }^{33}$ lut the doctrine of the text is sustained ly the highest anthority. ${ }^{34}$

$\$ 243$. Rule when instalment of principal or interest is overdue.- If the note be payalble ly instahments it is dislonored when the first instalnent becomes overdue and unpaid, and he who takes it afterward takes it subjeet to all equities letween the original parties." Wh Whether or unt the same rule applies when there is an instalment of interest

31, Story on Notes. \& 194; Dum r. Weston. 7l Me. 270; Davis r. Miller, $1+$ Gritt. (i.

$32110 w e l l$ v. Crame, 12 Lat. Ann. l2ti; Riegol v. Cumningham, 9 Phila. $17:$ : 1 inte, $\$ 201$.

33 Cluester v. Dorr, 41 N. Y. 279: Simons v. Morris, 53 Mich. 1.i. 34 Diniel on Negotiable lnstruments. 526 , and eases eited.

in Vinton r. King, 4 Allen, 562 ; Field v. Tibbetts, 57 Me. 359 ; Mart v. Stirkney, $41 \mathrm{Wis} 630$. 
overdue and mupaid is at controverted matter. The weight of authority is to the effect that the bona fide purehaser for value of negotiable paper is within the protection of the law merchint although interest is overdue and unpaid at the time of the purchase, interest being a mere ineident of the debt, and the holder losing no right as against the parties, whether makers or indorsers, by fialure to clemand it. ${ }^{3 i}$ This seems to be the correct rule, though the contrary riew is not withont some weighty considerations to support it. $^{3 i}$ Where more than one note is executed upon the same consideration, they are not all to be regarded as dishonored when one is overdue and mpaid. ${ }^{38}$

$\$ 244$. Transfer on last day of grace. $-\Lambda$ purchaser of a negotiable instrunent, before the close of business hours, on the last day of grace, and before its dishonor, has been held, and, as we think, correctly, to be fully protected as having received it while current; ${ }^{39}$ but a contrary view has been taken in Massachusetts. ${ }^{40}$

$\$$ 245. "Purchaser without notice."- The liolder must have acquired the paper withont notice of its dishonor. Sometimes a bill payable at so many days after sight, or after a certain event, is presented for acceptance, and dishonored before the time of payment by nonaceptance; and in such cases, the party aequiring it with notice of such dislonor stands upon the same footing as one who aequires it after maturity, and is chargeable in like mamer with constructive notice of any flaw in the right or title of his transferrer. ${ }^{+1}$ Sometimes the instrument bears upon its face the marks of its dishonor for nonaceptance, and in such cases it lear's, as has been said, "a death wound apparent on it." ${ }_{42}$

:) Natiomal Pank v. Kirby, 108 Mass. 497; Kelley v. Whitney, 45 Wi- 110.

37 Newell v. Gregge, 5l Barb. 263.

so loss v. Hewitt, 15 Wis. 260 ; Patterson v. Wright, 64 Wis. 291.

Fox v. Bank, 30 Kan. 442: Bosch v. Cassing, 64 Iowa, 314.

th Pine v. Sinith, II Gray, 38.

41 Crosily y. Hanl, 13 Eant. 498.

42 froodman v. Harvey, 4 Ad. \& El. 870; Byles on Bills [*160], 283. 
If it hats been dishonored for nompayment when payablo on denand or at sight, the like rule applies; but it is only whon the bill or note is payable at a day certain that the purehatere can perecive, by the very fact that it is overduc, that it has been dishonored. The Lnited States Supreme Court has observed on this subject that "a person who takes a bill which, rpon the face of it, was dishonored, camnot be allowir. to elaim the privileges which belong to a bone fide holdere. If he chooses to receive it muder the circumstances, he takes: it with all the infirmities loclonging to it, and is in no better condition than the person from whom he received it." 4 :"

$\$ 246$. Notice of fraud, defect of title, and illegality.- In order to stand upon a better footing than his transferrer, the holder must acquire the instrument withont notice of framd, defect of title, illegality of consideration, or other fact which impeaches its validity in his transferrer's hands; and the word notiee in this eonnection signifies the same as: knowledge. Knowledge of frand or illegality impeaches the bona fides of the holder, or at least destroys the superiorityof his title, and laves him in the shoes of the transferrer. ${ }^{4}$ And any frand mon the transferrer incapacitates the transferee or one acquiring from him with notice from recovering against the transferrer. ${ }^{45}$

$\$ 247$. Time of notice.- The notice affeeting the holder must exist at the time he acquires the paper, for then his relation to it is fixed; and subsequent notice does not affect his title or right to transfer it. ${ }^{40}$ If notice of frand be communicated to the holder before he pars for the paper. although the eontract has been entered into, he eamot stand upon the footing of a bona fide holder withont notiee, ${ }^{+i}$ and if he has paid a part of the amount agreed npon when he

43 Andrews v. Pond, 13 Pet. 65: Angle v. Insuranee Co., 92 L. S. 34I: District of Columbia v. Cornell, $130 \mathrm{~L}$. S. 66T.

4 Hananer v. Doane. I2 Wall. 342; Crampton v. Perkins, 6.5 Md. 24: Mare v. liemnely, os Mich. 39 .

45 Lenheim v. Fay, 27 Mirh. 70.

t6 Perkins v. White. 36 Ohio St. 5.30 .

47 Crandell v. Vickery, 45 Barb. 156; Davis $r$. Wait, 12 Oreg. 425. 
receives notice of fraud, he will only be protected to that extent, and no more. ${ }^{45}$ Actual notice of the defect is not required, where the evidence of the infirmity consists of matters apparent on the face of the instrument. ${ }^{49}$

$\$ 248$. Notice of accommodation paper. - It is to be observed, howerer, that knowledge of the nuere want of consideration as between the original parties will not alone prevent the purchaser from becoming a bona fide holder and occupying a better position than his transferrer. Accommodation paper is daily placed in market for discount or sale, and an indorse or purchaser who knows that a bill or note still current was drawn, made, accepted, or indorsed withont consideration is as much entitled to recover as if he had been ignorant of the fact, ${ }^{50}$ and even where he acquires it overdne. ${ }^{51}$ Nor is it a good ground of defense against a bona fide holder for value that he was informed that the note was made or the bill accepted in consideration of an executory contract, unless he was also informed of its breach. ${ }^{52}$ If he has such knowledge he cannot recover. ${ }^{53}$ And if anyone purchase accommodation paper with knowledge that the terms and conditions on which the accommodation was given have been violated, he is not a bona fide holder as against the party who lent his name for aceommodation. ${ }^{5 t}$ The defense must not only show that the paper was diverted from its purpose, but also that such diversion

48 Dresser v. M. \& I. R. Co., 93 U. S. 93; Weaver. Barden, 49 N. Y. 286.

49 Post, \& 251.

50 Thatcher $v$. West River Nat. Bank, 19 Mich. 202; Stephens v. Monongahela Nat. Bank, 87 Pa. St. 163; l'owell v. Waters, 17 Johns. 176.

51 Ante, \& 205.

62 Patten v. Gleason, 106 Mass. 439; Bank v. Cason, 39 La. Ann. 867.

5.) Wagner v. Diedrich, 50 Mo. 484; Bonman v. Van Kuren, 29 Wis. 218.

54 Buchanan v. Findley, 9 b. \& C. 738 ; Daggett v. Whiting, 35 Conn. 372. 
was known to the holder when he received it, misapplieation not being such fraud as shifts the burden of proof. The rule in New York is different, and there it is hekl that a diversion is such fraud as shifts the burden of proof upon the holder. ${ }^{\text {st }}$

$\S 249$. What amounts to diversion of accommodation paper. - It is immaterial that paper executed or indorsed for aceommodation is not used in precise conformity with agreement, when it does not appear that the accommodation party had any interest in the nanner in which the paper was to be applied. No change in the mere mode or plan of raising the money, though not applied to the purpose intended by the aceommodation party, will constitute a misappropriation. In order to constitute a misappropriation, there must be a frandulent diversion from the original object and design; and it is now well settled that where a note is indorsed for the accommodation of the maker, to be discounted at a particular bank, it is no fraudulent misappropriation of the note, if it is discomnted at another bank or nsed in the payment of a debt or otherwise for the credit of the maker. ${ }^{5 i}$ If the note has effeeted the substantial purpose for which it was designed by the parties, an accommodation maker or indorser camnot object that the accommodation was not effected in the precise manner contemplated, where there is no fraud, and the interest of the indorser is not prejudiced. ${ }^{58}$

$\S 250$. Express notice.- It is quite certain that if the notice or knowledge of the transferrer's defective title be express, it will destroy the purchaser's better position: for if he is actually informed of the infirmity - as when he is told by the maker that it is without consideration, and that it will not be paid - he errs willingly if he persereres in

55 Stoddard v. Kimball, 6 Cush. 469 ; Clark v. Thayer, 105 Mass. 216; Gray v. Bank of Kentucky. 29 Pa. St. 365.

56 Farmers and Citizens' Nat. Bank v. Noxon, 45 X. Y. 762.

57 Frank v. Quast, S6 Ky. (6.): Morris v. Morton, 14 Nebr. 360.

58 Duncan \& Sherman r. Gilbert. 29 X. I. L. 521: Briges- r. Boyd, 37 Vt. 538; Warlell v. Howell, 9 Wend. 170. 
negotiating for the paper, and has no claim whatever for peculiar protection. ${ }^{59}$

$\$ 251$. Implied or constructive notice from appearance of the paper.- Express notice is not indispensable. There may be evidence of the infirmity in the paper apparent on its face, or such indications as to put the purchaser upon inquiry. And in such cases constructive notice is held sufficient upon the ground that when a party is about to perform an act which he has reason to believe may affect the rights of third persons an inquiry as to the facts is a moral duty, and diligence an act of justice. ${ }^{60}$ In Connecticut the unusual character of the instrument - its being written on tracing paper, coupled with suspicions circumstances in the negotiation - was held to anthorize inquiry of a broker "whether a banker or a broker would discount a note of that character without a willful failure to inquire into the circumstances under which it was obtained," with a view to impeaching the good faith of the transaction. ${ }^{61}$ And so in New York, an unsigned blank left for signature was held to affect the purchaser with notice of the defect. ${ }^{62} A$ line drawn over the words "or order" and a memorandm written on the paper, "this note is not negotiable," would of courec notify the purchaser. ${ }^{63}$

In Maryland the doctrine of notice was applied to the case of a note parable to a certain person as "Trustee," and indorsed in the same style by the trustee, who sold the note and appropriated the proceeds; and the court held that the word "trustee" put the purchaser upon inquiry, and that he could not trace title as against the maker through such an indorsement, as the trustee had no power to dispose of the trust subject for his own benefit. ${ }^{64}$

59 Norvill v. Hudgins. 4 Munf. 496; Gilman v. New Orleans R. Co., 72 Ala. 581.

60 Jaris Machine Co. v. Best. 105 N. Y. 59; IIamilton v. Wilson, 67

Ga. 498; Angle v. Insurance Co., 92 C. S. 342.

61 Rowland v. Fowler. 47 Conn. 347.

62 Davis Machine Co. v. Best, 105 N. Y. 59.

6. Prins v. So. Pranch Jumber Co., 20 11l. App. 236.

6t Third Nat. Bank v. Lange. 51 Ma. 138. 
\$252. Constructive notice from extrinsic circumstances.The circumstances of the transaction may he of such a challacter as to intinute strongly a defect in the title, and if they aro such as to invite inquiry they will suflice, provideal the jury think that abstinenee from inquiry alose from a belief or suspreion that inquiry wonded discloce a viece in the paper." Then indeed his bona fides would he impeached. But further than this, gross negligence, which is not in itself proof of mala fides, may be so great as to amount to pronf of notice. "I agree," says Baron Parke, "that notice and knowledge mean not merely expless notice, but knowledge or the means of knowledge to which the party willfully shuts his eves." t6

\$ 253. Particular and general notice. - It is quite clear and well-settled that the purchaser need not have notice of the particular fraud, or equity or illegality, in order to be affected by it. It is sufficient that there be notice, actual or constructive, that there is some frand, or equity or illegality affecting the original parties. "Thus, if when lie took the bil! he were told in express terms that there was something wrong about it, without being told what the rice was, or it it can be collected by a jury, from circumstances fairly warranting such an inference that he knew, or believed, or thought that the bill was tainted with illegality or fraud, such a general or implicit notice will equally destroy the title." "it So if he knows that the maker denies his liability or refuses to acknowledge it. ${ }^{6}$

$\$$ 254. Circumstances constituting notice. - Yotice of framd. or defect of title. or of lefense valid between prior parties may be derived from circumstances, and be as effectual as personal observation, or hearing of the facts in question.

65 Hulbert r. Donglass, 94 X. C. 1220: Bank of Hamburg r. Flỵn, 33

Fed. 798: Ormsbee v. Howe, 54 Vt. 182.

e6 May v. Chapman, 16 M. \& W. 355.

6i Byles on Bill [*119], 226: Oakley r. Ooddeen, F. \& F. 6.59;

Henry v. Sneed, 99 MIn. 422.

6s Boyce r. Geyer, 2 Mich. N. P. Il; Studebaker v. Mamufacturing Co., 70 Mo. 274 . 
Thus, where the assignee of a note, at the time of assignment, requests and receives, as security from the transferrer, a converance of land for the purchase money of which the note is given, with a provision in the deed that the assignee is to comply with the terms of the contract of sale to the prior purchaser, the assignee will be chargeable with notice of the challacter of the note. ${ }^{19}$ Mere proof of an advertisement in a newspaper cantioning parties against purchasing a bill or note, even when made in the place of residence of the purchaser, is not of itself sufficient to show notice to the purchaser of any frand affecting its validity. ${ }^{70}$

$\$ 255$. Notice to agent.- It is a general principle of law that notice to an agent is notice to the principal, and therefore if the hokder in taking the bill employs an agent, though he be unaffected with notice to himself personally, ret notice to the agent so employed, express or implied, is notice to the holder. ${ }^{71}$ And notice to a subagent whose appointment has been anthorized by the prineipal is equally notice to the principal. ${ }^{72}$ But this rule is subject to the qualitication that the knowledge of the agent, in order to affect his principal, should either have been acquired in the same transaction, or at least so recently as that it may be presumed to have remained in his memory; and it must be knowledge of a fact material to the transaction, and which it would be the duty of the agent to communicate to his principal. ${ }^{73}$ That the principal is bound by snch knowledge or motice as his agent obtains in negotiating the partienlar transaction is everrwhere conceded. Constructive notice to an agent is not to be extended. ${ }^{74}$ Notice to the active managing officers of a corporation is notice to the corporation itself. It is immaterial what the official position may be if

69 Packwood v. Gridley, 39 Ill. 383.

70 Kellogre v. French, 14 Gray, 354.

71 Story on Agency, \& 140; Varnum v. Milford, 4 MeLean, 93; Henry v. Sneed, 99 No. 423.

72 Boyd v. Vandorkemp. I Barb. Ch. 273.

73 The Distilled Spirits, 11 Wall. 366 ; Le Neve v. Le Neve, 2 Lead. Cas. in Eq. 179.

74 Wyllie v. Pollen, 32 L. J. Ch. 782. 
the person is actively engaged in tho managenent of its interests. ${ }^{75}$ 'The mere fact, lowever, that the cashire of at bauk is a stocklobler and diecetor of a corporation which is the payce and indorser of a note, will not charge the hank with motice of epuities against the (onporation, when it aj)pears that the cashier has no luties to perfolm with reforeence to the note as director of the company, and no actual motice of such equities. ${ }^{\text {it }}$ Sotice to, or knowledere of, on member of a partuceship is notice to all of its members. 7

ir Natjonal Bank v. Howe, 40 Minn. 390; New England Hortgage Co. v. Ciay, 33 Fed. (i36).

76 First Nat. Bink v. loyhed, 2s Mimn. 396; Wilson v. Second Nat. 33ank. of Cent. T.s6.

т Bigelow v. Ilenringer, 33 Kan. 362. 


\title{
BOOK IV.
}

\section{FIXING LIABILITY TO PAY THE INSTRUMENT.}

\author{
CHAPTER X. \\ PRESENTMENT FOR ACCEPTANCE, AND ACCEPTANCE.
}

\section{SEC'TION I.}

WHAT BILLA OF EXCHAXGL SHOCLD IB PRESENTED FOR ACCEPTANCE.

$\$$ 256. General principles.-The subject-matter of this (chapter applies only to bills of exchange, foreign and inland. The law of presentment for acceptance and of acceptance can have no application to a negotiable contract, where, from its nature, there is or can be no acceptor. The certitication of checks, however, is closely allied to the subject of presentment for acceptance, and acceptance. This subject has been fully treated in a preceding chapter. ${ }^{1}$ It is the right of the holder of a liil to present it for, and incist on its, acceptance, even so late as the day before it falls due. If not presenter for acceptance until the day it falls due, the right to dentand acceptance becomes merged in the right to demand parment. If the bill be presented for acceptance before it falls due, it hecomes dishonored if acceptance be refued; and notice must be forthwith given to the parties whom it is intemberl to charge. Amel suit may at once be instituted against the crawer, and against the indorsers.2

1 Antr, $\$ \S 3 .,-3$, .

2 Townsley v. Sumrall. 2 Pet. 170: Landrum v. Trowbridge, 2 Mete. (Ky.) 281: National Bank r. Cunhouse. 17 S. C. 496: Woodward r. Row, Keb. 132. 
This rule of commercial law is so general and binding that a statute of a State which forbids a snit from being brought in such a case until after the matmity of the bill, can halve no effect upon suits brought in the Luited States conrts. The requisition of a State statute like this would be a rinlation of the general eommerecial law, which a State has no power to inpose, and which the compts of the Enited States would be bound to dispegard. So also if the State statute seeks to make the right of recovery, in a suit hrouglit in case of nonaceptance, dependent npon proof of subsequent presentment, protest, and notice for nomparment. ${ }^{3}$

$\S 257$. What bills must be presented for acceptance.- Bills payable on demand or at sight withont grace (which are immediately payable on presentment), or payable at a certain number of days after date, or after any other certain erent, or payable on a day eertain, need not be presented, for aceeptance at all, but only for payment. And the fiact that such bills are payable at a bank, or other particular place, does not alter the rule on the subject. ${ }^{*}$ But it is nsual and best, when the bill is payable at a future kay, to present it for aceptance, in order to ascertain whether it will eertainly be honored, and to procure the assurance of the acceptor's liability" And in such ases, if acceptance be refused, the holker must make protest, and give notice in the same mamner as if the bill were parable at so many dars after sight. ${ }^{6}$ There are, lowerer, three exceptions to this general rule that it is not neessary to present a bill payable at a fixed time for aceeptance, hut only at maturity for payment: First, when there is an express direction to the parce or holder of a hill: secend, when it is put into the. hands of an agent for negotiation: and, third, where the drawer and drawee are either the same person, or the drawer is a member of the firm or comnected with the eorporation

3 Watson v. Tarpley, 18 How. 517.

4 Bank of Washington v. Triplett, 1 Pet. 25: Townley v. Smmrall. 2 Pet. 170 .

"Lnited States v. Marker, 4 Wash. C. C. 464; Story on Dilli. s.s.

6 Allen r. Suylam, 20 Wend. 321: Landrum v. Trowbridge, 2 Mete. (Ky.) 281: Philpott r. Bryant. 3 Car. \& P. 244. 
which is the drawee. Thus, a bill drawn without being addresed to any drawee, or drawn by a party upon himself, or lis a partuer nuon the tirm of which he is a nember, for partiership purposes. A bill drawn by the president of a corporation in its behalt, on the treasmer thereof, would be a bill drawn by the corporation on itself, and hence not need ace eptance. ${ }^{i}$

Bills parable at sight, or at so many days after sight, or after demand, or after any other event not absolutely fixed, must he presented to the drawee for aceptance and payment, or for aceeptance only, without unreasonable delay, or the drawer and indorsers will be liseharged, for they have an interest in having the bills accepted immediately in order to shorten the time of parment, and thus put a limit to the perion of their liability; and also enable them to protect themselves lw other means before it is too late, if the bill is not accepted and paid within the time originally contemplated by them.s When the words "aceeptance waived" are embodied in a bill, the ordinary proceedings in acceptance are dispensed with, and merged into those of payment or nouparment. ${ }^{9}$

$\$ 258$. When drawer of bill requiring presentment for acceptance bound without such presentment.-Presentment to the drawee, it has been held, is necessary, even though the drawer has requested him not to accept; ${ }^{\text {in }}$ but the holder is not bound to present again after refusal to aceept and notice given, even though the drawer requests him to do so, and promises that the bill shall be honored. ${ }^{11}$

The only cases in which the holder of a hill which, according to its tenor, should be presented for acceptance, ean charge the drawer without presenting it for aceptance,

T Daniel on Negotiable Instruments, \& 465.

8 Bell v. Fisst Nat. Bank, 115 U. S. 379; Nitchell v. De Grand, 1 Mason, 176: Robinson v. Ames, 20 .Johns. 146.

9 Caron v. Rumerll, 26 Tex. 472: English v. Wall, 12 Rob. (Ta.) 132; Webly vears, a Wright, 222.

10 Hill v. Ifeap. Dowl. \& R. N. P. 57; 1 Parsons on Notes and Bills, 388.

11 Itickligg r. Hardey, 7 Taunt. 312. 
arise when the relations between the drawer and drawes are such ats to constitute the drawing of the bill at frand upon the holder. ${ }^{12}$ When the hill is presented the acerpotance must he aleeording to its tonos to pay in money. If it be to pay by another bill, it is no acceptance, and the bill should be protested. ${ }^{13}$

\section{SICTION II.}

BY ANI, TO WIOM IRESENTMLNT SHOLID BE MADE.

$\$ 259$. By and to whom; general rule.-The bill must be presented by the holder or his anthorized ayent, and to the drawee or his anthorized agent. The party in possession of the bill is with ostensible legal title thereto, presuned to be the holder, and to have the right to make presentment for aceptance or payment. ${ }^{1+}$ The drawee may acept without risk, and if he refuse, the protest will immre to the benefit of the rightful holder. ${ }^{15}$ If the drawee camnot be found, and any person has been indieated to be resorted to in ease of need (an besoin), the bill should be presented to that person. ${ }^{16}$

If the bill be drawn upon two persons not partners, it seems that it must be presented to both, if not paid by the first ${ }^{17}$ but this has been doulited, for the reason that the holder would not be bound to take the single acceptance of the other; and if he did. it wonld be at his own risk, if the bill were not protested. ${ }^{18}$ But if the bill be drawn upon a firm, presentment to any partrer is suftieient, ${ }^{19}$ and the fact

12 Bank of Washington v. Triplett, I Pet. 25; Smith's Mercantile Jaw (Holcombe \& Gholson's ed.). 304.

13 Russell r. Phillips, 14 Q. 13. 891.

14 Bank of Utiea $v$. Smith, is .Johns. 230: Freeman v. Bornton, 7 Mass. 483; Agnew $r$ Bank of Gettysburg. 2 Harr. \& Gill, 478.

15 Chitty on Bills (13th Am. ed.), 311.

16 Story on Bills, \$299: Eolwards on Bills, 402.

17 Willis $v$. Green, 5 Hill, 232 ; Story on Bills, $\$ 229$.

1s Story on Bills. \& 229 , note ?. Soe Harris r. ('lark, 10 Ohio. 5;

Greemough v. Smead, 3 Olio St. 4 is.

19) Greatlake $v$. Brown, 2 Cranch C. C. 541 ; Holtz v. Hoppe, $37 \mathrm{x}$. Y. 634. 
that the firm has been dissolved by bankruptey does not render it necessint to prescut the bill to both.

$\$ 260$. Presentment to agent of drawee.-The holder or his anent nust be careful, when he does not find the drawee in person, to assure himself that the party to whom he presents the hill for acceptance is his authorized agent. And though in the case of a presentment for payment it may suffice to demand payment at the residence of the acceptor, yet in case of a presentment for acceptance, the holder must cudearor to see the drawee or his anthorized agent, perwnally. And, therefore, where in an action against the drawee on a refusal to accept, it appeared that, the witness had carried the bill to a place which was deseribed to him as the drawee's house, and that he offered it to a person in a tanyard, who refused to aceept it; and the witness did not know the drawee's person, nor eould he swear that the person to whom he offered the bill was he, or represented himelf to be so, it was held that the evidence of presentment to the drawee for acceptance was insufficient. ${ }^{21}$ In aceordance with the principles stated, it may be added that there is no donbt that a elerk found in the drawee's counting-room is a competent person to whom the bill can be presented, and his refusal to accept is, in law, the refusal of the drawee. ${ }^{22}$

$\$ 261$. Presentment in case of drawee's death.- In the rent the drawee be dead at the time the lill shonld be presented for acceptance, the most that could be expected of the holder would be that he should inquire after the personal reprecentative of the deceased drawee, and if he live within a reasomable distanee, present the bill to hin. Chitty and Bryes hoth give their indorsement to this proposition. ${ }^{23}$ But some of the best text-writers, as well as many of the cases, state that the holder is not hound to present

20 Gates v. Beecher, 60 N. Y. 523.

21 Cherk v. Roper. '5 E-p. 17 .

22 Daniel on Negotials]e lnstruments. \$ 457.

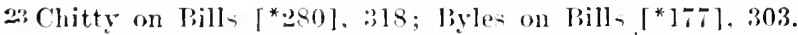


the bill to the executor or the administrator of the drawee. ${ }^{-4}$ In any event, the holder has the right, and it leeeness his duty, to protest the bill for nonaceptance, if there be, at the time of presentment, no executor or administrator of the deceased drawere. It should be olserved, in this ennnection, that an aceeptanee hy the personal representative of thr. drawee is binding upon the representative individnally, and not in his official "haracter, and further, that the holder is not ohliged to receive the alceptance of the exeentor of administrator at all. L Lon sound principle, therefore, it should follow that if the drawee be dead, the holder should have the right, and be inpresed with the duty, of protesting the bill without any presentment to the personal representative.

\section{SECTION III.}

THE PLACE WHERE, ANH IIOW, PRESENTMENT SHOTLD BE MAIME.

$\$ 262$. Sergeant 0nslow's act.-It was at one time a que:tion mueh litigated in England, whether, if a bill payable generally - that is, without specitication of a place of par"ment- Was accepted payalble at a particular place, such an areeptance was a qualitied one. It was decided in the House of Lords (eontrary, howerer, to the opinion of eight of the twelve julges to whom the question was referred), that such an aceeptance was a qualitied one, and that a demand at the particular place named was a condition precedent to a reeovery against the acceptor, as well as against the drawer and indorer. ${ }^{25}$ This decision led to the passige of the statute of 1 and 2 (ieorge IV., chap. is (called Sergeant Onslow's act), in which it was reeited that the pratetice and muderstanding of merohants had been different; and enacted that an aeceptance payable at a partieular place without further expression, should not he deemed a conditional aceeptanee: hut if it were palyable at a specified place "only.

24 Edwards on Bills, 401. 4.7. note 2.

2r Rowev. Young. 2 lirod. \& H. 165. 
and not otherwise, or elsewhere," it should be deened conditional. ${ }^{26}$

$\$ 263$. American statutes and decisions as to place of presentment for acceptance.- In many of the States of the United States the English statute has been substantially enacted; and the courts, with few exceptions, have, independently of statute, followed the judgment of the eight judges against the Ilouse of Lords. Therefore, by the American law, it is settled that denand of payment at the place speeified need not be averred by the plaintiff; but if the acceptor was at the place at the time specified, and ready to pay the money, it was a matter of defense to be pleaded on his part; which defense, however, is no bar to the action, but goes only in reduction of damages, and in prevention of costs. ${ }^{27}$

$\$ 264$. Residence, or place of business.-The presentment of the bill or note for acceptance should be at the place of the domicile of the drawee, whether it be payable generally, or at a particular place - the place of payment being immaterial until after acceptance. ${ }^{28}$ If the drawee has removed his residence from the place to which it is addressed - or really resided at a different place - the bill should be presented at his new or real place of domicile, if the holder can ascertain it by diligent inquiries. If by such inquiries the drawee's place of domicile cannot be ascertained, or if he has alssconded, the bill may be treated as dishonored. ${ }^{29}$ If the drawee has his dwelling-house in one part of the town or city, and his place of business at another, it may be made at either place; and if the drawee resides in one town, and has his place of business at another, the holder may present the bill at either, ${ }^{30}$

26. Danicl on Nrgotiable Instruments, \& 456.

27 Parsons on Notes and Bills, 305-311; Story on Bills, \$\$ 355-357;

Edwards on Bills, 426, 428.

28 Chitty on Bills (13th Am. ed.), 316 .

29 Anderson v. Drake, 14 Johns. 114; Freeman v. Boynton, 7 Mass. 483.

30 Story on Bille, $\$ 236$. 
$\$ 265$. How presentment for acceptance should be made.The holder of the bill should have it in his puscessinn, make an actual exhibit of it to the drawee, and request its ancepentance." "The term presentment imports not a mere metioe of the existence of a draft which the party hats in his. posiession, but the exhibiting of it to the person on whom it is drawn, that he nay see the same, and examine his accounts or eorrespondenee, and judge what he shall do; whether lie shall areept the draft or not." 32 But while it is better in all cases to aroid all question by observance of the formality indieated the drawer and indorsers may be charged by dine protest and notice where the bill is not thus actually exhibited to the drawee, but he is enabled by seeing it or otherwise to give, and does give, an intelligent response to the request to alecept it. ${ }^{33}$

$\$ 266$. Production of bill.- If the holder does not produce the bill, the drawee may require him to do so, and decline acepting, save in the proper form by writing his name on its face; and then unless the holder produces it the drawer cannot he charged with the penalties of nonaleeptance; but if the drawee makes no sneh requirement and does what is equivalent to aceptance he camnot afterward refuse to be held on the ground that he dirl not see the bill. ${ }^{34}$

If the holder leave the bill with the aceeptor, and by his negligenee enable a third party to get possession of it, he cannot hold the acceptor liable in an action of trover. ${ }^{35}$

\section{SECTION IV.}

TIME OF PRESENTMENT FOR ACCEPTANCE.

267. Time of day for presentment for acceptance; business hours.- And in the first plive: presentment for acceptance

81 l Parsons on Notes and Bills. 348 .

:a Fall River Lnion Bank v. Willard. 5 Mete. (Mass.) 2l6: Elwards nn Bills, 50 i.

33 First Nat. Bank v. IIatch, 76 Mo. 22; Fisher r. Beckwith, 19 Vt. 31 .

34 Fall River Tuion Bank r. Willarel. T Mete. (Mass.) 216.

30 Morrison v. Buchanan, if Car. \& P. ls. 
should in all cases be made during the usual hours of business, and such hours, except where presentment must he at at bank, generally range through the whole day to hour's of l'est in the evening. ${ }^{36}$ Eight o'elock in the evening would not be too late to present a bill for aceeptance to a tradesman. ${ }^{3 i}$ And it matters not at what hour it is made, provided an answer be given by an authorized person. ${ }^{3 s}$ But it is a mere nullity if made at an unreasonable hour - after bedtime or business hours - if no snch answer be given. ${ }^{39}$ If there is a known custom or usage in a town or city, which regulates business hours, that should govern in determining the proper hour for presentment at the drawee's place of business. ${ }^{40}$

$\$ 268$. Within what period of time presentment for accept. ance must be made.- It secms to be the general commereial law of the cirilized work, that when a bill is payable at a day certain - as, for instance, on a day named, or a fixed day after date - it need not be presented until the day of payment, in order to charge the drawer or an indorser. ${ }^{41}$ The reason of this is that the drawer, by fixing a day eertain for parment, assumes the responsibility of providing funds at that time, whatever may have heen his previous eredit with the drawee. And as to the indorser, by the very act of indorsment, he draws a new lill on the same terms; and, besides, he waives his right of immediate acceptanee by not enforcing it himself, but putting his bill into cireulation withont acceptance. $^{42}$ If payble at sight, or at a certain time after sight, or on demand, the only rule which ean be laid down is that it must be presented within a reasonable time, ${ }^{43}$ unless there be some well-established usage of trade

3f Elford v. Treed, I Maule \& S. 28; Cayuga County Bank v. Hunt, 2 IIill, 6.35.

37 Chitty on Bills [*313].

38 Chitty on Bills ${ }^{*} 3161$.

39 Story on Bills, $\$ 237$.

40 Story on Bills, $\$ \$ 236,349$; Story on Notes, $\$ 135$.

41 Townsley v. Sumrall, 2 Pet. 178; Bachellor v. Priest, 12 Pick. 399. 42 Allen v. Suydam, 17 Wend. 368.

4.3 Wallace v. Agry, 4 Mason, 336; Bridgeport Bank v. Dyer, II Conn. 136. 
which fixes a definte tinc for such presentuncut, in whinh case sncli nsage wonld control, If the bill be not presented within a reasomahle time, the drawere is diselatroed, although all the parlies continue solvent, and there is 10 , damage cansed by the delay."

$\$ 269$. Due diligence must be exercised.- lt is not necessary for the holder to take the first opporturity to present for acceptance, thomgh to aroid puestion in ease of loss it is advisable to do so - due diligence - that is, prescntment within a reasonable tine, is all that is necessiry. "The distinction is," as was said ly (iibbs, C. el., " helween hills payable at a cortain number of days after date, and hills payable at a certain number of clays after sight. In the former, the holder is bound to use all due diligence, and present the bill at maturity; but in the latter case, he has a right to put the hill into circulation before lo presents it, and then, of conrse, it is monertain when it will be presented to the drawce. It is to the projulice of the holder if he delays to do it, and he loses his money and interest." ti

There ane certain circumstances which may affect the question of reasonable time; for instance: (1) The passing of the libll into cisculation. In such case a langer latitude is allowed for presentument for areeptance, and a long delay, eren for as much as a year, would not be deemed neglienence. (2) Fluetuations of the rate of exchange. 'The falling or rising of the late of exchange in the place of residence of the drawee should be taken into eonsideration in

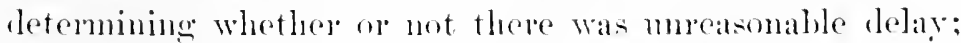
$i$ e. if exelange fell immediately after the sale of the bill, a more extended periol miglit firly and reasomalily be allowed the holder, in oreler to amalile lime bona fide to endeavor to make a falr profit, or. at all events, to emdearor

\footnotetext{
4t Melli-h r. Rawdon, a Bing. 4 l6.

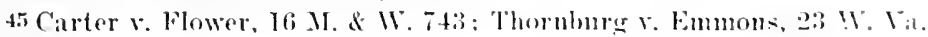
333.

46 Muilman r. D'Egruino, 2 II. B1. stis: Preseott Ban's r. Carerly, 7 Grav. 217 .

4i Goupy r. Harden, T Tamut. 1.s?.
} 
to secure himself from loss. (:) The facilities of communication between the partics. 'This includes the character of the commmication, the distance between the respective residenes of the holder and drawee, and the length of tine necessary to effoct commmnication between the one place and the other. (t) War, sickness, or accident. Iny reasonable cause, such as sickness, inevitable accident, or intervention of war, or other cireumstances beyond the holder's control, will excuse delay in presentment for acceptance. $^{48}$

\section{SECTION $\mathrm{r}$. \\ TIIE NATURE AND EFFECT OF AC'CE'TANCE.}

$\$ 270$. Liability of drawer before acceptance.- The drawer of a bill undertakes that when it is presented to the drawee he will accept it; and by acceptance is nncant an molertaking on the acepptor's part to pay the bill according to its tenor. ${ }^{49}$ Lntil the bill lias been accepted, the drawer is the primary debtor, and his liability is contingent and conditioned upon a strict compliance with the law as to presentment of the lill for acceptance (if the hill be of such a character that it is necessary to present it for acceptance), and due protest and notice of dishonor. After acceptance, the drawer becomes secondarily liable, and his position is that of the first indorser mpon a promissory note. ${ }^{\circ}$

\section{\$271. Relation of drawee to bill before acceptance.-Until} ho has arcepted the bill, so entirely is the drawee a stranger to it, that he may himself discount it. And he may then transfer it as the bone fide holder to another, who may sue and charge the drawer. ${ }^{51}$ He may discomnt it either for the drawer, the pavee, or an indorsee. "If the aceeptor" discounts the bill for the drawer, and then indorses it away, the rlawer will be liable upon it to the luolder, and the transfor by the drawer to the aceptor will operate as an in-

48 Daniel on Negotiable Instruments, $\$$ 468-478.

49 Story on Bills. \$ 272: Cox v. National Bank, 100 T. S. 712.

Ef Daniel on Nerotiable Instruments. \$ 479.

51 Desha r. Stewart, 6 Mla, S52: Swoper. Pons, t0 1':1. St. Isf. 
dolsement, although, at the time, the drawer does not intend to transfer by way of indorsement, being muder the inpression that the bill is discharged by coming into the hands of the aceeptor. Nol will the payment of the amomut, less the discoment, he desued a paynent of the hill by the acreptor:" is It the drawee comes into possession of the hill before its dishonor, there is no presumption that he takes it with the obligation to accept. 53

$\$ 272$. The effect of the acceptance of a bill is to coustitute the aceeptor the principal lebtor. ${ }^{54}$ The bill becones by the acceptance rery similar to a promissory note-the acceptor being the promisor, and the drawer standing in the relation of an indorser.

But in respect to the acceptor's position with regard to the drawer, and the amount for which he renders himself liable by accepting the bill, it is well to observe that the acceptance does not entitle the acceptor to charge it in account against the drawer from the date of acceptance, muless he pays the whole anomit at the time, or diseharges the drawer from all responsibility. ${ }^{55}$

Like the maker of a note, the acceptor is bound by all the terms of the instrument, and if it contain a stipulation for payment of attorney's fees, he is bound by it. ${ }^{56}$

If the acceptance be for the drawer's accommodation, the acceptor does not thereby becone entitled to sue the drawer upon the bill; but when he has paid the bill, and not before, he may recover back the amount from the drawer in an action for money had and received. ${ }^{5 \pi}$ If the acceptor put the bill in eirenlation, he is estopped from showing it was then paid. ${ }^{58}$

\footnotetext{
52 Swope r. Ross. 40 l'a. St. 186.

5is Desha r. Stewart, o Mla. 852.

54 Heurtematte $v$. Morris, 101 N. Y. 63: Capital City Ins. Co. r. Quinn, 73 Mla. 560.

55 Bracton r. Willing, 4 Call, 28s.

5o Smith v. Muncie Nat. Bank, 29 Ind. 158.

is Christian v. Keen, so Va. 37 : Martin v. Muney. 40 La. Ann. 190.

is Ifint on v. Bank of Columbus. ? Port. (Ala.) 463.
} 


\section{$\$ 273$. What acceptance admits: (1) Signature of drawer.-} It follows from the fact that the aceptor assumes to pay the bill, and becomes the prineipal debtor for the amount specitied, that aceeptance is an adnission of everything essential to the existence of such liability. Therefore, acceptance is, in the first place, an admission of the signature of the drawer, the drawee being supposed to know his correspondent's handwriting, and, by accepting, to acknowledge it; and in a suit against the aceeptor lie wonld not be permitted to plead or show that the handwriting was not the drawer's, and would be bound by his acceptanee eren though the drawer's name were forged. ${ }^{59}$

\section{$\$ 274$. (2) Admission of funds of drawer in drawee's hands.}

- In the second place, acceptance admits that the aceeptor had funds of the drawer in his hands, for the drawing of the bill implies this, and acceptance in the nsual course of business only follows when it is the fact. Therefore, the acceptor cannot deny that he was in funds when suit is brought by a holder of the bill; ${ }^{\text {in }}$ though as between himself and the drawer it is only prima facie evidence that the drawer had funds in his hands, and he may rebut this presumption by showing that the acceptance was for the drawer's acconmodation, or otherwise under circumstances which place him under no obligation to pay the bill to him. ${ }^{61}$ But, notwithstanding the presumption that the acceptor has funds of the drawer, get, where bills have been drawn upon letters of eredit to enable a party to purchase and ship merchandise, this presumption is rebutted, and the drawer becomes the primary debtor, and is liable to the acceptor for his advanees. But if the acceptor has notice that one of two joint drawer's of such a bill has merely loaned his name

59 Jenys v. Fawler, 2 Stra. 946; Hoffman \& Co. $v$. Bank of Milwatukce, 1.2 Wa1l. 1!13: Cinetz v. liank, 119 U. S. 556.

60 Raborg v. Peyton, 2 Wheat. 385; Hortsman v. Henshaw, 11 llow. 17 ; Heurtematte $r$ Morris, 101 N. Y. 63.

(51 Daniel on Negotialble Instruments, $\$ \$$ 174-176; Park v. Nichols, 20 Ill. App. 143; Klopfer v. Levi, 33 Mo. App. 322. 
to give enreney to the bill, such drawer is no more liable to the acceptor than if he had merely indorsed the bill.;

$\$ 275$. (3) Admission of drawer's capacity to draw. - In the third place, the acceptor admits the capareity of the drawore to draw the bill, for otherwise it would not be valid; therefore he camos set mp a plea, that the drawer of a lill, which ho hatr aceepted, was a body corporate having no legal authority to draw the hill, or was a bankrupt, infant, married womin, or fietitions person, "When the bill is drawn in the name of a tirm, aceeptance ambits that there is such a firm, and if it he drawn by a person as executor, it armits his right to sue in that character. ${ }^{65}$

$\$ 276$. (4) Admission of payee's capacity to indorse.- Iu the fourth place, the aceeptor admits the capacity of the payee to indorse the bill when it is drawn payable to the payce's order, for by the very act of acecptance he agrees to pay to his order; and, therefore, he cannot show that at the time of aceptance the payee was an infant, an insane person, a married woman, a bankrupt, or a corporation without leanl existence. it It is a general principle, applicable to all negotiable secorrities, that a person shall not dispute the power of another to indorese snch an instrument, when he asserts by the instrument which he issues to the world, that the other has such powere is Indeed, there condel be no reason why the aceeptor shomld he interested to show that the payee was incompetent to make the order; for he has been guaruteed in that regard he the drawer, and maly

(iz Turner v. Browder, is Bush, 2lti.

63. Story on lills, s 113; Byles on Bills [ ${ }^{*}$ J!3]. 825.

et Halifax v. Lyle, 3 Welsh., Hurl. \& (iord. (Exch.) Hiti: Braithwaite v. Aarliner, \& Q. B. 473: Taylor v. Croker, 4 k-p. 187: Cowton v. Wickersham, öt Pa. St. 30:2: Cooper v. Meyer, 10 B. \& C. 46 S.

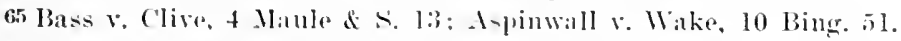

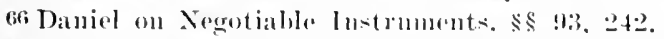

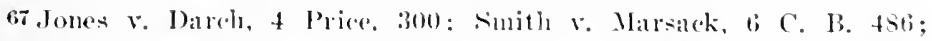

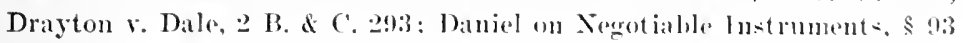
ct scq.

GS Daniel on Negotiable Instrumant-, rhap. 42, section :3. 
charge the amount in ateconnt against him whether the paree were competent ol not.

$\$ 277$. (5) Admission of agent's handwriting and authority. - In the fifth plices, if the bill be drawn by one professing. to act as agent of the drawer, the aleceptance admits his handwriting and authority as agent to draw. In the learling ease of Robinson r. Iatrow, the question arose between the acceptor and the indorsee of the drawer by procuration, and the doetrine is stated in the text in the language generally used by text-witers and judges. It is, however, contended with fore in a lonisiana ease, that the doetrine only applies as between the aceeptor and a bona fide transferee without notice of want of authority in the agent to draw; and that as between the aceeptor and the payee who has taken the bill from the agent, the former is not estopped from showing that the agent drew without authority, the payee being himself under obligation to make due incuiry io And this seems to be a reasonable limitation of the principle.

$\$ 278$. What acceptance does not admit: (1) Signature of payee.- But herond these admissions the aceeptance does not go. In the first place, it does not admit the genumeness of the signature of the payce when ito purports to bear his indorsement, or that of any other indorser, for with their handwriting he is not presuned to be familiar; and, thercfore, if the signature of the payee or other indorser be forged, the acceptor will not be hound to pay the bill to any one who is compelled to trace title through such indorsements. ${ }^{71}$ And if he has gone so far as to pay the hill to any one holding it under such forged indorsement, he may, as a general rule, reeover back the amount. ${ }^{72}$ The rule would uot apply, however, where the drawer had issued the bill with the forged indorsement upon it, for then the

\footnotetext{
6: Robincon r. Yarrow, 7 Taunt. 45.5: 1 Parsobi on Notes and Bills, 322.

70 Anged v. Elli-. 1 Mrgloin, 61.

71 Holt v. Porse, 54 X. Y. 474: Edwards on Bills, 432.

72 Holt v. Rose. 54 X. Y. 474 : Dick r. Leverich. 11 La. 573; Williams v. Drexel, $14 \mathrm{Md}$. 56 fi.
} 
acceptor could charge the amount in accomt against him, and as the forged indorsement could in such case sulject him to no loss, he would not be entitled to recover back the anome. ${ }^{i: 3}$ The aceptance does not armit the signatme of the indorser, even when the lill is payable to the dralwer's order, and purports to be indorsed by him in the sanc handwriting as the drawer's. ${ }^{7 t}$ But if the drawer is a fictitions person, and the bill is payable to the drawer's order, the acceptor's undertaking is that he will pay to the signature of the same person that signed for the drawer; and in such case the holder may show, as anainst the acceptor, that the signature of the tietitions drawer and of the first indorser are in the same handwriting. ${ }^{5}$

\section{$\S 279$. (2) Acceptance no admission of agency to indorse.-} In the second place, acceptance does not adnit agency to indorse, which must be proved ly the holker in order to recover against the acceptor, even though the acceptor acknowledges agency to draw the hill, and the indorsement was mon it at the time of acceptance. Thus, where a bill was drawn over the signature, “ A. Henry p. proe. C. Staeben a C'o.," and was explessed to be payable " to our order," and was indorsed in like mamer as drawn: " 1 . Henry p. proc. C. Staeben d Co.," and was aceepted by the defendant, and sued on ly the plaintiff, it was held that, in order to recover, he must prove the proenration to indorse. And Park, J., salid: "The nere aceeptance proves the drawing, hut it never proves the indorsoment; it is not at all necessary that a power given to draw bills by procuration should enable the agent to indorse by procuration; the first is a power to get funds into the agent's hands, the other to pay them ont." it

7a Hort-man r. IJenshaw, 11 How. 175; Cogrill v. American Exchange Bank, 1 X. Y. 113.

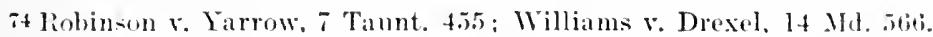

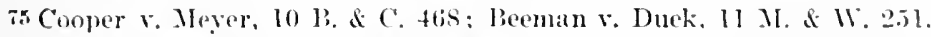

it Rohinson v. Yarrow, 7 Taunt. 455 ; Benjamin's Chalmers Digest, 211. 


\section{$\$ 280$. (3) Acceptance no admission of genuineness of terms} in body of the bill.- In the third place, the acceptance does not admit the gennineness of the terms contained in the body of that bill at the time of the acceptance; and, therefore, if at that time they had been altered so as to purport to bind the drawer for a larger sum, or in a different manner than that in the original bill, he will not be bound by his aceeptance to pay the amount, muless the drawer had by his own carelessness afforded opportunity for the alteration, and the acceptor could therefore charge him in account with the whole amount. ${ }^{i \pi}$ But where the drawer alters it himself, or acquiesces in an alteration, before acceptance, it binds him, and therefore the acceptor. ${ }^{78}$

If the drawer were not responsible for affording the opportmity for the alteration to be made, the acceptor could not only defend against a recovery upon the bill, but might himself recover back the amount paid upon it, or, at least, to the extent of the amount for which he would still remain liable to the drawer. ${ }^{79}$ If, however, the acceptor were himself responsible for issuing the bill in such a form as to admit of its being easily forged or altered - as where an acceptor wrote his acceptance in blank, on an agreement with the drawer that he should not draw for orer $\$ 1,000$, and the latter inserted a larger sum and passed the hill to the plaintiff - he would be bound for the whole amount, and could not recorer it back if paid. ${ }^{80}$

\section{SECTION VI.}

BY WIION, AND WHEN, BILLS SIIOULD BE ACCEPTED.

$\S 281$. Person who may accept.- The drawing of a bill imports a contract on the part of the drawer that the drawee is a person competent to accept; and, therefore, if the

77 Young v. Grote. 4 Bing. 253; Young v. Lehman, 63 Ala. 519; White v. Continental Nat. Bank, 64 N. Y. 320.

T\& Jangton v. Lazarus, 5 M. \& W. 628; Ward v. Allen, 2 Mete. (Mass.) $5 \pi$.

7s Pank of Commerce v. Tnion Bank, 3 N. Y. 230.

80 Van Duzer r. Ifowe. 21 N. Y. 531. 
holder upon presentment of the bill ascertains that the drawee is incapable of contracting - for instance, is a minor, an idiot, or a married woman - he may eause it to be protested, and proceed against antecedent parties, as usual in cases of dishonor. ${ }^{\text {1 }}$

It follows, therefore, as a general rule, that the bill should and can be acepted only by the party on whom drawn or his anthorized agent, except in the cases of acceptance for honor; ${ }^{82}$ and if a bill addressed to one be accepted by two persons, it has been thought that the aceoptane of the first will be vitiated hy having heen altered in an essential part, unless made with the acceptor's consent. But if any other person, after an aceptance, subsequently accepts the bill for the purpose of gratanteeing its eredit, at the acceptor's request, in the usual form of an acceptance, then, if there is a sufficient consileration, he may be bound thereby as a guarantor; but lie is not liable as an aceeptor. ${ }^{54}$. Ind the addition will not be a material alteration.

A party may be bound as an aeceptor by any name or designation he may see fit to aldopt, provided it clearly appears by extraneons evidener who was intended; and if he intends to contract hy a certain designation, he is estopped to deny that the name by which he asimed to enter into the contract was the appropriate appellation. "The West Tennessee Department of the Life Asociation of America" would therefore be bound upon an acceptanee made by its proper officer of a bill adidressed to "The Westem Department of the Life Association of America." s)

$\$ 282$. When accepted by stranger to the instrument.Where a person other than the one addressed as drawee writes his name across the face of the hill, it would be eom-

81 Edwards on Bills. :3sl; ('hitty on Bills [*]92], 2:2l; Tooting $v$ Hublard, 3 Bos. \& P. 29l.

82 Polhill v. Wilter, 3 B. \& Ad. 114; May r. Kolly, 27 Ala. 497;

Keenan v. Nash. 8 Minu. to9.

83 Thompson on Bills, 112. 212.

84 Story on Bills, \$ 2.4; Jackion v. Iludion. 2 (ampl. 4t7.

85. Smith r. Lockridge, \& Bush. 425 .

sti Hascall v. Life A-sul of America, 5) llun, 152. 
petent for him to show as between immediate parties (and on account of its ambignity, perhaps, als to others) in what character he intended to be bound.

But if a party aceept a bill in which no drawee is named, it will be regarded as acknowledging that he was the drawee and will operate as a complete accepted instrmment. ${ }^{\text {ss }}$

$\$ 283$. An acceptance may be made by an agent but certainly the holder may require the production by him of clear and explicit authority from his principal to accept in his name, and withont its production may treat the bill as dishonored $;^{59}$ and it has been doubted whether the holder is bound to acquiesce in an acceptance by an agent, as such an acceptance would multiply the proofs of the holder's title. $^{\text {gn }}$ But if the agency were clear, we think the holder would be bound to take the agent's acceptance - acceptance by procuration, as it is termed..$^{91}$ If the holder takes an acceptance from one mduly alleging his ageney, and without giving notice to antecedent parties, they will be released, if the principal refuses to ratify the act. ${ }^{92}$

If the bill be drawn upon an agent in his individual name, it would seem clear on prineiple that none but he, as an indivirlual, could accept. ${ }^{93}$

$\$ 284$. Bills drawn on joint parties and partners. - If a bill is drawn on two per'sons not partners, both should accept, and if either refuse, the hill may be protested for his nonacceptance; ${ }^{94}$ but the party accepting will be bound by his acceptance. 95 If the bill is addressed to two persons, "or"

86 Curry v. lieynolds, 44 Ala. 349.

8. Wheeler v. Webster, 1 k. D. Smith, 1; Gray $v$. Milner, 8 Taunt. 739: Davis r. Clarke, e. Q. B. 16.

8. Atwond $v$ Munnings, 7 B. \& C. 278: Roscoe on Bills, 71.

s) Coore r. Callaway, 1 lip. 115; Chitty on Bilis (13th Am. el.), 321.

\$1 Thompon on Pills, 211.

:2 Thompion on Bills. 211; Chitty on Bills (13th Am. ed), 321.

93 Danial on Negotialbe Instruments, $\$ 48 \pi$.

94 Dupays r. Shepherd, Holt, 297; Chitty on Bills (13th Am. ed.), 73,321 .

950 wen v. Van I'ster, 10 C. B. 318 ; Smith v. Melton, 133 Mass. 369. 
either of them," aceptance by either is a sufticient compliance with its mandate. ${ }^{91 \%}$

If a bill be drawn upon a fimn, it may be aceepted bỹ ang" one of the partners in the partuesship name; ${ }^{5 /}$ and it will be a good acceptance of the firm (as we think, althongh the authorities are in conflict), if only the name of the acecepting partner he signed, as it will be understood to signify that the firm responds to the request of the bill, and that the signing partner attests it." But whether the acceptance be in the name of the firm, or of the signing partner, it will not bind the firm as against the drawer cognizant of the facts, unless the bill was drawn for partnership purposes, ${ }^{60}$ execpt in the hands of a bona fide holder for value, without notice, in which event it would be valid whether drawn for partnership purposes or otherwise. ${ }^{1}$

If a bill drawn on an individual member of a firm be accepted ly him, it will hind him individually, but not the firm, although expresed to he on aceount of the firm.

$\S 285$. When acceptance may be made-The acceptor may make his aceptanee before the hill has heen signed by the drawer, and while it is otherwise incomplete, and deliver it to be completed by the necesenry insertions: 2 and his acceptance is valid if made after the bill is overdue, and after it has heen dishonored by refusal to accept, or hy nonparment, followed by protest. ${ }^{3}$ It is not necessary that the bill should be drawn by the sane person to whom the aceeeptor handed the blank aceptanes. Ant where the blank

o Thompson on Bills, 212.

"7 Pinkney v. Hall, 1 Salk. 126: Mason v. Rumsey, 1 Campb. 3s4.

as Mason v. Rumsey, I Camph. 394: Chitty on Bills (13th . Im. ed.). 5:3, 5t: Tolman v. Manmahan, 44 Wis. 133.

m Pinkney v. Irall. l Salk. 126.

1 Catskill laink v. Stall, 15 Menl. 3tit: Livingston v. Roosevelt. t Johns. 351 .

a Havey v. Cane, 34 L. T. R. (it: Daniel on Negotiable Instrunent-.

$\$$ ol et seq.

3 Mechanies Bank v. Livingston, 33 Barb. 4is: Spalding v. Androw. 48 Pa. St. 413: Wynne v. Raikes. 5 East. „13: Grart v. Shaw. 16i Mas: 344.

Schultz r. Ashley, 7 Car. \& 1', 9.9. 
aceeptance was filled up after the lapse of twelve years, and, as the jury found, after the lapse of a reasonable time, the acceptor was held liable to a bona fide indorsee." Furthermore, the acceptor in blank will be liable for any amount for which the bill is filled ul, when it has passed into the hands of any bona fide holder, withont notice that his authority has been exceederl."

Aceptance dates from delivery, mil which time it is revocable ${ }^{T}$ but if not in the hands of the acceptor, and acrepted verbally, this principle wonld have no application. ${ }^{8}$

$\$ 286$. Acceptance of bill after maturity, and after death of drawer. - There may be aceeptance of a bill after it has become payable, and after protest, in which case the bill is regarded as payalle on demand:" And after aceptance has been once refined, the drawee nay afterward accept, and bind himself as acceptor-lut he camot bind the other parties muless the bill was duly protested."

Death of the drawer is no revocation of a bill in the hands of a hona fide holder; and, therefore, after his death, it may le aceepted by the drawee, although he has knowledge of that fact. ${ }^{11}$ The presumption is that a bill was accepted lefore maturity, and within a reasonable time after date. $^{12}$

$\$ 287$. Drawee may deliberate twenty-four hours whether or not to accept.- When the bill is presented to the drawee for acecptance, lhe is entitled, if lie desires it, to a reasonable time to exanine into the state of his accomits with the drawer, and deliberate whether or not he will honor the bill. To afford him this opportmity, which it may be

5 Montague v. Perkins, 22 Fng. L. \& Eq. 516.

6 Pank of Commonwealth v. Curry, 2 Dana, 142: Moody v. Ihrelkold, ]:3 (ia. 5.5.

7 Cox v. Troy, 5 B. \& Ald. 474.

81 Parsons on Notes and Pills, 291.

9 Christie v. Pealrl, 7 II. \& W. 49l: Bank of lomisville v. Ellery, 34 Jarb. 630.

10 Wynne v. Raikes, 5) Ealst, 514: Thompson on Bills. 214.

11 Cutts v. Perkins, 12 Mass. 206: Hammond v. Barclay, 2 East. 227. 12 Roberts v. Pethel, 1:2 (. 13. 76s. 


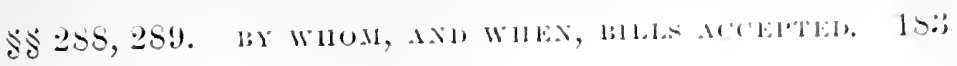

very necessary for hiun to arail of, he is allowed twentyfour hours, and it is usual to leare the bill with hin for that period; $;^{12}$ though it has been said that if the post goes out in the meantine, the bill should be probesterl inmucdiately if not aneepted, and notice of dishomor sent. ${ }^{14}$ lint this rule is too rigiel, especially in eomntries like the I nitad States, in which the mail facilities are so great; nol dow it consist with the rule allowing a whole day for preparation of notice. ${ }^{15}$

But if the drawee refuses to aecept within the twentyfour hours, the bill must lie protested inmediately; ${ }^{15}$ and if at the end of twenty-four hours the drawee does not signify his acceptance, protest must be immediately made, and notice given. ${ }^{17}$

$\$ 288$. As to the date of acceptance.-If the acceptance bears a date, it will be taken as prima facie evidence of the time when it wa made, even when the date is in al different landwriting from the rest of the areeptance. ${ }^{\text {is }}$ When the acceptance bears no date, there is no presmmption that it was made at the date of drawing; but, on the contrary, it will be presmued that it was made afterwarl. ${ }^{19}$ The presumption is, that it was made within a reasomalle time after drawing, and prior to the term of parment. ${ }^{2}$ It is sairl, in Pardessus, that it may be inferred to have been aceepted on the date of the hill. ${ }^{21}$

\$289. Acceptance for honor.- There is a peculiar kind of acceptance called aceeptance for honor, or supra protest.

13 Connelly v. MrKran, 64 Pa. St. 113: Overman v. Hoboken City Bank, 31 X. J. T. 563; Montgomery County Bank v. Albany City Bank. S Barb. 399.

1+ Bellasis v. Hester. I LdI. liaynu. 280: Thompson on 13ills. 213.

15 Morrison v. Buchuman, 6 Car. \& P. IS; Chitty on Bills (13th Am. ed.), $317-321$.

16 l Parsons on Notes and Bills. 348: Fdwards on Bills. 400.

17 Jugram v. Forstor, 2 J. P. Smith, 242.

1s Glossup v. Janoh, 4 Canuph. 2.27; Thompsou on Bills. :217.

19 Pegrli v. Levi, I C'. \&.J. 180.

20 Roberts $v$. Betliel, 22 L. J. C. P. 69.

21 Pardessus. 393. 
This most frequently happens when the original drawee (and the drawee an besoin, if any) refuses to acept the bill, in which ease a stranger may aecept the bill for the honor of some one of the parties thereto, which acceptance will inure to the benefit of all the parties subsequent to him for whose honor it was accepted.22

\section{$\$ 290$. Circumstances under which there may be such ac-} ceptance; method of.- In aceeptance for honor is only allowable when aleceptance by the drawee has been refused, and when the bill has been protested, and hence it is ealled acceptance supro protest. ${ }^{23}$

The reason assigned for this is that the drawers and indorsers have a right to say that the bill was not primarily drawn on the acceptor for honor; and the only proper proof of the refusil of the original slawee is by protest, that being the known instrument, by the custom of merehants, to estabiish the facts. ${ }^{24}$ The isual form used in such acceptance is, "Aecepted supra protest, for the homor of A. B." Inother approved form is, "Accepted under protest, for the honol of $\mathrm{A}$. B., and will be paid for his aceount, if regularly protested and refused when due." It is essential that the acecptor for honor appear before a notary public and declare that he accepts the protested bill in honor of the drawer or indorser, as the case nay be, and that he will pay it at the appointed time. ${ }^{25}$

It is the duty of the acceptor supra protest, as soon as he has male the areeptance, to notify the fact to the party for whose honor it is done ${ }^{26}$ and the party paying a bill under protest for honor must give reasonalile notice to the person for whowe honor he pays, otherwise loe will not be linemel to refund. ${ }^{27}$

22 Konigr v. Bayaurl. I Pet. 250: IJoare v. Cazenove, 16 East, 391 ;

Story on Bills, \$\$ 25i, 256.

2: Payley on 13ills, 177: Story on Bills, \$\$ 255, 256.

24 Story on Bills, \& $2 \pi 6$.

25 Gayzam v. Armstroner. 3 Dana, 5.54.

26 Story on Bills. \$ 259: Edwards on Bills, 441.

27 Wood v. Pugh. 7 Ohio, pt. II, 156. 


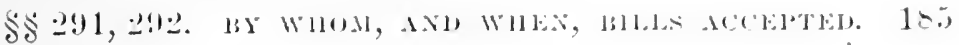

$\S 291$. As to who may be acceptor for honor. - $\perp$ stranger may undoubtedly accept for honor; and by the word stranger in this connection is meant any third person not at party to the bill. It scems that acceptance for honor may also be made by the drawee, who, if he does not choose to aecept the bill dratrin generally on accomt of the person in whose faror, or on whose account, he is advied it is dram, he may accept it for the honor of the drawer, or of the indorsers, or of all or any of them. ${ }^{28}$

But if the drawce wore bound in good faith to accept the bill, he camnot change his relations to the parties, and accept it supra protest for the honor of an indorser; he must either aceept or refuse. ${ }^{29}$

An acceptor supra protest for the honor of an indorser may, however, recover against snch indorser, though he accepted at the instance of the drawce, and as his agent, provided the indorser were not thereby damnified. The indorser might avail himself of any defense which he could have made, had the drawee acepted for his honor, and then sued upon the acceptance. ${ }^{3 \prime}$ It is immaterial, indeed, as to the defenses which a drawer or indorser may make against an acceptor for honor, whether such acceptor acted at the instance of the drawer, or as the agent of the drawee. ${ }^{31}$

$\S 292$. Several acceptors for honor of different parties.While there cannot be succestive acceptors of a bill, generally speaking, there may he several acceptors supm protest for the honor of different parties - that is, one maly accept for the honor of the drawer, another for the honos of the first indorser, and another for the honor of the secoml indorser, and so on. ${ }^{32}$

And the aceeptor supra protest may acept for the homor of any one, or all, of the parties to the hill: and his areept-

2s Story on Bills, $\$ 259$.

2) Schimmelpenuich r. Tayard. I Pet. 264.

30 Konigr r. Bayard, l Pet. 250.

31 Gazzam v. Armetrong. 3 Dana, 5ist: Wood r. Pugh. T Ohio, 1sti.

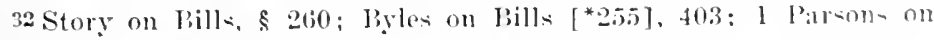
Notes and Bill-. 315. 
ance should designate for whose honor it was made, in which case it could be at once pereeived for whose benefit it inured. $^{33}$ If the acceptance do not specify for whose honor it was made, it will be construed to be for the honor of the drawer; ${ }^{34}$ and if for the honor of the bill, or of all the parties, it should be so expressed. ${ }^{35}$

$\S 293$. As to the rights of an acceptor for honor.-By his acceptance for honor, the acceptor has recourse against the party for whose honor ho acepts, and all parties whom the latter would have recourse against, and none others. ${ }^{36}$ But the acceptor for the honor of the drawer cannot recover against him without proof of a presentment for acceptance or parment, and refusal and notice to the drawer. ${ }^{37}$

If he accepts for the honor of the drawer only, he will in general have no recourse against the indorsers; and if for the honor of an indorser, he will have no recourse against a subserpent indorsers - the exception arising in cases where the person for whose honor he accepts the bill might have recourse against either, as when he is an accommodation drawer or indorser. ${ }^{39}$

$\$ 294$. As to the liability of the acceptor for honor.- The acceptance for honor or supra protest is not an absolute engagement like an ordinary acceptance for valne. It is a conditional engagement, and to render it absolute, the performance of several acts as conditions precedent are essential. Such an aceptance, says Lord T'enterden, C. J., " is to be considered not as absolutely such, but in the nature of a conditional aceptance. It is equivalent to saying to the holder of the bill, 'kcep this bill, don't return it, and when the time arrives at which it onght to be paid, if it be

3. Hussey v. Jacoh, 1 Ld. Raym. 8s; 1 Parsons on Notes and Bills, 313.

34 Clitty on Pills [*346], 387; 1 Parsons (n Notes and Bills, 313.

35 Gazzam v. Armstrong, 3) Dana, 552.

:66 Goodall v. Polhill, 1 C. 13. 233; Byles on Bills [*259], 406.

: 7 l Saring v. ('lalk, 19 Pick. 220; Schofield v. Bayard, 3 Wend. 488.

:8 Giazam v. Armstrong, 3 Dana, 554.

39 Story on Bills, \$ 256. 
not paid by the party on whom it was originally drawn, come to me and you shall have your money.' "An 'The nature of such an aceeptor's modertaking is more analogons to that of an indorser than that of an ordinary acceptor, and to render him alsolutely liable it is necessary:

First. 'To present the bill at maturity to the orjginal drawee, notwithstanding his prior refusal, becaluse betwecu the time of such refusal and the time of maturity, ceffects may have reached the drawee, out of which he might, if the bill were again presented, pay it; and the drawer and other partics are entitled to the ehane of any benefit which might arise from such second demand. And if it were not made (except in the case of a bill made payable at a place not being the residence of the drawee), the drawer and indorsers would be discharged; and as the acceptor supra protest would thereby lose recourse against them, he is also discharged. ${ }^{42}$

Second. Upon refusal by the original drawee to pay the bill when it is presented at maturity, it must be again protested for nonpayment, and such protest and presentment must be alleged in the declaration against the acceptor supro protest. And third, it is then necessary to present the bill in due time to the aceptor supra protest. ${ }^{43}$

If on such presentment the aceeptor supra protest refuses to pay, there must be another formal protest, stating the presentment for payment to the drawee, the protest for his nonpayment, the presentment of the bill and aceeptance to the acceptor supre protest, and demand of payment of him, and the protest for his nonparment: and notice thereof must be forthwith forwarded to the drawer and indorsers. ${ }^{44}$

\$295. Admissions of acceptor for honor.-There appears to be a confliet of opinion as to the extent of the almission

40 Williams v. Germaine, 7 B. \& C. 457.

411 Parsons on Notes and Bills, 315.

42 Barry v. Clark. 19 Pick. 220; Story on Bills. \$ 261.

43 Chitty on Bills [*350, 351], 392; Story on Bills, $\$ 261$.

4t Chitty on Bills [*352], 393; 1 Parsons on Notes and Bills, 320. 
of the acceptor supra protest. 'The rule has been broadly stated to be that he does not athit the genuineness of the signature of any party for whose honor the acceptance is given, not even the drawer's, and therefore he could recover money paid to the holder if the hill should prove to be a forgery; ${ }^{45}$ but the rule stated is certainly subject to the modification that one who accepts for the honor of the drawer is estopped from denying that the bill is a valid bill; and, consequently, it would not be competent for him to set up as a defense to an action by an indorsee that the payee is a fictitious person, and that he was ignorant of the fact at the time he accepterl the lill. ${ }^{43}$

\$296. Holder not bound to take acceptance for honor.The holder is in no case bound to take an acceptance for hranr ${ }^{47}$ but if he receives it, and it is for the honor of a particular party, he camnot sue such party until the matnrity of the bill, and its dishonor by the acceptor supre protest. $^{4 h}$ Ancl if the acceptance is for the honor of all the parties to the bill, he cannot sne any of them until it has matured and been dishonored. ${ }^{49}$

But there seems to be no reason why the holder may not sue prior parties, when the areeptance is for honor of a particular party, after giving them dne notice. ${ }^{50}$

\section{SEC'TION VII.}

FORM ANI VARIETES OF MCERPANCE.

\$297. Varieties of - According to the law merchant, an arecplalue: may be (1) expressed in words or (2) implied from the conduet of the trawee. (3) It may he verbal or written. (4) It may he in writing on the lill itself or on a separate paper. (5) It may be before the bill is drawn

45] Jarsons on Notes and Bills. 323.

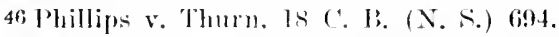

47 Mitford v. Walcoll, 12 Mor. 410; Chitty on Bills [*345], 387.

48 Williams r. (immaine, 7 l., \& C. 468.

49 Sitory on bills. \$ 258.

notory on Bills. $\$ 258$. 
or afterwals. And (6) there may be absolute, conditional, and (pualified acceptances. ${ }^{51}$

Aceptance by telegram has been held suflicient; ${ }^{52}$ amel under the statules of Xew York, which make an mucomelitional promise to areceret a bill before it is drawn equivalent to actual aceeptance in faror of a party, who ujon the faith thereof recoives it for valuable consileration, it has been adjudged that at telegram witen and sent by the promisor operates as aceceptance. 53

By statute in many of the States these principles of the law merchant governing arepeptances are nodified or re pealed in one lespect or another, as will be seen hereafter."

$\S 298$. Express acceptances. - An express acceptance is usually made by witing the word "accepted" across the face of the bill (which the drawee may do with pen or pencil), and adding the acceptor's signature. But ly the law merehant neither the work nor the signature is necessary - "accepted" withont a signatmre, " seen," "honored," "presented," . I will pay the bill," or writing the day and month when presented; or a witten direction of the drawee on the bill to some other person to pay it, or the signature of the drawee alone, or the word " $\mathrm{ex}^{-}$ cepted," it heing obviomsly intended for "accepted." so "Tho workls, "I take notice of the above," were held in Massachusetts not necessarily to import aceeptance; and eren if they did, mexplained, to be open to explanation, as between immediate partics. ${ }^{5}$ Where the drawee wrote his name across the bill, it was held inadmissille for him to show that he refused to wite "arepted," for the name alone imported

51 Daniel on Negotiable Instruments, $\$ 496$.

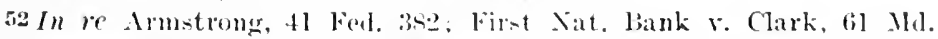
401: Nevitlat liank v. Luce, 139 Mass. 488.

53 Molson's Tank v. Howard, \& Jones \& s. 15.

54 Post, \$ 301 .

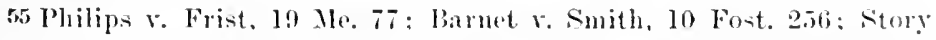

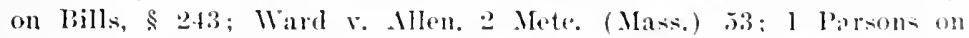
Notes and Pills, 243; Harper v. West. I Cr. C. C. 192; Spealr v. Pratl. 2 IIIll, 5s2; Miller $ง$ Butler, I Cr. C. C. 170.

5f Cook v. Baldwin. 120 Mass. 317. 
it." But merely paying and crediting a part of the amount on the bill would not amount to an aceptance in writing. ${ }^{5 s}$

\$299. Implied acceptance- - Acceptance may be inplied from the conduct of the drawee. Any act which clearly indicates an intention to comply with the request of the drawer, or any conduct of the drawee (no statute intervening) from which the holder is justified in drawing the conclusion that the drawee intended to arcept the bill, and intended to be so muderstood, will be regarded as an acceptance." Keeping a bill at eonsiderable length of time without returning an answer, may, under some circunstances, be considered ats an acceptance, especially if the drawee be informed that delay will he so considered, and there be an inference from the language of the drawee that he intended an acceptance. ${ }^{(x)}$ But the mere detention for an unreasonable time, mattended by special circumstances, will not, in law, amount to an acceptance. ${ }^{61}$

In an English case Lord Ellenborongh expressed thie opinion that destruction of the bill by the drawee would constitute an implied acceptance, especially if the drawes har not previonsly refused to accept. ${ }^{62}$ The correctness of this doetrine is doubted by eminent text-writers, ${ }^{63}$ and it does not seem to be consonant with somud prineiple. There is a statute in Now York which in substance provides that if the drawe destroy the lill, or refuse within twenty-four lours after its delivery to lim to retum the bill, snch conduct shall be deemed an aceeptanee. ${ }^{64}$

300. Verbal acceptance.- $\Lambda$ s has been seen, the law merchant, unaffected by statute, permits a rerbal acceptance,

5 Kaufman y. Barrenger, 70 La. Ann. 419.

58 Bassett v. Haines, 9 ('al. 261.

5 Andresen r. First Xat. Bank, 2 Fed. 125: Billing v. De Vaux, 3 ㄱ. \& (․ 565: MeC'utcheon v. lice, 56 Miss. 455.

co ('kitty on lill]. [*295], 334; Harvey v. Martiu, ] Campb. 425.

6l Mason v. Barff. 2 li. \& Ald. 26; Colorado Nat. Bank v. Boettcher, 5 Colo. 190.

62. Jeune v. Ward, 1 1: \& Ald. 653.

cachitty on lills [*296i]. 335: Edwards on Bills, 418.

6it R. S., \& I I (2d ed.), p. 757. 
and it is as binding upon the drawee as a written acerptance; but the holder may always insist nyon a written ateceptance, and in defanlt thereof treat the bill as dishomored."5 Any words ned by the drawee to the drawer or holder, which by reasonable intendment signify that he homors the bill, will anomit to such acceptance; though it would be different if the words were addressed to a stranger having no interest in the bill. Thus, where a foreign lill drawn on defendant was protested by nonaceptance aml returned, and afterwards the drawee told the plaintiff, "If the bill comes back I will pay it," was held an aceeptance. So, if the drawee say, "Leave your bill with me, and I will aceept it." 6 so, where the holder met in the street the drawee of the bill which had been sent to his comutinghouse, and returned unacepted, and the drawee said, "If you will send it to the comnting-honse again, I will give directions for its being acepted," Lord Ellenborough helel that if the bill had been sent aceordingly, it would operate as an acceptance, but otherwise not, the words being conditional. ${ }^{68}$ The words used, therefore, must erince a clear intention on the patrt of the drawee to lind hinself to the payment of the bill at all erents, in order to amomit to an aceptanee, and equivoral language will not suffice. Therefore, where the drawee said, on the day after presentment for aceptance, when the plaintiff's elerk called for the hill, "There is your bill, it is all right," it was held no aceeptance. ${ }^{69}$ It should be added that, in order to amonnt to at verbal acceptance, the words need numst he addressed to the drawer or holder, or their agent, or to some one who takes the bill on the faith and credit imparted by the words used.io

\footnotetext{
65 Chitty on Pills [*287], 326: Elwards on Bills, 417.

of Cox v. Coleman, Chitty, Jr., on Bills, 274.

it Chitty, Jr., on Bills, 12.

tis Anderson v. Hick, 3 Camph. 179.

69 Powell v. Jones, 1 Esp. 17.

io Daniel on Negotiable Instruments, $\S 507$; Martin v. Bacon, 2 S. C.
} 132. 
$\S 301$. Statutory rule as to written acceptance. - In the vear 1821 it was enacted in England, by the statute 1 \& 2 Geo.IV., chap. 78, \$2, that "no acceptance shall be sufficient to charge any person, muless such acceptance be in writing on such bill." Since that statute it has been laid down by high authority that a mere signature on the face of the bill, without any words of acceptance, may be an aceeptance in writing within the meaning of the statute $;^{71}$ and, on the other hand, that words of aceeptance without a signature, if intended as an acceptance, might suffice. ${ }^{72}$ By statute 19 \& 20 Victoria, chap. $78, \$ 2$, it was enacted "that no acceptance of any bill of exchange shall be sufficient to bind or charge any person, unless the same be in writing on such bill, and signed by the acceptor or some person duly authorized by him." After this enactment it was contended that inasmuch as before its passage a mere signature was deemed an acceptanee in writing - within the statute $1 \& 2$ Geo. IV., it was still not the less so; and that inasmuch as it was a signature of the acceptor, the bill was both aceepted in writing, and signed by the acceptor within the meaning of the statute $19 \& 20$ Victoria. But looking at the history of the statute, Lord Demman was of the contrary opinion; and the mere signature was held not to amount to an acceptance under the later statute. ${ }^{73}$ The decision, however, was immediately nullified by act of Parliament. ${ }^{74} \mathrm{Un}$ der a similar statute in New York, to that of 19 \& 20 Victoria, the mere signature of the drawee was deemed a sufficient acceptanee. ${ }^{i 5}$ In many of the Lniterl States statutes have been enacted which expressly require that all aceeptanees shall be in writing, and in most of these States the written accptance is required to be signed by the aceeptor.

il Byles on Lills (12th ed.), 191; Leslie v. Hastings, l Moody \& R. 119.

72 Dufaur r. Oxenden, I Moody \& R. 90.

7. Hindlaugh v. Blakey, 3 C. P. Div. 136.

it See Stecle v. McKinlay, 34 Eng. Rep. 106.

7ispear v. Pratt, 2 Hill, 582. 
$\$ 302$. Acceptance on separate paper.- There i- 110 donl, that, in the alsence of statutory interdiction, an alerefutane.

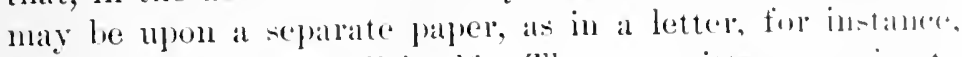

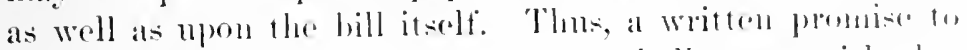
accept an existing bill, or " that it shall moret with dur. honor:" or that the drawee " will aceepent or coptainly las"

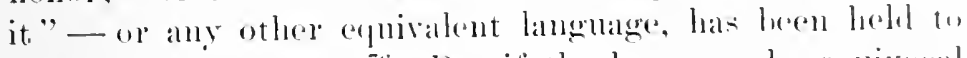

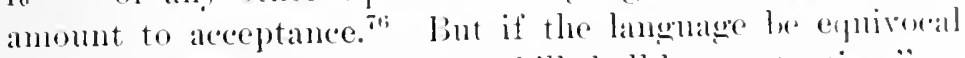
— if it be merely stated, " your hill shall have attemtion" -

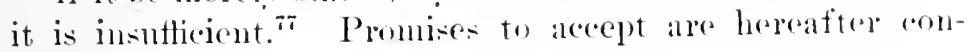
sidered. ${ }^{i s}$

$\$ 303$. Written and verbal promises to accept existing and nonexisting bills.- I written fromise to the drawer to areept an existing or nonexisting bill which is enmmmicated to a thired party, and induces him to take the bill moun the credit thereby exeited, is moloubtedly, by the decisions in England and in the luited States, the same as an aletual aleceptance. "a But where such promise was not eommmuicated to the holder, and therefore did not enter into the inducement to take the bill, the decisions are in a comblition of inextricable confusion." It the promise to aceept be verlat, and the bill in existence, and the promise is commumiented to the holder. such promise will amomt to an aceeptances. st lut if the promise be made to areeret a nomexisting bill, the better view is that it will not amomit to an aceeptance. ${ }^{2}$

$\$ 304$. What requisite to make promise to accept nonexisting bill amount to acceptance.- In order that the promise to accept a nonexisting bill shall amomit to aeceptance, there are two indispensable requisites: First, that it should be

in MeEvers v. Mason, 10 John 207 ; Greele v. Parker, j Wend. 4l4; Billing $\checkmark$. De Vaux. 3 ir. \& 6. 565.

it Rees r. Warwick. 2 B. \& Ald. 113.

7s P'ost. s $\$ 303-305$.

79 Daniel on Tegotiable Instruments, \$\$ 5.50, 551. and eases eited.

s Daniel on Negotiable Instruments. \$\$ 552-554, and cases eited.

s1, Johnson $r$, Collings. 1 Wast. 9s.

s2 Bank of Ireland r. Areher. 11 II. \& W. 383: Kennedy r. Gedles. \& Port. 268. 
written within a reasonable time before the bill is drawn, for otherwise the drawer will be presumed to have declined to act on the anthority granted him to draw, and the drawee will not be construed to have intended an indefinite liability. ${ }^{83}$ And sceond, the promise must so deseribe the bill that there an be no doubt of its applieation to it. ${ }^{84}$ High authorities go further, and declare that the promise must put its finger, so to speak, upon the speeific bill; and that otherwise, if the promise be broken, the promisor may he sued by the drawer for breacl of promise to accept; but cannot be sued by anyone as aceptor: ${ }^{85}$

$\$ 305$. To what bills promises to accept are applicable.The rule that the promise to aecept, designating the specific bill, amomts to an acceptanee, seems applicable only to the cases of bills payable on demand, or at a fixed time after date, and not to bills payable at or after sight; for, in order to constitute an acceptance in the latter cases, a presentment is indi-pensable, since the time that the bill is to run eamnot be otherwise ascertained. ${ }^{86}$ Ant a mere promise to aceept without more, it is thonght, applies only to bills payable at the drawce's or payce's place of business. ${ }^{87}$

S 306. Absolute and conditional acceptances; rights of holder as to.- It is the right of the holder of the bill to require an absolute and unconditional acceptance - that is, an acceptance in conformity with the tenor of the bill and may canse it to be protested mless it be so aceepted. ${ }^{8 s}$ The holder nay, however, at his risk, take a conditional, varying, or qualified acceptance, and in such eases the acceptor will, if the condition be complied with, or the qualification admitted, be bound thereby; and the holder will

s.3 Coolidge v. Payonn. 2 Wheat. 66; Greele v. Parker, 5 Wend. 414.

s4 Franklin Bank v. Lynch, 52 Md. 270.

s. Conlidge r. Pay-onl. 2 Wheat. 66: Boyee v. Edwards, 4 Pet. 111:

Schimmelpennich v. Bayard. 1 Pot. 264.

86 Wildes v. Sarage. ] Story C. C. 28; Franklin Bank v. Yỵnch, 52 Mrd. 270 .

87 Micligan State Bank $v$. Teavenworth, 28 Vt. 209.

s. Boehm v. Garriac. 1 Campb. 425: Parker v. Gordon, 7 Last, 385 ;

Gibson v. Smith. 76 Ga. 34. 
likewise be bound ly it." The burden of proof is wh the plaintiff to show perfomance of the condition of at (.o11ditional aceceptance; ${ }^{* *}$ and although absolute then it alumlel be set out as conditional, with an arement of performanee."

On the offer of a conditional or varring aceeptanee, if the holder resolve to reject it altogether, he may protest generally, or give general notice of nonaceptance; but if he is willing to accept the offer, he should then give notice of its exact tems to all the parties, and state his readiness to acept the offer if they will respectively consent. ${ }^{92}$ I general or unculalitied protest or notice of nonaceptance would, in such a case, evince that the holder did not acquiesee in the offer, and prechule him from afterward avaling himself of it: ${ }^{93}$ lut not if he was not aware of the acceptance when lie caused the bill to be noted or protested for nonacceptance. ${ }^{94}$

$\$ 307$. Qualification of rule-- The rule above stated is, in respect to the indorser's of a bill, of absolute and invariable application. But in respect to the drawer, it is subject to qualification. The drawer warrants that the drawee is in funds, and that he will accept and pay the bill. And he is bound to know whether or not the drawee is in funds. Therefore, when lie draws withont having a right to do so, he is not entitled to notice of dishonor. And upon the same prineiple it is thonght that he cannot be injured, and will not be discharged by the hokler's taking a qualitied acceptance payable at a future dar. ${ }^{9 *}$ True, such an aceptance is a departure from the tenor of the bill: but the drawer. hasing improperly drawn the bill, cannet emplain of the holiler

89. Anderson v. Hirk, 3 (ampb. 179: Taylor v. Newman, 77 Mn. 265; Hughes v. Fisher, 10 Colo. 383.

90 Road v. Wilkinson, 2 Wash. C. C. ilt: First Nat. Bank v. Bensley, l Fell. 609.

" Langston $\checkmark$. Corney, 4 Campb. liti.

92 Danie] on Negotiable Instrmments, \$ 510: Chitty on Bills [*301]. 340 .

93 Sproat $r$. Mathews. I T. R. 182.

94 patirlie $v$. Herring, 3 Bing. 625.

as Elwards on Bills. 4 es. 430.

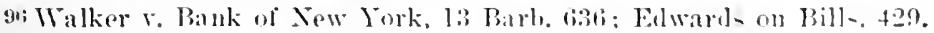


for taking those steps which seem essential to prevent its entire dishonor, and to secure its payment.

$\$ 308$. Illustrations of conditional acceptance.-Acceptances "to pay as remitted for"” " to pay when in eash for the cargo of the ship Thetis;" " to pary when goods consigned to me are sold;" " to pay when a cango of equal value is consigned to me;" " parable when house is ready for ocenpancy;" "to pay when in funds," are examples of conditional aceptances." In acceptance to pay "when in funds" renclers the drawee liable only when he has funds ${ }^{99}$ although it has been held that this implied when the drawee has funds which the drawer has a present right to demand and receive, and that it did not apply to wages for daily labor earned after acceptance, and reeded for the daily subsistence of the laborer." "When in funds" means "when in rash," and available securities will not answer this condition until actually converted into mones." If the funds are not recrived in the acceptor's lifetine, but are collected ly the administrator, the latter is liable as representative of the deceaterl:" lunt the eondition of the word "arlministrator" to an aceptance does not make it a conditional one, nor qualify his lialility. If the holder receive an acceptance to be paid "when in funds," he cannot resort to the drawer mutil the acceptor refuses to pay after he is in funds:" and the conditional acceptor will not be liable if the funds are intereepted, or compliance with the condition is prevented. ly operation of law.

sir Edwards on Bills, 429.

98 Banbury v. Lissett, 2 Stra. 1211; Julian v. Shorbrook, 2 Wills, 9; Smith v. Ablott, "Stra. 115״; Mason v. Hunt, „2 Doug. 297; Cook v. Wolfendile, 105 Mass. 401 ; Marshall v. Clary. 44 Ga. 513.

!9 Nlar*hall v. Clary, 44 Ga. 513.

1 Wintermute $v$. Post 4 Zalor. 420 .

2 camplell $x$ Pettengill, 7 Greenl. 126.

aswansey v. Breck, 10 Ala. 53:3; Gallery ve Prindle, 14 Barb. 186.

4 Tassey r. C'lumreh, 4 Watts \& S. 346.

5 Camplecll v. l'ettengill. T (irenl. 126; Gallery v. Prindle, 14 Barb. 186.

"Browne r. Coit, ] MrCorel, 408. 
Where the aceceplance is to pay out of the first monry received, the aceeptor is bound to pay from time to times,

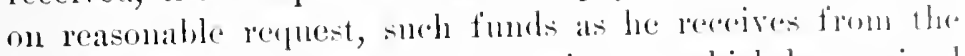
drawer; and a julgunent for a certain smm which he received is no bar to another action for a sum subsequently recoiverl.

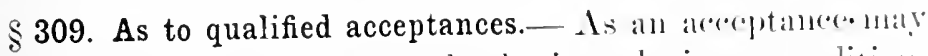
vary from the temor of the onler by introduring a comblition, so it may vary from it as to the smm, time, place, of morle enf parment." Such an acceptance is generally called a qualified acceptance, and the same princjules govern it ats govern a conditional aceeptance.

By receiving such qualified aceptance the holker discharges all antecedent parties, mless he obtains their eonsent. 'Thus, if the hill be addressed to the drawees at their place of residence, and it is aceepted, payable at a different town, it is a material variation if the holder receives it, and does not protest for nonaceeptance;" but a lill addressed generally to the drawee, in a city, may be accepted, parable at a particular bank in the eitr. ${ }^{11}$ If the drawee aceept to pay at a certain future day, different from that maned in the draft, and the holder receives such aceeptance, it will hear grace like all engagements by negotiable paper to pay at a certain time. ${ }^{12}$

As has been stated, an acceptance payable at a particular place does not constitute a qualified aceeptance, but the rule is otherwise if the acceptance specifies as the place of payment a particular place "only" and not otherwise or elsewhere."

$\$ 310$. Conditions to written and verbal acceptances. - If any conditions are annexed to a witten acceptance, ther

T Perry v. Harrington, 2 Mete. (Mass.) 368.

s Byles on Bills [*186], 31ti; C'hitty on Bills [*203], 3.2.; Vanstrum ․ Liljengren, 37 Minn. 191 .

9 Bytes on Bills [*1Si], 3Ht; Sebag r. Abithol, 4 Manle \& S. 4i2: Gibson v. Smitl, 7\% Ga. 33.

10 Niagara Bamk v. Faimman Comuty, 31 Barb. 403.

11 Troy City Bank v. Lamman, 19 X. Y. 47\%; Megers r. Standart, 19 Ohio (N. s.). 29 .

12 Green v. Raymond, 9 Nebr. 295. 
should appear on its face. It hats been laid down that acceptance miay be rendered conditional by another contemporaneous witing, ${ }^{13}$ but such eom lition could have no effect against a bond fide holder ignorant of it. ${ }^{14}$ The terms of an acceptance in writing cannot be varied by any contemporaneous parol agreement, as that is against the first principles of the law of evidence. ${ }^{15}$ There a verbal acceptance is competent, a condition annexed to a verbal acceptance nuay be shown, hecalle it does not vary or contradict the contract, hut shows what the contract was. ${ }^{16}$ But the acceptor having one accepted alsolutely, cannot by subsequent declarations annex a condition to his liability ${ }^{17}$.

1: lowerbank v. Monteiro, 4 Taunt. 884.

14 Cnited States v. Bank of Metropolis, 15 Pet. 37\%; Montague v. Perkins, 2.2 Eng. L. \& Eq. 516.

15 Adams v. Wordley, 1 M. \& W. 847: Goodwin v. MeCoy, 13 Ala. 271; Foster v. Clifford, 44 Wis. 569.

16 Fdwards on Bills, 426.

17 Wells v. Brigham, 6 Cush. 6. 


\section{CHAPTER XI.}

\section{PRESENTMENT FOR PAYMENT.}

$\$ 311$. Obligations of maker, acceptor, drawer, and indorser, respectively, as to payment; general rule.-'The engagenent entered into by the acceptor of a bill and the maker of a note is, that it shall be paid at its maturity - that is, on the day that it falls due, and at the place specitied for payment, if any place he designated - upon its presentument. This engagement is absolute, but that of the drawer of a bill and the indorser of a bill or note is conditional, and contingent upon the true presentment at maturity, and notice in case it is not paid. The maker and aceperor are bound, although the bill or note be not presented on the day it falls due ${ }^{1}$ but the drawer and indorser's are discharged if such presentment be not made, muless some sufficient cause exenses the holder for failure to perform that duty." It is important, therefore, to ascertain how the presentment should be provided for by the holder of the bill or note, lest by failure to observe the necessary precautions, the drawer. and indorsers may be diseharged, and the solvency of his debt destroyed or impaired. We shall consider. therefore, in order:

(1) The person by and to whom the instrunent should be presented.

$(2)$ The time of presentment.

(3) The place of presentument.

(t) The mode of presentment.

1 Sims v. National Com. Bank. 73 Ala. 2.51.

2 Magruder r. Bank of Washington, 3 Pet. 92: Cox r. National Bitnk, $100 \mathrm{C}$. S. 712: Harvey v. Girard Xat. Bank, 119 Pa. St. 21:2. 


\section{SECTION I.}

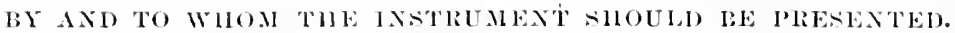

\$312. By whom.- Any bona fide holder of a negotiable instrument, or anyone lawfully in possestion of it for the purpose of receiving payment, may present it for parment at maturity." I notary public, or any agent duly authorized, may make presentment of the instmment for payment: and it is well settled that this anthority need not be in writing. ${ }^{*}$

The mere posiession of a negotiable instrument which is payahle to the order of the payee, and is indorsed by him in blank, or of a negotiable instrument payable to bearer, is in itself snthicient evidence of his right to present it, and to demand payment thereof. ${ }^{5}$ And payment to such person will always be valid, unless he is known to the payor to have acpuired possession wrongfully. And if the party holding possession of a negotiable instrmuent which is not indorsed by the paree, or has been indorsed by him specially, to another, and has not heen indorsed over by such indorsee but has been placed in the holder's hands as agent, for the purpose of receiving parment, such agent may present it for payment, and paynent to him will be valid; even, as it has been held, although made in a manner different from that prorided for in the instructions to the agent. The fact that the instrument is not indorsed by the owner is, as has been held, under such cireumstances, of no importance. Such indorsement wonld be necessary to the negotiation of the instrmment, but wonld not he necessary to the validity of the payment.

As has been indicated, the presentment may be made by the hokder or owner himself, or by his duly anthorized agent, and his anthority need not be in writing, although possibly the maker or acceptor may insist upon a written authori-

\footnotetext{
3 Ieftly v. Mills. 4 T. R. 170; Bachellor v. Priest, 12 Pick. 399.

4 Bank of Utica v. Sinith, 18 .Johns, 230; Hartford Bank v. Parry, 77 Nass. 94.

5 Weber r. Orten, 91 Mo. 680; Jackion v. Love. 82 N. C. 405.
} 
zation or indorsenent to the agent betinge being repringed an make pay'nuent."

$\$$ 313. Possession of unindorsed instrument.- Wh(11, lww"rere, a bill or note mindorsed by the palree, or indor-al ly the payee specially, and mindorsed by his indorsece, in in the possession of another person, the question whether ar not its hare possesion is eridence of his right to demand farment, is of a different charateter. Withont the indorsenent of the payce ar special indorsee, such possesion womlul alearly not entitle the holder to the privileges of a bona fide holder for value, as at best he would ouly hold the equitable title to the instrument, and conld not sne at haw mon it as a geround of action. ${ }^{\top}$ If, howerer, the holder have and rxhibit extraneons evidence of his ownership of the instrument, such, for instance, as an assignment and mortgage duly executed, this will suftice without indorsement, and the party to whom it is presented would then have no right to insist on an inclorsement. ${ }^{\mathrm{s}}$

314. Presentment by indorser.- Whether or not an indorser of a bill or note which has mon it a subseguent special indorsenent, and no prior indorsement in blank, is shown by mere possession of the paper to be entitled to demand paynent, has been much questioned. There are at number of cases which hold that such an indorser eanuot demand parment, for the reason that it womld secun from the face of the paper itself that he had parted with his title; and that a receipt. from the last indorsee, or a reindorsement to him, would be necessary to re-establish it. This doetrine was laid down in an eary ease ly the Supreme Comrt of the [nited States, ${ }^{9}$ and some of the State tribmals have taken the same riew: ${ }^{10}$ hut in a more recent case the

"Tiedeman on Billa and Notes, 311, note 2.

-Hull v. Conover, 35 Ind. 372: Portern v. Cushman, 19 111. 5i2: Bausmam r. Kelley, 3ৎ Minn. 205.

s Pease v. Viaren, 2.j Mich. 9: Daniel on Negrotiable Instruments, ș $.74,5 \%$.

" Welch v. Lindo. T Cranch. I,is.

10 Thompson v. Flower, 13 Mart. 301: Eprigre r. Cmuy, 19 Mart. 25:3; Dehers v. Harriott, l Show. 163. 
Supreme Court of the Inited States expressed the opposite "pinion, which seems to us the correct one. ${ }^{11}$ Some of the "ates hold that posiession of the lill by a prior indorser is -nfticient where the subecpuent indorsements are cancelled $;{ }^{12}$ but the better view seems to be, and it is sustained by nost respectable anthority, that it makes no difference that the subsequeni indorsements remain meancelled. ${ }^{13}$ The party may not be still the proprietor in interest of the instrument, lnit his possession of it would be prima facie evidence that le hawl paid it himself to a subsequent indorsee, and had reacouired the right to demand payment. And it would also be consistent with the idea that he was holding it and mine for the benefit of a subsequent indorsee. ${ }^{14}$

$\$ 315$. When holder is dead.- If the holder die before the tine for presentment for payment, it mist be made by his personal representative. ${ }^{1.5}$ If there be no personal representative at the time, presentment and demand within a reasomalile time after his appointment will be sufficient to charge subsequent parties, although presentment and demand were not made at maturity. ${ }^{16}$

If the holder's estate has passed to an assignee in bankruptey, the assignee, or some person authorized by him, should make presentment. ${ }^{17}$

If the holder is a feme sole, and she has become a married woman at maturity, the presentment should be made by her hushand; and a presentment by her, without his eonsent or anthority, womld be insufticient to charge the maker, or ralidate a pilyment. If the note belonged to a partnership,

11 Dugran $\checkmark$. Lnited States, 3 Wheat. 172.

12 lank of Ltica $v$. Smith, 18 .Johns. 230; Bowie v. Durall, l Gill \& J. 17.): ('hautaupua County lank v. 1)avis, 21 Wend. 584.

13 Ingan v. Tnited States, 3 Wheat. 172; Lonsdale v. Brown, 3 Wasl. C. C. 404; Tank of Kinsas ('ity v. Mills, 24 Kan. 610.

14 Bank of Lnited states v. Tnited States, 2 How. 7]l: Bachellor v. Priret, 1:2 l'irk. 399: Merz v. Kaiser, 20 La. Ann. 377.

151 Palarent on Notus and Bills, 360; Story on Notes, \$ 249.

16 White r. Stoddard, 1] Firay, 528.

17 l Parsons on Notes and Pills, 360: Edwards on Pills, 494. 
and one member be ilead at maturity, prencutument shomld be made by the survivor. ${ }^{18}$

\$ 316. To whom; general rule.- Prescontmront for palyurnt must he marle to the drawee or aceeptor of the hill, of wakele of the note, of to an anthorized agent. A peroonal demanul is not necessary, and it is sufticient to make the demand at his usual residenee or place of business of his wife of other agent; for it is the duty of an acceptor or promisor, if he is not present himself, to leave provision for the parnent of his bills or notes. ${ }^{10}$

There is no doult that a clerk found at the counting-room of the acceptor or promisor is a competent party for presentment for parment to be made to, without showing any special authority given him. ${ }^{20}$ But where the protest stated the mere fact of presentment " at the office of the maker," it will be considered insufficient, as not showing that the paper was presented to party at the oftice anthorized to pay or refuse pasment. ${ }^{2}$ I lemand mpon the servant of the owner "who nsed to pay moner for him," was held sutficient in England. 22

$\$ 317$. Presentment to person on premises. - If presentment he made at the place specified in the instrument, or in the ease of one payable generally at the place of business of the acceptor or maker during business hours, or at his domicile during a reasonable hour of the las, it is sufficient if it be made to any person to be fomd upon the premises, especially if the maker be absent or inacessible. ${ }^{23}$ Where presentment was made to the wife of the maker, she informing the holder that her hushand was out of town, it was heled

18 Daniel on Negotiable Instruments, $\$ 578$.

19 Matthews r. Haydon. 2 Esp. 509; Brown v. MeDermott, 5 Esp. ․․‥

9o Bralley v. Northern Bank, 60 Ala. 259: Stainback r. Bank of Virginia. 11 Gratt. 260.

21 Nave v. Richardson, 36 Мo. 130.

22 Bank of England $v$. Newman. 12 Mod. 241.

23 Cromwell r. Hymson. 2 Camph. 596: Phillip r. Attberer. 2 Tiunt. 206 ; Drapei $r$. Clemons, 4 Mo. 52 . 
sufficient."-t And so it wis deemed sufficient to eharge the indorser where the holder presented the bill to an inmate of the maker's honse, who was eoming out, and who stated that the acceptor hand removed - the holder leaving a eard containing notioe for the aceeptor of the maturity of the bill. ${ }^{25}$ Where there is no one to answer, presentment at the malker"s dwelling is sufficient. ${ }^{26}$

$\$ 318$. When acceptor or maker is dead.- If the aceeptor cr maker be dead at the time of the matmity of the bill or note, it should he presented to his personal representative, if one be alpointed, and his place of residence ean, by reasonable inquiries, be ascertained. ${ }^{2 \pi}$ If there be no personal representative, then presentment shonld be made, and payment demanded, at the dwelling-honse of the deceased, if the instrunent were payable generally. ${ }^{28}$ But if it was drawn payable at a particuar place, then it will be suffieient that it was presented at such place. ${ }^{29}$

$\$ 319$. Where there are several promisors. - When the note is excented hy sereral joint promisors who are not partners, but liable only as joint and several promisors, it has been held, and, as we think, correctly, that presentment shonld be male to cach, in order to fix the lialility of an indorser. ${ }^{30}$ But presentunent of a hill trawn lipon or aceepted br, and of a mote executed lis, a copartnership firm, is snfficient, if marle to any one of the members of such firm. ${ }^{31}$ And if the

24 Noodir y. Norrall, 1 Coust. Rep. 367.

2 Buxton r. Jones, 1 N. \& G. 83; Story on Bills (Bemnett's ed.), $\$ 350$, note 1 .

2tistivers v. Prentice, 3 P. Mon. 461.

$2 \pi$ Vagruder v. Cnion Bank, 3 Pet. 87 : . Huniata Tank v. Hale, 16 Serg. di. 16i.

28 Magrudre r. Inion Bank, 3 Pet. 87: Jumiata Batuk v. Hale, 16 Serg. \& R. 167: Story on Notes, \$253.

29 lioyd's Alum. v. ('ity Sar. Jank, 15 Gratt. 501; Holtz v. Boppe, 37 N. Y. (jist: Pllilpot v. Bryant, 1 Moore \& P. 754.

30 Blaks v. MreMlillen. 38 Iowa, 150; Union Bank v. Willis, 8 Mete. (Mass.) 504; Arnold v. Dresser, 8 Allen, 435.

31 Branch of State Bink v. MaLeran, 26 Iowa, 306 ; Shedd v. Brett, 1 Pick. 401. 
signature of the parties entitled to presentmont be apparcutly that of a partnership, as, for instunce, if signeal "Waller a Burr," presentment to either is sufficient."

Even after the discolntion of the firm, presentment to any one of the partners is sufficient, for as to the bill or note upon which they are liable, the liability eontinnes until duly. satisfied or discharged.:3

In the event of the death of one of the members of the firm to which presentment should be made before the maturity of the bill or note, the presentment slomld he made to the survivors, and not to the personal representative of the deceased, beeanse the liability devolves upon the surviving partner. ${ }^{34}$ The same rule obtains in the event of the deatl of one of two or more joint makers not bartuers. ${ }^{35}$

\section{SECTION II.}

TIME OF PRESEXTMEXT.

$\$ 320$. General rale as to time.- In respect to the maker of a note and the aceeptor of a bill, it is not importint upon what day the presentment is male, provided it he made at some time before the statnte of linitations bars action against them. ${ }^{36}$ In respect, however, to the drawer of a bill and the indorser of a bill or note, it is essential to the fixing of their liability that the presentment should be made on the day of maturity, provided it is within the power of the holder to make it. $3 z$ If the presentment be made before the bill or note is due, it ss entirely premature and mugatory, and, so far as it affects the drawer or indorser, a perfeet nullity. ${ }^{38}$ And if it be made after the day of maturity, it

32 Erwin r. Downs, 15 N. Y. 375.

3.3 Crowley v. Barry, 4 Gill, 194: Uubbard $v$ Matthews, 54 X. Y. 50. 34 Cayuga liank v. Hunt. 2 Hill, 635: Story on 13ills, $\$ \$ 346-362$.

35 Daniel on Negotiable Instruments, s 596.

36 Chitty on Mills [*354], 396: Metzuer v. Waddell, 1 x. Mex. 409.

37 l Parsons on Notes and Bills, 373; Pendleton $r$. Knickerbocker life Ins. Co., 7 lied. 170.

38 Griflin r. Goff, 12 Johus. 423; Jackson r. Newton, S Wiatts. 401; Farmers Bank v. 1)urall, i Gill \& .J. is. 
can, as matter of contse, be of no effect, as the drawer or indorser will already have been discharged, mless there were sufticient legal excuse for the delay. ${ }^{39}$ The evidence must he distinct as to the promptness of the presentment or the exeuse for delay, as the burden of proof is on the plaintiff. ${ }^{\prime \prime}$

$\$ 321$. Note payable in instalments. - If a note be payable in instalments, the presentment should be made on each consecutive instalment as it falls due, as if it were (as in fact it is legally considered) a separate note in itself. ${ }^{41}$ It would be different, probably, if the condition were annexed to the note that upon failure to meet any instalment, the whole should fall due, in which ease notice should be communieated to the drawer or indorser that the whole sum was due, and the holder looked to him for payment. ${ }^{42}$ If no time for payment be named in the bill or note it is payable on demand: ${ }^{43}$ and payable "on demand at sight," is equivalent to payable "at sight." 44

$\S 322$. At what hour of the day presentment should be made. - When the lill or note is made payable at a bank, it should be presented during banking hours, the parties exocuting their paper payable at a particular place, being bound by its usage: and in such case a presentment after banking lours is sufficient. ${ }^{45}$ But it is settled that when a bill or note is payale at a bank, a demand made at the bank after banking hours, the officers being there, and a refusal, the cashier or telles stating that there were no funds, is sufficient." Put if the instrument be payble generally "at

as Windham Jank $v$. Torton, 22 Conn. 213.

40 Rolsiman r. Blen. 20 Me. 109; Pendleton v, knickerlocker Life Ins.

Co., 7 Fed. 170.

41 Oridge r. Sherbune, ]1 Ml. \& W. 374.

421 Parsons on Notes and Bills, 374.

43 Collins v. Trottar. S1 Mo, 27s; 'Thompson r. Ketchmm, S Johns. 1s?;

Bowman v. Me('heney. 22 cratt. 609.

4 Bowman v. Mer'lemene. 22 Gratt. 609.

45 Jarker v. Gordon, 7 jatst, 385: Elford v. Teed, 1 Manle \& $S$. 2.

46 Reed v. Wilon. 41 X. J. L. 29); Salt Sirrings Nat. Bank v. Tiurton, is X. Y. 432 ; First Nit. liank v. Owen, 29 Jowa, 185. 
bank," no particular bank being named, the hom will be deternined by the usual banking hours at the several hank of the place where it is payable ${ }^{40}$ It is for the jury to sal what are business hours, and in fixing them otherwise than in respect to tho banks, they are to have reference to the general hours of business at the place, rather than to the custon of any particular trade. ${ }^{\text {s }}$ The courts of Englank take judicial vognizance of the banking hours of lomblon. but not of other cities or towns in the Empire, while the American courts take judicial notice of the banking homrs of any large eity within the jurisdiction of the court trying the cause; $i$. $e$, the courts of Massachusetts would not take eognizance of the banking hours of the city of New York, but would of Boston. ${ }^{50}$

If the instrument, by its terms, is not payalile at a bank ol other named place, presentment may le made at any" reasonable hour of the day, within what are termed " busness hours," which really means throughout the whole day" to the hours of rest in the evening. ${ }^{51}$

323. Business hours in reference to business places and places of residence. - When presentment is at the place of business it must be during the homrs when such places alre enstomarily open, ${ }^{52}$ or at least while some one is there competent to give an answer. It is only when presentment iat the residence that the time is extended to the hours of rest.: But presentment at any hour camot be considered mreasonable if any person competent to answer be found there who gives an answer refusing to pay, and an arer-

4ï Luited States Bank r. Camneal. 2 Pet. 543; Chureh r. Clark, 2-1 Pick. 310 .

4s Thompson on Bills, 302.

4) Parker v. Gordon, T East, 3s5; . Jameon r. Swinton, 2 Taunt, 2.25: Hare v. Henty, 10 C. J). (X. S.) 6is.

(w) Morse on Banking, 3il.

51 Salt Springs Xat. Bank v. Burtom, 5s X. Y, 432; Skelton v. Dum-tom, 92 III. 49 .

5e Lunt v. Adams. 17 Me. 230.

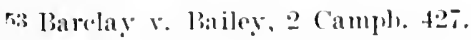

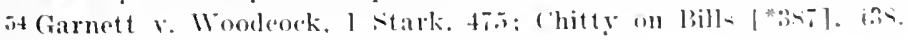


ment of presentment and denand at the maker"s oftice has been helel to import that it was during the usual hour's of business. 55

s324. When instrument payable on demand.- 111 bills of cxchange payable on demand are elosely assimilated to checks, and eontemplate the immediate payment of the amomnt called for. They are payable inmeciately on presentment, withont erace, and it the drawee and the payee or indorsee resile in the same place, it is laid down by a nmmber of the anthorities that they must be presented within bueiness hours of the day on which they are drawn in order to hold the lrawer in the event of the failure of the drawee to honor them. ${ }^{\text {s; }}$ And that if the drawee resides in a different place they numst be forwarded by the regular post of the day after they are received. ${ }^{57}$ But these rules are not inflexible. What is reasonable time must depend upon circumstances and in many cases upon the time, the mode, and the place of receiving the bills, and upon the relations of the parties between whom the question arises. os Where the draft required indorsement hy a school board, which had to be convened, delay of a week to forward it was held justifiable. ${ }^{59}$

Promissory notes parable on demand wonld seem to stand on a sonewhat different footing. In England a note on demand is regarded as a contiming secmity which it is not necessary to present for payment on the next day when the parties reside in the same place; or to send by the post of the next day when they reside in different places; ${ }^{60}$ but in the T'nited States, as a general rule, a different view is

5. Wallace v. Crilleo, 46 Wis. 577; Daniel on Negotiable Tnstruments, $\$$ (i03.

56 Kampmann v. Williams. 70 Tex. 57 : Medonigal v. Brown, 45 Ohio Sit. 504 .

57 Chitty on Jills (13th Am. ed.), 432; Parker v. Reddick, 65 Miss. 246. 58 Morgan v. Inited States, 113 U. S. 501 ; Marbourg v. Brinkman. 23 Mo. App. 513.

59 Muncy Borough School Dist. v. Commonwealth, 84 Pa. St. 464.

6o Morgan v. United States, 113 U. S. 501; Brooks v. Mitchell, 9 M. \& W. 15. 
taken, and payment must be speedily demanded, in order. to preserve recourse against the indorser, and to preserve tho noto from defenes which may be made against wiedue paper. ${ }^{61}$ It is better in all cases where the question is mot settled, to decline taking a note on demand by indorecuncust; or if taken, to present it with the utmost dispatch. Liut if the note is payable on demand with interest, it is regarded, both in England and the United. States, as a continuing interest-bearing security. In such case "it would be contrary" to the general course of business to demand payment short of some proper point for computing interest, such als a quarter, a half year, or a year;" but the authorities are in painful contrariety. ${ }^{2}$

$\S 325$. True principle involved; summary.- Where a pronlissory note payable on demand was indorsed at the time of making, and whether it bore interest or not, it wonkd bucome, by the very act of indorsenent, a draft by the indorser upon the nnaker; and the indorsee holding it should regard it, as it is in fact, a demand through him for the anomt due the indorser. And it should, therefore, be presented immediately, subjeet only to such qualifieations as apply to a bill payable at sights. ${ }^{63}$

Brles, in his work on bills, gives the following sound and correct summary on the subject of demand paper" ".1 common promissory note payable on demand differs from a bill payable on demand, or a eheek, in this respeet: the bill and eheck are evidently intended to be presented and paid immediately, and the drawer may have good reasons for desiring to withdraw his funds from the enntrol of the drawee without delay; but a common promissory note payable on demand is very often originally intended as a enotimuing security, and afterward indorsed as sneh. Tndeed, it is not uneonmon for the paree, and afterward the in-

61 Parsons on Notes and Bills, 376, 377; Keyes r. Fenstermaker. 24 Cal. 331.

62 Daniel on Negotiable Instruments, $\$ \$ 608-610$, and eases eited.

6.3 Daniel on Negotiable Instruments, $\$ 610$; Bassenhorst v. Willy, 45 Ohio St. 339. 
dorsee, to receive from the maker interest periodically for many years on such a note. And sometimes the note is expressly made payable with interest, which clearly indicates the intention of the parties to be, that though the holder may demand payment immediately, yet he is not bound to do so. It is, therefore, conceived that a common promissory note payable on demand, especially if made payable with interest, is not necessarily to be presented the next day after it has been received in order to charge the indorser; and when the indorser defends himself on the ground of delay in presenting the note, it will be a question for the jury whether, under all the circumstances, the delay of presentment was or was not unreasonable." 64

$\$ 326$. Days of grace; origin and nature of.-They were originally days allowed by way of favor to the drawee of a foreign bill to enable him to provide funds for its payment without inconvenience; and were called "days of grace," or" "respite days" because they were gratuitous, and dependent on the holder's pleasure, and not to be claimed as a right by the person on whom it was incumbent to pay the bill. ${ }^{\text {co }}$ By custom, however, they became universally recognized; and although still termed "days of grace," they are now considered wherever the law merchant prevails as entering into the constitution of every bill of exchange and negotiable note, both in England and the United States, and form so completely a part of it that the instrument is not due in fact or in law until the last day of grace. ${ }^{6 s}$ Therefore a demand of payment on the day before or after the third day of grace would not anthorize a protest, or charge drawer or indorser. ${ }^{67}$ And interest is chargeable on the period of grace allowed without impeachment as usurious. ${ }^{68}$

f4 Byles on Bills (Sharswood's ed.), 338.

for Chitty on Bills [*374], 422.

E6 Pank of Washington v. Triplett, 1 Pet. 25; Ogden v. Saunders, 12 Wheat. 213; Bell v. First Nat. Jank, 115 U. S. 373.

c7 liank of Washington v. Triplett, 1 Pet. 25; Donegan v. Wood, 49 Ala. 242.

6s Bank of Utica v. Wager, 2 Cow. 712; Ogden v. Saunders, 12 Wheat. 213. 
This indulgence was often important to the lrawee, who might not be instantly in funds, nor advised that the bill would at that time be presented for payment; and als, even when it was accepted, because of the scarcity of the precious metals in which payment was to be made. And they fixed a limit to the time which the holder might indulge the payor without being guilty of laches in not protesting it. ${ }^{69}$

$\$ 327$. What bills and notes entitled to grace; whether sight bills entitled to. -1 ll bills of exchange and negotiable notes are entitled to grace, ${ }^{i 0}$ except those payable on demand ${ }^{71}$ or without specitication of time, in which case on demand without grace is understood, ${ }^{i 2}$ or those expressly payable without grace. ${ }^{73}$ The authorities are uniform in support of this statement of the law, except in respect to its inclusion of sight bills and notes, which by some is denied and l,y others doubted. In England there has not been, that we are aware of, a direct decision of the question; but it has been taken for granted in some cases, and distinctly intimated in others, that a sight bill or note is entitled to three days' grace $;^{i t}$ and the weight of anthority in the United States is to the same effect. ${ }^{75}$ The expression "after sight" in a bill of exchange has a different signification from the like expression in a promissory note. In a bill of exchange it means after acceptance, or protest for nonacceptance, and not after a mere private exhibition to the drawee, for the sight must appear in a legal way. ${ }^{i e}$ But a note is incapable of acceptance, and the words "at or after sight" used in it

69 Story on Bills, $\$ 333$.

70 Brown $v$. Chancellor, 61 Tex. 440; 1 Parsons on Notes and Bills, 404.

71 Edwards on Bills, 523; Oridge v. Sherborne, I1 M. \& W. 374; Woodruff v. Merchants' Bank, 25 Wend. 673.

72 Story on Bills, \$ 343; First Nat. Bank v. Price, 52 Iowa, 570; ] Parsons on Notes and Bills, 381.

73 Daniel on Negotiable Instruments, \& 633.

74 Webb v. Fairmauer, 3 M. \& W. 473 : Coleman v. Saser, 1 Bam. 303;

Dehers v. Harriot, 1 Show. 163; Jansen v. Thomas, 3 Doug. 42l.

is Daniel on Negotiable Instruments, $\$ 617$.

76 Campbell v. French, 6 T. R. 212; Mitehell v. De Grand, 1 Mason, 176. 
would merely import that payment was not to be demanded until it had been again exhibited to the maker. ${ }^{i 7}$ If the bill or note be payable in instahments, it is entitled to grace on each instalment, for it is really so many instruments in one form. ${ }^{\text {is }}$ If it is payable "on demand at sight," it is the same as if payable "at sight." 79

\section{$\$ 328$. Number of days allowed by law merchant and by} custom.- The law merchant, as it prevails in England and the United States, limits the allowance of grace to three days, so and although it is settled that by special established usage in a particular locality it may be denied altogether, or a different number of days may be granted, ${ }^{\mathrm{s} 1}$ the courts take judicial notice of the period fixed by the law merchant, and will recognize that only unless the usage varying it is alleged and proved. ${ }^{82}$ In the District of Columbia the usage at one time prevailed to allow four days, and it was sustained as binding upon parties to negotiable instruments there payable, by the United States Supreme Court. ${ }^{83}$ It extended, however, only to notes discounted in bank. ${ }^{84}$ In Louisiana, at one time, ten days were allowed; but this was changed by statute to conform to the law merchant in the United States, ${ }^{85}$ and, of course, no custom can affect a positive enactment. ${ }^{86}$ In the absence of any statute, the usage of banks in particular localities in allowing grace, and the number of days, may alter the law merchant in that partienlar. ${ }^{87}$ The following principles on this subject may be re-

7 Holmes v. Kerrison, 2 Taunt. 323; Sutton v. Toomer, 7 B. \& C. 416.

7s Oridge v. Sherborne, 11 M. \& W. 374.

79 Dixon v. Nuttall, 1 Cromp., M. \& R. 307.

so Hill v. Lewis, Skin. 410; Wood v. Corl, 4 Mete. (Mass.) 203.

81 lienner $v$. Bank of Columbia, 9 Wheat. 581 ; Mills v. Bank of United States, 11 Wheat. 431.

82 Renner v. Jank of Columbia, 9 Wheat. 581; Reed v. Wilson, 41 N. J. L. 29.

83 Mills v. Bank of Inited States, 11 Wheat. 431.

84 Cookendorfer v. l'reston, 4 How. 317.

85 Dubreys v. Farmer, 22 La. Ann. 478.

86 Perkins v. Franklin Bank, 21 Pick. 483.

67 Renner v. Bank of Columbia, 9 Wheat. 581; Adams v. Otterback,

I5 How. 539. 
garded as established: First. That the usage must bo notorious, in order that an inference nuly be drawn that it is known to the public, and especially to those dealing with the bank, and therefore create the further inference of expressed or implicel assent. S'econd. That when a usinge has been sanctioned by judicial decision it beeonnes settled law. No further proot is necessary to establish it, and no evidence is aduissible to controvert the law laid down hy the court. Third. That it should apply to a place rather than to a particular bank. Fourlh. That it need not be known to the party dealing with the bank at a particular place. ${ }^{88}$

\section{$\$ 329$. The term "month" and computation of months.-} By the common law of England a montl is deemed a lmar month, and is computed accordingly in construing common law contracts and statutes; ${ }^{89}$ but by the law merchant, both in England and the Lnited States, a month is construed to mean a calendar month in all cases of negotiable instruments, and of mercintile contracts. ${ }^{90}$ Therefore a bill dated the first day of Jammary, and payable one month after date, would be payable (arace included) on the fourth day of February; and one rated February first, payable one month after date, would likewise be pavable (grace included) on the fourth day of March, although February is two, or three days (in leap-year), shorter than Tannary. When one month is longer than the next succecling month, the conputation of a month does not carry it into a thirel montl. Thus a month dating from the thirty-first of January would expire on the twenty-cighth or twenty-uinth of February, as the case might be; and in leap-year, a month connting from the thirty-first, thirticth, or twenty-ninth of January, would end on the twenty-ninth of Fehruary, and the last day of grace would be Jareh the third. But if a bill or note were dated January twenty-eighth, a month therefrom would ter-

88 Daniel on Negotiable Instruments, $\$ 623$, and cases cited.

89 Chitty on Bills [ $* 373], 420$.

90 Thomas v. Shoemaker, 6 Watts \& S. 179; McMfurchey $v$ Robinson, 10 Ohio, 496. 
minate on February twenty-eighth, and presentment shoura be on Malle the second. ${ }^{91}$

$\$ 330$. As to the computation of days. - In computing the number of days which a bill or note, payable at or in so many days from date, has to run, the day of clate is always exclucted: and it payable at so many days after sight, after demand, or after a particular erent, the day of sight, demand, or of the happening of the event is likewise excluded. ${ }^{92}$ So, if it he presented on one day, and aceepted on another, the day of acceptance is excluded.": The expressions, "in thirty dars," — " in thirty days from date," — " at thirty days," - and "thirty days after date," are svnonymons." As sail in Maine, by IIoward, J.: "If there be several notes of the sume date, some payalule in six months, some in six months from date, and some in six months after date, ther all have the same pay day. In all of them the day of the date is cxcluted." 95. But if a bill or note withont grace, or any noncommercial instrument for payment of money, falls due on a Sunday or a legal holiday, it is not payable until the next regular business day, for the payor is not compellable by law to pay on the exact cay named, and the next day is the first day that the creditor ean demand payment. "3ut the debtor cammot require the creditor to extend his indulgence beyond three calendar days; and therefore when erace on a bill or note entitled to it expires on a Sunday or other nonbusiness day, the bill or note would fall due on the day preceding. ${ }^{97}$

§331. Calendar by which computed.- The Gregorian calendar, or new style of computing time, is adopted in the

91 Wagner $\checkmark$. Kenner, 2 Rob. (La.) 120; Chitty on Bills [*373], 421;

1 Parsons on Notes and 13ills, 409.

92 Coleman v. Sayer, 1 Barn. 303; Hill v. Norvell, 3 MeLean, 583; Loring v. Halling, 15 Johns. 120; Mitchell v. De Grand, I Mason, 176; Barlow v. Planters' Bank, 9 llow. (Mliss.) 129.

93 Nitchell $r$. De Grand, I Mason, 176.

94 Ammidown v. Woodman, 31 Me. 580; Henry v. Jones, 8 Mass. 453. 55 Ammidown $v$. Woodman, 31 Me. 580.

96 Salter v. Burt, 20 Wend. 20.5; Kuntz v. Tempel, 48 Mo. 75.

$9 \pi$ lun-iad v. Levering, 6 Wherat. 192 ; Reed v. Wilson, 41 N. J. I. 29 ; Story an liblls. $38 s$. 
Lnited States, and everywhere clse, except in Russia, and those countries where the Cireck Church is the established religion. 'They use the Julian calendar, or old style, as it is called. There is the difference of twelve days between the two styles; and the addition of that number to the old makes the new style. The 1st of January in St. Petersbury, Russia, is, therefore, the 13th of Jamuary in England and the Lnited States. The style of the place of paynent, how"ver, always prevails; and if a bill were drawn in london on the 1st of September, payable in St. Petersburge on the Lst of Janury, it would fall due on the day corresponding to the 13th of January in England; and vice versa. This is becanse the parties are to be regarded as contracting in reference to the meaning of terms at the place of their fulfillment. ${ }^{98}$

\$332. How grace dispensed with.- By any language in the bill or note of that import, grace may be disallowed. And such words as "without grace," or " no grace," obrionsly disallow it: and the word "fixed" has been held to have the same import.99 But the expression "without defaleation" does not; ${ }^{1}$ nor would a mere marginal memorandum of the day of the month and year on which the time after date at which the instrument was expressed to be payable tell due. ${ }^{2}$ But where a bill at sixty lays sight was accepted on September 14 th, payale Norember 16 th, it was held that November 16 th was indieated by the aceptor to he the absolute day of payment, he having intended to allow for grace in his calculation, and that presentment on that dar was necessary. ${ }^{3}$

as Story on Bills, \$ 331; 1 Parsons on Notes and Bills, 388; Chitty on Bills ["369], 417; Daniel on Negotiable Instruments, § 632.

؛ Perkins v. Franklin Bank, 21 Piek. 483; Durnford v. Patterson. 7 Irait. 460.

1 Bell v. First Nat. Bank, 115 U. S. 382: MeDonald v. Lee, 12 La. 435.

2 Perkins r. Franklin Bank, 2l Pick. 483.

3 Bell v. First Nat. Bank, 115 U. S. 382; Kenner v. Creditors, 19 Mart. 540. 


\section{SECTION III.}

PLACE OF PRESENTALENT.

$\S 333$. When the instrument is payable generally.- The presentment of the bill or note for payment should be made at the eity, town, or other place in which the acceptor or maker has his home or domicile, or his place of business, provided there be no place designated in the instrument or agreed upon by the parties as the place where it shall be paid at maturity. ${ }^{4}$ If such place is designated or agreed upon, it will be sufficient to make presentment there. ${ }^{5}$ And averment of presentment there is always sufficient, without any addition." If the bill be addressed to the drawce in a particular city, as, for instance, to "A. B., New York," the eity named would be regarded as the place of presentment for payment, if the acceptance be without explanation or condition. ${ }^{7}$ If the maker or acceptor has both a drellinghouse and a business louse in the same city, town, or other place, the presentment may be made at either. ${ }^{8}$ And if the maker or acceptor have a dwelling-house or domicile in one city, and a place of business in another, it will, as it seems, be sufficient to present the instrument at either. ${ }^{9}$ If a bill be payable in a particular town, a presentment at all of the banker's houses there will suffice. ${ }^{10}$ In such case, where the maker used due diligence to find at what bank the note was left for presentment without success, he was relicved from a penalty for failure to pay it the instant of maturity. ${ }^{11}$

$\S 334$. When payor has well-known place of business.When, however, the maker or acceptor has a well-known

4 Cox v. National Bank, 100 U. S. 713 ; Mitchell v. Baring, 10 B. \& C. 11.

5 Brent's Exr. v. Mank of Metropolis, 1 Pet. 92; Eason v. Isbell, 47 Ala. 456 .

B Cox r. National liank, 100 U. S. 716 ; Hawkey v. Borwick, 4 Bing. ]36.

7 Cox v. National Pank, 100 U. S. 716.

8 Story on Jills, $\$ 236$.

9 Story on Bills, $\$ \$ 236,351$; 1 Parsons on Notes and Bills, 422, note. 10 Ilardy v. Woodroofe, 2 Stark. 319; Byles on Bills [*207], 323.

11 Anzel v. Olson, $39 \mathrm{Kan} .767$. 
house or place of business where he is aceustomed to trinsact his financial affairs, and where demand may be mitcle, it would be safer and nore appropriate to present it there. Certainly it would seem unreasonable to expect, dhring the business hours of the day, to find any one at a private residence to answer respecting the payment of a negotialse in: strument, when the maker or aceeptor, if he have any place of business, would be presumably there; and during sucit business hour's due diligence would not appear to have been exerted in demanding parment at his house." If, however, business hours latd closed, a presentment at the dwelling would seem sufficient. It is undoubted that a presentment and demand of parment at the place of business of the maker or acceptor is suffieient. ${ }^{13}$ Where it was contended that the demand should have been made at the maker"s house, it was held otherwise. ${ }^{14}$ But if the place of busines: eannot be found, then demand should be made at the maker": house. ${ }^{15}$

$\$ 335$. Usual place of business; rule when it is closed and abandoned.- The place of business must be the "usual place of business" of the party, and not that used for a mere temporary oceupation $;^{16}$ thongh if it be really the place where he transacts his financial concerns, it matters not that it is a mere office, or desk room in an office with others. and a demand there in lis absence made during business hours will be sufficient. ${ }^{17}$ If the party has elosed and abandoned his place of business at the time the bill or note matures, but has a place of residence in the eity or other place where his business was eonducted, which could he ascertained by reasonable inquiry, the presentment for pay-

121 Parsons on Notes and Bills, 423.

13 Lanussa v. Massicot, 3 Mart. 361.

14 Sussex Bank $v$. Baldwin. 2 llarrison, 487.

15 Jarvis v. Garnett, 39 Mo. $2 \overline{1} 1$.

16 Sussex Bank $r$ Baldwin, 2 Ilarrison, 487.

17 Williams $v$. Hoogewerff, 25 Md. 128; Bank of Commonwealth $v$. Mudgett, 44 N. Y. 514. 
ment should bo made at his residence, and a presentment at the former place of business will not suffice. ${ }^{18}$

$\$ 336$. When presentment is to party in person, place generally unimportant.- When the presentment is made to the maker or aceeptor personally, the place is not important, provided there is an express or implied refusal to pay. Presentment at the baln-yard has been held sufficient, the party "making no objection, and intinating no readiness to pay." "19, and eren in the street presentment would seem to be usually goorl, unless objected to as improper, or some reason were given for the refusal. ${ }^{20}$ This view seems to us eorrect. But it would be more business-like not to make deniand at such a place, and there are authorities which hold that the party is not bound to pay any attention to a demand so entirely outsicle of the enstom of merehants. ${ }^{21}$ In a case in Maine lemand on the street of the maker, he having no place of business, and raising no objection, was held sufficient to charge the indorser..$^{22}$

$\S 337$. Due diligence in seeking maker to make presentment. - Whether or not due diligence to find the maker of a note at the place where it is dated, will be suffieient, has been debated. The place of date is prima facie evidence that it is the place of the maker's residence and place of business; and it is sufficient, we should say, to charge an indorser to have the note in that place at the time of maturity, and to make proper inquiry after the place of the maker's resilenee or place of business, provided that the holder does not know that his resirlence is elsewhere. ${ }^{23}$ And if it were proved that the maker resided elsewhere, it would not devolve upon the holder the burden of showing that he had made inquiries as

18 (iranite Bank v. Ayres, 16 Pick. 392.

19 Baldwin r. Farnsworth, 1 Fairfax, 414.

2" I Parsons on Notes and Bills, 421; King v. Crowell, 61 Me. 244;

Townsend v. Dry Goods Co., 85 Mo. 508.

21 King v. llolmes, 11 Pa. St. 456.

22 King v. Crowell, 61 Me. 244.

23 Britton v. Nichols, 104 U. S. 757 ; Bank of Fayetteville v. Lutterloh, 95 ․ C. 499 ; Salishury v. Bartleson, 39 Minn. 366. 
to his residence." While this doetrine is sustained l, hig! authority both in England and the Lnited States, and is doubtless correct, there alre decisions contra."

\section{$\$ 338$. When payable at either of several places or banks.} If a bill of exchange be drawn payalble at either of two places, and is accepted aceordingly, as, for example, if drawn payable at Maidstone or Jondon, the holder has his choice to present it at either place for parment: and the like ruls applies to a note marle payable at either of two places. If the bill or note be not duly paid at the place where it is presented, the holder may protest it and give notice to the drawer and indorsers, who will be boumd by its presentment and dishonor at the plice of his election; although if presented at the other place it would have been duly paid; for in such eases all the parties agree to pay the bill or note upon due presentment at either place. ${ }^{26}$ And sometimes the instrument is made parable at any or eitler of the banks of a particular place. In all such places the stipulation as to the place of payment is understood to be for the aceommolation of the payce or holder, who is given the right to elect the bank at which the note should be presented in order to charge the indorsers; and if, upon presentment at any or either bank in the place named, parment is refused, the indorsers, as well as the maker, are bound. The maker's promise is to pay the mote at any of the banks in the place, and the duty is inposed upon him to look at all the banks for it, or provide funds to pay it at all of them when it is due. ${ }^{27}$

\section{SECTION IV.}

MODE OF PRESENTMENT.

$\$ 339$. Must be actually exhibited.- Presentment of the bill or note, and demand of parment, should be made by an actual exhibition of the instrument itself; or at least the de-

24 Smith v. Philbrick, 10 Gray, 252.

s Daniel on Negrotiable Instruments, $\$ 640$, and catses cited.

2t Daniel on Negotiable Instruments, $\$$ its: Beeching $v$. Cower, 1 Holt. 313; Story on Bills, \$ 354 .

27 Malden Bank $v$. Baldwin, 13 Gray, 1.jt. 
mand of payment should be accompanied by some clear indication that the instrument is at hand, ready to be delivered, and such must really be the ease. ${ }^{25}$ This is requisite in order that the drawee or aceeptor may be able to judge (1) of the genuineness of the instrument; (2) of the right of the bolder to receive payment; and (:3) that he may immediately reclaim possession of it upon paying the amount. If, on demand of parment, the exhibition of the paper is not asked for, and the party to whom demand is made declines to pay on other srounds, a more formal presentment by actual exhibition of the paper will be considered as waived. ${ }^{29}$ Where the note was in bank, a few rods from the maker's house, and the maker was informed by note from the cashier that it was there and requested payment, it was held sufficient $;^{30}$ and it was likewise so held, where the statement in the protest was that the notary went, with the draft, to the bank and demanded payment. ${ }^{31}$ So, if the maker ealls on the holder on the day of payment, at his place of business, declares his inability to pay it, and requests him to give notice to the indorser, it is sufficient to charge the indorser, as an 'xhibition of the paper would have been useless. ${ }^{32}$ But it is better in all cases to make an actual exhibition of the paper, in order to avoid all question. It seems that delivery of written demand to a servant at the house of the promisor is insufficient. $^{33}$ The demand of payment should not rary from the tenor of the paper; and if it be payable simply in money, without speeifying the kind, a demand for gold coin would be insufficient to charge an indorser. ${ }^{3 t}$

$\$ 340$. Presentment by mail. - Bills of exchange are most frequently drawn on parties at distant places, and it is un-

28 Musson v. Lake, 4 How. 262; Nailor v. Bowic, 3 Md. 251 ;

Crandall v. Schroeppel, 1 Hun, 557: Etheridge v. Ladd, 44 Barb. 69.

29 Lockwood v. Crawford, 18 Conn. 361; King v. Crowell, 61 Me. 244.

30 Tredick v. Wendell, 1 N. H. 80.

31 Jank of Vargennes v. Cameron, 7 Barb. 143.

32 Gilbert v. Demnis, 3 Metc. (Mass.) 495.

33 Duke of Norfolk v. Howard, 2 show. 235.

34 Langenberger v. Kroeger, 48 Cal. 147. 
roubtedly legal, ("nstomary, and proper to forwalel them by mail to correspondents or other agents at the place where the drawee is addressed, to be by them presented, in duo eonrer. And in such cases if by accident or defandt in the postal servies they are not received in due time to be presented at maturity, the dolay oreasioned is exeused, and the drawe. and indorsers are holil liable, provided that, when the delay is over, due diligence is exereised in making the presentment afterward." It has been said that presentment through the post-office may be sufficient. ${ }^{36}$ But such method of presentment of bills secms to be unknown to the law merchant, and it might prove a hazardous and fatal experiment to those who relied upon it. It has been held that ehecks may be so presented, ${ }^{37}$ lut the reasons for the permissibility of such mode of plesentuent do not seem to apply to bills drawn on others than bankers, and Prof. Parsons has well observed: "It is not easy to see how a sufficient demand can be made with safety through the post-office." 38

Presentment throngl the mail by a bank acting as collecting agent, has been held not sufticient to exonerate it from liability in ease of loss resulting from the failure of the drawee, who had renitted exchange on New York in payment, instead of eash. ${ }^{30}$

$\$$ 341. Leaving instrument in debtor's hands. - A bill or note, when presented for parment, camnot be left in the debtor's hands as when presented for acceptance; and if it is so left, presentment camnot he considered as made nutil payment is demanded. And if, in the meantime, the debtor has stopped payment, the holder would suffer to the extent of the difference between the value of the instrument at

is Daniel on Negotiable Iustruments, $\$ \$ 1068-1070$; Pier r. HeinrickShoffen, 67 Mo. 163.

36 Benjamin's Chahmers' Digest, 161.

87 Daniel on Negotiable Instruments, \& 1599.

38 l Parsons on Notes and Bills, 371; MeGruder v. Bank of Washinirton, 9 Wheat. 598; Story on Bills, $\$ 325$.

s9 Harvey v. Girard Nat. Bank, 119 Pa. St. 212; Drovers' Tat. lauk v. Provision Co., 117 Ill. 108. 
the time it was handed the debtor and the time payment was actually demanderl. ${ }^{40}$

$\S 342$. As to mode of presentment of negotiable paper payable at a bank. When a bill or note is made payable at a bank, it is eonsidered a sufficient presentment of it if it is actually in the bank at maturity, ready to be delivered up to any party who may be entitled to it on payment of the amount due; and if, at the close of business hours, the bill $0{ }^{\circ}$ note remains umpaid, it is considered as dishonored, and notice should be immediately given to the proper parties. ${ }^{41}$ Such also is the case when the instrument is payable at a partieular place. ${ }^{42}$ Sometimes a formal presentment of the bill or note, in such cases, at the bank, or upon the maker, is made; and the cases are miform in holding that such a presentment at the bank is suffieient, even when the place is mentioned in the memorandum; ${ }^{43}$ but it is settled that nothing more than the presenee of the paper there is neeessary. ${ }^{44}$

But it has been held by the United States Supreme Court, that though commereial paper be physieally in the bank at which it is parahle, yet if the bank is iguorant of this by reason of the fact that the letter in which it was sent slipped through a crack in the cashier's desk and disappeared before it had been seen by him, then there wonld be no presentment, though the acceptor had no funds there, and did not mean to pay the lill. And such a disappearanee earried with it a presumption of negligenee in the collecting bank, and threw upon it the burden of proof to rebut it; and that

40 Hayward v. Bank of England, 1 Stra. 5.50; Thompson on Tills (Wilson's ed.), 304.

41 Chicopee Bank v. Philadelphia Bank, 8 Wall. 64l; People's Bank v. Brooks, 31 Md. 7; Folger v. Chase, 18 Pick. 63.

42 Hunt v. Mayber, 7 X. Y. 266.

43 liank of Utica v. Smith, 18 Johns. 230; Woodbridge v. Brighan,

13 Mass. 550 ; Saunderson v. Judge, 2 H. Bl. 509.

44 Fullerton v. Bank of Cnited States, 1 Pet. 604; Merchants Bank r. Elderkin, 25 N. Y. 17 s. 
in the absence of such proof the bank wonld be responsible to the holder for the amount of the bill or note. ${ }^{45}$

\$343. Customary demand by notice through the mails.- In some of the States it has beeome colstomary for bauks of al particular place, which are the holders of negotiable biandr. to issue a notice to the promisor a few days before maturity. informing him that the paper is in bank, setting forth the date when it will hecome parable, and requesting him t. come there and pary it. Such notice constitutes a conventional denand, and a neglect to comply with it is such at refusal as amonnts to dishonor of the paper. The custon prevails where the paper is payale at the bank giving the notice, ${ }^{46}$ and has been sustained by judicial decision, as well where it is not made so parable, lut is placed there for collection. ${ }^{47}$ In Massachusetts this enstom has become so general and universal that every one who ineurs the liahility of maker and indorser is presumed to have contracted in reference to it, and knowlerge on his part may he presumed. $^{48}$ In respect to the maker of a note or the aceeptor. of a bill in terms payable at a partienlar plice, this eustom to inform him that his paper is there, and that he is requested to meet it, amounts to nothing more than a reminder from ereditor to debtor, which in law is a superfluous act so far as he is conecrned. But in respect to the drawer or indorser, the holder's contraet, when the instrument is parable generally is that he will present the instrument to the acceptor or maker; and the theory upon which the duty in this regard is considered relaxed by eustom is that the party secondarily liable has, in effeet, waived the formal presentment otherwise required ly law, and consented to the substitution of notice throngh the mails. ${ }^{\mathbf{9}}$

$\$ 344$. Knowledge of conventional method of demand.Knowledge by the drawer or inclorser of the eustom has:

45 Chicopee Bank v. Philadelphia Bank, \& Wall. 641.

46 Camden $r$. Doremus, 3 How. 51.; Lincoln \& liennebec Bank v. Page, 9 Mass. 155.

47 Jones $v$. Fales, 4 Mass. 245: Whitewell $v$ Johnson, 17 Mass. 44 ?.

48 Grand Bank v. Planchard, 23 Pick. 505.

48 Daniel on Negotiable Instruments, \& 660. 
been regarded as essential to its establishment as against him in some cases. ${ }^{50}$ But the United States Supreme Court say that parties are bound by an established usage of a bank at which the paper is payable "whether they lave a personal knowledge of it or not;" 51 and as the custom must be general, in order to obtain recognition as such, we cannot perceive that knowledge of it enters into the question any more than knowledge of any other rule of law. A eustom is not a special personal contract, but a general and controlling rule. "The parties are presumed by implication to he governed ly the usage of the bank at which they have chosen to make the security itself negotiable." 52

5o Leavitt $r$. Simes, 3 N. H. 14.

51 Mills v. Bank of United States, 11 Wheat. 431.

52 Jills r. Bank of United States, 11 Wheat. 431. 


\section{CILAPTER XII. \\ PROTEST AND NOTICE OF DISHONOR.}

\section{SEC'IION I.}

Plic't'les'l.

$\S 345$. Meaning of term.- The term includes, in a popular sense, all the steps taken to tix the liahility of a drawer or indorser, upon the dishonor of conmercial paper to which he is a party. More aleculately spealing, it is the solemn declaration on the part of the holder against any loss to be sustained by him by reason of the nonaceptance, or even nompayment, as the cate may be, of the bill in question; anc a calling of the notaly to witness that due steps have been taken to prevent it. The word "protest" signities to testify before: and the testimony hefore the notary that proper steps were taken to fix the drawer's liability is the substance, and the eertiticate of the notary the formal evidence, to which the term protest is legally applieable.

\$346. Protest for nonacceptance.-- Aceording to the English law, the protest must be made in the ease of dishonor by nonaceptance as well as dishonor by nomparment.2 And the same rule prevalils in the Inited States, ${ }^{3}$ although it was deeided by the Supreme Comt of the Inited States, in an action on a protest for nomparment of a foreign lill, that a protest for, or notice of, nonaceptance, need not be shown, inasmuch as they were not required by the enstom of merehants in this comntry. But the English rule has been deemed the most enusistent with commereial policy by the highest authorities, and Story and Kent adopt it as the true one. ${ }^{5}$

\footnotetext{
1 Diniel on Negrotiahle Instruments, $\$ 929$.

2 Gale v. Walsh, j T. R. ㄹ39; Benjamin's Chalmers Digest. 176.

:Mason v. Franklin, 3 Jolus. 202; Wation r. Loring. 3 Mass. 357; Phillips r. McCurly, 1 llarr. \& J. 1s; ; Story on 13ills, $\$ 2-i 3$.

4 Clarke v. Russell, 3 Dall. 29.); Brown v. Barry, 3 Dall. 36.

5 Kent Comm. 9,; Story on Bills, \& 273.
} 
$\$ 347$. What instruments must or may be protested. - When a foreign bill of exchange is presented for aceptance or payment, and acceptance or payment is refused, the holder must take what is ealled a protest, in order to charge the drawer or any indorser. According to the law of most foreign nations, a protest is essential in the case of the dishonor of any bill; ; but by the enstom of merehants in England, and wherever the law merchant prevails in the United States, the protest is only necessary in the case of foreign lills; though by statute in most of the States inland bills and promissory notes may be protested in like manner. So indispensable is the protest of a foreign bill in case of its dishonor, that no other eviclence will supply the place of it, and no part of the facts requisite to the protest can be proved by extrancons testimony, and it has been said, that it is a part of the constitution of a foreign bill. ${ }^{9}$ But, while the practice is usually followed to protest inland bills and notes, under the permissive statutes, it is not a practice which makes it incumbent to protest them; and the holder mas waive the privilege if he choose to do so, and produce other eridence of dishonor. ${ }^{10}$ Such was the convenience of evidenee in this form, obviating the necessity of the attendance of witnesses, and preserving their testimony where otherwise it might he lost by death or remoral, that it became common to protest inland bills, and promisory notes as well; and the holder was often disappointed in finding that such protest was not evidence of dishonor. ${ }^{11}$ This led to a very general enactment of statutes anthorizing protests in such cases; and giving them the like effect as in cases of forergn bills.

Following the reasons underlying the necessity and wisdom of the rule requiring protest of forcign bills of ex-

6'Thompson on lills (Wilson's ed.), 307.

7 Orr v. Maginnis, 7 East, 359; Gale v. Walsh, 5 T. R. 239.

8 Burke v. Mckay, 2 Ilow. 66; Young v. Bryan, 6 Wheat. 146; Ocean Nat. Jank v. Williams, 102 Nass. 141.

9 Union lank v. llyde, 6 Wheat. 572; Borough v. Perkins, 1 Salk. 12l. 10 Bailey v. Iozier, 6 lfow. 2:3; Wanger v. Tupper, s How. 234. 112 Rob. Pr. 121. 
change, some authorities say that foreign promisenry notes, - i. e., notes executed in one State ore ermutry and payable in anolher- mmst he protested;' but there are cases in which the opposite view has been taken. ${ }^{13}$

$\$ 348$. By whom the protest should be made, and how anthenticated. - Is to the person ly whom the protest should be made, it is necessialy, als a general rule, that it shomld be made by a notary public in person, and by the same notary who presented and noted the hill.'t The notary is a public officer, commissioned by the State, and possessing an official seal, and full faith and eredit are given to his oflecial acts, in foreign eountries as, well as his own. ${ }^{15}$ But when no notary can be conveniently found, the protest may he made by any respectable private individual residing in the place where the bill is dishonored. ${ }^{16}$ In England, by statite, ${ }^{17}$ the protest of inland bills by a private person must be authentieated ly the signature of the individual making the protest in the presence of two or more credible witnesses, but it does not appear to be meecsary that there should be witnesees to the protest of a foreign hill by a private person. ${ }^{\text {s }}$ If, lowerer, the protest is made by a notary, the official seal of the notary attached to the certificate of protest is everewhere receivel as a sutticient prima facie proof of its anthenticity. The eourts take judicial notice of the seal, and it proves itsclf hy its appearance mon the certificate. But it may be enntroverted as false, fictitions, or improperly annexed. ${ }^{19}$ But if the protest is made by a

12 Williams v. Putnam, 14 X. H1. 5t0: Ticonie Rank r. Stackphle, il Me. 302: lidwards on Bills, 5st.

1:3 Kirtland $v$. Wanzer, 2 Duer, $2-s$.

14 Ocean Nat. Iank v. Williams, 102 Mar-. 1tl; Sacriber r. Brown. 3 Xrelean, 4\$1: Conmercial liank r. Varnmm, 49 X. Y. 206: Commer-

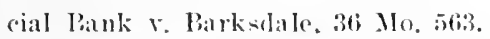

15 Daniel on Negrotialble Instruments. \$s 579.587.

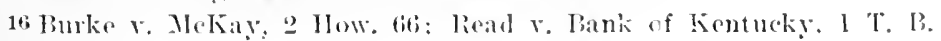
Mon, !1.

179 \& 10 Will. HI, ahap. 17.

18 lirook * Notary, 103: Chity on Bills [*3337. 37t, note $u$.

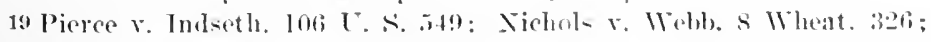
Bradley v. Northern Bank, 60 Ala. 258. 
notary, and the certificate is not authenticated by the notary seal, or if it is made by a private person, it does not prove itself, and there nunt be extraneous evidence to show that it was duly male by the person officiating. ${ }^{20}$ In some cases it has been held that a notary's certificate of protest is sufficient without a seal, the law giving full effect to his protestations and attestations. ${ }^{21}$

$\$ 349$. Place of protest. - It is usually made at the place where the dishonor oceurs.: ceptanec, the place of protest should be the place where the bill is presented for acceptance, and a like rule obtains if the protest be for nomparnent; $;^{23}$ but when the bill is drawn upon the drawee in one place, and by its terms made pavable in another, there is eminent authority for the statement that the protest for nonaceptance may be made at either place. ${ }^{24}$

$\$ 350$. The presentment and demand of payment; notary must have personal knowledge of.- The first step taken is the presentment of the instrmment to the drawee, or acceptor, or maker, by the notary, and a demand of parment. By- the law merchant, it is absolutely necessary that the notary himself should make this formal presentment and demand. Aml, although the holder may have already presented the hill and demanted acceptance or parment, and been refused, it is still necessary that the presentment and demand, which are to be made the basis of the notary's certificate, should he made by him in person. For otherwise his testimony contained in the protest would be hearsay and secondary, and woukl lack the very element of certainty which the protest is aspecially designed to assure. Tot even his elerk, nor, muless anthorized ly law, his deputy, ean

20 Carter r. Burley, 9 X. H. 55s; Chanoine v. Fowler, 3 Wend. 173.

21 Pank of Kenturky v. Pursley, 3 T. B. Mon. 240; Huffaler r. National liank, 12 Jis h, 293.

22 Benjamin's ('halmers' bigest, 175; 2 Ames on Bills and Notes. 450; Exwards on Bills, 580.

2: Story on Pills, \$ $28 \%$.

24 ('hitty on Bills 1*334], 374. 
perform these functions for the notary, as it is to his ofticial character that the law imputes the solemnity and sanetion which are accorded his certificate.

\section{$\S 351$. Time within which certificate of protest must be pre-} pared; skeleton protest.- As a general rule, it may be stated that the certificate of protest must be prepared and connpleted on the day of the formal presentuent and dishonor of the instrmnent; but the necessity for this may be obriated by noting the dishonor of the instrument on the day of its maturity and after formal presentment. BY " noting the dishonor" is meant the making by the notary of a minute on the bill, on a ticket attached thereto, or in his book of registry, of the initials of the notary, the month, the lay, the rear, the refusal of acceptance or payment, together with his notarial charges. This is the prelininary step toward the protest, which may be afterward written out in full-extended, as the claboration of these minntes is terued - at any time before it is actually needed in court. "Noting," it was said in an early calse, "is unknown to the law, as distinguished from the protest; it is merely a preliminary step to the protest, and has grown into practice within these few years." 2 But it is now quite well established in England, Scotland, and the Enited States, that the noting is a kind of "initial protest," as Thompson aptly terms it, not self-sufficient as a protest, but sufficient in the meantine, if the certificate of protest is regularly extended afterward. ${ }^{2 \pi}$ It must be made on the very day of dishonor by nomaceptance or nonpayment, otherwise it cannot be made the basis of the extended protest. For the notary will not he permitted to trust to his memory for the requisite particulars. It is to his contenporaneous whitten statement that the law gives credit. ${ }^{29}$

2.) Daniel on Negotiable Instruments, \$\$ 579, 587, 93\$.

26 Leftly $\therefore$. Nills, + T. R. 170.

2i Chaters $v$ Bell, 4 E.p. 4s: Folwards on Bills, 5sl: Thompon on Bills, 311 .

2s Dennistoun v. Stewart. 17 How. 606: Thompson on Bill- 312: Story on Bills. $s \$ 27 s, 2 s 3$. 
$\$ 352$. What certificate must contain.- The protest, or, more strictly speaking, the notarial certificate thereof, should set forth: (1) The time of presentment; (2) the plate of presentment; (3) the fact and manner of presentment; (t) the denand of paynent; (5) the fact of dishonor; (6) the name of the party by whom presentment was made; and $(7)$ the iname of the person to whom presentment was made. ${ }^{29}$

$\$ 353$. Time, place, and manner of presentment and demand. - It is essential that the time of presentment and demand should aftimatively appear upon the face of the certificate, and it has been accordingly held that if the eertifieate state that the bill was "this day protested," and is dated on a day previons to or after the day of maturity, it is invalid upon its face: $:^{31}$ and while the certificate should state that the presentment and demand were made during the usual business hours, it is not absolutely essential, becanse it will be presumed that the presentment was made at the proper time of the day ${ }^{31}$

If the instriment, by its terms, is payable at a specified place, the certifieate is insufficient unless it state that presentment and demand were made at such place; $;^{32}$ but if no place of parment is named the eertifieate need not state at what place it was presented.

The presentment of the bill and the demand of payment should be separately stater. The usual expression of the certificate is, that the notary "did exhibit said bill," and it is certain that there must be some expression importing ex vi termini that the hill was presented to the drawee or' acceptor. ${ }^{33}$ The mere statement that payment was "demanded" has leen helel by the Enited States Supreme Court to be insufficient in itcelf, because not necessarily implying

2) Daniel on Negotiable Instruments, \$ 950 .

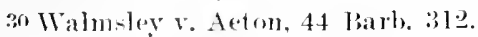

31 Burbank v. Brach, 15 Barb. 326: Skelton v. Dunstan, 92 Ill. 49.

$\therefore 2$ People's biank v. Prooks, 31 Md. 7.

33 Inion Pank v. Fowlkes. 2 Sneed, 555; Bank of Vergennes r. Cameron. 7 liarb. 143. 
a "presentment also." st but ther" can be no lowal denand without presentment, and the terme "demanded " has beren considered suflicient in lonisiana. ${ }^{35}$ The mere statrmunt uf "presenturent" is not in itself sullicient withont allo a satement of demand. 3 ;

$\$ 354$. Name of person to whom presented and fact of dishonor must be stated. - The name of the person upon whom demand was made should be stated, especially whon it was not made at the platee of business of the drawer or aceoptor. In the latter case, it is sufticient to describe the person as al clerk or person in charge. 37 lf a firm were the dlanor on acceptor, it would be fatally defective in not stating the name of the person ous whom demand was made, as woll ats that lie was a member of the firm. ${ }^{38}$

If the bill is parable at a bauk, nothing more neerl bu stated than that the notary presented it and demanded falyment at the bank, and that it was refuserl. without stating the mame of the persom or offieer of the lamk to whom it wat presented. 39

The dishomor of the bill must be stated, and it is usually expresser in the plirase that the person to whom it was presented "answered that it would not he aceepted or paid," or that such pereon " refused to accept or pay it," or some such language. If it loes not, in some terus, inform the party of the dislonor, it is fatally aefective. But it is not material what words are nsed."

$\$$ 355. Protest as evidence.- The original instrument of protest, or a duly anthenticated copy, is respected hy the

it Munon v. Lake, 4 How. 262; Knickerbocker Jife Jns. Co. $\therefore$ lendleton, $115 \mathrm{~L}$. S. 34.

sir Nott v. Beard, 16 Ja. 308.

a Nave v. Richardson, 36 Mo. I30; Farmers Bank v. Allesl, Is Mi. 475 .

37 Xol-on v. Jotterall, 7 Leigh, 179; Stainlack $v$. Bank of V̈irginia, 11 Gratt. $\because 60$.

sa Otnego County Bank r. Wruren, Is Barb. 290 .

:a Hildebum $v$. Turner, 6 How. 69.

40 Taylor v. Bank of Illinois, 7 T. B. Mon. 576 ; Arnold $v$. Kinlock, 50 Barb. 4t: Littledale $x$ Maberry. 43 MIe. 26it. 
courts of a foreign country, and whenever admissible in testimony is regarded as prima facie evidence of all the facts therein stated, so far as they come within the scope of the notary's duty in making the presentment and demand and protest. ${ }^{41}$ But it is prima facie evidence only, and any statement made in the protest may be rebutted by any competent testimony to the contrary. ${ }^{42}$ But as, by the law merehant, the protest is only necessary, or receivable as evidence of dishonor, in the ease of foreign bills or of indorsed notes. which are of the nature of foreign bills and come within the reason of the law respecting them, the protest of an inland hill or of an inland promissory note is not eridence of dishour in a foreign State, although it may be in the State where the dishonor occurred by statute. ${ }^{43}$ And where a State statute makes the protest, when executed by a notary of that State, evidence as to demand and notice, it foes not anthorize the notary to act heyond its territorial limits, or accord the same effect to his act when beyond them. ${ }^{44}$

\$356. Evidence only of facts that are and should be stated. - The admission of the ecrtificate of protest as evidence only makes it evidence of such facts as it should and does distinetly state. ${ }^{45}$ The purpose of the certificate, as it las been scen, is to enable the plaintiff, by this species of documentary evidence, to prove all of the essential requirements of a formal and legal presentment of the instrument for acceptance or payment, and that due demand was made and that the bill or note was in fact dishonored. It follows, therefore, that the certificate of protest can be taken as eridence only as to the essentials stated, and hence the certificate is not evidence of any collateral facts which may

41 Townsley $r$. Sumerall, 2 Pet. 170; Chase $v$. Taylor, 4 Harr. \& J. 54; Insurance Co. v. Wilson, 29 W. Va. 547.

42 Diekens v. Peal, 10 Pet. 582; Howard Bank v. Carson, 50 MId. 27; Applegarth r. Albott, (it ('al. 459.

43 Dutchiess County lank v. Ibbottson, 5 Den. 110; Kirtland v. Wanzer, 2 Duer, 278 .

44 Dutchess Comnty bank v. lbbottson, 5) Den. 110.

45 Daniel on Nexotiable In-truments, \& 962. 
be stated in it. Thus, if it state that the reason given by the drawee for nonaceptance wats, that he had no reffects or funds of the drawer, it is no evidence of the want of effects or funds. ${ }^{\text {fl }}$ Nor is it evidence that the drawee cxpressed his willingness to pay in certain bank bills; $;^{4 \pi}$ nol of the manner and service of the notice of dishonor, nnless by statute snch evidence is made admisible. ${ }^{45}$

\section{$\$ 357$. Presumptions in favor of protest; evidence to supply} omissions.-- But legal presumptions are made in falror of the protest under proper circumstances. Thus, when the certifieate of protest states that demand was mate of the clerk of the drawee, found at his office or place of business, the drawee himself being absent, it is eridence not only of the fact of demand, but also that the person named was the drawee's elerk, duly anthorized to refuse aceptance or payment. ${ }^{9}$ And it would be presumed, if not staterl, that the drawee was absent. ${ }^{50}$ So (where it is evidenee as to notice), if it state that notice was left "at the indorser's drek in the enstom house. he being absent, with a person in charge," it is prima facie evilence that such was his place of business, and that it was properly left there, it not appearing that hetter service enuld have been make ${ }^{51}$ So, if it states demand at his office or place of business, of his bookkecper, or agent, or elerk, ${ }^{52}$ it is evidence that such person was the drawee's agent.

When the protest has been male at the proper time and place, and in the proper manner, but does not upon its face make all the statements neessary to prove due demand aml notice, parol evidence is admisible to supply the omission,

46 Dakin v. Graves, 48 N. H. 45; Dumont v. Pope. 7 Blackf. 36 .

47 Maecoun v. Atehafalaya liank, 13 La. 342.

45 Walker v. Turner. 2 Gratt. 536; lank of Vergennes v. Cameron,

7 Barb. 144.

49 Nelson $\checkmark$. Fotterall, 7 ldigh, 179; Stainback $v$. Bank of Virginia. 11 Gratt. 260 .

50 Gardner $v$. Bank of Tennessee, I Swan. 420.

51 Bank of Commonwalth r. Mudgett, $44 \mathrm{x}$. Y. 514.

52 Phillips $v$, Poindexter, Is Ala, 579: Dickerson v. Turner, 12 lnd. 223; Bradley v. Northern Pank. 16 Ala. 259 . 
provided it be in furtherance of, and not inconsistent with or contrary to, the statements that are made in the protest. Thus, where the protest stated a demand of the cashier, but onitted to state that the note was in, or the cashier at the bank, it was held admissible to prove these facts by parol testimony. ${ }^{53}$

\section{SECTION II.}

\section{NOTICE OF DISIONOR.}

$\$ 358$. Necessity of notice; general rule.- When a negotiable bill or note is dishonored by nonaceptance on presentment for aceeptance, or by nonpayment at its maturity, it is the duty of the holder to give immediate notice of such dishonor to the drawer, if it he a bill, and to the indorser, whether it be a hill or note. The party primarily liable is not entitled to notice, for it was his duty to have provided for payment of the paper; and the fact that he is maker or acceptor for accommorlation does not change the rule. ${ }^{54}$

Notice is not due to any party to a bill or note not negotiable, the rules of the law merchant concerning notice and protest applying to none but strictly commercial instruments. ${ }^{55}$

It is regarded as entering as a condition in the contract of the drawer and indorser of a bill, and of the indorser of a note, that he shall only be bound in the event that acceptance or payment is only demanded; and he notified if it is not made. And in default of notice of nonacceptance or nomparment, the party entitled to notice is at once discharged, unless some excuse exist which exonerates the holder. ${ }^{36}$

$\$ 359$. Failure to notify party entitled to notice discharges debt for which bill was drawn or indorsed.- So absolute is the necessity for notice to an indorser, in order to charge

5.3 Macroun v. Walker, 49 Me. 420: Seneca County Bank v. Neass, 5 Den. 329 .

5.4 Hays v. X. W. Pank, 9 Gratt. 127.

5.) Pitman r. Preckenridge. 3 Gratt. 129.

56 Rothschild r. Currie, 41 Eng. C. L. 43; Musson v. Lake, 4 How. 262. 
him, that if a note has been indorsed to the holder in conditional payment of a debt, the failne to give notice to the indorser will not only discharge the indorsere ats at party to the note, hut also at debtor upen the original considerattion, even though it be secured by a mortgange or deed of trust. The note, then, is made an absolute diseharge of his liability, and the indorsee munt look solely to prior partices And so in respect to the drawer of a bill given in conditional payment. 5 sh the neglect to give notice to the drawer of at renewed bill not only discharges him from liability to pay that bill, but diselatreses him from liability to pay the prion bill, to satisfy which it was drawn: $:^{59}$ and this although it be expressly agreed that the taking of such second bill slatl not exonerate any of the parties to the first bill until actual payment. ${ }^{60}$

$\$ 360$. Notice may be verbal or written.- The notice need not be in writing; it is sufficient if it he given verbally : ${ }^{\text {il }}$ but for precision and safety written notice is preferable. Verlal notice must be necessarily confined to those cases in which notice is directly given to the party in person, or is sent by a messenger to his plaee of business or resilence. It seems that a verbal notice is less strictly construed than a written one, especially when its sufficiency is impliedly adnitted by the party's response. ${ }^{62}$ Thus, where the holder's clerk told the drawer that the bill had been duly presented, and that the acceptor conld not pay it, and the drawer replied that he would see the holder about it, this was held to be sufficient evidence to warrant the jury in finding that the fact. of the dishonor of the note was sufliciently communicated to the drawer. ${ }^{63}$

5i Shipman r. Cook, 1 Green, 251; Peacock v. Purcell, 14 C. B. (X. S.) 728.

as Bridges $r$. Berry, 3 Taunt. 130: Allan r. Eldred, 50 Wis. 136: Smith v. Miller, 43 X. Y. 171 .

59 Bridges v. Berry, 3 Taunt. 130; Chitty on Bills [ $\left.{ }^{*} 433,444\right], 458,5010$.

60 Reid r. Coats, Bro. P. ('. : Chitty on Bills [*434], 48 s.

61 Boyd's Admm. v. C'ity Sar. lank, 15 Gratt. 501: First Nat. Bank v. Ryerson. 23 Iowa, 50s: Stanley v. MeElrath, 25 Pac. 16.

62 Phillips r. Gould, s C. \& P. 35.5: Byles on Bills [*264], 211, 212.

es Metealfe v. Richardion, 11 C. B. 1011. 
Mere knowledge of dishonor does not constitute notice. ${ }^{\text {prt }}$ Notice signifies more; but when the fact of dishonor is communicated by one entitled to call for payment, it becomes notice, as it is then to be inferred that the intention is to hold the party notified responsible. ${ }^{65}$

$\$ 361$. Form of notice.- No partieular phrase or form is necessary. The olject of it is to inform the party to whom it is sent: 1, that the bill or note has been presented; 2, that it has bern dishonored by nonaceeptance, or nonpayment; and, :3, that the holder considers him liable, and looks to lim for parment. And in framing the notice, all that is necessary to apprise the party of the dishonor of the instrument is, to intimate that he is expected to pay it.

In order that a notice should answer these conditions, and duly intimate dishoror to the drawer or indorser, it should therefore, either expressly or by just and natural implieation, comprise the following clements: (1) A sufficient deseription of the bill or note to ascertain its identity. That it has been duly presented for acceptance or payment to the drawee, acceptor, or maker. (3) That it has been dishonorerl by nonaceeptance or nonpayment. (4) That the holder looks to the party notified for payment. ${ }^{66}$

$\$ 362$. Description of the bill or note dishonored.- The notice should deceribe the bill or note in mnistakable terms; should state where the note is, that the party notified may find it; should state who the holder is, and who gives the notice, or at whose request it is given. Such, at least in theory, are the requisites of a proper notice; and a good business man should never negleet to eomply with them. But the courts are not strict in requiring this thorough description of the dishonored instrument; and the requirements of the law are considered as satisfied by any deserip-

64.Juniata Bank v. Hale, 16 Serg. \& R. 15i ; Bank of Old Dominion v. McTeigh. 29 Gratt. 559.

65 Cannt r. Thompson, 7 (. B. 400 ; Miers v. Brown, 11 M. \& W. 372.

of Pank of Old Dominion $v$. MeVeigh, 29 Gratt. 558; Thompson v. Williams, 14 ('al. 162; Story on Notes, \& 348: Daniel on Negotiable Instruments. \& 973 . 
tion which, under all the ciremustances of the rase, sh designates the bill or note as to leave no doubt in the mind of the party, as a reasonable man, what libll or note was intended." Story says that "the deserijution of the note should be sufliciently definite to anable the indorser to know to what one in particnlar the notice applies; for an indorser may have indorsed many notes of rery different distes. sums, and times of payment, and payable to different persons, so that ho may be ignorant, muless the description in tho note is special, to which it properly applies or which it designates." fis But no misdescription of the amomut, or of the date, or of the names of the parties, or of the time the paper fell dur, or other defect will vitiate the notice, moles it misleads the party to whom sent. ${ }^{69}$

$\$ 363$. Statement as to presentment and dishonor.- It wats held at one time that the presentment and dishonol of the bill or note must appear on the face of the notice " in express terms or by necessary implication; " hut the later and better ruling is that it is sufficient if this appear by " reatsonable intemdment." 70 Thomel, properly understond, the sense of the two phrases is pretty much the same, for "necessary implication means not natulal necescity. but so strong a probability that an intention contrary to that which is imputed cannot he supposed." 71 But it is quite clear that it will not be sufficient merely to state in the notice the faset of nonparment of the hill or note, without stating that payment was lemanded of the maker, llawee, or acceptor, as the case may he, or stating some legal exeuse for unt making such demand. Tt should state whether or not the paper

67 Gilbert $v$ Dennis, 3 Metr. (Mass.) 4!j: Shelton $v$ Brathwaite, 7 M. \& W. 436 : Glicksman v. Early. 47 X. IV. 27.2.

as Story on Notes, $\$ 34$.

ca Bank of Alexandria v. Swan. 9 1'et. 33; Mills r. Bank of Inited States, 11 Theat. 431: Dennistoun v. Stewart, 17 110w. 606: Fnith v. Whiting. 12 Mass. 6.

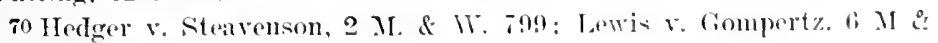
TV. 402 : Fdwards on Bills, 595.

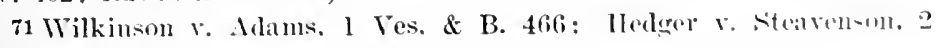
II. \& W. 799 . 
has been presented for payment; and if not, why not, for the reason that the indorser has a right to be informed of the facts on which the liability depends, to the end that he may judge for himself whether or not it is his duty to pay it. ${ }^{2}$

$\$ 364$. Statement that holder looks to drawer or indorser for payment; meaning of.- An express statement in the notice to this effect was, as it might seem, formerly held neeessary ${ }^{73}$ but the prevailing rule at the present time is, that the-mere fact of giving notice to the party implies that he is looked to for payment. ${ }^{i 4}$

On this suljeet it has been said by the Lnited States Supreme Court: "A suggestion has been made at the bar, that a letter to the indorser, stating the demand and dishonor of the note, is not sufficient, unless the party sending it also informs the indorser that he is looked to for parment. But when such notice is sent by the holder, or by his order, it necessarily implies such responsibility over. For what other purpose comld it be sent? We know of no rule that requires any formal declaration to be made to this effect. It is sufficient, if it may he reasonably inferred from the nature of the notice." in

$\$ 365$. By whom notice given.-- The notice of dishonor should chinate from the holder of the instrument at the time of its dishonor, and should be communicated to all the parties whom he means to hold lialole for its payment. But it is not alsolutely necessary that it should come from him, for the holder is entitled to the benefit of notice given in due time be any party to the instrument who wonld be liable to him if he, the holder, had himself given him notice of diskonos. ${ }^{i f}$ Thus if the holder duly notifies the sixth in-

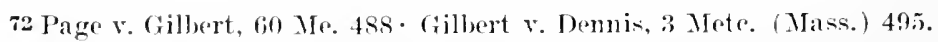

73 Tindal v. Brown, 1 T. L. 169: Solarte v. Palmer, 7 l3ing. 530.

74 Jiers v. Brown, 11 M. \& W. 372; Townend r. Lorain Bank, 2 Ohio St. 345; Townesud v. Mry Goods Co., 85 Mo. 508.

Ts Bank of United States y. Carneal, 2 Pet. 543.

Tf Chapman r. Keene. 3 Ar. \& E1. 193: Bank of Inited States v. Goddard, 5 Mason, 366 ; Stafford $r$. Yates, 18 Johns. 32-. 
dorser, and he the fifth, and he the fourth, and so on to the first, the latter will be liable to all the parties. ${ }^{7}$ Where the holder has duly notitied, or exrerised lowe diligrnoe to notify the several and suceessive indorsers, and an intronediate indorser who did not himself notify his prederesests, takes up the bill or note, there is no dombt that the notice sent them by the holice to whom he makes paymont inures to his benefit, provided it actually reached them. in bint it has been observed that it would seem to be still musettlen whether the notice inmed to the benetit of the intermediate indorser, when the holker's diligence in sending notice did not secure its actual reception. ${ }^{i 9}$ It is certain that notice from a nere stranger is insufficient, so and it is equally well established that a party to the hill who hat been discharged by laches, and who could not in any event sue, wannot give notice for his own or amother's benefit, he being then a mere stranger to the paper. ${ }^{-1}$

$\$ 366$. Notice by agent. - Notice given by an agent is the same as if by the holder himself, and it may be either in the agent's name, oy in the name of any party entitled to give notice. 'The notary to whom the hill or note has been given for presentment may, as the agent of the holder, give notice; ${ }^{83}$ but it is no part of his official duty; and a bank holding a bill or note for collection, or its ofticers or agents, should, as a matter of huty, give the notice necessary ${ }^{85}$ Any

7t llit on v. Sheplerd, 6 East, 14: Swayze r. Britton, 17 kan. 62-

is itallord v. Yates, 18 Jolns. 327.

79 1 Parsons on Notes and Bills, 627.

sestanton v. lilossom, 14 Mass. 116: Juniata Bank v. Ilale, J6 Seror. \& R. 15i: Brailsford v. Williams, 15 Md. 150.

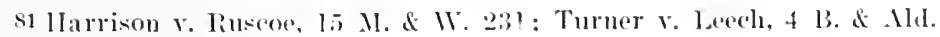
451: Thompson on Bills, 3.5.8.

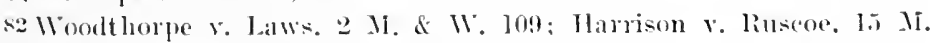
\& IV. 2231: Benjamin's Chalmers' Bigest, 182.

s. Smedes v. [tica bank, 20 Johns. 372; shed r. Brett. I Pick. 40]: Fulton v. Macracken. 18 Mh. 528.

st Harrison r. Robinson, 4 Hlow. 336: Insurane Co. r. Wilionn, "2? II. Va. $5+8$.

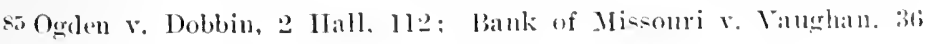
Mo. 90 . 
person indeed, in whose hands the bill lawfully is may give the notice as holder or agent, as the case may be, and if as agent, a verbal authority from the holder is sufficient. ${ }^{80}$ A bank or banker with whom a bill or note is deposited to present for acceptance or payment, or any agent to whom it is indorsed for collection, is to be regarded as a distinct holder for the purposes of notice, and has the same time to notify the principal, and the principal the prior parties, as if such bank or agent were the real omer. ${ }^{87}$

If the luolder he dead, his executor or administrator, if there be one, shonlel give the notice; lunt if none be appointer at the time of maturity, notice should be sert within a reasonable time after an appointment is made. ${ }^{88}$

$\$ 367$. To whom notice should be given; general rule.Each indorser of a bill or note is entitled to notice, and so also is the drawer of a bill payable to a third party, as lills generally are. ${ }^{89}$ The acceptor of a bill and the maker of a note are not entitled to notice, they being the primary debtors, nor are those who, from their irreginlar execution of the instrument, are adjudged joint makers or sureties, their contract being to pay in default of the principal, at all event.." Wh ${ }^{\prime \prime}$ Were there are several successive indorsers, the holder may, and ordinarily does, give notice to all, with a view to preserve his recourse mpon all. But he is not bound to give notice to all, in order to bind those to whom he does give it. He may, if he please, give notice to any one or more of the indorsers, who are then made liable to him; and the indorser receiving notice must then notify antecedent indorsers in order to assure himself. ${ }^{91}$ It is not, therefore, necessary for the notary to take any notice of the

xis (owperthwaite v. Sheffield, 1 Sandf. 416 ; Story on Bills, $\$ 303$.

si Bank of [nited States v. Goddard, 5 Mason, 366; Worden v. Nonrse, 36 Vt. $75(;$; Friend v. Wilkinson, 9 Gratt. 31.

88 White v. Storldard, 11 Gray, 38; 1 Parsons on Notes and Bills, $444,5.59$.

89 .Joseph v. Salomon, 19 Fla. 623; Swret v. Swift, 65 Mich. 91.

go Jitch r. Citizens' Nat. Bank, 97 Ind. 212; Hofheimer v. Losen, 24

110. App. 65\%.

91 Cardwell r. Allen, 33 Gratt. 167; Wood v. Callaghan, 61 Mieh. 402. 
residence of the maker of the note, or make any inquiry as to the residence of any of the indorsers except the last. I different rule would obstruet business, and is not required."

$\$ 368$. Notice to agent. - Sotice to the agent of the liaty for the general conduct of his business is the same at if given to the prineipal in person. But notice to the party": attorney or solicitor, muless he is specially anthorizod to le. ceive it, is insufficient. It an agent draw a bill in his wwn nane, notice shonld be given to him, and if given to his principal it will be insufficient, he being no party to the paper. ${ }^{95}$ If the paper he signed by a duly anthorized agent in the principal s name. notice should be given to the principal, who is the party liable." Whether or not the agent would he regarded as authorized to recoive it, is questioned; and it has been decided that authority to indorse is not anthority of itself to receive notice. ${ }^{37}$ The mele fact that a party is the "financial agent" of his prineipal does not of itself enstitute him an agent to receive notice. ${ }^{98}$ In agent ennstituted hefole the hreaking out of a war which serers him from his principal, with anthority to receive notice of dishonor, mav continue to act for that purpose: and untice served upon him will suffice to charge the indorser. ${ }^{90}$ If a note be pavable by instalments, demand and notice as to the last instalment hinds the indorser as to that.'

$\$ 369$. As to partners and joint indorsers.- If the drawers be a partuership, notice to any one partner is sufficient."

92 Lawson v. Farmers Bank, l Ohio St. 206: Warren r. Gilman. li Ne. 360 .

a: Crosice v. Smith, l Maule \& S. 545; Lake Shore Nat. Pank v. Colliery Co., 5s X. Y. S. C. 68.

94 Lonisiana state Bank $v$ Ellery, 16 Mart. 87; Crosse v. Simith. I Maule \& $\therefore$. istis.

so Grosienor $v$ Stone, s lick. 79.

96 Clay s. Oakley, 17 Mart. 133\%.

9T Valk r. Gailliurd, 4 Strob. 99; Wilcox r. Routh, 9 Smedes \& M. tit. os New York, ete. Co. r. Selma sav. Bank, 5l Ala. 305.

wo llubbard $v$. Matthews. 54 x. Y. jo.

1 Eastman r. Turman, 24 Cal. 383.

a Gowan v. Jackson, 20 ,Johns, 176: People's Bank v. Keech, 26 MAl. 52l: St. Louis Bank r. Altheimer, 91 Mo. 190. 
And it matters not that the firm was dissolved by war, and that one of the partners was separated from the other by a hostile line." If an indorser be a member of the firm, the notice to the firm is sufficient. ${ }^{4}$ The general rule, that notice to any partner is notice to the firm, is subject to this exception: that where one nember resides at a distance, and another at the place of protest, notice must be given to the latter. At least, it has been so held $;^{5}$ but if the drawers or indorsers are joint, but not partners, notice must be given to ach of them, and notice to one only wonld not even bind him.";

\section{$\$ 370$. Notice to indorsers for collection, and to accommoda-} tion and fixed drawers and indorsers. - The rule requiring notice to the indorsers of bills and notes extends to all indorsers, whether they are indorsers for value or mere agents for collection. A banking-house, or other agent, merely passing title to the bill or note by indorsement for purposes of collection, stands on the same footing as any other indorser in respect to notice." "In regard to notice, each branch of a bank is considered a separate establishment." 8

But where the indorsement npon the bill or note was made before its maturity, and after the bill or note had been transferred with it upon it, and had been returned to the indorser; and he, after paying it, and after the liability of all parties had been fixed, and reissned it with their indorsements upon it, the general rule requiring demand of the maker, and notice to the indorser, where the indorsement was marle after maturity, in order to charge the indorser, wonld not apply. For in such case the demand had

3 Hubbard v. Matthews, 54 N. Y. 50.

4 Rhett $v$. Pre, 2 How. 457.

5 Jume v. Watt, 5 Kan. 34.

6 Bank of United States v. Bierne, 1 Gratt. 234: Union Bank v. Willi-, 8 Metc. (Mass.) 5l2; Bealls v. Peck, 12 Parb. 245.

7 Seaton v. Scovill, 18 Kan. 435; Lynn Nat. Bank v. Smith, 132 Mass. 227 ; Butler v. Duval, 4 Terg. 265.

8 Clode v. Bayley, 12 M. \& W. 51. 
been made, the notice given, and his lialility determined lsefore he reissued the instrument."

An accommodation drawer or indorser is as much entitled to notice as if the drawing or indorsing was done for value:;" but if the drawer or indorser be himself the aceommodated, instead of the accommolating party, he is muler obligation to take up the bill or note, has no remerly on doing so against any other party, and ennequently is without legal possibility of injury, and is not entitled to notice. ${ }^{11}$

$\$ 371$. If drawer or indorser be dead or bankrupt.- If the party entitled to notice be dead at the time the bill or note becomes payable, and this is known to the holker, notice should be sent to his executor of alministrator, if there be any, and it can be ascertained by reasonable incuiry who or where he is; and under such rircumstances notice alddressed to the deceased by name would be insufticient." Notice addressed to the "legil representative," in a case in which the death of the indorser was recent, and no personal representative had as yet qualified, has been deemed sufficient;": but it has been held that if addressed to "the estate," it wonld not, that tem applying as well to the heirsat-law as to the executor or administrator. ${ }^{14}$ And where a personal representative has qualitied, and is known, or eonld be ascertained by due diligence, it would not be sufficient to address notice throngh the mail to "the administrator," "executor," or " personal representative," by official designation only, as it might lead to delay. The adrlress

")anicl on Negotiable Instruments, \$ 997 ; St. John v. Roberts, $3 \mathrm{I}$ N. Y. 441 .

10 Turner v. Samson, 2 Q. B. Div. 23; Thillman v. Gueble. 32 La. Ann. 260: Braley v. Buehanan, 21 Kan. 555.

11 Diniel on Negotiable Instruments, $\$ \$ 995 h$, I085.

12 Oriental Bank v. Blake, 22 Pick. 206: Cayuga County Bank v. Bemett, 5 Hill, 236 .

13 Boyd's Admr. v. City Sav. Bank. 15 Gratt. 501: Pillow v. Hardeman. 3 11 umplur. 538.

14 Cayuga County Bank v. Bennett. 5 Hill, 236; Massachusetts lank v. Oliver, $10 \mathrm{Cush}$. $55 \mathrm{~T}$. 
should be to such party by name. ${ }^{15}$ Notice to one of several exeentor's $01^{\circ}$ administrators is sufficient. ${ }^{16}$

If there be no personal representative, notico sent to the fanily residence of the deceased will be sufficient $;^{17}$ and it is likewise sufficient if notice be addressed to the leceased, when, withont negligence, the holder is not aware of his death. ${ }^{18}$

If the party be bankrupt, it is best to give notice to him, and to his ascignee also. If there be as yet no assignee appointed, notice to him is sufficient; $;^{19}$ and perhaps it might be sufficient even if one had been appointed. ${ }^{20}$ If given to the assignee alone, it would probably be sufficient. ${ }^{21}$

If the hankrupt has absconded, notice shonld be given his assignee, if any there be; and if there be none, to any one representing lis estate. ${ }^{22}$

$\$ 372$. How notice must be served when parties in same place. - If the notice is to be given to a party to whom it is not necessary or allowable to transmit it by mail, it should be sent to or given at lis place of domicile or place of husiness, and delivery of notice at either will be suffieient, ${ }^{23}$ eren when they are in different towns. ${ }^{24}$ When the party keeps a counting-rom or other business place, and has a private residence also, it is nenal to send notice to tho place of business rather than to the dwelling, and if notice is so sent to his place of business during hours when he or some of lis people might be reasonably expected there, it is sufficient;

1., Smalley v. Wright, 40 N. J. L. 471.

16. Bealls v. Perk, 12 Barb. 245; Lewis v. Bakewell, 6 La. Ann. 359.

17 (Gondnow v. Warren, 122 Mass. 82; Merehants' Bank v. Birch, 17 John<. 25.

18 barnes v. Reynolds, 4 How. (Miss.) 114; Maspero v. Pedesclaux, 22 La. Ann. 227.

19 F.r parte Moline, 19 Ves. 216.

20 Parsons on Notes and Bills, 500.

21 Callalan v. Kentucky Pank, 82 Ky. 231.

22 Rhode $v$. Prector, 4 B. \& C. 517.

23 Willianns $r$ l bank of United States, 2 Pet. 96 ; Nevins v. Bank of

Jansingburg, 10 $11 \mathrm{i} \cdot \mathrm{h}$. 547; Ireland v. Kip, 10 Johns. 491.

24 Bank of Geneva v. Howlett, 4 Wend 328; Donner v. Remer, 21 Wend. 10. 
and if no one be there in the usual hours, and in the ordinary course of business, it is not neecessary to leare al witten notice, or to send to the honse where he lives, or 10 make farther seareh for hin, or inguries about hin, it lecing considered that he has dispensed with notice. ${ }^{25}$ Notiec left with a elerk, or person in charge, at the party's place of business, in his alsence, or at his platee of business, without proof as to the person with whom it was left, is suffieient, ${ }^{26}$ and proof that such perron was not the party's agent has been held irrelerant, notice heing loft at the right place. ${ }^{2 \pi}$ Hence, leaving it with his private secretary at his public: oftice is sufficient. ${ }^{2 s}$ If service be somght on the party at his dwelling, it is suflieient to leare notice with lis wife, or with any other person on his prenises. ${ }^{29}$

$\S 373$. What is meant by expression "same place." - According to one class of (alses, all persons are to be regarded as of the same place who receive their mails through the samo post-oftice; and although the party entitled to notice may in fact have his residence several nules distant in the country, those cases do not adnit the post-oftice in the aity or town where he gets his mail matter, and where the holder is to be used as a means of eommunicating notice. They baso the decision upon the doctrine that the mail is to be used as a meane of transmission only, and not as a platece of deposit. ${ }^{30}$ The courts of Temessee. New York, Massalchusetts, Louisiana, Mississippi, Virginia, and Nebraska sustain this view.

E. Goldsmith v. Blane, 1 Maule \& S. 5ist: State Bank v. Henmen, 16 Nart. 226.

20 Mercantile liank v. Mcearthy, 7 Mo. App. 31s: Commercial liank

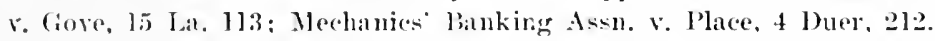

2 i Jacolss v. Town, 2 La. Ann. !nit.

בي Mer\% v. Kaiser, 20 la. Am. 37 .

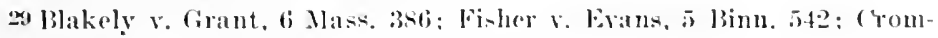
well v. llywon, 2 lip. 5ll.

:O Shelburne Falls Xat. Bank v. Townsley, 102 Mass. 17a: Barker v. IIall, Mart. \& Y, 183: lreland r. Kip, 10 Johns, 490: Forbes v. Omaha Nat. Bank, 10 Nehr. 33s: Louisiana Nitate lank v. Lowell. di Mart. inti; Patrick r. Beazley, (i llow. (Mliss.) 609: Brown v. Bank of Abingdun (Va.), 7 S. E. 357. 
According to another class, if the party has no regular place of business in the eity or town where the holder resides or the instrument is payable, and resides some distance in the country, but receires his mails in the city or town, the mere faet that he would get the letter out of the same oftice it was put in, instead of a distant one, would not vitiate the method of communieation, every reason of conrenience and certainty which apply in one ease applying with equal force in the other. To hold otherwise would require the holder to give personal notice to an indorser who did not reside in the same plaee as himself, or to send it by mail to a post-office where the indorser did not usually receive his letters.

The Supreme Court of the United States has adopted this view in preference to the more exacting view of the authorities referred to; and has held that where the plaintiff bank at which the note was payable was located in Georgetown, and the indorser, when the note fell due, resided two or three miles distant in the eomntry, having removed after it was made from Washington eity, hut received his letters through the Georgetown post-office, notice deposited in the Creorgetown post-office, addressed to him at that place, was sufficient. ${ }^{31}$

$\$ 374$. Exceptions to the rule- - To the rule that when the holder and the drawer or indorser live in the same place service of the notice of dishonor must be personally made, are the following exceptions: (1) If the party addressed actually receives the notice in due season, or it ean be properly inferred by the jury from the facts of the case that the notice was received, the mere manner of its transmission is wholly immaterial, whether transmitted by mail, telegraph, or otherwise. ${ }^{32}$ The distinetion between the different modes of giving notice is this: that where the holder

31 Bank of Columbia v. Lawrence, 1 Pet. 578; Bank of United States v. Norwood, 1 Marr. \& J. 423; Gist v. Lybrand, 3 Ohio, 307; Jones v. Lewis, 8 Watts \& S. 14.

32 Hyslop v. Jones, 3 Melean, 69: Dicken v. Hall, 87 Pa. St. 379; First Nat. Mank v. Wood, 51 Vt. 471. 
and indorser reside in different places, the former, if he deposits the notice in the post-otice in lue seasen, has mo further burden on him as to the actual receipt of it by the latter; but where both parties live in the saluo town, the sender of the notice is bound to show that it was alotmally"

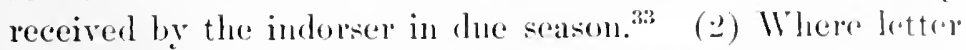
carriers are employed in the postal servior to deliver lottrers at the houses or places of husiness of fartios, who nsually receive their letters through then. lus such atses, if the notice be deposited in thr post-office carly enough in the day to go by the letter-arrier, on the same lay, to the party entitled to notice, it will be deemed sufficient. ${ }^{34}$ When the party entitled to notice has recently died, and no personal representative has been appointed. ${ }^{35}$ (4) Where there are sereral distinet villages or post-offices in a town, between which there is a regulas intereourse ly mail, it may be employed for the converance of notice, notwithstanding the fact that the parties reside in the same general mimmicipality. ${ }^{36}$

$\$ 375$. How notice must be served when parties in different places. - When the parties reside in different places, or the party entitled to notice resides at a place other than the particular place at which the bill or note is payable, it will, in general, be sufficient for the holder to put notice of dishonor in the post-oftice, adhressed to the party entitled thereto, whthin the proper time. This done, his duty is discharged, and it is not necessary that the notice should be received the holder not being respmsible for any misearriage of the mail. ${ }^{37}$ But the notice must be properly addressed to the party at a distance entitled to receive it; and if it be directed to "Darey" as indorser, instead of " Darer." the correct

3: Cabot Bank v. Warner. 10 Allen, 5.2.2.

34 Shoemaker v. Mechanies' Bank, 59 Pa. St. S3; Walters v. Brown. 15 Md. 292 .

25 Boydl's Admr. v. City Sar. Bank, 15 Gratt. 501.

36 Bell r. Hagerstown Bank, 7 Gill, 216 ; Shaylor v. Mlix, 4 Allen, 351; Gist r. Lỵbraml, 3 Olıio, 307.

3 Bussard $v$. Levering, 6 Wheat. 102; Shelburne Falls Nat. Bank r. Townsley. 102 Mass. 17\%. 
name, it is negligence which diseharges him. ${ }^{38}$ The notice should be directed to the post-office at, or nearest to, the party's place of residence, unless he is accustomed to receive his letters at another post-office, in which ease it should be directed thereto. ${ }^{39}$ If he live at one place and has his place of business at another, notice may be sent to either; ${ }^{40}$ and the place where the party actually resorts to for his letters is always the appropriate one, when known, for notice to be addressed to, whether or not the party lives there or has there his place of business. ${ }^{41}$ If the place be that of his actual residence at the time, it need not be his domicile. ${ }^{42}$

$\$$ 376. Address.- The indorser has a right to direet to what postal address, or to what place, notice shall be sent, and it will always suffice to pursue lis direction although he may have a place of residence or business elsewhere. ${ }^{43}$ Sometimes the place to which he desires notice to be sent is designated by memorandum on the instrument, as, for example, by writing the words " 214 E. 18th Street," or by adding his address to his signature, as, for instance, "Memphis, Tenn.," or "Wahnut Bend, Arkansas," or " 13 Chambers Street, New York," or "W. Moors, Manchester," or "'T. M. Barron, London," and he thereby impliedly directs notice to be sent to the place designated. ${ }^{44}$ It is not sufficient to direct notice enerally to a parish, county, or township within which there are a number of post-

28 Darey v. Jones, 13 Vroom, 28.

39 Bank of Columbia v. Lawrence, l Pet. 582 ; National Bank v. Cade, 73 Nich. 449; Northwestern Coal Co. v. Bowman, 69 Iowa, 103.

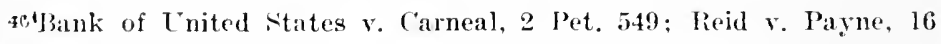
Johns. 218.

41 Farmers' liank v. Gunnell, 26 Gratt. 137 ; 1,indenberger v. Beall, 6 Wheat. I04: Mnun v. Baldwin, 6 Mass. 316.

42 Young v. Durgrin, 15 Gray, 264.

4:3 Pell v. Jagerstown liank, 7 Gill, 2l6; Dicken v. Hall, 87 Pa. St. $379 ;$ Tyson v. Oliver, 43 Nla. 455.

44'Bartlett $v$ Rolinson, 39 N. Y. 187; Carter v. Union Bank. 7 Humplır. 548; Peters v. Hoblss, 25 Ark. 67; Morris v. Husson, 4 Sandf. 93; Mann v. Moors, Ryan \& M. 149; Burmester v. Parron, 17 Q. B. 828. 
offices; ${ }^{45}$ but it has been held that it was sufficient to direct notice to the party at the shire town of the county, althongh there wats a post-othice nearer to hin which he was in the habit of nsing. Wh Where there ane two pust-otfices in the town where the party resides, notice may be lineotenl to the town generally, muless the holder knows, on shomle know, that he receives his letter's at one of them, in which case notice should he directed there. ${ }^{4 i}$ If the party live in one place and have his place of business at another, the holder of a bill or note protested at a third place should send notice to the place at which he usmally receives his letters; ${ }^{48}$ but if the holder does not know that he usially receives at the place where he is engaged in business, it will be sufticient to send it to the place where he lives.t" In the case of parties residing temporarily in a certain place - members of congress or of a State Legislature resinling at their respective capitals, while the bodies to which ther. belong are in session, for instance - it is sufficient and proper that notice should be sent to them at such place, or left there at their place of residenee $:^{50}$ but after the aljomrnment of the session the rule wonld no longer apply, and notice should be sent to the party's permanent place of residence. ${ }^{51}$ And while Congress is in session it will not be suffieient to deposit notice for the nember in the postoffice of the Senate or House of Representatives, as it should be served personally by a party in the same place at his residence, or where he might personally be.

45 Beencel s. Tournillon, 6 liob. (1.il.) 500.

qt Weakly v. 130ll, 9 Watts, 273; Story on lills, $\$ 297$.

47 burlingame r. Foster, les llass. 125; Saco Nat. Bank r. Sinborn. 63 Мre. 340.

ts Bank of Geneva v. Howlet 4 Wend. 32s; Reed v. Payne, 16 . Iolnt: 218.

49 Seneea County Bank v. Xeasm. 2 X. Y. 442.

5o) Choutean $r$. Webster, 6 Mete. Mass.) 1: Gralam v. Singston. I Mul. 5): Marr v. Johnson, 9 Yerg. 1.

"1 Bayley"s Almr. v. Chubb. lo Gratt. 284.

52 Hill r. Norrell, 3 MeLean, 583. 
\$ 377. Address, continued; several post-offices, large cities, etc.- Ithere there are two or three post-offices at which the indor'ser is in the habit of receiving his letter's, notice may be sent to either; ${ }^{n: 3}$ and where he lives at equi-distance from two post-oftices, notice addressed to one will suffice, althongh he was acenstomed to receive his letters at the other. ${ }^{5 t}$ Where the party lives in the United States, it is especially important in sending notices by mail to put the full address, town and State, as there are many cases in which the same name is applicable to towns and cities in different States. An omission to name the State, where there is more than one place bearing the name of the town, would be fatal if the notice were not duly received at the right place. ${ }^{5 j}$

It has been held in Fngland not suffieient to address the notice to a person at a large town, as, for instance, to "W. Iraynes, Bristol," without specifying in what part of it he resides, becanse there might be in so large a town many persons to whom so general an address might apply, the surnanc alone being given without any special designation that might iclentify him. ${ }^{56}$ But unless the name were very common - John Smith, for instance - an address to a large citr, giving the full christian name as well as the surname, would donlthess be regarded as sufficient. And in Massachusetts, where notice was addressed to "Mrs. Susan Collins, Boston," it was held sufficient to charge her as indorser, it not appearing that there was any other person of the same name. ${ }^{57}$ The soundness of the doctrine stated in the latter case has been doubted by some courts - the latter holding that such an address would be prima facie insufficient, even though the town to which it should be sent was not a large nue - the prineiple being that numerous per-

53 Bank of the United States v. Carneal, 2 Pet. 543; Shelburne Falls Nat. Bank v. Townsley, 102 Mass. 177 .

54 Rand v. Reynolds, 2 Gratt. 171; Follain v. Dupre, 11 Rob. (La.) 454.

5 Beckwith v. Smith, 22 Me. 125.

so Walter v. Hayne, Ryan \& M. 149.

5 True v. Collins, 3 Allen, 440; Morse v. Chamberlain, 144 Mass. 408. 
sons with the same surname may be, ambl frepuently are, fommd in the sime town. If one has a fixed residemere, the law presumes that it continues, and notice sent to the old address will be sufficient, unless the removal was under cireumstanees of pecmliar notoriety.

$\$ 378$. Time within which notice may or must be given.Referring to the time of the day of the dishonor at which the holder may give notiee, it is well settled that as soom as the demand is made, and the dishonor has vecurred, the holder need not wait until the close of business hours (n) send notice." Mr M. ('hitty says: "It seens rear that notice of nompayment may be given on the last day of grace, whenever, after due presentment and demand, the drawee makes an unqualified refusal to pay at all." 59 But it is clear that the holder is not obliged to give notice immediately on the very day of the dishonor, althongh he has the option so to do. The settled rule is that the holder has until the expiration of the following day to give notice; and he is not confined within the business hours of the day to give the notice at the party's dwelling. ${ }^{61}$ Ie may give it there at any time lefore the hours of rest; hut if he wives it at the place of business, it must be lone luring the hours of business. 62

$\$ 379$. When the parties reside in different places. - If the holder and the party or parties sought to he lound live in different places, and there is mail commmication between them, the rule laid down by the luited States supreme Court is, that the notice should be deposited in the post in time to be sent by the mail of the day after dishonor, provided snch mail is not closed before early and convenient

ss lank of Alexamlria r. Swan, 9 Pet. 33: Lenox $v$. Roberts, 2 Wheat. 373; Price $\checkmark$ Young, 1 McCord. 339.

59 Chitty on Bills $[* 482]$, 5.t4.

6 Darbishire $v$. l'arker, (i kast. s: Tindiall $r$ Brown, 1 T. R. 16s: Phejps r. Stocking, 21 Nelr. 44.

G1. Jameson y. Swint on. 2 Taunt. 224: Bayley on Bill, 176.

62 Palker v. Gordon, T East, 3ss; Alams r. Wright, lt Wis. 40s; Cayuga County batnk V. Ihunt, 2 Hill, 635. 
business hours of that day; in which case it must be sent by the next mail thereafter. ${ }^{63}$

In other words, the notice must be sent by the first mail which leaves after the day of dishonor is past, and does not close before early and convenient business hours of the day succeding the day of dishonor; the design of the law being to afford the holder an opportunity to mail the notice on the day succeeding that of dishonor.

This rule is sanctioned by numerous and eminent anthorities, either expressly or by implication, and, it seems to us, adopts the only principle which may be safely followed in all eases. ${ }^{\text {it }}$

What lowr of the next day after dishonor may be considered as reasonably early and conrenient within the meaning of this rule must depend upon the habits of the business commmity in each place, and no precise hour can be arbitrarily named. If the mail closes hefore early business hours of the day after dishonor, whether it be luring the night hefore, or at three, four, five, or six o'eloek A. xr. therenf. the notice need not, under the rule, be sent thereby ${ }^{65}$ Seven o'clock seems rebatable, ${ }^{66}$ at least the hour is not rlearly within early business hours, unless at some particular localities, and sunnise is certainly too soon. ${ }^{67}$.

$\$ 380$. Each holder has a day to give notice to his predecessor on the paper.-The party receiving the notice may desire to commmicate it to partios antecedent to him, and others before lim likewise to transmit it to those antecedent to them. In such eases the general rule also is, that

6.3 Inited States v. Barker, 12 Wheat. 5.59; Fullerton v. Bank of the Lniterl states, l let. 605.

64 Farmers" lank v. Duvall, 7 Gill \& J. Ts; Burgess v. Vreeland, 4

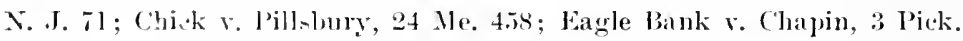
180 .

on Geill r. Jeremy, 1 Moody \& .11. 6I ; Mitchell r. Cross, 2 R. I. 437: Wemple v. Dangerfieh, 2 smedes \& M. 44.; West v. Brown, 6 Ohio it. 542; Chick r. Pillshury, 24 Me. 458.

of Stephenson v. Dickson, 24 Pil. St. 148; Commercial Bank v. Kingt,

: Rol. (1.a.) 243.

(i) Drmints v. Kirkman, I Smerles \& M. 644. 
each suecessive party who receives notice of dishonor is entitled to a full day to transmit it to any antecentent party who is chargealle over to him upon payment of the bill or note. $^{\text {es }}$ So that, if a palty receires notice on one day, he is not bound to forward it to a prior indor:er mutil the next day, and not then if the mail leaves hefore early businus hours. A different rule would subject every party to the inconvenience of giving an account of all of his other engagements, in order to prove that he enuld not reasonably be expected to send notice by the same dary's post which brought it. ${ }^{69}$

Upon receiving notice of dishonor, the indorser should if there be prior parties whom he wishes to hold liable immediately notify not only the one immediately antecedent to him, but all of them; for otherwise, by the negligenes of his previous indorser, or of some one of the sneesesive indorsers, he may lose recourse against some or all of them but the one notified by him. ${ }^{\text {io }}$

$\$ 381$. Transmission of notice over seas. - In the case of a foreign bill protested in one of the Lnited States, and the party entitled to notice resides in some other nationality bevond seas, it is suffieient to send notice by the first regular ship; and it is no objection that if sent by a chance ship it would reach him sooner. ${ }^{i 1}$ It should be sent by the ship going to the port at which the party resiles, or to some neighboring or convenient port aceording to the nsmal course of transportation of letters of business, if a reasonable time before its leparture is left for witing and forwarding the notice. ${ }^{2}$ Otherwise, it will he too late, mless the delay be exensed hy eiremmstances. ${ }^{i 3}$

68 Jameson v. Swinton, 2 Taunt. 224; Iawson v. Farmers' Bank, 1 Ohio St. 206: Seaton v. Scovill, is Kan. 435.

69 Bras v. Hadwen, 5 Maule \& S. Gis.

To Daniel on Negotiable Instruments, $\$ 1044$.

11 Muilman v. D'Eruino, 2 II. Bl. 565; Darbishire r. Parker, 6 Fast, 3: Byles on Bills [*272]. 421.

72 Story on Rills, \& 286: 1 Parsons on Notes and Bills, 485, note.

73 Lenox $\checkmark$. Leverett, 10 Mass. I. 


\section{CHAPTER XIII.}

\section{CIRCUMSTANCES OF A GENERAL OR SPECIAL NATURE WHICH EXCUSE WANT OF PRESENTMENT, PROTEST, OR NOTICE OF DISHONOR.}

\section{SECTION I.}

CIRCUMSTANCES OF A GENERAL NATURE WHICH EXCUSE WANT OF PRESENTIENT, PROTEST, OR NOTICE OF DISHONOR.

\$382. Classification. - The circumstances of a general nature which excuse the holder when there has been a failure on his part to make due presentment of the bill or note to the drawee, acceptor, or maker, or to convey dne notice of dishonor to the drawer or indorser, nay be classified as follows :

(1) The breaking out of a war between the country of tho holder and that of the party to whom presentment should be made or notice given.

(2) Public and positive prohibitions of commercial intercourse between the countries of the holder and that of the party to whom presentment should be made or notice given.

(9) The ocoupation of the country where the parties live, or where the bill or note is payable, by a public enemy, or by military forces, which obstructs or suspends commercial intereourse.

(4) Political disturbances amointing to a virtual interruption and obstruction of the ordinary negotiations of trade.

(5) The prevalence of a malignant epirlemic disease, which suspends the orlinary operations of business.

(6) Orerwhelning calamity, or unavoidable accident, which obstructs the usual channels of communication.

These circumstances are of a character not affecting the individual peculiary, but having such a general influcures upon the country or the community as to impede and pre- 
vent the ordinary pursuits of business, or olstruct the methods of communication, and they are recognized, alnost, if not quite, muversally, as exoncrating those who cone under their operation from the performance of the of ligat tions in respect to negrotiable instruments with which thery interfere.

$\$ 383$. When impediment ceases, duty to make demand or give notice revives. - Thesc exenses - war, military or political disturbance, interdiction of commerce, prevalence of di:ease, overwhelming aceidents, et cetera - do not justify a total dispensation of demand and notice, but only exense the delay which these eireumstances may occasion. As soon as the impediment ecases, the duty revives: and if demand and notice be not specelily made, the holder is in defanlt, and drawers and indorsers are discharged.' 'Thus, where the holder of a bill in New York delayed, for several months after restoration of commercial intereourse hetween Xew York and New Orleans (the former heing in the Tnited States, and the latter in the Conferterate States during the war of secession), to present the bill to the aceeptor in Xew Orleans for parment, it was held that the drawer was discharged." In Maryland, it was said by Stewart, J.: "There must be the earliest possible presentment when impediment ceased." 3

S 384. War, public interdiction of commerce, military disturbances, etc. - A declaration of war between the comutry where the holder is domiciled and that where the party to whom presentment should loe made or notice given is domiciled, or the breaking out of hostilities hetween such countries, operates as an interdiction of all commercial intercourse; and all communication between the subjects of the belligerents, or parties on opposite sides of the belligerent line, is prohibited. This is a general principle of the law of nations, recognized and applied to all kinds of transac-

1 House v. Adams, 48 Pa. St. 266: Farmers' Bank v. Gumell, 26 Gratt. 132: James v. Wade, 21 Ta. Ann. 548.

2 Durden $v$, smith, 44 Miss. 552.

3 Norris v. Despard, 3s IId. 491. 
tions; and it constitutes a clear and admitted justification of the onission to make due presentment of the bill or note or to give notice, during the continnance of hostilities or the suspension and prohibition of interconrse. Illustrative of the proposition stated, interesting cases have arisen growing out of the war between the States, some authorities adhering to the riew that as commercial intereourse between the United States and the seeession States was not interlieted until Angnst 16, 1861, by proclamation of President Lineoln, contracts between persons in the Union and the seceded States were not until that time illegal; ${ }^{5}$ others holding that the test is the existence or nonexistence of an actual state of war, and that no express prohibition is necessary to letermine that fact. ${ }^{6}$.

The interdiction of intercourse between the countries of the holler and of the party to whom presentment should be made would exense the holiler for nompresentment and notice as effectnally as a declaration or open state of war. ${ }^{7}$ It likewise follows that where the occupation of the country by the public enemy is of such a character as to sever the parties from each other by a hostile line, the same prineiple applies as if they were in fact domiciled in different eountries at war with each other. ${ }^{8}$

$\$$ 385. Political disturbances, epidemics, overwhelming calamities, etc. - When political disturbances virtually interrupt and obstruet the ordinary negotiations of trarle, they constitute a snfficient excuse for want of presentment or notier, upon the same principle that controls in eases of military oprations or interdictions of commerce. ${ }^{9}$

4 Harden r. Inyce, 59 Barb. 427; House v. Adams, 48 Pa. St. 261; Norr:s v. Despard. 38 .Id. 491.

5 Lrathres r. Connerticut Ins. Co., 2 Bush, 296; Union Nat. Bank v. Marr's Admr.. 6 Bush, 615.

s Bilgerry v. Branch, l9 Cimatt. 393; MeTeigh v. Bank of Old Dominion, E6 Giratt. 78.5. Se Criswold v. Waddington, 19 .Johns. 438.

7 Story on Notres, \$\& 25., 263; 1 Parsons on Notes and Bills, $46 \mathrm{i}$.

8 Polk v. Spinks. 5 Coldw. 431; Blair \& Hoge v. Wilson, 28 Gratt. 1،2; Tardy v. Poyd. 26 Gratt. 63.2.

9 Story on Notes, $\S 261$; Blair \& Hoge v. Wilson, 28 Gratt. 172. 
The prevalence of a malignant, contagions, or infectious disease, such as the choleria, yellow ferer, the plagne, or small-pox, which hals become so extensive als to suspend all commercial business and intereoure, or to renter it rere liazardous to enter into the infected district, is recognized by the text-writers as a sufticient excuse for not doing any act which would require an entry into anch district." Anl every consideration of public policy and of lumanity nunt sanction this rule.

The existence of an overwhelning calamity or ineritable accident, which suddenly intervene, without any dofault on the holder's part, and wheh render it impossible or inpracticable to make due presenturent or to give due notice, will exeuse the holder for his failure in regard to presentment and notice. Among the ciremustances of this class may be emmerated freshets which carry away bridges and destroy the means of communication; violent snow storms which render the roads impassable: tormadoes and earthquakes which paralyze all affairs for the time being, or render intercourse impracticable. ${ }^{11}$

\section{SECTION II.}

CHRCLASTANCES OF A SPECIAL NATLRE WIICII FITIIER EXCISF

WANT OF, OR SIOW ABSEXCE OF A RIGIT TO REQLIRE, PRESENTMENT, PROTEST, OR NOTICF OF DINHONOR.

386. Classification. - Besides the ciremnstances of a general nature which exeuse delay or absence of presentment, protest, or notice, there are some of a special nature which have the like effect. These special aircumstances may be classified as follows: I. Cirennstances showing an original absence of right to require these steps to be taken. II. Circumstances arising from special alets of waiver. III. Circmustanees which show an inability on the part of the

101 Parsons on Notes and Pills, 460, 331: Elwards on Pill-. 492: Story on Bills, \$ 308 .

11 Windham Bank v. Norton, 22 .Conn. 213: Hilton v. Shepherd, 6 Last, 16; Chitty on Bills [*451], 509: Story on Bills, $\$ \$ 283,286,30$. , $32-36.5$. 
holder to make duo presentment or protest, or give notice. IV. Special ciremustances arising from the conduct of the party. $\quad T$. Special waiver's by promises to pay and part payments after matnity. These cireumstances, thus elassified, will be now separately considered.

\section{$\$ 387$. Circumstances which show absence of right to require.} - When the drawer has drawn the bill without the right to do so, or withont any reasonable ground to expect that the drawee woukl honor it, the omission of the holder to make a due presentment of it for acceptance or payment (no aceptance intervening), or to give the drawer due notice of its dishonor by the drawee, will be exensed. ${ }^{12}$ This doctrine rests upon the ground that the drawer las committed fraud or folly in undertaking that the drawee would honor his bill, when he had no right or reasonnble ground to expect it; and that he can suffer no loss or injury from the failure of the holder to make a presentment to the drawee, which wonld naturally be fruitless, or to give him, the drawer, notice of a dishonor which he must have known by anticipation. And if the drawer has no funds in the drawee's hands with which to meet the bill, and the drawee has not in any way or to any extent obligated himself to accept it, the drawer has no right to expect or require formal presentment of the bill for acceptance. ${ }^{13}$ And if the bill has been accepted for the mere accommodation of the drawer, and he has undertaken to supply funds to meet it, a failure to present it to the aceeptor will be exensed as against the drawer, who could not suffer save from his own laches. ${ }^{14}$

If the drawer withdraws the funds which he had in the drawee's hands when he drew the bill, or intercepts funds which he had provided to meet the bill; or if he privately directs the drawer not to honor it, or otherwise prevents the due aceptance or payment of his draft, he eommits a

12 Chitty on Pills [*436], 490; Story on Bills, $\$ \$ 280,375$.

13 Beckerdike v. Bollman, 1 T. R. 405 ; Donnell v. Savings Bank, 80 Mo. 172; Compton v. Blair, 46 Mich. I. .

14 French v. Pank of Columbia, 4 Craneh, 141 ; Torrey v. Foss, 40 Me. 74; Ross v. Redell, 5 Duer, 462. 
frand upon the holder of the bill, and forfeits his riglit to require demand and notice. ${ }^{15}$

But the bone fide expectation of the drawer haserl npom his relations with the drawee, and the provision he has marde, or intends to make, and does make, are the ciremuntaneres to be regarded. If he has no funds in the drawee's hands when he draws, and yet provicles them before presutment, het should have notiee. ${ }^{16}$ If the drawer has any arrangenont by which, at the time the bill is presented, he has a right to expect it to be honored (i.e., rmming open areomint with drawee, with insufficient balanee to lis credit), we shomld say he should have demand and notice, ${ }^{17}$ for it would be presumed that such arrangenent was contemplated when ho drew.

$\$ 388$. Waiver; general principles. - When presentment of the bill or note at matmity has been dispensen with by prion agreement between the parties, or, in other words, has heen waved by the party entitled to require it, the holder is excused for his failure to make it. It wonld be a framd upon the holder to permit him to suffer by acting upou the assurance of the party to whom he looks as security upon the paper; and as prompt presentuent is a requirenent solely for the benefit of the drawer and inlorser, they are themselves the sole judges to determine whether or not they will enfore it. The waver mal he either verbally or in writing; it may be expressed in lotidem whis, or inferred from the words or acts of the party: and it matter's not what particular language may be ned, so that it comvers the idea that the presentment at maturity is dispeneed with. The like observations apply to the protest and notice. Where the indorser of a cheek wrote over his name. "wairing demand and notice." it was helil that he was not entitled to re-

15 Dickens $v$. Beal, 10 Pet. 5i2: Rhett. v. Poe, 2 How. 45i: Yalk v. Simmons, 4 Mason, 113; Sutclifte v. MeDowell, 2 Nott \& MeC. 251.

16 Rohins v. Gibson, 3 Campl. 334; 11 mmond v. Dufresne, 3 Campb. 145 ; Orear v. MeDonald, 9 Gill, 350 .

17 Thackray v. Plackett, 3 Camph. 164: Legge $v$. Thorpe, 12 East, 171;

1 Parsons on Notes and 13ills, 548. 
quire any demand of the maker, or notice to himself of nonparment, as conditions precedent to his liability. Such words have the effect of dispensing with the necessity for those formalities. ${ }^{18}$

$\S 389$. Character and effect of waiver.-The waiver may be express or implied. It may result, therefore, that the waiver may be either direct and positive, or may arise from implication and usage, or from any understanding between the parties which is of a character to satisfy the mind that a waiver is intended $;^{19}$ but there is authority to the effect that such waivers as we are now treating of should receive a strict construction. And it has been said that to show a wairer of demand and notice there must be clear and unequivecal evidence, and that equivocal cireumstances or agreements will not suffice. ${ }^{21}$ And it is well settled that a promise to pay after maturity, or an acknowledgment of continued liability, with knowledge that the usmal steps of demanu, protest, and notice were not duly taken, constitutes an implied waiver, and the liability of the drawer or indorser is absolutely fixed thereby; and part parment after matmity ly the drawer or indorser is presumptive evidence that the party was duly charged by demand and notice.

The waiver may he either written or verbal, and it is conceded on all sides that a rerbal waiver is as effeetual as a written one; and the weight of authority sustains the proposition that a parol promice to pay the note absolutely, made by the inclorser at the time he indorses it, or a promise to pay it if the maker does not, or a verbal agreement between the parties that parment should not be demauded until after maturity, is admissible to prove a waver of demand and notice. Snch evidence is not offored for the purpose of varying the written contract of indorsement, which is

18 Daniel on Negotiable Instruments, \& 1090 ; Enery v. Hobsen, 62 Me. 578; Woodman v. Thurston, 8 Cush. 157.

19 Fuller v. NeDonald, 8 Greenl. 213; 1 Parsons on Notes and Bills, 594.

20 Pird v. Le Blanc, 6 La. Ann. 470; Gregory v. Allen, Mart. \& Y. 74; Story on Bills, \& 371 . 
simply to pay the note after exercise of due diligenee against tho naker, but to show that the parties have between themselves settled the anomint of diligence to be resuirenl."-1 It has been held differently, ${ }^{2}$ but the doctrine of the test seems; to us more consistent with the principles upon which waivers are sustained.

It may be, if writen, either upon the instrmment itself, or upon a separate paper, written prior to, contemporaneously with, or subsequent to the indorsement." And the terms of the waiver may be either marrow or broad - either to include all the steps usually necessary to tix the liability of the indorser, or any one or nore of them; and while the tendeney of the comts is to construe a waiver as including all of the steps neeessary to fix liability, ret a waiver is not to be eonstrued to extend beyond the fair and reasonable import of its terms. Therefore, a waiver of notice, which is a separate and listinet step from the presentment, is not regarded as waiving the presentment or demand upon the drawee or maker. 'The drawer or indorser may have had confidenee that the drawee, aceeptor, or maker would honor the bill or note upon its presentment; or the holder may have insisted on not incurring the risk of diligenee required in giving prompt notice. ${ }^{24}$

\section{$\$ 390$. Circumstances which show inability on part of holder} to make due presentment or protest, or give notice; when no one in existence upon whom to make demand.- Where there is no person in existence upon whom demand can be made, or none who is legally liable, the presentment is exensed, for the reason that it is either an impossibility or that it woukl be a frand upon the holder to require it. Thus where

21 sigerson 1 . Mathews, 20 How, 496: Seager v. Falwell, 13 Wall, 12; Ross v. Hurd, 71 N. Y. 14; Armstrong v. Chadwiek, 127 Mass. 166: Dre v. Seott, 35 Ohio st. 194: Annville Nat. Bank v. Kettering, $106 \mathrm{~Pa}$. St. 531 ; Boyd v. Cloveland, 4 Pick. 52.5.

22 lieeler v. hrost, 70 Mo. 1s6; Barry v, Morse, 3 X. H. 132.

23 Daniel on Negotiable Instrumente, ss 1092b. 1093: Duwall v. Farmers' Bank, 7 Gill \& .J. 44; Spencer $v$. Jarvey. 17 Wend. 4s?.

24 Daniel on Negntiable Instruments, \$ 1096 ; Backass v. Shepherd. 11 Wend. 629: Voorhees $\therefore$. Atlee, 29 Iowa, 49. 
the maker has died before maturity, and there is no personal representative of whom payment conld be demanded, it cannot of eourse be made; but it would be otherwise if a personal representative had been appointed. ${ }^{25}$ And so in all eases, where there is an actual party bound as promisor, but no one then existing who represents him, the delay in making demand is exensed. But it is no excuse for want of notice to the drawer or indorser. ${ }^{26}$

$\$ 391$. When note is void, and indorser knows it.- Where the note is roid, as between the maker and payee, on aceount of an illegail consideration, the indorser may be held withont any proof of demand or notice; and the general principle is, that whenever the principal party is not bound, the indorser is bound withont demand or notice. ${ }^{27}$ 'The payee, when he indorses the note, warrants, by the rery aet of indorsement, that the maker is legally liable to pay it, knowing, as he necessarily must, that such is not the ease. 'The holder, in the belief of its truth, might look only to the maker, and fail to take the nsual steps to charge the indorser; and if, when he became aware that the maker was not legally bound, he conld not recover against the indorser, the latter wonld be protected by his own frand, and the holder suffer by the confidence placed in him. Thus, in Masichlusetts, where a note was void for usury between maker and payee, and the holder failed in suit against the maker on that account, it was held that he could hold the indorser withont any proof of demand or notice. ${ }^{28}$ Knowledge of the infirmity rendering the instrmment void, on the part of the indorser, is considered by high authorities essential to charge them without demand or notice - the transaction anounting in such case to a frand. The de(isions on this sulject, however, are not uniform. ${ }^{29}$

\footnotetext{
25 (Chitty on Pills 1*436, 437]; 1 Parsons on Notes and Bills, 444, 445. 2f Price v. Young, 1 McCord, 339.

27 Bayley on 13ills, 20.5: 1 l'arsons on Notes and 13ills, 444, 445; Perkins $v$. White, Ohio S. C., January, 1881.

28 Copp v. McDungall, 9 Mass. 1.

29 Daniel on Negotiable Instruments, $\$ \S 1113 a, 1113 b$.
} 
The principles herein announced with reference to indorsers are equally applicable to dratwers of bills of exchange.

$\$ 392$. Impracticability of finding party. - The want of due presentment, or due notice, will be exeused when the holder, after exereising due diligenee, camnot find the party to whom presentment should be made or notice given, or ascertain his place of residenee or business. When this exense is relied upon, it becomes often a question of nicety to determine whether or not the steps taken by the lobler to find the party to whom presentment should be made or notice given, or to aseertain his place of residence or business, amounted to the due diligenee which the law exacts, and it is therefore important to define in what such diligence consists. ${ }^{30}$ The burden of proving due diligence will be upon him who is recking to avail himself of that excuse. ${ }^{31}$ Due diligenee in making presentment for payment, and in communicating notice, eonsists, as a general rule, in making inquiries of such acessible persons, as from their conneetion with the transaction or place, or parties, are likely to be informed and in acting in accordance with the infornation derived from them." The holder is not bound to inquire further than a reasonable and prudent man should, and every possible exertion is not exacted of him. In the language of the Supreme Court of the United States, "It is enough to send the notice to the place where the information received reasonably requires him to send it. If the place it reaches is the wrong one, it is not his (the holder"s) fault." 33 It has been held that due diligenee would necessitate an inquiry by the holder of the indorser or other party to the instrument, to ascertain the whereabonts of the aceeptor or maker. ${ }^{34}$

30 Story on Pills, \& 351.

31 Martin v. Grabinsky, 3s Mo. App. 359.

32 Lambert v. Ghiselin, a How, 4.52: Chapman v. Lipscombe, I Iohna. 294.

33 Inarris v. Robin=on, 4 IIow. 336.

34 Wheeler v. Field, 6 Metc. (Mass.) 290; Grafton Bank v. Cox, 13 Gray, 505. 
$\S 393$. When place of business, or payment, closed; party absent from home, etc.- If the doors of the business office of the aceptor or maker are closed, and there be no one there to answer the demand after repeated ealls, it has been held by high authority that the bill or note may be protested without making further inquiries; for he is bound to have a suitable person there to answer inquiries and pay his biils and notes, if there demanded. ${ }^{35}$ Or if the holder, on the day of maturity, finds the bank or other place of payment closed, he is not bound to make ary further demand to charge either drawer or indorser. ${ }^{36}$ If the paper is payable at a certain bank that has ceased to exist, or at the countingroom of a firm which has dissolved before its maturity, it will certainly be suffieient to make presentment to the bank which has succeeded the former institution, if such there be, or at the counting-room of the suceceding firm, if such there be. ${ }^{37}$

If the party to be notified is traveling, or is absent from home for any reason, and his present address is known to the holler, or if his absence from home is known, and the holder has any means of learning lis address, or of ascertaining whom he has left behind to attend to his business, it would probably be his duty to send notice accordingly. But if a party leaves home withont taking the usual and proper precantions to facilitate sending business communications to him, undoubtedly this is his fanlt, and he can relieve himself from no responsiluility by such fault, and will be held to all narties as if duly notified, provided due diligence be need. ${ }^{38}$

Inability to find the maker or acceptor does not excuse want of notice to drawer or indorser; but inability to find

35 Sulplyarher $v$. Pank of .Charleston, 86 Tenn. 201; Baumgarden v. Reeres, 35 Pa. St. 250; 1 Parsons on Notes and Bills, 457.

3; Hine v. Allely, 4 B. \& Arl. 624: Central Bank v. Allen, 16 Me. 41 ;

Derg v. Abbott, 8.3 Pa. St. 158; Faulkner v. Faulkner, 73 Mo. 336.

3 Central Bank v. Nllen, 16 Me. 4l; Roberts v. Mason, 1 Ala. 373;

Sanderson v. Oakey, 14 Ta. 373.

33 Daniel on Negrotiable Instruments, \$ 1122; 1 Parsons on Notes and Bills, 493. 
the drawer or indorser, or alsertan his whereabouts, atter exercising due diligenee, dors exente want of notice,

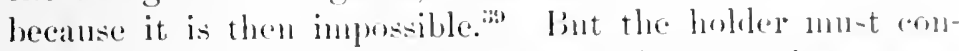
timue his inquilies from day to day, and give motice als sumb as he does ascertain the party's whereabonts - the "Xx.11-1" being coextensive only with the necessaly delay; anl the" imperliment being only temporare, the duty revives with it cessation. ${ }^{40}$

$\$ 394$. When instrument acquired too late to make demand or give notice. - Where the payee, or subsecpuent indorsec, does not transfer and inlorse the bill or note until so near its maturity that it is then impraticable on alcemuli of the distance from, or inacessilility to, the place where the maker or aceeptor has his place of husiness or reidlenee, or where the bill or note is pravable, the prape or othere indoreer so transferring it, will be presumed to have waved the taking of these steps which they must have known were impossille. This exenter, loweres, will only arail at between the immediate parties who have traneferred and received the instrument at on late a period: for as to the previous parties who transfered it long enongh hefore maturity to leave adepuate time for its due precentment. they have a right to insist on the strict performanee of their obligations by those who are subsequent holders. ${ }^{41}$

395. Illness or deatl of holder.- When sulden illness $n b^{\circ}$ death of, or aceilent to, the holler or his agent preventthe presentment of the bill or note in due season, or the commmication of notice, the delay is exensed, provided tha presentment is marle and notioe given as promptly afturward as the circumstances reatonably permit. ${ }^{42}$ This domtrine rests upon the sane principle as that which exemeswant of punctuality when overwhelming calamities or ale d-

391 Parsons on Notes and Bills, i27.

to Daniel on Negetiable lu-trmments. \$ 1120.

41 Daniel on Xerotiable lustruments. \$ 1124: 1 Parsonc on Xutes and Bills, 4inc: Story on Pills. $\$ 320$.

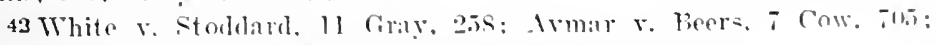
Hilton $r$. Shepherd. 6 East. 16: Story on Bills. 30 . 
dents of a general nature prevent. The sudden illness or death of his agent is on the same footing with that of the holder himself. ${ }^{43}$ If the excuse be illness, it. must be of such a character as to prevent due presentment and notice by the exereise of due diligenee. ${ }^{44}$

$\$ 396$. Special circumstances arising from the conduct of the party; when party has received funds with which to pay instrument. - The receiring by the drawer or indorser of money from the acceptor, maker, or other party for whose benetit the bill or note was made, for the arowed purpose of taking up the bill or note at its maturity, dispenses as to such drawer or indorser with the necessity of a presentment to the acceptor or maker, for the obvious reason that the indorser becomes himself the person who should meet it. And so, receiving any other property, with the agreement that he shall apply its proceeds to paying the bill or note at its maturity, has the same effect. ${ }^{45}$ The indorser in such cases has no remerly over against any one. His arrangement with his principal substitutes him in that principal's place; and it would be a frand for him to throw hack upon him the burden which he had assumed when provided with the means to bear it. ${ }^{46}$

In hamony with the prineiple just stated, it is well setthed that the receiving of security or indemnity by the indorser from the maker or other party for whose benefit the hill or note was exeented will bind the indorser without demand and notice. But in order to thus hold the indorser, the scemrity received must be full, or comprise all the maker's estate. ${ }^{47}$

$\S 39 \%$. When maker or acceptor has absconded or removed his domicile. - Then the maker or aceeptor of the instrument has actually absconded, and especially when he is notoriously

43 Duggan v. King. Rice, 239; Pothier de ('hange, note 144; Chitty on Bills (13th Am. ed.), 509, note a : Story on Bills, \& 309.

44 Turner $v$. Ifach, Hilary Term, 1818; Chitty on Bills [*452], 509;

1 Parsons on Notes and Pills, 532.

4.5 Ray v. Smitl, 17 Wall. 418; Wright v. Andrews, 70 Me. 86; Bond

v. Farniam, 5 Mass. 170.

46. Daniel on Negrotiable In-truments, \& 1128.

$4 \pi$ Jiniel on Xe'gotiable Instruments, s\$ 1129, 1130. 
insolvent, inquiries are unnecessary. Presentment to him personally is of course impossible, and presentment at his last place of residence or busines is altogether muecessary. The mere fact of absconding is all that it is mecessary for the holler to show. This doetrine is well settled in England, and by the current of American antlurities. $^{48}$ Even when he had absenmled to another place in the same State or eountry, the excuse for nompresentment would be sufficient, muless the holder knew where he was, in which ease he should seek him. ${ }^{49}$ But the abseonding of the maker or acceptor furnishes no sufficient excuse for want of notice to the drawer or indorser. "When the drawer or indorser has himself absconded, notice should be left at his last place of abode or with the person representing his estate. ${ }^{51}$ If between the time a note is marle or a lill accepted and its maturity the maker or aceptor remores from the place at which he resided and transacted business to another State or country, no obligation is imposed upon the holder to go ont of his own State in order to make a demand upon him personally, or at his new place of residence or business. It will be sufficient moler such circumstances to make a demand at the paror's last place of residence or business, and when that has been done due diligence requires no more.52 But when the remoral is to another locality within the same State or comntry, it is the duty of the holder to seek and demand payment of the promisor at his new place of residence or business. ${ }^{53}$

48 Bayley on Bills, 196; Chitty on bills [*3tï], 412 ; Lehman v. Jones, 1 Watts \& S. 126; Bruce v. Lytle, 13 Barb. l63; Gillespie v. Hamahan, 4 McCord, 503.

49 Reid r. Mlorison, 2 Watts \& s. 40 !; Dunean r. McCullough, 4 Serg. \& R. 400 .

50 May v. Coflin, 4 Mass. 341.

51 Ex parte Rohde, Mont. \& M. 430: 1 Parsons on Notes and Bill-. 52?. 52 McGruder v. Bank of Washington. 9 Wheat. 59s; Adams r. Leland, 30 X. Y. 309 ; Central lank v. Allen, 16 Mle. 41.

$5:$ Anderson v. Drake, 14 Johns. I14; Louisiana Ins. Co. v. Sham. burgh, 7 Mart. (N. S.) 260. 


\section{BOOK V.}

\section{ACTIONS AND DEFENSES.}

\section{CHAPTER XIV.}

ACTIONS.

\section{SECTION I.}

WHO MAY SUE.

$\S 398$. Holder with legal title may sue.- Any holder of a bill or note who ean trace a clear legal title to it, is entitled to sue upon it in his own name, whether he possesses the beneficial interest in its contents or not. ${ }^{1}$ If the note be payable to $A$. or B., it may be sued upon by them jointly or by either one of them. ${ }^{2}$ If there be a special indorsement, or assigmment to a particular person, he is the proper person to sue; and if he is in possession he may sue although his name be indorsed on the paper, after the special indorsement or assignment. For in such ease his indorsement will be presmmed to be a mere memorandum, or eridence that he had negotiated the paper and then taken it up. ${ }^{3}$

Agents, reeeivers, assignees, trustees, or personal representatives, may sue on a note or bill payable to bearer, or indorsed in blank. And the donee causa morlis of a note payable to the donor's order may use the name of his personal representative, even against his protest.5 But a mere

1 Caldwell v. Lawrence, 84 111. 161; Harpending v. Daniel, $80 \mathrm{Ky} .456$.

2 Westgate v. Irraly, 4 R. I. 524.

3 Humphreyville v. Culver, 73 Ill. 4 S5.

4 Law v. Parnell, 7 C. P. (N. S.) 282; Bowman v. Whod, 15 Mass. 334 ; Haxtun v. Bishop, 3 Wend. 13; Daniel on Negotiable Instruments. $\S 264$; 2 Parsons on Notes and Pilla, 446.

5 Grover v. Grover, 24 I'ick. 261 : Sessions v. Mosely, 4 Cush. s7. 
depositary of such a note cannot maintain suit." If the paper be indorsed specially to a particular persen, nome lout such person or his representative can sure ${ }^{7}$ A purty for accommodation who pays the bill nay sue prior partice, but not subsequent ones. If an aceptor or maker for aneommodation fays the bill he comnot sue drawer or indmose upon the bill, because, according to its terms, he is liable to them. But lie may sue the accommodation party for money paid at his recunest."

$\$$ 399. Partnerships; joint parties.-If a bill or note be made payable to, or inclorsed specially to a firm, all the partners inust join in the suit $;^{9}$ and if so payable or indor'sed to $A$. \& Co., 1 . camnot recover muless he shows that he alone composed the nominal firm. ${ }^{10}$ If, in fact, he alone composes the firm, the title to the paper is in him, and no indorsement is necessary to enable hini to maintain the suit. ${ }^{11}$ If one of the copaltners of a firm should die, suit shonld be brought ly the survivor or survirors; ${ }^{12}$ but if the paper be indorsed in blank to a fimm, either copartner may fill it up in his own name and sue, even though one of the copartners be elead, ${ }^{13}$ and if indorsed to one member of the firm, it may be filled up and suit brought on it in the firm name. ${ }^{14}$

A copartner camnot sue a firm of which he is a member, upon a bill or note payable by it to limself, becanse he would be in fact suing lime lf $:^{15}$ but if a fimm make its bill or note payable to the order of a copartner, and the latter

6 Sherwood v. Roys, 14 Pick. 172.

i Daniel on Negotiable Instruments, \& 692 , 11sla.

8 Stark v. Alford, 40 Tex. 260.

9 Guidon v. Robson, 2 Campb. 302.

10 Robl, v. Bailey, 1:3 1.i. Amin. 45i.

11 Smith $v$. IIanie, it Ga. 327.

12 Parsons on l'artnership, 447.

13 lovell v. Livertson, 11 Johns. 52; Weaver v. Bromley, 65 Mich. 2l3.

14 Ilutchinson v. ('rane, 100 Ill. 2i2.

15 Parsons on l'artnership, 510, note. 
indorse it, the indorsee may sue. ${ }^{16}$ But if a note indorsed by two of three payees to a third payee and a stranger be subequently indorsed loy the third payee, the indorsee may sue in his own name. ${ }^{17}$

Joint parties not partners must all unite in the action, if living. On the death of one of them, the remedies for collection survive to those living, who may lawfully reeeive parment, and sue at law or in equity, as may be appropriate, withont miting the personal representative of the deceased joint party. ${ }^{18}$ It has been held that one of two joint owners camot maintain an action thereon in his own name, though the note be payalbe to bearer and be in his possession. ${ }^{19}$

$\$ 400$. Married women.- On a bill or note given to a single woman, who afterward marries, the husband must join her in the action. ${ }^{20}$ If she dies, the right of action is in her personal representative, not in the husband. ${ }^{21}$ If the hushand dies, the right of action is in her, and not in the husband's personal representative. ${ }^{2}$ So the right of action survives to the wife, upon a note parable to husband and wife, when the husband dies, and does not pass to his representative. ${ }^{23}$

On a lill or note made pavable to a married woman after marriage the hushand may sue alone as payable to him, or he may join in an action with his wife. ${ }^{24}$ If payable to the husband, or to his wife, in the alternative, he should sue. ${ }^{25}$

The wife camnot sue her hushand on a note made by him to her after marriage; nor on a joint and screral note made

19; Thayer v. Buffum, 11 Mete. (Mass.) 398; Davis v. Briggs, 39 Me. 304.

17 Cioddard v. Lyman, 14 Pick. 268.

19 Lannay v. Wilson, 30 Md. 536: Allen v. Tate, 58 Miss. 586.

19 NeName v. Carpenter, 5f Iowa, 276.

3. Sherrington v. Yates, 12 M. \& W. 855.

21 Hart v. Stevens, 6. Q. B. 687.

22. Stanwood $v$. Stanwood, 17 Mass, 57; Dean v. Richmond, 5 Pick. 461.

23 May v. Boisseau, 12 Jeigh, 5l2: Draper v. Jackson, 16 Mass. 480.

24 Burrouglis v. Moss, 10 13. \& C. 558; Philliskirk v. Pluckwell, 2 Maule \& S. 393.

25 Young v. Ward, 21 111. 223. 
to her by him and others; ${ }^{26}$ but in this case if he dies she may sue the others. ${ }^{27}$

It should be observed, however, that the rights of marriod women, not only with reference to the acequisition of property and her contractual powers, but with reference to hien. right to sue, have been materially altered by remedial legislation in the different States.

$\$ 401$. Cause of action indivisible.- It is a general principle of law that a party camnot divide an entire denund or cause of action, and mantan several suits for its recovery; and a recovery for part of an entire demand will bar an action for the remander, if lue at the time that the first action was bronght. What constitutes an entire or single demand is often diflienlt to determine. When a note payable at a futmre day carries interest payahle ammally or semi-annually, the holker may, before its maturity, recover the interest as it matures withont haring an action as to the principal or macerued interest. ${ }^{28}$ If the interest be due by a coupon or other separate security, it can be sued for as an independent cause of action. ${ }^{29}$ Whether when the principle of a note, and its interest (not payale by separate seenrity), are both mature, separate actions may bo maintained, for each is controverted, some cases holding that they are maintainable $:^{30}$ others, the opposite. ${ }^{31}$ The better opinion sustains the right to the separate actions.

$\S 402$. Agents.- Upon the theory that the party entitled to sue is the one in whom the instrment shows the legal title to exist, it has been held that, when the bill or note is payable to a certain person by name, but describing lim as agent of another person alio nimed - as, for instance. "A. B., agent for C. D." - the suit must be brought in the

26. Sweat v. Hall, s Vt. 187 : Richards v. Riehards, 2 B. \& Ad. 447.

2i Richards v. Riehards, 2 B. \& Ad. 44 i.

23 Walker v. Kimble, 22 Hll. 53\%; Goodman v. Goodman, 65 111. 497.

29 Daniel on Negotiable Instruments, s 1509 et seq.

30 Andover Sav. Bank v. Adams, I Allen, 2s; Sparlawk v. Willis, d Gray, 163.

31 Howe v. Bradley, 19 Me. 31 ; larsons on Contracts, Vol. 11. p. 1i3ti. 
name of the agent, and cammot be brought in the name of the principal; ${ }^{32}$ and that a fortiori must the suit be so brought when the instrument is simply payable to "A. B., agent," no prineipal being named. ${ }^{33}$ But in either case, the better doctrine, an it seems to $1 \mathrm{~s}$, is that either the agent or the principal night sue. If snit were brought by the agent, the possession conforming to the express indication of the paper would elearly sustain the action. If suit were brought by the principal whose name is expressed in the instrument, possesion by him would be evidence that he had received from his agent the instrument of which he was entitled to the beneficial interest; and there conld be no good reason why it shonld be necessary for the prineipal to continue to use his agent's name, when it is clear from the face of the paper that if so used it would be as the representative of his own. ${ }^{34}$ And where the prineipal is undiselosed on the falce of the paper, he might also sue in his own name; but in such case mere possession of the paper would not be sutticient evidence that he was the prineipal intended, and it would be necessary for him to supply that element in his title to reeover by parol proof. ${ }^{35}$ In the ease of instruments parable to bank cashier's it might be different. Delivery of a note to an agent without indorsement would not authorize him to sue. ${ }^{36}$ The same principles apply to agents of corporations, public and private.

$\$ 403$. When payable to bearer.- The law is now too well settled to admit of longer controversy that an action on a bill or note payable to bearer, or indorsed in blank, may be maintained in the name of the nominal holder who is not the owner by the owner's consent; and that possession by snch nominal holder is prima facie sufficient evidence of his right to sue, and eamot be rebutted by proof that he has no beneficial interest, or by anything else but proof of

32 Cocke v. Dickens, 4 Terg. 29; Shepherd v. Evans, 9 Ind. 260.

33 Alston v. Hartman, 2 Ala. 699; Horah v. long, 4 Dev. \& Bat. 274.

34 Fairchild v. Ałams, 16 Pick. 383: Johnson v. Catlin, 27 Vt. 87.

35 Rutland, etc.. li. Co. v. Cole. 24 Vt. 38.

36 Nichols v. Gross. 26 Ohio st. 425. 
mala fides. ${ }^{37}$ If it were shown that the plaintiff, upon suing upon a note payable to bearer or indorsed in blank, has me interest in it, and in addition that he is suing against the will of the party beneficially interested, he could not recover, as his conduct would be in bad faith.: It matters not that such nominal holker will receive the amomnt as trustee, agent, or pledgee."3 The snit ly him holding the paper shows his title to recover; and it cammot matter to the defendant who discharges the debt that the plaintiff is accountable over to a third party. Evidence, however, that the plaintiff lats no interest in the instrument will be competent when foundation has been laid for its introduction by offer to prove offset, or other defense, arailable against a third person who is its true owner." And if the indorsement be expressed "for collection," it has been held that the indorsee is not such a holder as may sue. ${ }^{41}$ But in England it has been held that if the plaintiff has neither an interest in the instrument or right of possession at the time suit is brought, he eamot maintain the suit: ${ }^{42}$ and this view has been upheld in New York under the provision of the eode of that State which requires the real party in interest to sne. ${ }^{43}$

It should be noted, however, that an indorsement in blank by the payee will not affect lis right to sme upon a note payable to his order while it remains in his hands. ${ }^{44}$

$\S 404$. Rights of holder under a blank indorsement.- The holder of a note blank as to the payce may fill it up with lis own name and sue upon it. ${ }^{4 \pi}$ If payable to a fictitions

:5 Demuth v. Cutler, 50 Me. 300 : Rubelman v. MeNichol, 13 Mo. App. 554 .

:s Tonne v. Wasson, 128 Mass. $\pi 17$.

a Nicolay v. Fritschle, to Mo. (ii) King v. Fleece, T Heisk. bi ; Howman v. Wood, 15 Mass. 534.

40 Logan v. Cassell, ss Par. St. 290.

41 Rock County Nat. Bank v. Ilollister, 21 Minn. 385.

42 Emmett v. Tattenham, s Exch. sst.

43 Hays v. Hathorn. it N. Y. 4 sti.

44 Kerrick v. Stevens, is Mich. 297.

45 Crutchley v. Carence, 2 Maule \& S. 90. 
person, it may be sued on as payable to bearer. ${ }^{46}$ The holder of such a paper, in transferring it, should not use the fictitious name, but pass it by delivery only, or by indorsement, ${ }^{47}$ and even after the trial, where judgment has gone for the plaintiff under the impression that the indorsement had been filled up, the correetion being made nunc pro tunc. ${ }^{48}$

But the filling up of the blank indorsement is formal merely, and it is not neeessary that it should be filled up at all, for the mere act of suing upon it by the holder evidences his intention to treat the indorser as a transferrer and indorser to himself. ${ }^{49}$ And if the plaintiff omit to state in his declaration all the indorsements after the first indorsement in blank, he may strike out the intervening indorsements, and aver that the first blank indorser indorsed immediately to himself. ${ }^{50}$

$\S 405$. When indorsement is in full.- If the bill or note be not payable to bearer or indorsed in blank, or indorsed specially to himself, the holder camnot (unless authorized by statute) sine in his own name, for although he may possess the entire beneficial interest, the legal title is still outstanding in his transferrer, and he must use his name in order to maintain the suit. ${ }^{51}$ By leaving the instrument unindorsed, the transferrer necessitates and authorizes the use of lis name to the recovery of the amomt; and he cannot object to its use, or release the action when instituted. $^{52}$ If the transferrer indorses the paper, then his name cannot be used save by his own consent; for then the legal title and right to sne is vested in his indorsee..$^{53}$

462 Parsons on Notes and Pills, 448.

$4 \pi$ Nlaniort v. Roberts, 4 L. D. Smith, 83.

48 Whittier v. Hayden, 9 Allen, 408.

49 Rees $v$. Conocoeheague Bank, 5 Rand. 329; Poorman v. Mills, 35 Cal. 118.

5n Rand v. Dovey, 83 Pa. St. 281; Merz v. Kaiser, 20 La. Ann. 379; Byles on Bills [* 149 ], 268.

51 Allen $v$. Newbury, 8 lowa, 65; Robinson v. Wilkinson, 38 Mich. 301 ; Marsh v. Hayford, 80 Me. 97.

52 Paese v. IIirnt, 10 B. \& C. 123; Amherst Aeademy v. Cowles, 6 Pick. 427; Royce v. Nye, 52 Vt. 372.

53 Bowie v. Duval, I Gill \& J. 175; Mosher v. Allen, 16 Mass. 451. 
But if suit is commenced without his consent, he may subsequently assent to it. ${ }^{54}$

$\S 406$. Possession prima facie evidence of ownership.- P'ssession is in itselt prima facic evidence of the right of the party to slle and receive the money when he loblds muler a legal title, and also that the title, although not expressir, is actually vested in him. And therefore in order to defeat his suit, it must be shown that he is a male fide holder. As said in a Maryland ealso by Chambers, J.: "A bill payable to bearer, or a bill payable to order and indored in blank, will pass by delivery, and bare possession is primn facie evidence of title; and for that reason posession of such a bill would entitle the holder to sue." in And possession of the note or hill is prima facie evidence that the samo was indorsed by the person hy whom it purports to be indorsed ${ }^{5 \pi}$ and production at the trial is prima facie evidence that it remains mpaid. But possession of the instrument is not always necessary in order to institute a suit. If the holder hals indorsed a note in blank and pledged it as collateral security, he may negotiate it to a third person, while still pledged, and such person may sue as indorsee while it is still in pledge, and maintain an action by discharging the lien and producing the note at the trial.5s

\section{SECTION 11.}

WHO MAY HE: STED.

$\$ 407$. General principles. - Is a general rule, the holder may sue all the prior parties on the bill or note, but not any subsequent party. Thus a palyee may sue the acceptor or maker. An indorsee may sue the aceeptor or maker, and all prior indorsers. At common law the holder might commence and prosecute sereral actions againat each of the

54 Golder v. Foss, 43 Me. 364.

55 Wheeler v. Johmson, 97 Mass. 39: Wilson Sewing Machine Co. $r$. Spears, 50 Mich. 534; Union Nat. lank v. Barber, 56 Iowa, 562.

56 Whiteford v. Burekmyer, 1 cill, 127.

57 Jank v. Mallan, 37 Mlinn. 404.

58 Fisher v. Bradford, 7 Greenl. 29. 
prior parties at the same time; and an action instituted against one would not prectude any other remedy against the others. ${ }^{59}$ But satisfaction by any one would discharge all to the plaintiff from liability as to principal sum. ${ }^{60}$ Where a party was liable in the two eharacters of joint drawer and of acceptor, he might be sued jointly with the other drawers and separately as aceeptor. ${ }^{61}$

But by statute in many of the States an action may be maintaned and judgment given jointly against all the parties to a negotiable instrmment, whether drawers, indorsers, or acceptors, or against any one, or any intermediate number of them.

$\S 408$. When indorser can sue acceptor or maker.- The indorser of a bill or note cannot sne the acceptor or maker until he has paid or satisfied it. But as soon as he does this he may sue the acceptor or maker. ${ }^{62}$ And if one indorser snes a priol party, it is not necessary for him to show that he had received notice, provided it was duly received by such prior party. ${ }^{63}$ There there are a number of indorsers, any one may sue, by arrangement between them, all indorsements subsequent to his being stricken out. ${ }^{64}$

$\$$ 409. When drawer can sue acceptor and vice versa."The drawer," says Mr. Chitty, " may maintain an action on the bill against the aceeptor, in ease of a refusal to pay a bill already accepted, but not on a refusal to accept, in which latter ease the action must be special on the contract to accept." 65 Certainly the drawer may sue the acceptor if he has had to pay the bill, or may leave it in the hands of the indorsee to sue for his benefit; ${ }^{65}$ but it has been held

59 Chitty on Jills [*538, 539], 610, 611; Williams v. Jones, 79 Ala. 119.

60 E.r parte Wildman. 2 Ves. Sr. 115; Farwell v. Hilliard, 3 N. H. 318. 61 Wise $x$. Prowse, 9 Price, 393.

62 Hoyt v. Wilkinson, 10 Pick. 31; M!cDonald v. Magruder, 3 Pet. 470.

6.3 Ellsworth v. Jirewer, 11 Pick. 316.

64 Walwyn v. St. Quintin, 1 Bos. \& P. 652.

65 Chitty on Bills [ ${ }^{*} 537$ ] 608.

c6 Jouviere $v$. Laubray, 10 Mod. 36; Thurman v. Van Brunt, 19 Barb. 410 ; Williams v. James, 15 Ad. \& El. (N. S.) 69. 
that he eannot recover withont evidence that he has paid the bill. ${ }^{67}$

Whero the acceptance is for the drawer's arcommondation, and the acceptor pays the lill, he ammot sure the drawer upon the bill, for it imports no liability to him, hut he may sue for money pairl at his request. ${ }^{68}$ IBut an areoptor for honor of the drawer or indorser may sue such drawer of indorser upon the bill itself. ${ }^{69}$

\section{SECTION IIT.}

WIEN IRIGIIT OF AC'ION ACCRTES.

\$ 410. Can suit be instituted on day of maturity?- While the courts are at war with each other on this subject, it may be confidently and fairly amounced that the better view is that after demand and refusal on the last day of grace, action may be commenced against the maker." But. in the case of non-negotiable contracts to be performed upon a certain day, they are really solvable within that day; and as the promisor has the whole of the day for their performance, suit cannot be eommeneed until that day has passed. ${ }^{71}$ But when the maker of a note, or the drawer or acceptor of a bill, makes it payable on a day certain, his contract is to pay it on demand on any part of that day, if made within reasonable hours. ${ }^{\text {i2 }}$ The protest must he made on that day, which presupposes a default already made; and whether it be the last day of graee, or the day of maturity, when there is no grace, it is clear, upon prin-

67 Thompson v. Flower, 1 Mart. N. S. (La.) 301: 2 P'arsons on Notes and Bills, 453.

GS Bell v. Norwood, 7 La. 95: Stark v. Alford, 49 Tex. 260.

mo Parsons on Notes and Bills, 45.5.

70 Daniel on Negotialle Instruments, s l:07: 2 Parsons on Notes and Bills, 4hil 4t2: Staples v. Franklin Bank, 1 Mete. Mass.) 43: Leftly $\mathrm{r}$. Mills, 4 T. R. 170 .

71 Webh v. Fairmaner. 3 M. \& W. 473; Coleman v. Ewing, 4 Humphr. 241.

72 Leftly r. Mills, \& T. R. 170; Greeley v. Thurston, \& Greenl. 4i?; Chitty on Bills [*4811, 544 . 
eiple, that as soon as payment is refused, the action may be commenced. The view announced in the text is clearly stated by the Supreme Court of Massachusetts (Chief Justice Shaw delivering the opinion): "The rule in regard to notes like the one in question is, that the note is payable at any time, on actual demand, on the last day of grace; and if such actual presentment and demand is so made, and parment is not made, the maker is in defanlt, and notice of dishonor may forthwith be given to the indorser. But if no presentment or demand is made by the holder upon the maker, the latter is not in default until the end of the business day." 73

§ 411. Due-bills.-A due-bill, which is regarded in many States as a promissory note, is payable immediately, and upon principle there is no doubt, we think, that in such States action may be brought immediately on the very day of its date. The due-bill is predicated upon, and evidences the fact that the debt is then due - not to be due on that day (which in ordinary contracts means the same as within that clay), nor to be due in business hours of that day if demanderl, as is the ease with respect to negotiable paper which has a period of time to mature. It is true that the due-bill could not be sued upon during that fraetional part of the day preceding its making; but it does not follow that during the remainder of the day it is not mature for suit. For its very language and nature purport that it is instantly due; and as a breach of contract occurs by failure to pay it instantly, the creditor may sue instantly, indulgence for any time being mere matter of his diseretion and pleasure. This view is sustained by well-considered authorities, ${ }^{74}$ thongh not without dissent.

$\S 412$. Action lies against indorser as soon as notice is put in train of transmission.- In respect to the indorser, it has been held in a number of cases that suit against him cannot be commenced until time has clapsed for notice to be

73 Pierce v. Cate, 12 Cush. 190.

74 Cammer v. Harrionn, 2 Mreord, 246: Dews v. Eastham, 2 Yerg. 403; IIill v. Ifenry, 17 Ohio, 9: Daniel on Neqotiable Instruments. \& 1211. 
actually received by him, upon the theory that the holike $1^{\circ}$ title is not complete until the indorser is actually notitical that he is looked to for paynent, or at least that time for him to receive snch notice has transpired."5 But this is a misconception, as we think, of the law of notice. The holder must exereise due diligence to give the indorser notice. That duty is fultilled when he puts it in train to reach him, by sending it to his business or dwelling-house, ar depositing it in the postoflice, an the case may be. And for him to be delayed until time for its actual reception lial gone by would subject him to the hazards, vexitions, and uncertainties of various cireumstances which do not legitimately enter into the consideration of the indorer's liability. it

But in suits commencel on the last day of grace against an indorser, the platintiff must prove that before the wit was sued out notice was deposited in the post-office, when he lives in a different place, or sent to his resilence or place of business when he lives in the same. ${ }^{77}$ If the notice precedes the suit ever so short a time, it suftices: $:^{i s}$ but if it does not, it seems the irregularity cammot be cured by the sending and reception of notice afterward. ${ }^{\text {9 }}$

\$ 413. Action upon dishonor for nonacceptance.- When al bill is dishonored for nonacceptance, right of action acerues at once against the drawer, and also against the indorsers as soon as the protest is made and notice put in train to reach the party, without wating for the maturity of the bill. ${ }^{50}$ And if a note be payable in respect to principal or interest, in instalments, action will lie for each instalment as it falls due. ${ }^{\mathrm{s}}$

75. Smith v. Bank of Washington, 5. Serg. \& R. 31S: Wiggle v. Thomas. son, 11 smedes \& M. 452: MeFarland r. Pico, \& Cal. 626.

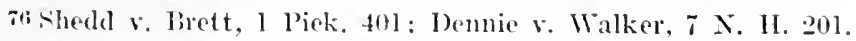

7t Manehester liank v. Fellows. \& Font. 302.

78 N. F. Bank r. lewis, ? I'ick. 12.5.

79 X. L. liank 1. Lewis, 2 l'ick. 113: Stanton r. Blossom, 14 Mase. 116.

co liobinson r. Ames, 20 Johns. 146; Tenox r. Cook. S Mate. tho;

ballingalls v. Closter, 3 Fast, 4 sl.

s1 Tucker v. Randall, 2 Mass. 2s3: Cooley $v$. Rose, s Man. a.21. 


\section{SECTION IV.}

\section{WIEX RIGHT OF ACTION EXPIRES.}

$\$ 414$. Origin of Statute of Limitations. - At common law, when once a right of artion acerned, it was immortal. But the disadvantages of permitting remedies to be sought at remote periods firom the time the transactions ocenred, and the desirability of having settlements while evidence was readily obtainable, led at an early date to the adoption of statutes fixing a limitation to actions. As early as 1270 an act wats passed relating to limitation of actions concerning real estate; but personal property, and especially choses in action, were at that time of so little consequence that no limitation of personal actions was preseribed milil 1623 . In this modern period, choses in action constitute a vast portion of the property of the eountry; and the time at which the right to reduce them into possession expires is a matter of prime importance. It is to be observed, in the first place, that statutes of limitation do not destroy the debt, but only bar the remedy. Therefore they must be specially pleaded, and cannot be given in evidence under a general issue." And as they do not enter into the essence of the contract, they must be regulated entirely by the laws of the comtry where suit is brought. ${ }^{83}$

$\$ 415$. When Statute of Limitations begins to run.- The statute of limitations begins to run from the very day the right of action acernes. Thus upon a bill or note payablo at so many days from the date, it begins to rum from the day of payment, and not from the day of date, lut the day of maturity is excluded in the computation of time. If payable at sight, the statute rums from sight. If so many days after sight, or after certain events, then from the time named after sight, or after the events have happened. $^{84}$ If the instrument be payable on demand, tho

82 Chapple v. Durston, 1 C.\& .T. 1.

83 Daniel on Negotiable Instruments, $\$ 884$.

84 Byles on Bills [*331], 499. 
statute begins to run immerliatcly as payment might be immediately demanded, or suit, bought without any previous demand. ${ }^{5}$ "On demand after date" is the same ats on demand.s' But if payale at a cortain time after clomand, or after notice, an arctual demand must he made, of notice given, in order to fix the projod of maturity when the statute commences. ${ }^{87}$ When right of action on the instrunent secured expires, all clain to rutoree the security which is a mere incident of the principal obligation, expires with it. ${ }^{\text {s. }}$ The indorsenent of an overdue note is a new eontract, and the statute begins to rum in faror of the indorser from the date of the indorsement. ${ }^{\text {: }}$

85 Mills v. Davis, 113 X. Y. 243: Mobile Sav. Bank v. MeDonnell, 83 Ala. 597 .

86 Fenno v. Gay, 146 Mass. IIs; Crim v. Starkweather, 88 N. Y. 339. 87 Little v. Blunt, 9 Pick. 488: Massie v. Byrd, s7 Ala. 681; Clayton v. Gosling, 5 B. \& ( . .360.

ss City of Fort Seott v. Schulenberg. 22 Kin. 6iss.

89 Graham v. Rohertson, 79 Ga. 72. For more claborate diseussion of the Statute of Limitations, see post, $\$ \$ 481,482$. 


\section{CHAPTER XV.}

\section{DEFENSES.}

\$416. Classification. - The defenses that may be interposed to an action upon a negotiable contract may be grouped or arranged into five classes: (1) That the defendant did not make the instrument; (2) that the contract sued upon is in law nonenforceable; (3) that the plaintiff is not entitled to sue thereon; (4) that the obligation created has been diseharged; (5) that the action upon the instrument is barred by the statute of limitations.

§ 417. Classification elaborated.- Under the first head, to wit, the defendant did not make the instrument, will be discussed and disposed of: (a) Forgery; (b) material alterations. Under the second, to wit, that the contract sued upon is in law nonenforceable: (a) Incapacity of the party; (b) want, failure, or illegality of consideration; $(c)$ that the paper was obtained by frand; (d) that it was obtained by duress. Under the third, to wit, that the plaintiff is not entitled to sue: That the legal title to the instrument is not rested in the plaintiff. Inder the fourth, to wit, that the obligation ereated has been discharged: (a) By payment; (b) by bankruptey, or assignment under insolvent laws; $(c)$ by accord and satisfaction; $(d)$ by release; $(e)$ by covenant not to sue; $(f)$ by substitution of another obligation; (g) by set-off; $(h)$ under what circumstances a surety or guarantor is discharged when the principal is not. Under the fifth, that the action upon the instrument is barred by the statute of limitations.

It will be seen that many of the defenses enumerated in this classification lave been elaborately treated and disposed of in other portions of this volume, and they are mentioned here for the sole purpose of enabling the student to propenly appreciate the place they occupy in a treatise on the subject of defense. 


\section{SEC'TION I.}

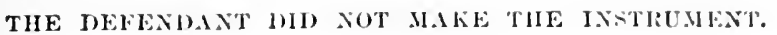

\$418. Forgery.- Forgery is the counterfeit making or altering of any writing with the intent to defrand. The most usual species of forgery is frandulently writing the name of an existing person; hut where one is in possession of a paper containing a genuine signature, and frandulentl. fills it up so as to malke it appear to be signed as maker, or indorser, or other party to a bill or note, it is as much a forgery as if the signature itwelf had been formed. ${ }^{1}$ So where one has authority to fill up a lill or note in blank, with a particular sum, and he framdulently inserts a larger sum, it is as much a forgery as if he had acted withont any authority at all:"

\$ 419. Illustrations of forgery. - P’asing a note signed br one person in lis nwn name, as the mote of another person of the same nane, if dome with intent to defrand, is a forgery ${ }^{3}$ and so appending to one's own name a false addition of description, as by residener or ocenpation, of another person of the same name; or indorsing a note by another person of the same name with the real paree, or special indorser.* So, one who, with intent fimululently to utter a promissory note as the note of a person other than the signer, procures to it the signature of an innocent party, who does not thereby intend to lime limselt, is guilty of forgery ${ }^{5}$ But where a person falsely represents himelf to te the indorwer of a bill, but writes mothing falsely himself, if there be a real person who did indorse the bill in his own proper name, the offense will not be forgery, hut obtaining

1 liex y. Hales, 17 st. Trials, 161: Pownll v. Commonwealth, 11 Gratt. 8:3.

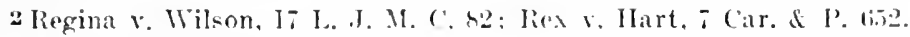

3 Tiex v. T'arke, 2 leach Cr. I. 6ilt.

4 Rex v. Webl, Rusu of R. ('. ( .72 : Rex v. Rogers, s Car. \& P. 629; Mead v. Young, 4 T. I. 2. .

s Conmonwealth v. Foster. lit Mass. 311. 
goods or money upon false pretences. ${ }^{6}$ And so as to any other genuine signature, though it be passed for another; yet if there be nothing upon the bill or note to apply it to that person, it is not a forgery. ${ }^{7}$

The signature of a fictitions name or firm, if made with intent to defraud, constitutes forgery. Thus uttering a forged order for the payment of money, signed "Rt. Venest," there being no such person in existence, is a forgery. So indorsing a bill in the fietitious name of "John Williams." 8

$\S 420$. Alteration is forgery.-The alteration of a completed instrument, by a material ehange in its terms, with intent to defraud, is as plain a forgery as the making of it altogether; for it fraudulently assumes to bind the parties to a contraet to which their eonsent is wanting. " Thus, where a clerk broke the seal of a letter, and altered a check which it eontained to a larger amount, it was deemed a forgery $;^{10}$ and so any fraudulent material change in the terms of the paper, whether in amount, place of payment, or time of payment. ${ }^{11}$ The making of the bill or note must be counterfeit and false in order to amount to a forgery, and if real, though fraudulently procured, it will be a fraud, but not a forgery. Thus, where a person writes a note for a certain sum, and procures another to sign it as maker, under the false representation that it is for a smaller sum, it is not a forgery. ${ }^{12}$

$\S 421$. Intent to defraud, and "uttering," essential.- $A n$ intent to defraud is essential to eonstitute forgery, and although a bill or note will not be binding upon those whom

- Hevey's Case, 1 Leach, 229 ; Chitty on Bills [*780].

7 Chitty on Bills [* ${ }^{\circ} \mathrm{S} 2$ ].

8 Commonwealth v. Chandler, Thatcher Crim. Cas. 157; Chitty on Bills [*782]; Lockett's Case, 1 Leach, 94; Taft's Case, 1 Leach, 172.

9 Wheelock v. Freeman, 13 Pick. 165.

10 Belknap v. National Bank, 100 Mass. 379.

11 Rex v. Post, Russ. \& R. 101; Rex v. Treble, 2 Taunt. 328; Rex v. Atkinson, 7 Car. \& S'. 669.

12 Commonwealth v. Sankey, 22 Pa. St. 390 ; People v. Getchell, 6 Nich. 496. 
it purports to bind if their names have been signed to it, or it has been altered without anthority, the party who hat ignorantly or innocently executed or altered it muler a supposed authority, will not be deemed guilty of a forgery. Nor will the mere imitation of another's writing, the assumption of a name, or the alteration of a written instrument, where no person can be injured therelyy, anount to forgery. ${ }^{14}$

The delivery of a bill or note, or other written contract, is necessary to its validity; and so the "uttering," which is the term used to describe the delivery by a forger or counterfeiter to some person of the forged instrument, is necessary in order to complete the crime of forgery. Giving the bill or note to a confederate to utter is an uttering thereof. ${ }^{15}$

\$ 422. Adopting of forged signature.- If one's signature i: forged, it is, as a general rule, a mere mullity as to him. It is legally accurate to say that he did not make the instrument. But if the person whose signature has been forged pronomes it gemune, or the instrument valid, the question arises whether or not such declaration renders him liable as if he were a party to a genuine instrument; and a variety of circumstances affect its just solution.

In the first place, when third parties buy the paper on his assurances or representations of the genumeness of his signature, or of the validity of the instrument, or are induced to act mon such assurances or representations, and would suffer loss if he were permitted to set up forgery as a defense, it is quite char unon principles of estopjel that such defense cannot he made. ${ }^{1 \mathrm{t}}$

In the second place, if $n$ prineiple of estoppel applies. and if through mistake a party states that a signature is gemine, and afterward he discovers his error, and speedily

1.3 Roscoe's Cr. Ev. 505.

1+ Chitty on Bills [*-85].

15 Rex y. Palmer. Rinss. \& R. C. C. 72.

18 Workman r. Wright. 33 (Hhio st. 405 ; Woodruff v. Monroe, 33 Md. 153; Beeman v. Duck, 11 M. \& W. 2.j. 
corrects it, and before the holder has changed his relation to the paper, or anyone has dealt with it upon the faith of his admission, forgery can be snceessfully pleaded. ${ }^{17}$

In the third place, it may be stated that where the party, knowing his signature to be a forgery, deliberately and understandingly adopts it as his own, he would be bound, because ratification thus made is equivalent to a previous authority, provided, however, that an imoeent third party has been indueed to aet upon the faith of the adoption in such a way as to suffer loss by its repudiation. This is based upon the familiar prineiples of estoppel. But whether such deliberate adoption of a forgery, without the consequent loss to a third party, acting on the faith thereof, would be binding is a mooted question, both in England and America. ${ }^{18}$

$\S 423$. When one party is estopped to deny the genuineness of another's signature.- The relation of one party to a negotiablo instrument is often such that he eannot deny the genuineness of another's signature, for, having treated it himself as genuine, it would be a fraud to permit hin to assert the contrary. Having issued or transferred the instrument as genuine in all respects, he would not only be bound by his guaranty that it is genuine, but it would be unjust to and frandulent upon others to permit him to deny it; and proof of his having so issued or used it would be sufficient to entitle the holder to recover against him. ${ }^{19}$

$\$ 424$. The position of drawer, indorser, drawee, acceptor, and transferrer in this respect.- The position of the drawer of a bill before aceeptance, in his relation to other parties, is ordinarily that of the maker of a note. If he issues the bill, as is generally the ease, withont any other name upon it but his own, he cannot be made responsible for the subsequent forgery of an indorsement or acceptanee; and if

17 Danicl on Negotiable Instruments, § 1352; Woodruff v. Monroe, 33 Ma. 158.

18 Daniel on Negrotiable Instruments, $\$ \$ 1352 a, 1352 b$, and cases cited. 19 Hortsman v. Henshaw; 11 How. 177 : Meaeher v. Fort, 3 Ilill (S. C.) 227; Alleman v. Wheeler, 101 Ind. 144. 
the name of the payee to whose order the bill is payable, or of a special indorsee, he forged, no recovery can he had against him." Sut if the drawer puts the lill in circulat tion with the nane of the payee indorsed upon it, he will be understood, by so doing, as aflirming that the indorsenent is in the handwriting of the payce, or written by his anthority. ${ }^{21}$ In respect to the drawce or aceptor of a bill, it is obvions that his relation to the instrument is very different from that of the parties who issued it. He shonld know his own correspondent's handwriting; and therefore the doctrine is laid down by numerous anthorities that if he aceepts the bill, or pays it, le cannot afterward, on dicovering that the signature of the drawer was a forgery, reroke the anecetance, or recover back the amount paid under mistake from the holder to whom he paid it. ${ }^{22}$

In respeet to the indorser of a negotiable instrument upon which the name of the drawer, naker, aeceptor, or of a prior indorser is forged, he, by indorsing it, warrants that he has clear legal title thereto, and that. the.instrunent is the gemuine alrticle it purports to be, and he is, therefore, bound hy his indorsenent to all parties subsequent to him, even thomgh the paper has been discomited for a prior party. ${ }^{23}$ Ite is hike the drawer of a bill who issues it with such names upon it. But if all the names of parties: antecedent to his own are genuine, he is then like the drawer of a bill who issnes it withont any names mon it; and if he pays it to anyone holding under a forged indorsement subsequent to his own, he may recover hack the amount. ${ }^{21}$ If the instrument be transferred by delivery simply, the aet of transfer by delivery of a negotiable instrument falls under the general rule of law, that in every sale of pereonal

20 Daniel on Negotiable Instruments, 3 ;35. 1356, 1361.

21 Hortsman v. Henshaw, 11 How. 17: Neacher v. Fort, 3 Hill (S. C.), 227.

22 Jyles on Bills |*324], 491; 2 Parsons on Notes and Bills, 5911, 511: itory on liills, $\S 411$.

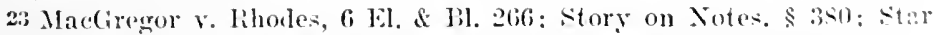

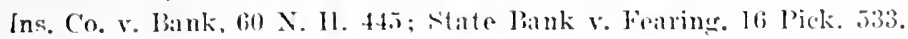

24 Daniel on Negrotiable lnstruments. s\$ 1225, 135.5, 1357. 
property the vendor impliedly warrants that the article is in fact what it is described and purports to be, and that the vendor has a good title or right to transfer it. ${ }^{25}$ Therefore, if the signature of the indorser be forged, the bank discounting the bill or note offered for discount with such indorsement upon it may recover back the amount from the party from whom it received it. ${ }^{26}$

\section{$\$ 425$. Acceptance no admission of indorser's signature.-} Ent the drawee who accepts or pays a bill is never regarded as thereby admitting the gemuineness of the simature of an indorser; for although it is true that every indorser is in respect to his liability the same as a new drawer to the bill, yet the acceptor cannot be presumed to have any such knowledge of this signature as he has of the drawer's, and therefore he is not presumed to admit it. ${ }^{27}$ If the drawee or acceptor of a bill were to pay it, and it turned ont that the indorsement of the payee or a special indorsee were forged, the result would be that he could not charge the amount in account against the chawer, and that the payment would be invalid; but as his act implies no admission of the genuineness of the indorser's signature, he conld recover back the amount from the holder to whom he paid it. ${ }^{28}$

$\S 426$. Whell money paid on forged instrument can, and when it cannot, be recovered.- It is a general principle of law that money paid under a mistake of fact may be recovered back. ${ }^{29}$ And accordingly, where one pays money on forged paper by discounting or cashing it, he can always recover it back, provided he has not himelf contributed raterially to the mistake by his own fault or negligence,

25aniel on Negotiable Instruments, \$\$ 731, 135s; Smith v. MeNair, 19 Kan. 330.

26 Jurgess v. Northern Bank of Kentucky, 4 Bush, 600; Cabot Bank r. Morton, 4 Gray, 15i.

27 White v. Continental Nat. Bank, 64 N. Y. 320; Story on Bills, $\$ \$ 262,412 ;$ Edwards on Bills, 190, 290, 400.

28 Lnited States v. National Park Bank, 59 Hun, 495; Canal Bank v. Bank of Albany, 1 Hill (N. Y.), 287; Smith v. Chester, 1 T. R. 654.

29 Louisiana v. Wood, 102 U. S. 298; Moses v. Nc.Terlar, 2 Burr, 1005; Carpenter v. Northboro Nat. Bank, 123 Mass. 69. 
and provided that by an immediate or sufficiently carly notice he enables the party to whom he has paid it to indemnify himself as far as possible ${ }^{30}$ And now the doctrine is favored that even negligence in making the mistake is no bar to recovery, unless it results in loss or damage."31 But it is undoubtedly necessary that the maker, aceeptor, or other party who demands restitution of money pail under a forged intorsement, or muder a forged signature of the drawer of a bill, shonld make the demand without umreasonable delay; ${ }^{32}$ but the mere space of time is not important, provided it be clearly shown that the holder will be put to no more liability, tronble, or expense by a restoration then than if it had been ealled for on the day of payment. ${ }^{33}$

Yet there may be ciremustances mnler which the acceptor, who has paid a bill under a forged indorement, conld not recover the amount from the holder. Thus, if the forged indorsement were upon the bill at the time when the bill ras issued by the drawer, the drawer or aceptor paying it could not maintain an action to recover the amount from the holder, for the reason why such actions are generally allowed would not apply. 'The holder conld himself recover from the drawer, as the latter conld not deny the genuineness of signatures which he had himself sent into the world. For the like reason the drawer or aceeptor could charge the amount in account against the drawer. ${ }^{34}$

\$427. Material alteration; general rule-Any ehangé in the terms of a written contract which varies its original le.gal effect and operation, whether in respect to the obligation it imports, or to its force as matter of evidenee, when

30 Frank v. Lazier, 91 N. Y. 115; Lovinger v. First Nat. Bank, 81 Ind, 358 .

31 Lnited States v. National Park lank, 6 Fed. 552; Fraker v. Little, 24 Kan. 599; Joung v. Lehnman, 63 Ala. 523.3.

:22 Luited States v. Clinton Nat. Jank, 20 Fed. 35\%.

3: Knontz v. Central Nitt. Bank, 51 Mo. 275; 2 Parsons on Notes and Bills, 59s: White $v$. Continental sat. Bank. 64 X. Y. 316.

at Daniel on Negrotiable Instruments. \$ 1366 . 
made by any party to the eontract, is an alteration thereof, unless all the other parties to the contract gave their express or implied consent to such change. And the effeet of such alteration is to nullify and destroy the altered instrument as a legal obligation, whether made with fraudulent intent or not. ${ }^{35}$ If the alteration be material, and made with a fraudulent intent, it is forgery; and if innocently made, and ret material, it ritiates the instrument, although it falls short of being forgery. ${ }^{36}$

$\S 428$. In what material alteration consists. - In order to constitute an alteration material, it must have the legal effect of changing the legal status or relationship of the parties to the instrument. This is true, without regard to the question whether it injures or benefits either the debtor or ereditor. Henee, a material alteration may consist in ehanging its date, or the time or place of payment, or the amount of prineipal or interest to be paid, or the medium or currency in which payment is to be made, or the number or the relations of the parties, or the character and effect of the instrument as matter of obligation or evidence. ${ }^{37}$ And the alteration may be effected by adding to the instrument some new provision, or by substituting one provision for another, or by obliterating or subtrating from it some provision ineorporated in it. As has been indieated, it will be no answer to a plea of alteration that its operation is farorable to the parties affected by it, whether in lessening or increasing the amount to be paid, or in enlarging or abbreviating the time of payment, ol otherwise. To man has a right to vary another's obligations at his discretion, whether for his good or ill. It eeases, when thus varied, to be that other's act, and it is sufficient for him to say: "This is not my contraet." 38

35 Nersman v. Werges, 112 U. S. 141; Angle v. Insurance Co., 92 U. S. 330; Heath v. Blake, 28 N. C. 406.

36 Daniel on Negotiable Instruments, \& 1373.

3i Daniel on Negotiable Instruments, \$ 1375; Drexler v. Smitlı. 30 Fed. 757 .

38 Weir v. Walmsley, 110 Ind. 246; Warden v. Ryan, 37 Mo. App. 466 ; Wager v. Brooks, 37 Minn. 392. 
Even a decrease of the amount destroys the identity, and confuses the traces of his obligation, and every reaton of pulieg and principle forbicl that the laws should rolerate tampering with the rights and engagements of others.

$\$ 429$. Changing date of instrument and time of payment.Any elange in the date imparts a new legal effect and operation to it, and is a material alteration, which aroids it at against prior parties and sureties eren in the hands of at bona fille holder without notice. ${ }^{39}$ The time the instrument becane a subsisting contract, and the time when the contract is to be performed in many cases, and a thousind circumstances may arise which may adhl consequence to the question when the instrument was issued. It matters not that the time of payment by relation to the date, may bo prolonged, for suffice it to say it wals not the time agreed on. Thus, in a case before the Inited States Supreme Court, where the maker of the note, drawn payable ono year from date, changed "September 11 " to "October 11 " before delivery, withont conent of his smety, it was held that the note was aroiled as to him. ${ }^{40}$

The alteration nuy be in the rear, or the month, or tho day of the montl, or in all three. ${ }^{41}$

Even where a note was altered in date to one day prerious, and the effect as to its time of maturity remained unchanged, because of the ciremstance that originally it would have fallen due, as its face imported, on Sunday, and therefore would have heen lecally dne on Saturday, and by the ehange of date it fell due on satuday, so that in point of fact Saturday in either ease was its day of paynent, it was held that it was aroided by the alteration. ${ }^{42}$ And the decision seems clearly right. And alecordingly, an insertion of a date in a blank left for that purpose in al note intrusted

Master v. Miller. 4 T. R. 3:0); ('rawford r. West side Bank. 100 N. Y. 5ti; liritton r. Dierker, ti Mo. 5i?.

to Wood vateele, fi Will. so.

41 Thomp $h$ on Bills, 111: Jacob, r. Hart. 2 Stark. 4i: Onthwaite v.

Luntley, 4 fimplo. 179: Walton $x$. llastings. 4 Campb. 2023.

42 Stevens r. Graham, 7 seres. \& R. 505. 
to the maker by the indorser, has been held not an alteration, as an authority to fill the blank will be implied from the relations of the parties. ${ }^{43}$

A change in the time of payment is obviously of the same nature as a change in the date, identical in principle and effect; and whether such change delays, accelerates, or preserves in legal effert the time specified or implied for parment, it constitutes a material alteration. ${ }^{44}$

$\S 430$. Changing place of payment.- When the instrument has been drawn payable at a particular place, the obliteration of such place, so as to make it payable generally, constitutes a material alteration as against all the parties not consenting ${ }^{45}$ and likewise where no place is designated, it is a material alteration to insert one. ${ }^{43}$ And a fortiori it is a material alteration to obliterate one place and insert another' as, for instance, to erase an acceptance payable at "Bloxham \& Co.'s," and insert the name of "Esclaile \& Co." in liew. ${ }^{4 i}$ Where the drawer of a bill, after aceeptance and without acceptor's consent, wrote after the acceptance "payable at Mr. B.'s, Chiswell street," it was held a materiai alteration and the acceptor discharged ${ }^{48}$ though in England it was formerly held otherwise. ${ }^{49}$ So, striking ont "in London," and thus making the bill payable generally. So, adding to a note "payable at the Bank of Smyrna." so Even a bona ficle holder cannot recover upon an acceptance so altered, nor upon a note so altered against parties prior to the one making the alteration. ${ }^{51}$ Changing the place of

43 Nitchell v. ('ulver, 7 Cow. 336.

$4 \pm$ Bathe $v$. Taylor, 15 East, 412 ; Miller v. Gilleland, 19 Pa. St. 119.

45 McCurbin v. Turnbull, Thompson on Bills, 112.

46 Nazro 5 . Fuller, 24 Wend. 374; Townsend v. Star Wagon Co., 10

Nebr. 615; Whitesides v. Northern Bank, 10 Bush, 501.

47 Tidmarsh v. Frover, 1 Maule \& S. 735; Bank of Ohio Valley v. Lockwood, 13 W. Va. 392.

48 Cowie v. Ilalsall, 4 B. \& Ald. 197.

49 Trapp $v$. Spearman, 3 Esp. 57.

so Burchfield $v$. Noore, 25 Eng. L. \& Eq. 123; Sudler v. Collins, 2 Houst. 5.38; Bullard v. Insurance ${ }^{\circ}$ Co., 81 Ind. 239.

51 Nazro v. Fuller, 24 Wend. 374; Sndler v. Collins, 2 Houst. 538. 
date would ehange the rights of the parties, and henee is an alteration. ${ }^{\mathbf{2}}$

The effect of statutes in Fngland and in the Lnited Siates which provide that aceeptances of bills drawn payalule at a banking-houso or other particular place shall lwe deemed general acceptances do not vary the principles applicable to alteration, because, though the acceptance bo general, the insertion of a particular place induces the holder to present the bill there, instear of to the acceptor himself. ${ }^{53}$

$\S 431$. Change in amount of principal or interest. - Iny change in the amount of the principal for which the instrument is executer is a material slteration, whether it be increased or lessensel; as where, for instance, the anount is changed from $\$ 500$ to $\$ 400$, for it is a palpable variance of the instrument's legal eflect in its most vital part. ${ }^{51}$ Indeed, an alteration to a larger anomnt is a forgery; and so also of a smaller anomut, if with f'andulent intent.

It has been held that where the principal altered a note so that its anomt was lessened, and then delivered it to the payee, the surety was not discharged.5 Certainly the identity of the contract was destroyed, and it is difficult to reconcile this case with the principles and anthorities already stated. Donbtless, the idea that it was a release, and therefore a benefit to the surety, pro lanto, had a weight, influence with the court; but the law denominates any change in the legal effect of a contract an alteration, and its poliey is to tolerate no tampering with written instruments.

Any addition of words making the bill or note bear interest when it originally dicl not, or changing the time when interest should rm, or valring the percentage of interest,

52 Mahliawe lank v. Douglass, 31 Conn. 170.

53 Daniel on Nexrotiable lustruments, \$ 1379.

b4 lank of Commerce $v$. Union lank, 3 N. Y. 230: Patchelder $v$. White, 80 Va. 103; Stevers $v$. Grahum, 7 Serg. \& R. 505; Hewins $v$. Cargill, 67 MIe. 554.

55 Ogle v. Graham, 2 Pa. 132. 
is of the same character as if it ehanged the prineipal. ${ }^{58}$ If the rate of interest be left blank, authority is not implied to the holder to fill in an amount greater than the legal rate, and he would effect a material alteration in doing so. ${ }^{57}$ But he may insert the legall rate. ${ }^{5 s}$ Where the words "with lawful interest" were written on the corner of the note; where "with interest from date" were incorporated in it; and where "with interest" were written by the maker after it had been indorsed, but before delivery to the payee, it was alike held to be material, and to avoid the note as against noneonsenting parties ${ }^{59}$ where " with interest payable semi-annually" were inserted before delivery to payee, and where they were inserted afterward, the surety was discharged;" and where "with interest" mas added, but without frandulent intent, and "interest to be paid annually." 61 So adding, " eight per cent. interest; " or " bearing ten per cent. interest from maturity;" or "with half legal interest until maturity;" and so where "after maturity" was added to interest clause; and so where the like words in the interest clause were erased. ${ }^{62}$ A change of pereentage is of like effect. Thus, where "nine per cent." was added to the words of a note "on demand and interest;" and where twelve per eent. was changed to ten. ${ }^{63}$

$\S 432$. Change in medium of payment. $-A$ change of the kind of curreney, as by the addition of the words "in specie" to a bond after the sum; or the word "gold" after the term "dollars" in a note; or of the denomination, as "from

56 Iarsh v. Klepper, 28 Ohio St. 200; Woodworth v. Anderson, 63 Jowa, 503; Davis v. Henry, 13 Nebr. 500.

57 Jloopes r. Collingwood, 10 Colo. 107.

ss First Nat. Bank v. Carson, 60 Micli. 437.

69 Warrington v. Early, 2 El. \& Bl. 763; Brown v. Jones, 3 Port. (Ala.) 420; Waterman v. Tose, 43 Me. 504.

60 Neff v. Iforner, 6.3 I'a. St. 32i; Dewey v. Reed, 40 Barb. 16.

e1 Fay v. Smith, 1 Allen, 477; Boalt v. Brown, 13 Ohio N. S. 364.

62 Hart v. Clouser, 30 Ind. 210 ; Jee v. Starbird, 55 Me. 491; Jamar

v. Brown, 56 Ala. 157; Coburn v. Webb, 56 Ind. 96; Dietz v. Harder,

72 Ind. 208.

63 Irory v. Michael, 33 Miss. 398; Whitmer v. Frye, 10,Mo. 348. 
pounds into dollars; from sterling pounds into current pounds," even though it conld do no possible injury, would aroid the instrument, ${ }^{6+}$ and there might be cases in which positive or possible injury would result. Anel so the erasure of such words would equally amomit to alteration. In a reent case before the United States Supreme Court, the words in an order which made it payalle " in elrafts to the order of H. G. A." were erased with a pen, and " in current funds" inserted in their stead; and the palper was held avoided therely. sit So, if the instrument be parable in goods, on the sime principle, if the strle or character of the goods were changed, it would be vitiated. It was so hell where a note was payable " in merchantable meat stock," and the word "young" was interpolated after merehantable;" so, adling" "good hard" before " wood," or writing" "good" before "merchantable wool." is

$\S 433$. Change as to parties. - Any alteration in the personality, number, or relations of the parties is, as a general rule, a material alteration. Thus, where C., nember of the firm of C. \& C co., obtained an accommodation indorsement to his individual note, and then added " \& Co." to his: signature, thus making it his firm's note, it was held a m:lterial alteration. ${ }^{69}$ When there are sereral maker's or ensureties, the addition of another maker or cosurety constitutes a material alteration; for the addition of anothe: maker destroys the integrity of the original contract; and the addition of another eosurety (hamges the right of the surcties in respect to the proportion of contribution for which each is liable to the others." Ind the erasure of the

6t Darwin v. Rippey, 63 X. C. 31s: Pogarth v. Breedlove, 39 Tex. 561 ; Stevens v. Grahan, 7 Serg. \& R. 505.

is Church r. Howard, $16 \mathrm{Il} \mathrm{un}$, 5.

66 Angle v. N. W., ete., Ins. Co.. 92 L. S. 330.

67 Martendale v. Follett, 1 N. Il. 9.5.

6s Schwalm v. Melntyre, 17 Wis. 232.

6 Haskell v. Champion, 30 Nliss. 136.

70 Hamilton $r$. Hooper, 46 Iowa, 516; Houck v. Graham, 106 Ind. 195; MeVean v. Seott, 46 Barb. 379; Sullivan v. Rudisill, 63 lowa, 15s; Monson v. Drakeley: 40 Conn. 552. 
name of one of two drawers or makers, or payees, who have indorsed the paper, or of one of several cosureties, or the name of the payee and inserting another, is likewise a material alteration. ${ }^{71}$ So the substitution of one drawer or drawee, or maker or comaker for another, is of like effect. ${ }^{{ }^{2}}$ Whether or not the addition of another name to that of the maker (when there is but one) is a material alteration, which discharges hin, is a question upon which the authorities are divided. Applying sound principle to the controversy, it would seem that the alteration should be regarded as inmaterial. The addition does not vary the original maker's liabilities in any respect. There could be no motive of fraud upon him or others to induce the addition. And while it would come within the letter of those declarations of courts that maintain anything which affects the integrity of the instrument to be a material alteration, it does not seem to come within their spirit. ${ }^{73}$

$\$ 434$. Change affecting the character of the obligation.-A change in the character or effect of the instrument, whether in respect to its obligation or to its weight in evidence, is a material alteration. Thus, the addition of a seal to the signature of the maker of a note converts it into a bond, against which no plea of want of consideration can be made, and thus invests his contract with attributes which he declined to impart to it. ${ }^{74}$ Consequently the note is avoided. So a bond is avoided by detaching the seal. ${ }^{75}$

So when a seal is added to the name of one of several comakers of a note, all are discharged, because the holder could not have the same recourse against the three which he held before; one would be estopped from denying a

71 Mason v. Bradley, 11 M. \& W. 590; Cumberland Bank v. Hall, 1 Hals. 215; MeCramer v. Thompson, 21 Iowa, 244; Robinson v. Berryman, 22 Mo. Al]1. 510; Horn v. Bank, 32 Kan. 521.

72 Davis v. Coleman, 7 Ired. 424 ; , State v. Polk, 7 Blackf. 27.

73 Daniel on Negotiable Instruments, $\$ \$ 1388,1389$, and eases eited.

74 United States v. Linn, 1 How. 104; Marshall v. Gougler, 10 Serg. \& P. 164.

5 Pierey v. Piercy, 5 W. Va. 199. 
want of consideration which might inure to the benefit of all, and new relations and obligations would be created.

"The interlining of the words " juintly and severally," or "severally", or "or either of us" in a note joint and not several, would be a material alteration, as they wonld engraft upon the joint a several obligation. it But where a joint note hils the effect to bind the parties jointly and severally, the insertion of those words would be immaterial, becanse merely expressing what was alrearly implied. ${ }^{i 7}$

And the changing of a note from "I pronise" to "We promise" is material, because it ehanges a joint and several note into one joint only. is Adling the word "collector" by the payee to his name has been held in New Jersey a material alteration. ${ }^{i 9}$

The addition of the name of a witness to an instrument required by law to be witnessed is a material alteration, but if the instrument need not lee witnesed or if it already has on the number of witnesses required by law, the alteration is immaterial.

\$ 435. Change in consideration.- It has been held that if a bill be expressed generally "for value received," and words are added describing such ensideration as "for the good-will and lease in trade" of a certain person, or "for a certain tract of land," it is materially altered and avoided." The reasons assigned are, first, that it makes the note a confession in evidence of a fact which might otherwise require extraneous proof; and, second, that it puts the holder upon inquiry whether that consideration passed. ${ }^{\text {s1 }}$

$\$ 436$. Change in words of negotiability.- The addition of the negotiable words, "or order," or "bearer," is not an

78 Perring v. Hone, 2 Car. \& P. 401; Draper v. Wood, 112 Mass. 315.

77 Gordon v. Sutherland, Thompson on Bills, 113: Miller v. Reed. 27 Pa. St. 244.

78 Humplireys v. Guillow, 13 N. II. 385: Hemmenway v. Stone. 7 Maสะ. 58.

70 York v. Jones, 43 N. J. L. 332.

80 Knill v. Williams, 10 East, 413 ; Low v. Argrove, 30 Ga. 129.

812 Parsons on Notes and Bills, 562; Daniel on Negotiable Instruments, \& 1394 . 
alteration when they were intended to have been inserted, and were aecidently left out. ${ }^{52}$ But where the effeet of such addition is to impart negotiability to an instrument not designed to be negotiable, it is a most material alteration in the nature of the contract, and the bill or note is thereby aroided. .3 So the interlineation of "or bearer" in a negotiable note, payable to a certain person or order, is an alteration of it, because it materially ehanges the mamner of its negotiability. ${ }^{84}$

$\$ 437$. Immaterial alterations.- If the legal effect be not changed, the instrument is not altered, althongh some ehange may have been made in its appearance, either by the addition of words which the law would imply, or by striking out words of no legal significance. ${ }^{85}$ Thus, writing out the name of the bank after the name of the signature "eashier," which was intended to bind the bank, is merely expressing more elearly the legal effect of the signature, and is not an alteration. ${ }^{s i}$ So the insertion of a dollar mark before the mumerals expressing the amount in dollars; or insertion of the word "ammully" after the interest elanse in a note parable on or before a certain time; or ehanging the marginal figures so as to eonform them to the written amount; or the addition in full of the christian names of the drawers whose surnames had been affixed before the acceptanee; the interlineation of the surname of the payee, after lelivery; the rumning of a pen through the words "Providence SteamPipe Co.," which was one name under which a firm did business, and writing over it their style in the eopartners' names, were likewise adjudged immaterial. ${ }^{87}$ So also where

\$2 Kiershaw v. Cox, 3 Esp. 246 ; Byrom v. Thompson, 11 Ad. \& El. 31. 83 liruce v. Westcott, 3 Barb. 274; Johnson v. Bank of the United States, 2 B. Mon. 310.

84 Booth v. Towers, 56 N. H. 30; Union Nat. Bank v. Roberts, 45 Wis. 373 .

85 Tutt $v$. Thornton, 57 Tex. 35; Fulfer v. Green, 64 Wis. 164.

86 Jank of Genesee v. Patchin Bank, 13 N. Y. 309; Folger v. Chase, 18 l'ick. 63.

87 Houghton v. Francis, 29 111. 244; Leonard v. Phillips, 39 Mich. 182; Smith v. Smith, 1 R. 1. 398; B]air v. Bank of Tennessee, 11 Humphr. 84; Manchet v. Cason, I Brev. 307; Arnold v. Jones, 2 R. I. 345. 
a bill was addressed to a firm ly the style of " $\Lambda$. I3. \& Co.," and on being accepted by them in the nane of " $\Lambda$. $\mathrm{L} B$.", and the address was changed to conform to the areceptance, there being no question as to the identical firm intended, and the acceptors being liable cither way. It may he gonerally stated that no change in the phrareologe of the instrument is material when it does not essentially change its legal effect. ${ }^{89}$

$\$ 438$. Change authorized.-It is quite obvions that where all the parties to a bill or note expressly agree to a change in any of its terms they cannot complain of such change as an alteration." They have as much right to change as to make a contraet. And where all do not consent, those consenting are bound, while the rest are discharged."

Consent may be given before the change is made, or it may be given afterward by ratification. It ma be express, or it may be implied from custom, or from the acts of the parties. ${ }^{93}$ Where one indorses for accommodation of the maker, a note in which the place of paynent is left blank, authority to the maker to fill the blank will be presumed, that being indispensable to the negotiability of the instrument, and the use of it for the purpose intended. ${ }^{94}$

$\S 439$. Bights of bona fide holder of altered instrument.As a general rule, the material alteration of an instrument will vitiate it, even in the hands of a bona fide holder without notice. But when the drawer of the bill or the maker of the note has himself, by eareless execution of the instrument, left room for any alteration to be made, either by insertion or erasure, withont defacing it, or exeiting the

8s lonrquhar r. Sonthey, Moody \& M. 14.

89 Ilolland $r$. Ilatch, 15 Olio St. 464.

(n) Wallow v. Jist, 41 Ohio St. 414.

91 Grimstead v. liriggs, 4 Iowa, 5.59; lank of Ohio Valley $v$. Lockwood, 13 W. Va. 392.

92 Nitional Stite Bank v. Rising, + IIm, 793; Camnon v. Grigsby. 116 I11. 151.

93 Woodworth v. liank of America, 19 Johns. 391 ; Clute r. Small. 17 Wend. 238.

9t Wessell r. Glenn, los Pa. St. 105. 
suspicions. of a careful man, he will be liable upon it to any bona fide holder without notice when the opportunity which he has afforded has been embraced, and the instrument filled up with a larger amount or different terms than those which it bore at the time he signed it. ${ }^{95}$ The true prineiple applicalble to such cases is that the party who puts his paper in eirculation, invites the public to receive it of any one having it in possession with apparent title, and he is estopped to urge an actual defect in that which, through his act, ostensibly has none." "It is the duty of the maker of the note to guard not only himself, but the publie, against frauds and alterations by refusing to sign negotiable paper made on such a form as to admit of fraudulent practices upon them with ease, and without ready deteetion." 97 The inspection of the paper itself furnishes the only criterion by which a stranger to whom it is offered can test its charaeter, and when the inspection reveals nothing to arouse the suspieions of a prudent man, he will not be permitted to suffer when there has been an actual alteration, to which the payor by his negligence eontributed.9s

If the alteration were made withont any fault on the part of the maker, drawer, or aceeptor, neither will then be bound, although the alteration were so skilfully made as to eseape notice upon eareful observation. Thus, where a banker's eheck had been dexteronsly altered by a chemical process, the original sum being expunged, and a larger inserted, the banker was not allowed to recover of the drawer more than the sum for which the draft actually called when he drew it. ${ }^{99}$

$\$ 440$. Effect of material alteration fraudulently made.When a party to a bill or note fraudulently alters its legal

95 Garrard v. Haddan, 67 Pa. St. 82 ; Johnston Harvester Co. v. McLean, 57 Wis. 258; Lowden v. National Bank, 38 Kan. 533.

96 Van Duzer v. Howe, 21 N. Y. 538.

97 Zimmerman v. Rote, 75 Pa. St. 18s; Brown v. Reed, 79 Pa. St. 370. 98 Daniel on Negotiable Instruments, § 1405; Blakey v. Johnson, 13 Bush, 204.

99 Hall v. Fuller, 5 B. \& C. 750. 
effect, he not only destroys the instrument ly thus destroying its legal identity, but he also extinguishes the debt for which it was given. And it camot afterward be made the basis of, or evidence for, a recovery in any form of action whatever ${ }^{1}$ though, of course, it might be adnissible to defeat a claim on the ground of frand, or convict a party of a crime." It is necessary that the law shonld impose this forfeiture of the debt itself upon one who frandulently tampers with the instrument which evidences or secures it; and it is done upon the prineiple that "no man should be permitted to take the chance of gain by the commission of a fraud, without rmming the risk of loss in the case of detection." 3

\section{$\$ 441$. Effect of material alteration innocently made.- If} the alteration is material, and was made innocently, the instrument, notwitlstanding, is vitiated, and no suit thereon can be maintained. ${ }^{*}$ But the holder may sue upon the original cause of action $;^{5}$ but he could not sue any party whose remedr, after making payment, wonld be impaired by the alteration." In a New York case the law applicable to the situation stated has been thus expressed: "If the alteration was made without frandulent intention the payee may resort to the original indebtedness, if that was independent of the note, and has not been discharged by the execution of it, and pursues the maker upon that. But to have such resoit, he must le able to produce and surrender the note.": There is a class of calses, however, that announees the rule to be that the instrument is ipso facto

1 Wheelock v. Freeman, 13 I'ick. 16.5; Booth v. Powers, 56 N. Y. 31; Wallace v. Harmstad, 44 Iar. St. 492.

a Chitty on Bills [*191], 219.

8 Newell r. Maybery, \& Leigh, 254; Vogle v. Ripper, 34 Ill. 107.

4 Angle v. x. W.. ete., Ins. Co.. 92 U. S. 34: Harsh v. Klepper, 20 Ohio St. 200; liooth v. Powers, 5t N. Y. 31; Moore v. Ilutchinson, 19 Mo. 429.

6 Atkinson v. Hawden, 2 Ad. \& Hl. 169: Owen v. Hall, 70 MId. 100;

Sloman v. cox, I Cromp., M. \& R. $4 \pi$ I.

6 Alderson r. Jangdale, 3 B. \& Ald. 660.

T Booth r. Powers. if $\mathrm{N}$. Y. 31. 
aroided, and the original consideration forfeited, regardless of the intention with which the alteration was made.

\section{$\$ 442$. Effect of immaterial ehange with fraudulent intent.-} It is said by some of the anthorities, and by Greenleaf in his treatice on Evilence, that if the alteration be frandulently made by the party chaming under the instrument, it does not seem important whether it be in a material or an immaterial part; for in either ease, he has brought himelf maler the operation of the rule established for the prevention of framl; and having fraudulently destroyed the identity of the instrument, he must take the peril of all the consequences. ${ }^{9}$ There are cases that support the conchsion just amounced, but it seems to be at variance with correct principle. If the change destroys the identity of the instrument, it is material; but it has been well said, "an immaterial alteration may be treated as no alteration;" and accordingly held that if the act itself is immaterial and can work no injury, it is irrelerant to inquire into the motives with which it was committed. Intent not manifested in a material respect is nugatory, and this we conceive to be the true doctrine. ${ }^{10}$

$\S 443$. Burden of proof of alteration.- The question as to the burden of proof in respect to alterations is generally affected by all the surromding circumstances; and one fact or another shifts it to and fro, the jury being left to weigh the testimony and determine the issue with all the lights that can be thrown upon it. ${ }^{11}$ Very slight ciremmstances may operate to shift the burden of proof, and it has been well said by IForton, C. J., in Kansas, that " it is impossible to fix a castiron rule to control in all cases." 12 "The an-

S Bigelow v. Stephens, 3.5 Vt. 525; Martendale v. Follett, 1 N. H. 99: Savings Jank $v$. Shaffer, 9 Nebr. 1.

9 Greenleaf on Evidence, vol. 1, p. 568.

10 Daniel on Negotiable Instruments, \& 1416; Moge v. Herndon, 30 Miss. 120.

11 Admrs, of leaman v. Russell. 20 Vt. 210; Bailey v. Taỵlor, 11 Conn. 531; Kount\% v. Kennedy, 63 Pa. St. 190.

12 Neil v. Case, 25 Kan. 510. 
thorities are every way upon the proposition, and from the resulting confusion the most that cau be generally said is that each case must rest largely upon its own peculialr surroundings. Chief Justice llorton, in the Kansas care referred to, stated the conflict of the cases on this subject as follows: "lhis in a rexed question, and the books are full of diverse decisions. Four different rules are generally stated. (1) That an alteration on the face of the writing raises no presumption either way, but the question is for the jury. (2) That it raises a presumption against the writing, and requires, therefore, somo explanation to render it admissible. (:3) That it raises such a presumption when it is suspicious, otherwise not. (4) That it is presumed, in the absence of explanation, to have been mide before delivery, and therefore requires no explanation in the first instance. $* * *$ Generally the instrument should be given in evidence, and in a jury case should go to the jury upon ordinary proof of its execution, leaving the parties to such explanatory evidence of the alteration as they may choose to offer. If there is neither intrinsic nor extrinsic evidence as to when the alteration was made, it is to be presuned, if any presmuption is said to exist, that the alteration was male before, or at the time of, the execution of the instrument. Perhaps there might be eases when the alteration is attended with manifest cireumstances of suspicion that the court might refuse to allow the instrument to go before the jury until some explanation."

\section{SECTION 11.}

THE CONTRACT SUED UPON IS IN LAW XONENFORClADLE.

$\$ 444$. Incapacity of the party.-This subject lias been heretofore fully and extensively treated in Book II, under the head of "Parties to the Instrument," 13 and repetition is munecessary. If the party sned habor under a legal disability, whether the disahility exists for the sake and pro-

13 Ante, $\$ \$ 116-167$. 
tection of the incapacitated party, or grows out of a settled public policy, the obligation is a nonenforceable one. This detense is available not only as between immediate parties, but also as against a bona fide holder for value.

$\$ 445$. Want, failure, or illegality of consideration. - While consideration is presumed in all cases of negotiable contracts, and the plitintiff can rely upon this presumption, and thrs east the burden of showing its absence upon the defendant, the presmmption is rebuttable, and when the want or failure of a sufficient consideration is attacked and substantial evidence is offered to sustain this defense, the burden shifts, and it rests with the plaintiff upon the whole case to show by a preponderance of the eridence a consideration sufficient to support the instrument sued on. The defense of absence or failure of consideration is good only between immediate parties.

The consideration is presumed to be legal, and, so far as presumptions and burden of proof are concemed, is governed by the same prineiples that apply to want or failure of consideration; but if in consequence of the illegality of consideration, the instrument is by law declared void, this defense avails not only as between the immediate parties, but also against the bona fide holder for value.

These general observations are suffieient in this place and connection - the entire subject having been heretofore treated in a separate chapter. ${ }^{14}$

$\$ 446$. Fraud.-Bishop, in lis work on Contracts, defines fraud to be: "Any spoken or acted falsehood, whereby one is inchced to enter into what in form is a contract, under the belief that it is a different thing from what it is, or that there is for it a motive which does not in truth exist." 15 In the sharp phrase of Lord Chief Baron Pollock, in a leading English case, "Frand cuts down everytling." There seems to be no assignable limit beyond which fraud

\footnotetext{
14 Ante, $\$ \$ 90-115$.

1. Tishop on Contracts, \& 643 .

16 Rogers v. Hadley, 32 L. J. Exch. (N. S.) 248.
} 
is destitute of legall coffect. "It ritiates every" transaction, whether of contract, of judicial proceeding, or otherwise, into which it enters." If a party, thromgh the framel of another, is induced to exeente a contract wholly different from what he meant, and he is without laches in the transaction, the fraul partakes of the natme of a forgery, and the instrument signed by him is not in law his eontract. It is not merely voilable, lut void - void in the hamels of an innocent thied party, as well as between the original parties. If, however, the frand consists in the induecencent or consideration to the entering inte the contract, and the party executed the instrunent he intended to, the defente will avail between the immediate parties, but will not be effectual against a bona fide holder for value.

\$ 447. Duress._. " Inuress is atetual or" threatened personal violence or physical restraint to a persom, or, in some cates, to the person's husband or wife or near blool relative, or to his fortune, such as will inchere lim to perform some act muler such ciremustances that that act is not the prodnet of his will." "This subject hats been elewhere treated, with special reference to the rights of bona fide holder: for value. ${ }^{18}$ In this connection the student shonlul remember that chross is always a good lefense between the parties to the transaction, and that while the authorities are not uniform, the current of the decisions supports the view that this defense is good even against the bona fide holder for value.

\section{SECTION III.}

THE PLANTIFE IS NOT ENTTIEL TO SUE.

\section{$\$ 448$. Legal title to instrument not vested in plaintiff.- As} has been seen, the transferee of a non-negotiable contract must bring action in the name of the original payee, to the wise of the transferece. This is mon the theory that, notwithstamling the assignment, the legal title remains in the

17 Am. \& Eng. Eneye of Law (2d ad.) vol. X, p. 321. 18.4 ntr. $\$ 224$. 
original owner. But the transfer of a negotiable contract carries with it the legal title thereto, and the owner thereof nust bring aetion in his own name. It follows that if the plaintiff is not the legal owner of the instrument, los camnot maintain suit thercon in his own name. Any defense which attacks the method and mamner of transferring the legal title to a negotiable instrmment, or that would invalictate the transfer, or any denial of the existence of a transfer to the plaintiff, either by delivery, or by indorsement and delivery, as the ease may be, would, if made out, constitute a legal bar to an action brought thereon. What has been heretofore said on the subject of transfer by indorsement and delivery, and of the steps that may be necessary in detail to effectuate a change of legal ownership from one person to another, need not be repeated here. As to when one ean maintain suit in his own name, and when he must sue in the name of another, was fully disenssed in the ehapter on the subject of actions. It is generally sufficient here to say that if the plaintiff is not the owner or the agent or trustee of the owner, a defense suecessfully setting up the fact will defeat recovery.

\section{SECTION IV.}

THE OBLIGATION CREATED IIAS BEEN DISCHARGED.

\$449. Payment, nature of.- By payment is meant the digcharge of a contract to pay money by giving to the party entitled to receive it, the amount agreed to be paid by one of the parties who entered into the agreement. Payment is not a contract. It is the diseharge of a contract in which the party of the first part has a right to demand payment, and the party of the second part has a right to make payment. A sale is altogether different. It is a contract which does not extinguish a lill or note, but continues it in cireulation as a valid security against all parties. And it is necessary to constitute a trausaction a sale that hoth parties should then expressly or impliedly agree, the ono 
to sell, and the other to purchase the palprer. ${ }^{19}$ Whether the transaction is a purchase or payunent, is a question for the jury where the farets ale in rispute, to be resolved atecording to the intention of the panties, and losking to the substance of the matter rather than its form. ${ }^{20}$

Credit given by the drawee of a bill, or by a party lo al bill or note, who is liable tor its paynent to the holule at lis request, is equivalent to paynent. ${ }^{2}$ But if a bill alcrepted for the drawer's accommodation be sent to bank fol' collection, and he credited to the holder at maturity, it has been ledel that the bank, as its holder, may sue the aceceptor."2- "Payment of a delot is not necessarily a paymont of money; but that is payment which the partics contract shall be accepted as paynent," or which the law recognizes as such.:" When a party to the instrument pays to the holder the amount due upon it, he camnot show that he was acting as the secret agent of another, and convert the payment thus male into a purchase.

$\S 450$. Who may make payment. - Iny party to a bill or note may pay it, and an indorser who has been discharged by fallue of notice may still sue a prior indorser or other parties who were not discharged, because, although not eompelled to pay it, he acquires the right of the holder from whom he took the instrument, or is remitted to his own rights as indorsee. ${ }^{24}$ But it seems that if the indorser has another note given him to secure and indemnify him for his indorsement, and, not being notitied, waives the detense, and voluntarily pars the bill or note, he eamot enforce the note given him as indemnitr." Ind a stranger has no rinht to pay or discharge the contract of another, and cannot,

19 Laneey v. Clark, 64 X. I. 209: Eastman v. Plumer. 32 X. H. 23૭.

20 longherty v. Deeney, 4., Iowa, 443: Rand v. Barrett, 66 Iowa. $33 . \overline{\text { : }}$ Swope r. Leflingrwell. 72 Mo. 34s.

21 Savage $\because$ Merle. 5 lick. si3.

ma Iacific Bank v. Miteluall, ? Mete. Mass.) 297.

23 Huffmanns r. Walker, 20; Giatt. 315; Lionberger v. Kinealy, 13 Mo. Apl. 4.

24 Ellswortl v. Brewer. 11 ['ick. 316.

क Bachellor $v$. Priest, 12 Pick. 39?. 
pay a bill or note so as to acquire the rights of a holder, except supra protest, as hereinafter indicated. ${ }^{26}$ But a stranger may always purehase a bill or note with the consent of the holder. Where the drawer, when discharged hy the failure of the collecting agent of the holder to present in dne time, nevertheless took up and paid his draft, lout under protest, to protect his eredit, he was hedd a mere volunteer with no right to reeover against the collecting agent of the lolder through whose defanlt he was discharged from payment. ${ }^{2 \pi}$

$\$ 451$. Payor should see that holder traces legal title.- The maker of a note or the acceptor of a bill must satisfy himself, when it is presented for payment, that the holder traees his title through genuine indorsements; for if there is a forged indorsement, it is a nullity, and no right passes by it. And payment to a lolder moler a forged indorsement would be invalid as against the true owner, who might require it to be paid again. ${ }^{2 \times}$ But the maker or aceeptor might recover back the noney as paid under a mistake of fact. ${ }^{29}$ When, howerer, the signature of the drawer is forged, should the drawee accept or pay the bill, he becomes absolutely bound, lecanse it is his duty to know the drawer's handwriting; and if he pays the money he cannot recover it back. ${ }^{30}$ But aeceptance does not admit the signature of the drawer as indorser also; nor the anthority of an agent to inclorse a bill drawn by him as agent of the drawer. ${ }^{31}$ If an indorser pays a bill or note upon which there is a prior forged indorsement, he cannot recover back the amount, because his indorsement was in itself a warranty that the

26 Edwards on 13ils, 535; Burton v. Slaughter, 26 Gratt. 919.

o Harvey v. Girard Nat. Bank, 119 Pa. St. 212.

28. Smith v. Chester, l 'T. I. 654; Goddard v. Merchants' Bank, 2 Sandf. 247.

29 Daniel on Negotiable Instruments, \& 1369 et seq.

30 Pank of the Inited States $v$. Bank of Georgia, 10 Wheat. 333; Johnson v. Bank, 27 W. Va. 343.

:31 liobinson v. Yarrow, 7 Taunt, 455; Story on Bills, $\$ 412$; Daniel on Negotiable Instruments, $\$ \$ 538$, 539. 
prior indorsements were genume. ${ }^{32}$ The payor hombl also satisfy himself of the identity of the holker; for he "amot defend himself against the real payce by showing that he paid the amount of the hill or mote to another pereon of the same name in goorl faith and in the unat course of burines...33

$\S$ 452. Payments under mistake of law or fact.- It is a gencral principle that money paich with knowlerlge of facts, but under a mistake of law, camot he recovered hack.34 But a party paying money muder a mistake of the real facts may recover it back. Therefore, where a bank paid a post-clated check to a holder who knew that the drawer was insolvent, and that the drawe had no funds, but was in expectation of them that day, and none were received by the bank, it was held that the amount might le recovered back. ${ }^{36}$ Su an indorser, discharged by laches, who pays a bill to the holder moler a misrepresentation of facts, may recover back the amount, and so if snch indor'ser pars the lill, relving on the notarial certificate of due presentment, when in fact no such presentment was made. ${ }^{37}$

$\$ 453$. Surrender of instrument and giving receipt as evidence of payment.- The party making payment should insist on the presentment of the paper hy the party demanding payment, in order to make sure that it is at the time in his posession, and not ontstanding in another. And if at the time he makes parment it is ontstanding, and held by a bone fide holder for value, he will be liable to par it again, and a receipt taken will be $n 0$ protection. ${ }^{35}$ The party making payment of the bill or note should also not fail to insist mpon its being snrendered up, as a voncher that the party receiving the money was entitled to do $=0$,

\footnotetext{
32 Daniel on Negotiable Instruments. \& 6i2.

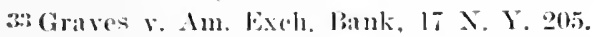

34 Adams v. Reeves, lis N. C. 134.

35 National Bank of the ('ommonwealth, 139 Mass. 513.

: Martin $x$. Morgan, 3 Moore. 635.

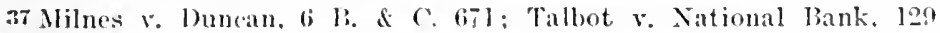
Mass. 67.

so Wheeler $v$ (inild, 20 P'ick, its; )avis $v$. Miller, 14 Gratt. 1.
} 
and also that he has paid it to him. ${ }^{39}$ The posiession of the note by the maker is presumptive evidence that he has paid it $;^{40}$ and so, likewise, is the possession of the bill by the acceptor, provided it can be shown that it passed oat of his hands after he accepted it, though otherwise it would seem not. ${ }^{41}$

In addition to the surrender of the instrument, the fact that it has been paid should be indorsed upon the paper itself. This at once advertises the fact of payment to every person who might subsequently come into possession of the instrument ly aceident or frand. This precantion is especially wise and necessary if the instrmment has been paid before maturity. When an indorser makes payment, it is especially desirable that he should take a receipt as well as require delivery of the instrmment. ${ }^{42}$ If there be a general receipt of parment on the back of the instrument, it will be presumed that it was made by the maker or acceptor, who was primarily liable; and this presumption would exist even when the drawer had possession and sued the acceptor upon a bill indorsed with such a receipt. ${ }^{43}$

$\$ 454$. To whom payment may be made.- Payment of a bill or note should be miade to the legal owner or holder thereof, or some one authorized by him to receive it. ${ }^{4+}$ If it be payable to bearer or indorsed in blank, any person having it in possession may be presumed to be entitled to receive payment, mless the payor have notice to the contrary; ${ }^{45}$ and a pryment to snch person will be valid, althongh he may be a thief, finder, or fraudulent loolder. ${ }^{46}$

:00tinfield v. Mayberry, 63 Me. 197.

40 J)ugan $r$. United States, 3 Wheat. 172; Norris v. Badger, 6 Cow. 449 .

41 Pfiel v. Vaulatenberg, 2 Campl. 439; Barring v. Clark, 19 Pick. 220. 42 Story on Notes, \$ 452 .

43 Scholey v. Walsly, Peake Cas. 24; Jones v. Fort, 9 J. \& C. 764.

44 Stevenson v. Woodhull, 19 Fed. 575; Draper v. Pice, 56 Jowa, 114. 45 Chappelear v. Alartin, 45 Ohio St. 132; Bremnan v. Merchants' Bank, 62. Nich. 343.

tib Bank of the Cnited States v. Inited States, 2 How. 711: Dugan v. Lnited States, : Wheat. 172; Bank of Utica r. Smith, 18 Johns. 2:30. 
It has been lield that a pavment to any person in actual possession will still be valid, lecenuse, althomph he maly have

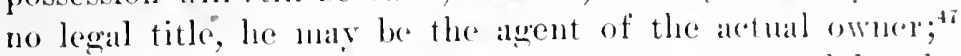
but this is musomul doctrine, and is not supponted hy the weight of anthority"s But jayment may he siffely made to one who is a special indorsec, althongh there may be subsequent uncanceled indorsenents of limself and nothers on the paljerp: or to the assignee of a baukrupt, ${ }^{50}$ we to the representative of a dead owner or to the ginallian of an infant or insine person, or to the hushand whose wite is payee." on the instrment be parable to $\mathrm{L}$. for the use of B., parment must be made to $1 .^{54}$ Payment to me of two joint parees will extingmish the deht, and likewise if made to a menuler of a partucrship, or a duly constituted officer of a corporation. $5 t^{5}$

$\$ 455$. When payment may be made.-Payment cum only be made before naturity ly consent of both debtor and ereditor: ${ }^{5 \pi}$ And it can only le made with perfect safety at or after the maturity of the instrument, mbless the payor receives it in lis hands and cancels it: for a parment before matmity is not in the msual comre of business: and should the bill or note afterwalds. and lefore matmity, reach the hands of a bona fide holder for value withont notice, such holder could enforee a second parment. is If,

47 Batchellor v. I'riest, 12 Pick. 406.

4s Daniel on Negotiable lnstruments, \& 1230: Porter v. Cusluman. 1!) 111. 572: Doubleday v. Kress, 50 X. Y. i13.

49 Dugan v. Tinited fitates, 3 Wheat. 17:2.

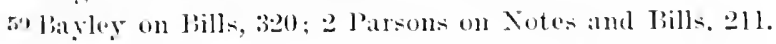

al biyley on liblls, 320; 2 Parsons on Notes and Jills. 2ll: Chitty on Bills |*3!3], 444.

a bayley on 13ills, 320; 2 l'arsons on Notes and Bills, 22ll; Clitty on Jills [*393], 444.

5:: Clitty on Jill: I 393,3947 , 4t4.

54 Cramlinerton v. Watus, 2 Vent. $30 \pi$.

55 L.yman v. Gedney, 111 111. 406.

af Janicl on Nergotiable Instruments. \$ 1:3:)1.

si Ebersole v. Ridelingr, 2.2 lud. 2:3:2.

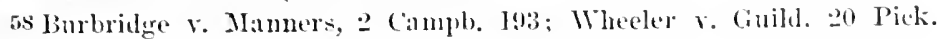
545. 
however, the instrument be paid at or after maturity to the holder, the ease is different. The instrument is not cnly extinguished, but shonld the holder fail to deliver it up, and transfer it to another party, sneh party wonld receive it with notice npon its face that it was overdne, and he could acquire no better right or title than his transferrer; and the plea that it was paid before the transfer would be available against him. Still, the payor, in making payment after maturity, must be sure that it is made to the then holder. For, if it should have been transferred after maturity, and before payment, to a third party, a payment to the transferrer wonld he invalid, and the transferce holding the instrument conkt himself enforce payment. ${ }^{59}$

$\$ 456$. Time of day when payment may be made.- Payment may be demanded at any time after the conmencement of business hours on the day of maturity of the bill or note. And if payment be then refused, or if the house at which the instrument is payable be shut up, and no one is there to answer, it may be treated as dishonored, notice given, and resort taken upon the drawer and indorsers. ${ }^{60}$ But the maker or acceptor has the whole day in which he is privileged to make payment, and thongh he should in the course of the day refuse payment, yet if he subsequently on the same day makes payment, it is good, and the notice of dishonor becomes of no avail. ${ }^{61}$

$\$ 457$. In what medium payment may be made.- The party bound to make payment has no right to do so in any other medimn than that expressed on the face of the instrument - that is, he must make payment in money. ${ }^{62}$ And an agent holling the instrument for payment can take

59 Davis v. Niller, 14 Grat.t. J; Adair v. Lenox, 15 Oreg. 493; Coppman v. Bank of Kentucky, 41 Miss. 212.

6n L.r parte Moline, 1 Rose, 303; Burbridge v. Manners, 1 Campb. 193 ; Hine v. Allely, 4 13. \& Ad. 624.

61 Hartley v. Case, 1 Car. \& P. 555; Citizens' Bank v. Lay, 80 Va. 440. 62 Story on lills, \$ 419; Edwards on Bills, 550; Corbett v. Ilughes, 7.) Jowa, 282. 


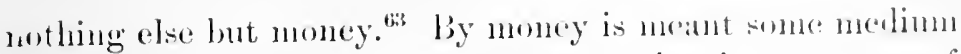
of exchange made by law a legal tender in payment of debts. And if there be two or more kinds of money-i. c., gold, silver, and paner — either will suflice to discharge the obligation, muless the instrument specities tiat paynent shatl bo made in a particular kind of money, in which rovent the debtor cammot insist mpon paynent in any other. It is competent to provile in the instrument for payment in lowalender money of any amontry. Sometimes chereks, dratts, or notes are offered by the debtor in discharge ut the debt, and the creditor may, if he pleases, acept the: sance in absolute disclange thereof; but where the check, lraft, or note is received hy the ereditor, there is no prow smmption that he takes it in paynent, lut, on the contrary, the inplieation is that it is only to be regarded as payment if ashed or paid. ${ }^{6 t}$

$\$ 458$. Creditor's acceptance of depreciated currency is absolute. - If the debtor tenders a depreciated currency in fuil satistaction of his lebt, or any ofher currency than gold when it is specifically payable in gold, the creditor cammot by protest accept the medimm tendered, and then reeover the anomet that sold exceeled it in value. He must refuse the tender or aceept it; and if he accepts it without special atgreement, he will be comsidered to have taken it as oflered in full satisfaction. ${ }^{(5)}$ And the same rule applies in all eases where bank bills are temlered in discharge of debts parable in money. ${ }^{60}$ In like numer, thongh the instrument be payable in bank notes, legal tender notes, or other medium less valuablo than coin, vet, if the ereditor fonder sold or silver coin, withont there being any contrat as to the rate at which it is to be taken, and it be reepived. he cammot require it afterward to be applied otherwise tham a dollar of eoin for each dollin of the amount due, nor

63 Maddur v. Bevan, 39 Ml. 46is: Herimon v. Shomon, 24 Kan. 35.

64 Small v. Franklin Mining Co., 99 Mass. 277: Davison v. City bank,

57 N. Y. S2; Heartt v. lihodes, (iti III. 3.il.

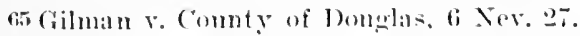

fic Danicl on Negrotiable Instruments, s lit: rt srq. 
make any counterelaim for the value of the coin in excess of the value of the medimu of payment expressed in the contract. .67

$\$$ 459. Appropriation of payment.- When a debtor is indebted to the same creditor in sereral items of account, and pays him a sum of money in part liquidation of his entire indebtedness, it often becomes a nice and important question, not only between debtor and ereditor, but also as to third parties, to what item the eredit shall be applied. With certain limitations and exeeptions, the following general principles apply in such cases: (1) The debtor making payment may appropriate it to whatever item he pleases when the parment is not under compulsion of law. (*) If the debtor do not make application of payment, the creditor may apply it as lie pleases; ${ }^{69}$ and the silence of the debtor is construed as leaving the matter to the payee, provided it is not an applieation peculiarly injurions to him, or against his implied intention." This right in the ereditor does not apply to debts not due if there are debts already due, nor to compulsory payments, nor to umlawful demands, as for usurious interest; nor to a debt denied or disputed by the debtor, to the exclusion of the one acknowledged. ${ }^{i 1}$ (3) When neither party appropriates the payment, the law will apply it according to equitable principles, and with regarl to the probable intention of the parties. ${ }^{2}$ Hence, the law will apply payment to the debt more burdensome to the debtor, especially to one bearing interest, or subjecting lim to a penalty or eriminal charge, rather than to those which are less burdensome. ${ }^{73}$ In accordance

fat Bush v. Baldrey, 11 Allen, 367.

6s Tayloe r. Sandiford, 7 Wheat. 13; United States $v$. January, 7 Cranch, 572; Linerle v. Cook, 32 Gratt. 272.

f99 Pattison v. IIull, 9 Cow. 747 ; Benmell v. Wilder, 67 Ill. 327.

70 Smith v. Screven, ] MeCord, 368; Jlair v. Carpenter, 75 Mich. 167.

i1 Bobe v. Stickney, 36 Ala. 482; Blackstone Bank v. Hill, 10 l'ick. 1.29: Brown v. Lacy, 83 Ind. 436; Tayloe v. Sandiford, 7 Wheat. 13.

i2 Chitty on 13ills [*403, 404], 455, 456; Lingle v. Cook, 32 Gratt. 272.

7: Wright v. Laing, 8 13. \& C. 165; Spiller v. Creditors, 16 Ja. Amn. 292: Stone v. Seymour, 15 Wend. 29. 
with these principles, tha haw will impute the parnont to interest before principal; and where the interest itself heans interest, it will impute it, first, to interest on interest; sccond, to interest on principal; and thiret, to the principal. ${ }^{i t}$ It will also impute payment to those dolits which aro prior in date; and to minecured in proference to secured debts, muless the latter are secured by a surety, in which case the appropriation will be made for his relicentis

$\$ 460$. Payments by partners and joint debtors. - If a !allner owes a debtor, of whom his tirm is debtor also, and pays the money of the firm, it will he appropliated by law to the debt of the fimm;i and if he pays such debtor his own money, it will be appropriated to his own debt. is Anl no appropriation will be allowed which has the effect of paying one man's debt with another man's noney. ${ }^{i 9}$ When at person owes the sanne debtor on joint and on individual acecomnt, and simply pays an amomt, withont appropriating it specifically, or it appearing whother it came from his individual or his joint funds, the creditor may apply it to either account. $^{\text {so }}$ " Where one of several partners dies, and the partnership is in debt, and the surviving partuers contime their dealings with a particular crectitor, and the latter joins the transactions of the oht and new firms in one entire account, then the paynents made from time to time by the sliviving partuers must he applied to the old deht." st

it Jatsh r. Edgerton, 13 Minn. 2lo; Starr v. Rithmond, 30 Ill. 2iti: Monroe v. Fohl, iz Cal. 56s; Anketel v. Converse, 7z Ohio st. 11.

in Lnited States $i$. Kirkpatrick, 9 Wheat. 700; Mills r. lowlkes. i lBing. X. C. 4til; Boie v. Stickney, 36 Ali. 482.

it Lash v. Edrerton, 13 Minn. 210; Cole v. Withers, 33 ciratt. 201: Plain צ. Roth, I07 IIl. 594: Marryatts v. White, 2 stark. I0l.

it Thompson v. Brown, Moody \& M. 40.

is Fairchild r. Holly, lo comm. lis.

7: Thompson v. Brown, Hoerly \& M. 40.

" so Van Rensselacr's lixis. v. Roberts, 5 Den. 5j0; Baker v. Stackpole,

9 cow. 4.01).

st simon v. Ingham, 2 li. \& C. T2; Ilooper v. Keay. 2 (2. li. Dir. lis. 
$\$ 461$. Payment supra protest.-When the bill has been protested for nompayment, and not before, ${ }^{, 2}$ a stranger may pay it for the honor of the drawer, or aceeptor (if it has been accepted), or of any indorser, or he may pay it for the honor of all the parties - for honor generally, as sueh a payment is termed. And such a payment does not, like a simple payment by the original drawce, operate as al satisfaction of the bill, but itself transfers the holder's rights to the party paying, unless the party paying limits and narrows them. ${ }^{83}$ If the payment is made for the honor of a particular indorser, the party paying may sue such indorser, and all parties prior to him whom he could have resorted to, but not subsequent indorsers, for it stands like a payment made at the request of the indorser, for whose honor it is made, and the payor supra protest narrows and limits his right to recover against them only. ${ }^{84}$ But if he pays for honor of the bill generally, it is the same as payment for the honor of the last indorsee, and he may recover against all parties to the bill. ${ }^{85}$

The privilege of payment supra protest is not extended by the law merchant to promissory notes, which are not designed for sueh general cireulation as bills of exchange, and the party making such payment aets at his peril. ${ }^{86}$

$\S 462$. Payor supra protest is subrogated to rights of party for whose honor he pays.- As the party paying supra protest becomes substituted, as against parties anterior to the one for whose honor he pays, to the rights and remedies which such party for whose honor he pays would have had against them, had he himself paid, it follows that the right of one who pays for the honor of the drawer to sue the aceeptor depends upon whether or not the aceeptance was

s2 Vandewall v. Tyrrell, 1 Moody \& M. 87; Chitty on Bills [*50s, $509], 575$.

83 Chitty on Bills [ $\left.{ }^{*} 509\right], 576$.

84 Mertens $v$. Withington, 1 Esp. 112; Chitty on Bills [*509], 577.

85 Fairlcy v. Roch. Lntw. 691; Edwards on Bills, 441; Byles on Bills [*261], 408.

86 byles on Bills [*262]: Story on Notes, $\& 453$. 
for value. ${ }^{8 r}$ In lingland it wals at first held that he could sue the acceptor, whether he had effects of the drawer in his hands or not; by but this view was subserquently orerruled, and the doctrine of the text established. ${ }^{\text {s' }}$

$\$ 463$. Mode of making payment supra protest. - The party proposing to make such payment goes hefore a notary public after the bill has been noted for protest (though it is not necessary that the protest should have been formally extended), and makes a declaration for whose honor he makes payment, which declaration should be recorded by the notary, either in the protest or in a separate instrument. Ho must then, in a reasonable time, notify the party for whose honor he pays, otherwise such party will not be bound to refind. ${ }^{91}$

$\S 464$. Effect of tender.- Tenter made by the aeceptor of a bill or maker of a promissory note at maturity discharges the drawer and indorsers absolutely, and stops the accrual of interest, costs, and damages so far as the primary debtor is concerned." But a tender made after maturity, and after the liability of the drawer and indoreers has been fixed by protest and notice of dishonor, will not discharge the obligation, either of the prinary or secomelary debtors, but as to all alike the tender prevents further accinal of interest and costs. In oreler to lave the effect heretofore stated, the person making the tender must have been not only willing but ready, and not only ready, hut must have actually offered to pay. And when a plea of tender is marle, it must be pleated with a profert of the moner. ${ }^{94}$ To constitute a

si byles on lills [*260], 407, 408: Chitty on Bills ["508], 575.

so lir parte Wackerlath, 5 les. $5 i t$.

s. E.r marte Lambert. 13 Ves. Jr. 179.

(n) Vandewall v. Tyrrell, I Moody \& M. si: Geralopulo v. Wieler, 10 C. B. 6990; lyyles on Bill [*260)], 407 ; Rdwards on Bills, 44 .

91 Wood r. Pughts, i llam. l64.

92 Fitch v. Hammer, 17 (olo. 59): Wright v. Robinson \& co.. st Ilun, 172.

$9 \%$ Otis v. Burton, 10 N. H. 433.

at Caldwell s. Cassidy, S Cow. 2il; Adams v. Hackensack Co., 15 Vroom, 638 . 
jegal tencier, money must have been offered, and the offer miust have been absolute and muconditional.

$\$ 465$. Bankruptcy and insolvency. laws; power of Congress and of the States to enact.- The Constitution of the United States gives Congress the power "to establish *** miform laws on the subject of bankrupteies throughout the United States." Congress at different periods in the country's history has enacted bankrupt laws in accordance with the provision of the Federal Constitution just quoted, the acts refered to having been enacted in the years $1800,1841,1867$, and 1898 , respectively. At one time it was contended that the clause of the Federal Constitution giving (Congress power to establish miform laws on the subject of bankruptey throughout the United States operated to exclude the right of the States to legislate on the same subject, and there are decisions which support that contention, but the Supreme Court of the United States has dccided that there is no such exclusion, except where the power has actually been exercised by Congress; and subject to the modification just stated, the right of the States in this respect is now well established. In other words, so long as Congress does not exercise its constitutional power in this regard, the States have the right to enact bankrupt or insolvent laws for themselves, and if it should happen that an act on that subject is passed by Congress while State statutes exist, as long as the former continues in force on the statute books, the latter are suspended.

$\$ 466$. Discharge by bankruptcy or insolvency laws.-The right of a debtor to a discharge, when it exists at all, exists only by rirtue of the statute cuacting the law; and to determine whetler, in any case, a dobtor has such a right, reference must be had to the statute governing the matter. One of the principal objects of all hankmutry laws is to discharge from liability debtors who are muble to pay their debts in full. In England, discretionary power is lodged with the courts to grant or refuse an absolute or a conditional dischares, while in the United States the courts are 
generally compellad to discharge the debtor from all liatbility, once he is adjulged a bankrupt.

\$ 467. Accord and satisfaction.- The giving lye thater or aceeptor and the aceptance by the holdere of andere collateral thing in discharge of the instrunent is an ancond and satisfaction, and utterly extinguishes the olligations For whatever anoments to satisfaction of a bill or mole be the aceptor or inalier is satisfaction as to all paldies whe alre collaterally liable. Satisfaction mate hy one partuer of a firm, which are either maker's or indorsers, discharges all the palduers; and so where a person is partner in two tirms, one of which are the makers, and the other indorsers of the note, satisfaction by him discharges both firms." If an excentory contract is the consideration of another executory contract, both may be mutually rescinded, the giving up one? being the consideration for giving up the of her:

But a contract upon an executed consideration camnot be discharged either before or after the hreach, save by a release, or by satisfaction for a valualle consileration. ${ }^{93}$ If the holder of a bill or note remounces his claim and gives up the instrument, the drawer and indorsers are as much discharged as by payment, and he cannot sue the maker or aceptor upon it. And having voluntarily relinquished the evidence of the debt, it may he toubted if he could sue the maker or acceptor at all. ${ }^{\circ}$

$\S 468$. Part payment is ordinarily only payment pro tanto.$\Delta$ part payment of a bill or note which has fallen lue only. extinguislies it pro tanto, and an agreement that it shall le in full discharge of the deht does not make such part payment any more effectual at to the resilue, there being w. suffieient consideration for the discharge of the whulc.'

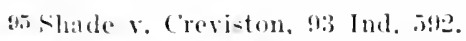

of Atkins vowens, 4 Nev. \& Min. 123.

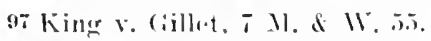

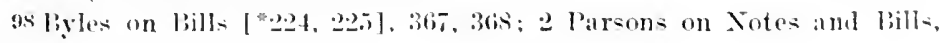
23 is.

99 Daniel on Negotiahle In-truments, s less.

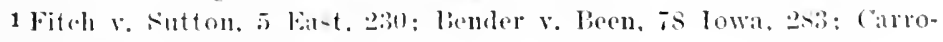
way v. Mdeneal, sti Miss. ags. 
But any agreement by way of compromise, or eomposition, into which any new element entered, would be sustained, and if the claim were disputed, agreement to receive part payment in full would discharge it. ${ }^{2}$ After a smaller"amount than the existing debt has been acepted in full satisfaction by way of compromise, there is no consideration for a note afterward exeented for the amount released by the creditor. ${ }^{3}$ But if the part payment were before maturity, or were made by a stranger, or was made by a bill or note with a suretr, or collateral security, or were in any way more adrantageous to the creditor, it would suffice to support any agreement based upon it. ${ }^{4}$ The same rule would apply if a number of notes, some of which were due and some of which were not due, were delivered up for less than face value; and also if the old note were by agreement surrendered up for a new one, the contract then being executed. ${ }^{5}$ Where suit had been brought on a note, and a compromise was effected, the holder agrecing to indorse on the note a credit of $\$ 50$, if defendant would pay balanee on a certain day, and under this agreement suit was dismissed, it was held, that on failure of defendant to pay the balance the payee might erase the eredit given. ${ }^{6}$

$\$ 469$. Release- $-A$ release is technically an instrument under seal, the seal importing a consideration. But the release of a party to a bill or note by any agreement, upon a valuable consideration, is as effectual as if made under seal. ${ }^{\top}$ And it discharges a joint party, and all parties who are subsecquent to the one released, and might have looked to him on making payment for reimbursement. It is not

2 Sibree v. Tripp, I5 M. \& W. 23; Cumber v. Wane, 1 Stra. 425; Wells v. Morrison, 91 Ind. 62; Murray v. Snow, 37 lowa, 410.

: Rasmussen v. State Nat. Bank, 1 I Colo. 304.

4 Bowker $v$. Clilds, 3 Allen, 434; Welby v. Drake, I Car. \& P. 557; Hardman r. Bellhouse, 9 M. \& W. 596; Lewis v. Jones, 4 B. \& C. 506.

5 lsowker v. Childs, 3 Allen, 434; Draper v. Hill, 43 Vt. 439 ; Ellsworth v. Fogg, 35 Vt. 2.55 .

(i Chamberlin v. White, 79 Ill. 549.

7 Benjamin v. McConnell, 4 Gilm. 536; Milliken v. Browne, 1 Rawle, 391. 
necessary that the releasor should be the holder of the instrument at the time of making the release. ${ }^{8}$ But a relaase of a drawee before he acepts is no bar to a suit on his acceptance, for it can only operate on existing rights."

If there is not a technical release under seal, which, as hats been said, imports a consideration, no agreement can operate as a release, unless it is upon a sufticient eonsideration. ${ }^{11} \quad \Lambda$ verbal agreement of the payce of a note with the maker to release him, and aceept a third party in his stead, who signs in pursuance of such agreement, is upon sufficient consideration, and is valid. ${ }^{11}$

$\$ 470$. Covenant not to sue- $-A$ general covenant not to sue the maker or acceptor will operate as an extinguishment of the debt as to him, and will, of course, operate as a discharge of the drawer and indorsers. ${ }^{12}$ But such a covenant does not discharge another who is jointly liable with the corenautee ${ }^{13}$ nor will such a covenant not to sue, given by one of two ereditors, operate as a release. ${ }^{14}$ And a corenant not to sue for a limited time will not affeet a release as between the parties (though it will discharge the sureties), mnless it be stipulated that it may be pleaded in bar. ${ }^{15}$ Nor will an agreement not to sue for a limited time discharge the party with whom it is made. ${ }^{16}$

$\$ 471$. Substitution of another obligation.- The substitution of another debtor, or of another obligation, or of another security for the instrument, if the intention of the partics be really to substitute the one for the other, will operate as a discharge of all liability upon the instrument for which the substitute was given. In other words, the

s Scott v. Lefford, 1 Campb. 246: Flanagan v. Brown, 70 Cal. 254.

9 Hartley v. Manton, 5 Q. 1. 247; Brage v. Netter, 1 Ld. Raym. 65.

10. Keeler v. Bartine, 12 Wend. 110; Carter v. Zemblin, 68 Ind. 405.

11 Curpenter v. Murphee, 49 Ala. 84: Lyon v. Aiken, 70 lowa, 16.

12 Story on Notes, $\$ 409$; Bỵles on 13ills, 3s4; First Nat. Bank v. Day,

64 Iowa, 120.

13 Dean $v$. Newhall, 8 T. R. 168; Twopenny v. Young, 3 B. \& C. 208.

14 Walmsley v. Cooper, 11 Ad. \& Wl. 216.

15 Drage v. Netter, 1 Ld. Raym. 65; Hartley v. Manton, 5 Q. B. 247. 16 Ford v. Beech, 11 Q. B. S42. 
doctrine of substitution and the legal effect thereof depend, after all, mpon the agreement between the parties, and ane governed by the general law of contracts. ${ }^{1 i}$

$\$ 472$. Set-off; meaning and nature of.- By set-off is neant the discharge of one clain hy another, which is "set off" against it. It was formerly sometimes called "stoppage," because the anomut sought to be set off was "stopped" or" deducted firom the cross-demand.

Set-off was mknown to the common law, it being considered inconvenient to try two opposing clains in one suit. But still greater inconvenience arose from disallowing it; and courts of equity tirst introdnced it, the want of it at law being prodnctive of great mischief.

Set-oft has heen made the subject of legislation both in England and in most, if not all, of the United States, a statute with reference to the setting off of cross demands having been enacted in Virginia as early as the vear $16+1$.

In England, and generally in the Cnited States, actions ex contractu are the only suits to which matters of set-off may be pleaded, and they must be actions for definite ascertainable amounts. Actions sommding in damages, snch as trespass, trover, etc., are not subject to the defense of setoff, because the smus recorerable are muliquidated; and actions ex contructu for minuidated damages follow the same rule. ${ }^{18}$

$\$ 473$. Its applicability to negotiable instruments.-The loctrine of set-oft has but a limited application to negotiable paper, it being a distingnishing characteristic of negotiable scenrities that when they have passed into the hands of third partice for value, no set-off admissible in pleadings between original parties is available. Between the original partics, however, or parties hetween whom there is a privity - that is, between makel and payce, drawer and acceptor, indorser

17 Daniel on Negotiable Instruments, § 1292.

182 latsons on Notes and Bills, 616; Vancleave v. Beach, 110 lnd. 269; Gordon v. Brown, 2 Jolins. 150. 
and immediate indorsec - a set-off inay lx bleaded fo negurtiablo securitics as well as to any other kind."

$\$ 474$. Purchaser of overdue negotiable instrument not subject to set-off that would apply to his transferrer. - The rul. lhat a party taking an overdne bill or note takes it subjocet to the equities to which the transferrer is subject, does not extend so far as to admit set-offs which might be availablo. against the transferer. I set-off is not an cquity; and the general rule stated is qualified and restricted to those equities arising ont of the bill or note transaction itself, and the transferee is not subject to a set-off which would be good against the transferere, arising out of collateral matter.. ${ }^{21}$

This is the English rule on the subject, while in thr. United States there is a conflict of lecisions. In some of the States the Enghish rule, excluding set-offs whirh existerl at the time of the transfer of the orerelne paper, is follower. In others such set-rofts are adunited."2 But it seems to be the miforn ruling everyhere, that, althongh the palper be transferred after maturity, no set-offis between ontecelent parties, which arose after the transfer, will be arailable against the indorsee." In some of the States this question is settled by express statute on the subject. In New lork, for instance, the statute almits set-offs existing at the time of transfer of the orerdue note or bill. ${ }^{2+}$

The right to plead an equitable set-off is a personal privilege of the principal, and does not extend to the surety, unless the defense amounts to total want or failure of consideration. ${ }^{25}$

$\$$ 475. What discharges a surety; general principles of surety's liability.- The aceeptor of a bill and the maker of a note, when the aceptance is made or note exeruted upon a

19 Diniel on Negotiable Instruments, s 1435.

20 Barnes r. MeMullins, is Io. 260 ; Drexler r. Smith, 30 Fed. 4.s.

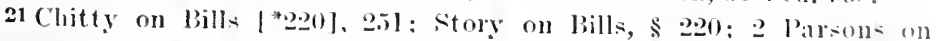
Notes and Bills. 603. 604.

22 See cases cited in Daniel on Negrotiable Instruments, s 1437.

2:- Davis v. Mliller, 14 Gratt. B.

24 Edwards on liblls, elio.

250 sborn v. Hryee, 23 led. 177. 
valuable consideration, are undoubtedly prineipals as to all the parties thereto. And the drawer of such a bill, and the indorser's of such a bill or note, are sureties of the acceptor or maker to the holder. ${ }^{26}$ But though all the parties to such a bill are sureties of the acceptor, they are not as between themselves cosureties, liable for contribution to each other in the event that anyone should pay the amount for the acceptor; but each prior party is a principal as between himself and each subsequent party. Thus, if the bill were payable to the drawer's order, and accepted, and then indorsed by the drawer and two subsequent indorsers suecessively, to the holder, the drawer and indorsers would be sureties of the acceptor to the holder. But as between the holder and the drawer, the drawer is prineipal debtor, and the indorsers sureties. As between the holder and second indorser, the second indorser is principal, and the third indorser is surety. ${ }^{27}$

The fact that the liability of the drawer or indorser is fixed by due demand and notice, does not alter their relation as sureties of the debt; it simply fixes their liability as sureties for its payment, provided nothing is done by the creditor to exonerate them. This view is established by great weight of authority, and may be regarded as settled. ${ }^{28}$

$\S 476$. Whatever discharges acceptor or maker discharges drawer and indorsers. - As a general rule, whatever discharges the acceptor of a bill or maker of a note discharges the drawer and indorsers who are sureties, for the contract which they undertook to assure thus passes out of existence by the act of the beneficiary. He camnot discharge the party primarily bound for the performance of an engagement, and then insist that another shall stand responsible for its performance. Besides, the drawer or indorser, on making payment for the maker or acceptor, wonld be en-

26 Wallace v. McConnell, 13 Pet. 136; Gmmis v. Weigley, 114 Pa. St. 194: Blair v. Pank of Tennessee, 11 IIumphr. 84.

27 Newcomb v. Raynor, 21 Wend. 108; Byles on Bills [ $\left.{ }^{*} 236\right], 379$.

28 Gould v. Robson, 8 Wast, 576; Bank of United States v. IIatch 6 Pet. 250; IIubbly v. Brown, 16 Johns. 70. 
titled to the holder's remedies against hin; and if the holiler has discharged him from his obligation, the trawer or indorser would be remediless and have no resort for reimhursement. ${ }^{29}$ And whatever discharges a prior indorene lischarges all subsequent indorsers, for the reiteon that he stured between them and the holder, and on making paymont "ach one conld have had reconrse against him, but from which his discharge precindes them. ${ }^{30}$ It follows from the sane raloning that discharge of a subsequent indorser can discharge no prior party; for such subsequent indorser could, under no circunstances, be liable to such prior party. ${ }^{31}$

$\$ 477$. Misrepresentation, duress, diversion, alteration, or tender will discharge surety.- If the surety has been induced to becone a party to the instrument through any nisrepresentation or frandulent conecalment of a material fact, his contratet is void from the beginning as letween himself and all parties privy to such misrepresentation or concealment. $^{32}$ If the prineipal signed under duress, the holder guilty of the duress could not enforee the obligation against a surety. ${ }^{33}$ If the payee is neither cognizant of, nor participates in the frand, he is not affected by it. ${ }^{34}$ Any frand which deceires the surety after he has become a party releases him. ${ }^{35}$ And where a bill is drawn or acecpted, or a noto made or indorsed for accommodation, with an agreement that it shall he need for a particular purpose, any tiversion in its use operates a discharge of the alecommonlation party as to all other parties who have knowledge of such diversion. ${ }^{3:}$ The sulject of alteration is elsewhere fully 539.

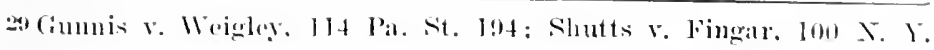

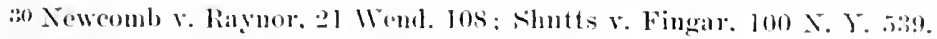

3) liank of United States v. Hatch. (i Pet. 250; White v. IIopkin-. :3 Watts \& S. 99; Lynch r. Reynolds, 16 .Jolins. 41.

:32 Melick v. First Xat. liank, 52 Iowa, 94: Solser r. Brock, : (hio) St. 302 ; North Rritish In.. Co. r. Jloyd. 10 Exch. 523.

33 Griflith v. Sitgreaves, 90 P'a. st. 161.

st Amlerson v. Warne, il Ill. 20.

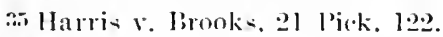

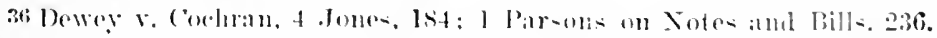


treated. ${ }^{37}$ And, as has been seen, a tender of payment made at the maturity of the instrument discharges the drawer and indorsers. ${ }^{38}$

\section{\$478. Parting with security discharges surety.-Upon} making payment of the debt, the surety is undoubtedly entitled to all the rights, remedies, and securities which the creditor could have enforced. ${ }^{3: 5}$ And while the crectitor may not only abstain from active measures, but may even relinquish steps already commeneed, ${ }^{40}$ he must do nothing which can impair the rights and remedies of the surety. Therefore, if any collateral security which the ereditor held be released, or a judgment lien given up, or a lery withdrawn, the surety is discharged. ${ }^{41}$ But the withdrawal of an execution from the hands of the sheriff before a levy will not discharge the surety. Nor will an omission to revive a judgment, ly means of which the lien and the land are lost; nor discontinuance of steps to foreelose a mortgage. ${ }^{42}$ But neglect to record a mortgage, whereby its value is lost, mould discharge the surety, and this even though the original mortgage would have been worthless, if recorded, by reason of prior liens. ${ }^{43}$

But the surety will not be discharged in any case where it ean le clearly proved that the act of the creditor has worked no real injury. And he is diseharged only to the extent that he would be injured if held bound. ${ }^{44}$ Thus with-

:A Ante, \$s 42/-443.

38 Ante, \& 464 .

39 Treanor v. Yingling, 37 Md. 491; King v. Baldwin, 2 Johns. Ch. 317; Humphrey r. llitt, 6 Gratt. 509.

40 Bellow' v. Lovell, 5 Pick. 307; Lawson v. Sayder, 1 Md. I7] ; Montpelier Jank v. Dixon, $4 \mathrm{Vt} 399$.

41 Shutts v. Fingar, 100 N. Y. 539; Allen v. O'Donald, 23 Fed. 573; Commonwealth v. Haas, 16 Serg. \& R. 252; Mayhew v. Boyd, 5 Md. 102.

42 Lenox $v$. Prout, 3 Wheat. 520; Ilumphrey v. Hitt, 6 Gratt. 509; Farmers' Bank v. Reynolds, 13 Ohio, 84; Butler v. Gambs, 1 Mo. App. 466 .

43 Barr v. Boyer, 2 Nebr. 265; Atlanta Nat. Bank v. Douglass, 51 Ga. 20.5.

44 Payne v. Commercial Bank, 6 Smedes \& M. 24; Neff's Appeal, 9 Watts \& S. 36. 
drawal of a levy on property only entithes the surety to at crealit for the value of the property levied ou.

$\$ 479$. Extension of time will discharge surety.-The principle that whatever dischanges the principal disehareges the surety is of extended application, and it is operatio whenerer anything is done which relaxes the terms of the exact legal contract by which the princijul is boumd, or in anywise lessens, impars, or delays the remedies which the ereditor may lesort to for its assurance or enforeenent. For, whenerer the creditor relaxes his hold npon the principal debtor, he impairs the hole upon him which the surety would acquire by sulstitution in his place on making payment; and good faith and fair dealing repuire that the surety should not be exposed to the injuries which night thus be inflicted upon him. ${ }^{4 ;}$ In the immense majority of cases the act done does not actually damage the surety a shilling, yet the doctrine is so firmly established that only legishtive enactment can change it. ${ }^{47}$

Extension of time for payment is the most frequent form in which the ereditor so deals with the prineipal as to disclarge the surety; and whenever such indulgenee is granted in pursuance of a binding legal contract, the surety is at once released from his obligations. ${ }^{48}$ And the same effect follows (the discharge of the surety) if time is given to one of the joint makers of a note of which the surety is mdorser. $^{49}$ If the creditor takes a time draft, or a remewai note from the principal, the presumption is that right of action is suspended, and time of parment extended to its maturity, and an indorser of the original bill or note is thereby presumptively discharged. ${ }^{\text {so }}$

$\$ 480$. Elements in indulgence necessary to discharge surety. - The following elenents or ciremmstances must unite in

45 Ward $v$. Vass, 7 Leigh, 135.

46) Daniel on Negrotiable Instruments, $\$$ 1312: Thompson on Pills. 390. 47 Swire v. Redman, 1 Q. B. Div. 536.

4s Siebeneck $v$. Anehor Sav. Bank, 111 Pa. St. 1si: Pamelee v. Williams, 72 Ga. 43: Shutts v. Fingar, 100 X. Y. 539.

49 story on Notes. $\$ 414$.

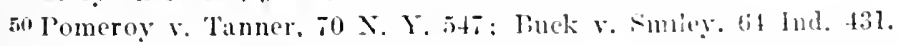


order to eonstitute an indulgence which will discharge the surety: (1) A ralid consideration, for withont it the promise would not be binding. (2) A promise or agreement to indulge, for withont it the hands of the ereditor are not tied, although he may have received collateral seeurity for the debt. (3) The promise must not be altogether indefinite, for an indefinite promise of forbearance is roid and nugatory, sinee it might be for an hom, which would be of no advantage to the debtor. (4) The indulgenee must be without the surety's assent, for if he assents he is a party to it. (5) The indulgence must be withont reservation of remedy against the surety, for that would reserve the surety's recourse on his prineipal. (6) The agreement must be with the prineipal, and not with a stranger. ${ }^{51}$

\section{SECTION $r$.}

\section{STATUTE OF IIIITATIONS.}

$\$ 481$. Part payment by joint maker, joint and several maker, or cosurety.-In the chapter on "Actions," the subject of the statute of limitations, with special referenee to the obligation of the principal debtor, was disposed of. The problems presented when only one debtor is involved are not difficult of solntion, whether the answer to the plea of the statutory bar is a new promise or a partial payment; but when the new promise or partial payment was made by one of two or more joint or joint and several makers or by a cosurety, and it is sought to hold a party other than the new promisor or the one making the partial payment, the questions presented are much more complex. There are many authorities which sustain the view that the statntory bar is removed upon the principle of mutual agency;

51 Danicl on Negotiable Instruments, § 1315.

52 See ante, $\$ \$ 414,415$.

63 Whitcomb v. Whiting, 2 Doug. 652; Sheply v. Waterhouse, 22 Me. 497 ; Woonsocket Inst. for Sav. v. Ballou, 16 R. I. 351, 16 Atl. 144; Elliott $v$. Nichols, 7 ( iill, 85; Schindel v. Gates, 46 Md. 604, 24 Am. Rep. 526; Turner v. Poss, l R. I. 88; Perkins v. Barstow, 6 R. I. 505; Carpenter v. McLaughlin, 12 R. I. 270. 34 Am. Rep. 63s; Joslyn r. Smith, 13 Vt. 353; Bissell v. Adams, 35 Conn. 299. 
but the cases to the contrary are almost, if not quite, at numerous. ${ }^{54}$ The hetter view, mpon sommd principle, secmes to be that if the olligation be joint, the payment will extend tho statutory linitation, lut if it be joint and serrarl, it will not.

If one of two or nore sureties make a parnent upon the obligation before it is bared by the statute of linitations. such surety may maintain an action against his cosurety ol cosureties for contribution after the bar of the statute a = to the original obligation is complete, mon the principle that the right of action accrues only fiom the date of the payment by lim. 5

$\S$ 482. Part payment by indorser or other surety. - I part payment made by an indorser does not prevent the bar of the statute as against the maker." On the other hand, a part payment by the maker will not render the indorse: liable, but a payment by the principal will bind his surety. But there are decisions which hold that if the note be at joint one of a principal and surety, a part payment hy the principal will not bind the surety ${ }^{\circ}$ I parment made by a surety will not revive a note already bared by the statute of limitations as aganst the principal. ${ }^{59}$

5t Hallenbach v. Dickinson, 100 111. 427,39 Am. Rep. 47; Shoemaker $r$. Benedict, 11 N. Y. 176, 62 Am. Dec. 9.5, note: Bell v. Morrison, I Pet. 612; Steele v. Soule, 20 Kan. 39: Colcman r. Forbes, 2-2 Pa. St. 156. (i1) Am. Dee. 7.5; Lowenthal r. Chappell, S . lla. 3.53.

us McCrady r. Jones, 4t s. C. 406, s. S. E. 414: Singleton r. Townsend, 45 Mo. 3i: 2 Piursons on Notes and Bills, 254. $\$$ Suretyship, \$ 259. and notes.

56 Byles on Bills and Notes, 35S: Harrling v. Edgecmmbe, 2S L. .T. Exch. 313; Randolph on Conmereial Paper, 1629.

si Hunter v. Robertson, 30 Ga. 479: Woollouse r. Simmons, 73 x. ('. 30: Wyatt $v$. llodson. s Bing. 309; Hunt $r$. Brilgham, 2 Piek, 5s1: Kent v. Hart, s Par. St. 337; Joselyn r. Simitl, 13 Vtt. 353; Gliek v. Crist, 37 Ohio St. 38s; Smith v. Caldwell, 15 Rich. 36.5.

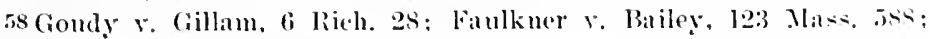
Burleigh $v$. Stott, 8 1s. \& C. 36.

50.Jones r. Iones, 23 Ark. 212: Raudolph on Commereial Paper. 1629?. But see contrit, Whipple $x$. Stevens, 22 N. II. 219. 


\section{CHAPTER XVI.}

\section{CONFLICT OF LAWS.}

$\$ 483$. Importance of subject.- No treatise, however brief, on the suljeet of negotiable instruments, and especially with. reference to actions thereon and defenses thereto, would be complete withont a general summary of the law that governs and controls. Of all kinds of contracts, there is none other puite so perambulatory as negotiable instruments. One of the very purposes of the law merchant is to relieve all negotiable contracts of luggage, and thus, so to speak, to encourage them to travel without regard to State or national boundary lines. It not infrequently happens, therefore, that a negotiable contract is made in one juriscliction, payable in another, and indorsed in still another; and when it is considered that every indorsement is a new, separate, and independent contract, the question as to what law govems as to each and every of the contracts that may be entered into and built upon the original obligation becomes a subject of peculiar importance. And it should also be remembered that each one of the United States is, in contemplation of its own and of the Federal Constitution, a distinet and independent sorereignty, with its own peculiar code of laws and sristem of judicature. And while, in the aggregate, they compose one integral confederacy, which is itself an independent nation, paramount in certain respects to the States, in all other respects the States retain their separate autonomies, and are deemed as much foreign to each other as if not in anywise associated together. The regulation of contracts comes peculiarly within the province of the States, and, therefore, contracts between citizens of the different States, while they may be enforced by process in the Federal comts, nevertheless are to be constried and effectuated not by a general system of laws which orerspread the whole country, but in accordance with the principles of interma- 
tional law whicle govern transactions lectween parties of different nations.

$\$ 484$. General principles._The following mat be regarded as established:

(1) Every contratet is in respect to its formalities and authentieation to be regulated by the laws of the State of country in which it is entered into; and it is also regulated by the laws of the state or comntry in which it is manke, in respect to its nature, validity, interpretation, and effect, except when it is to be performed in another State or country.

$(2)$ When a contract is made in one State or comntry to be performed in another State or country, it is to be regulated by the laws of the place of performance, without regard to the place at which it was written, signed, or dated, in respect to its nature, validity, interpretation, and effect.

(3) In determining the place where a contract is made, the place where it was delivered, as consummating the bargain, controls; and not the place where it was written, signed, or dated.

(4) If a party contracts while in transitu, and without identity with any other place, the place of his domicile is deemed the place of the contract.

(5) If a eontraet be illegal and void at the place where it is made, it is roid everywere.

(6) The laws of a State or country have no extraterritorial foree, properio rigore; and are only exeented by other States and comntries from considerations of eourtesy or poliey, termed the comity of nations.

(7) The laws of a State or eomntry being only executed in another by conity, they will be exceuted only sn far as they may be consistent with religion, good norals. and with the publie rights and interests of the State or country in which the remedy is sought.

(8) The courts of a State or comutry cannot take judicial notice of the laws of a foreign State or country: 
and when such laws are sought to be applied, they must bo alleged and proved.

(9) The law of the place where suit is brought, the lex fori, as it is termed, regulates the form of the action and the nature and extent of the remedy.'

$\S 485$. The comity of nations. - It results from the principle that the laws of a country have no binding force beyond its own bomdaries, that the appeal for their enforecinent addresies itcelf entirely to the comity and discretion of the formu in which suit is brought. That eomity is freely exercised by civilized countries, which look for and receive reciprocal courtesies from other nations; and the close relations of the several States of the Union with each other, the family likeness of their institutions, and the homogencity of their people, are powerful incentives to the exerciee between them of a comity peculiarly liberal and expanive. ${ }^{2}$ But, nevertheless, a State must be just before it is generous; and therefore no State should exereise comity in fircor of contracts which violate its own laws, or the law of nature, or the law of God." It must eonsult sound morals and the interests and public policy of its own people, and if to enforce the laws of another State or country would lead to their infringement, it would be treacherous to its own duties to lend aid to their execution. ${ }^{4}$

\section{SECTION I.}

\section{LEX LOCI CONTRACTUS.}

$\$ 486$. To what extent lex loci contractus governs.- The rule is of gencral aceptation that the law of the place where the contract is made regulates the formalities of its execution and anthentication and the consideration necessary to

1 Daniel on Newotiable Instruments, \$ 865.

2 Jathrop v. Commercial Bank, s Dana, 118.

3 Forbes v. Corlirane. 2 B. \& $C 448$.

4 Armstrong v. Toler. Il Wheat. 258: Pearsall v. Dwight, 2 Nass. 8t: Danicl on Negotiable In-truments, $\$ 866$. 
its validity; and also regulates its interpretation, nature, "ubligation, and eflect. ${ }^{5}$ If fomally execonted upon a legal consideration there, it is valid everywhere $;^{\prime 3}$ and if defective there in either respect, it is invalid evervwere. by interpretation of the contract is meant the ascertanment of the true meaning and intention of the parties. This beromes a matter of sulstantial moment when it is renembered that the same words are frequently ned with different rignitications in different communities, and import different obligittions. It follows that the interpretations placed upon then must be according to the signification and effect attached to them in the State or comntry in which the contract is made: otherwise the intention of the parties will be defeated, instead of effectuated. Thus, by the word " month" is sometimes meant a lunar, and sonetimes a calendar month, and if it were used in a contract entered into in a foreign State or comntry, evidence would he admissible to show in what sense the term was there understood. So the word "pounds" when employed in kngland would means pounds sterling; while in the United States it would mean pounds in Ameriean enrency, which is a fourth less in value.

\section{$\S 487$. Nature and obligation of the contract; meaning of.-} By the nature of the contract is meant those qualities which pertain to it. Thus, whether it be joint or several, or joint and several; whether alsolute or comlitional; whether of prineipal or surety; whether personal or real, are points which eoneern the nature of the contract, and are to be governed by the law of the platee at which it is entered into. This is well illustrated in an English calse, where suit wats brought in England upon a hill aceepted at Leghom, where the law is, that if the aceeptor have not in his hands sufficient funds of the drawer, and the drawer then fail, the

5 King r. Sarria, 69) X. Y. 24: Wans v. Anderson, is 111. 558; Armendiaz v. Siana, 40 'Tex. 291.

6. Indrews v. Poud, 13 Pet. 65; Fant v. Miller, 17 Gratt. 47.

7 Pearsall $r$. Dwight, 2 Mass. st: Kanaga $r$ Taylor, 7 Ohio St. 134.

8 Daniel on Negotiable Instruments, s sil. 
acceptance is thereupon racated. It was held that the law of Leghom should prevail. ${ }^{9}$

By obligation of the contract is meant the legal existence or nonexistence of a promise to pay, and the extent thereof. For instance, if by the law of the eomitry where the contract is made the legal effect is to bind the rem (i. e., land mortgaged), and not to ereate a personal obligation, the law of that jurisdiction will govern. Again, the question whether or not the promice or obligation is primary or secondary, absolute or conditional, is governed by the lex loci contractus. Following that principle, the extent and character of the obligations of sureties, indorsers, and guarantors are fixed and determined. ${ }^{10}$

$\$ 488$. What constitutes place of execution; presumptions.The place where a contract is made depends not upon the place where it is written, signed, or dated, but upon the place where it is delivered as consummating the bargain. ${ }^{11}$ 'Thus, the law of the place where a bill or note is written, signed, or dated does not necessarily control it, but the law of the place where it is delivered from drawer or maker to payee, or from indorser to indorsee. A note drawn and dated in Maryland, but delivered in New York, in payment of goods there purchased, or money loaned, is payable in and governed by the laws of New York. ${ }^{22}$ And if a note be dated and signed in blank in Virginia, and sent to Maryland, and there filler up and niegotiated, it is a Maryland, and not a Virginia, note. ${ }^{13}$

It should be further observed that where the parties acquiring a bill for value, and in the usual course of business, have no knowlerge that it was not issued and delivered as a subsisting instrument at the place where it bears date, it

9 Daniel on Negotiable Instruments, $\$ 872$; Burrows v. Jemimo, 2 Stra. 733.

10 Daniel on Negotialble Instruments, $\$ 873$.

11 Freese $x$. Brownell, 35 N. J. L. 286 ; Lawrence v. Bassett, 5 Allen, 140.

12 Cook v. Moflat, 5 How. 295; Hyde v. Goodnow, 3 X. Y. 266.

13 Fant v. Miller, 17 Gratt. 47. 
is but just that they should be entitled to regari its ostensible as its real character, and shonld at least not be permitted to suffer by reason of the after-diseoveren fiact that it was not there delivered. ${ }^{14}$ In the absence of cridunce to the contrary, it will be presumed that a note was execonted and delivered at the place where it bears date. ${ }^{15}$

$\S$ 489. Lex domicilix.- Ifter all, the question as to what law governs in the interpretation, construction, etc., is me of intention; and if the instrument does not specify the place of payment or execution, the domicile of the maker or aceptor may be invoked for the sole purpose of ascertaining the intention of the parties as to the place of execution. If one be a sojommer in a State or country other than hi: home or place of lomicile, and the instrument does not specify the place of performance, the law presumes that the lex domicile determines the loci contractus. In other words, that the contract was made and intended to be performed at the place of residence of the obligor, and that such place, presumably being the place where the contract was made, will govern in the construction of the instrument, the formalities of its execution, and the nature and character of the obligation entered into. As has been indicaterl, however, this is a mere presmuption, which may be rebutted by the circumstances attendant upon the execution of the eontract, cr by the nature of the transaction out of which the contract grew. Thus, if it were al debt for board at al hotel, or articles of personal subsistence or necessity, it would be payable by usage before the sojourner left the place, and therefore payable there. and controlled by its laws. ${ }^{16}$

$\S 490$. Lex loci solutionis; exception to rule.- But the law of the place where the contract is made rields in certain respects to that of the place of performanee; for it is in

14 Parsons on Notes and Bills, it: Quaker City Bank r. Showare. 26 W. Va, 52: Nat. Bank r. Smoot. l Macirth. 3il.

15 Parks v. Evans. 5 Del. 5 if.

16 Daniel on Negotiable In-truments, $\$$ si6; Wharton on contlict of Laws. ş $414-116.426$. 
view of, and in reference to, the laws of the place of performance, that it is to be presumed the terms of the contract were selected, and its stipulations entered into. "The general principle as to contracts made in one place to be performed in another," says Chief Justice Taney, " is well settled. They are to be governed by the law of the place of performance." 1s Thus, in Massachusetts, a note payable to $A$. or order at any or either bank in a eity, is negotiable; but if such a note were made in Massachusetts, and were payable in Virginia, it would not be negotiable, because not payable at a particular bank, as the Virginia statute requires. ${ }^{19}$ Where a part of the contract is to be performed in one comnty, and a part in arother, each part is to be governed by the law of the place where it is performable. ${ }^{2 n}$

And whenever it is alleged that a bill is payable by the acceptor, or a note by the maker, at a place different from that at which such acceptance or making took place, it is necessary to show it, either by the express language of the instrument itself, or by intendment and construction of law arising from the attendant circumstances. And if the note be dated at a particular place and payable generally - that is, withont designation of a particular place - the law attaches to it the presumption that it is to be paid where made. $^{21}$ So it is to be presumed that an acceptance of a hill, naming no place of payment, is to be paid where made; and the address of the drawee generally indicates where such place of acceptance is. ${ }^{22}$

\section{$\S 491$. Lex loci rei sitæ; further exceptions.- Of course} real estate is controlled, in respect to the validity and form of the conveyance, by the lex loci rei site - that is, by the

17 Andrews v. Pond, 13 Pet. 65; Pierce v. Indseth, 106 U. S. 546; Shoe \& Leather Nat. Bank v. Wood, 142 Mass. 567.

18 Andrews r. Pond, 13 Pet. 65.

19 Freeman's Bank v. Ruckman, 16 Gratt. 126.

20) Pomeroy v. Ainsworth, 22 Jarb. 118; Young v. Harris, 14 R. Mon. 556.

21 Wilson v. Lazier, 11 Gratt. 477; Thompson v. Ketchum, 8 Johns. 189. 22 Todd v. Bank of Kentucky, 3 Bush, 66. 
law of the place where it is situated. But the question has been much litigated in the Lnited States, as to what law applies when a mortgage is given as seemrity for a loan, and the mortgage is in one state, and the place of paynent of the loan in another. "The true test is, wals the nortgange merely a collateral security, the money being anpluent in another State, and under other laws, or was the money employed on the land for which the mortgange was griven! If the former be the case, then the law of the place where the money wis actually used, and not that of the nurtwatge, applies. $^{23}$ If the latter, then the law of the place where the mortgage is situate must prevalil." 24 Where money was borrowed, and the note made payable in New York but dated in Nebraska, where a mortgange to seeure it wats executed on land, the mortgage was held to be a mere incident of the loan, and the transaction being usurions by New York law, it was held rojd. ${ }^{2-5}$ In New Jerey the court refused to enforce a contract in New York secured ly a New Jersey mortgage on real property in that State, the contrat being opposed to the poliey of the New Jersey statutes prolibiting stock gambling. ${ }^{26}$

$\S 492$. By what law liability of maker, acceptor, drawer, and indorser determined.- The lialibities of the naker and acceptor, respectively, of a note and bill of exchinge are controlled by the law of the place where the obligation is entered into. ${ }^{2 \pi}$ The contrict is deemed to have been made with reference to the law of such place, and hence the lex loci contractus will control the obligation. The eontrat of the drawer of a bill or of the indorser of any negotiable contract is also to be determined and interpreted hy the lex loci contractus - that is to say, by the law of the place

23 De Wolf $v$. Johnson, 10 Whent. 3s.3; Kennedy v. Kuight, 21 lii

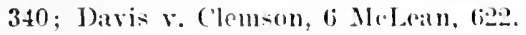

2t Wharton on Contlict of Laws. 510 ; Arnold v. Potter, a. lwwal. 194: Chapman v. Robinson, 6 laige, 627.

ss sands v. Simith, I Nelır. Jos.

26 Flageg v. Baldwin, 11 stew. 219.

27 J)aniel on Negotiable In-truments, \$\$ \$?5, s\$6. 
where the bill was drawn or the contract indorsed. Thus, if a merchant in New York draw a bill on another in Richmond, Virginia, requiring him to pay a certain amount without specifying any place of payment, the drawee will, if he accepts, be bound to pay the amount in Richmond, that being implied by the address of the bill to him at that place. But it does not follow that the drawer would be himself bound to pay the amount of the bill in Richmond in the event of dishonor for nonpayment by the acceptor. ${ }^{28}$ His undertaking is not to pay it in Richmond himself, but a guaranty that it (the bill) shall be paid there by the drawee, and a further undertaking that if not so paid by the drawee, he will pay the amount in New York, provided the bill be duly presented, and he has received lue notice of its dishonor. In other words, the drawer of a bill does not bind himself to pay it specially where the arceptor is impliedly or expressly called on to pay it; but his contract is to pay generally, and is consequently construed to be a contract to pay at the place where the bill is drawn. ${ }^{29}$ The same principle, as thus illustrated, is equally applicable to the contract of indorement. As has been stated, an indorsement constitutes a wholly new, separate, and independent obligation, and as such the party that enters into it must be taken to have contracted with reference to the law of the place where it was entered into, just as unequivocally as the maker of a promissory note or the aeceptor of a bill of exchange. This doctrine, that the drawer and indorser are bound according to the law of the place of drawing or indorsing, althongh sustained by great weight of opinion and an overwhelning eurrent of authorities, has not eseaped criticism and dissent. ${ }^{30}$

28 Daniel on Negrotiable Instruments, $\$ \S 898,899$.

20 Bank of United States v. United States, 2 IIow. 711; Freese v. Brownell, 35 N. J. L. 286 ; Everett v. Vendryes, 19 N. Y. 436.

30 See Daniel on Negotiable Instruments, $\S \S 899-902$. 


\section{SECTION II.}

1.EX FOLI.

\$493. General principles. - It is a settled prineiple of law that the remedies for breach of any contract must be pursued accorling to the law of the place where suit is homght. Those remedies are devised by the State in consonance with its own views of justice, public. policy, and convenience; and comity does not recuire that it shonld depart from the courses of procedure which it applies to its own inhabitants, and extend greater or different privileges to strangers. ${ }^{31}$ The foreigner who snes must take the law as he finds it."

This doctrine extends to the deternination of (1) the parties who may sne and be sned; $(2)$ the tine within which suit may be brought; (3) the form of action; and (4) the nature, effect, and extent of the remedy applied.

$\$ 494$. Who may sue.- Who may sne is generally a question of the renedy; and the nere designation of the plaintiff is always made by reference to the lex fort. And as a general rule, if allowed by the lex fori, an assignee may sue in his own manc, although he camnot so sue at the place of the assigmnent. ${ }^{33}$ And if not allowed by the lex fori, he camot sne in lis own name, although he might do so at the place of assignment. ${ }^{34}$ lint we think this doctrine should not he pushed farther than to indieate the nere nominal parties to the suit. when it is purely at question of remerly. Thus, if a note were non-uegotiable in Virginia, and cond not be there indorsed or asigned, ret if negotiahle and ace tually indorsed in kentucky on as to empletely vest title in the indoree, the holder wonld then have an absolute right to recover the amomit, and the lex loci controctus

31 Bank of Luited Statew r. Donally. s Pet. 372; Scoville v. Car ield, 14 Johns. 33s: What on on Contlict of Laws, $\$ 747$.

32 De la Vega v. Vianna, 1 B. \& Ad. 28.4.

3: Foss v. Nutting. 14 Gray, 4st: Wharton on Confliet of Laws, \$.5.

34 lisk r. Brackett. 32 Vt. 79s: Wharton on Conflict of Laws. 535 ;

2 Parsons on Notes and Bills, 368. 
should govern. ${ }^{35}$ So if by the law of the place of transfer, an executor or administrator may indorse or assign a note, so as to rest title and right to sue completely in his transferee, the latter should be permitted to sue anywhere. ${ }^{36}$ This is due to a liberal comity. But the anthorities predominate in number the other way. ${ }^{37}$

$\S 495$. Time within which suit may be brought.- The time within which suit may be bronght is purely a question of the forum. Thus suit may be brouglit immediately in one State by attachment, although at the time no action would lie in the State where the cause of action arose. ${ }^{35}$ And in like manner the statute of limitations of the form prevails; and no suit can be maintained if it be barred there, although by the law of the contract there was no limitation, or a less restricted limitation. ${ }^{39}$ And suit may be maintained where the limitation of the lex fori has not attached, althongh by the lex loci contractus action has been formally barred. ${ }^{40}$ This doctrine rests upon the ground that the time of suit is purely a matter for local municipal regulation. It may be different in cases where the right, in contradistinction to the remedy, is held by foreign law to be extinguished. Such extinction might operate by comity everywhere. ${ }^{41}$

$\S 496$. Form of action, remedy, and questions of evidence.The necessity of selecting the form of action according to the law of the forum has been well illustrated in the United States in a number of eases where the instrument

35 Lee v. Selleck, 33 N. Y. 615; Story on Bills, \$ 173; Trimbey v. Vigmer, I Bing. N. C. 159.

36 Harper v. Butler, 2 Pet. 239; Owen v. Moody, 29 Miss. 79; Barrett $v$. Barrett, 8 Greenl. 353.

:T Goodwin v. Jone;, 3 Mass. 514; Thompson v. Wilson, 2 N. H. 291; fitearus v. Burnham, i) Greeul. 26I.

ss Clark v. Comner, "- Strobh. 346; 1 Rob. Pr. 317.

39 Mineral Point R. ('o. v. Barrou, 83 III. 367; Nieolls v. Rodgers, 2 Paine C. C. 437; Jones v. IJook, 2 Rand. 303; British Linen Co. v. Drummond, 10 B. \& ( 903 .

40 Power v. Ilathaway, 43 Barb. 214; 13ulger v. Roche, 11 l'ick. 36.

41 Williams v. ,Jones, I3 Last, 439. 
sued upon was deemed a specialty where made, and a simple contract where the suit was brought, or vice eersu. Thus, in some of the States a scroll attacherl to the promisor's name is the same as a common-law seal; amel covenant or debt would be the proper remedy in the state where the promise was made, assmmpsit not lying on a reallad instrument. And, noreover, by the local law the defomdant could not plead want of consileration, becanse of the instrument being sealed. But if snit were bronght in a state where a seroll is not recognized as a seal, it has been repeatedly held, that assumpsit would be the proper renedy, and that want of consideration might be plested. ${ }^{+2}$ And the converse hals been also held, that although where matle the instrument might be a simple promissory note, yet if where suit was brought it was regarded as a specialty, the appropriate action of debt or covenant should be brought, and the sanctity attached to seals would be imputed to it. ${ }^{43}$ At one time it was held that the extent of the remedy was to be determined by the law of the place of contract, and where suit was brought in England upon a French contract, upon which by the laws of France no arrest conld be made, it was held that the defendant could not in England be held to bail; ${ }^{4 t}$ but the contrary doctrine is now well settled.

Questions of evidence appertain to the remedy, and consequently are controlled by the law of the form. "Whether a witness is competent or not; whether" a certain matter requires to be proved by writing or not; whether certain evidence proves a certain fact or not - this is to be letermined by the law of the comntry where the question arises, where the remely is somglit to be enforced, and where the conrt sits to enforec it," is the language of Lord Brougham. It follows that the lex fori muloubtedly applies to the com-

42 lank of Cnited States v. Donally. \& Pet. 361: Le Roy v. Beard, 8 How. 45I; Warren v. lyuch, is Johus. 239.

43 Thrasber v. Eerhart, 3 Gill \& .J. 319.

44 De la Vega v. Vianna, 1 B. \& C. 284: Peek v. Ilozier, 14 Johns. 346; Hindley v. Marean, 3 Mason, 90 .

45 Bain $v$. Whitehaven, ete., R. Co., 3 H. I. Cas. I: Whart on on Conflict of Laws, $\$ 765$; Story on Conllict of Laws, $\$ 635$. 
peteney and eredibility of witnesses, but not as to the number of attesting witnesses necessary to the validity of a writing. ${ }^{46}$

$\$ 497$. Whether party is bona fide purchaser for value. - So the effect of the transaction in fixing the relations of the parties is, as between them, determined by the lex loci comtractus. Thus, if by the lex loci contractus the purchaser aequires the note as a bonu fide holder, not subject to the defense of a prior payment, such paynent cannot be pleaded, although the lex fori would permit it. ${ }^{4 \pi}$ And whether or not the proprietor of the bill or note is a bona fide holder, is to be determined by the lex loci contractus that is, the place of parment. ${ }^{4{ }^{\prime}}$ The mode and measure of recorery would, however, scen to be a question of the forum. ${ }^{49}$

\$ 498. In respect to set-off, it is laid down by text writers, and hy the courts of common law, that a set-off to any action allowed by the local law is to be treated as a part of the remedy; and that, therefore, it is admissible in claims between persons belonging to different States or countries, although it may not be admissible by the law of the country where the debt which is sned was contracted." The same principle applies to the mode of attacking consideration. When the lex fori allows a plea of want of consideration in a suit on an obligation, which by the lex loci contractus was sealed, and to which by such latter law no such plea could be offered, the lex fori controls. ${ }^{51}$ So as to other legal and equitalle defenses, where the rery contract itself does not exclude them, they are to be controlled by the lex

46. Wharton on Conflict of Laws, $\S 769$.

47 Harrison v. Ldwards, 12 Vt. 65l.

48 Allen v. Bratton, 47 Miss. 129; Woodruff v. Hill, 116 Mass. 310.

49 Woodruff v. 1lill, 116 Mass. 310; 2 Ames on Bills and Notes, 306.

60 Mineral Point R. Co. v. Barron, 83 Ill. 366; Gibbs v. Howard, 2 N. H. 296.

61 Wharton on Conflict of Laws, $\S 788$. 
fori. Statutes providing certain exemptions from levy and sale upon execontion affect the remedy, and lhose of the formu prevail. ${ }^{53}$

$\$ 499$. The courts can take no judicial notice of the laws of another country. When relied upon, theg must lie proved as facts, and otherwise it will be presumed that they are the same ats the laws of the formu in which suit is bronght ${ }^{5+4}$ or what is the same in eflect, when the laws of the foreign country are not put in proof ats facts, the condt will apply to the transaction in suit the laws of the formm. Thus the law as to the rate of damages will he presumed to be the sane where the bill is drawn in one comtry, and is sued on in another; 50 it will be presmed, where the law of the formm anthorizes an indorse to sue before exhansting recourse against the maker, that the law of the place of the contract is likewise; ${ }^{5 i}$ and so, where by the law of the formm a farty signing in a certain way is regarded as an indorser, the foreign law will be presmed to be likewise." But where the question is one relating to the law merehant, which is of general application, as, for instance, the number of dars of grace, it would be presmed that they were fixed by the law merchant, that is, that three days of grace were allowed - the law merehant being regarded as part of the eommon latr. ${ }^{\text {sis }}$ Bonds and eompons in form negotiable aceording to the law merehant as now recognized would be presumed in one State to be negotiable in another. ${ }^{59}$

$\$ 500$. What law governs as to presentment, protest, and notice of dishonor.- In order to rharge the drawer or indorser, the holder must exercise due diligence in presenting

Fie Bliss $x$. Hougliton, 13 X. 11. 126.

53 Nineral Point li. (o. v. liarron, s3 Ill. 366.

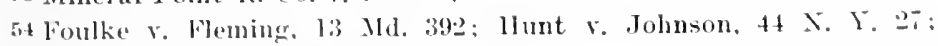

Whidden v. Seelye, 40 Me. 247.

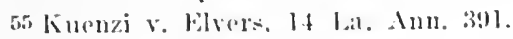

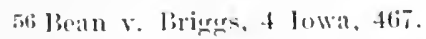

5i Daniel on Xegotiable Instruments. \$\$ \$\$1, S95.

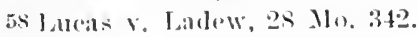

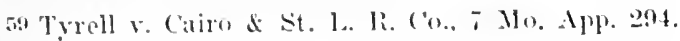


the bill to the drawee, or aceptor, and the note to the maker; and as the acts necessary to constitute a due presentment are to be done at the place. upon which the bill is drawn, or at which the bill or note is payable, they must. be gorerned by the law of the place upon which it is drawn, or at which it is payable, as the case may be. Aceordingly, the question whether or not the bill should have grace would be determined by the law of the place of payment; and also, if allowable, in how many days grace shonld consist. In France no grace is allowable, while in England and the Cnited States it is generally three days. But it ranges in different places from three to thirty days, and in each case the law of the partienlar place would determine. ${ }^{60}$

When a foreign bill is dishonored, it is necessary that it should be protested, and the protest should be made at the time, in the manner, and by the persons preseribed in the place where the lill is refused acceptance or payment, as the case may be. ${ }^{61}$

In respeet to notice, it has been distinguished from the presentment and protest in an often quoted American case, ${ }^{62}$ in which it is held that it must conform to the law of the place where the drawing or indorsement ocenrs, in order to charge the drawer or any particular indorser, on the ground that the nature and extent of the liabilities of the drawer or indorser are to be determined according to the law of the place where the bill is drawn or indorsement made, and that the mode and time of notice constitute an implied condition of the eontract. ${ }^{63}$

60 lank of Washington v. Triplett, 1 Pet. 25; Aymar v. Sheldon, 12 Wend. 439; Jewell v. Wright, 30 N. Y. 264.

61 Daniel on Negotiable Instruments, $§ 909$.

62 Aymar v. Sheldon, 12 Wend. 439.

63 Lee v. Selleck, 33 N. Y. 8 I5; Williams v. Putnam, 14 N. H. 543 ; Story on Bills, $\$ 285$. 
APPENDIX.

[345] 



\section{A P P E N I X.}

\section{THE NEGOTIABLE INSTRUMENTS LAW.}

Mr. Daniel, in the vear 1876, concluded the first edition of his work on "Negotiable Instruments" with the following expression of hope for a uniform system of commercial law throughout the country: ". We will never immolate truth, justice. and the law because a state tribunal has erected the altar and deereed the saerifice." And for the facilitation of trade, and the fair understanding of mercantile negotiations among all mereantile men, it is to be boped that the day is not far distant when it may be truly said (in the language of Cicero, approvingly quoted by Manffeld and Story), respecting the law of our subject, wherever industry turns a wheel or commerce sets a sail. - Ion erit alia lex Roma, alia Athenis, alia nune, alia posthac, sed et apud omnes gentes, et omni tempore, una calemque lex obtinebit."

Appreciating the necessity for revision and uniformity, the English Parliament in the year 1882 passed the " English Bills of Exchange Act." and on May 19, 1897, the Legislature of New York enacted "In act in relation to Negrotiable lnstruments." This law was first recommended at the conference of the Commissioners on Lniformity of Laws in 1895, and was based upon the "English Bills of Exchange Act." In 1597 the States of Connecticut, Colorado, and Florida adopted the New lork statute: in 1898, Masichmetts, Maryand, and Virginia fol. lowed; in 1899. Thode Island. Tennessee. North Carolina, Wisconsin. Corth Dakota, Ctalt, Oregon, Washington, and the Distriet of Colnmhia: in 1901, Pennsylvania and Arizona; and in 1902, Ohio, New Jersey, and Iowa.

* Swift $v$. Tyson, 16 Pet. l. 


\section{PROVISIONS OF THE ACT.}

\section{ARTICLE I.** \\ General Provisions.}

Section 1. Short title.

2 . Definitions and meaning of terms.

3. Person primarily liable on instrument.

4. Reasonable time. what constitutes.

5. Time, how eomputed; when last day falls on holiday.

6. Application of chapter.

7. Rule of law merchant; when governs.

$\$$ I. Short title. - This act slall be known as the negotiable instruments law.

$\S$ 2. Definitions and meaning of terms.- In this act, unless the context otherwise requires:

"Acceptance" means an acceptance completed by delivery or notification.

"Action" includes counterclaim and set-off.

"Pank" includes any person or association of persons carrying on the business of banking, whether incorporated or not.

"Bearer" means the person in possession of a bill or note which is payable to bearer.

"Bill" means bill of exchange, and " note" means negotiable promissory note.

"Delivery" means transfer of possession, actual or constructive, from one person to another.

"Holder" means the payee or indorsee of a bill or note, who is in possession of it, or the bearer thereof.

"Indorsement" means an indorsement completed by delivery.

"Instrument" means negotiable instrument.

"Issne" means the first delivery of the instrument, complete in form, to a person who takes it as a holder.

"Person" inchides a boly of persons, whether incorporated or not.

"Vahe" means valuable consideration.

"Written" includes printed, and "writing" inchues print.

$\S 3$. Person primarily liable on instrument.- The person "primarily" liable on an instrument is the person who by the terms of the instrument is absolntely required to pay the same. All other parties are "sceondarily" liable.

\$ 4. Reasonable time, what constitutes.-. In determining what is a "reasonable time" or an " unreasonable time," regard is to be had to the nature of the instrument, the usage of trade or business (if any) with respect to such instruments, and the facts of the particular case.

* The numbers of the sections of this article in other States than New York are as follows: Colorado, Iowa, Massachusetts. New Jersery. North Carolina, North Dakota, Pennsylvania, Utah, Virginia, and Washington, 190-196: Maryland, 13-19: Ohio, 3178-3178e; Oregon, 190-192; Phode Island, 1-7; Wisconsin, 1675. In Arizona, Conneetient, District of Columbia, Florida, and Tennessee, these sections are not numbered. 
\$ 5. Time, how computed; when last day falls on holiday.Where the day, or the last day, for doing any atet herein required or permitted to be done falls on Sunday or on a holiday, the act may be done on the next succeding seeular or business day.

\$6. Application of chapter. - The provisions of this act do not apply to montiable instruments made and delivered prior to the passige hereof.

$\$$ 7. Law merchant; when governs. - In any case not provided for in this act the rules of the law merchant shall govern.

\section{ARTICLE II.*}

\section{Form and Interpretation.}

SECrios 20. Form of negotiable instrument.

21. Certainty as to sum: What coustitutes.

2.2. When promice is nuconditional.

23. Determinable future time: what constitutes.

24. Alditional provisions not alfecting negotiability.

25. Onissions; seal; patticular money.

26. When payible on temand.

27. When payible to order.

28. When parable to bearer.

29. Torms when sutlicient.

30. Date, prosumptions as to.

31. Ante-ditud ind post-diated.

32. When diste may be inerted.

33. Blanks, when inay be filled.

34. Heomplete instrument not delivered.

35. Defivery: when effectual: when presumed.

36. Contruetion where instrument is ambignous,

37. liability of person sipning in trate or asumed name.

38. Simature by arent: anthority: how shown.

39. Linlility of person signing as igent, et cetera.

40. Signatrie by procurations redlect of.

41. Eillect of indorsement by infant or corporation.

4.2. For ged signature: allect of.

$\S 20$. Form of negotiable instrument.-An instrument to be negotiable munt "onform to the following requirements:

l. It must be in writing and signed ly the maker or drawer.

$\because$. Mu-t contain an unconditional promise or order to pay a sum certain in money.

3. Nust be payalole on demand, or at a fixed or determinable future time.

4. Must he payable to order or to hearer: and

5. Where the inctrument is addresed to al drawee, he must be named or otherwise indicated therein with reasonable certainty.

*The numbers of the sections of this article in other states than Tew York are as follows: Arizona, 3304-3326: Colorado. Connectient, District of Columbia, Florida. Iowa, Massaehusetts. New Jersey, North

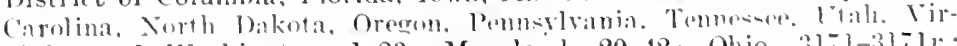
ginia, am Wa-hington, 1-23; Maryland, 20-42: Ohio, :371-317le; Rlode 1sland, 9-31: Wisconsin, $1675-1$ to $1675-23$. 
\$2 I. Certainty as to sum; what constitutes. - The sum payable is a sum certain within the meaning of this act, although it is to be paid :

l. With interest: or

2. By stated instalments; or

3. By stated instalments, with a provision that upon default in payment of any instalment or of interest, the whole shall become due; or

4. With exchange, whether at a fixed rate or at the eurrent rate; or

5 . With costs of collection or an attorney's fee, in case payment shisll not be made at maturity.

$\$$ 22. When promise is unconditional. - An unqualified order or promise to pay is meonditional within the meaning of this act, though coupled with:

1. An indication of a particular fund out of which reimbursement is to be made. or a particular account to be debited with the amount; or

2. A statement of the transaction which gives rise to the instrument.

But an order or promises* to pay out of a partieular fund is not unconditional.

\$ 23. Determinable future time; what constitutes.- An instrument is payable at a determinable future time, within the meaning of this act. which is expressed to be payable:

1. At a fixed period after date or sight; or

2 On $\omega^{\circ}$ before a fixed or determinable future time speeified therein: or

3. On or at a fixed period after the oceurrence of a specified event, which is certain to happen, though the time of happening be uncertain.

An instrument payable upon a eontingency is not negotiable, and the happening of the event does not cure the defect.

$\S 24$. Additional provisions not affecting negotiability. - An instrument which contains an order or promie to do any act in addition to the payment of money is not negotiable. But the negotiable character of an inatrument otherwive negotiable is not affected by a provision which:

1. Authorizes the sale of collateral securities in ease the instrument be not paid at maturity; or

2. Authorizes a confession of judgment if the instrument be not paid at maturity: or

3. Waives the lenefit of any law intended for the advantage or protection of the obligor: or

4. Gives the holler an rlection to require something to be done in lieu of payment of money.

But nothing in this section slall validate any provision or stipulation otherwise illegal.

§ 25. Omissions; seal; particular money.- The validity and negotiable chararter of an instrument are not affected by the fact that:

1. It is not dated: or

2. Does not specify the value given, or that any value has been given therefor; or

3. Does not specify the place where it is drawn or the place where it is payable; or

4. Bears a seal: or

5. Designates a particular kind of current money in which payment is to be made.

* Error in engrossing. 
But nothing in this section shall alter or repeal any statute requiring in certain eases the mature of the consideration to be stated in the instrument.

\$ 26. When payable on demand. - An instrument is payable on demand :

1. Where it is expressed to be payable on demand, or at sight, or on presentation; or

2. In which no time for payment is expressed.

Where an instrument is issued, accepted or indorsed when overdue, it is, as regads the person so issuing, accepting or indorsing it, paly. able on demand.

\$ 27. When payable to order.-The instrument is payable to order where it is drawn payable to the order of a specified person or to him or lis order. It may be drawn payable to the order of:

1. A payee who is not maker, drawer or drawee; or

2. The drawer or maker; or

3. The dratwee; or

4. Two or more payees jointly; or

5. One or some of several payees; or

6. The holder of an oflice for the time being.

Where the instrument is payable to order the payee must be named or otherwise indicated therein with reasonable certanty.

$\S 28$. When payable to bearer. - The instrument is payable to bearer:

1. When it is expressed to be so payable: or

2. When it is payable to a person nimed therein or bearer: or

3. When it is payable to the order of a fictitious or non-existing person, and such faet was known to the person making it so parable: or

4. When the name of the payee does not purport to be the name of any person; or

5. When the only or last indorsement is an indorsement in blank.

$\$$ 29. Terms when sufficient.- The instrument need not follow the language of this act, but any terms are suflicient whieh elearly indicate an intention to conform to the requirements hereof.

30. Date, presumption as to. - Where the instrument or an acceptineo or any indorsement thereon is dated. such date is deemed prima facic to be the true date of the making, drawing, acceptance or indorsement, as the case may be.

\$ 3r. Ante=dated and post=dated. - The instrument is not invalid for the reason only that it is ante-dated or post-dated, provided this is not done for an illegal or fraudulent purpose. The person to whom an instrument so dated is delivered acquires the title thereto as of the date of delivery.

$\S 32$. When date may be inserted.- Where an instrument ex. pressed to be payable at a fixed period after date is issued undated, or where the acceptance of an instrument payable at a fixed period after sight is undated, any holder may insert therein the true dite of issue or aceeptance, and the instrument shall be payable accordingly. The insertion of a wrong date does not aroid the instrument in the hands of a subsequent holler in due course: but as to him, the date so inserted is to be regarded as the true ditte.

$\S 33$. Blanks; when may be filled.- Where the instrument i= wanting in any material partieular. the person in possession therwof has a prima facie authority to emplete it by filling up the blank therein. And a signature on a blank paper delivered by the person making the signature in order that the paper ma be converted into a negotiable 
instrument operates as a prima facic authority to fill it up as sueh for any amount. In order, howerer, that any such instrument, when completed, may be enforced against any person who beeame a party thereto prior to its completion, it must be filled up strietly in accordanee with the authority given and within a reasonable time. But if any such instrmment, after completion is negotiated* to a holder in due course, it is valid and effeetual for all purposes in his hands, and he may enforce it as if it had been fillel up strietly in aceordance with the athority given and within a reasonable time.

\$ 34. Incomplete instrument not delivered.- Where an incomplete instrument has not been delivered it will not, if completed and negotiated, without authority, be a valid contract in the hands of any holder, as against any person whose signature was placed thereon before delivery.

$\S 35$. Delivery; when effectual; when presumed.- Every contract on a negotiable instrument is ineomplete and revoeable until delivery of the instrument for the purpose of giving effect thereto. As between immediate parties, and as regards a remote party other than a holder in due eourse, the delivery, in order to be efleetual, must be made either by or under the authority of the party making, drawing, accepting, or indorsing, as the ease may be; and in such case the delivery may be shown to have been conditional, or for a special purpose only, and not for the purpose of transferring the property in the instrument. But where the instrument is in the hands of a holder in due course, a valid delivery thereof by all parties prior to him so as to make them liable to him is conclusively presumed. And where the instrument is no longer in the possession of a party whose signature appears thereon, a vilid and intentional delivery by him is presumed until the contrary is proved.

\$ 36. Construction where instrument is ambiguous. - Where the language of the instrument is ambiguous, or there are omissions therein, the following rules of construction apply:

1. Where the sum payable is expressed in words and also in figures and there is a discrepancy between the two, the sum denoted by the words is the sum payable; but if the words are ambiguous or uncertain, references may be had to the figures to fix the amount;

2. Where the instrument provides for the payment of interest, without specifying the date from which interest is to run, the interest runs from the date of the instrument, and if the instrument is undated, from the issue thereof;

3. Where the instrument is not dated, it will be considered to be dated as of the time it was issued;

4. Where there is a conflict between the written and printed provisions of the instrument, the written provisions prevail;

5. Where the instrument is so ambiguons that there is doubt whether it is a bill or note, the holder may treat it as either at his election;

6. Where a signature is so placed upon the instrument that it is not clear in what capacity the person making the same intended to sign, he is to be deemed an indorser;

7. Where an instrument containing the words "I promise to pay" is signed by two or more persons, they are deemed to be jointly and severally liable thereon.

§ 37. Liability of person signing in trade or assumed name.No person is liable on the instrument whose signature does not appear thereon, except as herein otherwise expressly provided. But one who

* The word "negotiated" substituted for "negotiable" by Laws of N. Y. 1898, e. 336. 
signs in a trade or assumed name will be liable to the same extent as if lee had signed in his own name.

\$ 38. Signature by agent; authority; how shown.- "Th" sirnatir. of any paty may he male by a doly anthorized agent. No particular form of appointment is necessary for this purpons; and the authority of the anent may be established as in other cases of agrency.

\$ 39. Liability of person signing as agent, etc.- Mhere the instrument contains or a person adds to his signature words indicating that he signs for or on behalf of a principal, or in al representitive capacity, he is not liable on the instrument if he was duly authoriond; but the mere addition of words describing him as an agent, or as filling a representative character, without disclosing his principal, does not exempt him from persomal liability.

\$ 40. Signature by procuration; effect of.- A signature by " procuration" operates as notice that the agent has but a limited authority to sign, and the principal is boumd only in case the agent in so signing acted within the actual limits of his authority.

$\$ 4$. Effect of indorsement by' infant or corporation.- 'The indorsement or assigmment of the instrument by a corporaticn or by an infant passes the property therein, notwithstanding that from want of capacity the corporation or infant may ineur no liability thereon.

$\$$ 42. Forged signature; effect of.-Where a signature is forged or made without anthority of the person whose signature it purports to be, it is wholly inoperative, and no right to retain the instrument, or to give a discharge therefor, or to enforce payment thereof against any party thereto, ean be acquired through or miner such signature, unless the party arainst whom it is sought to enforce such right is precluded from setting up the forgery or want of authority.

\section{ARTICLE III.*}

\section{Consideration of Negotiable Instruments.}

Section 50. Presumption of consideration.

51. What constitutes consideration.

52. What constitutes holder for value.

53. When lien on instrument constitutes holder for value.

54. Fifect of want of consideration.

55. Liability of accommodation party.

$\S$ 50. Presumption of consideration.- Every negotiable instrument is deemed prima facie to have been issued for a valuable consideration; and every person whose signature appears thereon to have become a party thereto for value.

\$ 5 r. Consideration, what constitutes. - Value is any eonsideration sufficient to support a simple contract. An antecertent or preexisting debt constitutes value; and is deemed such whether the instrument is payable on demand or at a future time.

* The numbers of the sections of this article in other states than New York are as follows: Arizona, 3327-3332; Colorado. Connectieut, District of Colmmbia, Florila, Lowa, Massachusetts, New Jersey. North Carolina, Nortl Dakota, Oregon, Pennsylvania. Tennessee, Etih, Vircrinia. and Washinerton. 24-2!): Marvamil. 43-4s: Ohio, 31716-31720: Rhode lsland, 32-37: Wisconsin, $1675-50$ to $165 \overline{5}-5 \overline{5}$. 
$\S 52$. What constitutes holder for value.- Where value lats at any time been given for the instrument, the holder $\mathrm{i}$ - deemed a holder for value in respect to all parties who became such prior to that tine.

$\$$ 53. When lien on instrument constitutes holder for value.Where the holder has a lien on the instrument, arising either from contract or by implieation of law, he is deemed a holder for value to the extent of his lien.

$\$ 54$. Effect of want of consideration.- Alsence of failure of consideration is matter of defense as against any person not a lrolder in due course; and partial faihure of consideration is a defense pro tanto, whether the failure is an ascertained and liquidated amount or otherwise.

\$ 55. Liability of accommodation party.-An accommodation party is one who luas signed the instrument as maker, drawer, acceptor, or indorser, without receiving value therefor, and tor the purpose of lending his name to some other person. Such a person is liable on the instrument to a holder for value, notwithstanding such bolder at the time of taking the instrument knew him to be only an accommodation party.

\section{ARTICLE IV.*}

\section{Negotiation.}

Section 60. What constitutes negotiotion.

61. Indorsement; how made.

62. Indorsement must be of entire instrument.

63. Kinds of inclorsement.

64. Special indorsement: indorsement in blank.

65. Blank indorsement; how changed to special indorsement.

66. Whien indorsement restrictive.

67. Effect of restrictive indorsement; rights of indorsee.

68. Qualified indorsement.

69. Conditional indorsement.

70. Indorsement of instrument payable to bearer.

71. Indorsement where payable to two or more persons.

72. Effeet of instrument drawn or indorsed to a person as cashier.

73. Indorsement where name is misspelled, et cetera.

74. Indorsement in representative capacity.

75. Time of indorsement: presumption.

76. Place of indorsement: presumption.

77. Continuation of negotiable character.

78. Striking ont indorsement.

79. Transfer without indorsement; effeet of.

80. When prior party may negotiate instrument.

$\S 60$. What constitutes negotiation.- An instrument is negotiated when it is transferred from one person to another in such mafner as

* The numbers of the sections of this article in other States than New York are as follows: Arizona, 3333-3353; Colorado, Connecticut. District of Columbia, Florida. Iowa, Massachusetts, New Jersey. Nortli Carolina, North Dakota, Oregon, Pennsylyania, Tennessee, Utah. Virginia, and Washington, 30-50; Maryland, 49-69; Ohio, 3172b-3172v; Rlode Island, 38-58; Wisconsin, 1676 to $1676-20$. 
to constitute the transferee the holder thereof. If payalie to learer it is negotiated by delivery; if payable to order it is motiated by the indorsenent of the holder completed hy delivery.

\$ 6x. Indorsement; how made.-The indorsement must be written on the instrument itself or upon a paper attached thereto. The signature of the indorsar, withont additional words, is a sutlicicnt indursement.

\$ 62. Indorsement must be of entire instrument.- The indor-e. ment must be an indorsement of the entire instrument. An indorement, which purports to trausere to the indorsee a part only of the amount payable. or which purports to transfer the instrumcule to two or more indorsers severally, does not operate as a negrotiation of the instrument. But where the instrument has been paid in part. it may be indorsed as to the residue.

\$ 63. Kinds of indorsement.-An indorsement may be either - incial or in hlank; and it may also be either restrictive or qualitied, or conditional.

$\$ 64$. Special indorsement; indorsement in blank. - A sperial indorsement specifies the person to whom, or to whose order the instru. ment is to be payable: and the indorsement of such indorsee is necessary to the further negotiation of the instrument. An indorsement in blank specifies $n o$ indorsee. and an instrument so indorsed is payable to bearer, and may be negotiated by delivery.

$\$ 65$. Blank indorsement; how changed to special indorsement. - The holder maly convert a blank indorsement into a special indorsement by witing over the signature of the indorser in blank any contract consistent with the character of the indorsement.

$\S 66$. When indorsement restrictive. - An indorsement is restrictive, which either:

1. Prohibits the further negotiation of the instrument; or

2. Constitutes the indorsee the agent of the indorser: or

3. Vests the title in the indorsee in trust for or to the use of some other person.

But the mere abence of words implying power to negotiate does not make an indorsement restrictive.

$\S 67$. Efiect of restrictive indorsement; rights of indorsee.A restrictive indorsement confer's upon the indorsee the right:

1. To receive payment of the instrument;

2. To bring any action thereon that the indorser conld bring:

3. To transer his rights as such indorsee, where the form of the indorsement atuthorizes him to do so.

But all subsequent indorsers anpuire only the title of the fir-t indorsee under the restrictive indorsement.

\$ 68. Qualified indorsement. -1 qualified indorsement constitutes the indorser a mere assignor of the title to the instrument. It may be made by adding to the indorser's signature the words " without recourse" or any words of similar import. Such an indorsement does not impair the negotiable character of the instrument.

"The dash and the words "a qualified indorsement" omitted in the original aet through error were added by Laws N. Y. 1898, c. 336. 
\$ 69. Conditional indorsement.- Where an indorsement is conditional, a party required to pay the instrument may disregard the condition and make payment to the indorsee or his transferee, whether the condition has been fulfilled or not. But any person to whom an instrument so indorsed is negotiated will loold the same, or the proceeds thereof. subject to the rights of the person indorsing conditionally.

$\$$ 7o. Indorsement of instrument payable to bearer.- Where an instrument, payable to bearer, is indorsed specially, it may, nevertheless, be further negotiated by delivery; but the person indorsing specially is liable as indorser to only such holders as make title through his indorsement.

\$ 7I. Indorsement where payable to two or more persons. Where an instrument is payable to the order of two or more payees or indorsees who are not partners, all must indorse, unless the one indorsing has anthority to indorse for the others.

$\S 72$. Effect of instrument drawn or indorsed to a person as cashier. - Where an instrument is drawn or indorsed to a person as "cashier" or other fiscal officer of a bank or corporation, it is deemed prima facic to be payable to the bank or corporation of which he is such oflicer; and may be negotiated by either the indorsement of the bank or corporation, or the indorsement of the officer.

$\S 73$. Indorsement where name is misspelled, et cetera.-Where the name of a payee or indorsee is wrongfully designated or misspelled, he may indorse the instrument as therein described, adding, if lie think fit, his proper signature.

$\$ 74$. Indorsement in representative capacity. - Where any person is under obligation to indorse in a representative eapaeity, he may indorse in sueh terms as to negative personal liability.

$\S$ 75. Time of indorsement; presumption.- Exeept where an instrument bears date after the maturity of the instrument, every negotiation is deemed prima facie to have been effeeted before the instrument was overdue.

$\S$ 76. Place of indorsement; presumption.- Except where the contrary appears every indorsement is presumed prima facie to have been made at the place where the instrument is dated.

\& 77. Continuation of negotiable character. - An instrument negotiable in its origin continues to be negotiable until it has been restrictively indorsed or discharged by payment or otherwise.

\& 78. Striking out indorsement.- The holder may at any time strike out any indorsement which is not necessary to his title. The indorser whose indorsement is struck out, and all indorsers subsequent to him, are thercly relieved from liability on the instrument.

\& 79. Transfer without indorsement; effect of.-Where the holder of an instrument payable to his order transfers it for value without indorsing it, the transfer vests in the transferee such title as the transferrer had therein, and the transferce aequires, in addition, the right to have the indorsement of the transferrer. But for the purpose of determining whether the transferee is a holder in due course, the negotiation takes effect as of the time when the indorsement is actually made. 
8 80. When prior party may negotiate instrument. - Where an instrument is negotiated back to a prior party, such party may, subject to the provisions of this act, reissme and further negotiate the same. But he is not entitled to enforce payment thereof against any intervening farty to whom he was personally liable.

\section{ARTICLE V."}

\section{Rights of Holder.}

SEction 90. Right of holder to sue; payment.

91. What constitutes a holder in due comse.

92. When person not elecmed holder in due course.

93. Notice before full amount paid.

94. When title elofective.

95. What constitutes notiee of defeet.

96. Rights of holder in due course.

97. When subject to original dofenses.

98. Who deemed holder in due course.

8 9o. Right of holder to sue; payment. - The holder of a negotiable instrument may sue thereon in his own name; and payment to him in due course discharges the instrument.

$\S 91$. What constitutes a holder in due course.- A holder in due course is a holder who has taken the instrument under the following conditions :

1. That it is eomplete and regular npon its face:

2. That he became the holeter of it before it was overdue, and without notice that it had been previously dishonored, if such were the fact;

3. That he took it in good faith and for value:

4. That at the time it was negotiated to him he had no notice of any infirmity in the instrument or defect in the title of the person negotiating it.

$\S 92$. When person not deemed holder in due course.- Where an instrument payable on demand is negotiated an unreasonable length of time after its issue, the holder is not deemed a holder in due eourse.

\$ 93. Notice before full amount paid.- Where the transferee reeeives notice of any infirmity in the instrument or defect in the title of the person necotiating the sane before he has pail the full amount agreed to be paid therefor, he will low deened a holder in due rourse only to the extent of the amomnt theretofore paid by him.

$\$ 94$. When title defective.- The title of a person who negotiates an instrument is defective within the meaning of this act when he obtained the instrument, or any simature thereto. by fratul, duress. or force and fear, or other unlawful means, or for an illegal condideration,

" The numbers of the sections of this artucle in other states than New York are as follows: Mrizonat 33.54-336i2: Coloralo. Connectiont. District of Columbia, Florida. Jowa. Missildhusetts, Now Jerses. North Carolina, North Dakota. Orexon. Pennsylvania, Tennessee. lath. Yirginia, and Washington. 51-59: Maryland, 70-7s: (Mhio. 317-26-3173d; Rhode Island, 59-67; Wisconsin, 1676-21 to $1676-29$. 
or when he negotiates it in breach of faith, or under such eircumstances as amount to a fraud.

$\S 95$. What constitutes notice of defect.-To constitute notice of an infirmity in the instrument or defect in the title of the person negotiating the same, the person to whom it is negotiated must have had actual knowledge of the infirmity or defect, or knowledge of such facts that his action in taking the instrument amounted to bad faitl.

$\S 96$. Rights of holder in due course.-A holder in due eourse holds the instrument free from any defect of title of prior parties among thenselves, and may enforce payment of the instrument for the full amount thereof against all parties liable thereon.

\$ 97. When subject to original defenses. - In the hands of any holder other than a holder in due course, a negotiable instrument is subject to the same defenses as if it were non-negotiable. But a holder who derives his title through a holder in due course, and who is not himself a party to any fraud or illegality affecting the instrument, has all the righits of such former holder in respect of all parties prior to the latter.

\$ 98. Who deemed holder in due course.- Every holder is deemed prima facie to be a holder in due course; but when it is shown that the title of any person who has negotiated the instrument was defective, the burden is on the holder to prove that he or some person under whom he elains aequired the title as a holder in due course. But the last-mentioned rule does not apply in favor of a party who became bound on the instrument prior to the acquisition of such defective title.

\section{ARTICLE VI.*}

\section{Liabilities of Parties.}

SECTION 110. Tiability of maker.

111. Liability of drawer.

112. Liability of aceeptor.

113. When person deemed indorser.

114. Liability of irregular indorser.

115. Warranty; where negotiation by delivery, et cetera.

116. Liability of general indorsers.

117. Liability of indorser where paper negotiable by delivery.

118. Order in which indorsers are liable.

119. Liability of agent or broker.

\& 110. Liability of maker.-- The maker of a negotiable instrument by making it engages that he will pay it aceording to its tenor; and admits the existence of the payee and his then eapacity to indorse.

\$ II. Liability of drawer.- The drawer, by drawing the instrument, admits the existence of the payce and his then capacity to in. dorse; and engages that on due presentment the instrument will be

* The numbers of the sections of this article in other States than New York are as follows: Arizona, 3363-3372; Colorado, Conneeticut, District of Columbia, Florida, Iowa, Massachusetts, New Jersey, North Carolina, North Dakota, Oregon, Pennsylvania, Tennessee, Utah, Virgrinia. and Washington. 60-69: Maryland, 79-88; Ohio, 3173e-3173n; Rhode Island, 68-77; Wisconsin, 1677 to $1677-9$. 
accepted and* paid, or both, according to its tenor, and that if it be dishonored and the necessary proceedings on dislionor be duly taken. he will pay the amount thereof to the holder, or to any subsequent indorser who may be compelled to pay it. IBut the drawer may insert in the instrument an express stipulation negativing or limiting lis own liability to the holder.

§I2. Liability of acceptor.- The acceptor by accepting the in. strument engages that he will pay it aceording to the tenor of his aeceptance: and admits:

1. The existence of the llawer, the genuineness of his signature, and his eapacity nnd autlority to draw the instrument; and

2. The existenee of the payee and his then eapacity to indorse.

$\S 1 \times 3$. When person deemed indorser.-A person placing his signature upon an instrument otherwise than to maker, drawer, or aeceptor is deemed to be an indorser, unless lie clearly indieates by appropriate words his intention to be bound in some otlier capacity.

$\$$ r 1 . Liability of irregular indorser. - Where a person, not otherwise a party to an instrument, places thereon lis signature in blank before delivery, he is liable as indorser in accordance with the following rules:

1. If the instrument is payable to the order of a third person, he is liable to the payee and to all subsequent parties.

2 . If the instrument is payable to the order of the maker or drawer, or is payable to bearer, he is liable to all parties subsequent to the maker or drawer.

3. If he signs for the aceommodation of the payee lie is liable to all parties subsequent to the payee.

\& I 5. Warranty where negotiation by delivery, et cetera.Every person negotiating an instrument by delivery or by a qualified indorsement, warrants:

1. That the instrument is genuine and in all respeets what it purports to be;

2. That he has a good title to it:

3. That all parties had eapacity to contraet;

4. That he has no knowledge of any fact which would impair the validity of the instrument or render it valueless.

But when the negotiation is by delivery only, the warranty extends in favor of no holder other than the immediate transferee. The provisions of subdivision three of this section do not apply to persons negotiating public or corporate securities, other than bills and notes.

§ r 6. Liability of general indorser.- Every indorser who indorses without qualifieation, warrants to all subsequent loolders in due course:

1. The matter and things mentioned in subdivisions one, two, and three of the next preceding section; and

2 . That the instrument is at the time of his indorsement ralid and subsisting.

And, in addition, he engages that, on due presentment, it sliall be accepted or paid, or both, as the ease may be, according to its tenor, and that if it be dishonored. and the neeessary proceedings on dishonor be duly taken, he will pay the amount thereof to the holder. or to any subsequent indorser who may be compelled to pay it.

* Error in engrossing. The word in the Commissioners draft is " or." The mistake was not corrected by Laws X. I. IS98, e. 336 . It occurs only in the New York statute. 
\$ I 7. Liability of indorser where paper negotiable by delivery. - Where a person places his indorsement on an instrument negotiable by delivery he incurs all the liabilities of an indorser.

$\S$ I 8 . Order in which indorsers are liable. - As respeets one another, indorsers are liable prima facie in the order in which they indorse: but evidence is admissible to show that as between or anong themselves they have agreed otherwise. Joint payees or joint indorsees who indorse are deemed to indorse jointly and severally.

$\$ 119$. Liability of agent or broker.- Where a broker or other agent negotiates an instrument without indorsement, he incurs all the liabilities prescribed by section one hundred and fifteen* of this act, unless he discloses the name of his principal, and the fact that he is acting only as agent.

\section{ARTICLE VII.†}

\section{Presentment for Payment.}

Sectiox 130. Effect of want of demand on prineipal debtor.

131. Presentment where instrument is not payable on demand. 132. What eonstitutes a sufficient presentment.

133. Place of presentment.

134. Instrument must be exhibited.

135. Presentment where instrument payable at bank.

136. Presentment where principal debtor is dead.

137. Presentment to persons liable as partners.

138. Presentment to joint debtors.

139. When presentment not required to cliarge the drawer.

140. When presentment not required to charge the indorser.

141. When delay in making presentment is excused.

142. When presentment may be dispensed with.

143. When instrument dishomored by non-payment.

144. Liability of person secondarily liable, when instrument dishonored.

145. Time of maturity.

146. Time; how compited.

147. Rule where instrument payable at bank.

148. What constitutes payment in due course.

$\S$ r3o. Effect of want of demand on principal debtor.-Presentment for payment is not necessary in order to charge the person primarily liablet on the instrument: but if the instrument is. by its terms, payable at a speeial place, and he is able and willing to pay it there at maturity and has funds there available for that purpose, such ability

*Amended by Laws of N. Y. 1898, c. 336, so as to give eorrect number.

$\rightarrow$ The numbers of the sections of this article in other States than New York are as follows: Arizona, 3373-3391 ; Colorado, Connectient, District of Columbia, Florida, Iowa, Massachusetts, New Jersev, North Carolina, North Dakota. Oregon, Pennsylvania. Tennessee, Utah, Virginia. and Washington. 70-88; Maryland, 89-107; Ohio, 3173o-3174f; Rhorle Island, 78-96; Wisconsin, 1678 to 1678-18.

F The word "liable" omitted in the New York Act of 1897 supplied by Act of 1898 , e. 336 . In the Wisconsin aet all of the first sentence after the words "primarily liable on the instrument" is omitted. 
and willingness are equivalent to a tender of payment upon his part. But except as herein otherwise provided, presentment for payment is necessary in order to eharge the drawer and indorsers.

\$131. Presentment where instrument is not payable on demand.- Where the instrument is not payable on demand, precentment must be made on the day it falls due. Where it is payable on clemand. presentment must be nade within a reasonable time after its j-slle, rexept that in case of a bill of exchange, presentment for payment will lwe sullicient if made within a reasonable time after the last negotiation thereof.

\$132. What constitutes a sufficient presentment. - Presentment for payment, to be suflicient, must be mate:

1. Iy the holder, or by some person authorized to receive payment on his belall ;

2. At a reasonable hour on a business day:

3. At at proper place as herein detined;

4. To the person primarily liable on the instrument, or if he is absent or inacessible, to any person found at the place where the pusentment is made.

\$ I33. Place of presentment.- Presentment for payment is made at the proper place.

1. Where a place of payment is speeified in the instrument and it is there presented;

2. Where no place of payment is specified, but the address of the person to make payment is griven in the instrument and it is there presented;

3. Where no place of payment is specified and no address is, given and the instrument is presented at the usual place of business or re-inlenee of the person to make payment.

4. In any other* ease if presented to the person to make payment wherever he can be found, or if presented at his last known place of business or residenee.

\& 134. Instrument must be exhibited.-The instrument must be exhibited to the person from whom payment is demanded, and when it is paid must be delivered up to the party paying it.

$\S$ 135. Presentment where instrument payable at bank.-Wher. the instrument is payable at a bank, presentment for payment must b. made during banking hours, unless the person to make payment has no funds there to meet it at any time during the day, in which eato presentment at any hour before the bank is closed on that day is sutlicient.

$\$ 136$. Presentment where principal debtor is dead. - Where the person primarily liable on the instrument is dead. and no place of payment is speejfed. presentment for payment must be made to his personal representative, if such there be, and if with the exereise of reasonable diligence, he ean he found.

\$ 137. Presentment to persons liable as partners. - Where the persons primarily liable on the instrument are liable as partuers, and no place of payment is specified. presentment for payment may lwe made to any one of them, even though there has been a dissolution of the firm.

"The word "other" omitted from the New York statute of 1s!: through mistake supplied hy Act ls9s, c. 336. 
\& I3. Presentment to joint debtors. - Where there are several persons not partners, primarily liable on the instrument, and no place of parment is specified, presentment must be made to them all.

\& 139. When presentment not required to charge the drawer.Presentment for payment is not required.in order to charge the drawer where he has no right to expect or require that the drawee or acceptor will pay the instrument.

$\$$ I 40. When presentment not required to charge the indorser. - Presentment for payment is not required in order to charge an indorser where the instrument was made or accepted for his aecommodation, and he has no reason to expect that the instrument will be paid if presented.

$\S 14 \mathrm{I}$. When delay in making presentment is excused.-Delay in making presentment for payment is exeused when the delay is eaused by circumstances beyond the control of the holder and not imputable to his default, miceonduct, or negligence. When the cause of delay ceases to operate, presentment must be made with reasonable diligence.

$\$ 142$. When presentment may be dispensed with.- Presentment for payment is dispensed with:

1. Where, after the exercise of reasonable diligence, presentment as required by this act annot be made;

2. Where the drawee is a fietitious person;

3. By waiver of presentment, express or inplied.

1 43. When instrument dishonored by non=payment. - The instrument is dishonored by non-payment when:

1. It is duly presented for payment and payment is refused or cannot be obtained; or

2. Presentment is excused and the instrument is overdue and unpaid.

$\S$ I 44. Liability of person secondarily liable, when instrument dishonored. - Subject to the provisions of this act, when the instrument is dishonored by non-payment, an immediate right of recourse to all parties secondarily liable thereon, aecrues to the holder.

\$ 145. Time of maturity.-Every negotiable instrument is payable at the time fixed therein without graee. When the day of maturity falls upon Sunday or a holiday, the instrument is payable on the next succeeding business day. lustruments falling due or beeoming payable* on Saturday are to be presented for payment on the next succeding business day, except that instruments payable on demand may, at the option of the holder, be presented for payment before twelve o'clock noon on Saturday when that entire day is not a holiday.

\& 1 46. Time; how computed.- Where the instrument is payable at a fixed period after date, after sight, or after the happening of a specifierl event. the time of payment is determined by excluding the day from whicin the time is to begin to run, and by ineluding the date of payment.

\$ 147. Rule where instrument payable at bank.- Where the instrument is made payable at a bank it is equivalent to an order to the lank to pay the same for the aceount of the principal debtor thereon.

$\S$ I 48 . What constitutes payment in due course.- Payment is made in due course when it is made at or after the maturity of the instrument to the holder thereof in good faith and without notice that his title is defertive.

* The words "or beeoming payable" were added ly Laws N. Y. 1895, c. 336. They are not in the statute in the other States. 


\section{ARTICLE VIII.*}

\section{Notice of Dishonor.}

Seotiox 160. To whom notice of dishonor must be given.

161. By whom given.

162. Notice given by agent.

163. Eilect of notice given on behalf of helder.

164. Eilleret where notice is given ly party entitled thereto.

16is. When agent may give notice.

166. When notice sullicient.

16i. Form of notice.

168. To whom notice mily be given.

169. Notice where party is dead.

170. Notice to partners.

171. Notice to persons jointly liable.

172. Notice to bankrupt.

173. Time within which notice must be given.

17. Where parties reside in same place.

175. Where parties reside in diflerent places.

176. When sender deened to have given due notice.

177. Deposit in post-oflice, what constitutes.

178. Notice to subsequent parties. time of.

179. Where notice must be sent.

180. Waiver of notice.

181. Whom atlected by waiver.

182. Waiver of protest.

183. When notice dispensed with.

184. Delay in giving notice: how excused.

185. When notice need not be given to drawer.

186. When notice need not be given to indorser.

187. Notice of non-payment where aceeptanee refused.

188. Effect of omission to give notice of non-acceptance.

189. When protest need not be made; when must be made.

8 I60. To whom notice of dishonor must be given. - Exeept as herein otherwise provided, when a negotiable instrument has been dishonored by non-aceeptance or non-payment, notice of dishonor must be given to the drawer and to each indorser. and any drawer or indorser to whom such notice is not griven is discharged.

§ 61 . By. whom given. - The notice may be given by or on behalf of the holder, or by or on behalf of any party to the instrument who might be compelled to pay it to the holder, and who, upon taking it

* The numbers of the sections of this article in other States than New York are an follows: Arizona, 3:392-34:21: Colorado. Connectient. Distriet of Columbia. Florida, lowa, Massachusetts, Now Jerser. North Carolina, North Dakota, Oregon, Pennsylvania, Tennessee, Ttah, Virginia, and Washington, 89-118: Maryland. 108-137: Ohio, 3174g-3175i; Rhode Island, 97-126; Wisconsir, 167s-19 to $1678-4 s$. 
up, would have a right to reimbursement from the party to whom the notice is given.

$\S$ 162. Notice given by agent.- Notice of dishonor may be given by an agent either in his own name or in the name of any party entitled to give notice, whether that party be his principal or not.

\& 163. Effect of notice given on behalf of holder. - Where notice is given by or on behalf of the holder, it inures for the benefit of all subsequent holders and all prior parties who have a right of recourse against the party to whom it is given.

$\S 164$. Effect where notice is given by party entitled thereto.Where notice is given by or on behalf of a party entitled to give notice, it inures for the henefit of the holder and all parties subsequent to the party to whom notice is given.

\& 165 . When agent may give notice.- Where the instrument has been dishonored in the hands of an agent, he may either himself give notice to the parties liable thercon, or he may give notice to his principal. If he give notice to his principal, he must do so within the same time as if he were the holder, and the principal, upon the receipt of such notice, has limself the same time for giving notice as if the agent had been an independent holder.

$\S$ 166. When notice sufficient.- A written notice need not be signed, and an insufficient written notice may be supplemented and validated by verbal communication. A misdescription of the instrument does not vitiate the notice unless the party to whom the notice is given is in fact misled thereby.

\$ 167. Form of notice.-The notice may be in writing or merely oral, and may be given in any terms which sufficiently identify the instrument, and indicate that it has been dishonored by non-acceptance or non-payment. It may in all cases be given by delivering it personally or through the mails.

\$ 168 . To whom notice may be given.-Notice of dishonor may be given either to the party himself or to his agent in that behalf.

\& 169. Notice where party is dead.- When any party is dead, and his death is known to the party giving notice, the notice must be given to a personal representative, if there be one, and if with reasonable diligence he can be found. If there be no personal representative, notice may be sent to the last residence or last place of business of the deceased.

$\S$ I 70. Notice to partners. - Where the parties to be notified are partners, notice to any one partner is notice to the firm, even though there has been a dissolution.

$\S$ I I. Notice to persons jointly liable.- Notice to joint parties who are not partners must be given to each of them, unless one of them has authority to receive such notice for the others.

$\S$ 172. Notice to bankrupt. - Where a party has been adjudged a bankrupt or an insolvent, or has made an assignment for the benefit of creditors. notice may be given either to the party himself or to his trustee or assignee.

$\S$ I 73. Time within which notice must be given.- Notice may be given as soon as the instrument is dishonored; and unless delay is excused as hereinafter provided. must be given within the times fixed by this act. 
$\$ 174$. Where parties reside in same place. - Where the person giving and the person to receive notice resile in the same place, nutice must be given within the following times:

1. If given at the place of business of the person to recrive notice, it inust be given before the close of business hours on the day following;

2. If given at his residence, it must be given before the usmal hours of rest on the day following:

3. If sent by inail, it must be deponited in the post-ofice in time to reach him in usual course on the day following.

$\$ 175$. Where parties reside in different places. - Where the person giving and the person to receive notice reside in different places, the notice must be given within the following tines:

1. If sent by mail. it must be deposited in the po-t-oflice in time to go by mail the day following the day of dishonor, or if there be no mail at a convenient hour on that day, by the next mail thereafter.

2 . If given otherwise than through the post-oflice, then within the time that notice would have heen received in due course of mail, if it had been deposited in the post-ollice within the time specified in the last subdivision.

$\S 176$. When sender deemed to have given due notice.-- Where notice of dishonor is duly addressed and deposited in the post-ollice, the sender is leemed to have given due notice, notwithstanding any misearriage in the mails.

$\$ 177$. Deposit in post=office; what constitutes. - Notice is deemed to have been deposited in the post-office when depositel in any braneh post-ofliec or in any letter-box under the eontrol of the PostOffice Department.

\& 178 . Notice to subsequent party; time of. - Where a party receives notice of dishonor, he has, after the reeeipt of such notice, the same time for giving notice to antecedent parties that the holder has after the dishonor.

\$179. Where notice must be sent.-Where a party has added an address to his signature, notice of dishonor must be sent to that address; but if he has not given such address, then the notice must be sent as follows:

I. Either to the post-ofiee nearest to his place of residenee, or to the post-oflice where he is aceustomed to receive his letters; or

2. If he live in one place, and have his place of business in another, notice may be sent to either place; or

3 . If he is sojouming in another place, notice maly be sent to the place where he is so sojourning.

But where the notice is actually reeeived by the party within tho time speeified in this act, it will be sufheient, though not sent in aecordance with the requirements of this seetion.

$\$$ 180. Waiver of notice.- Notice of dishonor may be waived, either lefore the time of giving notice has arrived or after the omission to give due notiee, and the waiver ma be express or implied.

\$ 181. Whom affected by waiver.-Where the waiver is embodied in the instrument itself. it is binding upon all parties: but where it is written above the signature of an indorser, it binds lim only. 
\$ 182. Waiver of protest.-A waiver of protest, whether in the ease of a foreign bill of exchange or other negotiable instrument, is deemed to be a waiver not only of a formal protest, but also of presentment and notice of dishonor.

$\S 183$. When notice is dispensed with.- Notice of dishonor is dispensed with when, after the exereive of reasonable diligener, it eannot be given to or does not reach the parties sought to be eliarged.

$\$ 184$. Delay in giving notice; how excused.- Delay in giving notice of dishonor is excused when the delay is cansed by eiremmotanees bryond the control of the holder and not imputable to his default, miseonduct or negligence. When the eause of delay ceases to operate, notice must be given with reasonable diligence.

$\S$ 185. When notice need not be given to drawer.- Notice of dishonor is not required to be given to the drawer in either of the following eases:

l. Where the drawer and drawee are the same person;

2 . Where the drawee is a fictitious person or a person not having eapicity to contract;

3. Where the drawer is the person to whom the instrument is presented for payment;

4. Where the drawer has no right to expect or require that the drawee or acceptor will honor the instrument;

5. Where the drawer has countermanded payment.

$\S$ r 86. When notice need not be given to indorser.- Notice of dishonor is not required to be given to an indorser in either of the following cases:

1. Where the drawee is a fictitious person or a $\mathrm{p}$ rson not having capacity to contract, and the indorser was aware of the faet at the time he indorsed the instrmment;

2. Where the indorser is the person to whom the instrument is presented for parment;

3. Where the instrument was made or accepted for his accommodation.

$\$$ I 87. Notice of non=payment where acceptance refused. - Where due notice of dishonor by non-aeceptance has been given, notice of a subsequent dishonor by non-payment is not necessary, unless in the meantime the instrument has been accepted.

$\S$ 188. Effect of omission to give notice of non=acceptance.An omission to give notice of dishonor by non-aeceptance does not prejudice the rights of a holder in due course subsequent to the omission.

$\S$ I 89. When protest need not be made; when must be made.Where any negotiable instrument has been dishonored it may be protested for non acceptance or non-payment, as the case may be; but protest is not required, except in the case of foreign bills of exchange. 


\section{ARTICLE IX.*}

\section{Discharge of Negotiable Instruments.}

SEoTion 200. Instrument; how discharged.

201. When person secondarily liable on, discharged.

202. Right of party who discharges instrument.

203. Renunciation by holder.

204. Cancellation; unintentional; burden of proof.

205. Alteration of instrument; effect of.

206. What constitutes a material alteration.

$\$$ 200. Instrument; how discharged. $\dot{i}-A$ negotiable instrument is discharged:

1. By payment in due course by or on behalf of the prinempal debtor;

2. By payment in due course ly the party accommodated, where the instrument is made or accopted for accommodation;

3. By the intentional eancellation thereof by the holder;

4. By any other act which will discharge a simple contract for the payment of money;

5 . When the principal dobtor becomes the holder of the instrument at or after maturity in his own right.

\& 2or. When person secondarily liable on, discharged.-A person secondarily liable on the instrument is discharged:

1. By any act whieh discharges the instrument;

2. By the intentional cancellation of his signature by the holder;

3. By the discharge of a prior party;

4. By a valid tender of payment made by a prior party ;

5. By a release of the prineipal debtor, unless the holder's right of recourse against the party secondarily liable is expressly reserved;

6. By any agreement binding upon the holder to extend the time of payment or to postpone the holder's right to enforce the instrument, $+\frac{t}{t}$ unless the right of recourse againut such party is expressly reserved.

\$ 202. Right of party who discharges instrument.- Where the instrument is paid by a party secondarily liable thereon, it is not dis. charged; but the party so paying it is remitted to his former righte as regards all prior parties, and he may strike out his own and all subsequent indorsements, and again negotiate the instrument, except:

1. Where it is payable to the order of a third person, and has been paid by the drawer: and

* The numbers of the sections of this article in other States than New York are as follows: Arizona, 3422-3428; Colorado, Connectient, District of Columbia, Florida, Iowa, Massachusetts, New Jer-ey. North Carolina, North Dakota, Oregon. Pennsylvania, Tennessee. [Tah. Vir. ginia, and Washington, 119-125: Marylaml. 139-144: Ohio, 3155j$3175 p$; Rhode Island, 127-133: Wisconsin, 1679 to $1679-6$.

Through an error in enerosing the words in the headnote have been transposed. It was intended to read, "IIow instrument diseharged." The error was not eorreeted by the let of 189.

$\ddagger$ By an error in engrosing. the words "unless male with the assent of the party secondarily liable, or " after the word "inatrument" are omitted in the New York Act. They were not supplied by Laws 1898 , c. 336 . 
2. Where it was made or accepted for accommodation, and has been paid by the party aecommodated.

$\$$ 203. Renunciation by holder.- The holder may expressly renounce lis rights against any party to the instrument, before, at or after its maturity. An absolute and unconditional renunciation of his rights againsi the principal debtor made at or after the maturity of the instrmment, discharges the instrument. But a remunciation does not affect the rights of a lolder in due conrse without notice. A renumeiation nust be in writing. unless the instrument is delivered up to the person primarily liable thereon.

$\$ 204$. Cancellation; unintentional; burden of proof.-A cancellation made unintentionally, or under a mistake, or without the authority of the holder, is inoperative; but where an instrument or any signature thereon appears to have been canceled the burden of proof lies on the party who alleges that th: cancellation was made unintentionally, or under a mistake or without authority.

$\S 205$. Alteration of instrument; effect of.-Where a negotiable instrument is materially altered withont the assent of all parties liable thereon, it is avoided, except as against a party who has himself made, authorized or assented to the alteration and subsequent indorsers. But when an instrument has been materially altered and is in the hands of a holder in due course, not a party to the alteration, he may enforce payment thereof according to its original tenor.

$\S$ 206. What constitutes a material alteration.- Any alteration which ehanges:

1. The date;

2. The sum payable, either for principal or interest;

3. The time or place of payment:

4. The number or the relations of the parties;

5. The medium or eurreney in which payment is to be made;

Or which adds a place of payment where no place of payment is specified, or any other ehange or addition which alters the effect of the instrument in any respect, is a material alteration.

\section{ARTICLE X.*}

\section{Bills of Exchange; Form and Interpretation.}

Section 210. Bill of exchange defined.

211. Bill not an assignment of funds in hands of drawee.

212. Bill addressed to more than one drawee.

213. Inland and foreign bills of exehange.

214. When bill may be treated as promissory note.

215. Referee in case of need.

\$ 2xo. Bill of exchange defined.-A bill of exchange is an unconditional order in writing addressed by one person to another, signed

* The numbers of the sections of this article in other States than New York are as follows: Arizona, 3429-3434; Colorado, Connecticut, Distriet of Columbia, Florida, Iowa, Massachusetts, New Jersey, North Carolina, North Dakota, Oregon, Pennsylvania, Tennessee, Utah, Virginia, and Washington, 126-131: Maryland. 145-150: Ohio, 3175q$3175 v$; Rhode Island, 134-139; Wisconsin, 1680 to $1680 e$. 
by the person giving it, requiring the person to whom it is addressed to pay on demand or at a fixed or determinable future time a sum certain in money to order or to bearer.

\$ 211 . Bill not an assignment of funds in hands of drawee.A bill of itself does not operate as an assignment of the funds in the hands of the drawee available for the payment thereof, and the drawee is not liable on the bill unless and until he accepts the same.

\$ 212. Bill addressed to more than one drawee. $-A$ bill mat be addressed to two or more drawees jointly, whether they are partinery or not; but not to two or more drawees in the alternative or in succession.

$\$ 213$. Inland and foreign bills of exchange. - An inland bill of exchange is a bill whieh is, or on its face purports to be, both drawn and paynble within the State. Any other bill is a foreign bill. Cnless the contrary appears on the face of the bill, the holder may treat it as an inlind bill.

$\S 214$. When bill may be treated as promissory note.- Where in a bill the drawer and drawee are the same person, or where the diawee is a fietitious person, or a person not having ealpacity to contract, the holder ma treat the instrument, at his option, either as a bill of exchange or a promissory note.

$\$ 215$. Referee in case of need.- The drawer of a bill and any in. dorser may insert thereon the name of a person to whom the holder may resort in case of need, that is to say, in case the bill is dishonored by non-acceptance or non-payment. Such person is called the referee in case of need. It is in the option of the holder to resort to the referee in case of need or not, as he may see fit.

\section{ARTICLE XI.}

\section{Acceptance of Bills of Exchange.}

Sectios 220. Aeceptance, how made. ct cetera.

221. Holder entitled to acceptance on face of bill.

222. Acceptance by separate instrument.

223. Promise to accept: when equivalent to acceptance.

224. Time allowed drawee to accept.

225. Liability of clrawee retaining or destroying bill.

226. Acceptince of incomplete bill.

227. Kinds of acceptances.

228. What constitutes a general acceptance.

229. Qualified acceptance.

230. Rights of parties as to qualified acceptance.

$\$ 220$. Acceptance; how made, et cetera.-The acceptance of a bill is the signification by the drawee of lis assent to the order of

*The word "or" onitted in the original New York statute sup. plied by Laws N. Y. 1898 , e. 336 .

$\rightarrow$ Tine numbers of the sections of this article in other States than New York are as follows: Arizona, 3435-3445; Colorado, Connecticut, District of Colmmbia. Florida. Iowa. Mascachusetts. New Jersey, North Carolina, Nortl, Dakota. Oremon. Pennsylunia. Temmessee. Utah. Virginia. and Washington. 132-1.12: Marvland. 151-161: Ohio, 3175u 3176f: Rhode Island, 140-150; Wisconsin. 1680f to $1650 p$. 
the drawer. The acceptance must be in writing and signed by the drawee." It must not express that the drawee will perform his promise by any other means than the payment of money.

$\$ 22 \mathrm{x}$. Holder entitled to acceptance on face of bill. - The holder of a bill presenting the same for aceeptance may require that the acecptance be written on the bill, and if such request is refused, may treat the bill as dishonored.

$\$$ 222. Acceptance $k y$ separate instrument.-Where an acceptance is written on a liljer other than the bill itself, it does not bind the acceptor, except in faror of a person to whom it was shown and who, on the faith thereof, receives the bill for value.

$\$ 223$. Promise to accept; when equivalent to acceptance.- An uneonditional promise in writing to accept a bill before it is drawn is deemed an actulal acceptance in favor of every person who, upon the faith thereof, receives the bill for value.

$\$ 224$. Time allowed drawee to accept.- The drawee is allowed twenty-four lours after presentment in which to decide whether or not he will accept the bill; but the acceptance if given dates as of the day of presentation.

8 225. Liability of drawee retaining or destroying bill.- Where a drawee to whom a bill is delivered for acceptance destroys the same, or refuses within twenty-four hours after such delivery, or within such other period as the holder may allow, to return the bill aecepter or non-accepted to the holder, he will be deemed to have accepted the same.

$\S 226$. Acceptance of incomplete bill.- A bill may be accepted before it has been signed by the drawer, or while otherwise incomplete, or when it is overdue, or after it has been dishonored by a previous refusal to aceept, or by non-payment. But when a bill payable after sight is dishonored by non-aceeptance and the drawee subsequently accepts it, the holder, in the absence of any different agreement, is entitled to have the bill aceepted as of the date of the first presentment.

$\$ 227$. Kinds of acceptances. - An aeceptance is either general or qualified. A general aeceptance assents without qualifieation to the order of the drawes. A qualified acceptance in express terms varies the effect of the bill as clrawn.

$\$ 228$. What constitutes a general acceptance.-An acceptance to pay at a particular place is a general aceeptance unless it expressly states that the bill is to be paid there only and not clsewhere.

\$229. Qualified acceptance.-An acceptance is qualified which is:

1. Conditional, that is to say, which makes payment by the acceptor dependent on the fulfillment of a condition therein stated;

2. Partial, that is to say, an acceptance to pay part only of the ainount for which the bill is drawn;

3. Local, that is to say, an acceptance to pay only at a partieular place;

4. Qualified as to time;

5. The aceptance of some one or more of the drawees, but not of all.

$\S 230$. Rights of parties as to qualified acceptance.- The holder may refuse to take a qualified acceptance, and if he does not obtain an unqualified aeceptance, he may treat the bill as dishonored by non-

"The word "drawee" substituted for "drawer" by Laws N. Y. 1898, c. 336 . 
acceptance. Where a qualified acceptance is taken, the drawer and indorsers are discharged from liability on the bill, unless they have expressly or impliedly authorized the holder to take a rualified aceceptance, or subsequently assent thereto. When the drawer or an indorser receives notice of a qualified acceptance, he must within a reasonable time express his dissent to the holder, or lie will be deewed to bave assented thereto.

\section{ARTICLE XII.*}

\section{Presentment of Bills of Exchange for Acceptance.}

SECTION 240. When presentment for aeceptanee must be made. 24l. When failure to present releases drawer and indorser. 242. Presentment: low made.

243. On what days presentment may be made.

244. Presentment; where time is insufficient.

245. When presentment is excused.

246. When dishonored by non-aeceptance.

247. Duty of holler whire bill not aceepted.

248. Rights of holder where bill not accepted.

$\$ 240$. When presentment for acceptance must be made.- Presentment for acceptance must be made:

1. Where the bill is payable after sight or in any other case where presentment for acecptance is necessary in order to fix the maturity of the instrument: or

2. Where the bill expressly stipulates that it shall be presented for acceptance: or

3. Where the bill is drawn payable elsewhere than at the residence or place of business of the drawee.

In no other case is presentment for aceeptance necessary in order to render any party to the bill liable.

$\$ 241$. When failure to present releases drawer and indorser.Except as herein otherwise provided. the holder of a bill which is reguired by the next preceding section to be presented for acceptance muit either present it for acceptance or negotiate it within a reasonable time. If he fails to do so, the drawer and all indorsers are diseharged.

$\S$ 242. Presentment; how made.-Presentment for acceptance must be made by or on behalf of the holder at a reasonable hour, on a business day, and before the bill is overdue, to the draweet or smur person authorized to accept or refuse aeceptance on lis behalf: and

1. Where a bill is addressed to two or more drawees who are not partners, presentment must be made to them all, unless one hals au-

* The numbers of the sections of this article in other States than New York are as follows: Arizona, 3446-3454: Colorado, Connecticut, District of Columbia, Florida. Iowa, Massachusetts, New Jersey. North Carolina, North Dakota, Oregon, lennsylvania. Tennessee, Ciah, Virginia, and Washington, 143-15l: Maryland, 162-170: Ohio, $3176 g-$ 31760: Rhode Island, 151-159: Wiseonsin, 1681 to 1681-8.

$\div$ The word "drawee" substituted for "drawer" by Laws $\mathrm{N}$. Y. 1598 , c. 336 . 
thority to accept or refuse acceptance for all, in which case presentment may be made to him only;

2. Where the drawee is dead, presentment may be made to his personal representative;

3. Where the drawee has been adjudged a bankrupt or an insolrent, or has made an assignnent for the benefit of creditors, presentment may be made to him or to his trustee or assignee.

\$ 243. On what days presentment may be made.-A bill may be presented for acceptance on any day on which negotiable instruments may be presented for payment under the provisions of sections one humlred and thirty-two* and one hundred and forty-tive $\bar{t}$ of this act. When Saturday is not otherwise a holiday, presentment for acceptance may be made before twelve o'clock noon on that day.

$\$ 244$. Presentment when time is insufficient.- Where the holder of a bill drawn payable elsewhere than at the place of business or the residence of the drawee has not time with the exercise of reasonable diligence to present the bill for acceptance before presenting it for payment on the day that it falls due, the delay caused by presenting the bill for aceptance before presenting it for payment is excused and does not discharge the drawers and indorsers.

$\$ 245$. Where presentment is excused.- Presentment for acceptonce is excused and a bill may be treated as dishonored by non-acceptance in cither of the following cases:

1. Where the drawee is dead or has abseonded, or is a fictitious person or a person not having capacity to contract by bill;

2. Where after the exercise of reasonable diligence, presentment cannot be made;

3. Where, although presentment has been irregular, acceptance has been refused on some other ground.

$\$ 246$. When discharged by non=acceptance. - A bill is dishonored by non-acceptance:

1. When it is duly presented for acceptance, and such an acceptance as is prescribed by this act is refused or cannot be obtained; or

2. When presentment for acceptance is excused and the bill is not accepted.

\$ 247. Duty of holder where bill not accepted.- Where a bill is duly presented for acceptance and is not accepted within the prescribed time, the person presenting it must treat the bill as dishonored by non-acceptance or he loses the right of recourse against the drawer and indorsers.

$\$ 248$. Rights of holder where bill not accepted.-When a bill is dishonored by non-acceptance, an immediate right of recourse against the drawers and indorsers accrues to the holder, and no presentment for payment is necessary.

* Number "one hundred and thirty-two" substituted for seventytwo by Laws 1898, c. 336 .

(Id.) 


\section{ARTICLE XIII.*}

\section{Protest of Bills of Exchange.}

Secroo 260. In what cases protest necessary.

26il. Protest; how made.

26:2. Protest; by whom made.

26i3. Protest; when to be made.

264. Protest; where made.

2(i). Protest botli for uni-acepplance and non-payment.

266. Protest before maturity where aceptor insolvent.

2ti7. When protest dispensed with.

268. Protest; where bill is lost, et cetera.

\$ 260. In what cases protest necessary- Where a foreign bill appearing on its face to be such is dishonored by non-acceptince. it must be duly protested for non-aeceptance, and where such a bill which has not previously been dislonored by nom-acentance is dishonored by non-payment, it must be duly protested for non-payment. If it is not so protested, the drawer and indorsers are discharged. Where a bill does not appear on its face to be a foreign bill, protest thereof in ease of dishonor is unnecessary.

$\$ 261$. Protest; how made.- The protest must be annexed to the bill, or must contain a copy thereof, and must be under the hand and seal of the notary making it. and must specify:

1. The time and place of presentment:

2. The fact that presentment was made and the manner thereof;

3. The ealuse or reason for protesting the bill;

4. The demand made and the answer given, if any, or the fact that the drawee or acceptor could not be found.

\& 262. Protest; by whom made.-Protest may be made by:

1. A notary public; or

2. By any respectable resident of the place where the bill is dishonored, in the presence of two or more creditable witnesses.

\$ 263. Protest; when to be made.- When a bill is protested, such protest must be made on the day of its dishonor, unless delay is excused as herein provided. When a bill has been duly noted, the protest may be suberquently extended as of the date of the noting.

\$264. Protest; where made. $-A$ bill must be protested at the place where it i- di-honored, exept that when a bill drawn payable at the place of business or residence of some person other than the drawee, has been di-honored by non-acceptanee, it must be protested for non-parment at the place where it is expressed to be parable, and no furtler presentment for payment to. or demand on, the drawee is necessary.

* The numbers of the scetions of this article in other states than New York are as follows: Arizona, 3455-3463: Colorado. Comneeticut, District of Columbia, Florida, Jowa, Massachusetts, New Jerser. North Carolina, North Dakota, Oregon, Pennsylrania. Temnessee. Liah, Virgima, and Washington, 152-160: Maryland. 17l-179: Ohio. 3170p$3176 x$; Rhode lslind, 160-168: Wisconsin. 1681-9 to 1681-17. 
$\$$ 265. Protest both for non=acceptance and non=payment. - A bill which has been protested for non-aceeptance may be subsequently protested for non-paninent.

\$ 266. Protest before maturity where acceptor insolvent.Where the aceptor has been adjudged a bankrupt or an insolvent, or has made an assigmment for the benefit of creditors, before the bill matures, the holder may cause the bill to be protested for better security against the drawer and indorsers.

$\$ \mathbf{2 6 7}$. When protest dispensed with.- Protest is dispensed with by any cireumstances which would dispense with notice of dishonor. Delay in noting or protesting is exeused when delay is caused by eircumstances beyond the control of the holder and not imputable to his default, misconduct, or negligence. When the carse of delay ceases to onerate, the bill must he noted or protested with reasonable diligence.

$\S 268$. Protest where bill is lost, et cetera.-- Where a bill is lost or destroyed, or is wrongly detained from the person entitled to hold it. protest may be made on a copy or written particulars thereof.

\section{ARTICLE XIV.*}

\section{Acceptance of Bills of Exchange for Honor.}

SECTIOX 280. When bill may be accepted for honor.

281. Aeceptance for honor; how made.

28. When deemed to be an acceptance for honor of the drawer.

283. Liability of acceptor for honor.

284. Agreement of acceptor for hollor.

285. Naturity of bill payable after sight; aecepted for honor.

286. Protest of bill accepted for lronor. et cetera.

287. Presentment for payment to aeceptor for honor; how made.

288. When delay in making presentment is excused.

289. Dishonor of bill by acceptor for honor.

$\$ 280$. When bill may be accepted for honor.-Where a bill of exchange has been protested for dishonor by non-acceptance or protested for better seeurity and is not overdue, any person not being a party already liable thereon may, with the consent of the holder, intervene and accept the bill supra protest for the honor of any party liable thereon or for the lionor of the person fort whose accomit the bill is drawn. The acceptance for honor may be for part only of the sum for which the bill is drawn; and where there has been an aceeptance for honor for one party, there may be a further acceptance by a different person for the honor of another party.

* The numbers of the sections of this article in other States than New York are as follows: Arizona, 3464-3473; Colorado, Connecticut, District of Columbia, Florida, Iowa, Massachusetts, New Jersey, North Carolina, North Dakota, Oregon, Pennsylvania, Tennessee, Utah, Virginia. and Washington, 161-170; Maryland, 180-189: Ohio. 3176y$3177 g$; Ihode Island, 169-178; Wisconsin, 1681-18 to 1681-27.

$\rightarrow$ The worl "for" omitted in the original New York Aet supplied by Lawi 1898 , e. 336 . 
\$ 281. Acceptance for honor; how made.- An areeplance for honor supra protest must be in writing and imlic:at to that it is an acceptance for honor, and must be signed by the acceptor for honor.

$\S 282$. When decmed to be an acceptance for honor of the drawer. Whiere all aceeptance for lowne does not expressly state for whose honor it is made, it is deemed to be an alrepentine for the honor of the drawer'.

\$283. Liability of acceptor for honor.- "The aceptor for honor is lialble ta the holder and to all parties to the bill subserpuent le the party for whose honor he his atepepted.

$\$ 284$. Agreement of acceptor for honor.- The acceptor for honor by such acceptime engilges thit he will on due presentment pily the bill aceording to the terms of his acerenance. provided it shall not hate bern paid by the drawe. and provided alno that it shall hatse heen duly presented for payment and protested for non-palyment and notice of dishonor given to him.

\& 285. Maturity of bill pavable after sight; accepted for honor. - Where a lill payable after sight is acepted for honor, its maturity is calculated from the dite of the noting for non-aceptance and not from the date of the acceptance for honor.

$\S 286$. Protest of bill accepted for honor, et cetera.- Where a dishonored bill his becn aceepted for honor supra protest or contains a referener in eare of need, it must he protested for non-payment briore it is presented for payment to the acceptor for honor or referee in ease of need.

$\S 287$. Presentment for payment to acceptor for honor; how made. - Presentment for payment to the aceptor for honor must be made as follows:

1. If it is to be presented in the place where the protest for non. payment was male, it must be presented not later than the day following its maturity:

2. If it is to be presented in some other place than the place where it was protested, then it must be forwarded within the time specified in section one hundred and seventy-five."

$\$$ 288. When delay in making presentment is excused.-The provisions of section one hundred and forty-onet apply where there is delay in making presentment to the aceptor for honor or referee in case of need.

$\$ 289$. Dishonor of bill by acceptor for honor.- When the bill is dishonored by the aceptor for honor it must be protested for nonpayment by lim.

* Number one hundred and seventy-five substituted for one hundred and four by Laws N. Y. 1898, e. 336 .

$\dagger$ Number one hundred and forty-one sub-titutel for eighty-one by Laws N. Y. 1898 , c. 336 . 


\section{ARTICLE XV.*}

\section{Payment of Bills of Exchange for Honor.}

Section 300. Who may make payment for honor.

301. Payment for honor; jow made.

302. Declaration before payment for honor.

303. Preference of parties oftering to pay for honor.

304. Effect on subsequent parties where bill is paid for honor.

305. Where holder refuses to receive payment supra protest.

306. Rights of payer for honor.

8 300. Who may make payment for honor.- Where a bill has been protested for non-payment, any person may intervene and pay it supra protest for the honor of any person liable thereon or for the honor of the person for whose account it was drawn.

$\S$ 3or. Payment for honor; how made.-The payment for honor supra protest in order to operate as such and not as a mere voluntary payment must be attested by a notarial aet of honor, which may be appended to the protest or form an extension to it.

$\S$ 302. Declaration before payment for honor.- The notarial aet of honor must be founded on a declaration made by the payer for honor, or by his agent in that behalf declaring his intention to pay the bill for honor and for whose honor he pays.

$\S$ 303. Preference of parties offering to pay for honor.- Where two or more persons offer to pay a bill for the honor of different parties, the person whose payment will discharge most parties to the bill is to be given the preference.

$\S 304$. Effect on subsequent parties where bill is paid for honor. - Where a bill has been paid for honor all parties subsequent to the party for whose honor it is paid are discharged, but the payer for honor is subrogater for, and sncceeds to, both the rights and duties of the holder as regards the party for whose honor he pays and ali parties liable to the latter.

\& 305. Where holder refuses to receive payment supra protest. - Where the holder of a bill refuses to receive payment supra protest, he loses his right of reconrse against any party who would have been discharged by such payment.

$\S 306$. Rights of payer for honor- - The payer for honor, on paying to the holder the amount of the bill and the notarial expenses incidental to its dishonor, is entitled to receive both the bill itself and the protest.

* The numbers of the sections of this artiele in other States than New York are as follows: Arizona, 3474-3480; Colorado, Connectient. District of Columbia, Florida, Iowa, Massachusetts, New Jersey, North Carolina, North Dakota, Oregon, Pennsylvania, Tennessee, Utah, Virginia, and Washington, 171-177; Maryland, 190-196; Ohio, 3177h$3177 n$; Rhode Island, 179-185; Wisconsin, 1681-28 to 1681-34. 


\title{
ARTICLE XVI.*
}

\author{
Bills in a Set.
}

Sectios 310. Bills in sets constitute one bill.

311. lights of holders where different parts are negotiated.

312. Liability of holder who indorses two or nore parts of a set to different persons.

313. Areeptance of bills drawn in sets.

314. Payment by acceptor of bills drawn in sets.

315. Effect of discharging one of a set.

\$ 310 . Bills in sets constitute one bill. - Where a bill is drawn in a set, each part of the set being numbered and containing a reference to the other parts, the whole of the parts constitute one bill.

\$II. Rights of holders where different parts are negotiated. - Where two or more parts of a set are negotiated to diflerent holder in due course, the holder whose title first acerues is as between such holders the trize owner of the bill. But nothing in this section affects the rights a a person who in due course accepts or pays the part first presented to him.

$\S 312$. Liability of holder who inderses two or more parts of a set to different persons.- Where the liolder of a set indorses two or more parts to diflerent persons he is liable on every such part, and every indorser subsequent to him is liable on the part he has himseli indorsed, as if such parts were separate bills.

\& 3r3. Acceptance of bills drawn in sets. - The aeceptance may be written on any part, and it must be written on one part only. if the drawee accepts more than one part, and such accepted parts are negotiated to different holders in due course, he is liable on every such part as if it were a separate bill.

\$ 3r4. Payment by acceptor of bills drawn in sets. - When the acceptor of a bill drawn in a set pays it without requiring the part bearing his acceptance to be delivered up to him, and that part at maturity is outstanding in the hands of a holder in due course, he is liable to the holder thereon.

$\$ 315$. Effect of discharging one of a set.- Except as herein otherwise provided, where any one part of a bill drawn in a set is discharged hy payment or otherwise the whole bill is discharged.

* The numbers of the sections of this article in other States thin New York are as follows: Arizona, 3481-348t; Colorado, Connectieut. District of Colmubia, Florida, Iowa. Massachusetts, New Jersey. North Carolina, North Dakota, Oregon, Pennsylvania, Tennessee. Ciah, Virginia, and Washington, 17s-183: Maryand, 197-202; Ohio, 31750$3177 t$; Rhode lsland, 186-I91; Wisconsin, $1681-35$ to $1681-40$. 


\section{ARTICLE XVII.*}

\section{Promissory Notes and Checks.}

Section 320. Promissory note defined.

321. Check defined.

322. Within what time a check must be presented.

323. Certification of check; effect of.

324. Effeet where holder of cheek procures it to be certified.

325. When check operates as an assignment.

\$ 320. Promissory note defined.-A negotiable promissory note within the meaning of this act is an unconditional promise in writing made by one person to anotler, signed by the maker, engaging to pay on demand or at a fixed or determinable future time a sum certain in money to order or to bearer. Where a note is drawn to the maker's own order, it is not complete until indorsed by him.

\& 321. Check defined.-A check is a bill of exehange drawn on a bank, payable on demand. Except as herein otherwise provided, the provisions of this act applicable to a bill of exchange payable on demand apply to a check.

$\S$ 322. Within what time a check must be presented.- A cheek must be presented for payment within a reasonable time after its issue or the drawer will be discharged from liability thereon to the extent of the loss caused by the delay.

\$ 323. Certification of check; effect of.-Where a check is certified by the bank on whieh it is drawn the certificationt is equivalent to an acceptance.

$\S 324$. Effect where the holder of check procures it to be certified. - Where the holder of a cheek proeures it to be aecepted or certified the drawer and all indorsers are discharged from liability thereon.

\$ 325. When check operates as an assignment.-A check of itself does not operate as an assignment of any part of the funds to the credit of the drawer with the bank, and the bank is not liable to the holder, unless and until it accepts or certifies the cheek.

* The numbers of the sections of this article in other States than New York are as follows: Arizona, 3487-3491; Colorado, Connectieut, District of Columbia, Florida, Iowa, Massachusetts, New Jersey, North Carolina, North 1)akota, Oregon, Pennsylvania, Tennessee, Utah. Virginia, and Washington, 184-189; Maryland, 203-208; Ohio, 3177u3]77 $\approx$; Rhode Island, 192-197; Wisconsin, 1684 to 1684-5.

$\rightarrow$ The word "eertification"' substituted for "certificate" by Laws N. Y. 1898 , c. 336 . 


\section{ARTICLE XVIII.*}

\section{Notes Given for Patent Rights and for a Speculative Con. sideration.}

Secriox 330. Negotiable instruments given for patent rights.

331. Negrotiable instruments given for a speculative considera. tion.

332. How negotiable bonds are made non-negotiable.

8 330. Negotiable instruments given for patent rights. - I promissory note or other negotiable instrument, the consideration of which consists wholly or partly of the right to make, use or sell any invention claimed or represented by the vendor at the time of sile to be patented, must contain the words "given for a patent right" prominently and legibly written or printed on the face of such note or instrument above the signature thereto; and such note or instrument in the hands of any purchaser or holder is subject to the same defen-es as in the hands of the original holder; but this section does not apply to a negotiable instrument given solely for the purelase price or the use of a patented article.

\$ 331. Negotiable instruments for a speculative consideration. - If the consideration of a promissory note or other negotiable instrument consists in whole or in part of the purchise price of any farm product, at a price greater by at least four times than the fair market value of the same product at the time, in the locality, or of the member. ship and rights in an association, company or combination to produce or sell any farm product at a fictitious rate, or of a contract or bond to purchase or sell any farm product at a price greater by four times than the market value of the same product at the time in the locality, the words, "given for a speculative consideration," or other words elearly showing the nature of the consideration, must be prominently and legibly written or printed on the face of such note or instrument above the signature thereof; and sueh note or instrument, in the hands of any purchaser or holder, is subject to the same defenses as in the hands of the original owner or holder.

\$32. How negotiable bonds are made non=negotiable. - The owner or holder of any corporate or municipal bond or obligation (except such as are designated to circulate as money, parable to bearer), heretofore or hereafter isisued in and payable in this state, but not registered in pursuance of any State liw, may mike such bond or obligation; or the interest coupon accompanying the same, non-negotiable, by subseribing his name to a statement indorsed thereon that such bond, obligation or coupon is his property: and thereon the principal sum therein mentioned is payable only to such owner or holder, or his legal representatives or assigns, unless sueh bond, obligation or coupon be trinsferred by indorsement in blank. or payable to bearer, or to order, with the addition of the assignor's place of residence.

* This article appears only in the statute as enacted in New York and Ohio. 


\section{ARTICLE XIX. \\ Laws Repealed; When to Take Effect.}

SECTION 340. Laws repealed.

341 . When to take effect.

\$ 340. Laws repealed.- The laws or parts thereof specified in the schedule hereto annexed are hereby repealed.

$\$ 34 \mathrm{I}$. When to take effect.- This chapter shall take effect on the first day of October, eighteen hundred and ninety-seven.

\section{Schedule of Laws Repealed.}

\section{Revised Statutes.}

Sections.

Subject-matter.

R. S., pt. II., ch. 4, tit. II.. All.... Bills and notes.

\begin{tabular}{|c|c|c|c|}
\hline Laws of & Chap. & Sections. & Subject-matter. \\
\hline & 14 & All. & Notice of protest; how given. \\
\hline & & & Commercial paper. \\
\hline & 309 . & All. & st of foreign bills, etc. \\
\hline & 43 & & $\begin{array}{l}\text { ability of corporate bonds; } \\
\text { limited. }\end{array}$ \\
\hline 1871 & 8 & All. & $\begin{array}{l}\text { Negotiable bonds; how made non- } \\
\text { negotiable. }\end{array}$ \\
\hline 1873 & 595 & All & $\begin{array}{l}\text { Negotiable bonds; how made ne- } \\
\text { gotiable. }\end{array}$ \\
\hline 187 & 65. & 1,3 . & $\begin{array}{l}\text { Negotiable instruments given for } \\
\text { patent riglits. }\end{array}$ \\
\hline 188 & 46 & Al & $\begin{array}{l}\text { Effect of holidays upon payment } \\
\text { of commercial paper. }\end{array}$ \\
\hline 188 & 229 & All. & $\begin{array}{l}\text { One hundredth anniversary of the } \\
\text { inauguration of George Wash- } \\
\text { ington. }\end{array}$ \\
\hline $1891 \ldots$ & 26 & & $\begin{array}{l}\text { Negotiable instruments given for } \\
\text { a speculative consideration. }\end{array}$ \\
\hline 994. & 607 . & All & Days of $g$ \\
\hline
\end{tabular}




\section{N D E X.}

[381] 



\section{IN DEX.}

[References are to paragraphs marked \$.]

ABSCONDING.

of maker or acceptor, as exeuse for nonpresentment, ete., 397 .

ABSENCE.

from home of maker or aceptor, as excuse for nompresentment, ete., 393.

ACCEPTANCE. See also Acceptaxce Supra Protest ; Acceptor; ACCeptor Supra Protest; Presentalent for ACceptance.

meaning of, 270.

applies only to bills of exelange, 256 .

what bills do and do not require, 257.

liability of drawer before and after, 270, 311, 424, 475.

relation of drawee to bill before and after, 271,272 .

effect of 272 .

must be aecording to tenor of bill, 258 .

of foreign bills drawn in sets, 66 .

what acceptance admits -

signature of drawer, 273,424 .

funds of drawer in aceeptor's hands, 274.

capacity of drawer, 275.

capacity of payee to indorse, 153, 166, 276.

handwiting and authority of agent of drawer, 277 .

what aceeptance does not admit -

signature of payee or indorser, 278,425 .

ageney to indorse, 279 .

genuineness of terms in body of bill, 280.

who may accept -

when drawee ineapacitated, bill may be treated as dishonored,

281.

drawee or his authorized agent may, 281.

acceptance by two where bill drawn on one, 281.

acceptance by stranger to instrument, 282.

aeceptance by agent, 283 .

aceptanee where drawees are joint parties or partners, 284.

when aeceptance may be made -

may be in blank hefore execution by drawer, 285.

or after dishonor. 285.286.

or after death of drawer. 2 sti.

drawee las twenty-four hours within which to accept or refuse, 287.

time of acceptance, presmmptions as to. $28 s$.

aceptance dates from delivery, and until then is revocable, 285. express, forms of 298.

implied, what will amount to, 299 .

verbal, 300 . 
ACCEPTANCE - continued.

statutes as to written, construction of, 301 .

may be on separate paper, 302 .

promises to accept, $303-305$.

absolute and conditional acceptances, 306, 307, 310 .

qualified acecptanees, $262,309$.

by what law governed, 492 .

for honor. Sce Acceptance Supra Protest.

presentment for. Sec Piesentment for Acceptance.

ACCEPTANCE, PRESENTMENT FOR. See Presentment for AcCEPTANCE.

ACCEPTANCE SUPRA PROTEST. See also Acceptance.

what is, 289.

cireumstances under which made, 290 .

forms of, 290 .

method of, 290.

acceptor should notify party for whose honor acceptance made, 290.

who may aceept for honor, 291.

may be for honor of one or all parties, 292.

presumed to be for honor of drawer, if party not specified, 292.

several acceptors for honor of different parties, 292.

rights and liabilities of acceptor for honor, 293, 294.

admissions of acceptor for honor, 295 .

holder not bound to take, 296 .

ACCEPtor. See also Acceptor Supra Protest.

contract of, 272,311 .

is principal debtor, 272,475 .

presentment for payment not necessary to bind, 311,320 .

not entitled to notice of dishonor, 358,367 .

what acceptor admits, $273-277,424$.

what acceptor does not admit, 278-280, 425 .

rights of, as to recovery of money paid on forged paper, 278,280 ,

424,425 .

who may accept, 281-284.

when drawer and indorser may sue, 408, 409.

when may sue drawer, 409.

death of, presentment for payment in case of, 318 .

by what law liability of, governed, 492 .

acceptor supra protest. See AcCEPTOR SUPRa PRotest.

ACCEPTOR SCl'PA PROTEST.

who may be, 291.

should notify party for whoso honor acceptance made, 290 .

reveral acceptors for honor oi different parties, 292.

rights and lial,ilities of, $293,294$.

admissions of, 295.

may sue drawer or indorser if compelled to pay, 409.

ACCIDENT.

as excuse for nonpresentment, etc., 385 .

ACCOMMODA'TION PAPER.

definition of, 93.

liabilities and rights of parties to, 93-96.

issued by onc partner without consent of all, 138. 


\section{ACCOMMODATION PAPER - continued.}

issned by corporations, 145.

notice of accommodation character, eflect of, $200,248$.

whether accommodation charaeter of instrument is an equity at. taching after maturity, $205,242$.

diversion of -

what amounts to, 249.

effeet of. : 24 , 47 .

notice of, affeet of, 248 .

aeceptor or maker of, suit by, 272. 398, 409.

indorser of, entitied to notice of dishonor, $3 \overline{7} 0$.

anount of recovery on, $216,236$.

ACCORI) AXI) SATISWACTION.

defined. 4 tii.

effect of, $46 \bar{i}$.

part payment, 468.

AC'TIONS. Sec also DFFENSEs.

who may sue, $398-406$.

who may be sued, $40 \bar{\imath}-409$.

when right of action acerues, 410-413.

when right of action expires, $414,415$.

cause of action indivisible, 401.

at common law acceptor, maker. drawer, and indorsers could not be sued in one action, $40 \bar{t}$.

statutory changes of coimmon-law rule, 407 .

form of action governed by lex fori, $484,496$.

\section{IDDRESS.}

of cheek, 30 .

of party entitled to notice of dishonor, 376 .

ADMINISTRATORS. Sce ExectTors Axp ADMINistrators.

\section{ADMISSIONS.}

by aceptinee, $273-277,424$.

of acceptor for lonor, 295.

\section{ADOPTION.}

- of forged signature, effect of, 421 .

\section{AFTER SIGHT.}

meaning of in bills and notes, 327 .

paper payable certain time after sight entitled to grace, $32 \pi$.

\section{AGENTS.}

depositing to his private aceount funds of undisclosed principal may sue bank for dishonor of cheek, 41.

as parties to negotiable instruments, 121-133.

who may aet as, 121 .

authority of, how ereated, 122. 146.

authority "by procuration." 123.

implied athority of, 124, 12.).

how agent should sign, 126 .

undiselosed principal not liable, 127 .

when agent individually bouml. 128.

ratifieation of agent's aets, 129.

revocation of ageney, 130. 
AGENTS - coniinucd.

banks as collecting agents, 131 .

duty of collecting agent to present for acceptance and payment, 132.

ownership of paper in hands of collecting agent, 133.

effect of delivery by, in violation of instructions, 211 .

notice to, 255 .

presentment for acceptance to, of drawee, 260 .

authority of, to draw admitted by acceptance, 277 .

authority of, to indorse not admitted by acceptance, 279 .

acceptance by, 283.

presentment for payment by, 312 .

presentment for payment to, 316 .

notice of dishonor by, $365,366$.

notice of dishonor to, 368,372 .

when, may sue on negotiable instruments, 402 .

can take nothing but money in payment, 457 .

\section{ALIEN ENEMIES.}

contracts with, void, 163.

as drawer, acceptor, indorser, etc., 164.

ALLONGE, 180.

ALTERATION.

what constitutes material, 427,428 .

effect of, $427,440-442$.

if material, and fraudulently made, is forgery, 420,427 .

changing date, and time of payment, 429 .

changing place of payment, 430 .

changing amount of principal or interest, 431 .

changing medium of payment, 432.

changing personality, number, or relations of the parties, 433 . adding or detaching seal, 434.

changing joint into joint and several note, etc., 434 .

adding name of witness, 434 .

change in consideration, 435.

addition of, or change in, words of negotiability, 436 .

immaterial alterations, illustrations of, 437 .

alterations by agreement of parties, 438 .

rights of bona fide holder of altered instrument, 222, 439.

when material and fraudulently made, effect of, 440.

when material, but innocently made, effect of, 441 .

immaterial alteration with fraudulent intent, effect of, 442.

burden of proof of, 443 .

ALTERNATIVE.

drawees, 284.

AMOUNT.

to be paid must be certain, 82-85.

AMOUNT OF RECOVERY.

when less than full value paid, 216, 217.

ANTECEDENT DEBT.

as a consideration, 100 .

APPLICATION OF PAYMENTS.

rights of partics as to, 459,460 . 
[Reforences are i"

paragraphs marked $\$ .1$

\section{APIROPRIATION OF PAYMENTS.}

rights of parties as to, 459,460 .

ASSIGNEE.

takes subject to all equities, 168 .

of bankrupt, notice of dishonor to, 37 l.

\section{ASSIGNUENT.}

eflect of bills and nonnegotialle orders as, 10-14.

assignee takes subject to all equities, 108.

AT SIGIIT, sce sigut.

ATTORNEY'S FELS.

effect on negotiability, of stipulation to pay, 84,85 .

AUTHORITY.

of one partner to bind firm, 134-13i.

of agents, 122-125, 146 .

BANK BILLS OR NOTES.

deseription and characteristies of, $24,25$.

\section{BANK CHECKS. Sce CuEcks.}

\section{BANKRLPTCY.}

dissolves partnership, 140.

presentment for acceptance in case of dissolution of partnership

by, 259 .

presentment for payment in case of, 315.

notice of dishonor in ease of, 371 .

BANKRUPTCY AND INSOLVENCY LAWS.

power of Congress and of States to enact, 465.

discharge of debtor under, $\mathbf{f t 6}$.

\section{BANKS.}

reeiving bills and notes for eollection are holders for value, 98 .

as collecting agents, 131 .

duty of, to present for acceptance and payment, 132.

ownership of paper in hands of eollecting banks, 133 .

presentment for payment when instrument payable at, 322, 342.

usage of, may alter law merchant as to days of grace, 328.

denand by, by notice through maik, $343,344$.

notice of dishonor by, 366 .

\section{BEARER.}

instrument payable to, transferable by delivery, 165 .

indorsement in blank makes instrument payable to, 183.

who may sue on instrument payable to, 398, 403, 404.

BILLS OF CREDIT.

definition and nature of, 43 .

States prohibited from enitting, 42.

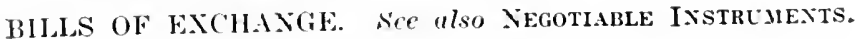
definition of, 35 .

origin and histury of. 2. 3. 


\section{BILLS OF EXCHANGE - continucd.}

foreign and inland, what are, 5,7 . difference between, 6 .

when character of, as foreign or inland, not disclosed on face, 9. sets in foreign, 64-66.

parties to, $15,56$.

difference between, and promissory notes, 17.

difference between, and checks, 28 .

effect of. as assignment of fund in drawce's hands, 10-14.

must contain direction to pay, 75 .

BILLS OF LADING.

definition and nature of, 50 .

how far negotiable, 51 .

transfer of, operates as constructive delivery of goods, 51, 52 .

vendor's right of stoppage in transitu defeated by bona fide transfer of, 51.

\section{BLANK.}

indorsement in, 183.

who may sue on instrument indorsed in, 398, 403.

rights of holder under blank indorsement, 404.

indorsement in, by payee does not affect his right to sue, 403.

filling up blank indorsement, 404.

blank acceptances, 285 .

instruments intrusted to another and wrongfully filled up, 209.

BONA FIDE HOLDER.

what constitutes a, 199,226 .

general statement as to rights of, $197,198$.

bont fides essential, 227 .

efject of neoligence on bona fidcs, 229, 229.

must acquire instrument for valuable consideration, 230.

when price paid by, conveys notice of fraud, 231,232 .

purehase must be purchase in fact, and not mere bookkeeping entry, 233.

instruments taken as collateral security for eontemporancous and pre-existing debts, 234, 235.

amount of recovery when instrument held as collateral security, 236 , must acquire instrument in usnal course of business, 237.

transfers not in usual conrse of business, examples of, 238.

must aequire instrument before maturity, 239.

but transferce after maturity aequires all his transferrer's title, 201, 239.

when instruments payable at sight or on demand deemed over. due, 240.

presumption that instrument is aequired before maturity. 241.

rule as to accommodation paper aequirc loverdue, 242.

rule when instalment of principal or interest is overdue, 243.

transfers on last day of grace, 244.

must acquire instrument without notice of equities, 245.

notice of dishouror by nonaceptance or nonpayment, 245 .

notice of framd, defect of title, illegality of consideration, etc., 246 .

time when notice must exist, 247.

notice of accommorlation character of instrument, 200, 248.

notice of diversion of accommodation paper, 248 .

what amounts to diversion, 249 .

express notice, 250 . 
BONA FIDE HOLDER - continucd.

inplied notice, 251, 252, 254.

notiee of particular fraul, illegality, ete., not necessary, 2.53.

notice to agrent, 25.5.

one in possession and producing instrument presumed to be a, 199. what rebuts the presumption, 200 .

one though not himself a bona fide holeler acquires title of his trans-

ferrer, 201, 203 .

riglits of indorsee after maturity, 201-205.

rights of -

where instrument originated in fraud or mistakc, 206, 210, 220.

where undelivered instruments stolen and put in cireulation, $207,208,223$.

where instrument delivered with blanks, which are fraudulently filled, 209.

where instrument delivered in escrow, and put in cireulation in violation of instructions, 211-213.

where instrument executed by infant, insane person, married woman, ete., 219.

where instrument declared void by law, 221.

where instrument forged or materially altered, 222 .

where instrument exeeuted under duress. 224.

where there is want or failure of consideration, $248,446$.

defenses against, excluded by estoplel. 214, 215.

defenses arailable against, 218-224.

infaney, eoverture, insanity, etc., of maker, 219, 444.

fraut, when, $220,446$.

instrument declared void by law, $221,446$.

want of consent of maker - forgery, alterntion, etc.. 22.2. 439.

instrument stolen while ineomplete and undelivered, 208, 223.

duress, 224, 447 .

real defenses admissible against, 225 .

amount of recovery hy, 216, 217,236 .

set-off cannot be pleaded against, 473.

whether one is, determined by lex loci contractus, 497.

BONDS. Sce Coupox Boxns; Muxicipal Bonds.

\section{BURDEN OF PROOF.}

as to boua fidc ownership, 199, 200.

of diligenee, as exeuse for nonpresentment, etc., 392.

as to promptness in presentment for payment or excuse for delay, 320 .

as to alteration, 443 .

as to consicleration. 445 .

as to payment, 453 .

\section{BLSINESS.}

bona fidc holder must aequire paper in usual course of, 237.

transfers not in usual course of, examples, 238 .

BLSINESS IIOURS.

what are, is question for jury, 322 .

what are, 322,323 .

presentment for payment must be made during, 322, 323 .

BLSINESS, PLACE OF.

presentment for acceptance at, 264.

presentment for payment at, $316,334,335$. 
BUSINESS, PLACE OF - continuet.

presentment may be made to person found at, 317 .

presentment at, slould be dinring business hours, 323 .

notice of dishonor to, $372,376,378$.

\section{CALAMITY.}

as excuse for nonpresentment, ete., 385 .

CALENDAR MONTH. See Moxth.

CAPACITY.

of payce to indorse warranted by drawer, acceptor, and maker, 153, $166,276$.

of drawer to draw warranted by acceptor, 275 . warranty of, by indorser, 177.

CASHIER.

of bank, anthority of, to certify checks, 38.

CAUSE OF ACTION.

cannot be split up, 401.

recovery for part bars action for remainder, 401 .

interest nay be recovered without barring action for principal, 401 .

\section{CERTAINTY.}

as to engagement to pay, 75,76 .

as to fact of payment, $77-81$.

as to amount to be paid, 82-85.

as to medium of payment, 86-89.

CERTIFICATE of PROTEST. See Protest.

\section{CERTIFICATES OF DEPOSIT.}

definition of, 26.

origin and nature of, 26.

negotiability of, 27 .

\section{CERTIFICATES OF STOCK.}

description and nature of, 45.

transfer of -

as between transferrer and transferce, 46 .

as between transferee and creditor of transferrer, 47 .

as between transferee and third party who has purchased the shares, 48.

usual methods of transfer, 49.

\section{CERTIFICATION OF CHECKS. See CHecks.}

\section{CHECKS.}

definition of, 28 .

differences between bills of exchange and, 28.

is a draft or order, 29.

must be drawn on a bank or banker, 30 .

purports to be drawn on a deposit of funds, 31 .

must be for payment at all events of a certain sum of money, 32.

payable to a certain person therein named, or to him or his order, or to bearer. 33.

is payable instantly on demand, 28,34 .

when should be presentod for prayment, 39.

laches in presenting for payment, effect of, $29,39$. 
[References are to

\section{CHECKS - continued.}

when statnte of limitations begins to run on, 28 .

not entitled to grace, 34 .

stale, status of, 39 .

whether loolder of uncertified clicek may sue bank, 40 .

damages for inuproper dislionor of, 41 .

effect of, as assignment of fund, 10-14.

payment by, $45 \pi$.

certification of -

bank under no obligation to certify, 35 .

similar to acceptance of bill, 35 .

effect of, $36,3 \pi$.

bank becomes solely liable, 36.

drawer and indorsers diseharged, 36,37 .

form of, 38 .

by whom made, 38 .

CHOSE IN ACTION.

not assignable at common law, 1 .

relaxation of common-law rule, $I$.

\section{CIRCUMSTANCES.}

may amount to notice, $251,252,254$.

excusing nonpresentment, ete. See Exceses for Nonpresextmext, Protest, ANd Notice.

CIVII. WAR. See War between the States.

\section{CLERK.}

presentment to, 316 .

notice of dishonor to, 372 .

COLLATERAL SECURITY.

instruments taken as, for contemporaneous and pre-existing debts, 234,235 .

amount of recovery on instruments taken as, 236 .

parting with, effert of, on surety's liability, 478 .

receipt of, by maker or aceeptor as excuse for nonpresentment, etc., 396.

COLLECTION AGENTS.

banks as, 131.

duty of, to present for aceeptance and payment, 132.

ownership of paper in hands of, I33.

COMITY OF NATIONS, 485.

COMMERCE.

interdiction of, as excuse for nompresentment, ete., 384 .

Comalercial PAPler. sece Negotiable Ixstrumexts.

COMMON LAW.

choses in action not assignable at, 1 .

whether promissory notes negotiable at, 4.

COMPOUNDING OF CRIMES.

as a consideration, 103 . 


\section{COMIROMISE.}

as a consideration, 97 .

by part payment, 468 .

COMIPUTATION.

of time, 329-331.

CONDITION.

instrument parable on, not negotiable, 77 .

delivery on, $i 1,211-213$.

CONDITIONAL ACCEPTANCES, 306-309.

CONDITIONAL INDORSEMENT.

defined, 184.

examples of, 184.

condition in, does not affeet negotiability, 184.

CONDITIONAL PAINENT, 457.

CONFEderate WAR. Sce War between the States.

CONFLICT OF LAIIS.

importance of subject, 483 .

general prineiples, 484 .

comity of nations, 485 .

lcx loci contractus governs as to validity, interpretation, nature, obligation, ete., $105,106,486$.

interpretation, meaning of, 486 .

nature and obligation, meaning of, 487 .

what constitutes place of exeeution, 488 .

domicile of maker or aceeptor presumed to be place of execution, 489 .

what is loci contractus of maker, acceptor, drawer, and indorser, 492 .

when lcx loci solutionis governs, 490.

when lex loci rei site governs. 491.

lex fori governs as to remedy. ineluding parties plaintiff, statute of limitations, form of action, evidence, set-off, exemptions, ete., 493$496,498$.

lex loci contractus determines whether one is a bona fidc holder, 497 . by what law presentinent, protest, and notice of dishonor governed, 500 .

\section{CONCIRESS.}

pwer of, to enact bankruptcy laws, 465 .

CONSENT.

want of, as defense against bona fide holder, 222.

\section{CONSIDERATION.}

defined, 90 .

must be proved in nonnegotiable contracts, 90, 91 .

seal imports a, 1,90 .

presumed in negotiable instruments, 1, 90, 91, 445.

between what parties consideration open to inquiry, 1, 93, 110-113, 445.

accommodation pajer, 93-96.

valuable, examples of, 97-100, 118.

pre-existing debts as a, 100 .

instruments taken as collateral seeurity for contemporaneous and pre-existing delts, $234,235$. 
[References ate 10] paragraphs marlied \$.]

CONSIDERATION - continued.

illegal, examples of, 101-104.

legality of, presumed, 445.

by what law Iegality of, determined, 105, 106.

failure of, 108,445 .

partial want, fallure, or illegality of, 107-109, 145.

of renewal notes, 114,115 .

burden of proof as to, 445 .

ehange in, constitutes material alteration, 435.

CONSTITUTION OF UNITED STATES.

States prohibited by, from emitting bills of eredit, 42.

provision in, empowering Congress to pass bankrupt laws, 465.

CONSTHUCTIVE Notice. See Notice.

CONTAGIOUS DISEASE.

existence of, as exeuse for nonpresentment, ete., 385.

CONTEMIPORANEOL'S DEBT.

collateral security taken for, 234.

CONTRIBUTION.

none between successive indorsers, ISS, 475.

equal indorser's entitled to, lss.

when right of action for, accrues, $4 \$ 1$.

COPARTNERSHIP. See Partakes.

COPROMISORS.

presentment for payment to, 319 .

CORPORATIONS. See also Musicipal Corporatioxs.

public and private, detinitions and examples of, $1+2$.

power of, to execute negotiable instruments, $143,144$.

negotiable instruments of, presumed to be issued in course of its business, 145 .

accommodation paper issued ly, 145 .

agents of, appointment and authority of, 146 .

doctrine thit, can only bind themselies by contract under seal, obsolete. 21 .

whether instrument of, under seal negrotiable, 73 .

CosTs.

of collection, stipulations as to, $S 4,85$.

COLPON BONDS.

by whom issued, ls.

description of 19.

meaning of term " coupon." 20.

closely assimilated to promissory notes, 20.

negotiability of, 21 .

COURSE OF BLSINESS.

bona fide holder must aequire instrument in usual course of business. 237 .

transfers not in usual course of business, 238 .

COTEXINT NOT TO SLE.

eflect of. 470. 
COVERTURE. See Married Womex.

CREDIT, BILls OF. See Bills of Credit.

CURRENCY.

instrument payable in, not negotiable, $27,87$.

\section{CUSTOM.}

authority implied from, 125.

\section{DATE}

of negotiable instruments, 62,70 .

change in, constitutes material alteration, 429.

DAYS.

computation of, 330 .

DAYS OF GRACE. See Grace, Days of.

DEAT'H.

revokes agency, 130.

dissolves partnership, 140.

of holder -

as excuse for nonpresentment, etc., 395 .

presentment for payment in case of, 315 .

notice of dishonor in case of, 366 .

of maker or acceptor, presentment for payment in case of, 318 .

of drawee, presentment for acceptance in case of, 261.

of drawer, bill may be accepted after, 286 .

of drawer or indorser, notice of dishonor in case of, 371.

of partner, presentment for payment in case of, 315, 319 .

DEBTS.

pre-existing, as a consideration, 100 .

instruments taken as collateral security for contemporaneous and pre-existing, 234, 235.

DEFAULT.

in presentment, etc. See Excuses for Nonpresentment, Protest, AND Notice.

DEFENDANTS.

to aetions on negotiable instruments, 407-409.

DEFENSES.

real and personal, defined, 225.

between immediate parties, 113 .

against indorsee of overdue paper, 204.

against bona fide holder for value, 218-224.

excluded by estoppel, 214 .

classification of, $416,417$.

defendant did not make the instrument -

forgery, 418-426. See Fongery.

material alteration, 427-443. Śe Alteratron.

the contract sued upon is in law nonenforceable -

incapacity of party, 444. See Parties to Negotiable InstroMENTs.

want, failure, or illegality of consideration, 445 . See Coxsid. FRATION.

fraul, 446. See Fraud.

duress, 447. See Duress. 
DEFENSES - continued.

plaintifl not entitled to sue -

legal title to instrument not vested in plaintifr, 448 .

the obligation created has been discharged -

by payment, 449-463. S'ec l'armext.

by tender, 4tit. sec Texder.

by hankruptey or insolvency, 465, 466. See baxkruptcy AND Ixsorvescy Laws.

by accord and satisfaction, 467,468 . See Accond AxD Satis. FACTIOX:

by release, 469. Sice Reiesse.

by covenant not to sue, 470 . Ne Corexast xot To Sie.

by novation, 471. Sec Jovation.

by set-off, 472-474. See SET-OFF.

defendant is a surety, and is discharged, 475-480. Sire Srretr. action barred by statute of limitations, $414,415,481,482$. Sce STat-

UTE of Limitatioss.

DELAY.

in precentment, ete. Sec Excrises for Noxpresextmext, Protest, AxD Notice.

\section{DELIVERY.}

necessity of, $69,71,169$.

constructive. 6!.

instrument takes effect on, 70 .

presumptions as to, 70 .

in eserow, $71,212$.

in violation of instructions, 211.

transfer by: without inlorsement, 168.

transferrer by, warranties of, 424 .

law of place of, governs, 488.

place of execution is where delivery made, 488.

presumption as to place of, 488 .

DEMAND.

eheeks always payable on, 28, 34 .

when instruments payable on, deemed overdue, 240.

bills payable on, do not require presentment for acceptance, 257 .

instrument payable on, where no time specified, 321 .

presentment for payment when instrument payable on, 321, 324, 325. instrument payable on. not entitled to grace, 324.

when statute of limitations begins to run on instrument payable on, 415 .

Demand of Paymext. see Presextmext for Paymext.

DEPOSIT.

check purports to be drawn on, 31 .

DEposit, CERTIFiCATES OF. See Certificates of Deposit.

DEPOSITARY.

of negotiable instrument cannot sue, 398 .

DEPRECIATED CURREXCY. acceptance of, by creditor, absolute, 458.

DESTRTETION. of bill, whether amomts to implied acceptance, 299. 


\section{DETENTION.}

of bill, whether amounts to implied acceptance, 299 .

DILIGENCE.

in presentment for acceptance. 269.

in presentment for payment. $337,392$.

DISABILITY. SeE IxCAPACITY.

\section{DISCHARGE.}

of drawer and indorsers by eertification of eheek, 37 .

of surety, $475-480$.

by parment, 449-463. See PAYMext.

by tender, 464 . See Twider.

by bankruptey or insolvency, 465,466. See Bankruptcr AND INSOLVENCY LAWS.

by aceord and satisfaction. $46 \pi, 468$. See Accond axd Satisfactiox. by release, 469 . Sce Release.

by eovenant not to sue. 470 . See Covenant vot to Sue.

by novation, $4 \overline{7}$ l. See Novation.

by set-off: $472-474$. See SET-OFF.

DISEASE.

existence of, as exeuse for nonpresentment, etc., 385 .

DISHONOR, NOTICE OF. Sce Notice of Disironor.

\section{DISSOLUTION OF PARTNERSHIP.}

how caused, 140 .

when notice of, necessary, 140.

effect of, 140, 141 .

DISTURBANCES.

military and political, as exeuse for nonpresentment, ete., 384, 385 .

DIVERSION.

of aceommodation paper-

what amounts to, 249 .

effect of, 248,477 .

DOCK RECEIPTS. See WAREHotse Receipts.

\section{DOMICILE.}

of maker or aceeptor -

change of, as exeuse for nonpresentment, etc., 397.

when presumed to be place of execution, 489 .

DONATIO CAUSA MORTIS.

of negotialsle instrument, suit by donee, 398 .

DORMANT I'ARTNER.

notice of retirement of, not necessary, 140 .

DRAWEE.

relation of, to bill before and after acceptance, $271,272$.

where incapable of contracting, holder may treat bill as dishonored, 281.

joint drawees, aceeptance in cace of, 284.

alternative Irawees, 284.

has twenty-four hours within which to aecept or refuse, 287. 
DRAIIER.

liability of, before and after aceeptance, 270, 311, 424, 475.

when bouml without presentment for acceptance, 258 .

signature and capacity of, admitted by acceptance, 273, 275.

bill may be aceepted after death of, 2 ist.

dischariged unlesi hill presented at maturity and notice of dishonor given, $311,320,358,359,367$.

action ayrainst, for nonaceptanee, 413.

when can sle acceptor, $408,409$.

when aceptor and indorser can sue, 405. 409.

whin estopled to deny gemuineness of indorsement or aeceptance, 424.

by what law liability of, governed, 492.

DRUNKEN PERSONS.

contraets of, 161 .

degree of drunkenness sufficiont to eonstitute valid defense, 101.

ratification of contracts made while drunk: 162 .

\section{DUF BILL.}

whether a promissory note, 76 .

when suit may be commenced on, 411 .

\section{DURESS.}

defined, 447 .

defense of, 224,447 .

to principal, ellect of, on surety's liability, 477 .

\section{ENTIFE DEIIAND.}

what constitutes, 401.

cannot be split up. 401 .

recovery for part bars action for remainder, 401.

interest may be recovered without barring action for principal, 401 .

\section{FPIDEMICS.}

existence of, as excuse for nonpresentment, ete., 385 .

\section{EQUITABIE ASSIGNMENT.}

effect of bills and nonnegotiable orders as, 10-14.

\section{EQUITIES.}

bona fide holder takes diseharged of, 1, 197, 198.

assigrnee takes subject to, 168 .

indorse of overdur pajer takes subject to what equities, 202, 204.

whether accommodation character of instrument is an equity attaching after maturity, 205, 242.

\section{ESCROW.}

delivery in, $71,212$.

difference between specialties and negotiable instruments delivered in. 213.

delivery by eustodian in violation of instruetions, 211-213.

ESSENTIAL REQUISITES OF NEGOTIABLE INSTRLMENTS.

must be open - i. e., unsealed. 73,74 .

engagement to pay must be eertain. 75, 76.

fact of payment must be certain. $7 i-S 1$.

amount to be paid must be eertain. S2-S5.

medium of parment must be money sti-89. 


\section{ESTOPPEL.}

defenses excluded by, 214.

good faith esscutial to, 215 .

by adoption of forged signature as genuine, 422 .

to rleny genuineness of signature, position of drawer, indorser,

drawee, aceptor, and transferrer, $273,423,424$.

by acceptance, $273-277$.

EVIDlixCE. Sce also Parol Eninexce.

statute of limitations cannot be given in, under general issue, 414 .

place of date prima faeie evidence of maker's residence and place of business, 337 .

protest exclusive evidence of dishonor of foreign bill, 347 .

certificate of protest as, 355-35\%.

possession prima facie evidence of ownership, 406.

questions of, governed by lex fori, 496 .

EXCHANGE.

instrument payable with, negotiable, 83.

EXCHANGE, BILLS OF. See Bills of Exchaxge.

EXCUSES FOR NONPRESENTMENT, PROTEST, AND NOTICE. war, 384.

interdiction of conmerce, 384 .

military disturbances, 384 .

political disturbances, 385 .

epidemies, 385 .

overwlielming calamities, 385 .

when drawer has no right to require, 387 .

when presentment, protest, and notice have been waived, 388, 389.

when no one in existence upon whom to make demand, 390 .

when bill or note is void, and drawer or indorser knows it to be so, 391.

when party cannot be found after due diligence, 392 .

when place of buciness or payment closed, 393 .

when party traveling, absent from home, etc., 393.

when instrument acquired too late to make demand or give notice, 394.

sudden illness or death of holder, 395 .

when drawer or indorser has received funds to pay instrument, or has received security or indemnity, 396 .

when maker or acceptor has alsconded or removed his domicile, 397 .

when impediment ceases, duty to make demand or give notice revives, 383 .

inability to find maker or acceptor does not excuse want of notice to drawer or indorser, but inability to find latter does, 393.

\section{EXECUTION.}

formalities of governed by lex loci contraetus, 486 .

place of, what constitutes, 488.

place of, when domicile of maker or acceptor presumed to be, 489 .

exemptions from, governed by lex fori, 498.

\section{EXECUTORS AND ADMINISTIRATORS.}

cannot bind estate by negotiable instrument, 117.

are individually bound, $117,118$.

how individual liahility excluderl, 118.

may transfer instrument pavalile to order of deceased, 119.

one of several, may transfer by indorsement, 119. 
EXECUTOLS ANI ADMIXISTRATORS - continued.

presentment for acceptance to. 261.

presentment for payment by, 31\%.

presentment for piyment to, 318 .

notiee of dishonor bi, 366 .

notice of dishonor to, 371 .

EXEMPTIONS.

from exeeution, governed by lex fori, 498 .

EXPRESS ACCEPTANCE. S'C ACCEPTANCE.

EXPRESS NoTICE. Sce Notice.

\section{FALSE REPRESTATATIONS. Sec FraUd.}

\section{FEDERAI, COURTS.}

rules of decision of, in respeet to negotiable instruments, 8 .

sometimes disregarl state statutes in applying law merehant, 256.

have jurisolietion of suits hetween eitizens of different States, 483.

FEES, ATTORNEYS. eflect on negotiability, of stipulation to pay, 84,85 .

\section{FELONIES.}

compounding, illegill, 103.

FEME COVER'T. See Married Womes.

\section{FEME SOJE.}

presentment for parment in ease of marriage of, 315 .

\section{FICTITIOUS NAML.}

signing of. with intent to defrad, is forgery, 419.

FIDUCIARIES AS parties. See Executors axd Admistrators: Gualimaxs: Trustees.

\section{FORBEARANCE.}

to sue, as a consideration, 97 .

FORFIGX Bíl.s OF ExCHANGE. See Birls of Exchayge.

FOREIGN LAIIS.

courts will not take judieial notice of, 499.

\section{FORGERY.}

definition of, 418 .

illustrations of, $418,419$.

alteration is, when, 420,427 . Sce Alteration.

making must be comnterfoit anel false in order to amount to, 420 .

if real, though fraudulently proeured, does not amount to, 420 .

intent to defrand, and uttering. esiential, 421.

adoption of forged signature, 422.

estoppel to deny gentulueness of signature, position of drawer. in-

durser, drawer, areceptor. and tran=ferrer, 423. 125.

aceptanee no admi-ion of indorser's signature. 42.5.

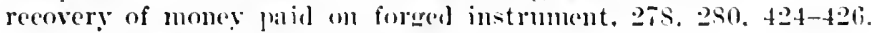
good defense against bonn fidr holder. 202.2. 


\section{FORMAL REQUISITES OF NEGOTIABLE INSTRUMENTS.}

no particular form required, $5 \pi$.

signature, 58 .

material on which written, 58 .

whole instrument nust be in writing, 59 .

date, 62 .

words of negotiability, 63.

stamps, 67 , is.

delivery, $69-\bar{i} 1$.

\section{FRALD.}

defined, 446.

effect of, 446.

defeuse of, generally available only between immediate parties, 206, 210,446 .

when a good defense against a bona fide loolder, 220, 446.

when price jail by purchaser conveys notice of, 231,232 . .

material alteration fraudulently made, effect of, 440 .

inmaterial alteration fraululently made, effect of, 442 .

fraudulently procuring signature is not forgery, 420 .

amomnt of recovery by bona fide lolder when instrument has incep-

lion in, 217.

efiect of, on surety's liability, 477 .

FUNDS.

alsence of, in lyawee's hands as excuse for nonpresentment, etc., 387 . withdrawal of, by drawer, as excuse for nonpresentment, etc., 387. receipt of, by maker or indorser, as excuse for nonpresentment, etc., 396.

check purports to be drawn on deposit of, 31 .

FUTURES, 102.

GENERAI ISSUE.

statute of limitations cannot be given in evidence under, 414 .

\section{GENUINENESS.}

warranty of, by indorsement, 175.

acceptance no admission of gen:lineness of terms in body of bill, 280 .

GIVING TIMIE.

effect of, on surety's liability, 479,480 .

GRACE, DAYS OF.

origin and mature of, 326 .

what instruments entitled to, 34,327 .

number of days allowed. 328.

presentment for payment when last day of grace falls on Sunday or holiday, :380.

how dispensed with, 332.

whether paper deemed overdue when transferred on last day of grace, 244.

whether action can be instituted on last day of grace, 410 .

by what law governed, 500 .

GREGORIAN CALENDAR, 331.

ripOSS NEGIIGENCE. Sce Neguidirnce. 
GUARANTOR.

contract of, 196 .

difference between liability of, and of indorser and surety, 195, 196.

GUARANTY.

difference between, and suretyship, 195.

difference between, and indorsement, 196.

GUARDIANS.

as parties to negotiable instruments, 120.

HOLdDFR. See Bona Fide Hotder.

HOLIDAY:

presentment for payment when instrument falls due on, 330 .

honor. See Accelpance Supra l'rotest; Acceptor supra Protest; Payment Supra Protest.

HGUR.

at what hour of day presentment for payment should be made, 32:-, 323.

IDIOTS. See Insane Persons.

\section{ILLEGAL CONSIDERATIONS.}

examples of, 101-104.

by what law legality of eonsiderntion determined, $105,106$.

ILLNESS.

of holder, as excuse for nonpresentment, etc., 395 .

IMBECILeS. Sce Ixsane Persoxs.

IMIIATERIAL ALTERATION. Sce Alteration.

illustrations of 437 .

effect of, 437,442 .

IMMEDIATE PARTIES.

who are, 110.

defenses admissible between, $110,113,445-44 \pi, 473$.

IMIPLIED ACCEPTANCE.

what will anount to, 299.

IMPLIED AUTHORITY.

of agents, 124, 125.

of one partner to bind firm, I34-137.

of corporations, 143,144 .

IMPIIEI) NoTICE. See Notice.

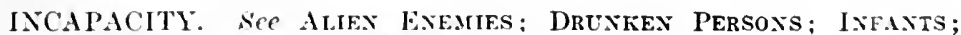
Ixisane Plosoxs: Markied Moyex.

defense of, 444.

defense of, good against bona fide holder, 219, 444.

INDEMITITY".

receipt of, by maker or indorser as exeuse for nonpresentment, etc., 396. 
INDORSEMENT. Ste also INDORSEK.

when negotiable instruments transferable by, 168 .

of instrument payable to bearer or indorsed in blank, effect of, 168 .

transfer not completed without delivery, 169.

meaning of term, 170 .

is a separate and independent contract, 171 .

liabilities created by, 172-17s.

liabilities created by indorsenent without recourse, 173.

warrantics by, $172-i 7 s$.

place of, 179 .

may be on separate paper, 180.

allonge, 180.

indorsement in full. 18:.

indorsement in blank, 183.

absolute and conditional indorsements, 184.

restrietive indorsements, 185.

indorsements without recourse, 186.

joint indorsements, 187 .

successive indorsements, 188.

irregular indorsements, 1S9 194.

difference between guaranty and, 196 .

who may sue on instrument indorsed in blank, 398, 403.

rights of lolder under blank indorsement, 404.

who can sue on instrument indorsed in full, 405 .

filling up blank indorsement, 404.

where indorsement speeial to partienlar person, none but such person or his representative ean sue, 398 .

infant may transfer title by, 153 .

right to strike out indorsements, 404

INDORSEMENT IN BLANK.

defined, 183.

effect of, 183 .

\section{INDORSEMENT IN FULL.}

defined, 182.

effect of, $182,183$.

INDORSEMENT WITHOUT RECOURSE.

effect of, 186.

liabilities ereated by, 173.

INDORSER.

contract of, 172-178, 196, 311 .

warranties by, $172-178,424$.

joint and successive indorsers, 1s7, 188.

irregular indorsers, 189-194.

difference between liability of, and guarantor, 196 .

when snit can be begun algainst, 412, 413.

action against, for nonacceptanee, 413.

aceptance no admission of signature of, 278,425 .

is surety of acepptor or maker, 475 .

new promise or part payment by, effect on statute of limitations, 482.

by what law liability of, governed, 492 .

\section{INDORSER WITIHOUT RECOUTSE.}

liability assumed by, 173.

liability of, eontrasted with lialility of regular indorser, 173.

warranties by, 173 . 


\section{INFAN'TS.}

who are, 150.

contracts of, generally voidable, 150 .

may bind themselves for necessaries, 151 .

liable for torts, 151.

cannot bind themselves on negotiable instrument, 152.

may be payee, 153.

may transfer by indorsement, 153, 154.

ratification by adult of necotiable instrument executed whin an infant, $155,156$.

whit will amount to ratification, $155,156$.

may act as agents, 12l.

where drawee is, bill may be treated as dishonored, 281.

defense of infancy good against bona fide holder, 219, 44.

INITIALS.

sullicient as signature, 58.

INLAND BILLS OF EXCHANGE. Sce BILls of EXciraxge.

INSANE PERSONS.

sanity presumed, 157.

insanity must be specially pleaded, 157.

negotiable contracts of. voisl, $15 \pi$.

what legree of incalpacity sullices to render contract void, 158.

ignorance of incapacity, efleet of, 159 .

contracts of, for necessaries. valid, ltio.

ratification after recovery, 162 .

where drawee insane, hili may be treated as dishonored, 2S1.

insanity revokes acreney, 130.

insanity good defense against bona fide holder, 219, 444.

INSANITY. Sec Insave Persoxs.

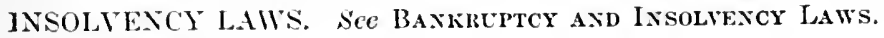

\section{INSTALMENTS.}

instruments payable in, when deemed overdue, 243 .

presentment for payment when instrument payable in, 321.

maker entitled to grace on each instalment, 327.

action lies for each instalment as it falls due, 413.

\section{INTENT.}

to defrand, essential to constitute forgery, 421.

INTERDICTION OF COMMIERCE.

as excune for nonpresentment, ete., 384.

\section{INTEREST.}

whether paper deemed overdue when instalment of, remains unpaid, 243.

note payalle on demand with, is continuing security, 324 .

whether separate action may be maintained for, 401 .

may be recovered withont barring action for principal, 401.

change in rate of constitutes material alteration, 431 .

INTERPRETATION.

meaning of, 486 .

govermed by lex loci contractus, 486.

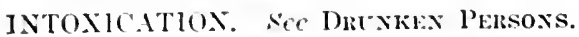




\section{IRREGULAR INDORSEMENTS.}

examples of, I89-19l.

liability of one not payee writing his name on paper before delivery to payee, 191 .

conflict of decisions as to, 192 .

parol evidence of intention almissible between immediate parties, 193.

whether parol evidence of intention admissible between remote parties, 194.

\section{JOINT DRAIVEES.}

if not partners, all must accept, 284.

if drawn on firm, may be acepted by one partner in firm name, 284 .

JOINT PARTIES.

suits by, 399.

new promise by one, effect of, on statute of limitations, 481.

several payees not partners must indorse jointly, 187.

acceptance by, 284 .

effect of indorsement by one of several payces, I87.

presentment for parment to, 319 .

notice of dishonor to, 369 .

JUDICIAI, NOTICE.

of seal of notary public, 348 .

of days of grace allowed by law merchant, 328 .

when taken of bauking hours, 322 .

courts will not take, of laws of another State or country, 484, 499.

IUDICIAL SAI.E.

purehase at, not in usual course of business, 238 .

JULIAN CALENDAR, 331.

JURY.

what are business hours is question for, 322 .

\section{LACHES.}

in presentment for acceptance, effect of, 28, 39, 268.

LADING, BILLS OF. See BIlls OF Ladjeg.

\section{LAW NERCHANT.}

principles of, when applied by Federal courts, 8, 499.

LEGAL HOLIDAYS.

presentment for payment when instrument falls due on, 330 .

LEGAL TENDER.

instrument must be pavable in, 87,88 .

what constitutes a, 464 .

LEGAL TITLE.

must be vested in plaintiff to entitle him to sue in own name, 448.

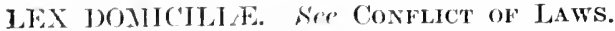

LEX FORI. Sire CoNflict of Laws.

JFX LOCI CONTRAC'TUS. SCe CONFLICT OF LAWS. 
I.EX LOCI REI SITA. See Coxflict of LAWs.

LFX IOCI SOJUTIONIS. Sice CoNflict of LAWs.

IMITATION UF AC'TIONS. See STATUTE of ImMitatioxs.

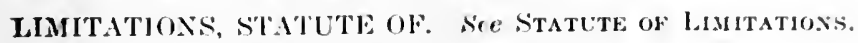

Lunatics. See Ixsaxe Persons.

MAIL.

presentment for payment by, 340 .

customary demand by bankis ly notice through, $343,344$.

when notice of dishonor may be given by. 373, 375-377.

MAKER.

obligation of, 311 .

presentment for payment not necessary to hind, 311, 320.

not entitled to notice of lishonor, 358,367 .

death of, presentment for payment in ease of, 315 .

estopped to deny capacity oi prave. 153. 166.

warrants genuineness of signatures on palper when put in circulation, 424 .

by what law liability of, governed, 492.

MAJAA FIDISS.

negligence as evidence of, 228, 2209.

MARK.

as a signature, 58.

MARIIAGE.

of feme sole, presentment for payment in case of, 315 .

MARRIED WOMAN'S ACTS.

reference to, $16 i, 400$.

MARRIED WOMEN.

incapacity of, to contract at eommon law, 165 .

as payee and indorser, 160 .

exceptions to rule of ineilpacity to contract, 167 .

statutory changes as to contractuill powers of, $167,400$.

may act as agent, 121 .

presentment for parment in ase of marriage of feme sole, 315.

husband must join in suit on bill or note given to feme sole who afterward marries, 400.

on death of husband, right of action survives to wife, 400 .

on deatl of wife, right of action goes to her personal representative, 400.

where bill or note given to married woman, husband may join wife or sue alone. 400.

wife eannot sue husband, 400.

coverture, defence of, grood agrainst bona fide lolder, 219. 444.

suits on newotiable instruments held by, 400 .

where drawee is a, bill mily be treated as dishonored. 251.

MATURITY. Sce Orende Papre.

MLDILAL OF PAYMl:NT, sti-89, 45i. 


\section{MILITARY DISTURBANCES.}

as excuse for noupresentment, etc., 384 .

MINORS. Sce INFAnts.

MISDESCRIPTION.

in notice of dishonor, 362 .

mistiepresentation. Sce also Fraud. where instrument executed under, rights of bona fide holder, 210, 220.

effect of, on surety's liability, 477.

MISTAKE.

where instrument exeeuted under, rights of bona fide holder, 210. of fact and law, payments made under, 452.

MONEY.

nerotiable jnstrument must be payable in, $86-89$.

parment must be made in, 457 .

nothing but money constitutes lawful tender, 464.

rccorery of, when paid on forged instrument, 424-426.

MONTH.

what constitutes, at common law and under law merchant, 329 .

computation of months, 329 .

MORTGAGE.

lex rei sitce governs instrument secured by, on real estate, 491 .

MUNICIPAI. BONDS.

can only be issued for public purpose, 22.

what are public purposes, 23.

MUNICIPAL CORPORATIONS.

definition and examples of, 142.

power of, to exceute negotiable instruments. 147.

power of, to issue bonds, $22,23$.

NECESSARIES.

contracts of infants, insane persons, and married women for, 151 , ] 60,167 .

\section{NEGLIGLXCE.}

effect of. on bona fides, 228 , 229.

line of demareation between. and notice, 232.

leaving room for alteration. by negligent execution, renders party liable to bone fide inolder, 439.

\section{NEGOTIABILTT.}

meaning of, 1 .

words of, 63 .

addition or ehange in words of, is material alteration, 436.

negotiable instruments. See Bills of Excilange; Promissory Notes; CoUjon BoNds; MUNICIPAL Bonds; BaNk BILls or Notes; Certificates of Deposit ; Checks; Bills of Credit; Certificates of Stock: Bil.ls of Lading; Wareilouse Receipts. peculiarities of, 1 .

words of nergotiability, 63. 


\section{NEGOTIAIBLE INSTRUMENTS - continued.}

different kinds of $15-55$.

bills of exchange, 15, 17.

promissory notes, $16,17$.

conpon boinds, 18-21.

municipal bouds, 22, 23.

bank notes, 24, 25.

certificalte's of deposit, 26, 27.

cheeks, 29-4l.

bills of eredit: 42,43 .

quasi-necotialle inst ruments, 44-55.

crrtificates of strok, $45-4 !$.

bills of lading, 50-52.

warelionse or lock receipts, 53-55.

essential requisites of -

must be open $-i$. $c_{\text {., }}$ unsealed, 73, 74 .

engagement to pay must be certain, 75, 76.

fact of payment rimst be ecrtain, $i \bar{i}-8 I$.

amount to be paid must he cortain. 82-85.

medimm of payment must be money, 86-89.

formal requisites of -

no particular form required, 57 .

signature, 58 .

material on which written, 58.

whole instrument must be in writing, 59 .

date, 62 .

words of negotiability, 63 .

stamps, $6 \vec{T}$. (is.

delivery, $69-71$.

parol evidence gemerally inadmissible to vary, 60.

when parol evidence admissible. 61. 62.

contemporaneous written agreemeuts, when admissible, 61.

\section{NEW PROMISE.}

by joint maker, surety, indorser, ete., effect of, on bar of statute of limitations, 481, 482 .

\section{NONACCEPTANCE.}

action upon dishonor for, 413 .

Notari PUlilic. sece also Protest.

may make presentment for payment. 312.

generally protest should be niade by. 348.

seal of, eourts take judicial notice of, 348 .

seal of prima facie proof of anthenticity of eertificate of protest. 348.

must have personal knowledge of presentment and demand of payment in order to make eertificate of protest. 350 .

not part of ollicial duty to give notice of dishonor, 366 .

NOTICE.

bona firle holder must aequire instrmment without. 245-2.5.

but one taking with notiee from bona fide holder acquires title of his transferrer, 201.

of dishomor hy nomaceptanee or nomparment, 245.

of framl, defoet of title, illegality of enisideration, ote., 246 .

time of acquiring, 247 .

of accommodation cliaracter of paper, $200,248$. 
NOTICE - continued.

of diversion of accommodation paper, 248.

express, 250.

eonstructive, 251, 252, 254.

of particular fraud, illegality, etc., not necessary, 253.

when price paid ly purchaser conveys notice of fraud, 231, 232 .

line of demareation between negligence and, 232.

notice to agent, 255 .

of dissolution of partnership, when necessary, 140 .

\section{NOTICE OF DISHONOR.}

necessity of, to parties secondarily liable, 358 .

primary debtor not entitled to, $3 \dot{5} 8$.

applies only to negotiable instruments, 358 .

effect of failure to give, $311,358,359$.

may be verbal or written, 360 .

knowledge of dishonor does not constitute, 360 .

form and contents of, 361-364.

by whom given, 365,366 .

when notice by one inures to benefit of anotber, 365 .

notice by agent, 366 .

when holder dead, 366.

to whom should be given, $367-371$.

drawer and indorsers entitled to, but maker and acceptor not, 358, 367.

notice to agent, 368.372 .

notice to partners and joint indorsers, 369 .

notice to indorsers for collection and to accommodation and fixed indorsers, 370 .

notice when drawer or indorser is dead or bankrupt, 371 .

how served -

when parties in same place, 372 .

what is meant by same place, 373 .

exceptions to rule that service must be personal where parties live in same place, 374 .

when parties reside in different places, 375-377.

drawer or indorser may direct to what place notice shall be sent, 376 .

where party lives in one place and has place of business in another, 376.

where party resides temporarily in certain place, 376 .

time within which given -

may be given immediately on dishonor, 378 .

holder has until expiration of day following dishonor in which to give, 378 .

when parties reside in different places, notice must be sent by first mail of day succeding dishonor, unless unreasonably early, 379.

each holder has a day within which to give, to his predecessor, 380 .

transmission of notice over seas, 381 .

excuses for failure to give. See Excuses for Noxpresentment, Protest, and Notice.

what law governs, 500 .

NOTING DISIIONOR, 351.

NOVATION.

effect of, 471 . 
OBLIGATION.

of contract determined by lex loci contractus, 486 .

meaning of, 487.

OCCUPATION OF COENTRY BY ENEMY.

as excuse for nompresentment, etc., 384 .

OVERDUE PAPER.

transferce of, tithes subject to what equities, $201-205,474$.

when instruments payable on sight or demand deemed werduce, 240. accommodation paper aepuired overdue, 205, 242.

rule where instalment of prineipal or interest overduc, 2.13.

whether decmed overdue when transferred on last day of grace, 24.4

OVERWHLLMING CALAMITY.

as excuse for nonpresentment, etc., 355 .

PAROL EVIDFACE. Sce also Evinexce.

generally inadmissible to vary or contradiet written instrument, 60. when admissible, 9, 61, 62.

admissibility of, to show intention in cases of irregular indorsement, $193,194$.

when admissible to supply omissions in certifieate of protest, 357 .

PARTICLLAR FLND.

instrument not negotiable when payable out of, 81 .

PARTIES TO NEGOTIBLE INSTRLMENTS.

exeentors and iduinistrators, 11i-119.

guardians, 120.

trustees, 120.

agent:, 121-133.

partners. $134-141$.

corporations, 142-149.

infants, $150-156$.

lunaties, imbeciles, and drunkards, 15i-162.

alien enemies, $163,164$.

married women, l65-16i.

inmediate and remote, who are, $110,111$.

defenses admissible between immediate parties, 110, 113, 445-44i. 473.

warranty of eapacity of. $153.166,175,275,276$.

parties to bills and notes, 56 .

change in personality, number, or relation of, constitutes material alteration, 433.

\section{PARTYFRS.}

general authority of one partuer to bind firm, 134, 135.

trading parturehipe, newotiable instruments executed by one partner lind tirm, 136.

one member of nontrading partnership cannot execute negotialile instrument without eoment of all, 137.

examples of nontraling partuerships. 13\%.

accommodation paper exented by one partuer not hinding on firm. 138.

where one partner signs firm name as surety, firm not bouml. 13s. firm not lialde on paper is:ued in firm name for private debt of one partner, 139. 


\section{PARTNERS - continued.}

dissolution of partnership, how caused, and effect of, 140, 141. when notice of dissolution necessary, 140.

presentment for acceptance to, $\mathbf{2 5 9}$.

aeceptance by, 284 .

presentment for palyment by and to, 315, 319 .

notice of dishonor to, 369.

parment by, appropriation of, 460 .

satisfaction by one discharges all, 467.

suits by, 399 .

\section{PARTNELSHII'. See P'ARTNERS.}

\section{PART PAYMENT.}

ordinarily only payment pro tanto, 468.

when operates as satisfaction, 468.

by drawee does not amount to acceptance, 298.

after maturity, as waiver of nonpresentment and notice, 389.

by joint maker, indorser, etc., effect of, on statute of limitations, $481,482$.

PAYEE.

eapacity of, to indorse admitted by acceptance, 153, 166, 276 .

signature of, acceptance no admission of, $278,475$.

infants and married women as, 153, 166.

\section{PAYMIENT.}

defined, 4.49 .

distinguished from sale, 449.

fact of, must be certain, $77-81$.

time of, need not be definitely ascertained, if sure to come, 78 .

who may make, 450.

payor should see that holder's title is genuine, 451.

payments under forged indorsement and under mistake of fact and law, 45l. 452.

payor should demand surrender of instrument, and take receipt, 453 .

to whom parment may be made, 454 .

when payment may be made, $455,456$.

medium of, s6-89, 449.457.

by check, note, etc., 457 .

acceptance of depreciated currency by creditor absolute, 458 .

appropriation of payments, 459,460 .

payments by partners and joint debtors, 460.

change in time, place, or medium of, is material alteration, 429, 430. 432 .

part payinent. See Part Payment.

payment supra protest. Sce Paymext Supra Protest.

\section{PAYMENT SUPRA PROTEST.}

when may be made, 461 .

effect of: 461 .

applies only to hills of exchange, 461.

payor subrogated to rights of party for whose honor payment made, 461,462 .

mode of making, 463 .

payor should notify party for whose honor payment made, 463 .

PENCII.

signature in 58. 


\section{PERFORMANCE.}

law of place of, governs when, 490 .

PERSONAI, DLFIENSES.

defined. $2: 5$.

adnissible between whom, 225.

PERSONAL REPRESENTATIVES. See Fxecetors axd ADMixistraTors.

\section{PLAINTIFFS.}

to actions on negotiable instruments, $398-406$.

who are proper parties plaintir determined by lex fori, 494.

must have legal title in order to sue in own name, 448.

\section{PLEADING.}

plea of tender, profert of ninney must accompany, 464.

statute of limitations must be specially pleaded, 414 .

\section{PLEDGE.}

of negotiable instruments, 234-236.

POLITICAL DISTURBANCES.

as excuse for nonpresentment, ete., 385 .

\section{POSSESSION.}

presumptions from, 259.

when sullicient evidence of right to present for payment, 312-314.

prima facie evidence of ownership. 403, 406.

not alway's neetssary in order to institute suit, 406.

POST-OFFICE. See MaIL.

\section{PRE.EXISTING DEBTS.}

as a consideration for negotiable instruments, $100,234,235$.

\section{PRESENTIIENT.}

excines for want of. See Excesles for Soxpresextuext, Protest, Axd Notice.

\section{PRESENTMENT FOR ACCLPTANCE.}

acceptance applies only to bills of exchange, $\mathbf{2 5 6}$.

what bills do and do not repuire presentment for acceptance, 25\%.

when drawer bound without presentment, 258.

by whom made. 25!?.

to whom made, 25!-201.

where drawees joint, 259.

where drawees jartners, 25a.

prescentment to atgent of dralwee, 260 .

where drawe dead, 261.

place of. 262-26.t.

how made. 26i5, 260.

time of, $26 \bar{i}-26 ?$ ?

duty of colleeting bankis as to, 132 .

what law governs, 500 .

\section{PRESFNTIIENT FOR P.MYIIENT.}

not necessary to bind acepepter or maker, 311, 320.

drawer and indorsere clischarged unless duly made and notice of dishonor given, 311,320 . 
PRESENTMENT FOR PAYMENT - contimucd.

by whom made -

may be made by any bona fide holder or his agent, 312 .

when mere possession sufficient evidence of right to present, $312-314$.

if holder is dead, representative must make, 315 .

if holder is bankrupt, assignee must make, 315 .

if partner die, survivor must make, 315 .

if feme sole marry, husband must make, 315.

to whom made -

may be made to acceptor or maker or their agents, 316 .

personal demand not necessary, 316 .

sufficient if made to any person found on premises, 316, 317.

where no one to answer, presentment at dwelling sufficient, 317.

when maker or acceptor dead, should be presented to personal representative, 318 .

if no representative, should be made at dwelling of deceased, or at place where payable, 318 .

where several promisors not partners, should be made to each, 319.

presentment to one partner sufficient, even after dissolution, 319.

on death of copromisor or partner, should be made to survivor, 319.

time of -

should be on day of maturity, 320 .

if before maturity, nugatory, 320 .

if after maturity, without effect, mless excused, 320.

when payable on demand, $321,324,325$.

when payable in instalments, 321.

at what hour of day, 322,323 .

when entitled to grace, $326-328,332$.

when day of maturity falls on Sunday or holiday, 330 .

computation of time, 329-331.

mode of -

instrument should be actually exhibited, 339 .

presentment by mail, 340 .

leaving instrument in debtor's hands, 341 .

when payable at bank, 342 .

custonary demand by notice through the mails, 343,344 .

place of -

when payahle generally. 333 .

when place of payment specified, 333.

when at place of business and when at residence. $334,335$.

when presentment made in person, place nimportant, 336 .

whether due diligence to find maker at place where instrument dated is suffieient, 337.

when payable at either of sereral places, 338 .

by holder of check, laches in, 28, 39.

of checks, time of, 39 .

duty of collecting banks as to, 132 .

what law governs, 500 .

\section{PRESUMPTIONS.}

as to eonsideration, $1,90.91,445$.

as to legality of consideration, 446 .

as to fact and place of delivery, 70,488 . 


\section{PRESUMPTIONS - eontinued.}

as to sanity, $15 \pi$.

that one produeing instrunent is bona fide holder, 199.

that instrument aequired before maturity, 241.

arising from possession, 199, 259.

as to date of acceptance, 288.

in favor of protest, $35 \%$.

when domicile of maker or acceptor presumed to be place of execution, 489.

as to foreign laws and as to law merehant, 499 .

PRIXCIPAL. S'ce also AGEXT.

undisclosed, not liable on negotiable instrument, 127.

ratification by, of aets of agent, 129 .

whether can sile on instrmment given to "A. B., agent for C. D.," 402. change in amount of, constitutes material alteration, 431.

\section{PRINCIPAL AND SLRETY. S'Ce SuRETX.}

\section{PRIVT PAR'TIES.}

who are, 110.

defenses admissible between, 110, 113, 444-447, 473 .

\section{PROCURATION.}

authority by, 123.

\section{PROFERT.}

of money must accompany plea of tender, 464 .

\section{PROMISE.}

to pay, as waiver of nonpresentment, ete., 389 .

PRONISES TO ACCEPT, 303-305.

\section{PROMISSORY NOTES. See also Negotiable Ixstruanexts.}

defined, 16.

origin and history of, 2,4 .

whether negotiable at common law, 4 .

declared negotiable by statute 3 and 4 Anne, chap. 9, 4 .

parties to, 16, 56 .

difference between, and bills of exchange, 17 .

certainty of promise in, 76 .

protest of, under statute, 347 .

foreign, whether protest essential on dishonor of, 347 .

PROOF, BLRDEN OF. , see BLRDKX OF PRoOr.

\section{PROTEST.}

meaning of, 345 .

must be made for nonaceptance and nonpayment, 346 .

what instruments must or may be protested, 6.347 .

certificate of. exchusive evidence of dishonor of foreign bills, 347 .

by whom made. 348 .

how authenticated, 348 .

place of, 349.

notary must have personal knowledge of presentment and demand of parment, 350.

time within which certifieate of, must be prepared, 351.

skeleton or initial protest. 351 . 
PROTEST - continued.

what certiticate of, must contain, $352-354$.

certificate of, as cvidence, 355-35i.

what liw governs, 500 .

exeuses for want of. See Excuses for Nonpresentmext, Protest, AxD Notice.

PLBLIC ENEMY. occupation of country by, as excuse for nompresentment, ete., 384 .

PLBLIC POLICY.

examples of considerations opposed to, 103.

PUBLIC PURPOSE.

municipal bonds ean only he issued for, 22 .

what are public purposes, 23.

PLRCIIASER, BONA FIDE. s'ee Boxa FIDE Ifolder.

\section{QUALIFIED ACCEPTANCE, 262, 309.}

QUASI-NEGOTIABLE INSTRLIIENTS.

possess some but not all qualities of negotiable instruments, 44.

diflerent kinds of, 44-55.

certificates of stock, $45-49$.

bills of lading, 50-52.

warchouse or dock receipts, 53-55.

\section{RATIFICATION.}

by principal of unauthorized acts of agent, 129 .

of contracts made while an infant, 155,156 .

of contracts made while insane or drunk, 162.

of forged signature, 422.

REAL DEFENSES.

defined, 225 .

admissible against bona fide holder, 225.

REAL ESTATE.

governed by law of place where situated, 491.

REASONABLE TIME,

instruments payable on sight or demand must be presented in, 268 . what is, 269 .

\section{RECEIP'T.}

payor should take, 453.

\section{RECEIVERS.}

do not acquire instruments in usual course of business, 238 .

RECOIRSE, INDOHSEMENT WITHOUT. See INDORSEMENT WITIoUt Recourse.

RECOLRSE, INDORSER WITIIOL'T. See Ixdorser Without Recovese.

\section{RECOTERS.}

of money paid on forged instrunent, 27s, 2s0. 424-426.

amount of, when less than full value pairl. 2]6, 217. 


\section{RELEASE.}

effect of, 469 .

REAIEDY.

governed by lex fori, 484, 493.

REAIOTE PALTILS. who are, 111.

REMOTAL. of unker or acceptor, as exeuse for nonpresentment, ete., 397.

RENEWAL NOTES, $114,115$.

RESIDENCL.

presentment for acceptance at, 264.

presentment for payment at, $316,323,334,335$.

presentment may bi male to person found at, 317 .

presentment at, sulficient when maker or acceptor dead, and no personal representative appointed, 318.

notice of dishonor to, $372,376,378$.

RESTRICTIVE INDORSEMENT.

defined, 185.

examples of, 185.

rights of indorsee under, 185.

REVOCATION.

of ageney, 130.

SALE.

payment distinguished from, 449.

SANITY.

presumption of, I57.

SATisfaCtion. Sce Accord axd Satisfaction; Paymext.

SEAL.

effeet of, on negotiability, $21,73,74$.

what is sealed instrument, 73 .

imports a consideration, 90.

doetrine that corporations ean only bind themselves by contracts under, obsolete, 21.

adding or detaching, constitutes material alteration, 434 .

SECl'Rity. Sec Collateral Sectrity.

\section{SERVICES.}

as a concideration, 99.

SET-OFF.

defined, 472.

unknown at common law, 472 .

to what actions applicable, ti2.

may be pleaded only between immediate parties. 473.

not an equity attaching to overdue paper, $204,474$.

governed by lex fori, 498.

SETS.

of foreign bills of exchange, 64-66. 
SICKNESS.

as exeuse for nonpresentment, ete., $269,385,395$.

SIGHT.

when instruments payable on, deemed overdue, 240 .

bills payable at, do not require presentment for aceeptance, 257 .

time of presentment for payment where bill payable at or after, 268 .

"on demand at sight" equivalent to "at sight," $321,327$.

whether instruments payable at, entitled to grace, 327.

meaning of "after sight." 327 .

when statute of limitations begins to run on instrument payable at, 415 .

\section{SIGNATURE.}

place of, 58

how made, 58 .

what will suffice for, 58 .

by agents, 126 .

of drawer admitted by acceptance, 273,424 .

of payee or indorser, acceptance no admission of, $278,425$.

SPECIAL INDORSEE.

where indorsenent special, none but indorsee or his representative ean sue, 398.

\section{STALE CHECKS.} status of, 39 .

STAMPS.

upon negotiable instruments, 67,68 .

STATES. of Union, foreign to each other, 7, 483.

prohibited from emitting bills of eredit, 42 .

power of, to enact bankruptey and insolvency laws, 465.

\section{STATUTE OF LIMITATIONS.}

origin of, 414.

does not destroy debt, but merely bars remedy, 414 .

must be speeially pleaded, 414 .

governed by lex fori, 414,495 .

begins to run when, 28,415 .

new promise or part payment by joint maker, joint and several maker, indorser or surety, effect of, $481,482$.

\section{STOLEN INSTRUMENTS.}

rights of bona fide holder where undelivered instruments stolen and put in eirculation, 207, 208, 223.

thief may transfer good title to negotiable instrument when payable to bearer, 1.

STOPPAGE IN TRANSITU.

effect of transfer of bill of lading on, 51 .

STRANGER.

aceeptance by, 282.

SUBROGATION.

of payor supra protest to rights of party for whose honor he pays, $461,462$. 
[References are to

paragraphs marked \&.I

INUEX.

SUBSTITUTION.

of another obligation, effeet of, 471 .

SUITS. See ActioNs.

SUNDAY.

presentment for payment when instrument falls due on, 330.

SUPRA PROTEST, See ACceptaxce SUPla Protest icceptoh Sepra Protest; Payment surka l'botest.

\section{SURETY.}

contract of, 195.

difference between liability of, and of guarantor, 195 .

not entitled to notice of dishonor, 367 .

drawer (after aceeptance) and indorsers are sureties to acceptor or maker, 475.

not cosureties, and not entitled to contribution, 45 .

each prior party is a principal as between himself and each subsequent party, 475 .

what will discharge -

whatever discharges principal debtor will discharge surety, 476. misrepresentation, duress, diversion, alteration, tender, ete., 477 .

parting with security, ete., 478 .

extension of time, 479,480 .

new promise or part payment by, effect of, on bar of statute of limitations, $481,492$.

TELEGRAPII.

aeceptance by, 297 .

TENDER.

what is a sufficient, 464 .

effect of, 464,477 .

plea of, must be made with profert of money, 464 .

THILF

may transfer good title to negotiable instrument when payable to bearer, 1 .

TIME.

eomputation of, 329-33I.

extemion of effect of, on surety's liability, 4is, 450 .

TITLL:

thief may transfer good, to negotiable instrument if parable to bearer. 1.

legal, any holder with, may sue. 39 s.

legil. must be vented in plaintiff to entitle him to sue in own name, 4.4 .

TR.ADING PARTNERSIIIS.

negotiable instrument exeeuted ly one partner binding on firm. 136.

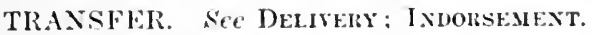

TRATELINF:

when party is, as exeuse for nonpresentment, ete., 393.

TRLSTEES.

as pirties to negotiable instruments, I20. 
USAGE.

as to proper hour for presentment for aceeptance, $267,268$. of banks, as to days of graee, may alter law merchant, 328 .

USUAL COURSE OF BUSINESS. Sce Business.

USURY, 104.

UTTERING.

meaning of, 421 .

essential to constitute forgery, 421.

VALIDITY.

governed by lex loci contractus, 486.

VALUABLE CONSIDERATION. Sce Consideration.

\section{VERBAL.}

aeceptances, 300 .

notices of dishonor, 360 .

VOID.

where instrument declared void by law, good defense against bona fide holder, 221 .

when instrument known by drawer or indorser to be, nonpresentment, ete., exeused, 391.

\section{WAGERS, 102.}

WAIVER.

of presentment, protest, and notice, 388,389 .

WAR.

effect of, on intereourse, 163.

does not revoke ageney, 130.

as excuse for nonpresentment, ete., 384 .

\section{WAR BETWEEN THE STATES.}

cases growing out of, 80 .

citizens of United States and Confederate States alien enemies, 164.

WAREHOUSE RECEIPTS.

description and nature of, 53, 54 .

difference between, and bills of lading, 53 .

statutory enactments in regard to, 55 .

WARRANTIES.

by indorsement. $172-178,424$.

by aceeptance. $273-277,424$.

by aceptance for honor, 295 .

Without RECOURSE. Sce Indorsement Without Recourse; Indorser Without Recourse.

WITNESS.

adding name of, is material alteration, when, 434 .

[Whole Number of Pages 452.] 




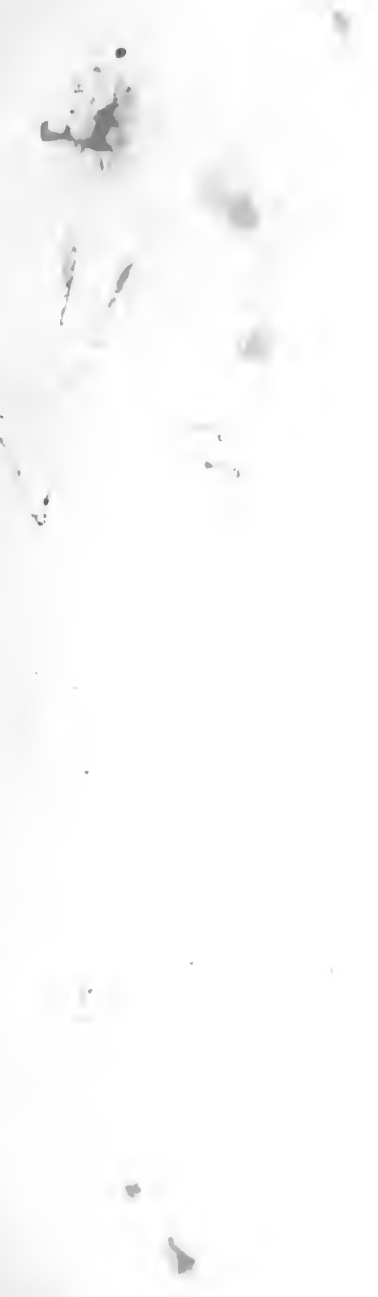


LAW IIBRARY

UNIVERSITY' OF CALIFORNIA

LOS ANGELES 


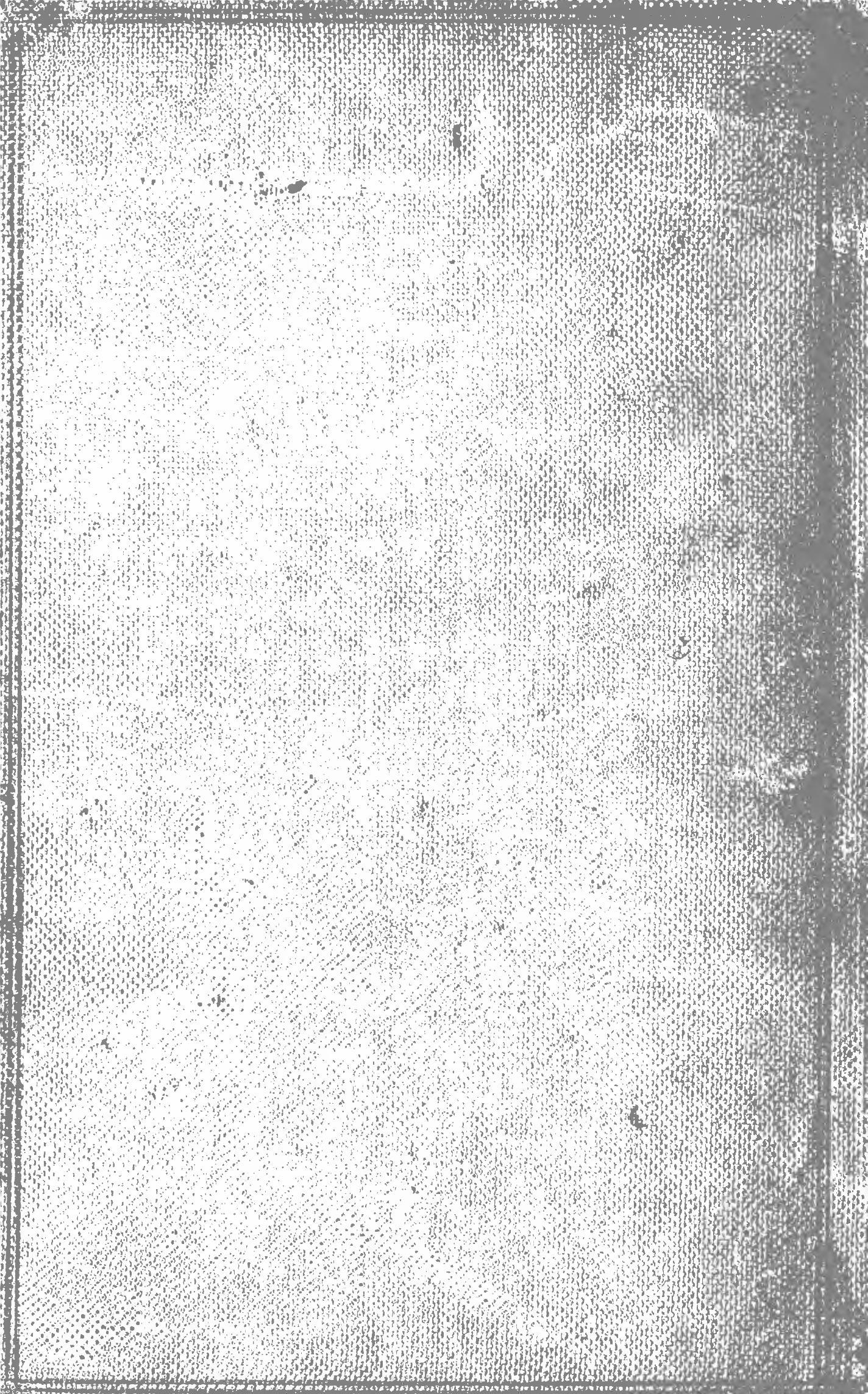

